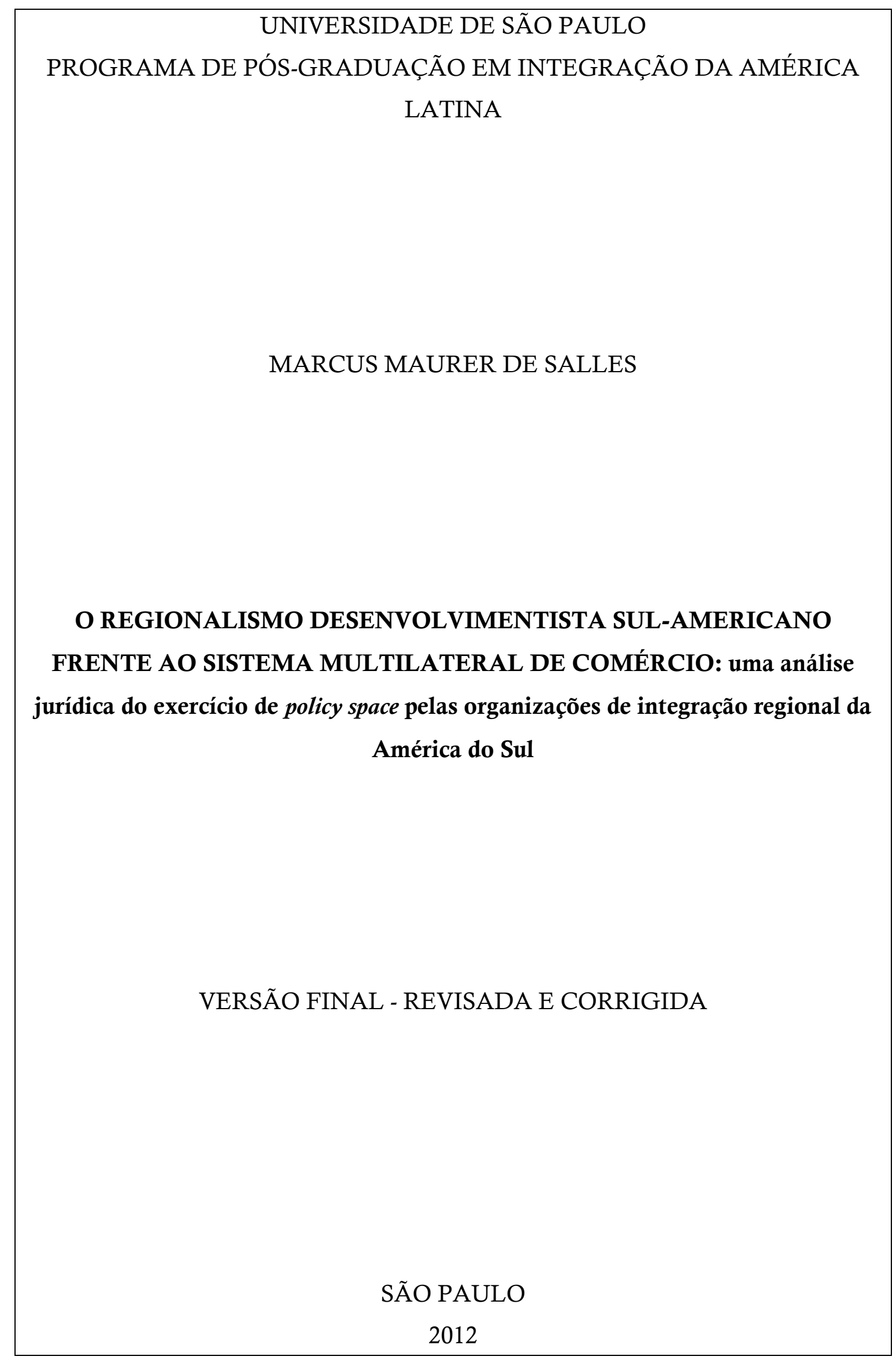




\title{
O REGIONALISMO DESENVOLVIMENTISTA SUL-AMERICANO FRENTE AO SISTEMA MULTILATERAL DE COMÉRCIO: uma análise jurídica do exercício de policy space pelas organizações de integração regional da América do Sul
}

\author{
Tese apresentada ao Programa de Pós- \\ Graduação em Integração da América \\ Latina da Universidade de São Paulo para \\ obtenção do título de Doutor em Integração \\ da América Latina
}

Orientador: Professor Associado Umberto Celli Junior

SÃO PAULO

2012 


\section{FOLHA DE APROVAÇÃO}

Nome: MARCUS MAURER DE SALLES

Orientador: UMBERTO CELLI JUNIOR

Título: O REGIONALISMO DESENVOLVIMENTISTA SUL-AMERICANO FRENTE AO SISTEMA MULTILATERAL DE COMÉRCIO: uma análise jurídica do exercício de policy space pelas organizações de integração regional da América do Sul

Tese apresentada ao Programa de Pós-

Graduação em Integração da América

Latina da Universidade de São Paulo para obtenção do título de Doutor em Integração da América Latina

Aprovado em:

Banca Examinadora

Prof (a). Dr. (a): Instituição:

Julgamento: Assinatura:

Prof (a). Dr. (a): Instituição:

Julgamento: Assinatura:

Prof (a). Dr. (a): Instituição:

Julgamento: Assinatura:

Prof (a). Dr. (a): Instituição:

Julgamento: Assinatura:

Prof (a). Dr. (a): Instituição:

Julgamento: Assinatura: 


\section{AGRADECIMENTOS}

Agradeço à Universidade de São Paulo (USP), em especial, ao Programa de Pós-Graduação em Integração da América Latina (PROLAM) por ter aceitado a minha proposta para desenvolver a pesquisa de doutorado entre 2009 e 2012. A estrutura de excelência internacional da USP possibilitou a realização da presente pesquisa com o financiamento da Coordenação de Aperfeiçoamento de Pessoal de Ensino Superior (CAPES), tanto para as pesquisas realizadas no Brasil, quanto no exterior, especialmente junto à Universidade de Barcelona, durante o estágio doutoral.

Agradeço ao Professor Umberto Celli Junior que, desde que nos conhecemos em 2007, em um Seminário de Direito Internacional na Universidade Católica de Santos, sempre foi receptivo às minhas ideias e valores. Durante os quatro anos de convívio, além da orientação da tese, tive o privilégio de participar de projetos internacionais de pesquisa em conjunto e de acompanhá-lo sistematicamente como seu assistente tanto nos cursos de graduação quanto de pósgraduação. Com o Professor Celli, aprendi lições para a vida acadêmica e profissional, mas principalmente, levo um grande exemplo para a vida pessoal.

Uma menção especial deve ser feita a um grupo de professores com os quais tive a oportunidade de conviver ao longo destes primeiros dez anos da carreira acadêmica, em Santa Maria, Florianópolis, São Paulo e Barcelona. Estes professores, com quem humildemente me propus a dialogar na introdução desta tese, representam uma notável e necessária renovação do direito internacional no Brasil. Sobre eles, tecerei breves comentários a seguir.

Agradeço a professora Deisy Ventura pelo privilégio de convívio há dez anos, desde que me acolheu na Universidade Federal de Santa Maria, como minha orientadora junto ao Mestrado em Integração Latino-Americana. Tudo o que venho aplicando ao longo destes anos de docência em ensino superior aprendi com a Professora Deisy. Seus valores e motivações em torno da educação serão minha referência por toda a carreira acadêmica. 
Agradeço ao professor Alberto do Amaral Junior por ter sido extremamente receptivo desde a minha chegada em São Paulo, acolhendo, orientando e encorajando o projeto acadêmico que me propus a desenvolver junto à Universidade de São Paulo.

Agradeço aos professores Fernando Aguillar e Márcio Bobik Braga, pelas valiosas contribuições que me brindaram no exame de qualificação desta tese. Suas observações auxiliaram a delimitar e aprofundar as minhas pesquisas que resultaram nesta tese.

Agradeço aos professores Welber Barral e Luiz Otávio Pimentel, por terem me integrado em um ambiente de alto nível de discussão na Universidade Federal de Santa Catarina, no qual tive o privilégio de conviver durante os anos entre o mestrado e o doutorado. Devo a eles muitas das reflexões acerca da relação entre o direito, o comércio internacional e o desenvolvimento que vêm sendo amadurecidas desde então.

Agradeço igualmente ao Professor Glauco Arbix, que hoje ocupa a presidência do FINEP e fortalece a jovem Agência Brasileira de Inovação, pelas discussões durante o curso que ministrou sobre BRICs e Desenvolvimento. Tais reflexões contribuíram sobremaneira para que esta tese tomasse o rumo das conclusões sobre a relevância do fenômeno global do novo desenvolvimentismo para a América do Sul.

Agradeço ao Professor Ramon Torrent da Universidade de Barcelona que, gentilmente me recebeu para um estágio de pesquisas de quatro meses junto à Cátedra Internacional OMC/Integração Regional. Ao longo desde estágio, consolidei e ampliei a minha visão de mundo. Os efeitos deste estágio sobre a minha visão de mundo até hoje, me influenciam e estimulam.

Agradeço ao apoio dos meus amigos, na pessoa do Marco Aurélio Torronteguy. Além de ser um dos jovens acadêmicos mais brilhantes que já conheci, tivemos o prazer de desenvolver uma cumplicidade e camaradagem ao longo destes anos em São Paulo que criaram laços eternos de amizade.

Agradeço aos meus queridos pais, Luiz Antonio e Maria Elizabeth, por todo o apoio e incentivo que me deram ao longo do doutorado. Os exemplos que 
representam para mim são a razão pela qual nasci professor e pesquisador. Agradeço igualmente ao meu irmão Rafael e à minha cunhada Rosana pelo companheirismo ao longo deste período, mas especialmente, por terem me brindado com a mágica companhia do pequeno Matheus. Quis o destino que, para eu expandir as minhas vocações, precisasse me distanciar da minha família gaúcha. Enfim, chegou a hora de compensarmos este tempo distante.

Agradeço a minha família santista, Cláudia, Ivo, Eduardo, Roze, Bruna e Victória, pela acolhida tão generosa que me brindaram desde que me mudei para Santos em dezembro de 2007. Junto a vocês, desfrutei de incontáveis momentos de alegria e comunhão que tornaram esses anos de doutorado muito mais felizes.

Por fim, os agradecimentos mais importantes vão para a Marcela, minha mulher. Só quem vive um doutorado ao lado de uma pessoa amada sabe a relação de confidência, companheirismo e superação que se cria ao longo destes anos de desafios e fortalecimento interior. Tu és a pessoa que traz encanto, poesia, música, beleza, aroma e sabor à minha vida. Esta tese eu dedico para ti. 
La historia es una red y no una vía.

Jorge Drexler 


\section{RESUMO}

SALLES, Marcus Maurer de. O REGIONALISMO DESENVOLVIMENTISTA SUL-AMERICANO FRENTE AO SISTEMA MULTILATERAL DE COMÉRCIO: uma análise jurídica do exercício de policy space pelas organizações de integração regional da América do Sul. 2012. 469 páginas. Tese (Doutorado) - Programa de Pós-Graduação em Integração da América Latina, Universidade de São Paulo, São Paulo, 2012.

Resumo: A presente tese se propõe a responder a seguinte questão: É correto afirmar que o regionalismo desenvolvimentista sul-americano, implantado ao longo do século XX, e o novo regionalismo desenvolvimentista, implantado ao longo da primeira década do século XXI, são compatíveis com as regras do sistema multilateral de comércio? Em outras palavras, as organizações de integração regional da América do Sul têm balizado as suas políticas desenvolvimentistas no policy space decorrente das prerrogativas jurídicas para o desenvolvimento do sistema multilateral de comércio? Para tratar o refrido tema, parte-se da premissa que os países da América do Sul historicamente sempre fizeram uso das prerrogativas jurídicas para o desenvolvimento, desde que tais surgiram no sistema multilateral de comércio, e possibilitaram a implantação de políticas no plano nacional e regional. Ao longo da tese, é analisada, desde uma perspectiva jurídica, a compatibilidade com as regras do sistema multilateral de comércio dos principais aspectos desenvolvimentistas das organizações de integração regional criadas na América do Sul, desde a ALALC, em 1960, até a UNASUL, em 2008. Concluiu-se que tanto o velho quanto o novo regionalismo desenvolvimentista da América do Sul foram levados adiante em concordância com o direito internacional do comércio, seja ao longo do período GATT, seja ao longo do período OMC. Mesmo com a redução de policy space decorrente da entrada em vigor dos acordos da OMC, a América do Sul vislumbrou manter um relativamente alto nível de espaço político (policy space) para a criação de políticas públicas de desenvolvimento. Atualmente, percebe-se uma tendência das organizações de integração regional da América do Sul, especialmente da UNASUL e do MERCOSUL, de levar adiante políticas públicas em torno de temas não-regulados pela $\mathrm{OMC}$, o que caracterizaria uma estratégia $O M C$-extra. O novo regionalismo desenvolvimentista sul-americano está finalmente se constituindo para além do policy space do sistema multilateral de comércio, o que, por não configurar, a priori, uma incompatibilidade dos processos de integração com as regras da OMC, contribui para fortalecer o primado do direito internacional na América do Sul.

Palavras-chave: América do Sul; Regionalismo desenvolvimentista; Policy Space; Sistema Multilateral de Comércio 


\section{RESUMEN}

SALLES, Marcus Maurer de. EL REGIONALISMO DESARROLLISTA SUDAMERICANO FRENTE AL SISTEMA MULTILATERAL DE COMERCIO: un análisis jurídico del ejercicio de policy space por las organizaciones de integración regional de Sudamérica. 469 páginas. Tesis (Doctorado) - Programa de Posgrado en Integración de América Latina, Universidad de São Paulo, São Paulo, 2012.

Resumen: La presente tesis se propone a contestar la siguiente cuestión: ¿Es correcto afirmar que el regionalismo desarrollista sudamericano, implantado al largo del siglo XX, y el nuevo regionalismo desarrollista, implantado al largo de la primera década del siglo XXI, son compatibles con las reglas del sistema multilateral de comercio? En otras palabras, ¿las organizaciones de integración regional de América del Sur balizan sus políticas desarrollistas en el policy space advenido de las prerrogativas jurídicas para el desarrollo del sistema multilateral de comercio? Para tratar del referido tema, partiese de la premisa de que los países de América del Sur históricamente siempre utilizaron las prerrogativas jurídicas para el desarrollo, desde que tales surgieron en el sistema multilateral de comercio, y posibilitaron la implantación de políticas en el plan nacional y regional. Al largo de esta tesis se analiza, desde una perspectiva jurídica, la compatibilidad con las reglas del sistema multilateral de comercio de los principales aspectos desarrollistas de las organizaciones de integración regional creadas en América del Sur, desde la ALALC, en 1960, hasta la UNASUR, en 2008. Concluyese que tanto el viejo cuanto el nuevo regionalismo desarrollista de América del Sur fueron llevados adelante en conformidad con el derecho internacional del comercio, sea durante el período GATT, sea durante el período OMC. Aún con la reducción del policy space decurrente de la puesta en marcha de los acuerdos de la OMC, la América del Sur vislumbró mantener un relativo alto nivel de espacio político (policy space) para la creación de políticas públicas de desarrollo. Actualmente, percibiese una tendencia de las organizaciones de integración regional de América del Sur, especialmente de la UNASUR y del MERCOSUR, de llevar adelante políticas públicas alrededor de temas no-reglados por la OMC, que caracterizaría una estrategia OMC-extra. E1 nuevo regionalismo desarrollista sudamericano está finalmente se constituyendo más allá del policy space del sistema multilateral de comercio, facto que, por no configurar, a priori, una incompatibilidad de los procesos de integración con las reglas de la OMC, ha contribuido para fortalecer el primado del derecho internacional en América del Sur.

Palabras-clave: América del Sur; Regionalismo desarrollista; Policy Space; Sistema Multilateral del Comércio 


\section{ABSTRACT}

SALLES, Marcus Maurer de. THE SOUTH AMERICAN DEVELOPMENTAL REGIONALISM VIS-À-VIS THE MULTILATERAL TRADING SYSTEM: a legal analysis of the exercise of policy space by the South-American regional integration organizations. 469 pages. Thesis (Doctor of Philosophy) - PostGraduate Programme in Latin American Integration, São Paulo University, São Paulo, 2012.

Abstract: This thesis aims to answer the following question: Can it be said that the South American developmental regionalism, carried out throughout the twentieth century, and the new developmental regionalism, implemented during the first decade of this century, are compatible with the rules of multilateral trading system? In other words, have the regional integration organizations in South America based their developmental policies in the policy space resulting from the developmental legal prerogatives of the multilateral trading system? To treat such theme, we start from the premise that the countries of South America have historically made use of legal rights for development, since these arose in the multilateral trading system, and enabled the implementation of policies at the national and regional levels. From a legal perspective, the thesis analyses the compatibility of the main developmental aspects of regional integration organizations created in South America since the LAFTA in 1960 to UNASUR, in 2008 with the rules of the multilateral trading system. It was concluded that both the old and the new developmental regionalism in South America were brought forward in accordance with international trade law, either through the GATT period, either during the WTO period. Even with the reduction of policy space resulting from the entry into force of the WTO agreements, South America managed to maintain a relatively high level of policy space for the creation of developmental public policies. Currently, there is a perceived trend of regional integration organizations in South America, especially the MERCOSUR and UNASUR, to carry out public policies on topics unregulated by the WTO, which would characterize a strategy WTO-extra. The new South American developmental regionalism is finally going beyond the policy space of the multilateral trading system, which, by not setting a priori incompatibility of the integration processes with WTO rules, contributes to strengthen the rule of international law in South America.

Key words: South America; Developmental Regionalism; Policy Space; Multilateral Trading System 


\section{LISTA DE ABREVIATURAS E SIGLAS}

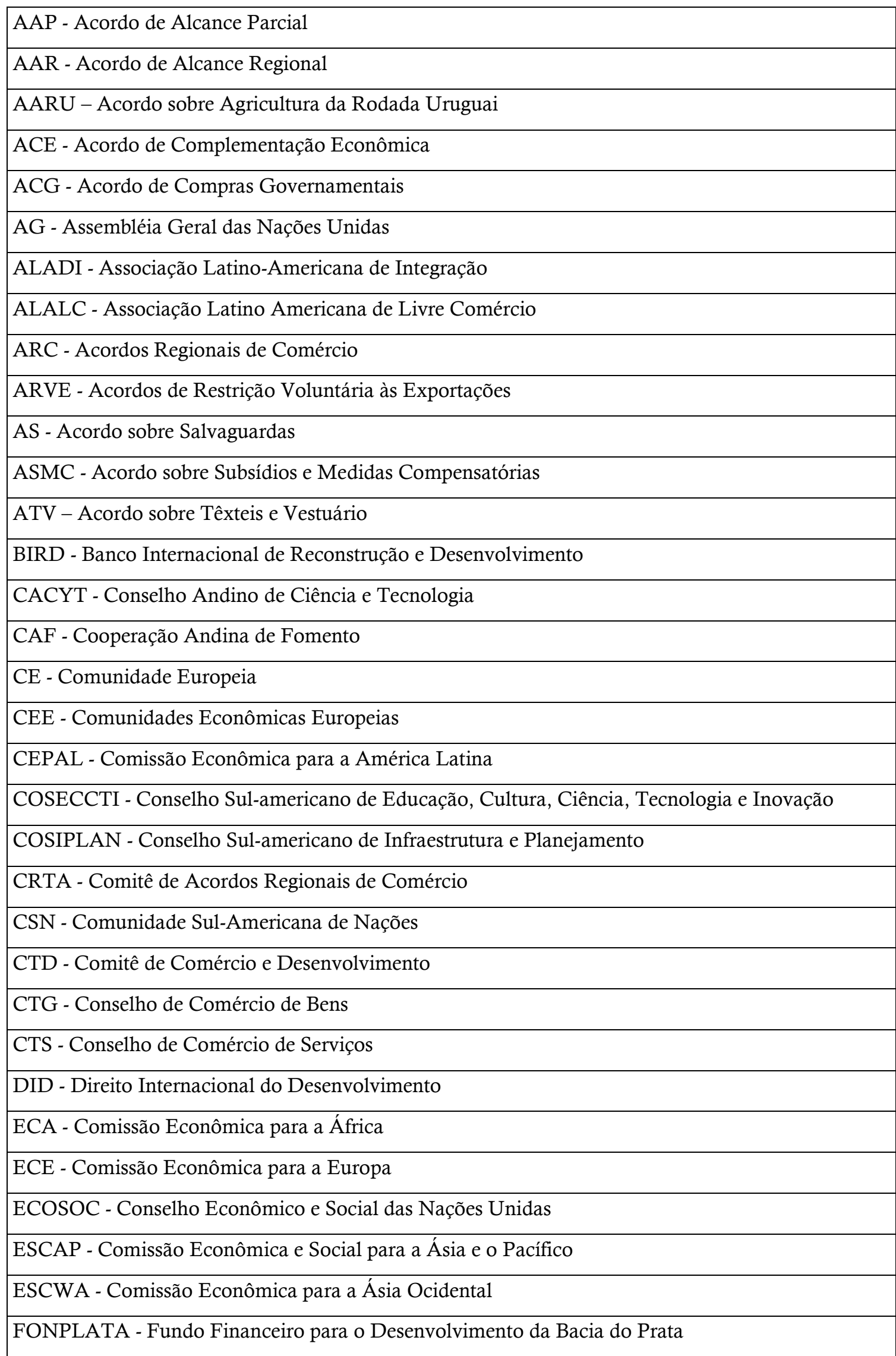




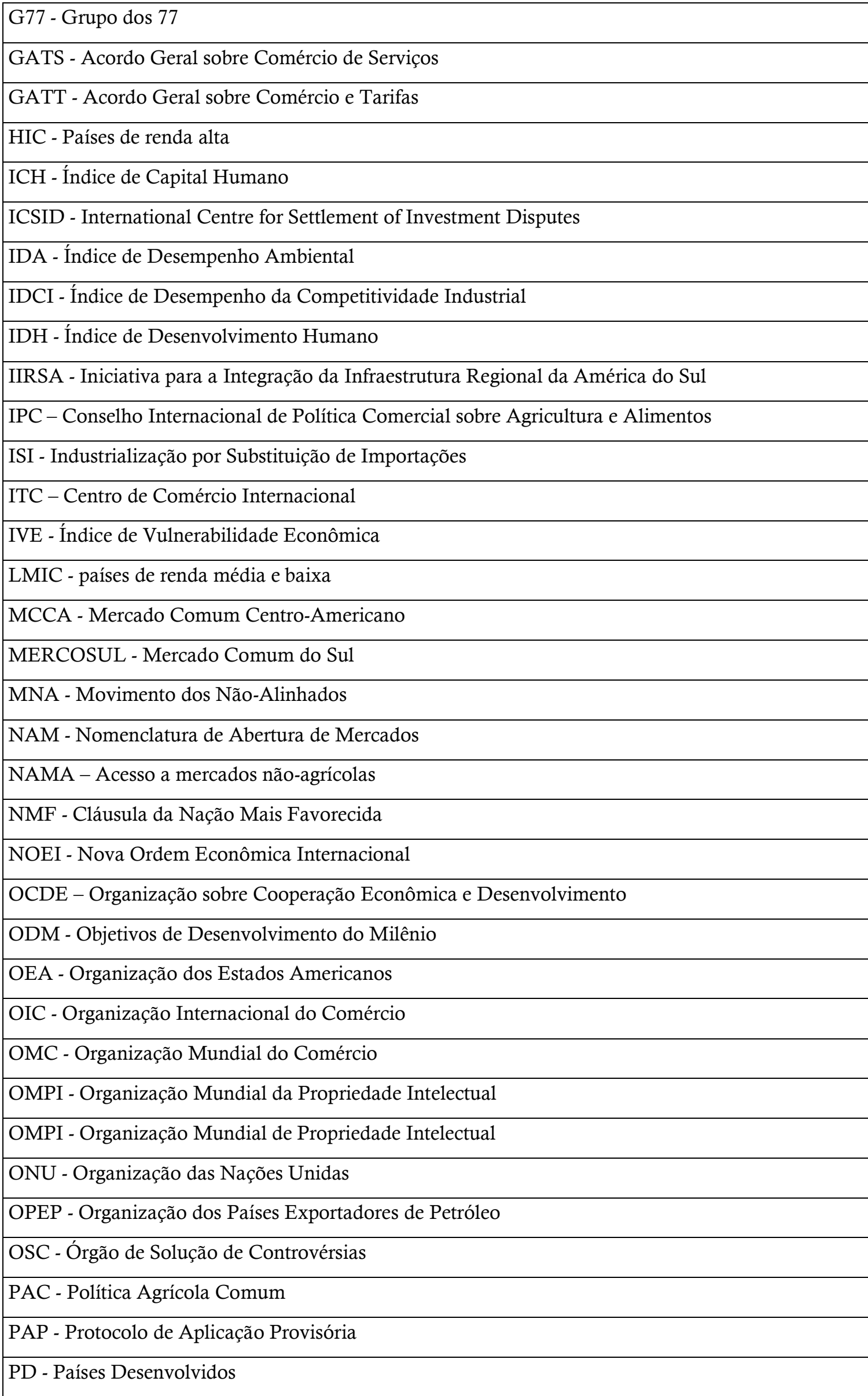




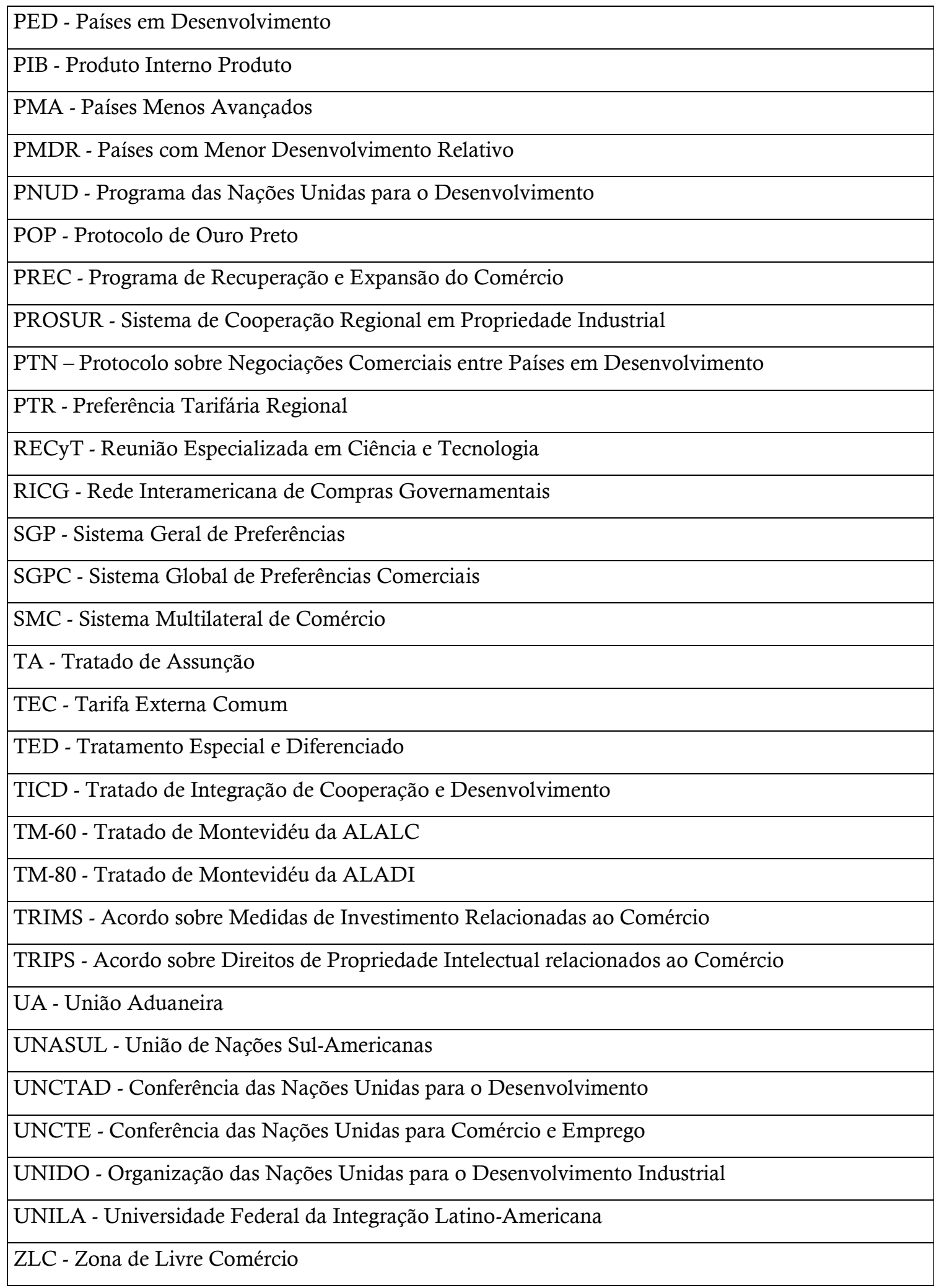




\section{LISTA DE TABELAS}

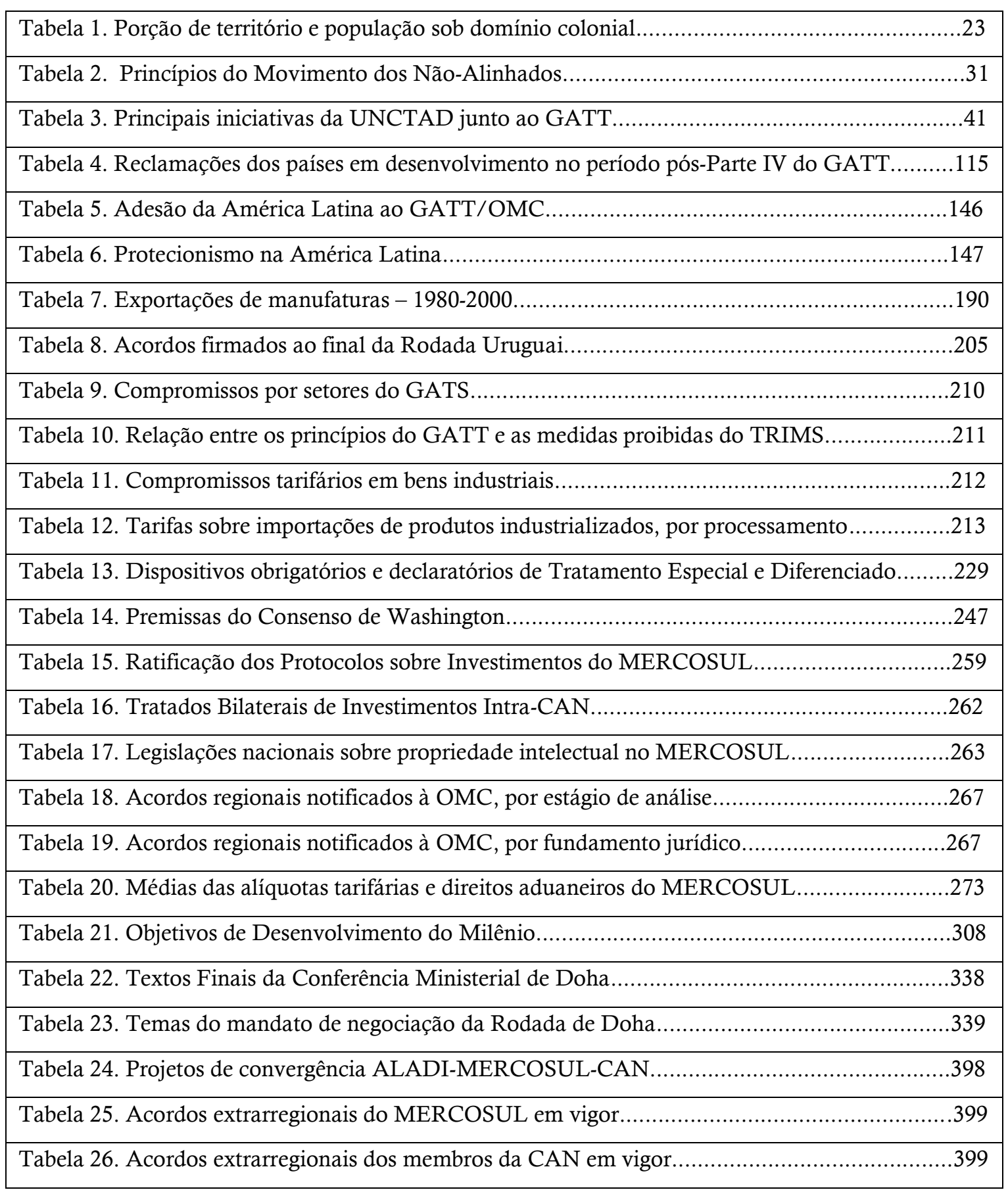




\section{ÍNDICE}

INTRODUÇÃO

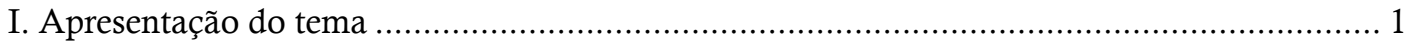

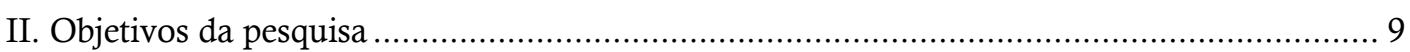

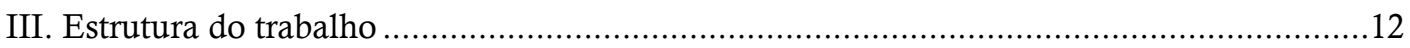

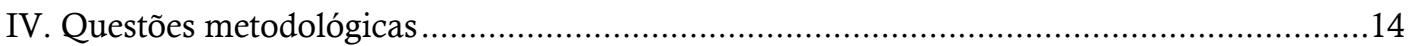

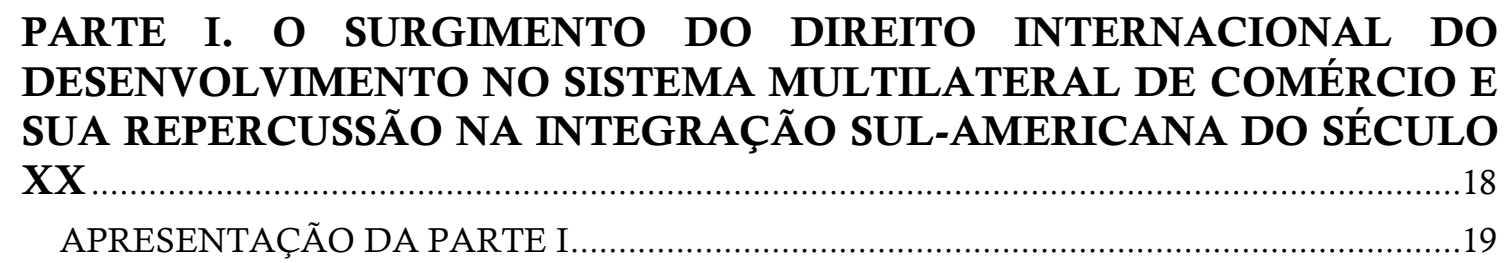

CAPÍTULO 1. A EMERGÊNCIA DO DESENVOLVIMENTO ENQUANTO FUNDAMENTO JURÍDICO DAS RELAÇÕES INTERNACIONAIS ..............................20

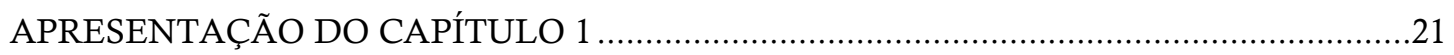

1.1. O CONTEXTO JURÍDICO DA DESIGUALDADE ENTRE AS NAÇÕES DO PÓS-

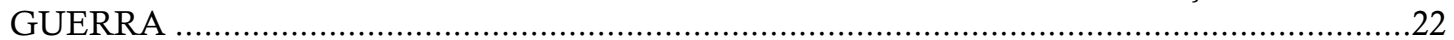

a) As premissas clássicas do direito internacional ao final da Segunda Guerra Mundial..........22

b) A descolonização e o reconhecimento da desigualdade econômica entre os Estados............26

c) A articulação do Terceiro Mundo perante o direito internacional .......................................29

1.2. A CONSTRUÇÃO DO SISTEMA ONU EM PROL DO DESENVOLVIMENTO .............33

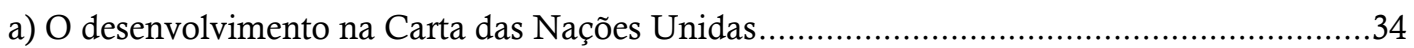

b) Os países em desenvolvimento nos órgãos originários da ONU ...........................................35

c) A UNCTAD e as novas instituições da ONU para o desenvolvimento ................................39

1.3. A CONSOLIDAÇÃO NORMATIVA DO DIREITO INTERNACIONAL DO

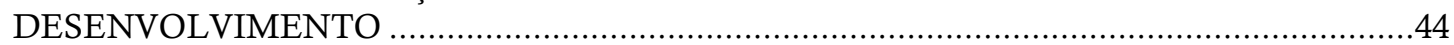

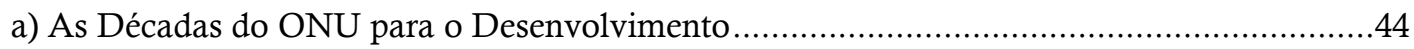

b) Elementos normativos da nova ordem econômica internacional..........................................52

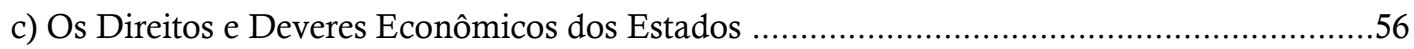

d) O Desenvolvimento Progressivo dos princípios da NOEI ....................................................57

1.4. A NATUREZA PECULIAR DO DIREITO INTERNACIONAL DO

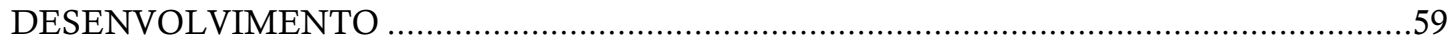

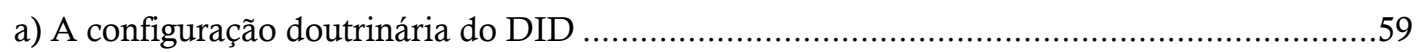

b) A transformação do direito internacional pelo mundo em desenvolvimento .......................62

c) A crise do direito internacional do desenvolvimento........................................................64

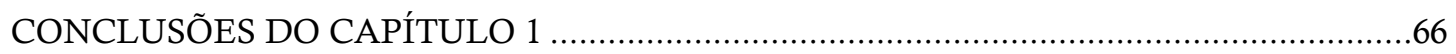

CAPÍTULO 2. AS PRERROGATIVAS JURÍDICAS PARA O DESENVOLVIMENTO NO

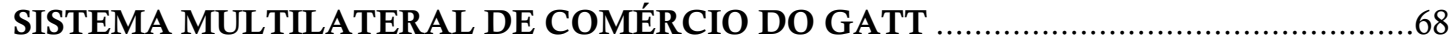

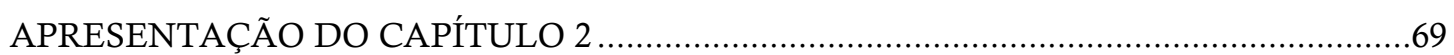


2.1. A PRERROGATIVA DO DESENVOLVIMENTO NAS NEGOCIAÇÕES OIC/GATT .70

a) O contexto antecedente às negociações da OIC/GATT …..................................................70

b) Os países em desenvolvimento nas negociações da OIC e do GATT …...............................78

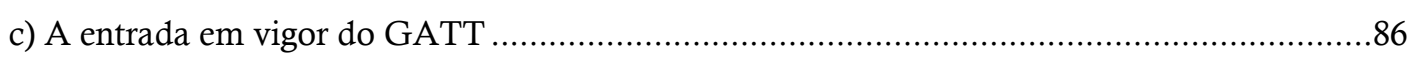

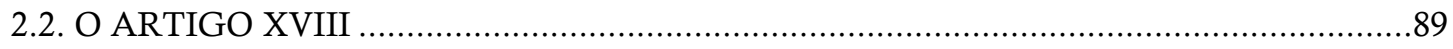

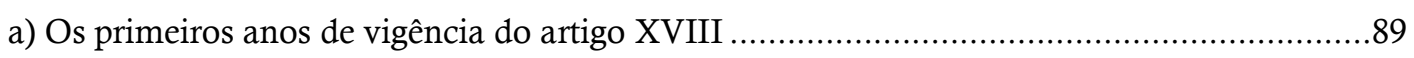

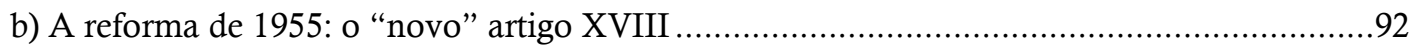

c) Um balanço do artigo XVIII no período GATT …...........................................................96

2.3. A PARTE IV DO GATT - COMÉRCIO E DESENVOLVIMENTO ……….....................99

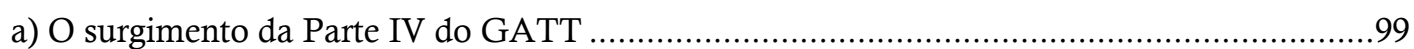

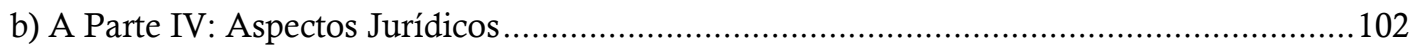

c) A Rodada Kennedy: primeira rodada na vigência da Parte IV .........................................105

d) A Relevância da Parte IV para o Sistema Multilateral de Comércio ..................................107

2.4. A CLÁUSULA DE HABILITAÇÃO ................................................................................ 109

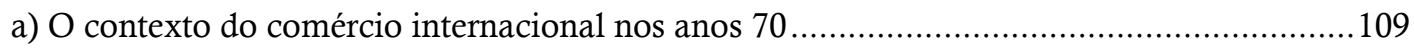

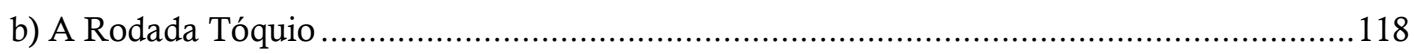

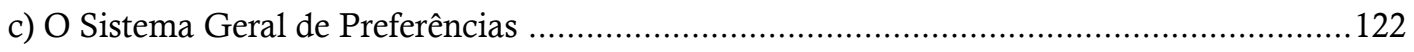

d) O Sistema Global de Preferências Comerciais ..................................................................126

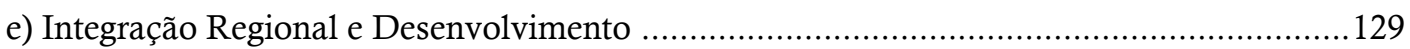

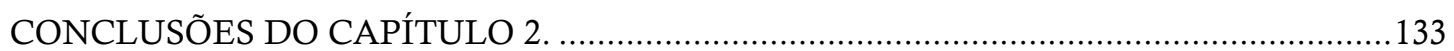

CAPÍTULO 3. O EXERCÍCIO DAS PRERROGATIVAS JURÍDICAS DESENVOLVIMENTISTAS NA INTEGRAÇÃO SUL-AMERICANA DO SÉCULO XX 137

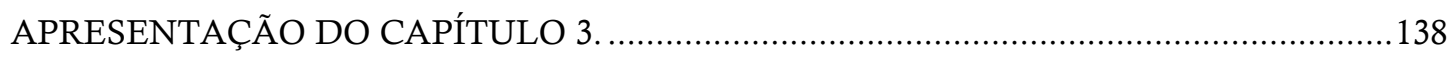

3.1. O MODELO DESENVOLVIMENTISTA DA AMÉRICA DO SUL ................................140

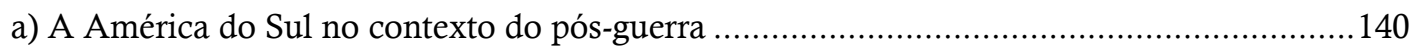

b) O Modelo ISI e as contribuições da CEPAL ……..........................................................142

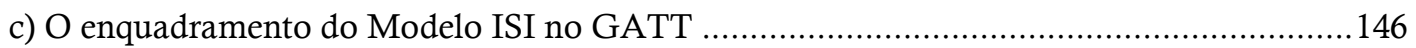

d) A relação entre integração e desenvolvimento na América Latina ......................................148

3.2. A ASSOCIAÇÃO LATINO-AMERICANA DE LIVRE COMÉRCIO (ALALC) .............150

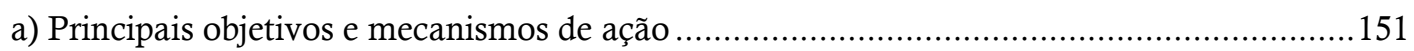

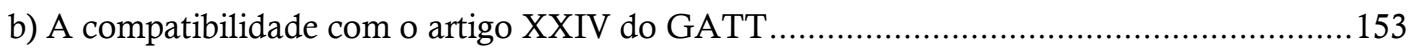

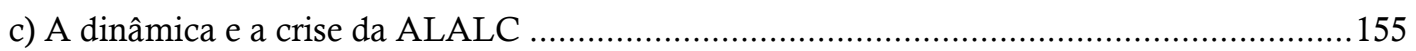

d) A demanda pela integração sub-regional e os efeitos do Pacto Andino ..............................156

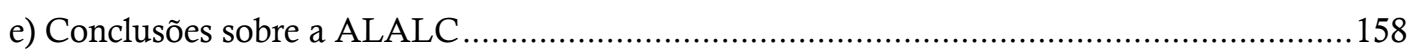

3.3. A ASSOCIAÇÃO LATINO-AMERICANA DE INTEGRAÇÃO (ALADI) .....................159

a) A ALADI vis-a-vis a Cláusula de Habilitação ................................................................159

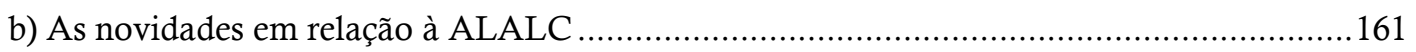

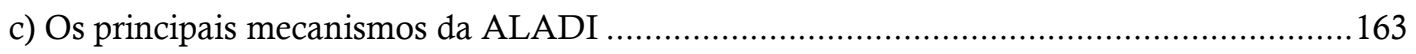

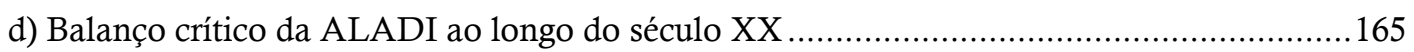

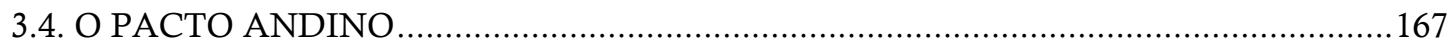

a) O surgimento no âmbito da ALALC ...............................................................................167 


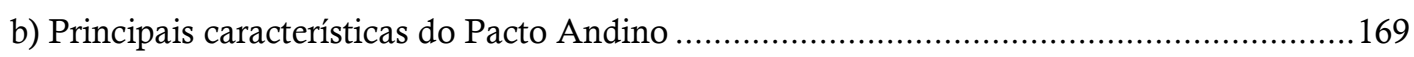

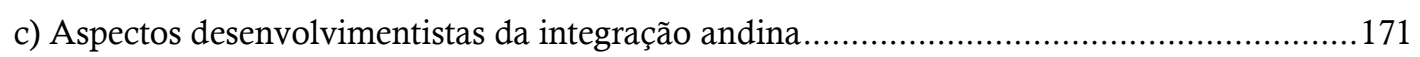

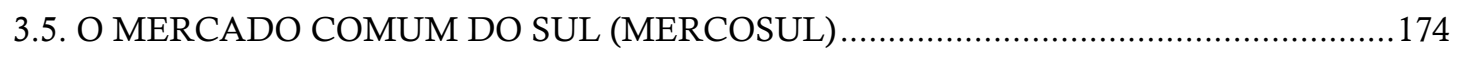

a) O surgimento do MERCOSUL no âmbito da ALADI ........................................................ 174

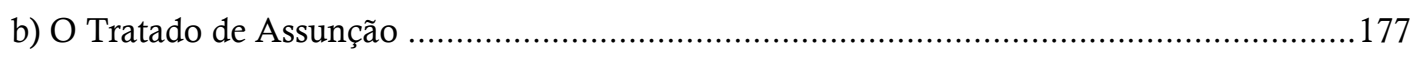

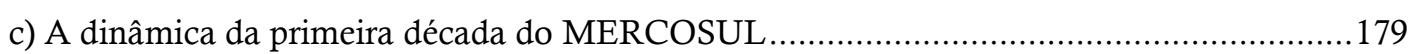

d) Aspectos desenvolvimentistas da primeira década do MERCOSUL .................................183

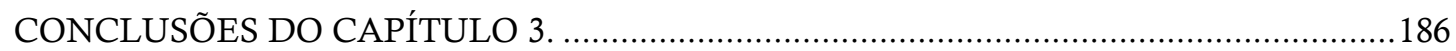

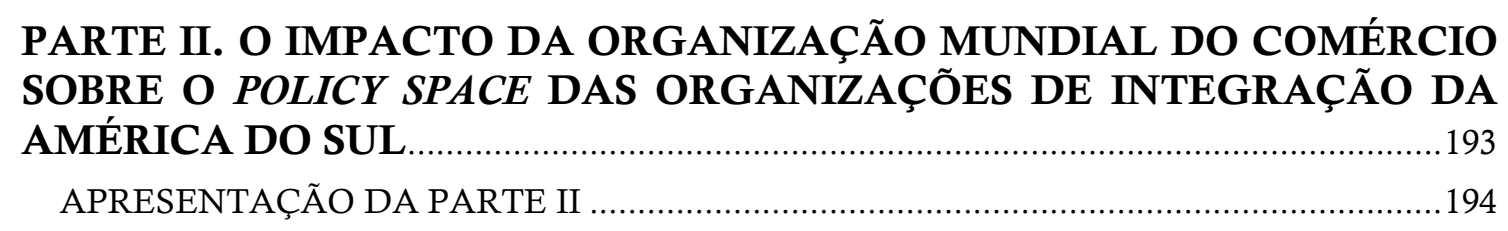

CAPÍTULO 4. A CRIAÇÃO DA ORGANIZAÇÃo MUNDIAL DE COMÉRCIO E A RELATIVIZAÇÃO DO DIREITO INTERNACIONAL DO DESENVOLVIMENTO .......195

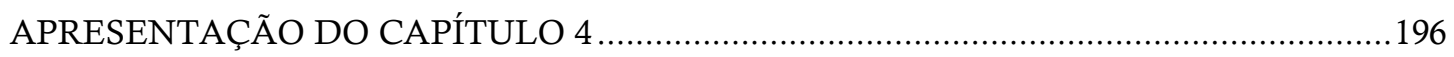

4.1. A RELATIVIZAÇÃO DO DESENVOLVIMENTO QUANDO DA CRIAÇÃO DA

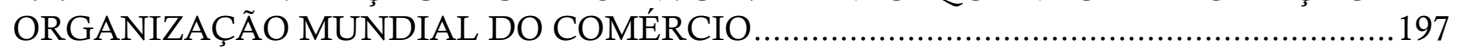

a) $\mathrm{O}$ desenvolvimento nas negociações da Rodada Uruguai ................................................197

b) Os efeitos da OMC: Institucionalização, alargamento e aprofundamento ...........................202

c) A nova concepção do desenvolvimento decorrente da criação da OMC ...........................214

4.2. AS LIMITAÇÕES DO DESENVOLVIMENTO POR MEIO DO TRATAMENTO

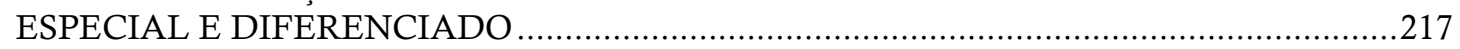

a) A condição jurídica de "Membro em desenvolvimento" na OMC ....................................217

b) A natureza jurídica dos direitos do Tratamento Especial e Diferenciado na OMC .............223

4.3. AS PRERROGATIVAS JURÍDICAS DO DESENVOLVIMENTO NO OSC DA OMC 230

a) O artigo XVIII interpretado: o caso Índia - Restrições Quantitativas................................230

b) A Cláusula de Habilitação interpretada: o caso CE - Preferências Tarifárias .....................2235

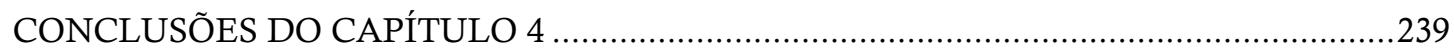

CAPÍTULO 5. A COMPATIBILIZAÇÃO DAS ORGANIZAÇÕES DE INTEGRAÇÃO SUL-AMERICANA COM AS REGRAS DA ORGANIZAÇÃO MUNDIAL DO

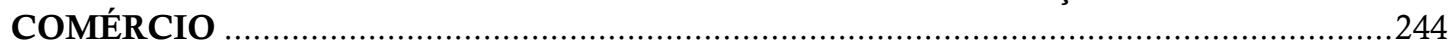

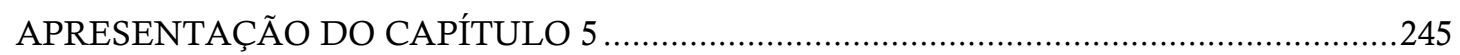

5.1. O REGIONALISMO NEOLIBERAL DA AMÉRICA DO SUL ...................................246

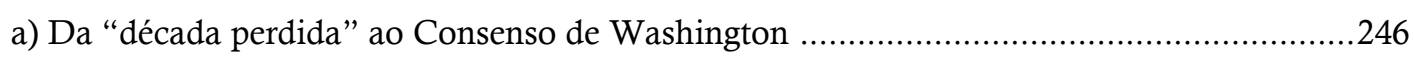

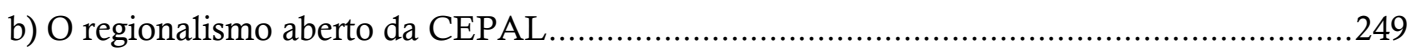

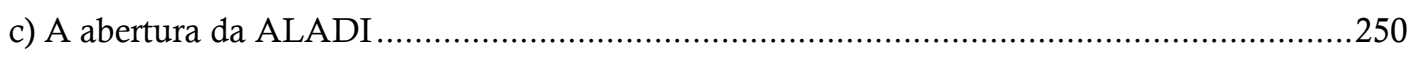

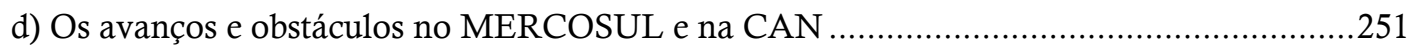

5.2. A INCORPORAÇÃO DAS REGRAS DA OMC NA INTEGRAÇÃO SUL-AMERICANA

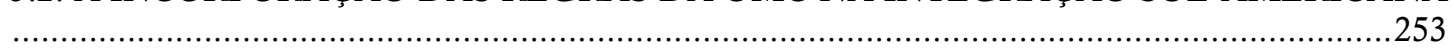

a) Comércio de serviços na integração sul-americana .........................................................25

b) Comércio e investimentos no MERCOSUL e na CAN ..................................................259 


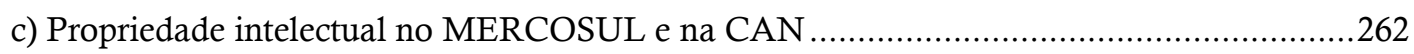

5.3. A COMPATIBILIDADE DA INTEGRAÇÃO SUL-AMERICANA COM A OMC ........264

a) Esclarecimentos sobre o processo de consideração dos acordos regionais de comércio pelo

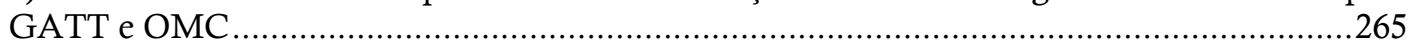

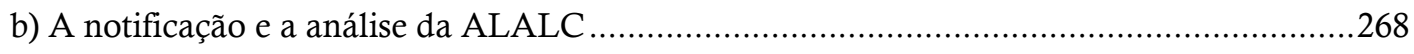

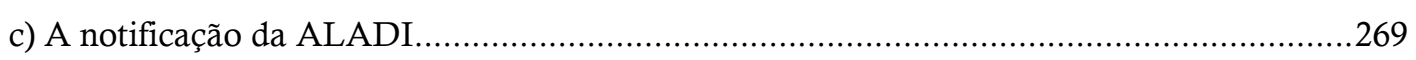

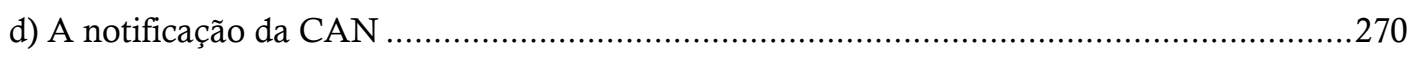

e) A notificação e a análise do MERCOSUL .......................................................................22

f) Os casos do OSC da OMC envolvendo o MERCOSUL ....................................................224

g) Considerações sobre os processos de análise de compatibilidade da integração sul-americana

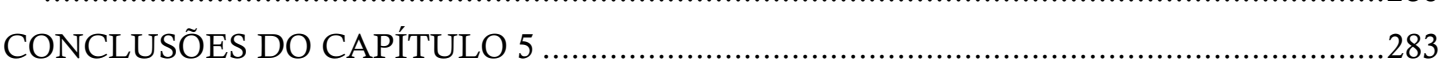

PARTE III. O NOVO DESENVOLVIMENTISMO NA ORGANIZAÇÃO

MUNDIAL DE COMÉRCIO E NA INTEGRAÇÃO SUL-AMERICANA:

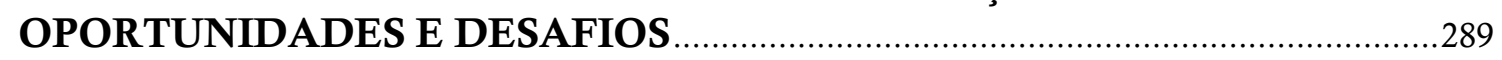

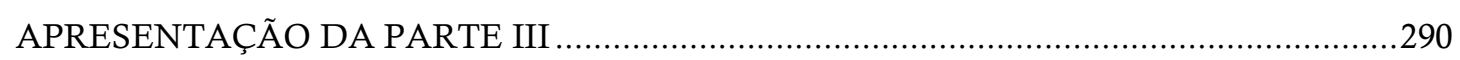

CAPÍTULO 6. O RESSURGIMENTO DO DIREITO INTERNACIONAL DO

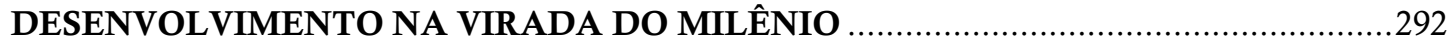

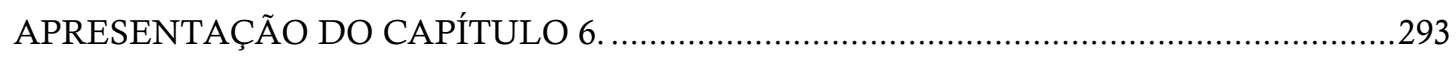

6.1. O DIREITO AO DESENVOLVIMENTO HUMANO E SUSTENTÁVEL DOS ANOS 90

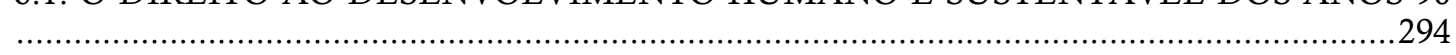

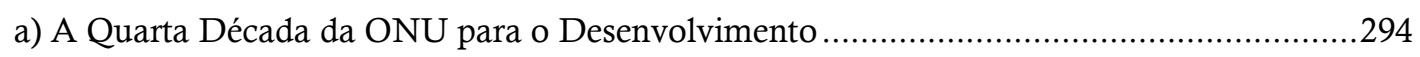

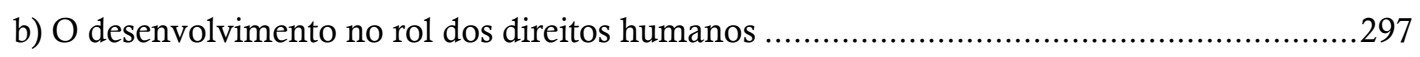

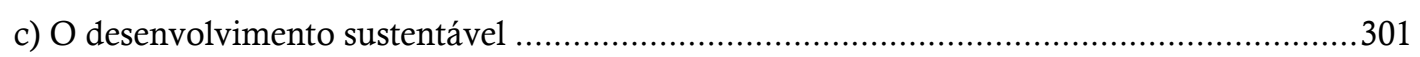

6.2. A ABORDAGEM INTEGRAL DO DESENVOLVIMENTO DO NOVO MILÊNIO......305

a) A Declaração e os Objetivos do Desenvolvimento do Milênio...............................................305

b) A relação entre os Objetivos de Desenvolvimento do Milênio e a Conferência de Monterrey

c) A relação entre os Objetivos de Desenvolvimento do Milênio e a OMC

6.3. O RESSURGIMENTO DA UNCTAD NO INÍCIO DO SÉCULO XXI............................314

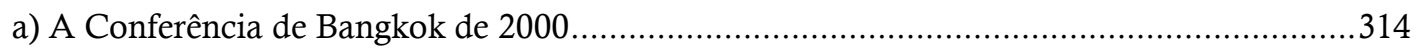

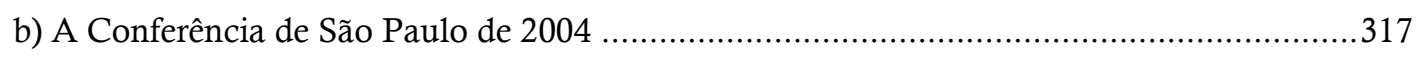

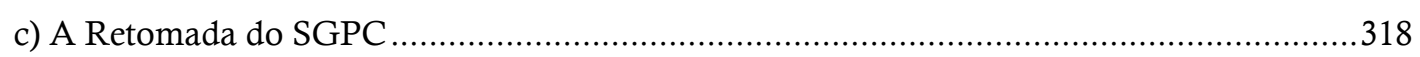

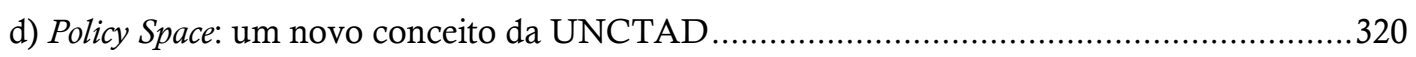

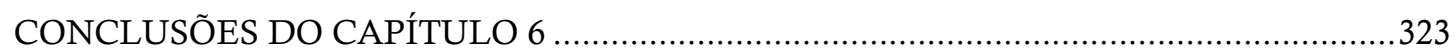

CAPÍTULO 7. O NOVO DESENVOLVIMENTISMO NA ORGANIZAÇÃO MUNDIAL DO COMÉRCIO: OPORTUNIDADES CONTEMPORÂNEAS DE POLICY SPACE ..........326

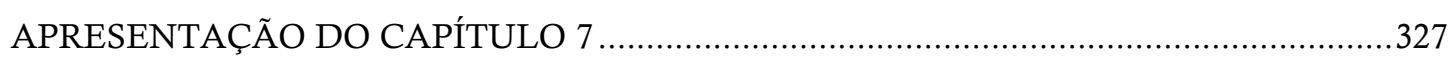

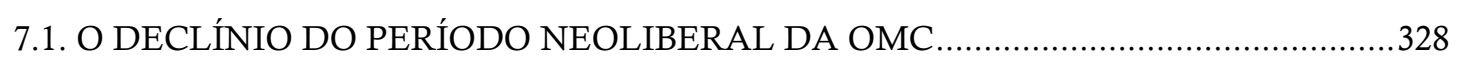

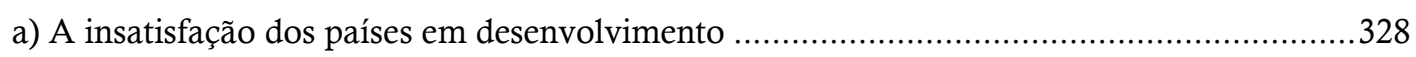

b) As conferências ministeriais durante o período neoliberal da OMC ...................................330 
c) Conclusões sobre o fim do período neoliberal da OMC

7.2. A EMERGÊNCIA DO NOVO DESENVOLVIMENTISMO NA RODADA DOHA ......337

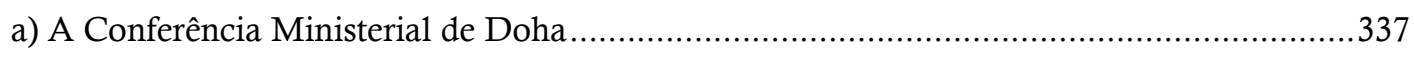

b) Principais avanços das negociações desde Doha até os dias atuais .......................................344

c) Tentativas e propostas de classificação de países em desenvolvimento na Rodada Doha ...350

7.3. FUNDAMENTOS PARA UMA INTERPRETAÇÃO NEODESENVOLVIMENTISTA

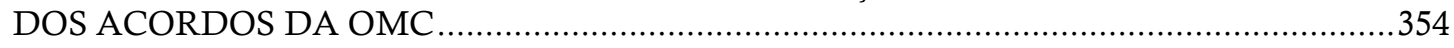

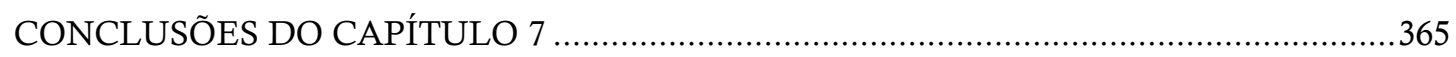

\section{CAPÍTULO 8. O NOVO REGIONALISMO DESENVOLVIMENTISTA DAS ORGANIZAÇÕES DE INTEGRAÇÃO REGIONAL DA AMÉRICA DO SUL ..................368

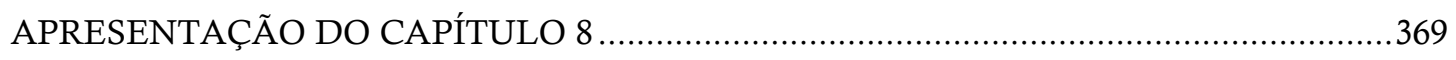

8.1. O RELANÇAMENTO E A RENOVAÇÃO DA INTEGRAÇÃO SUL-AMERICANA ...371

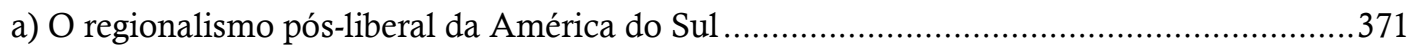

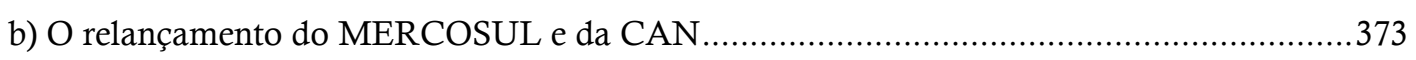

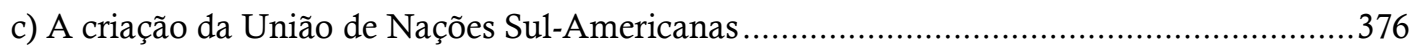

8.2. OS NOVOS VETORES NEODESENVOLVIMENTISTAS DAS ORGANIZAÇÕES DE

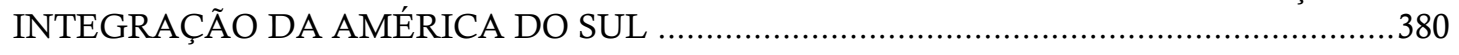

a) Instituições neodesenvolvimentistas específicas da América do Sul ..................................380

b) A infraestrutura como novo vetor da integração sul-americana...........................................386

c) A emergência da inovação enquanto tema da integração sul-americana...............................393

8.3. OS DESAFIOS PARA A CONSOLIDAÇÃO DO NOVO REGIONALISMO

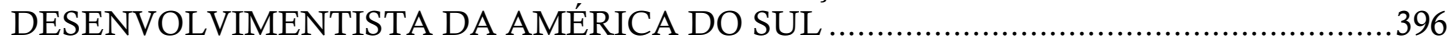

a) UNASUL: a operacionalização de uma organização sul-americana OMC-Extra ...............396

b) ALADI: entre a convergência regional e a abertura global................................................397

c) A consolidação institucional de MERCOSUL e da CAN …............................................400

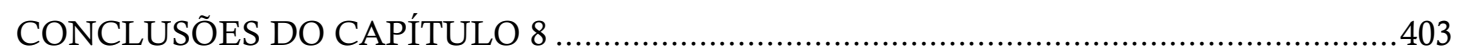

CONCLUSÕES

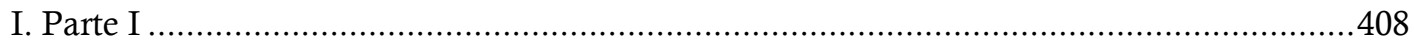

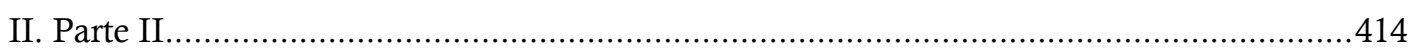

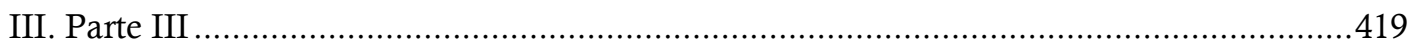

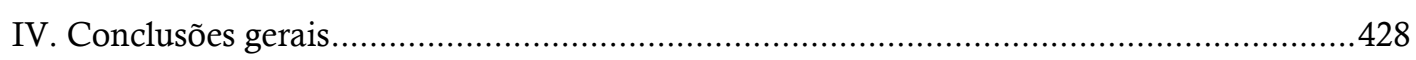

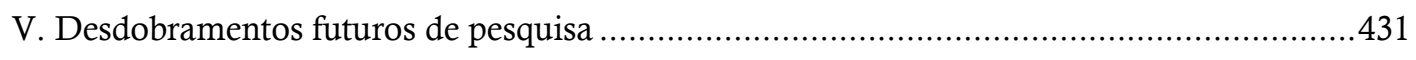

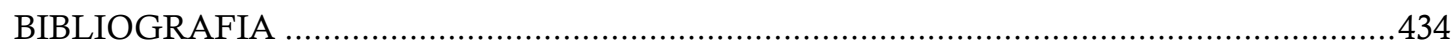




\section{INTRODUÇÃO}

\section{Apresentação do tema da tese}

Há dois enfoques possíveis para conceber a integração regional: o liberal e o estruturalista. Essas diferentes visões e concepções permearam durante longo período as discussões sobre os modelos de integração, com especial intensidade na América do Sul. ${ }^{1}$

O enfoque liberal concebe a integração como um processo que encerra várias medidas destinadas a abolir discriminações existentes entre dois ou mais Estados visando alcançar a ausência de várias formas de discriminação entre as economias nacionais. Para tanto, a integração estaria fundada em um programa escalonado de eliminação de barreiras artificiais ao comércio de bens e aos demais fatores produtivos (capital e trabalho).

A integração econômica, sob este diapasão, atingiria sua plenitude com a simples abolição das barreiras aduaneiras, por incrementar ao máximo os benefícios do sistema de liberdade comercial com o desenvolvimento pleno da concorrência. O processo de integração seria completado com a ampla vigência dos princípios clássicos da economia liberal.

No pós-guerra, o grau de intervenção estatal na vida econômica dos Estados aumentou muito e surgiu, também, a necessidade de certo planejamento estatal para o crescimento econômico acelerado. A introdução de elementos de coordenação e unificação nos processos de integração, próprios do dirigismo e do enfoque estruturalista, confrontava a essência do enfoque puramente liberal.

A integração econômica sob o prisma estruturalista é concebida como um processo que tende a organizar toda a atividade econômica de dois ou mais países não apenas no que tange o seu comércio, ou suas trocas, mas também, no que se

${ }^{1}$ CELLI JUNIOR, Umberto. Teoria Geral da Integração: em busca de um modelo alternativo. In CELLI JUNIOR, Umberto; et al (Org.). Blocos Econômicos e Integração na América Latina, África e Ásia. Curitiba: Juruá, 2008, p. 25-36. 
refere à sua produção, formando um quadro econômico complexo, coerente e equilibrado. A integração estruturalista implicaria a adoção de políticas destinadas a criar uma nova entidade econômica complexa e caracterizada pela solidariedade entre seus membros.

A solidariedade decorre da constatação de que, quanto mais desigualmente desenvolvidos forem os países participantes do processo, mais a integração via mercado tenderá a aumentar as desigualdades, engendrando, consequentemente, novos desequilíbrios e concentrando os frutos desse processo. Daí ser necessário conceber a integração econômica como uma integração das economias, que não se circunscreva aos mecanismos de mercado e que, ao contrário, empregue instrumentos e procedimentos que conduzam a um desenvolvimento autônomo em benefício das populações participantes.

A partir da década de 90, contudo, a consagração e a consolidação do modelo neoliberal de economia de mercado, as quais foram propiciadas pela disseminação das propostas do Consenso de Washington, acabaram por também direcionar o processo de liberalização da economia internacional, fortalecendo o modelo de expansão do mercado via livre comércio, com a consequente erosão dessas diferentes visões da integração econômica e seus objetivos.

Contudo, Umberto Celli Junior argumenta que:

O aumento das desigualdades sociais e das assimetrias entre os países, resultante, em larga medida, de acordos de cooperação e de integração econômica, em âmbito multilateral e regional, forjados no contexto neoliberal da economia, conduz à indagação sobre a necessidade de se "repensar" essa visão ou modelo predominante. ${ }^{2}$

Assim, esse "repensar" talvez pudesse permitir a visualização de um modelo sob o qual a integração não se circunscrevesse exclusivamente às regras de mercado, mas empregasse também instrumentos e procedimentos que conduzissem a um desenvolvimento autônomo e sustentável, com a inclusão de temas e programas que tivessem como beneficiários últimos, as populações abrangidas.

\footnotetext{
${ }^{2}$ CELLI JUNIOR (2008), op. cit., p. 36.
} 
Em qualquer processo de integração, independentemente de seu nível de ambição, faz-se necessário programas de liberalização dos intercâmbios com a coordenação e a harmonização das políticas econômicas nacionais. Além disso, esses programas de liberalização dos intercâmbios devem ser antecedidos ou ao menos, executados em conjunto, com um cuidadoso programa de política industrial de cada um dos países envolvidos.

Ocorre que esse "repensar" propugnado por Umberto Celli Junior demanda a inclusão de uma variável fundamental, não concebida em geral pelos teóricos da integração: a necessidade de compatibilizar tais modelos com o direito internacional, especialmente a partir da entrada em vigor da Organização Mundial do Comércio (OMC) e dos acordos sob seus auspícios.

Fato é que as normas da OMC limitaram, com maior ou menor intensidade, a flexibilidade dos Membros quanto à escolha dos instrumentos que podem ser utilizados na implantação de objetivos de política pública. Quando não limitam expressamente, deixam em aberto essa possibilidade, qual seja, a de restrição do direito dos Membros de fazer políticas públicas (policy space) como muitos dos Membros, sobretudo os desenvolvidos, fizeram no passado. ${ }^{3}$

Ao longo deste estudo, utilizam-se expressões como políticas nacionais, regionais, econômicas, comerciais, industriais, e de desenvolvimento, entre outras, conforme o caso. Todas essas expressões se abrigam no conceito mais abrangente que é o de políticas públicas. Políticas públicas são, portanto, um instrumento de governo dos Estados desenvolvimentistas. ${ }^{4}$

A regulação de novos temas no sistema multilateral de comércio revela uma tendência de "invasividade no campo normativo e decisório das autoridades nacionais e dos ordenamentos jurídicos internos pelas políticas e normas votadas num fórum internacional e externo aos Estados" 5 .

\footnotetext{
${ }^{3}$ CHANG, Ha-Joon Kicking away the ladder: Development Strategy in Historical Perspective. Londres: Anthem Press, 2002.

${ }^{4}$ CELLI JUNIOR, Umberto. Comércio de Serviços na OMC: liberalização, condições e desafios. Curitiba: Juruá, 2009, p. 38.

${ }^{5}$ SOARES, Guido. Curso de direito internacional público. São Paulo: Atlas, 2002. v.1, p. 435.
} 
É fato que as opções de que dispõem os países em desenvolvimento no que se refere à promoção de políticas de desenvolvimento foram reduzidas pelo disposto no regime jurídico da OMC. Muito embora essa questão sobre "espaço regulador" ou espaço para adoção de políticas públicas (policy space) e sua limitação não seja nova, ela continua atual e a suscitar divergências.

$\mathrm{Na}$ ideia de policy space, subjaz a concepção de agir em conformidade com o direito internacional. Exercitar o policy space significar atuar dentro margem de manobra prevista nas regras do sistema multilateral de comércio, que nada mais é do que o direito internacional do comércio.

Policy space sempre foi uma premissa fundamental para a consecução dos objetivos do desenvolvimento dos países da América do Sul. Do ponto de vista integracionista, projetou-se que o desenvolvimento do continente só ocorreria por meio de uma integração endógena, voltada para dentro, industrializando a partir das demandas locais, e não a partir de uma suposta divisão internacional do trabalho.

A rationale latino-americana, gerada principalmente no âmbito da Comissão Econômica para a América Latina (CEPAL) se constituiu numa perspectiva inédita até então para as relações econômicas internacionais, servindo de contraponto ao pensamento hegemônico vigente nas regras das organizações econômicas internacionais, em especial nas regras do Acordo Geral sobre Tarifas e Comércio (GATT).

A perspectiva latino-americana das relações internacionais estabeleceu como premissa que, para que a inserção de um país em desenvolvimento no sistema multilateral de comércio aconteça de forma bem-sucedida, gerando efetivo desenvolvimento e não mero aumento do fluxo comercial, o país em desenvolvimento deve manter margem de manobra para implantação de políticas públicas que orientem a natureza de sua inserção internacional.

Esta contribuição do pensamento latino-americano embasou toda a linha argumentativa da diplomacia do então Terceiro Mundo. Nesse período, a América Latina formulava uma ideologia verdadeiramente regional, engajada, revolucionária, capaz de desvelar a crença cega no liberalismo econômico e 
comercial e resgatar a função regulatória e orientadora dos Estados que ainda lutavam por auto-determinação, soberania e capacidade institucional de promover os direitos humanos, econômicos e sociais de suas populações.

A partir dessa lógica, tornou-se mainstream entre os países em desenvolvimento a opção por manter como setores estratégicos de policy space o fomento à industrialização das suas economias, a fim de superar a natureza agrária e manufatureira da inserção no comércio internacional, e passar a inserir-se por meio de produtos de maior valor agregado. Isto geraria maior número de emprego, maiores salários, maior distribuição de renda, maior arrecadação fiscal, etc. Exemplos simultâneos, porém distintos, são os modelos de industrialização levados adiante pela América Latina, pela China e pelos Tigres Asiáticos.

É no âmbito do GATT que a CEPAL e a sua teoria vai exercer maior influência. Com uma capacidade ímpar de articulação, os países em desenvolvimento institucionalizam a Conferência das Nações Unidas para o Comércio e Desenvolvimento (UNCTAD), uma iniciativa que se propõe a religar as concepções de comércio internacional e desenvolvimento econômico e social, desassociadas quando da institucionalização do sistema multilateral de comércio no pós-guerra. Nessa época, diversos instrumentos desenvolvimentistas são regulamentados no âmbito dos marcos regulatórios, consagrando o direito ao tratamento especial e diferenciado no âmbito do sistema multilateral de comércio.

Alberto do Amaral Junior, ao fazer um balanço sobre os resultados deste movimento desenvolvimentista levado adiante junto às organizações multilaterais, afirma que:

$\mathrm{Na}$ década de 1970, o desenvolvimento foi objeto de intenso debate na Assembleia Geral das Nações Unidas, que culminou, em 1974, com a proposta de estabelecimento de uma Nova Ordem Econômica Internacional. Esta iniciativa, não obstante à sua importância, produz poucos resultados práticos. ${ }^{6}$

Uma das pretensões desta tese é demonstrar que, na realidade, esta iniciativa em prol do desenvolvimento na ONU produziu sim muitos resultados práticos,

\footnotetext{
${ }^{6}$ AMARAL JÚNIOR, Alberto. (Org.). Direito internacional e desenvolvimento. Barueri: Manole,
} 2005. p. vii. 
tanto junto ao sistema multilateral de comércio, quanto nos processos de integração da América do Sul.

Na década de 70, as crises do petróleo levaram o mundo a uma recessão global e fizeram com que os investimentos necessários aos processos de industrialização em marcha nos países em desenvolvimento desacelerassem e levassem estes países a um endividamento perante os países desenvolvidos investidores, bem como às organizações internacionais financiadoras, como o Fundo Monetário Internacional (FMI) e o Banco Mundial (BIRD).

Neste momento, desenvolve-se uma nova rationale das relações econômicas internacionais. A partir do super-endividamento pelo qual passava o mundo na época, o liberalismo econômico ressurge, rebatizado de neoliberalismo, para apontar que um dos grandes culpados do cenário era exatamente o policy space: a ação estatal intervencionista que, atuando contra a lógica do mercado, fomentou empresas e indústrias ineficientes, levando os países em desenvolvimento à falência e os países desenvolvidos a esgotar seus recursos pelas linhas de financiamento destas industrializações.

Entre a década de 60 e a década de 80, o policy space perdeu radicalmente legitimidade internacional. O mainstream intelectual das décadas de 80 e 90 rechaçou esta premissa do policy space, tanto dos países desenvolvidos como dos países em desenvolvimento, entre eles os sul-americanos. O Consenso de Washington partia da premissa inversa, quanto menos policy space, melhor.

Segundo esta lógica, a livre concorrência e a livre competitividade ditariam os melhores fluxos comerciais e os melhores fornecedores de cada mercadoria, seja agrícola, manufaturada ou industrializada. O desenvolvimento decorreria daí, da otimização na alocação dos recursos. É nesse contexto que a OMC é criada como organização internacional orientada para o viés da liberalização do comércio internacional, que ocorrerá mediante a redução das barreiras tarifárias e nãotarifárias, bem como a redução do volume de subsídios concedidos pelos Estados às indústrias nacionais.

Em termos de Estado, diversas mudanças estruturais e institucionais decorrem da entrada em vigor da OMC e das suas regras. De um lado, limitações 
ao uso de cotas, tarifas e medidas não-tarifárias. Por outro lado, os direitos de propriedade intelectual ficaram mais rígidos. Tais mudanças tolheram dos países em desenvolvimento, dentre eles os sul-americanos, os principais instrumentos para implantar políticas de desenvolvimento, que foram amplamente utilizados pelos atuais países industrializados ao longo dos séculos XIX e XX. O grau de discricionariedade e liberdade deixado para as políticas públicas de intervenção na economia tornou-se questão fundamental.

Neste sentido, Fernando Aguillar afirma que:

As políticas de liberalização alfandegária deixaram de ser uma opção nacional para adquirirem estatuto de verdadeiro dever por parte dos países signatários de acordos como o GATT. Firmado para vigorar a partir de 1948, o GATT teve como missão reduzir ou eliminar as restrições ao comércio mundial. Mas ganhou impulso principalmente após o ressurgimento das políticas liberais na economia, que culminou com a criação, em 1995, da Organização Mundial do Comércio (OMC), encarregada de implementar as políticas decorrentes do GATT. ${ }^{7}$

No alvorecer do século XXI, a retomada de consciência em torno da necessidade de policy space ressurge tanto no contexto global como no contexto latino-americano. Essa reorientação em torno do policy space se intensifica ainda mais depois da crise financeira mundial de 2008. Tanto países desenvolvidos como países em desenvolvimento retomam políticas intervencionistas. Isso é encorajado pelo BIRD e FMI, mas segue contestado pela OMC, por receio de ondas protecionistas que pudessem fazer retroceder o processo de liberalização do comércio mundial.

Se, de um lado, as opções de que dispõem os países em desenvolvimento no que se refere à promoção de políticas de desenvolvimento foram reduzidas pelo disposto no regime jurídico da $\mathrm{OMC}$, de outro, também é certo que, tendo em vista o próprio mandato ou os objetivos da organização, existe a possibilidade de reafirmação ou manutenção da capacidade dos membros de implantar políticas de desenvolvimento dentro desse mesmo regime ou sistema. ${ }^{8}$

A recalibração do sistema e a consequente reafirmação do espaço para a implantação de políticas públicas pelos Membros encontram respaldo naquilo que

\footnotetext{
7 AGUILLAR, Fernando Herren. Direito Econômico: do direito nacional ao direito supranacional. $2^{\mathrm{a}}$ Ed. São Paulo: Atlas, 2009. p. 62.

${ }^{8}$ CELLI JUNIOR (2009), op. cit., p. 146.
} 
Lafer, com base em Grócio, descreve como "potencial de socialibilidade e solidariedade na esfera internacional". 9

A recalibração das prioridades, dos valores e dos modos de funcionamento do sistema multilateral implicaria a efetiva inclusão de temas relacionados a questões sociais e de desenvolvimento, que não podem ser dissociadas do objetivo de liberalização do comércio internacional. ${ }^{10}$

Alberto do Amaral Junior afirma que "no mundo plural, do limiar do século $\mathrm{XXI}$, é complexa a tarefa de obter acordos sobre valores essenciais que devem orientar a vida internacional". ${ }^{11}$

Não obstante a dita complexidade, a presente tese pretende sustentar que, ao longo da primeira década do século XXI, foi alcançado um relativo consenso em torno da questão do desenvolvimento. Isto ocorreu no âmbito da ONU, por meio da Declaração do Milênio, que estabeleceu os Objetivos do Desenvolvimento do Milênio, e no âmbito da OMC, por meio do lançamento da Rodada Doha, com a Agenda do Desenvolvimento.

Sobre o direito internacional do desenvolvimento, Deisy Ventura e Ricardo Seitenfus alertam que:

As disparidades socioeconômicas entre o Norte e o Sul se aprofundam e parecem tornar-se perenes. $O$ atual enfraquecimento do direito internacional do desenvolvimento, é mau presságio. Nessas condições, dois desafios essenciais apresentam-se ao direito internacional no atual século: por um lado, elaborar um marco jurídico de caráter supranacional para enquadrar a globalização e, por outro, construir uma solidariedade ativa e efetiva entre os Estados e os seus povos, sem a qual o direito internacional continuará sendo percebido por muitos como o caudatório de um mundo injusto, e não o instrumento transformador desta inaceitável realidade. ${ }^{12}$

Em resposta a este alerta, esta tese pretende demonstrar que, de um lado, o direito internacional do desenvolvimento não está, de fato, enfraquecendo, e por

\footnotetext{
${ }^{9}$ LAFER, Celso. A OMC e a regulamentação do comércio internacional: uma visão brasileira. Porto Alegre: Livraria do Advogado, 1998, p. 28, apud CELLI JUNIOR (2009), op. cit., p. 146.

${ }^{10}$ CELLI JUNIOR (2009), op. cit., p. 138.

${ }^{11}$ AMARAL JUNIOR, Alberto. Introdução ao Direito Internacional Público. São Paulo: Atlas, 2008. p. 112.

${ }^{12}$ SEITENFUS, Ricardo; VENTURA, Deisy. Direito Internacional Público. $4^{\text {a }}$ Ed. Porto Alegre: Livraria do Advogado, 2006. p. 236.
} 
outro, que os desafios estão paulatinamente sendo enfrentados. Nesse sentido, a presente tese sustenta que o desenvolvimento está dentre as finalidades primordiais que atualmente persegue o direito internacional.

Nesse sentido, urge que a comunidade acadêmica reconheça a oportunidade histórica da Rodada Doha e proponha-se a um "repensar" sobre a função do sistema multilateral de comércio diante do atual cenário de (sub)desenvolvimento dos Estados do Sul. Como consolidar um marco regulatório no âmbito do sistema multilateral de comércio que viabilize políticas públicas de desenvolvimento?

\section{Objetivos da pesquisa}

Com base neste contexto a presente tese se propõe a responder ao seguinte questionamento:

- É correto afirmar que o regionalismo desenvolvimentista sul-americano, implantado ao longo do século XX, e o novo regionalismo desenvolvimentista, implantado ao longo da primeira década do século XXI, são compatíveis com as regras do sistema multilateral de comércio?

- Em outras palavras, as organizações de integração regional da América do Sul têm balizado as suas políticas desenvolvimentistas no policy space decorrente das prerrogativas jurídicas para o desenvolvimento do sistema multilateral de comércio?

Para tratar as referidas questões, parte-se da premissa de que os países da América do Sul sempre fizeram uso das prerrogativas jurídicas para o desenvolvimento, desde que tais surgiram no sistema multilateral de comércio, e possibilitaram a implantação de políticas no plano nacional e regional. Parte-se igualmente da premissa de que as iniciativas constituídas ao longo do século XX condicionam as atuais e futuras políticas públicas de integração e desenvolvimento que por ventura venham a implantar os países da América do Sul. 
Em razão das organizações internacionais de integração da América do Sul (ALADI, CAN e MERCOSUL) terem sido constituídas com base nas prerrogativas jurídicas para o desenvolvimento do sistema multilateral de comércio, as mesmas tem o direito de formular políticas pró-desenvolvimentistas. Além disso, como será demonstrado ao longo da presente tese, as regras do sistema multilateral de comércio proporcionam mais policy space para as iniciativas de integração regional do que para os países individualmente considerados.

A presente tese trabalha com a hipótese de que, desde o seu surgimento, o sistema multilateral de comércio, por meio dos seus acordos, tem se revelado como uma condicionante estrutural, em nível internacional, aos modelos de desenvolvimento da América do Sul. No entanto, ao mesmo tempo em que impôs restrições e limites às políticas de desenvolvimento na região, os acordos garantiram algum grau de policy space aos países que desejam implantar políticas públicas de desenvolvimento.

A América do Sul usufruiu do policy space existente no âmbito do GATT durante o período 1947-1994. Nesse sentido, implantou o Modelo ISI, criou organizações de integração regional (ALALC, ALADI, MERCOSUL, CAN), estabeleceu relações comerciais preferenciais com EUA e CE, além de criar vínculos comerciais com os demais países em desenvolvimento.

A partir de 1995, houve uma radical redução de policy space do ponto de vista ideológico, que se refletiu nas negociações da Rodada Uruguai e no resultado das mesmas, os acordos da OMC. Tais acordos promoveram um encolhimento do policy space dos países em desenvolvimento no que se refere à utilização de diversas práticas desenvolvimentistas ligadas ao comércio.

Ocorre que, conforme se depreende dos debates da Rodada de Doha, há um incômodo consenso entre os países em desenvolvimento de que os privilégios e as exceções conquistadas ao longo da vigência do GATT-47 e da Rodada Uruguai, nos novos acordos da OMC, estão esgotados e pouco beneficiam os países em desenvolvimento nas suas políticas nacionais e regionais. 
No entanto, ao contrário do que reza o senso comum da literatura que trata das questões do desenvolvimento no âmbito da $\mathrm{OMC}$, existe sim, policy space, à disposição dos países em desenvolvimento dentro do atual marco regulatório da OMC, especialmente quando se interpreta os acordos para além do tratamento especial $e$ diferenciado. Significa dizer que os países em desenvolvimento que desejam implantar políticas de desenvolvimento, em especial aquelas fundadas em parâmetros de inovação tecnológica, devem, além de beneficiar-se das regras específicas para os países em desenvolvimento, buscar também as brechas jurídicas existentes para os membros em geral, que são as brechas existentes para os países industrializados.

A complementaridade entre o policy space existente para os membros em geral e o policy space disponível exclusivamente para os países em desenvolvimento pode proporcionar uma equação jurídica favorável para os países da América do Sul e suas respectivas organizações de integração regional implantarem políticas de desenvolvimento.

A fim de verificar estas premissas optou-se por uma perspectiva histórica. Fernando Aguillar, ao justificar a necessidade de assimilar o direito à história, por meio do que denomina de historicismo crítico, sustenta que:

A partir da assimilação do historicismo crítico, percebe-se que o direito não é estático, como percebem os positivistas e dogmáticos, mas é dinâmico, fruto do seu tempo e das ideologias reinantes à época de sua produção. ${ }^{13}$

Ao aplicar este olhar historicista sobre o direito econômico, Fernando Aguillar afirma que:

Pudemos perceber, pela primeira vez com apoio na história, que o papel do Estado oscila de maneira pendular, ora com maior intervenção, ora com retração estatal. E que a primeira oscilação desse pêndulo levou duzentos anos para se concluir, chegando ao ápice da intervenção estatal. A segunda oscilação levou vinte anos para tomar rumo de volta a um cenário mais

\footnotetext{
${ }^{13}$ AGUILlAR, Fernando Herren. Metodologia da Ciência do Direito. $4^{\mathrm{a}}$ Ed. São Paulo: Atlas,
} 2009. 
liberal na economia. E agora vemos novamente o pêndulo sinalizar que está voltando para um quadro de maior ingerência estatal na economia. ${ }^{14}$

A partir desta noção de movimentos pendulares da história, percebe-se estes movimentos tanto no âmbito do sistema multilateral de comércio quanto nas políticas de desenvolvimento das organizações de integração regional da América do Sul. É a partir desses movimentos cíclicos que surge a proposta do plano de tese, para que, em ambos os níveis, multilateral e regional, seja constatada a regulação e implantação de práticas, ora mais liberais, ora mais desenvolvimentistas.

Alberto do Amaral Junior descreve o desafio atual do investigador voltado aos temas do direito internacional:

\begin{abstract}
À semelhança de uma rede na qual os fios são cuidadosamente entrelaçados, a construção da coerência requer trabalho paciente, sob impulso do caso concreto, para identificar a convergência entre normas que pertencem a subsistemas diferentes.
\end{abstract}

Nesse sentido, a presente tese procura identificar a convergência entre as normas do direito internacional geral, do direito internacional do comércio e do direito da integração sul-americana, levando como valor-fonte de todos os valores ${ }^{15}$, o direito internacional do desenvolvimento.

Imbuído destes prismas historicista e pragmático, propugnados por Fernando Aguillar e Alberto do Amaral Junior, e visando um repensar dos modelos de regionalismo da América do Sul, como sugerido por Umberto Celli Junior, é que se lança a presente tese.

\title{
III. Estrutura do trabalho
}

\footnotetext{
14 AGUILlaR, Fernando Herren. Direito Econômico: do direito nacional ao direito supranacional. $2^{\text {a }}$ Ed. São Paulo: Atlas, 2009. p. xxii.

15 REALE, Miguel. Fontes e modelos do direito: para um novo paradigma hermenêutico. São Paulo: Saraiva, 1999. Apud. AMARAL (2011). op. cit., p. 297.
} 
A tese foi estruturada em três partes: A Parte I, referente ao período de vigência do GATT-47; a Parte II, que corresponde ao período de criação da OMC e da entrada em vigor dos novos acordos do sistema multilateral de comércio; e a Parte III, que atine ao período a partir do lançamento da Rodada Doha no âmbito da OMC até os dias atuais.

A Parte I abrange o período entre o pós-2 ${ }^{\mathrm{a}}$ Guerra Mundial e o Fim da Guerra Fria. Como será demonstrando ao longo desta parte da tese, tal período é fundamental para a compreensão da história do desenvolvimento, enquanto princípio de direito internacional, enquanto prerrogativa do sistema multilateral de comércio e enquanto fundamento jurídico das políticas públicas dos países da América do Sul.

Ao longo deste período, o Acordo Geral sobre Tarifas e Comércio (GATT) foi o marco regulatório fundamental que balizou juridicamente as políticas comerciais da comunidade internacional. Sob os auspícios do GATT, a América do Sul se lançou no projeto de constituição de diversas organizações internacionais de integração econômica regional. Paralelamente, no cenário internacional, emerge o Terceiro Mundo, que insere na agenda internacional a questão do desenvolvimento, visando à transformação do direito internacional.

Como esta transformação se deu nas regras do sistema multilateral de comércio e consequentemente, influenciou as organizações de integração regional da América do Sul? É o que se buscará responder na Parte I.

A Parte II foca o período entre o Consenso de Washington, que se consolidou na esfera comercial por meio da Rodada Uruguai e a criação da OMC, e a crise do neoliberalismo, cujo ápice é o fracasso da Conferência de Seattle da OMC. Durante este período, o neoliberalismo foi disseminado e implantado praticamente em escala global, por meio da criação da OMC. Houve um consenso global, no qual se incluiu a América do Sul, em torno de modelos de desenvolvimento fundados no neoliberalismo. 
A questão motivada da Parte II é a seguinte: de que maneira a entrada em vigor da OMC e os seus respectivos acordos internacionais repercutiu no policy space das organizações de integração regional da América do Sul?

Por fim, a Parte III abarca o período que se inicia com a crise do neoliberalismo global e o ressurgimento da agenda do desenvolvimento nas relações internacionais. Esta nova agenda desenvolvimentista tem origem ainda na década de 1990, período no qual o desenvolvimento, de um lado, passou a fazer parte do rol dos direitos humanos e, por outro, foi associado à preservação do meio ambiente. Na virada do século, tanto a ONU, por meio da Declaração dos Objetivos de Desenvolvimento do Milênio, quanto a OMC, por meio do lançamento da Rodada Doha, consagram em definitivo o desenvolvimento enquanto fundamento jurídico das relações internacionais contemporâneas.

Nesse sentido, a Parte III busca compreender em que medida este ressurgimento da agenda desenvolvimentista influenciou as organizações de integração regional da América do Sul.

\section{Questões metodológicas da pesquisa}

A presente tese fundou-se nos procedimentos de revisão bibliográfica e documental.

A revisão bibliográfica procurou esgotar a literatura nacional a respeito do tema, ao mesmo tempo em que analisou uma vasta gama de autores estrangeiros que foram incorporados ao longo do texto. Toda a citação de autores estrangeiros foi vertida livremente para o português pelo autor.

Destaca-se que a pesquisa e a redação, tanto sobre o direito internacional do desenvolvimento, quanto sobre a OMC e sobre a Rodada Doha, só foi possível em razão da bibliografia estrangeira, obtida durante as investigações do estágio 
doutoral realizado junto à Cátedra Internacional OMC/Integração Regional da Universidade de Barcelona

Já a análise documental esteve centrada nas fontes primárias da tese, quais sejam: os tratados constitutivos das organizações internacionais multilaterais, especialmente a ONU e a OMC; os tratados constitutivos das organizações de integração regional da América do Sul; a normativa derivada dos órgãos tanto das organizações multilaterais quanto regionais.

Ao longo da análise documental das fontes apresentadas acima, realizou-se uma tentativa de se encontrar os fins sociais da normativa, de identificar um viés desenvolvimentista nos tratados e acordos internacionais, e também de compreender as organizações internacionais da América do Sul por meio de suas funções e seus objetivos, estabelecidos em seus tratados constitutivos, originários e derivados.

À título de delimitação da tese, cabem algumas ressalvas. Muito embora a tese faça constantes remissões a temas de fundo político-econômico, a presente tese se restringirá a analisar aspectos de direito internacional e de direito da integração. Sob este escopo, será analisado o direito produzido no âmbito das organizações internacionais de integração regional da América do Sul - em contraponto ou em consonância - com o direito internacional do comércio e o direito internacional do desenvolvimento.

Outro ponto de delimitação foi a opção de analisar exclusivamente as iniciativas de desenvolvimento de cunho regional, em detrimento das iniciativas de âmbito nacional, muito embora a investigação desse exercício das prerrogativas jurídicas do direito internacional do comércio no plano nacional seja um terreno extremamente fértil para posteriores trabalhos, especialmente para pesquisa de direito e desenvolvimento comparado.

Resta aclarar que para fins desta tese, optou-se por estudar apenas as organizações de integração regional cuja área de abrangência seja exclusivamente a América do Sul, quais sejam, ALALC, ALADI, MERCOSUL, CAN e UNASUL. A América do Sul compreende Brasil, Argentina, Uruguai, Paraguai, Venezuela, 
Chile, Bolívia, Colômbia, Peru e Equador. São estes os Estados que participam das organizações de integração regional, objeto de análise nesta tese. A única ressalva é o México, que fez parte da ALALC e ainda formalmente faz parte da ALADI.

Não foi pretensão desta tese analisar as ordens jurídicas de cada país da América do Sul. Nesta tese, a tarefa de constituir tal base de dados foi iniciada primeiramente no âmbito do direito das organizações de integração regional, ao avaliar e analisar as práticas geradas no âmbito de cada uma das iniciativas de integração regional.

Por fim, cabe apontar as pretensões de ineditismo desta tese.

Na Parte I desta tese, o ineditismo se constata no fato de que não existe produção acadêmica aprofundada na literatura brasileira sobre a participação dos países em desenvolvimento, seja na história do direito internacional, que resultou no direito internacional do desenvolvimento, seja em sua relação com o sistema multilateral de comércio, seja na relação entre ambas estas ordens jurídicas internacionais e a integração sul-americana.

$\mathrm{Na}$ Parte II, o ineditismo está centrado na realização de um estudo comparado entre as formas pelas quais as organizações de integração regional e sub-regional da América do Sul internalizaram os tratados da OMC. A análise comparada sobre como cada uma utilizou-se do policy space disponível no sistema multilateral de comércio é inédita.

O ineditismo presente na Parte III se apresenta pela proposição da ideia do renascimento do direito internacional do desenvolvimento na primeira década do século XXI, bem como a sua influência na formação de elementos desenvolvimentistas junto à OMC. Da mesma forma, há ineditismo no mapeamento das iniciativas neodesenvolvimentistas contemporâneas das organizações de integração regional da América do Sul.

Por fim, do ponto de vista geral, há um último elemento de ineditismo, que é tentar perceber as organizações de integração regional enquanto sujeitos de direito internacional capazes de exercitar policy space, por serem organizações 
internacionais com competência para conduzir os processos de integração notificados ao sistema multilateral de comércio. Nesse sentido, o fato da presente tese não analisar o policy space em nível nacional, mas sim o policy space regional, a torna inédita, quiçá, inclusive no contexto da literatura internacional. 
PARTE I. O SURGIMENTO DO DIREITO INTERNACIONAL DO DESENVOLVIMENTO NO SISTEMA MULTILATERAL DE COMÉRCIO E SUA REPERCUSSÃO NA INTEGRAÇÃO SULAMERICANA DO SÉCULO XX 


\section{APRESENTAÇÃO DA PARTE I}

A Parte I da tese analisa o processo de consolidação do desenvolvimento, enquanto fundamento jurídico, em três diferentes âmbitos: no direito internacional, no sistema multilateral de comércio, e na integração sul-americana. O objetivo desta Parte da tese é demonstrar que, na medida em que o desenvolvimento foi se afirmando enquanto princípio de direito internacional (capítulo 1), isto reverberou nas regras do sistema multilateral de comércio, com o surgimento de prerrogativas jurídicas à disposição dos países em desenvolvimento (capítulo 2). Com a entrada em vigor destas prerrogativas jurídicas no sistema multilateral de comércio, os países da América do Sul passaram a implantar políticas de integração e desenvolvimento compatíveis com as novas prerrogativas desenvolvimentistas do GATT (capítulo 3).

A Parte I se faz necessária, pois, apesar de haver extensa e profunda literatura estrangeira e nacional a respeito de cada uma das três dimensões em separado, a literatura estrangeira é escassa, e a literatura nacional ausente, de uma análise crítica acerca da influência histórica e da compatibilidade, tanto do direito internacional do desenvolvimento, quanto das regras do sistema multilateral de comércio do Acordo Geral sobre Comércio e Tarifas (GATT) nos processos de integração da América do Sul.

Compreender que a América do Sul vem constituindo historicamente os seus processos de integração amparada nas regras do sistema multilateral de comércio, e, de acordo com as tendências normativas do desenvolvimento no direito internacional, é premissa fundamental. Somente sob este contexto será possível analisar, nas Partes II e III da tese, a atualidade dos desafios apresentados aos processos de integração sul-americanos que, sob a égide do novo desenvolvimentismo, necessitam renovar as políticas integracionistas, em concordância com as atuais regras da Organização Mundial do Comércio. 


\title{
CAPÍTULO 1. A EMERGÊNCIA DO DESENVOLVIMENTO ENQUANTO FUNDAMENTO JURÍDICO DAS RELAÇÕES INTERNACIONAIS
}

\begin{abstract}
Os países do Terceiro Mundo devem levar em conta que este itinerário ambicioso e obstinado se perderá provavelmente umas mil vezes antes de desembocar em seu objetivo; por isso, devem estar convencidos de que, em um mundo abissalmente dialético, tudo se está criando, se está por fazer e desfazer, em um vasto e prodigioso combate contra a desigualdade.
\end{abstract}

Mohamed Bedjaoui, Pour un nouvel ordre économique international, 1978 


\section{APRESENTAÇÃO DO CAPÍTULO 1}

O capítulo 1 analisa o processo de surgimento do fundamento jurídico do desenvolvimento nas relações internacionais durante a segunda metade do século $\mathrm{XX}$, com a emergência de um corpo normativo voltado a regular as relações entre países desenvolvidos (PD) e países em desenvolvimento (PED), ao qual se convencionou denominar direito internacional do desenvolvimento (DID). Para tanto, este capítulo está subdividido em quatro momentos.

No subcapítulo 1.1, será analisado o contexto jurídico e político no qual se encontravam as relações internacionais ao final da segunda guerra mundial, a fim de avaliar as condicionantes e as premissas em que estavam inseridos os países em desenvolvimento à época.

No subcapítulo 1.2, faz-se necessário apresentar o processo de construção, aprofundamento e ampliação do sistema institucional da Organização das Nações Unidas (ONU) em prol do desenvolvimento, no seio do qual se desenvolveu a articulação dos países em desenvolvimento a fim de tentar modificar as premissas jurídicas das relações internacionais e passar a consagrar direitos diferenciados em favor dos países em desenvolvimento.

No subcapítulo 1.3, serão analisados brevemente os programas e planos da ONU para o desenvolvimento, lançados no início de cada década, desde 1960, bem como as principais resoluções que constituíram o conjunto normativo originário que conformam o DID.

Por fim, no subcapítulo 1.4, será analisado o conjunto normativo do DID, identificando aspectos da sua natureza jurídica, alcance, eficácia e limites, a fim de efetuar um balanço das primeiras décadas do DID. 


\subsection{O CONTEXTO JURÍDICO DA DESIGUALDADE ENTRE AS NAÇÕES DO PÓS-GUERRA}

\section{a) As premissas clássicas do direito internacional ao final da Segunda Guerra Mundial}

Desde o período das grandes navegações, as potências da navegação do século XV e XVI - Portugal, Espanha, Holanda, Inglaterra e França - expandiram seus domínios territoriais, populacionais e de matérias-primas, com o respaldo jurídico do direito internacional da época. Nesse sentido, o direito internacional era constituído de forma a consolidar juridicamente toda e qualquer conquista de uma nação sobre outra. ${ }^{16}$

Destas potências, aquelas que estavam ligadas à Igreja Católica possuíam igualmente mandato divino para tais conquistas, por meio das bulas papais, instrumentos jurídicos que outorgavam direitos sobre os territórios e povos descobertos, garantindo uma espécie de legitimação divina da colonização. ${ }^{17}$

Diversos teóricos do direito internacional da época, considerados fundadores do direito internacional enquanto ciência autônoma, dedicaram-se a construir embasamentos jusfilosóficos para os processos de conquista, colonização e exploração dos territórios dominados ao longo destes séculos, nas Américas, na África, na Ásia e na Oceania. ${ }^{18}$ Nesse sentido, afirma-se que o direito voltado a regular os descobrimentos ultramarinhos dos séculos XV e XVI configurava um verdadeiro direito internacional de apropriação. ${ }^{19}$

Após a Paz de Vestefália, o direito internacional passa a fundar-se na noção do Estado soberano, detentor absoluto da personalidade jurídica internacional e, consequentemente, único detentor de direitos e obrigações no plano das relações internacionais.

\footnotetext{
${ }^{16}$ ADDA, Jacques. As origens da globalização da economia. Barueri: Manole, 2004, p. 45.

${ }^{17}$ Para acessar as bulas papais, vide SEITENFUS, Ricardo. Legislação Internacional. Barueri: Manole, 2004. pp. 1898-1904.

${ }^{18}$ Destacam-se Francisco de Vitoria, Os índios e o direito da guerra, Hugo Grocio, Direito da Guerra e da Paz, Emer de Vattel, $\mathbf{O}$ direito das gentes.

19 BEDJAOUI, Mohammed. Hacia un nuevo orden económico internacional. Salamanca: Ségueme, 1979, p. 11.
} 
Se, por um lado, o surgimento da figura do Estado soberano traz segurança jurídica para as potências da época, por outro, relega os povos sem soberania a serem passíveis de conquista e apropriação pois, a partir do momento em que tais povos eram subjugados à condição de colônia de um Estado soberano, tornavam-se extensão territorial da metrópole, perdendo sua identidade política, cultural e econômica.

Nessa época, o direito internacional clássico era caracterizado por servir aos então "países civilizados", leia-se, a sociedade de Estados da Europa, limitada a um número restrito de Estados, que deveriam praticar em seu seio o respeito ao outro, por meio de um postulado fundamental, o da igualdade soberana dos seus Membros, que constituiria um dos princípios de base do direito internacional. Disso resulta notadamente que nenhum Estado poderá interferir nas competências de outro Estado, o que leva ao princípio da não ingerência em assuntos internos e também ao princípio de imunidade jurisdicional dos Estados estrangeiros. ${ }^{20}$

Maurice Flory apresenta a ideia de que a igualdade entre os Estados parece ter duas fontes principais: uma político-filosófica, que vem da escola naturalista, que parte da analogia entre o Estado e a pessoa humana, inclinando-se sobre o antigo regime, em que o Estado ainda patrimonial se encarna no príncipe; nesse caso, a igualdade é considerada como uma situação natural do homem, e por extensão, da nação. A outra fonte, jurídica, é a soberania. A igualdade aparece aqui como uma consequência lógica da soberania estatal e adquire, desse fato, a mesma força que o princípio da soberania. $^{21}$

No entanto, qualquer que seja a vestimenta filosófica aplicada à ideia de uma igualdade teórica entre os Estados, a verdadeira justificativa foi, em realidade, mais concreta e pragmática. A igualdade formal entre Estados era o postulado necessário para a coexistência dos Estados soberanos em um contexto da sociedade internacional do século XIX. Na verdade, o postulado teve - e segue tendo - a sua utilidade prática. É por isso que ele continua a ser invocado e a desempenhar um papel importante na sociedade internacional atual.

\footnotetext{
${ }^{20}$ FLORY, Maurice. Droit international du développment. Paris: Presses Universitaires de France, 1977, p. 18

${ }^{21}$ FLORY, op. cit., p. 16.
} 
Já nos séculos XVIII e XIX, o invento da máquina a vapor e a revolução industrial engendraram um sistema de relações econômicas e políticas internacionais, que consolidou um direito colonial de confisco, fundado, de um lado, na supremacia da Europa, e de outro, na subjugação dos povos de ultramar, que foram apagados da sua existência internacional e incorporados ao sistema colonial, com o intuito principal de servir de reserva de matéria-prima e de destino para produtos manufaturados. ${ }^{22}$

A título de ilustração, Vladimir Lênin apresenta números que retratam o estágio da colonização ao final do século XIX. Nesta época, os continentes estavam assim colonizados: África: 90\%, Polinésia: 99\%, Ásia: 56\%, Oceania: 100\% e Américas: $27 \%$. Em números, as Potências possuíam as seguintes porções de território e população do globo: ${ }^{23}$

Tabela 1 - Porção de território e população sob domínio colonial

\begin{tabular}{|c|c|c|}
\hline Grã-Bretanha & $33,8 \mathrm{mi} \mathrm{km}^{2}$ & 440 mi habitantes \\
\hline Rússia & $22,8 \mathrm{mi} \mathrm{km}^{2}$ & 170 mi habitantes \\
\hline França & $11,1 \mathrm{mi} \mathrm{km}{ }^{2}$ & 95 mi habitantes \\
\hline Alemanha & $3,4 \mathrm{mi} \mathrm{km}{ }^{2}$ & 72 mi habitantes \\
\hline Estados Unidos & $9,7 \mathrm{mi} \mathrm{km}^{2}$ & 106 mi habitantes \\
\hline Total do globo & $133 \mathrm{mi} \mathrm{km}^{2}$ & 1.650 mi habitantes \\
\hline
\end{tabular}

Este cenário oligárquico das relações internacionais começa a mudar ao final da $1^{a}$ guerra mundial, com o fim dos impérios europeus, e se consolida ao final da $2^{\mathrm{a}}$ guerra mundial. As duas grandes guerras do século XX foram golpes profundos no poder das potências europeias. Com o início da Guerra Fria, o poder global deslocou-se para os Estados Unidos e a União Soviética. A Grã-Bretanha e a França se tornariam potências de segunda classe. A Alemanha, derrotada e

\footnotetext{
${ }^{22}$ BEDJAOUI, op cit., p. 11.

${ }^{23}$ ULYANOV, Vladimir Ilyich. O imperialismo: fase superior do capitalismo. $4^{\mathrm{a}}$ ed. São Paulo: Global, 1987, p. 79.
} 
dividida, foi excluída do clube das grandes potências. Os demais Estados da Europa perderiam influencia mundial. ${ }^{24}$

Paralelamente, nas três primeiras décadas do pós-guerra, cerca de 100 novos países independentes ingressaram na ONU, atestando a mundialização do sistema internacional. Para estes novos Estados, a origem da sua situação atual podia ser encontrada na época do colonialismo, que foi desfrutada pelas potências coloniais para criar em seus domínios estruturas produtivas totalmente dependentes das necessidades econômicas das metrópoles. A independência politica destes territórios, que se iniciou ao longo do século XIX e intensificou-se na metade do século XX, não significou independência econômica.

O Estado soberano, invenção europeia do século XVII, tornou-se o modelo mundial de organização política destas novas sociedades. ${ }^{25}$

Estes novos Estados, embora politicamente independentes, mantiveram um alto grau de dependência econômica, dentro de um sistema de relações econômicas internacionais altamente desigual e desfavorável, que restringia seriamente a capacidade de desenvolvimento econômico e social dos novos Estados. Isto é, a igualdade jurídica alcançada quando tais colônias se tornaram Estados soberanos revelou-se mera igualdade formal, padecendo de um mínimo de igualdade material se comparadas aos Estados que eram os antigos colonizadores.

Além disso, esta nova comunidade de Estados passa a arguir que as regras tradicionais de direito internacional criadas ao final da segunda guerra mundial sem a participação destes novos sujeitos de direito internacional, serviram apenas para manter, e inclusive agravar, o nível de dependência econômica dos países em desenvolvimento. Tais regras os teriam impedido de exercer controle sobre os seus próprios recursos naturais, de fazer ingressar seus produtos nos mercados dos países ricos, de regular investimentos em território nacional, de ter acesso a tecnologia, e de participar efetivamente na tomada de decisões nas organizações internacionais, especialmente as de natureza financeira.

\footnotetext{
${ }^{24}$ HOBSBAWN. A era dos extremos: o breve século XX: 1914-1991. São Paulo: Companhia das Letras, 1995, p. 337.

${ }^{25}$ CREVELD, Martin Von. Ascensão e declínio do Estado. Martins Fontes, São Paulo, 2004, p. 377.
} 
Ora, se a igualdade apareceria como uma consequência da soberania, uma lógica mais rigorosa dessa mesma soberania conduziria o direito internacional inevitavelmente a reconhecer a noção de desigualdade, ou no mínimo, levá-la em consideração. Estava claro que, daquele período em diante, as ex-colônias não se contentariam com a simples condição de Estado soberano, centrado na ideia da igualdade jurídica. Seria necessário criar regras que possibilitassem reduzir a desigualdade econômica. Ir além da soberania política e alcançar uma soberania econômica.

\section{b) A descolonização e o reconhecimento da desigualdade econômica entre os Estados}

O processo de descolonização dos países e povos coloniais introduz uma série de novos elementos nas relações internacionais e no direito internacional. Dentre eles, talvez um dos mais relevantes seja o de haver posto em manifesto, no plano das relações internacionais, a existência de países subdesenvolvidos; categoria na qual se inclui a grande maioria dos antigos povos colonizados, agora Estados independentes.

A Guerra Fria serviu como pano de fundo para o processo de descolonização, que dissolveu os impérios coloniais erguidos entre os séculos XVI e XIX. Esses impérios refletiam o poder e a influência das antigas potências mercantis (Holanda, Espanha e Portugal), ou principalmente, das potências industriais do século XIX (Grã-Bretanha, França, Alemanha, Itália e Bélgica). O deslocamento dos eixos mundiais do poder, no pós-guerra, desfez os pilares do colonialismo. Consequentemente, fez com que os territórios antes dominados, se tornassem campos férteis para movimentos de libertação nacional, guerras separatistas e tentativas neo-colonialistas. ${ }^{26}$

\footnotetext{
${ }^{26}$ Os movimentos nacionalistas na Ásia e África do pós-guerra assumiram novos significados e conteúdos, se distinguindo dos movimentos nacionalistas europeus. Os nacionalismos europeus dos séculos XIX e XX assentaram-se sobre noções étnicas, culturais, linguísticas, e em muitos casos, evoluíram para formas expansionistas e belicistas. Já os nacionalismos da Ásia e África estruturamse em torno de lutas anti-imperialistas, exigindo igualdade de direitos e soberania política in MAGNOLI, Demetrio. Relações internacionais: teoria e história. São Paulo: Saraiva, 2004. P. 155.
} 
Chegava-se, assim, à era da descolonização. Em parte outorgada, em parte conquistada, os países conquistavam sua independência. Em todo caso, o fenômeno ampliava-se, e de repente, passou a se organizar e a teorizar sobre si mesmo. $^{27}$

Como já afirmado, ao longo do processo de descolonização, há uma consolidação do modelo de Estado como modelo político adotado pelas sociedades independentes, que no âmbito externo, sobreviveram inicialmente com base nos fundamentos basilares de direito internacional: a igualdade jurídica entre Estados e a não-intervenção em assuntos internos. Todas as sociedades, que antes se relacionavam de maneira subordinada e hierárquica, passaram a ter voz própria, mesmo que de maneira desigual.

No entanto, tais fundamentos, no estágio de regulação e interpretação em que se encontravam à época, não satisfaziam inteiramente as necessidades dos países recém-independentes. Fazia-se necessário que o direito internacional se readequasse ao novo cenário que as relações internacionais lhe apresentavam. Essa necessidade levou a uma articulação até então inédita entre os países subdesenvolvidos, que viria a provocar uma verdadeira revolução nos paradigmas das relações internacionais e do direito internacional.

Maurice Flory afirma que:

O direito internacional, originariamente, foi constituído por duas ou três dezenas de estados que se consideravam como soberanos e iguais. Depois da Segunda Guerra Mundial, o direito internacional entrou em uma fase de profunda transformação. Ele se torna um direito que, lucidamente, não conseguia mais ignorar as realidades econômicas altamente polarizadas da sociedade internacional, no que se refere ao nível de desenvolvimento. A desigualdade passa, de agora em diante, a constituir a maior preocupação da comunidade de nações. ${ }^{28}$

A noção econômica do desenvolvimento passou a revelar a desigualdade dos Estados que, daquele período em diante, não se podia mais ignorar. A atenção à evolução do desenvolvimento após 150 anos resumia a situação: de 1830 a 1970,

\footnotetext{
${ }^{27}$ A descolonização percorreu dois caminhos principais: o primeiro, baseado na retirada voluntária da potencia colonial, com a concessão da independência; o segundo, baseado em guerras de libertação conduzidas por movimentos de libertação nacional. Exemplos do primeiro caminho foram a retirada norte-americana da Indonésia e dos britânicos da Índia e do Paquistão. Entre os exemplos dramáticos do segundo momento estão as Guerras da Indochina e da Argélia, contra a França, e de Angola e Moçambique, contra Portugal. Ver MAGNOLI, op cit. P. 157.

${ }^{28}$ FLORY,op. cit., p. 11.
} 
o Produto Interno Bruto (PIB) do conjunto dos países industriais foi multiplicado por 6, contra 2,5 do século anterior. Mais da metade deste progresso realizado nos últimos 20 anos. Durante este mesmo período, o PIB dos países do Terceiro Mundo somente dobrou tendo em conta o caso relativamente favorável da América Latina. ${ }^{29}$

A descolonização vai, então, levar ao reconhecimento da desigualdade $e$ se constituir e demandar a revisão do conceito da igualdade soberana. O postulado da igualdade jurídica aplicado a estes novos Estados não ofuscou as heranças do período colonial: é a desigualdade econômica que separa os novos Estados dos mais velhos.

Uma nova realidade, portanto, se impõe. A desigualdade de fato, facilmente ignorada em benefício da igualdade jurídica e formal dos Estados, é um fenômeno complexo, que exige uma análise mais detalhada. A desigualdade de fato conduz à distinção atual em dois tipos diferentes de distorção: a velha desigualdade de poder e a nova desigualdade de desenvolvimento.

O velho princípio da igualdade, enquanto ficção jurídica, tornou-se insustentável nos anos 60, dada a tamanha discrepância entre os Membros da comunidade internacional. Ora, se a comunidade internacional não pode evitar que existam Estados mais poderosos que outros, por seu tamanho ou suas características geográficas, ao mesmo tempo sabe que existem remédios contra a desigualdade do desenvolvimento de suas economias. Tais remédios não se encarregam de negar tal desigualdade, mas de corrigi-la.

Em plenos anos 70, Maurice Flory concluía que:

Para desenvolver tais corretivos, é preciso notadamente enfrentar o sistema que detém uma responsabilidade primordial sobre esta situação, o liberalismo econômico no qual vive a comunidade internacional atual. Assim se explica o interesse que o direito internacional começa a dar aos problemas econômicos. Essa penetração da economia na ordem jurídica que acreditava poder ignorar até o presente, é uma inovação rica de consequências que, de acordo com alguns, desencadeará mesmo uma verdadeira mutação do direito internacional.

${ }^{29}$ BETHELL, Leslie (Org). História da América Latina (Vol. 6). São Paulo: EDUSP, 2009. pp. $142-161$. 
É em torno desta relação entre o direito internacional e os problemas econômicos da desigualdade, detectada por Maurice Flory, que os novos Estados Membros da comunidade internacional vão investir coletivamente, de maneira a questionar a legitimidade dos mesmos e pretender dar nova roupagem a esses dogmas do direito internacional.

\section{c) A articulação do Terceiro Mundo perante o direito internacional}

Como analisado acima, ao longo das primeiras décadas do pós-guerra, as excolônias adquirem, em quase todas as regiões do mundo, sua independência política. No entanto, alcançada tal independência, fazia-se necessário alcançar uma independência não menos importante: a independência econômica.

De acordo com Bedjaoui:

a descolonização que estava em marcha nos últimos 20 anos, que não havia esgotado seus efeitos nem acabado de surpreender por suas consequências profundamente inovadoras no mundo internacional é, na ordem das "regras do jogo internacional", tão importante quanto foram as conquistas ultramarinas do século XV e XVI ou a constituição dos grandes impérios coloniais decorrentes da revolução industrial". ${ }^{30}$

De fato, a descolonização constituiu indubitavelmente uma etapa nova e fecunda da história da humanidade. A renúncia forçada aos impérios coloniais e a aparição de um grande número de novos atores das relações internacionais abalaram inevitavelmente, em diversos graus e com uma amplitude variável, os Estados dominantes desses impérios, dos seus pontos de apoio econômico, político e estratégico ao redor do mundo.

Daí a importância da invenção do conceito de Terceiro Mundo. Seu mérito foi o de lembrar a existência de uma imensa zona do planeta para a qual a questão primordial não era a do alinhamento em um ou outro campo, mas qual seria a atitude dos Estados Unidos e da União Soviética em relação a ela. ${ }^{31}$

\footnotetext{
${ }^{30}$ BEDJAOUI, op. cit., p. 11.

${ }^{31}$ A respeito do Terceiro Mundo, ver o capítulo 12 do livro "A Era dos Extremos: o breve século XX”, de Eric Hobsbawn. HOBSBAWN.op. cit., p. 337-390.
} 
Ao englobar todos os países subdesenvolvidos numa única expressão, a noção de Terceiro Mundo destacava ao mesmo tempo as características comuns, próprias a todos esses países, e também o fato de que eles não estavam necessariamente implicados na Guerra Fria. A fórmula também dizia respeito ao esforço de certos intelectuais em criar uma "terceira força" entre os partidos e os governos comunistas e anticomunistas. ${ }^{32}$

Inscrever-se na história da qual haviam sido expulsos, ou melhor, amordaçados, e derrocar os impérios que haviam repartido o planeta: esse era o sentido da luta dos povos colonizados, lutas que se intensificaram na segunda metade do século XX.

A ação coordenada que os países subdesenvolvidos iniciam fora do marco da ONU se manifesta em duas frentes, uma de natureza política, com a criação do Movimento dos Não-Alinhados (MNA), e outra de natureza econômica, com a criação do Grupo dos 77 (G77). ${ }^{33}$

A Conferência de Bandung é considerada o evento inaugural do Terceiro Mundo. De 18 a 24 de abril de 1955, se reuniram em Bandung, capital da Indonésia ${ }^{34}$, os representantes de 29 países afro-asiáticos, recém-independentes. ${ }^{35} \mathrm{~A}$ Conferência foi o primeiro manifesto articulado dos países subdesenvolvidos contra o imperialismo europeu, do qual haviam recém se libertado, e contra as iniciativas neoimperialistas, que os Estados Unidos e a União Soviética ensaiavam no escopo da Guerra Fria. Formularam inclusive propostas de tornar o imperialismo um

\footnotetext{
${ }^{32}$ George Balandier, inventor em 1952 junto a Alfred Sauvy, da expressão Terceiro Mundo, explicava assim seu significado: Não se tratava de definir um terceiro conjunto de nações, junto aos blocos (capitalista e soviético) em Guerra Fria. Era, sim, uma referencia ao Terceiro Estado do Antigo Regime, da Revolução Francesa, remetendo ao texto de Sieyès: "O que é o Terceiro Estado? Tudo. O que foi, até hoje, na ordem politica? Nada. O que ele quer? Tornar-se alguma coisa." WALLERTEIN, Immanuel. O que era mesmo o Terceiro Mundo? in Biblioteca Diplô. Agosto, 2000. In http://diplo.org.br/2000-08,a1805. Acesso em 18/05/2012.

${ }^{33}$ Uma obra recente de referência sobre o Terceiro Mundo é PRASHAD, Vijay. The Darker Nations: a people's history of the Third World. Nova York: The New Press, 2007.

${ }^{34} \mathrm{O}$ presidente indonésio Sukarno, anfitrião desta conferencia, evocou o congresso constitutivo da Liga contra o Imperialismo, celebrado em 1927, em Bruxelas e que, pela primeira vez, havia reunido os representantes dos "povos de cor", linguagem adotada pelo texto deste congresso ao se referir aos povos coloniais, que já no período entre-guerras reivindicava um amplo processo de descolonização nos continentes africano e asiático.

${ }^{35}$ Os países participantes foram os seguintes: Afeganistão, Arábia Saudita, Birmânia, Camboja, Laos, Líbano, Ceilão, República Popular da China, Filipinas, Japão, Índia, Paquistão, Turquia, Síria, Israel, República Democrática do Vietnã, Irã, Iraque, Vietnã do Sul, Nepal, Iémen do Norte, Etiópia, Líbia, Libéria e Egito.
} 
crime contra a humanidade, passível de ser julgado por um Tribunal da Descolonização, que nunca se concretizou.

$\mathrm{Na}$ Conferência de Bandung, foram formulados os princípios políticos que de daquele momento em diante orientariam o Terceiro Mundo, por meio das suas duas manifestações mais institucionalizadas: o Movimento dos Não-Alinhados e o Grupo dos 77.

Dando prosseguimento à Conferência de Bandung, foi realizada, em 1961, em Belgrado, atual Mianmar, a Primeira Conferência dos Chefes de Estado e de Governos Não-Alinhados. ${ }^{36}$

Nessa primeira conferência, a principal preocupação dos 25 países participantes era a corrida armamentista, contra a qual se opuseram, e recusaram qualquer tipo de alinhamento com os Estados Unidos ou com a União Soviética. A partir da segunda Conferência, realizado no Cairo em 1964, o Movimento dos Não-Alinhados (MNA) começa a angariar maior participação dos países em desenvolvimento, contando então com 47 Membros.

A partir de Cairo, a pauta de mobilização do MNA amplia-se consideravelmente, para além do tema securitário, e passa a abranger questões envolvendo o estágio de subdesenvolvimento econômico em que se encontravam, com destaque para o clamor pela recuperação das riquezas nacionais, cujo movimento viria a alcançar seu apogeu na década de 1970 com a nacionalização das empresas petrolíferas. É também no âmbito do MNA que são formuladas as premissas da proposta por uma nova ordem econômica internacional (NOEI), que será detalhada a seguir.

Dentre as principais contribuições do MNA para o direito internacional, está o fato de que, desde a Conferência de Bandung, o grupo de países em desenvolvimento está constantemente invocando e reforçando princípios do direito internacional vigente para subsidiar suas reivindicações, o que garantia ainda maior legitimidade e credibilidade para o Movimento.

\footnotetext{
${ }^{36}$ Site oficial do Movimento dos Não-Alinados: http://www.nam.gov.za/.
} 
Os princípios orientadores do MNA para sua atuação internacional foram os seguintes:

\section{Tabela 2 - Princípios do Movimento dos Não-Alinhados ${ }^{37}$}

\begin{tabular}{|l|}
\hline 1. Respeito aos Direitos Fundamentais, da Carta da ONU \\
\hline 2. Respeito à Soberania e à Integridade Territorial \\
\hline 3. Reconhecimento da Igualdade entre Raças e Nações \\
\hline 4. Proibição de Interferência em Assuntos Internos \\
\hline 5. Direito de Defesa Individual e Coletiva, com base na Carta da ONU \\
\hline 6. Proibição de Acordos de Defesa Coletiva, de Natureza Ideológica \\
\hline 7. Recusa à utilização de atos de agressão ou pressão, militares ou econômicos. \\
\hline 8. Solução pacífica dos conflitos internacionais, seguindo a Carta da ONU \\
\hline 9. Estímulo à cooperação de interesse mútuo \\
\hline 10. Respeito aos tribunais internacionais e às obrigações internacionais
\end{tabular}

Atualmente o MNA conta com 115 Membros e permanece ativo, por meio de Conferências Ministeriais, Declarações, Resoluções e Relatórios dos seus órgãos. A mais recente Reunião Ministerial organizada pelo MNA foi a III Reunião dos Ministros sobre a Promoção e o Desenvolvimento da Mulher, em fevereiro de 2012, bem como a XVI Cúpula do Movimento dos Não-Alinhados, realizada em agosto de 2012. ${ }^{38}$

No âmbito das reivindicações relacionadas às relações econômicas internacionais, a articulação mais bem estruturada do Terceiro Mundo foi por meio da criação do Grupo dos $77 .{ }^{39}$

O G-77 foi estabelecido em 1964, no âmbito da $1^{\text {a }}$ Conferência das Nações Unidas para o Comércio e Desenvolvimento (UNCTAD), com o objetivo de aumentar a capacidade de articulação e pressão dos países em desenvolvimento nas questões de natureza comercial, que eram tratadas no âmbito do GATT, mas que,

\footnotetext{
${ }^{37}$ Disponível em http://www.nam.gov.za/. Acesso em 01/08/2012.

38 Ver http://www.un.org/apps/news/story.asp?NewsID $=42775 \& \mathrm{Cr}=$ aligned\&Cr1=movement. Acesso em 03 setembro de 2012.

${ }^{39}$ Site oficial do G77: http://www.g77.org/.
} 
ao longo da década de 60, passaram a sofrer influência direta da ONU, por meio da UNCTAD. Essa aproximação entre o GATT e a UNCTAD, por meio do esforço de atuação do G-77, será objeto de estudo mais aprofundado no próximo capítulo.

Com base nessas duas frentes, o MNA e o G-77, o Terceiro Mundo rapidamente ganhou espaço e legitimidade internacional ao longo dos anos 60 . O resultado mais expressivo do Terceiro Mundo foi alcançar um nível nunca antes visto de coesão das políticas dos países subdesenvolvidos no âmbito da ONU, junto aos seus órgãos e agências, e também junto ao GATT, ao criar um forte grupo de pressão na hora de marcar as diretrizes em matéria de iniciativas voltadas para o desenvolvimento.

E com motivos para fazê-lo: desde 1960, ano do início das independências africanas, as nações do Terceiro Mundo dispunham, na Assembleia Geral (AG), de uma maioria que lhes permitia impor uma série de declarações legitimando aspirações anticoloniais. Foi assim que fizeram dos anos 70 a década do desenvolvimento. $\mathrm{O}$ apogeu desse esforço foi a decisão coletiva dos países da Organização dos Países Exportadores de Petróleo (OPEP), em 1973, de aumentar o preço do petróleo, provocando pânico no Ocidente.

Essa ação articulada se faz sentir a partir dos primeiros anos da década de 60, quando se institucionaliza, no âmbito da Assembleia Geral, a primeira década da ONU para o desenvolvimento.

Os países do Terceiro Mundo ingressam na ONU sob a égide desse viés da igualdade jurídica dos Estados. É com base na igualdade que se tornam maioria dentro da ONU ao longo da década de 60, o que lhes vai permitir, no âmbito da AG, tomar decisões por maioria e passar a ditar a pauta da agenda internacional, propugnando pelo surgimento das décadas para o desenvolvimento.

\subsection{A CONSTRUÇÃO DO SISTEMA ONU EM PROL DO DESENVOLVIMENTO}




\section{a) O desenvolvimento na Carta das Nações Unidas}

\section{i. Desenvolvimento no Pacto da Liga das Nações}

Ao final da $1^{\text {a }}$ Guerra Mundial, o Pacto da Liga das Nações fazia referência ao desenvolvimento como princípio norteador da atuação da sociedade internacional, por meio do artigo 22 do Pacto, que dispunha que:

Os princípios seguintes aplicam-se às colônias e territórios que, em consequência da guerra, deixaram de estar sob a soberania dos Estados que precedentemente os governavam e são habitados por povos ainda incapazes de se dirigirem por si próprios, nas condições particularmente difíceis do mundo moderno. $\mathbf{O}$ bem-estar e o desenvolvimento desses povos formam uma missão sagrada de civilização, e convém incorporar no presente Pacto para o cumprimento dessa missão (grifo do autor).

Entretanto, ao estabelecer os princípios e os procedimentos para a Liga das Nações lidar com as ex-colônias, em vez de estabelecer mecanismos de fomento ao desenvolvimento soberano dessas ex-colônias, a Carta da Liga previa os regimes de Mandatos e Tutelas, razão pela qual o Sistema da Liga das Nações, manteve, e na maioria dos casos, piorou, a situação de dependência das ex-colônias no período entreguerras. ${ }^{40}$

\section{ii. Desenvolvimento na Carta da ONU}

Diferentemente da Carta da Liga das Nações, não se encontra referência expressa na Carta da ONU ao tratamento dos países subdesenvolvidos. No entanto, isso não significa que a questão do desenvolvimento seja totalmente estranha ao conteúdo da Carta. De maneira esparsa, é possível encontrar as bases jurídicas das quais derivaram as posteriores atividades da ONU em prol do desenvolvimento.

\footnotetext{
${ }^{40}$ Sobre a Liga das Nações, ver SEITENFUS, Ricardo. Manual das Organizações Internacionais.
} $3^{\mathrm{a}}$ Ed. Livraria do Advogado: Porto Alegre, 2003. 
Em primeiro lugar, o preâmbulo da Carta dispõe que:

NÓS, OS POVOS DAS NAÇÕES UNIDAS, resolvidos a preservar as gerações vindouras do flagelo da guerra, que por duas vezes, no espaço da nossa vida, trouxe sofrimentos indizíveis à humanidade, e a reafirmar a fé nos direitos fundamentais do homem, na dignidade e no valor do ser humano, na igualdade de direito dos homens e das mulheres, assim como das nações grandes e pequenas, e a estabelecer condições sob as quais a justiça e o respeito às obrigações decorrentes de tratados e de outras fontes do direito internacional possam ser mantidos, e a promover o progresso social e melhores condições de vida. dentro de uma liberdade ampla (grifo do autor).

Dentre os propósitos da ONU, a Carta estabelece, em seu artigo 1.3:

Conseguir uma cooperação internacional para resolver os problemas internacionais de caráter econômico, social, cultural ou humanitário, e para promover e estimular o respeito aos direitos humanos e às liberdades fundamentais para todos, sem distinção de raça, sexo, língua ou religião.

Esse objetivo da ONU se materializa por meio dos capítulos IX e X da Carta, dedicados respectivamente a Cooperação Econômica e Social e ao Conselho Econômico e Social.

Para que o trabalho da ONU em matéria de cooperação econômica e social seja mais efetivo, o Capítulo IX estabelece, por meio do artigo 56, que os Estados Membros estão obrigados a tomar medidas, em conjunto ou separadamente, em cooperação com a ONU, para realizar esse objetivo. Também o artigo 57 obriga a organização a que coordene, através de acordos, com outras organizações intergovernamentais que tenham atribuições em matérias de caráter econômico, social, cultural ou educativos.

Durante os primeiros anos de existência da ONU, tais bases jurídicas não receberam muita atenção e raramente foram invocadas. Mas, à medida que o processo de descolonização se disseminou e as ex-colônias foram alcançando a independência e tornaram-se Membros da ONU, perceberam que, ao somar seus votos na Assembleia Geral, o problema do subdesenvolvimento poderia se converter em um tema relevante para a ONU.

\section{b) Os países em desenvolvimento nos órgãos originários da $\mathrm{ONU}$}




\section{i. A Assembleia Geral (AG)}

A institucionalização da atuação internacional para o desenvolvimento criado pela própria Carta é relativamente simples: a Assembleia Geral (AG), órgão de maior representação democrática da ONU, por estarem representados todos os Membros, tem a responsabilidade fundamental no que diz respeito à cooperação internacional em matéria de caráter econômico e social.

À AG corresponde dar as diretrizes e orientar as políticas a serem seguidas. A concretização desta política é a realização prática destas diretrizes são missões encomendadas ao Conselho Econômico e Social das Nações Unidas (ECOSOC), que atua sempre de acordo com a autoridade da AG, concedido pelo artigo 60 da Carta.

No que diz respeito ao funcionamento específico da $A G$, deve-se levar em conta o fato de que a maioria dos seus Membros está hoje constituída por Estados que se incluem no grupo dos subdesenvolvidos; isto, atrelado ao sistema decisório da AG (cada Estado um voto, com decisão por maioria de votos), resulta decisivo tanto na hora de selecionar e aprovar os temas que serão objeto de debate, bem como na adoção das resoluções que proponham as diretrizes ou medidas concretas em relação à cooperação para o desenvolvimento.

Deve-se levar em conta, no entanto, que o funcionamento democrático da AG fica fortemente condicionado ao fato de que quase $2 / 3$ do volume total do orçamento dos programas de ajuda da ONU são financiados por 6 ou 7 países industrializados (EUA, Suécia, Alemanha, Canadá, Reino Unido, e em menor escala, Dinamarca e Países Baixos). Isto faz com que as propostas de ação ou as resoluções aprovadas majoritariamente na $\mathrm{AG}$, que não contem com a aprovação destes países, sejam praticamente inviabilizadas. Por isso, muitas vezes, há decisões por consenso, a fim de garantir sua eficácia. ${ }^{41}$

No entanto, durante muito tempo, especialmente nas primeiras décadas das estratégias para o desenvolvimento da ONU, tal consenso não ocorreu e os

\footnotetext{
${ }^{41}$ A respeito deste assunto, ver VELASCO, Manuel Diez. Las Organizaciones Internacionales. $15^{\mathrm{a}}$ ed. Madri: Tecnos, 2008. pp. 320-321.
} 
Membros da AG decidiam independentemente dos países industrializados, como forma de expressão do poder (ainda que meramente formal), dos países em desenvolvimento.

ii. O Conselho Econômico e Social (ECOSOC)

O órgão concretizador das resoluções da AG é o ECOSOC. O ECOSOC é competente, com base no artigo 62 da Carta, para tratar de todas as questões relativas à cooperação para a solução de problemas internacionais de caráter econômico e social. No exercício das suas funções e sempre se referindo à matéria objeto de sua competência, o ECOSOC tem poderes para fazer informes, iniciar estudos, fazer recomendações à AG, aos Estados Membros da ONU, aos organismos especializados, além de formular projetos de tratados para submetê-los à $A G$ e convocar conferências internacionais.

A complexidade e a amplitude de temas objeto de competência do ECOSOC fez com que este órgão tivesse cada vez mais necessidade de criar organismos subsidiários para o desempenho de suas funções.

De um lado, os critérios levados em conta pelo ECOSOC para a criação de órgãos subsidiários tem sido a especialização dos problemas a examinar, com a criação de comitês e comissões especializados em razão da matéria objeto de sua competência. Assim, por exemplo, existe o comitê assessor sobre a aplicação de ciência e tecnologia para o desenvolvimento, o comitê de planejamento do desenvolvimento, o comitê do programa de estudos para o desenvolvimento dos recursos naturais, etc.

Por outro lado, o ECOSOC orientou-se por um critério geográfico, criando comissões econômicas regionais especializadas em razão da área geográfica sobre a qual atuam. Foi neste contexto que foi criada a Comissão Econômica para América Latina (CEPAL), vinculada ao ECOSOC, comissão na qual se formulou as premissas teóricas que, em certa medida, embasaram teoricamente o movimento terceiro-mundista que levaria a NOEI e a criação da UNCTAD. 
iii. A Comissão Econômica para a América Latina (CEPAL)

A CEPAL foi criada pela Resolução 106 do ECOSOC da ONU em 25/02/1948. Ela está sediada em Santiago, Chile. Além da CEPAL, o sistema ONU, através do ECOSOC, criou as seguintes Comissões Econômicas Regionais:
a. Comissão Econômica para a África (ECA)
b. Comissão Econômica e Social para a Ásia e o Pacífico (ESCAP)
c. Comissão Econômica para a Europa (ECE)
d. Comissão Econômica para a Ásia Ocidental (ESCWA)
e. Comissão Econômica para a América Latina e o Caribe (CEPAL)

As Comissões Econômicas Regionais da ONU tem como função auxiliar o desenvolvimento socioeconômico em suas respectivas regiões e fortalecer as relações econômicas dos países em sua área de atuação, tanto entre si como com outros países do mundo. ${ }^{42}$

Estas comissões econômicas regionais, particularmente a CEPAL, foram bastante influenciadas por um relatório da ONU de 1949, da Subcomissão para o Desenvolvimento Econômico das Nações Unidas, intitulado "A relação dos preços pós-guerra no comércio entre países industrializados e países subdesenvolvidos". Os objetivos propostos pelo documento tinham como motivação uma evidência já constatada nos primeiros trabalhos da subcomissão, criada dois anos antes: o aumento relativo no preço dos bens de capitais e serviços de transportes produzidos nos países desenvolvidos. ${ }^{43}$

Com isso, o relatório alertava para a necessidade de se verificar acerca da tendência nos preços dos bens primários, uma vez que a situação poderia se tornar

\footnotetext{
${ }^{42}$ Para acesso a documentos institucionais da CEPAL, vide http://www.eclac.org/.

${ }^{43} \mathrm{Um}$ excelente texto sobre as fontes teóricas do estruturalismo latino-americano é LOVE, Joseph (1996). Las fuentes del estrucuturalismo latino-americano. Desarrollo Económico (Vol. 38. No. 141.). Instituto de Desarollo Económico y Social.
} 
cada vez mais prejudicial para os países menos desenvolvidos. Havia uma tendência de deterioração dos termos de troca, desfavorável aos bens primários. ${ }^{44}$

Este trabalho da ONU foi particularmente marcante na elaboração do primeiro documento realizado por Raul Prebisch no âmbito da CEPAL, publicado originalmente no mesmo ano, em 1949, intitulado "O desenvolvimento econômico da América Latina e alguns dos seus principais problemas". O trabalho de Prebisch conteria as bases para a construção do arcabouço analítico sobre os problemas latino-americanos.

Como afirma Marcio Bobik Braga:

\begin{abstract}
O pensamento protecionista defendido na América Latina esteve longe de ser original. Muitos pensadores, sobre o predomínio da escola clássica, também procuraram defender um processo em curso no século XIX: a industrialização de alguns países dos hoje denominados de grandes potências industriais. Para tanto, utilizara-se, dentre outros conceitos e contextos, da concepção de indústria nascente, sugerindo a ideia da existência de efeitos dinâmicos não considerados pelo princípio das vantagens comparativas. ${ }^{45}$
\end{abstract}

Se é verdade que a teoria latino-americana não representou novidade para a literatura econômica, a influência dela, sim, representou novidade fundamental no cenário diplomático internacional ao longo das décadas de 60 e 70 . Sobre tal influência, se discorrerá com profundidade na seção seguinte.

\title{
c) A UNCTAD e as novas instituições da ONU para o desenvolvimento
}

As instituições mais significativas criadas no marco da ONU, no que se refere ao desenvolvimento econômico e social dos países em desenvolvimento, são a Conferência das Nações Unidas para o Desenvolvimento (UNCTAD), o Programa das Nações Unidas para o Desenvolvimento (PNUD) e a Organização das Nações Unidas para o Desenvolvimento Industrial (UNIDO).

${ }^{44}$ BRAGA. Marcio Bobik. Raul Prebisch e o Livre Comércio: as origens do pensamento econômico estruturalista. Cadernos PROLAM/USP. Ano 7, Vol. 2. 2008, p. 79.

${ }^{45}$ BRAGA. op. cit., p. 86. 
i. A Conferência das Nações Unidas para o Comércio e Desenvolvimento (UNCTAD)

Estes organismos têm como tarefa principal colocar em prática, respectivamente, as três linhas básicas que até o momento caracterizam a estratégia da ONU para o desenvolvimento: a cooperação, a fim de corrigir os efeitos prejudiciais que o comércio internacional prova nas economias dos países em desenvolvimento; a canalização das ajudas financeiras para atividades de investimentos; e a promoção das indústrias de exportação e de substituição de importações nos países em desenvolvimento.

A UNCTAD é fruto direto da Conferência de Belgrado, apresentada acima, na qual os países desenvolvidos e os países em desenvolvimento concordam em propor uma conferência para debater as relações entre comércio e desenvolvimento. Neste sentido, a Conferência de Belgrado refletia o espírito da Conferência de Bandung, na qual se oficializou o nascimento do Movimento dos Não-Alinhados.

Dentre as razões que motivaram a constituição da UNCTAD, merece atenção o significativo aumento do número de ações independentes nos anos 60, do qual são principais atores as nações africanas e asiáticas que emergiram do movimento de descolonização para integrar-se à comunidade internacional. Essa ampliação das nações independentes, formalmente iguais, contrastava-se com a imensa desigualdade material entre estes recém-chegados e as clássicas potências das relações internacionais. Isto acarretou tensões e conflitos no sistema da ordem internacional então vigente. Os países desenvolvidos insistiram na manutenção do status quo, em conformidade com seus interesses.

Os países em desenvolvimento estavam diante de um sistema econômico internacional organizado por uma minoria, baseado na igualdade formal dos atores envolvidos e que não refletia as necessidades específicas desse novo bloco de países recém-chegados à comunidade internacional. Nestas circunstâncias, contestaram as normas vigentes e reivindicaram mudanças nos fundamentos das relações 
econômicas internacionais, que tornavam necessárias alterações e inovações nos institutos e instrumentos jurídicos pertinentes ao assunto.

Contribuíram também para o surgimento da UNCTAD o fato de que os países desenvolvidos, notadamente os EUA, inviabilizaram a entrada em vigor da Organização Internacional do Comércio (OIC) e, consequentemente, surgiu o GATT. Com limites orgânicos e institucionais, o GATT, em seu princípio, mostrava-se alheio ao problema do desenvolvimento. Por isso, havia a necessidade de consolidar uma organização internacional com competência para tratar dos temas relacionados a comércio e desenvolvimento.

Nesse sentido, a UNCTAD, em sua origem, pretendia introduzir a perspectiva dos países em desenvolvimento no âmbito do comércio internacional, como contraponto ao GATT, que até então regulava o comércio internacional a partir dos interesses dos países desenvolvidos.

Assim, a partir da uma conferência provisória da ONU, convocada em 1963, a UNCTAD foi estabelecida. Por iniciativa dos países em desenvolvimento, sob oposição dos países industrializados, realizou-se uma conferência internacional para debater a relação entre comércio e desenvolvimento. O que era inicialmente para ser um fórum de debates acabou por transformar-se numa estrutura permanente para auxiliar os países em desenvolvimento a alcançar melhores condições nas negociações comerciais internacionais, tanto bilateralmente como multilateralmente, no âmbito do GATT-47. ${ }^{46}$

Realizada em Genebra, no início de 1964, esta conferência debateu e adotou uma série de proposições relacionadas ao desenvolvimento dos países menos avançados (PMA). A maioria destas resoluções foi aprovada com uma votação extremamente dividida onde, de um lado os países em desenvolvimento, que eram a maioria, votaram em favor, e de outro, os países industrializados, votaram contra ou se abstiveram.

${ }^{46}$ ALMEIDA, Paulo R. O Brasil e o multilateralismo econômico. Porto Alegre: Livraria do Advogado. 1999. 
A UNCTAD foi estabelecida em 30 de dezembro de 1964, por meio da resolução $\mathrm{n}^{\text {o }} 1995$ da Assembleia Geral da ONU. Sob o status de um órgão subsidiário da Assembleia Geral que buscava expressar essa concepção do Sul a respeito do Direito Internacional Econômico, nutria a ideia de uma renovação da organização da economia mundial que assumisse um caráter mais redistributivo.

Sediada em Genebra, Suíça, a UNCTAD teve como primeiro SecretárioGeral o próprio Raul Prebisch (1963-1969), oriundo diretamente da CEPAL. ${ }^{47}$

Segundo Jackson:

O surgimento da UNCTAD teve um impacto moral e psicológico sobre os negociadores do GATT, especialmente sobre os representantes dos países desenvolvidos. Indubitavelmente, o GATT era o lugar apropriado para esta força moral transformar-se em ação. ${ }^{48}$

Como o GATT era o fórum internacional que mais se guiava, efetivamente, por direitos e obrigações juridicamente estabelecidos, seria questão de tempo até que a UNCTAD começasse a exercer a sua força moral no âmbito do GATT.

Depois da primeira influência da UNCTAD no âmbito do GATT, com a criação da Parte IV, outras iniciativas sobrevieram. Por meio das reuniões da UNCTAD, os países em desenvolvimento alcançaram os seguintes avanços, no âmbito do sistema multilateral de comércio:

Tabela 3. Principais iniciativas da UNCTAD junto ao GATT

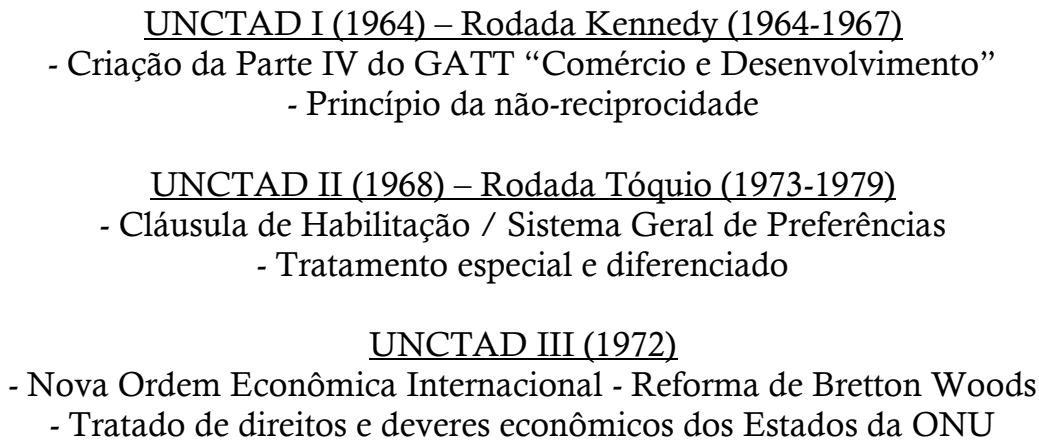

${ }^{47}$ Para aprofundar a história da UNCTAD, ver UNCTAD (1984). The History of UNCTAD: 1964-1984. Nova York: UNCTAD. e UNCTAD (2004). Beyond Conventional Wisdom in Development Policy: an Intellectual History of UNCTAD 1964-2004. Genebra: UNCTAD. ${ }^{48}$ JACKSON, John H.. World Trade and the Law of GATT: a legal analysis of the General Agreement on Tariffs and Trade. Nova York: The Bobbs-Merrill Company, 1969, p. 645. 


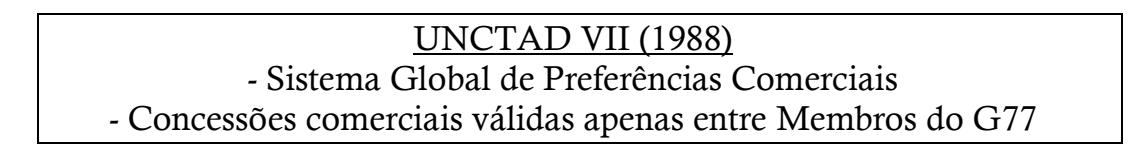

Além da UNCTAD, outras duas iniciativas institucionais são constituídas ao longo da primeira década da ONU para o desenvolvimento: O Programa das Nações Unidas para o Desenvolvimento (PNUD) e a Organização das Nações Unidas para o Desenvolvimento Industrial (UNIDO).

ii. O Programa das Nações Unidas para o Desenvolvimento (PNUD) e a Organização das Nações Unidas para o Desenvolvimento Industrial (UNIDO)

O PNUD foi criado pela Resolução 2.029 (XX) mediante a fusão de dois organismos existentes anteriormente, o Fundo Especial e o Programa ampliado de Assistência Técnica, os quais passaram a constituir duas seções separadas dentro do recém-criado PNUD. ${ }^{49}$

O objetivo do PNUD é servir de apoio para a disposição de assistência técnica de modo sistemático a todos aqueles setores que considere necessários para o desenvolvimento dos países menos desenvolvidos. Mais concretamente, sua função consiste em constituir e realizar um programa de ajuda multilateral para projetos de pré-investimentos a fim de criar condições e infraestruturas necessárias para que os investimentos sejam realmente eficazes e para atrair novo capital aos países em desenvolvimento. ${ }^{50}$

Já a UNIDO é uma agência especializada da ONU responsável pela canalização da cooperação em matéria de desenvolvimento industrial. Inicialmente, tal cooperação se limitava à assistência técnica e ao financiamento de

${ }^{49}$ Página oficial do PNUD: http://www.undp.org/.

${ }^{50}$ VELASCO. Op. cit.p. 337. 
projetos concretos para a instalação ou recuperação de indústrias de exportação ou de substituição de importações nos países em desenvolvimento. ${ }^{51}$

A partir da década de 70 , as linhas básicas da cooperação para o desenvolvimento industrial seguem o objetivo de aumentar a participação dos países em desenvolvimento (PED) na produção industrial mundial, até chegar pelo menos aos $25 \%$ do total em 2000 .

A respeito destas três instituições da ONU, estas serão tratadas novamente na segunda parte desta tese, quando forem analisadas as adequações pelas quais o sistema ONU passou a partir da década de 90, especialmente após o lançamento dos Objetivos de Desenvolvimento do Milênio.

\subsection{A CONSOLIDAÇÃO NORMATIVA DO DIREITO INTERNACIONAL DO DESENVOLVIMENTO}

\section{a) As Décadas do ONU para o Desenvolvimento}

Como mencionado anteriormente, até os anos de 1960, não existia uma estratégia clara da ONU em relação ao desenvolvimento dos países subdesenvolvidos.

É certo que as referências ao problema do subdesenvolvimento no âmbito da cooperação econômica e social se iniciaram na ONU a partir das Resoluções 198 (II) e 307 (IV) adotadas respectivamente em 1948 e 1949.

Ambas as resoluções da AG tem o propósito de instar o ECOSOC e as comissões econômicas regionais a analisar e propor metas e iniciativas para reduzir

\footnotetext{
${ }^{51}$ Página oficial da UNIDO: http://www.unido.org/.
} 
o nível de subdesenvolvimento dos países mais pobres. Além disso, a resolução $n^{\circ}$ 198 incorpora o Banco Internacional de Reconstrução e Desenvolvimento (BIRD) nas discussões, a fim de que revise as suas linhas de financiamento para a criação em empréstimos específicos para os países pobres; já a resolução 306 abarca a questão sob a ótica dos acordos de comércio internacional, afirmando ser necessário questionar a relevância da revisão de ditos acordos com vistas a beneficiar o nível de desenvolvimento dos países insuficientemente desenvolvidos.

Ocorre que, tanto estas, quanto as demais resoluções posteriores a esta que apareceram ao longo da década de 50, eram dispersas e programáticas, sem articular um plano concreto para as ações da ONU ao longo da sua primeira década.

No entanto, este período serviu para a AG estabelecer os pontos de partida básicos para sua ação futura que, fundamentalmente, podem se concentrar em dois pilares: ${ }^{52}$

a) entender que o desenvolvimento dos países subdesenvolvidos envolve uma problemática distinta da que se apresenta aos países industrializados, o que obriga a um estudo prévio e particular dos problemas específicos destes países antes de adotar qualquer medida em relação ao seu desenvolvimento, e;

b) considerar que os problemas do desenvolvimento econômico e social são interdependentes, de modo que o desenvolvimento econômico deve ser coordenado com o social.

Com base nestas noções formuladas ao longo da década de 50, é a partir dos anos 1960 que o Sistema ONU passa a agir pragmaticamente, no sentido de enfrentar os resultados medíocres em matéria de desenvolvimento alcançados até então, e passa a dar forma real a uma ordem normativa em favor do desenvolvimento.

\section{i. A Primeira Década: lançamento e reforma do sistema ONU}

\footnotetext{
${ }^{52}$ Ver BARONA, Ignacio et al. Lecciones de derecho internacional público. Valencia: Tirant Lo Blanch, 2011, p. 372.
} 
A primeira década do desenvolvimento (1961-1970) lançou as bases normativas que criaram os direitos $\mathrm{e}$ as obrigações a serem observados pelos Estados-Membros no âmbito dos órgãos e programas criados. Este conjunto normativo tornou-se tendência e, com maiores ou menores variações, tornou-se referência para as décadas seguintes.

Esta preocupação se consolidou por meio da Resolução 1515 (XV), de 1960, intitulada "Ação concertada em prol do desenvolvimento dos países economicamente pouco desenvolvidos". Tal resolução inaugura este novo momento do Sistema ONU, pois se trata da primeira iniciativa da AG que estabelece um programa articulado de ação para o desenvolvimento, como uma necessidade.

Como decorrência, em 19 de dezembro de 1961, a Resolução 1710 (XVI) estabeleceu a Primeira Década das Nações Unidas para o Desenvolvimento.

Nesta primeira década, foram estabelecidos os seguintes objetivos gerais:

- Promover o crescimento do produto interno produto (PIB) de 5\% anuais dos PED;

- Os países ricos deveriam destinar 1\% dos seus PIB em forma de transferências de recursos, para o desenvolvimento dos PED;

- Oportunizar aos PED a adoção de políticas que lhes permitissem incrementar suas exportações de produtos primários a preços estáveis e remunerativos;

- Permitir aos PED obter parte equitativa dos benefícios provenientes da exploração dos seus recursos naturais, realizadas com capital estrangeiro;

- Garantir que os PED recebessem maior volume de recursos públicos e privados para o desenvolvimento.

A primeira década se complementaria no ano seguinte com a adoção de outra resolução, mais incisiva. Em 14 de dezembro de 1962, a AG adotava a Resolução no 1803 (XVII), intitulada "Soberania Permanente sobre os Recursos Naturais".

Nesta resolução, estão estabelecidos 8 princípios que reforçam o direito dos povos e dos Estados à soberania permanente sobre suas riquezas e recursos naturais. Do ponto de vista da afirmação da autonomia jurídica dos países em desenvolvimento, a resolução afirma que o acesso e a exploração de tais recursos 
por empresas estrangeiras, deveriam adequar-se às regras e condições que os Estados considerassem necessários ou desejáveis para autorizar, limitar ou proibir tais atividades.

Estas três resoluções constituem as bases jurídicas da primeira década da ONU para o desenvolvimento. Tais resoluções, em conjunto, constituem a primeira tentativa de planejamento global da cooperação internacional em matéria econômica e social, planejamento este de médio prazo, projetado para o período 1961-1970.

Ao observar os objetivos fixados, os resultados da primeira década das Nações Unidas para o Desenvolvimento podem ser considerados um fracasso. Apenas um pequeno número de países em desenvolvimento alcançou a taxa de crescimento de $5 \%$ e poucos países industrializados alcançaram $1 \%$ do seu PIB, em termos de destinação de recursos para os países em desenvolvimento.

No entanto, isto não quer dizer que esta primeira década não teve valor. Ao contrário, esta primeira década serviu para reconhecer que o problema do subdesenvolvimento era um problema de todos, que deveria ser solucionado, tanto pelos países em desenvolvimento, quanto pelos países ricos, tanto bilateralmente quanto multilateralmente. A partir de então, os países em desenvolvimento estavam legitimados a demandar sobre uma cooperação internacional para 0 desenvolvimento e proclamar o princípio da solidariedade entre países ricos e pobres.

Além disso, do ponto de vista institucional, é durante a primeira década da ONU que se instrumentaliza a criação de órgãos específicos encarregados de levar os planos de ação a cabo, constituindo um importante passo para a institucionalização do Sistema da ONU para o desenvolvimento.

A principal herança deste período foi o comprometimento dos órgãos e instituições da ONU com os objetivos do desenvolvimento econômico. Entre os órgãos criados nesta década, cabe apontar a importância dos três analisados mais aprofundadamente na seção anterior: o Programa das Nações Unidas para o Desenvolvimento (PNUD) competente em matéria de assistência técnica, a Conferência de Comércio e Desenvolvimento (UNCTAD), competente em matéria 
de comércio e desenvolvimento, e a Organização das Nações Unidas para o Desenvolvimento Industrial (UNIDO), competente em matéria de políticas industriais.

\section{ii. A Segunda Década: O Choque do Petróleo e a ascensão do Terceiro Mundo}

Os importantes avanços no âmbito do Sistema ONU descritos acima tiveram, no entanto, êxito limitado. No início dos anos 1970, a grande maioria dos países pobres ainda tinha que enfrentar diversas barreiras ao seu desenvolvimento. Para tentar superá-las, a AG adotava em outubro de 1970 a Resolução no 2.626 (XXV), que estabelecia a Estratégia Internacional para o Desenvolvimento para a Segunda Década das Nações Unidas para o Desenvolvimento.

A segunda década da ONU cobre o período entre 1971 e 1980, e seus objetivos básicos estavam contidos na Resolução no 2.626 (XXV). Esta resolução parte da ideia de que a responsabilidade primordial para alcançar o progresso econômico e social recai sobre os próprios países em desenvolvimento, que, entretanto, não poderiam, por si só, alcançar as metas de desenvolvimento desejadas com a rapidez necessária, tanto por carecerem de recursos financeiros suficientes, quanto por necessitarem de políticas econômicas e comerciais mais favoráveis no seu relacionamento com os países desenvolvidos.

Com base em tais premissas, esta resolução mantém as metas da década anterior, avançando em torno de alguns casos. Por exemplo, a segunda década fixava uma meta maior do que a Primeira Década, e objetivava alcançar um crescimento médio de $6 \%$ anual do PIB dos países em desenvolvimento. Para tanto, se propunha uma série de medidas que variavam da esfera comercial (fortalecer o comércio produtos básicos dos países em desenvolvimento aos países desenvolvidos a preços que fossem estáveis, remunerativos e justos) até o financeiro (por meio da proposta aos países industrializados que destinassem um mínimo de $1 \%$ dos seus PIB aos países em desenvolvimento, em forma de transferências de recursos para o desenvolvimento). 
Ocorre que a prática desta estratégia da segunda década foi seriamente comprometida devido aos acontecimentos que tiveram lugar logo no início da década, em 1971, nos EUA. Como consequência do enorme endividamento durante a Guerra do Vietnã, os EUA se viram forçados a abandonar o sistema monetário internacional constituído ao final da Segunda Guerra, com o Acordo de Bretton Woods. Abandonava-se o sistema baseado em tipos de câmbios fixos relacionados a um padrão-ouro, por um sistema de câmbios flutuantes.

Os efeitos desta mudança de sistema monetário sobre os preços do petróleo e da inflação se viram agravados em 1973, pelo início da guerra entre Israel e os Estados Árabes, que conduziu a um embargo petrolífero por parte dos países exportadores de petróleo, o que quadriplicou os preços do produto. A chamada "Crise do Petróleo" pôs fim aos anos dourados do crescimento econômico do pósguerra. Os países desenvolvidos tiveram que enfrentar uma situação de estancamento econômico, acompanhado de uma crescente inflação e desemprego.

Os países em desenvolvimento, ao contrário, emergiram da situação como atores poderosos graças ao seu controle sobre a produção e exportação de matériasprimas essenciais para o funcionamento das economias desenvolvidas.

Conscientes da sua nova situação de poder, os países em desenvolvimento convocaram uma sessão especial da AG para estudar o problema das matériasprimas e do desenvolvimento. O objetivo era o de pressionar os países desenvolvidos a introduzir mudanças na ordem econômica internacional, a que consideravam como principal responsável pela situação de atraso econômico em que se encontravam e, ao mesmo tempo, acusá-los pelo fracasso no descumprimento das metas das duas primeiras décadas das Nações Unidas para o Desenvolvimento.

A consciência das profundas desigualdades existentes entre os países e relação desse desequilíbrio com o funcionamento do sistema econômico internacional culminou, em 1974, com a proposta de uma Nova Ordem Econômica Internacional (NOEI). ${ }^{53}$

\footnotetext{
${ }^{53}$ MAGALHÃES, José Carlos. Direito Econômico Internacional: tendências e perspectivas.
} Curitiba: Juruá, 2005. p. 77. 
Em maio de 1974, a AG adotava a Resolução n 3201 (S-VI) que continha a "Declaração sobre o estabelecimento de uma Nova Ordem Econômica Internacional", e a Resolução n 3202 (S-VI), que continha o "Programa de Ação para o Estabelecimento de uma Nova Ordem Econômica Internacional". A estas resoluções, se seguiram em dezembro do mesmo ano a Resolução no 3281 (XXIX), que continha a "Carta de Direitos e Deveres Econômicos dos Estados".

Conclui-se que esta segunda década (1971-1980) foi marcada pelo choque mundial do petróleo, que levou a uma grave crise econômica mundial, na qual os países em desenvolvimento, por desempenharem um papel fundamental na estabilidade econômica internacional ao longo do Choque do Petróleo, viram uma oportunidade de lançar, no âmbito da ONU, a terceira e fundamental década para o desenvolvimento da ONU.

\section{iii. A Terceira Década: Por uma Nova Ordem Econômica Internacional}

Em 1981, a Resolução no 35 (XXXVI), estabelecia a Estratégia Internacional de Desenvolvimento para a Terceira Década das Nações Unidas para o Desenvolvimento. Todas estas resoluções, em conjunto, constituem-se no que se denominou a Nova Ordem Econômica Internacional (NOEI).

A adoção da estratégia internacional de desenvolvimento para a Terceira Década da ONU para o desenvolvimento não pode ser considerada como uma continuação das primeiras duas décadas.

A terceira década foi o momento no qual foram criados dois textos da ONU que são considerados basilares para o que viria a ser denominado de Direito Internacional do Desenvolvimento: A Carta de Direitos e Deveres Econômicos dos Estados, e a Declaração sobre o Estabelecimento de uma Nova Ordem Econômica Internacional.

Existe uma mudança fundamental: a partir dos primeiros anos da década de 1970, diversos países em desenvolvimento, em diversos fóruns internacionais, começaram a criticar a filosofia da ONU sobre cooperação para o 
desenvolvimento, apresentando novas análises econômicas que colocavam em dúvida os próprios fundamentos desta cooperação. Tal atitude se consolidou em 1974, com a formulação pela AG da Declaração para o Estabelecimento de uma NOEI.

Do ponto de vista do direito internacional, interessava cada vez mais ao Terceiro Mundo situar os seus problemas no âmbito das relações econômicas internacionais, e ver até que ponto estas relações e suas regras jurídicas estavam incidindo no fenômeno do subdesenvolvimento. Mais além, fazia-se necessário analisar o sinal positivo ou negativo da sua incidência, e como se regularia tal cenário a fim de superar coletivamente o problema do subdesenvolvimento.

Essa Declaração faz com que a adoção da estratégia internacional de 1981 para a terceira década tenha na declaração seu marco de referência, considerado como um instrumento para viabilização e concretização desta NOEI.

A estratégia da terceira década se propõe a acelerar o desenvolvimento dos países em desenvolvimento, fixando e ampliando novamente as metas anteriores:

\footnotetext{
- Taxa anual média de 7\% de crescimento do PIB do conjunto dos países em desenvolvimento;

- Taxa anual superior a 7,5\% e a $8 \%$ de importações e exportações de bens e serviços, respectivamente, dos países em desenvolvimento;

- Nível de investimento nos países em desenvolvimento equivalente a $28 \%$ do seu PIB para 1990, o que supõe que estes países deverão mobilizar plenamente seus recursos financeiros internos, e que os países desenvolvidos deverão alcançar a meta internacionalmente conveniada de $0,7 \%$ do PIB a titulo de ajuda oficial para o desenvolvimento (AOD), e que o total de recursos financeiros transferidos para tais países alcance $1 \%$ do PIB dos países desenvolvidos.

- A produção manufatureira dos países em desenvolvimento em seu conjunto deverá incrementar-se em uma taxa anual média de $9 \%$.
}

A formulação destas metas e objetivos enceta a concepção de economia internacional interdependente, pois a conquista desta NOEI passa a ser considerada como responsabilidade de todos os governos, no sentido de que todos se beneficiaram desta nova ordem. Ainda, tendo em vista o fato de que, ao longo da década de 70, todos perderam com as crises do petróleo e foram os países em desenvolvimento que sustentaram a economia internacional na época. 
De acordo com o texto da resolução que lança a terceira década, a estratégia é concebida "como um grande empreendimento que alcança a toda a comunidade internacional, destinada a fomentar a cooperação internacional para 0 desenvolvimento", e baseada na "justiça, equidade e benefício mútuo".

Dentre outras novidades significativas da estratégia para a Terceira Década, destacam-se:

a) a atenção especial aos problemas mais urgentes, à situação dos menos avançados, e aos problemas específicos dos países em desenvolvimento sem litoral e insulares, mais afetados;

b) a referência expressa ao respeito aos princípios relativos à soberania e à independência dos Estados, à proibição do uso da força e à solução pacífica de controvérsias, como uma questão de importância capital para o êxito da estratégia;

c) a relação que se estabelece entre desarmamento e desenvolvimento, em virtude da qual a aplicação urgente de medidas de desarmamento liberaria consideráveis recursos adicionais para serem utilizados no desenvolvimento econômico e social, particularmente em benefício dos países em desenvolvimento.

\section{b) Elementos normativos da nova ordem econômica internacional}

Há um antecedente imediato da declaração sobre o estabelecimento da NOEI que merece breve atenção. Foi a conferência dos chefes de Estado ou de governo dos países não alinhados, celebrada em Argel, em setembro de 1973.

Em sua declaração final, se denunciava:

"o fracasso da estratégia internacional do desenvolvimento se deve tanto à
falta de vontade política por parte dos países desenvolvidos para tomar
medidas de urgência, como o inadequado objetivo de crescimento frente às
verdadeiras necessidades dos países em desenvolvimento (...). As posições
dos governos de determinados países desenvolvidos, assim como a conduta
das empresas multinacionais e outras companhias monopolísticas que se
aproveitam da exploração dos países em desenvolvimento, não tem
contribuído com o estabelecimento de uma conjuntura econômica exterior
e de acordo com os objetivos da estratégia internacional de
desenvolvimento (...). Além disso, a alta inflacionista do custo das 
importações, as pressões exercidas sobre o balanço de pagamentos devido às transferências efetuadas por investidores privados estrangeiros, $\mathrm{o}$ reembolsos dos empréstimos, e o oneroso custo do serviço da dívida externa (...). ${ }^{54}$

Como resultado desta conferência do MNA, o presidente argelino Houari Boumedian, na qualidade de presidente em exercício do Grupo dos países NãoAlinhados, dirigiu uma mensagem ao Secretário Geral da ONU em 30 de janeiro de 1974, na qual destaca que:

neste contexto, os países em desenvolvimento devem assegurar o crescimento de suas economias recorrendo, em primeiro lugar, à mobilização dos seus recursos naturais, esperando que a comunidade internacional possa garantir o estabelecimento de novas relações econômicas mais justas e equitativas. Que se faça avançar o procedimento adequado para convocar um período extraordinário de sessões da AG para examinar o tema de estudo dos problemas das matérias primas e o desenvolvimento. ${ }^{55}$

O período extraordinário de sessões da AG se celebrou entre os dias 09 de abril e 2 de maio de 1974, e seu resultado foi a aprovação da Declaração sobre o estabelecimento de uma nova ordem econômica internacional e de um programa de ação para a sua execução, por meio das resoluções 3.201 e 3.202.

Os textos básicos através dos quais a NOEI é formulada juridicamente são:

Resolução 3.201 (S-VI) (Declaração sobre o estabelecimento de uma NOEI)

Resolução 3.202 (S-VI) (Programa de ação para o estabelecimento de uma NOEI)

Resolução 3.281 (XXIX) (Carta de Direitos e Deveres Econômicos dos Estados)

Resolução 3.362 (S-VII) (Desenvolvimento e cooperação econômica internacional)

${ }^{54}$ PRASHAD, Vijay. op. cit., p. 119.

${ }^{55}$ Idem. p. 120. 
Esse conjunto de resoluções formou o corpo normativo ao qual se convencionou denominar por "direito internacional do desenvolvimento", que será objeto de uma análise mais detida na seção seguinte.

O ponto de partida inicial da declaração sobre a NOEI está em seu preâmbulo, no que se reconhece que:

a atual ordem econômica internacional está em contradição direta com a evolução das relações políticas e econômicas internacionais do mundo contemporâneo, pois se trata de um "sistema que se estabeleceu em uma época em que a maioria dos países em desenvolvimento nem sequer existiam como Estados independentes e que perpetua a desigualdade", razão pela qual o objetivo básico da declaração se centra na eliminação do desequilíbrio existente entre os países desenvolvidos e os em via de desenvolvimento.

Neste sentido, o programa de ação apresenta como novidades importantes:

a) a modificação da divisão internacional do trabalho a fim de que seja racional, justa e equitativa;

b) a adoção de medidas para inverter a tendência contínua ao estancamento ou ao declínio dos preços reais de diversos produtos básicos exportados pelos países em desenvolvimento, apesar do aumento geral de tais produtos, o que conduz a uma diminuição dos ingressos da exportação destes países;

c) o controle, por parte dos países subdesenvolvidos afetados, dos investimentos estrangeiros, das atividades das empresas multinacionais em seu território e da propriedade dos meios de produção, questões que deveriam reger-se pela legislação interna destes países e submeter-se à jurisdição de seus tribunais;

d) a participação mais efetiva dos países em desenvolvimento nas instituições financeiras internacionais e em particular no processo de tomada de decisões, mediante uma revisão adequada dos sistemas de votação estabelecidos nos seus tratados constitutivos.

A NOEI consistia na tentativa dos países em desenvolvimento de conceber um novo marco jurídico para a economia mundial, que fosse mais equitativo que o existente. A NOEI estava consolidada em quatro objetivos:

1. Assegurar que todos os Estados pudessem controlar as atividades econômicas dentro de suas fronteiras: para tanto, objetivava-se obrigar a todos os Estados e empresas multinacionais a respeitar a soberania nacional sobre seus recursos naturais, exigindo que os investidores estrangeiros fossem tratados de igual forma que os 
nacionais. Assim, se estenderia para o tema dos investimentos estrangeiros, o princípio do tratamento nacional, já vigente no âmbito do GATT. Para os países em desenvolvimento, que almejavam nacionalizar a baixo custo as empresas estrangeiras que exploravam seus recursos naturais, os investidores estrangeiros deveriam respeitar e estar sujeitos às leis e jurisdição exclusiva do Estado anfitrião. Isso implicaria que todas as controvérsias relativas a investimentos ou ao tratamento do investidor estrangeiro deveriam ser resolvidas nos tribunais do Estado anfitrião e de acordo com as suas leis, tal qual eram resolvidas as questões com os investidores nacionais.

2. Assegurar que as relações econômicas entre Estados estivessem desenhadas para proporcionar aos países em desenvolvimento arrecadações estáveis decorrentes das suas exportações de matérias-primas, bem como maior acesso à tecnologia e aos financiamentos internacionais: para isso, promoveram a adoção de uma série de códigos de conduta para as empresas transnacionais, as práticas empresariais restritivas de concorrência e a transferência de tecnologia. Tais códigos regulariam os direitos e as responsabilidades respectivas dos Estados e empresas estrangeiras, de modo que as transações internacionais não perpetuassem as relações econômicas desiguais, características da era colonial, e que, em certa medida, estavam mantidas pelo sistema econômico internacional vigente.

3. Reforçar o papel dos países em desenvolvimento no governo da economia mundial: para tanto, se pretendia converter a ONU como foro de discussão dos assuntos de interesse dos países em desenvolvimento. $\mathrm{O}$ marco da ONU era preferível ao das instituições de Bretton Woods (Banco Mundial e Fundo Monetário Internacional), porque na AG cada Estado tem um voto, enquanto que nestas organizações internacionais, o sistema de voto ponderado colocava os países em desenvolvimento em larga desvantagem.

4. Impor novas obrigações aos países exportadores de capital: pretendia-se que os países ricos aceitassem a obrigação de transferir o mínimo de $0,7 \%$ do seu PIB em forma de ajuda ao desenvolvimento dos países em desenvolvimento. 
Outro documento fundamental na consolidação do direito internacional do desenvolvimento foi a Resolução 3.281 (XXIX), através da qual se instituiu a Carta de Direitos e Deveres Econômicos dos Estados.

A formulação da Carta tem sua origem em decorrência do discurso do presidente do México, Luis Echeverria, na $3^{\mathrm{a}}$ sessão da UNCTAD, celebrada em Santiago do Chile.

Neste discurso, o presidente mexicano traçou as bases do que, em sua opinião, deveriam ser "os princípios que regem o reconhecimento por parte da comunidade internacional de nações das justas demandas dos povos". Estes princípios, entre outros, eram:

1) o respeito ao direito de cada povo adotar a estrutura econômica que lhe convenha, assim como a imprimir à propriedade privada as modalidades que estejam em conformidade com o interesse público;

2) a renúncia ao emprego de instrumentos de pressão econômica para reduzir a soberania política dos Estados;

3) a subordinação do capital estrangeiro às leis de cada país;

4) a proibição expressa das companhias multinacionais.

A iniciativa do presidente Echeverria foi favoravelmente acolhida na UNCTAD, criando um grupo de trabalho encarregado de elaborar o Projeto da Carta de Direitos e Deveres Econômicos dos Estados, que deveria ser submetido posteriormente ao exame da AG. A Carta foi aprovada pela AG em 14 de dezembro de 1974, no período de sessões $n^{\circ}$ XXIX.

A Carta de Direitos e Deveres Econômicos dos Estados, juntamente com a resolução 3.362, sobre desenvolvimento e cooperação econômica internacional, vem completar a declaração sobre a NOEI, ao expressar e concretizar, em forma de direitos e deveres dos Estados, as linhas básicas propostas pela Declaração e seu programa de ação. 
É precisamente neste programa que se estabelece que a Carta, ainda em fase de projeto, "constituirá um instrumento eficaz para criar um novo sistema de relações econômicas internacionais, baseado na equidade, na igualdade soberana e na interdependência dos interesses dos países desenvolvidos e dos países em desenvolvimento".

Neste sentido, a Carta expressa em seu artigo $8^{\circ}$ o dever dos Estados de "cooperar para facilitar relações econômicas internacionais mais racionais e equitativas e para fomentar mudanças estruturais no contexto de uma economia mundial equilibrada, em harmonia com as necessidades e interesses de todos os países, em particular dos países em desenvolvimento, e com este propósito deverão adotar medidas adequadas".

Os termos em que a Carta é redigida apontam, pois, à transformação das relações econômicas internacionais como compromisso juridicamente expresso, que deverá ser assumido por todos os Estados.

A Carta igualmente explica que as questões mais conflitantes durante sua elaboração foram as relativas às nacionalizações, ao controle de investimentos estrangeiros, ao status jurídico das empresas multinacionais, à transferência de ciência e tecnologia; todas elas representando a expressão da capacidade dos Estados em incidir na mudança das atuais relações econômicas internacionais. Estas questões aparecem reguladas na Carta no mesmo sentido da Declaração e do Programa de Ação sobre a nova ordem econômica internacional.

\section{d) O Desenvolvimento Progressivo dos princípios da NOEI}

Uma vez formuladas estas premissas jurídicas da NOEI, através de resoluções da $A G$, a questão seguinte que se propunha era referente ao valor jurídico dessa NOEI. Isto remete a duas questões de caráter geral: de um lado, o valor das resoluções e declarações da $A G$ da ONU, e, de outro, a referência aos princípios gerais de Direito Internacional, que levam ao seguinte questionamento: até que ponto a formulação da NOEI constitui um aprofundamento dos princípios 
contidos na Carta da ONU, quando esta trata das relações econômicas internacionais?

Nesta linha, a ONU procedeu a um exame amplo do tema sob o título de Desenvolvimento Progresso dos princípios e normas do Direito Internacional relativos a NOEI. O tema foi introduzido na $\mathrm{AG}$ por proposta das Filipinas, por entender que "as resoluções sobre a NOEI contém, em seu conjunto, princípios e normas de direito econômico que devem reger as relações entre os Estados de diversos níveis de desenvolvimento e diferentes sistemas econômicos", e que, por consequência, conforme o artigo 13.1 da Carta, é a AG quem deve proceder à sua consolidação.

Por decisão da AG de 15 de dezembro de 1975, o tema foi atribuído a uma comissão especializada, que recomendou à AG encarregar à UNITAR (Instituto da ONU para Formação Professional e a Investigação) a preparação de "uma lista dos princípios e normas existentes e em evolução do direito internacional relativos a NOEI, que concernem às relações econômicas entre Estados, organizações internacionais e outras entidades de direito internacional, e às atividades das empresas transnacionais".

O resultado desta investigação levada adiante pela UNITAR foi a identificação de certos princípios já consagrados pela prática dos Estados, ou em período de formação, e que estão na base da NOEI.

Conforme a análise da UNITAR, os princípios são os seguintes:
a) tratamento preferencial para países em desenvolvimento;
b) estabilidade da receita de importação (balanço de pagamentos) dos países em desenvolvimento;
c) soberania permanente sobre os recursos naturais;
d) direito dos estados de se beneficiar da ciência e da tecnologia;
e) direito dos países em desenvolvimento a receber assistência para o desenvolvimento;
f) igualdade de participação dos países em desenvolvimento nas relações econômicas internacionais;
g) patrimônio comum da humanidade;
h) liberdade de eleição do sistema econômico. 
Finalizada a tarefa da UNITAR, o tema foi retomado na AG em 1991, criando no marco da comissão especializada um grupo de trabalho encarregado de desenvolver os princípios e normas de direito internacional relativos a NOEI. Desde então, a AG nunca mais se manifestou sobre o tema.

De forma pontual, a NOEI foi igualmente objeto de atenção na Comissão das Nações Unidas para o Direito Internacional do Comércio (UNCITRAL). O tema foi incluído na Comissão de Direito Internacional, mesmo com a oposição de diversos países industrializados, que não consideravam oportuno incluir o tema entre os trabalhos de codificação da Comissão.

Como conclusão, pode-se afirmar que, na prática, estes princípios só tiveram uma aplicação parcial e limitada a alguns aspectos do desenvolvimento dos países subdesenvolvidos. Não obstante, sua formulação tem tido uma incidência significativa no desenvolvimento progressivo do direito internacional, na medida em que ditos princípios supõem uma postulação jurídica diferente dos direitos e obrigações dos Estados no que diz respeito ao desenvolvimento dos países subdesenvolvidos.

\subsection{A NATUREZA PECULIAR DO DIREITO INTERNACIONAL DO DESENVOLVIMENTO}

a) A configuração doutrinária do DID

O conceito de direito internacional do desenvolvimento foi pela primeira vez lançado em 1964, nas primeiras reuniões da UNCTAD ocorridas em Genebra e 
Nice, por André Philip ${ }^{56}$, Membro da seção francesa da Internacional Socialista, e um dos idealizadores da UNCTAD. Posteriormente, sua concepção foi detalhada e aprofundada por Michel Virally, catedrático do Instituto de Altos Estudos Internacionais de Genebra, em um estudo intitulado "vers um droit international du developpment" ${ }^{\prime 57}$.

Como sugeria Michel Virally à época das primeiras formulações do DID:

Deve-se partir de regras e de práticas existentes que constituem atualmente "o direito internacional das desigualdades do desenvolvimento"; a partir daí, poder-se-á averiguar com os meios fornecidos do direito internacional, as adaptações necessárias. Sobre a base dos grandes princípios desenhados no nível da comunidade internacional, cada estado pode, no âmbito da sua soberania e de sua ordem jurídica, estabelecer as medidas necessárias ao seu desenvolvimento. ${ }^{58}$

Neste sentido, o DID teria como objetivo a redução significativa da pobreza em que vive a maior parte da população mundial e dos seus efeitos mais dramáticos sobre os direitos fundamentais (tais como: fome, baixa expectativa de vida, altas taxas de mortalidade infantil, acesso reduzido à educação e a saúde, analfabetismo).

Para alcançar tais objetivos, o DID se propôs a reformar as estruturas da ordem econômica internacional e redistribuir mais equitativamente a renda do planeta entre os países ricos e pobres, reduzindo assim as enormes diferenças de desenvolvimento econômico e social entre os diferentes Estados que compõe a sociedade internacional.

Conforme Antonio Augusto Cançado Trindade:

o direito internacional do desenvolvimento, com seus vários componentes, emerge como um sistema normativo internacional objetivo a regular as relações entre Estados juridicamente iguais, mas economicamente desiguais e visando a transformação destas relações, com base na cooperação internacional e em considerações de equidade, de modo a remediar os desequilíbrios econômicos entre os Estados e a proporcionar a

\footnotetext{
56 Os primeiros elementos são encontrados em um artigo de sua autoria, de setembro de 1964, (PHILIP, André. developpment et civilisation, setembro de 1964); depois sua contribuição ao Colóquio de Nice (PHILIP, André. l'adaptation de l'ONU au monde d'aujord'hui, maio de 1965).

${ }^{57}$ VIRALLY, Michel. Vers um droit international du developpment. AFDI, 1965.

${ }^{58}$ VIRALLY, op. cit., p. 3.
} 
todos os Estados - particularmente os países em desenvolvimento oportunidades iguais para alcançar o desenvolvimento. ${ }^{59}$

Nesse mesmo sentido, de acordo com Ignacio Barona et al:

O Direito Internacional do Desenvolvimento (DID) é formado por um conjunto de princípios e regras jurídicas que visam reger o comportamento e as relações entre países desenvolvidos e países em desenvolvimento. É composto de normas de cooperação mútua que consideram as desigualdades existentes entre Estados e as falhas do mercado, de forma a inserir na agenda internacional o tema da redistribuição de riqueza no plano internacional, em função de critérios de justiça e equidade. ${ }^{60}$

O DID, enquanto expressão jurídica da "Nova Ordem Econômica Internacional", se refere a um conceito preciso de relações entre países desenvolvidos e os países subdesenvolvidos ou países em desenvolvimento, e a um conteúdo específico de estratégia internacional para o desenvolvimento.

Trata-se de um conceito preciso, pois supõe "uma tentativa de reestruturação do próprio marco institucional existente, com o objetivo de que o sistema econômico internacional possa respaldar os esforços dos países em desenvolvimento". Com isso, se contrapõe a concepção das estratégias anteriores para a $1^{\mathrm{a}}$ e a $2^{\mathrm{a}}$ décadas para o desenvolvimento, que se limitavam à adoção de medidas que visavam uma melhor redistribuição de renda em nível mundial, mas que em absoluto questionavam as relações e o sistema econômico internacional, em que dita renda se produz.

Igualmente, trata-se de um conteúdo específico, pois a novidade da NOEI são as medidas relativas à reforma do quadro institucional em que se estabelecem as relações entre os países desenvolvidos e os países em desenvolvimento (por exemplo, medidas que visavam introduzir mudanças na atual divisão internacional do trabalho e no comércio internacional), e às dirigidas a consolidar o denominado princípio da autonomia ou da auto-suficiência coletiva.

Tal princípio consiste em dar prioridade às relações de cooperação e integração econômica dos países em desenvolvimento entre si, sobre a base do

${ }^{59}$ CANÇADO TRINDADE, Antonio Augusto. Direitos humanos e meio ambiente: paralelos dos sistemas de proteção internacional. Porto Alegre: Fabris, 1993, p. 176.

${ }^{60}$ BARONA, Ignacio et al (2011), op. cit., p. 369. 
controle por estes países de seus próprios recursos naturais. Com isto se opera uma mudança significativa na própria concepção da estratégia de desenvolvimento, já que o eixo tradicional desta estratégia - as relações norte-sul, como centro da cooperação internacional para o desenvolvimento - é substituído pelas relações entre os próprios países em desenvolvimento - as relações sul-sul, como meio de diminuir a dependência econômica dos países em desenvolvimento com respeito aos países desenvolvidos, e a de aumentar sua capacidade de negociação frente aos mesmos.

\section{b) A transformação do direito internacional pelo mundo em desenvolvimento}

Como precedentemente afirmado, o processo de descolonização acabou com a uniformidade política e jurídica, o que fez o debate sobre a igualdade formal evoluir para a noção de igualdade material, para que os desiguais fossem tratados de forma desigual. Essa é a questão de fundo da crítica da igualdade soberana (formal), fundamentada sobre uma base abstrata, que ignora um pressuposto fático fundamental: as diferenças de desenvolvimento entre países desenvolvidos e países em desenvolvimento.

Os países em desenvolvimento, quando da descolonização, conquistaram a igualdade jurídica, mas assistiram à manutenção de sua desigualdade material. A independência jurídica não foi acompanhada de independência política e econômica. Pela primeira vez na história das relações internacionais, existe concomitantemente um conjunto de estados com igualdade jurídica entre si, mas com o reconhecimento expresso de desigualdade econômica entre si.

Antes da formulação do DID, o processo de desenvolvimento nacional supunha, em princípio, uma mobilização das políticas nacionais e uma organização do país em favor do desenvolvimento, uma intervenção enérgica do Estado e a participação ativa da população. Nesse sentido, o direito interno serviria ao objetivo de reorientar todas as ordens jurídicas em torno do imperativo do desenvolvimento. 
No entanto, um dos principais legados do movimento do Terceiro Mundo e do DID é a constatação de que o processo de desenvolvimento não pode - e não deve - ser percebido apenas desde sua perspectiva interna. Primeiramente, porque muito dos fenômenos econômicos ultrapassam os limites do território estatal (moeda, comércio, crédito, mão-de-obra). Em seguida, porque as economias menos favorecidas precisarão de uma conjunção de fatores exteriores para se desenvolver, uma conjunção que os grandes organismos financeiros internacionais terão que avaliar.

Afirma-se que o movimento do Terceiro Mundo tinha natureza revolucionária, tendo em vista sua natureza de oposição aos princípios vigentes na ordem internacional, propugnando o lançamento das bases de um novo contrato social internacional.

No entanto, o direito do desenvolvimento não é mais o direito do Terceiro Mundo, ou fruto de uma ideologia particular; ele é verdadeiramente, o direito internacional, ou seja, o direito da comunidade de nações. O direito do desenvolvimento não se apresenta mais como um direito revolucionário, em ruptura com o direito internacional dito clássico. ${ }^{61}$

O direito internacional, que deve ser todo o contrário de algo imutável e estático, pois desempenha uma função social, está vinculado, necessariamente, às transformações do mundo. Ao mundo bipolar e oligárquico correspondeu um "direito internacional do confisco": confisco das independências e da soberania de uns estados satélites de blocos. Ao contrário, ao mundo multipolar que se está por construir, corresponderá um "direito internacional de participação", participação de todos os Estados na formulação e na aplicação das normas que regem as relações entre eles.

Assim, durante os 30 anos de formulação do DID, houve um esforço considerável no plano doutrinal, institucional e normativo para se ter em conta a

\footnotetext{
${ }^{61}$ Isto porque ele não renega nenhum dos fundamentos tradicionais do direito internacional, em particular a soberania do Estado; se ele introduz uma finalidade econômica nova, não está mais em contradição com a finalidade geral do direito que é alcançar a justiça e a paz. Bem ao contrário, ele introduz mais exigência e mais precisão na realização desta finalidade; ele mitiga o imperativo da soberania, ele rejeita a hipocrisia e a boa consciência de um normativismo que se esquece do essencial. Ver FLORY. op. cit., p. 30.
} 
desigualdade do desenvolvimento e aportar seus remédios. O cenário econômico conduziu à necessidade de intervenção do direito internacional. Os Estados aceitaram instituir um conjunto de instituições destinadas ao avanço da solução deste problema. $^{62}$

O direito internacional se dota de uma finalidade precisa, de que ao desenvolvimento econômico se agrega a ideia geral de paz. Esta finalidade tende a transformar o antigo direito internacional liberal, que sempre respeitou a liberdade e a autonomia de cada Estado, em um direito internacional intervencionista, que vai procurar regulamentar com um viés do desenvolvimento, as relações econômicas internacionais.

\section{c) A crise do direito internacional do desenvolvimento}

O DID evoluiu ao longo do tempo até se transformar em uma ordem jurídico-política com ênfase no desenvolvimento principalmente econômico, na qual se objetivava a reforma da ordem econômica internacional, como solução aos problemas dos países pobres.

Ao final da Terceira Década do Desenvolvimento da ONU, já em plena era da globalização neoliberal, o DID passou a viver uma crise de legitimidade nos fóruns internacionais. O dirigismo econômico ficou ultrapassado. O espírito de Bandung desapareceu. Ao final do século XX, a pá de cal do movimento do Terceiro Mundo, e juntamente com ele, do DID, veio com o Consenso de Washington.

O conceito de Terceiro Mundo fazia sentido na política dos anos 60 . Marginalizado nos anos 80, ficou completamente morto nos anos 90. Mas a realidade à qual pertencia permanece, hoje, de forma ainda mais manifesta do que ontem. O quadro no qual foi forjado - a Guerra Fria - desapareceu. Mas o novo quadro que o substituiu - a Globalização - clarificou as verdadeiras questões: a

\footnotetext{
${ }^{62}$ FLORY, op. cit., p. 28.
} 
inacreditável polarização da economia-mundo capitalista e sua crise estrutural, que colocou a comunidade internacional diante de escolhas históricas. ${ }^{63}$

No entanto, como será demonstrado na Parte III desta tese, ao final dos anos 90, o DID não estava superado. A sua natureza transformadora e revolucionária alcançaria novos horizontes, expandindo-se até a concepção atual de desenvolvimento humano, sustentável e integrado que balizou a década de 90 e a primeira década do século XXI, orientando os Objetivos do Desenvolvimento do Milênio da ONU e pautando as negociações da Rodada Doha da Organização Mundial do Comércio.

${ }^{63}$ WALlerteIN, Immanuel. O que era mesmo o Terceiro Mundo? in Biblioteca Diplô. Agosto, 2000. In http://diplo.org.br/2000-08,a1805. Acesso em 18/05/2012. 


\section{CONCLUSÕES DO CAPÍTULO 1}

A história do direito internacional do desenvolvimento é a história da luta pela independência - política, econômica e cultural - das nações que viveram durante séculos na periferia mundial.

Os fundamentos jurídicos originários do processo de colonização levado adiante entre os séculos XV e XVIII permaneciam vigentes na segunda metade do século XX. Se, por um lado, conferiam igualdade jurídica e legitimidade política aos novos Estados, por outro, ignoravam a desigualdade econômica e o subdesenvolvimento das ex-colônias, que estavam se tornando independentes desde o século XIX. A composição da comunidade internacional se alterava, enquanto o direito internacional permanecia estático.

Até o fim da $2^{\mathrm{a}}$ Guerra, o direito internacional é eurocêntrico. A partir da descolonização do Sul, altera-se substancialmente a geopolítica das Relações Internacionais. O processo de descolonização provoca uma mudança da agenda internacional, com a passagem do foco securitário da Guerra Fria para a pauta desenvolvimentista.

Com o processo de descolonização do pós-guerra, a comunidade internacional, passa por uma transformação radical, tanto do ponto de vista quantitativo, pelo aumento vertiginoso do número de novos Membros, quanto qualitativo, pelo surgimento de alianças diplomáticas das antigas colônias, novos Estados independentes.

Em razão do processo maciço de libertação e independência das antigas colônias e o consequente surgimento e articulação do Terceiro Mundo, a mera igualdade formal já não mais bastaria para a manutenção da ordem internacional. O Terceiro Mundo alegava que era necessário o reconhecimento jurídico da desigualdade econômica entre os Estados e, a partir daí, construir um novo sistema jurídico-político internacional, no âmbito das organizações internacionais, que pudesse ser condizente com a nova configuração mundial. 
Esta transformação na geopolítica internacional levou à articulação do Terceiro Mundo e à institucionalização do Movimento dos Não-Alinhados (MNA) e do Grupo dos 77 (G77). No âmbito de tais articulações é gerido o Direito Internacional do Desenvolvimento (DID), com um objetivo revolucionário: tentar transformar as premissas - jurídicas e políticas - vigentes para passar a consolidar a questão do desenvolvimento enquanto fundamento jurídico efetivo das relações internacionais.

Foi no âmbito da ONU e de seus órgãos que a mudança na composição estrutural da comunidade internacional se fez sentir de maneira mais emblemática, e fez com que a ONU servisse de plataforma para alavancar reformas em outras organizações internacionais e tratados internacionais, especialmente o GATT.

Ademais, tão importante quanto a reforma era a formulação de planos de ação no âmbito das organizações internacionais, para que o abismo de desigualdade fosse efetivamente encurtado e aproximado. A partir das "décadas da ONU para o desenvolvimento", a comunidade internacional passou a forjar um conjunto de regras que se convencionou chamar de direito internacional do desenvolvimento. Nesse momento, tanto a CEPAL quanto a UNCTAD exerceram papel de destaque na formulação e na condução desse sistema internacional emergente.

Muito embora o conjunto jurídico do DID seja alvo de numerosas críticas e defeitos por parte dos países Membros da comunidade internacional, são inegáveis os méritos do direito internacional do desenvolvimento, pois foi no âmbito deste movimento de reforma da arquitetura política e jurídica das relações internacionais, que os países em desenvolvimento lograriam o reconhecimento de dita desigualdade econômica no âmbito do sistema multilateral de comércio. O Terceiro Mundo finalmente alcançaria sua missão: transformar os fundamentos da ONU e do direito internacional clássico.

Como se verá no capítulo seguinte, um dos ramos mais influenciados pelo DID foi o Direito Internacional Econômico, mais especialmente aquele decorrente do Sistema Multilateral de Comércio, no âmbito do Acordo Geral de Tarifas e Comércio (GATT). 


\title{
CAPÍTULO 2. AS PRERROGATIVAS JURÍDICAS PARA O DESENVOLVIMENTO NO SISTEMA MULTILATERAL DE COMÉRCIO DO GATT
}

\begin{abstract}
A regra da igualdade não consiste senão em quinhoar desigualmente aos desiguais, na medida em que se desigualam. Nesta desigualdade social, proporcionada à desigualdade natural, é que se acha a verdadeira lei da igualdade. O mais são desvarios de inveja, do orgulho ou da loucura. Tratar com desigualdade a iguais ou a desiguais com igualdade seria desigualdade flagrante e não igualdade real.
\end{abstract}

Rui Barbosa, Oração aos moços, 1949 


\section{APRESENTAÇÃO DO CAPÍTULO 2}

O capítulo 2 analisa o processo de incorporação do direito internacional do desenvolvimento pelo sistema multilateral de comércio. É a partir da influência do DID nas negociações do GATT que uma série de prerrogativas jurídicas em prol do desenvolvimento vão se consolidando no sistema multilateral de comércio.

O subcapítulo 2.1 analisa o tratamento da questão do desenvolvimento nas negociações iniciais da OIC e do GATT, a fim de compreender a natureza da participação e as posições dos países em desenvolvimento nas negociações, bem como identificar a existência - ou não - de alguma prerrogativa especifica para os países em desenvolvimento quando da entrada em vigor do GATT.

O subcapítulo 2.2 trata do artigo XVIII do GATT, um dispositivo voltado à promoção das indústrias nascentes, destinando tanto aos países em desenvolvimento quanto aos países industrializados que estavam no processo de reconstrução do pós-guerra. Nessa seção, serão analisadas as principais regras constantes no artigo XVIII, o histórico da sua aplicação, a revisão pela qual sofreu em 1955, até chegar a um balanço da sua vigência ao longo do Período GATT.

O subcapítulo 2.3 aborda o surgimento da Parte IV do GATT, como resultado mais marcante da influência do DID no sistema multilateral de comércio. Nessa seção, serão avaliadas as principais contribuições da Parte IV do GATT, por meio do princípio da não-reciprocidade, as suas limitações, bem como seus impactos sobre o avanço das negociações ao longo do período GATT.

Por fim, o subcapítulo 2.4 detalha a consolidação da Cláusula de Habilitação, Para tanto, em um primeiro momento, será realizada uma breve apresentação da Rodada Tóquio (73-79), na qual os países em desenvolvimento tiveram a maior capacidade de coordenação e legitimação das suas reivindicações, que resultou na consolidação permanente das três prerrogativas clássicas para os países em desenvolvimento, quais sejam: o Sistema Geral de Preferências; o Sistema Global de Preferências Comerciais e; a Integração Regional envolvendo países em desenvolvimento. 


\subsection{A PRERROGATIVA DO DESENVOLVIMENTO NAS NEGOCIAÇÕES OIC/GATT}

\section{a) $\mathrm{O}$ contexto antecedente às negociações da OIC/GATT}

Antes de ingressar na análise do processo negociador da OIC e do GATT, faz-se necessário tecer alguns comentários sobre três elementos que estão presentes no cenário do final da $2^{\mathrm{a}}$ Guerra Mundial, que influíram diretamente no processo de negociação do sistema multilateral de comércio: a) a proximidade histórica do período de graves guerras comerciais entre as grandes potências; $b$ ) as limitações impostas pelo fast-track dos EUA, isto é, pelos poderes outorgados pelo congresso dos EUA para negociação de acordos comerciais; c) as reivindicações dos países em desenvolvimento por um sistema econômico mundial menos prejudicial a eles. Estes elementos devem ser levados em consideração para contextualizar as principais condicionantes que viriam a influenciar diretamente os resultados das negociações da OIC e do GATT.

\section{i. As recentes guerras comerciais}

Do ponto de vista econômico, a Grande Depressão detém parcela considerável da culpa pela $2^{\mathrm{a}}$ Guerra Mundial. Durante a $2^{\mathrm{a}}$ Guerra, havia uma certeza, além da excessiva austeridade das medidas impostas contra a Alemanha pela $1^{\text {a }}$ Guerra Mundial por meio da Paz de Versalhes, de que os maiores erros cometidos pelas grandes potências foram em matéria de políticas comerciais. ${ }^{64}$

O período do entre-guerras, que durou de 1920 a 1939, foi marcado pela proliferação de diversas técnicas protecionistas, dentre as quais se destacaram o

${ }^{64}$ KEYNES, John Maynard. As Conseqüências Econômicas da Paz. São Paulo: Imprensa Oficial do Estado, 2002. 
recurso às barreiras tarifárias, bem como às praticas de dumping, subsídios, desvalorização monetária, apontadas no seu conjunto como uma das causas mediatas que resultaram na eclosão da $2^{\text {a }}$ Guerra Mundial. Um exemplo marcante das políticas comerciais desta época é o US Smoot-Hawley Tariff Act de 1930, por meio do qual os EUA elevaram mais de 20.000 tarifas para proteção de produtos nacionais, elevando o nível tarifário dos EUA para o maior nível da sua história. ${ }^{65}$

Como reação mundial ao US Tariff Act, o que se viu foi uma série de protestos e retaliações por parte de vários outros países, que eram parceiros comerciais dos EUA e que, caso não tivessem acordos comerciais bilaterais em vigor com os EUA, ficariam sujeitos a tais barreiras tarifárias. Consequentemente, tais países seguiram o exemplo estadunidense e iniciaram uma série de medidas protecionistas que, além das elevações tarifárias, impuseram restrições quantitativas por quotas.

A generalização deste enfoque levou a uma espiral de guerras comerciais, que estrangulou as vias do comércio internacional e desencadeou ondas protecionistas ao redor do mundo. O resultado final foi o agravamento da crise econômica. Por exemplo, o índice de desemprego norte-americano, que estava na casa dos $8 \%$ em 1930, atingiu a impressionante marca de $25 \%$ em menos de três anos. $^{66}$

Ao final da Segunda Guerra Mundial, para evitar o resurgimento da situação do entre-guerras, restava claro para a comunidade internacional que seria necessário estabelecer um sistema jurídico-político-institucional que prevenisse, ou ao menos, limitasse, o uso de tais instrumentos de política econômica e comercial. Os pronunciamentos dos vencedores da $2^{\mathrm{a}}$ Guerra tinham o sentido ressaltar a importância de se estabelecer instituições econômicas do pós-guerra que prevenissem a repetição dos erros em matéria de política comercial.

Neste sentido, em 1944, foi realizada a Conferência de Bretton Woods, nos Estados Unidos (EUA), com o objetivo de consolidar um ambiente de ampla

\footnotetext{
${ }^{65}$ JACKSON, John H. The World Trading System: law and policy of international economic relations. Boston, MIT, 2002, p.36.

${ }^{66}$ JACKSON, op.cit., (1969), p. 27.
} 
cooperação em áreas vitais da economia internacional: as dimensões comercial, monetária e bancária. O resultado dessa conferência ficou conhecido como o Acordo de Bretton Woods. ${ }^{67}$

Nesse Acordo, decidiu-se pela criação de três organizações internacionais. A primeira organização seria o Fundo Monetário Internacional (FMI), com a função de manter a estabilidade das taxas de câmbio e assistir aos países com questões envolvendo balanço de pagamentos. Para isso, disporia de fundos especiais de saques que garantiriam tal estabilidade, e assim, desestimularia a prática corrente até então de utilizar restrições ao comércio cada vez que surgisse um desequilíbrio do balanço de pagamentos.

A segunda organização seria o Banco Mundial, também chamado de Banco Internacional para Reconstrução e Desenvolvimento (BIRD), cuja finalidade era fornecer capitais necessários para a reconstrução dos países atingidos pela guerra e financiar o desenvolvimento econômico dos países subdesenvolvidos.

A terceira seria a Organização Internacional do Comércio (OIC), que teria a função de coordenar a negociação das regras de comércio internacional e supervisionar o cumprimento das mesmas, baseada em dois princípios: multilateralismo e consolidação tarifária. O primeiro tinha o objetivo de reduzir o grau de bilateralidade discriminatória decorrente dos acordos comerciais, que estabeleceram as zonas de influência comercial do entre-guerras; o segundo objetivava não uma liberalização absoluta do comércio internacional, mas apenas impedir o aumento das tarifas consolidadas e acordadas entre as partes do sistema muliltilateral de comércio, evitando o ressurgimento das escaladas protecionistas em nível global.

ii. O Fast-Track dos EUA

${ }^{67}$ Para maiores informações sobre as Reuniões de Bretton Woods, o FMI e o BIRD, ver ALMEIDA, op.cit.; GILPIN, Robert. The political economy of international relations. Nova Jersey: Princeton University Press, 1987; JACKSON, op.cit., (2002). 
Outro elemento marcante para o processo de negociação da OIC e do GATT foi o fast-track dos EUA. Paralelamente às negociações para a constituição do sistema de Bretton Woods, os Estados Unidos já haviam iniciado um amplo programa de acordos comerciais, sob os auspícios do fast-track concedido pelo Congresso Nacional ao Poder Executivo, denominado Reciprocal Trade Agreements Act, de $1934 .^{68}$

Com base neste fast-track, os EUA celebraram, entre 1934 e 1942, 27 acordos bilaterais de comércio, incluindo 16 países em desenvolvimento, quase a totalidade da América Latina: Cuba, Haiti, Brasil, Honduras, Colômbia, Guatemala, Nicarágua, El Salvador, Costa Rica, Equador, Turquia, Venezuela, Argentina, Peru, Uruguai e México. Inclusive, afirma-se que o acordo com o México, de 1942, o último e mais avançado dos acordos bilaterais, foi o modelo utilizado pelos EUA para elaborar a primeira versão do GATT, apresentada em 1946.

Este fast-track foi peculiar, pois o Congresso havia autorizado as negociações com base na extensão do Reciprocal Trade Agreements Act de 1945, que apenas autorizava o presidente a firmar acordos de redução tarifária, mas não autorizava a adesão às organizações internacionais. Nesse sentido, na tentativa de moldar o texto da OIC para aprovação no Congresso dos EUA, os negociadores precisariam deixar expresso que as decisões multilaterais da organização seriam tomadas pela "ação conjunta das partes contratantes", em vez de por um órgão de uma organização internacional.

Em 1945, o Congresso reeditou o Reciprocal Trade Agreements Act por um novo triênio e foi sob a vigência deste fast-track que o Poder Executivo dos EUA tomou parte das negociações da OIC e do GATT. No entanto, durante as negociações da OIC, o presidente dos EUA e seus negociadores perceberam que a criação de uma organização internacional do comércio, caso constituída, deveria ser submetida ao Congresso para aprovação.

Como se verá mais adiante, foi na vigência de um fast-track que se limitava a autorizar a celebração de acordos de redução tarifária, gerando tal dualidade na

${ }^{68}$. In HUDEC, Robert E. Developing Countries in the GATT/WTO legal System. Washington: Cordell Hull Institute, 1987, p. 19. 
política comercial norte-americana - firmava acordos bilaterais e, ao mesmo tempo, negociava um acordo multilateral - que viria a se verificar a grande causa do fracasso da OIC.

iii. As necessidades dos paises em desenvolvimento

Do ponto de vista dos países em desenvolvimento, as preocupações eram outras. Ao adentrar as negociações para a criação do sistema multilateral de comércio, os países em desenvolvimento estavam envolvidos por um contexto histórico-econômico que balizou de forma direta as posições destes países nas negociações. James Scott propõe que este contexto pode ser apresentado por três condicionantes: a) as políticas de colonialismo industrial; b) a flutuação do preço das commodities e; c) o paradoxo tarifário. ${ }^{69}$

Além da necessidade dos países em desenvolvimento de se industrializarem, para garantir o fornecimento de bens manufaturados sem depender dos países industrializados, havia igualmente um forte desejo de industrialização decorrente do recente sentimento de independência política e econômica, como resposta ao legado das políticas de colonialismo industrial a que estiveram submetidos muitos dos países em desenvolvimento.

Como afirma Hudec, "antes de 1939, o princípio organizacional das relações econômicas internacionais entre países ricos e pobres era o colonialismo". A maioria dos países da África e da Ásia era composta por colônias, do ponto de vista do direito internacional. ${ }^{70}$

\footnotetext{
${ }^{69}$ SCOTT, James. Developing Countries in the ITO and GATT negotiations. In Journal of World Trade Law and Policy. Vol. 9, n ${ }^{\circ}$ 1, 2010, p. 11.

${ }^{70}$ Quando a OIC estava prestes a ser negociada, o poder econômico e comercial estava altamente concentrado nos EUA. Em 1948, os EUA controlavam 3/4 das reservas globais de ouro, e correspondiam a $1 / 3$ das exportações mundiais, enquanto ocupavam apenas a $10^{\mathrm{a}}$ posição no ranking das importações globais. No entanto, o Reino Unido e a França, com seus extensos impérios coloniais, ainda exerciam grande relevância. Portanto, a necessidade de afirmação econômica dos países recém-descolonizados era vital. In SCOTT. Op. cit.p. 12.
} 
A experiência colonial pode ser considerada a primeira das muitas desindustrializações sofridas pelos países colonizados. Os primeiros anos do colonialismo foram de alto protecionismo por parte dos países colonizadores contra produtos manufaturados competitivos de países colonizados, enquanto a produção doméstica se capacitava para a concorrência. Paul Bairoch ilustra com clareza:

\begin{abstract}
No início do século XVII, as indústrias manufatureiras da Inglaterra haviam conseguido banir as importações dos têxteis indianos; mas entre 1769 e 1813, a indústria algodoeira inglesa havia se mecanizado. Isto levou a um enorme aumento de produtividade no setor, que passava por uma completa reversão na estrutura comercial: A Índia agora estava forçada a reverter de exportador de bens manufaturados (cerca de $70 \%$ das suas exportações) à importadora de têxteis ingleses em troca de algodão in natura e outros produtos agrícolas. ${ }^{71}$
\end{abstract}

Nesse sentido, a política comercial colonial de abertura comercial do país colonizado, em paralelo ao fechamento do país colonizador, levou a uma desindustrialização massiva das colônias ao longo do século XIX. Logo, esta política comercial - denominada por Bairoch de Liberalismo Econômico Compulsório desempenhou papel crucial no empobrecimento dos países coloniais. ${ }^{72}$

Este aspecto do período colonial não foi esquecido pelos países em desenvolvimento, em especial pela Índia, ao ingressar nas negociações da OIC. Havia a sensação de que as potências colonizadoras tinham tentado impedir a industrialização das colônias e que esse impedimento continuaria nas negociações da OIC. ${ }^{73}$

Com esse contexto de suspeitas e preconceitos arraigados do período colonialista das relações internacionais, não surpreende o fato de o projeto de negociação da OIC e do GATT estar eivado de suspeitas de ambas os lados, tanto das ex-colônias como dos ex-colonizadores.

\footnotetext{
${ }^{71}$ BAIROCH, Paul. The paradoxes of economic history: Economic laws and history, European Economic Review, Elsevier, vol. 33, 1989. pp. 225-249.

${ }^{72} \mathrm{O}$ conceito de livre comércio ficou manchado pelo legado do colonialismo. Enquanto os países recém descolonizados alcançavam suas independências, não é de surpreender que eles desejassem reverter às políticas que eles haviam sido forçados a adotar pelos governos colonizadores. Para tanto, demandavam por liberdade para utilizar das medidas de proteção e restrição comerciais que as antigas potências colonizadoras haviam lançado mão no passado. A liberdade política recém alcançada clamava também por liberdade na implantação de políticas comerciais. In BAIROCH, op. cit., p. 231.

${ }^{73}$ SCOTT, op. cit., p. 11.
} 
O segundo problema a ser enfrentado era a flutuação dos preços das commodities, a ideia da criação de um sistema de liberalização comercial, que confiaria nos mercados internacionais para manutenção da estabilidade e lucratividade, tanto em termos de demanda como de preços, não era muito atrativa para aqueles países em desenvolvimento dedicados fundamentalmente à exportação de commodities.

Isto porque, ao longo da primeira metade do século $\mathrm{XX}$, estes países em desenvolvimento haviam enfrentado as maiores crises nas suas exportações, decorrentes de três graves choques externos: a primeira guerra mundial, a grande depressão e a segunda guerra mundial. Estes três eventos que marcaram o comércio internacional ao longo da primeira metade do século $\mathrm{XX}$, e que precediam as negociações da OIC, fizeram que com que os países em desenvolvimento perdessem a confiança na estabilidade do mercado mundial e se assegurassem de que teriam capacidade de produzir bens manufaturados no plano nacional, em vez de continuar dependendo simultaneamente de exportações de commodities, como das importações de manufaturados, da Europa e dos EUA. ${ }^{74}$

Por fim, a questão do paradoxo tarifário. Além do recente legado colonialista, que maculava a ideia de livre comércio levada adiante nas negociações da OIC, outro ponto surgiu como desafeto do projeto de liberalização comercial do pósguerra. $O$ fato de que as experiências de desenvolvimento levadas adiante nos séculos XIX e XX pelas potências industriais pouco contribuíam para consolidar os argumentos em torno dos benefícios do livre-comércio.

Os historiadores da economia afirmam que o protecionismo durante este período estava geralmente atrelado a maiores taxas de crescimento e liberalização comercial com menor crescimento. Bairoch sustenta que:

\footnotetext{
${ }^{74}$ Tais crises, todas com origem externa às economias dos PED, tiveram forte repercussão nos preços das commodities. Por isso, os argumentos para uma estratégia de desenvolvimento orientado por exportações não eram muito convincentes, ao final de segunda guerra mundial. Muito pelo contrário. O impacto mais notável destas três crises econômicas mundiais foi o ímpeto que todas deram aos PED de reduzirem a dependência econômica das exportações de commodities, por meio do estabelecimento de processos ISI. Este impulso se deu de maneira marcante na América Latina. Este processo foi aprofundado pela Segunda Guerra Mundial. Indústrias criadas durante o período entre-guerras passaram a necessitar ainda mais de proteção estatal, tendo em vista a recuperação das indústrias mais competitivas e eficientes que estava em marcha na Europa.
} 
É quase certo que durante o século XIX, ao contrário do modelo clássico, para muitos dos atuais países desenvolvidos, senão todos, livre comércio significou depressão econômica, e proteção significou crescimento e desenvolvimento. Também é certo que, para os atualmente denominados países em desenvolvimento, a liberalização comercial na época significou a aceleração do processo de subdesenvolvimento econômico. ${ }^{75}$

Ou seja, os países em desenvolvimento que estavam ingressando nas negociações da OIC tinham pouquíssimas bases empíricas que os convencessem a aceitar a ideia de livre-comércio. Pelo contrário, as lições da história econômica ensinavam o oposto, em especial, na América Latina. De acordo com Victor Bulmer-Thomas:

O modelo de industrialização pela substituição de importações desempenhou um papel fundamental no período posterior à Grande Depressão, especialmente na recuperação da Argentina, Brasil, Chile, Colômbia, Costa Rica, México e Peru. Para estes países, a associação positiva entre proteção e crescimento antes de 1939 refutava enfaticamente qualquer argumento no sentido contrário. ${ }^{76}$

Com base nestes três elementos históricos analisados brevemente nesta seção - os impactos dos choques econômicos da primeira metade do século XX, o ranço colonialista e as lições protecionistas das potências industriais - é que os países em desenvolvimento ingressaram nas negociações do OIC.

Nesse sentido, Hudec afirma que, pelo fato de a OIC se propor a ser uma organização internacional com natureza de governança econômica global, essa responsabilidade lhe era inata:

De acordo com as regras políticas do século XX, o poder de governar geralmente traz consigo o dever de tomar conta dos Membros menos privilegiados do grupo a ser governado. Por isso, era natural que os Membros menos privilegiados da comunidade da OIC achassem que os demais Membros deveriam "fazer algo a respeito" para ajudá-los. A OIC não tinha dinheiro para dar, apenas regras. Portanto, assistência e benefícios legais era a ajuda a ser buscada nas negociações. ${ }^{77}$

\footnotetext{
${ }^{75}$ BAIROCH, op. cit., p. 225-249.

${ }^{76}$ BULMER-THOMAS, Victor apud BETHELL, Leslie (Org). História da América Latina (Vol. 6). São Paulo: EDUSP, 2009.

${ }^{77}$ HUDEC, op. cit.p. 23.
} 
No entanto, apesar desses elementos, o que se viu ao longo das negociações é que tais condicionantes não se traduziram em oposição por parte dos países em desenvolvimento ao surgimento da OIC em si, tampouco ao GATT. Ao contrário, se tivesse de surgir um projeto de organização internacional para regulação do comércio mundial, que este contemplasse as peculiaridades das necessidades específicas dos países em desenvolvimento e que não se esquecesse das lições da história.

\section{b) Os países em desenvolvimento nas negociações da OIC e do GATT}

\section{i. Uma visão geral das negociações}

Em novembro de 1945, dando continuidade às negociações de Bretton Woods, os EUA tomaram a iniciativa das negociações multilaterais e circularam o relatório "Propostas para a Expansão do Comércio Mundial e do Emprego", ${ }^{78}$ que havia sido redigido em conjunto com o Reino Unido, como resultado do Acordo de Bretton Woods, que daria início às negociações da futura OIC. ${ }^{79}$

Em fevereiro de 1946, o Conselho Econômico e Social (ECOSOC) é criado no âmbito da recém-criada Organização das Nações Unidas (ONU) ${ }^{80} \mathrm{Na}$ sua primeira reunião, o ECOSOC aprovou por unanimidade uma resolução na qual contemplava a proposta dos EUA de se realizar uma conferência sobre comércio e emprego, com o propósito de discutir o relatório circulado e elaborar a constituição da OIC.

\footnotetext{
${ }^{78}$ Acessível em http://www.worldtradelaw.net/misc/gatttexts.htm.

Para decisões e resoluções da ECOSOC de 1946 em diante, ver http://www.un.org/en/ecosoc/docs/resdec1946_2000.asp

${ }^{79}$ As referências feitas aos documentos preparatórios das negociações da OIC e do GATT, ao longo deste capítulo, são provenientes das referências existentes na obra de John H. Jackson, de 1969, World Trade and the law of GATT: a legal analysis of the GATT. Pela tecnicidade e profundidade no trato dos documentos originários das negociações da OIC e do GATT, esta obra serviu de fonte indireta a esta tese, tendo em vista que tais documentos (cerca de 27.000 páginas em 10 volumes, de acordo com Jackson) não estão acessíveis on-line.

${ }^{80}$ O ECOSOC é o principal órgão coordenador de iniciativas de cooperação internacional econômica, nos termos dos artigos 61 a 72 da Carta da ONU.
} 
Em decorrência dessa resolução ${ }^{81}$ foi criado um comitê preparatório, cuja primeira reunião ocorreu em outubro de 1946, na qual os EUA publicaram sua proposta de carta constitutiva para uma organização internacional do comércio. Tal texto constituiu a base para o início das negociações da OIC e do GATT.

Este comitê realizou quatro reuniões preparatórias, entre 1946 e 1948. A primeira sessão do comitê preparatório ocorreu entre outubro e dezembro de 1946, em Londres. A segunda foi uma reunião do comitê redator que ocorreu em Nova York, de janeiro a fevereiro de 1947. A terceira sessão do comitê preparatório ocorreu em Genebra, de abril a outubro de 1947. A quarta e última foi a Conferência de Havana, formalmente denominada Conferência das Nações Unidas sobre Comércio e Emprego, que ocorreu entre 21 de novembro de 1947 e 24 de março de 1948.

Ao longo destas quatro reuniões preparatórias, houve três focos de negociações: um primeiro grupo lidou com a preparação de um estatuto constitutivo da OIC; um segundo grupo, focou a negociação de um acordo multilateral de redução recíproca de tarifas; um terceiro grupo se concentrou em redigir cláusulas gerais de obrigações relacionadas à obrigações tarifárias. ${ }^{82}$

Em razão das dificuldades apresentadas para a ratificação da Carta de Havana no âmbito interno dos EUA, os esforços das quatro reuniões preparatórias da OIC se deram no sentido de se concentrar mais nos trabalhos dos grupos focados nas cláusulas gerais e nas negociações dos compromissos de redução tarifária. Não houve, portanto uma concentração de esforços propriamente na redação do estatuto da organização internacional. A segunda e terceira parte,

\footnotetext{
${ }^{81}$ (Resolução n ${ }^{\circ} 13$, ECOSOC/ONU)

${ }^{82} \mathrm{~A} 1^{a}$ sessão foi marcada pela afirmação da necessidade de um acordo sobre tarifas e comércio, o GATT, para garantir as concessões tarifárias alcançadas nas negociações multilaterais. $\mathrm{Na} 2^{\mathrm{a}}$ sessão, se produziu a primeira versão completa do GATT, a partir do texto já negociado até o momento da Carta da OIC. A partir desta reunião, optou-se por conceber o GATT como um acordo comercial que vigeria no âmbito institucional da OIC, que forneceria suporte para sua operacionalização. A $3^{\mathrm{a}}$ sessão foi marcada pelo reconhecimento das futuras dificuldades de entrada em vigor da OIC, especialmente em razão dos EUA, e pela necessidade de criação de um mecanismo temporário para viabilizar a entrada em vigor do GATT, enquanto se desenrolasse as ratificações necessárias. Por isso, formalizou-se durante a segunda sessão o Protocolo de Aplicação Provisória (PAP). Na $4^{\text {a }}$ sessão, a Conferência de Havana, foi aprovado, em um primeiro momento o GATT, e posteriormente, a Carta da OIC, por meio da formalização da Carta de Havana. A Carta de Havana, por conter o PAP, permitiria no futuro próximo a entrada imediata em vigor do GATT, independente da OIC.
} 
reunidas, constituíram o texto que, ao final das negociações, acabou entrando em vigor.

ii. A posição dos países em desenvolvimento nas negociações OIC/GATT

Resta fundamental um olhar mais atento para compreender como se deu a participação dos países em desenvolvimento nas negociações do OIC e do GATT, a fim de compreender de que maneira se abordou a questão do desenvolvimento, bem como do policy space, nas negociações que levaram à criação do sistema multilateral de comércio.

Como afirma James Scott:

$\mathrm{Na}$ tentativa de compreender a visão do mundo em desenvolvimento em relação a OIC e ao GATT, nós lhe fazemos um desserviço ao reduzir as suas ideias a uma busca obstinada e desorientada pelo Modelo ISI. (...) Ao relegar estes outros pontos ao esquecimento, perde-se de vista a complexidade dos interesses dos países em desenvolvimento naquele momento crucial e determinante da história das relações econômicas internacionais. ${ }^{83}$

Embora seja razoável e justificável o desejo dos países em desenvolvimento de manter um maior grau de liberdade em suas políticas comerciais que lhes permitisse a introdução de projetos de proteção às indústrias nascentes, e que isto se tornasse o ponto central nas negociações multilaterais, outros pontos foram igualmente importantes ao longo das negociações.

Além disso, no decorrer das negociações do acordo de Bretton Woods, refutou-se qualquer linha argumentativa que fosse mais state-oriented, de intervenção estatal, em razão dos traumas que o mau direcionamento estatal em matéria de política comercial havia deixado na comunidade internacional. Logo, as negociações que se iniciariam no pós-guerra baseavam-se na lógica de que, quanto menos espaço para intervenção estatal no comércio internacional, melhor seria para

\footnotetext{
${ }^{83}$ SCOTT, op. cit., p.6.
} 
a paz mundial. Quanto menos policy space, menores as chances de uma nova guerra mundial. Portanto, a linha argumentativa dos países em desenvolvimento em prol de policy space deveria ser estrategicamente posicionada, de forma a não permitir ser refutada como uma brecha para o retorno das guerras comerciais do passado.

\section{Como afirma Ho:}

Muito antes do termo "globalização" tornar-se corrente, a demanda por policy space foi articulada por muitos dos pioneiros do desenvolvimento econômico. Desafortunadamente, o que de fato eles articulavam, e como eles articulavam, foi muitas vezes distorcido e mal interpretado pelos economistas do mainstream, enquanto estes últimos propunham debates intelectuais visando reduzir o policy space de acordo com suas crenças de que o livre funcionamento do mercado promoveria o desenvolvimento. Tais distorções e más-interpretações, e o consequente formato em que se deu tal debate, marcaram os discursos políticos e contribuíram com as pressões do mainstream em favor da globalização. ${ }^{84}$

Nas primeiras versões da OIC e do GATT que foram elaboradas por EUA e Reino Unido, o único dispositivo existente que dizia respeito aos países em desenvolvimento era o parágrafo 2 do artigo 1, que delimitava expressamente algumas preferências comerciais que seriam mantidas, sem serem consideradas violações à regra geral do artigo I. Estas preferências, originárias, visavam perpetuar a estrutura colonialista do pós-guerra, e estavam assim distribuídas:

1.2.a. As preferências de natureza imperial, em vigor entre dois ou mais dos territórios enumeradas no anexo A do GATT ${ }^{85}$;

1.2.b. As preferências de natureza colonial, em vigor entre dois ou mais territórios que, em $1^{\circ}$ de julho de 1939 , estavam unidos por uma soberania comum ou por relações de proteção ou dependência, que estavam enumerados nos anexos $\mathrm{B}^{86}, \mathrm{C}^{87}$ e $\mathrm{D}^{88}$;

${ }^{84} \mathrm{HO}$, Sai-Hing. Arguing for policy space to promote development: Prebisch, Myrdal, and Singer. Journal of Economic Issues. Jun, 2008, p.2

${ }^{85}$ Territórios do anexo A: Reino Unido da Gra-Bretanha e Irlanda do Norte e seus territórios dependentes, Canadá, Commonwealth da Austrália e seus territórios dependentes, Nova Zelândia e seus territórios dependentes, a União Sul-Africana, incluído a África do Sul, Irlanda, Índia, Terra Nova, Rodésia do Sul (Atual Zimbabue), Birmânia (Atual Mianmar) e Ceilão (Atual Sri Lanka).

${ }^{86}$ Territórios do anexo B: Territórios da União Francesa: França, África Equatorial Francesa, África Ocidental Francesa, Cameron sob mandato francês, Costa Francesa da Somália e Dependências Estabelecimentos Franceses na Índia, Estabelecimentos Franceses na Oceania, Estabelecimentos Franceses do Condomínio das Novas Hébridas, Guadalupe e Dependências, Guiana Francesa Indo-China, Madagascar e Dependências, Marrocos (Zona Francesa), Martinica, Nova Caledônia e Dependências, Réunion, Saint-Pierre e Miquelon, Togo sob mandato francês, Tunísia.

${ }^{87}$ Territórios do anexo C: Territórios da União Aduaneira da Bélgica, Luxemburgo e dos Países Baixos: União Econômica da Bélgica e Luxemburgo, Congo Belga, Ruanda Urundi, Países Baixos, Índias Holandesas, Suriname, Curaçau.

${ }^{88}$ Territórios do anexo D: Territórios dependentes dos Estados Unidos da América e a República das Filipinas. 
1.2.c. As preferências entre Estados Unidos e Cuba;

1.2.d. As preferências concedidas entre países vizinhos, em vigor entre os territórios listados no Anexo $\mathrm{E}^{89}$ e $\mathrm{F}^{90}$.

Assim que os EUA apresentaram a primeira proposta de texto da OIC em Londres, em 1946, os países em desenvolvimento protestaram pela ausência de disposições relativas aos problemas específicos dos países em desenvolvimento. Ao chegar ao ECOSOC e envolver um maior número de países, e com maior diversidade, a questão do desenvolvimento não poderia ser mais ignorada.

A resolução do ECOSOC que estabeleceu a Conferência das Nações Unidas para Comércio e Emprego (UNCTE), na qual o Comitê Preparatório iria elaborar o Projeto de Estatuto da OIC, por meio de Colômbia e Equador, alertou o Comitê Preparatório que este deveria:

Levar em consideração as condições especiais existentes nos países que as respectivas indústrias manufatureiras ainda se encontram em estágio inicial de desenvolvimento, bem como as questões relacionadas a commodities, que sofrem problemas de ajuste no mercado internacional. ${ }^{91}$

A presença dos países em desenvolvimento nas negociações da OIC foi significativa: nove dos dezoito países convidados para compor o Comitê Preparatório da ECOSOC eram considerados países em desenvolvimento. ${ }^{92}$

O Brasil, apoiado por diversos países em desenvolvimento, propugnava que a OIC deveria ter como objetivo central "encorajar e promover o desenvolvimento econômico e industrial dos países Membros, particularmente daqueles menos avançados". ${ }^{93}$

De acordo com a Índia:

Como potências industriais, a prosperidade de ambos (o Reino Unido e os EUA) depende do pronto abastecimento de matérias-primas baratas e da expansão do mercado para seus bens manufaturados. O objetivo fundamental das duas potências é o aumento em escala incessante das exportações, ao invés de desenvolvimento

\footnotetext{
${ }^{89}$ Territórios do anexo E: Preferências em vigor exclusivamente entre o Chile, por um lado, e 1. Argentina, 2. Bolívia, 3. Peru, por outro lado.

90 Territórios do anexo F: Preferências em vigor exclusivamente entre a União Aduaneira SírioLibanesa, de um lado, e 1. Palestina, 2. Transjordânia, de outro lado.

${ }^{91}$ Resolução ECOSOC.

${ }^{92}$ HUDEC. op. cit.,p. 12.

${ }^{93}$ UNCTE, 1946a. paragrafo 3 apud SCOTT (2010) p. 15.
} 
interiorizado. A insistência na redução tarifária em escala global, na remoção de barreiras comerciais e na igualdade de acesso aos mercados e bens primários do mundo, que tem marcado os discursos de ambos os governos, é facilmente explicável. ${ }^{94}$

Nesse mesmo sentido, de acordo com a Austrália:

As propostas dos EUA iriam fossilizar a divisão internacional do trabalho vigente em favor das nações altamente industrializadas, ameaçando quaisquer planos de industrialização ao redor do mundo. De fato, de uma perspectiva australiana, aquilo que os EUA e o Reino Unido enaltecem como liberalização comercial mais parece neo-imperialismo anglo-americano. ${ }^{95}$

Por isso, logo na primeira sessão de negociações da OIC, foi constituído um comitê especial encarregado de redigir um capítulo sobre desenvolvimento industrial. O resultado deste comitê foi uma primeira versão de um capítulo que tratou basicamente de princípios gerais, mas que permitia às partes se eximirem do cumprimento das regras do acordo, quando implantassem políticas de desenvolvimento ou de reconstrução, desde que houve autorização prévia da OIC. ${ }^{96}$

Os países em desenvolvimento desejavam lançar mão das mesmas medidas comerciais utilizadas pelos países industrializados durante seus respectivos períodos de industrialização e não puderam deixar de apontar a hipocrisia da posição norteamericana que, naquele momento, era o país com maior grau de interferência estatal nas políticas comerciais, tanto pelas altas tarifas quanto pelas restrições quantitativas. Nesse sentido, argumentavam que:

O alto grau de desenvolvimento econômico alcançado por certos países é devido em larga medida ao uso de tarifas e outros instrumentos regulatórios; e é apenas justo que o uso de tais tarifas e instrumentos não seja negado aos países que estejam no início da caminhada do desenvolvimento. ${ }^{97}$

\footnotetext{
${ }^{94}$ UNCTE, 1946b. p. 5 apud SCOTT (2010) p. 11.

${ }^{95}$ CAPLING 2000, p. 5 apud SCOTT (2010). P. 12.

${ }^{96} \mathrm{O}$ ponto-chave das demandas dos países em desenvolvimento era a capacidade de proteger indústrias nascentes, por meio de tarifas e restrições quantitativas. Os EUA se opuseram não ao fim, mas ao meio proposto. Segundo os EUA, a medida mais benéfica economicamente para os PED seria, ao invés da utilização de restrições quantitativas, a concessão de subsídios para os produtores domésticos. Os PED contra-argumentaram que subsídios não eram apropriados para o caso deles pois devido às pressões fiscais e inflacionárias decorrentes do uso excessivo desse mecanismo. SCOTT (2010). op. cit., p. 16.

${ }^{97}$ UNCTE, 1946b. p. 61 apud SCOTT (2010), p. 15.
} 
$\mathrm{Na} 2^{\mathrm{a}}$ sessão, de 1947, em Nova York, ficou decidido que alguns pontos do capítulo sobre desenvolvimento industrial seriam incluídos no GATT, enquanto outros permaneceriam na Carta da OIC. Entre os que seriam incluídos no GATT, destaca-se aquele que estabelece que uma parte tenha direito de postular uma isenção em relação às obrigações do GATT, em caso de proteção ao desenvolvimento industrial. No entanto, tal dispositivo não satisfazia os países em desenvolvimento, pois ainda estava condicionado à autorização das partes da OIC.

$\mathrm{Na}^{\mathrm{a}}$ sessão, a Conferência de Genebra de 1947, este debate se intensificou, pois os países em desenvolvimento insistiam que deveriam ter direito a implantar medidas de desenvolvimento industrial sem estar condicionados à autorização prévia da OIC.

Desde logo já se percebe que, nas primeiras reuniões de negociação da OIC e do GATT, na verdade não existia uma atitude antinegociadora dos países em desenvolvimento. O que existia, de fato, era a demanda por um reconhecimento de suas necessidades peculiares, devido à fase inicial de industrialização e desenvolvimento em que se encontravam.

Neste momento, os países latino-americanos desempenharam papel importante como oposição. Muitos países latino-americanos haviam implantado ao longo do início do século XX uma política de desenvolvimento orientado por exportações e estavam desiludidos com os resultados de tais escolhas, e também com a postura das grandes potências econômicas da época. Como afirma BulmerThomas:

As grandes potências freqüentemente agiram de maneira irresponsável (Tarifa Smoot-Hawley) e egoísta (Pacto Roca-Runciman). O resultado foi uma crescente sensação de nacionalismo em diversos países da América latina, além de um grande compromisso - apesar de muito mal articulado - em torno de um modelo de desenvolvimento orientado para dentro e industrializante, ao invés do modelo falido levado adiante até o momento. ${ }^{98}$

O debate ao longo das negociações da OIC e do GATT, entre países industrializados e países em desenvolvimento, não tratava de uma dialética

\footnotetext{
${ }^{98}$ BULMER-THOMAS apud BETHELL, Leslie (Org). op. cit., p. 238.
} 
liberalismo x protecionismo. Cada grupo desejava que houvesse controle jurídico internacional sobre algumas medidas e sobre outras não. Ambos os lados desejavam usar certos instrumentos de proteção, enquanto queriam a limitação de outras. A controvérsia girava em torno de quais medidas estariam sujeitas ao maior controle internacional e quais seriam mais flexibilizadas.

Do ponto de vista dos países em desenvolvimento, os países mais ricos queriam liberdade para utilizar as restrições que apenas eles eram mais capazes de efetivamente utilizar, tais como subsídios, em razão da sua maior capacidade financeira, enquanto os países em desenvolvimento preferiam lançar mão de restrições quantitativas, que não oneraram os cofres públicos como os subsídios, e permitiam um controle mais pontual do volume de mercadorias ingressantes no mercado interno.

Esta oposição se tornou ainda mais exacerbada nas negociações de Havana, tendo em vista que a grande maioria dos países em desenvolvimento presentes naquele momento participava das negociações pela primeira vez. Durante as reuniões preparatórias apenas oito países em desenvolvimento participaram das negociações. Durante a Reunião de Havana, mais de 50 países participaram, dos quais, mais da metade, em desenvolvimento. Portanto, pela primeira vez estes novos países em desenvolvimento tomavam ciência dos compromissos decorrentes da OIC, e pela primeira vez puderam expressar suas posições.

Ao avaliar o fracasso das negociações em atender minimamente os interesses dos países em desenvolvimento, James Scott afirma que:

Dada a falta de disciplina em produtos agrícolas, combinado com a falta de regras em medidas não-tarifárias, que eram os maiores obstáculos enfrentados pelos países em desenvolvimento, ficava difícil enxergar os benefícios da adesão ao GATT. O fracasso do GATT em enfrentar os grandes problemas do comércio internacional de matérias primas pode ter empurrado os países em desenvolvimento em sentido contrário, ou seja, no sentido de implantar modelos de desenvolvimento hacia adentro, voltados à industrialização, ao invés de orientados para o mercado internacional. ${ }^{99}$

\footnotetext{
${ }^{99}$ SCOTT (2010), op. cit., p. 20.
} 
Como se pode perceber, em linhas gerais, o comportamento dos países em desenvolvimento no GATT foi guiado por um compromisso em torno do Modelo de Industrialização por Substituição de Importações (ISI) e uma demanda por tratamento especial e diferenciado. Todavia, muito embora a preocupação com a manutenção da liberdade de proteção de indústrias infantes tenha sido a razão fundamental da posição dos países em desenvolvimento nas negociações da OIC/GATT, este foi apenas um aspecto do conjunto de ideias e posições apresentadas pelos países em desenvolvimento ao longo das negociações da OIC e do GATT.

\section{c) A entrada em vigor do GATT}

Ao final das negociações, o GATT foi concluído em novembro de 1947 e entrou em vigor em $1^{\circ}$ de janeiro de 1948. Esta sessão foi igualmente reconhecida como a primeira Rodada de Negociações do GATT. Já o Estatuto da OIC foi finalmente concluído e aprovado pelas partes negociadoras em março, na conclusão da Conferência de Havana. ${ }^{100}$ Restava aguardar o processo de ratificação dos EUA.

Em 1949, as partes contratantes do GATT se reuniram para a segunda rodada de negociações tarifárias em Annecy, França, e no ano seguinte, ocorreu a terceira rodada em Torquay, Inglaterra. Ao final de ambas as rodadas, parecia claro que a Carta da OIC não seria mais ratificada pelo Congresso dos EUA, o que culminou com a extinção prematura da OIC, levando à "provisoriedade permanente" do GATT.

O GATT foi constituído como um acordo multilateral, composto por cronogramas nacionais de concessões, contendo milhares de compromissos de reduções tarifárias, que se estenderiam a todos os demais signatários, por meio das cláusulas gerais do GATT, quais sejam, a Cláusula da Nação Mais Favorecida

${ }_{100}$ Para acessar o conteúdo integral da Carta de Havana, ver MERCADANTE, Araminta. Consolidação das normas do GATT 47, GATT 94 e OMC: legislação brasileira. São Paulo: Quartier Latin, 2007. 
(Artigo I) e o Tratamento Nacional (Artigo III), que se aplicariam às Listas de Concessões (Artigo II). Tais compromissos foram incluídos para estarem submetidos à OIC, quando esta entrasse em vigor.

Os 23 países signatários originários do GATT são: Austrália, Bélgica, Brasil, Mianmar, Canadá, Sri Lanka, Chile, China, Cuba, Tchecoslováquia, França, Índia, Líbano, Luxemburgo, Países Baixos, Nova Zelândia, Noruega, Paquistão, Rodésia do Sul (atual Zimbábue), Síria, África do Sul, Reino Unido e os Estados Unidos da América.

Como apontado acima, o GATT se institui com natureza de tratado de direito internacional, com base no Protocolo de Aplicação Provisória (PAP). Tal Protocolo foi idealizado tendo-se em vista que as negociações do GATT já estavam concluídas antes da Reunião de Havana, e que, portanto, já havia certo pessimismo em relação às reais probabilidades da imediata entrada em vigor da OIC. Por este motivo, os negociadores criaram um mecanismo que possibilitaria a entrada em vigor do GATT quase de imediato, independentemente do eventual impedimento do congresso norte-americano a OIC. ${ }^{101}$

${ }^{101} \mathrm{O}$ texto do PAP é o que segue abaixo:

1. Os Governos da Comunidade da Austrália, do Reino da Bélgica (no que diz respeito ao seu território metropolitano), do Canadá da República Francesa (no que diz respeito ao seu território metropolitano) ; do Grão-Ducado da Luxemburgo, do Reino dos Países-Baixos (no que diz respeito ao seu território metropolitano, do Reino-Unido da Grã Bretanha e da lrlanda do Norte (no que diz respeito ao seu território metropolitano) e dos Estados Unidos da América, acordam entre si, desde que o presente Protocolo seja assinado em nome de todos os governos acima enumerados, no mais tardar até 15 de novembro de 1947, em aplicar, a título provisório e a partir de 1 de janeiro de 1948:

a) as partes I e III do Acordo Geral sobre Tarifas Aduaneiras e Comércio;

b) e a parte II deste acordo em tudo que for compatível com a legislação em vigor.

2. Os governos acima mencionados aplicarão, a titulo provisório. o Acordo Geral nas condições enunciadas acima no que diz respeito a outros de seus territórios, além dos metropolitanos, a partir de 1 de janeiro de 1948 ou depois desta data, logo que expirado o prazo de trinta dias a contar da data em que o Secretário Geral das Nações Unidas tenha recebido notificação da decisão de aplicar o Acordo, a título provisório, em um ou vários desses territórios.

3. Para qualquer outro governo signatário do presente Protocolo, a aplicação Provisória do Acordo Geral nas condições acima mencionadas efetuar-se-á a partir de 1 de janeiro de 1948; ou depois desta data, expirado o prazo de trinta dias, a contar da data na qual o presente Protocolo for assinado em nome desse governo.

4. O presente Protocolo permanecerá aberto na sede das Nações Unidas:

a) até 15 de novembro de 1947, para a assinatura dos governos enumerados no $\S 1^{\circ}$ do presente Protocolo, que não o tenham feito de hoje;

b) até 30 de junho de 1948, para a assinatura dos outros governos signatários do Ato Final adotado no término da segunda sessão da Comissão preparatória da Conferência das Nações Unidas sobre Comércio e Emprego, que não o tenham feito na data de hoje. 
A "pressa" dos negociadores do GATT e da OIC se justifica pelo fato de que a extensão do Reciprocal Trade Agreements Act de 1945 estava prestes a expirar. Logo, nenhum negociador queria perder os diversos compromissos de abertura comercial conquistados nas negociações com os EUA, firmados no âmbito do GATT. A comunidade internacional que estava engajada nas negociações comerciais não queria perder o já conquistado - os compromissos de abertura comercial do GATT - pelo duvidoso - a criação da OIC.

Além disso, outro problema candente remetia à questão dos ritos de internalização dos tratados internacionais, que variavam na forma e no tempo, conforme as partes signatárias do GATT. Muitas das cláusulas gerais do GATT especialmente a exigência de tratamento nacional - exigiriam reformas constitucionais, as quais não seriam internalizadas sem serem debatidas e aprovadas pelos respectivos poderes legislativos.

Como previsto que, em seguida à conclusão das negociações do GATT, seria finalizada a negociação do Estatuto da OIC, as partes negociadoras preferiam encaminhar aos legisladores ambos os textos (Estatuto da OIC e o GATT) como um "pacote". Neste meio tempo, o GATT vigeria de maneira provisória.

Assim, por meio do PAP, oito das 23 partes signatárias originárias concordaram em aplicar o tratado "provisoriamente" a partir de $1^{\circ}$ de janeiro de 1948, enquanto os demais se comprometiam a cumprir o GATT dentro de no máximo, um ano. ${ }^{102}$

Com base nesse dispositivo do PAP, as obrigações e os compromissos fundamentais estabelecidas na Parte II do GATT estavam salvaguardados pela

5. Será lícito a todo governo que tiver posto em aplicação o presente Protocolo, suspendê-la, tornando-se efetiva essa denúncia depois de expirado o prazo de sessenta dias, a contar da data na qual o Secretário Geral das Nações Unidas tenha recebido, por escrito, a respectiva notificação.

6. O original do presente Protocolo ficará em poder do Secretário Geral das Nações Unidas, ao qual incumbe fornecer cópias autenticadas do referido documento a todos os governos interessados.

Em fé do que, os representantes, infra-assinados, depois da apresentação dos seus plenos poderes, achados em boa e devida forma, assinaram o presente Protocolo.

Dado e passado em Genebra, em um único exemplar, nas línguas francesa e inglesa, fazendo fé ambos os textos, em trinta de outubro de mil novecentos e quarenta e sete.

102 Além disso, o PAP orientou a entrada em vigor do GATT de modo a estabelecer que as Partes I (obrigações gerais) e III (procedimentos) do GATT entrariam em vigor de forma completa, sem condicionalidades excepcionais, enquanto ao Parte II (artigos III a XXIII) poderia ser implementada "da maneira mais consistente possível com cada legislação nacional existente". 
Grandfather Clause, a "Cláusula Avô", assim denominada por garantir prevalência da legislação nacional vigente, mais antiga, em detrimento dos novos compromissos do GATT previstos na Parte II. A "Cláusula Avô" vigoraria até a entrada definitiva em vigor do GATT e da OIC, quando todas as alterações legislativas internas das partes contratantes ocorreriam em conjunto.

A partir da internalização do Pacote GATT/OIC, as partes não mais teriam direito de invocar a legislação nacional como justificativa para descumprimento de algum compromisso da Parte II do GATT. Como a história demonstrou, o Pacote GATT/OIC não obteve êxito e a Cláusula Avô vigorou até o fim do período GATT.

\subsection{O ARTIGO XVIII}

\section{a) Os primeiros anos de vigência do artigo XVIII}

\section{i. As negociações do artigo XVIII}

Ao longo da Conferência de Havana, foi criado um dispositivo intitulado Assistência Governamental para Reconstrução e Desenvolvimento Econômico, que permitia às partes contratantes obter permissão das demais partes para usar medidas que estivessem em conflito com as obrigações da Carta de Havana, com a finalidade de promover o estabelecimento, o desenvolvimento ou a reconstrução de indústrias ou setores específicos. Tal artigo era igualmente dirigido aos países em desenvolvimento e às potências destruídas pela $2^{\mathrm{a}}$ Guerra Mundial. Logo, Reino Unido e França poderiam gozar do mesmo tratamento mais favorável que os países em desenvolvimento. 
Ao longo da Conferência de Havana, houve uma cisão definitiva entre os participantes, de um lado, os países desenvolvidos e industrializados, e de outro, os países em desenvolvimento, que levou à revisão e modificação de diversos artigos da Carta da OIC, dentre os quais se destaca o Artigo XVIII. ${ }^{103}$

Como afirmado anteriormente, durante a reunião de Havana, formou-se um comitê especial, exclusivamente para tratar das questões envolvendo desenvolvimento industrial. O relatório deste comitê foi finalmente aceito por todas as partes envolvidas na negociação e chegou-se a um consenso. O relatório levou a uma ampliação considerável das disposições envolvendo desenvolvimento na Carta da OIC, e o conjunto de artigos se transpôs ao GATT sob a forma do artigo XVIII.

Tais disposições mantiveram a exigência de consentimento prévio da OIC para eximir-se das obrigações do GATT. Ademais, outro artigo, também transposto para o GATT dentro do artigo XVIII (parágrafo 6), outorgou, tanto aos países em desenvolvimento, quanto aos países em reconstrução, a Cláusula Avô, que permitia a estas partes manter suas políticas comerciais em vigor, incluindo cotas, desde que outras partes do GATT fossem notificadas destas medidas, antes que tais países se tornassem signatários do GATT.

Esta mudança adicionou ainda mais dispositivos ao já extenso artigo XVIII, tornando-o o artigo mais extenso do GATT. Dos três parágrafos iniciais da versão de Londres, passou-se para sete parágrafos na versão de Genebra e conclui-se a versão de Havana com 14 parágrafos.

\section{ii. A vigência do artigo XVIII}

\footnotetext{
${ }^{103}$ A esta altura das negociações, as modificações estavam sendo realizadas diretamente na Carta da OIC, e não no GATT, pois já havia um consenso em torno do GATT, que já estava planejado entrar em vigor em $1^{\circ}$ de janeiro de 1948 , enquanto as negociações de Havana, que contemplava a OIC a primeira rodada de reduções tarifárias, continuariam até março do mesmo ano. Por isso, as partes haviam acordado que todas revisões e alterações que fossem decididas ao longo da Conferencia de Havana seriam consolidadas na Carta da OIC. Isto porque havia a expectativa de finalizar o texto da Carta da OIC e, só aí, as partes iram submetê-la aos respectivos congressos para ratificação, todas de uma só vez.
} 
Entre 1948 e 1955, os pedidos feitos por países em desenvolvimento para o descumprimento de suas obrigações com base no artigo XVIII forma examinados em grupos de trabalho para assegurar que as condições das disposições fossem cumpridas. Por outro lado, as exceções fundadas nos artigos XII e XIV, sobre balanço de pagamentos, não necessitavam de aprovação prévia e, por isso, viriam a ser largamente utilizadas pelos países em desenvolvimento para se afastarem do cumprimento das normas do GATT.

As restrições fundadas em balanço de pagamentos, usadas de forma massiva nas políticas comerciais, reduziam a necessidade de outras formas de proteção. Isto porque as exceções dos artigos XII e XIV, relacionadas ao balanço de pagamentos, não exigiam consentimento prévio das partes da GATT. Portanto, a grande maioria dos países em desenvolvimento considerou que, ao longo dos primeiros anos do GATT, era mais interessante - e mais fácil - justificar o uso de restrições quantitativas (cotas) fundadas nas exceções de balanço de pagamentos do que fundadas no artigo XVIII.

Em $1^{\circ}$ de janeiro de 1954, 16 dos 20 países desenvolvidos e nove dos 14 países em desenvolvimento, todos parte do GATT, estavam restringindo importações por motivos de balanço de pagamentos. Destes 25 países que adotavam restrições com base no artigo XII, 23 o faziam de maneira discriminatória. ${ }^{104}$

O recurso ao artigo XVIII, pré-reforma de 1955, foi muito limitado, tendo sido aplicado apenas quatro vezes durante a vigência do GATT-47, nas quais se concederam dispensas a Cuba ${ }^{105}$, Índia ${ }^{106}$, Ceilão (Atual Sri Lanka) ${ }^{107}$ e Haiti ${ }^{108}$. Nesse cenário, estes países em desenvolvimento utilizaram distintas previsões do artigo XVIII, desde o controle de importações por cotas - Cuba e Índia -, até a

\footnotetext{
${ }^{104}$ HUDEC. Op. cit.P. 32.

${ }^{105}$ GATT. Dispensa para manter as medidas notificadas com base no parágrafo 2 do artigo XVIII. Decisão de 10 e 11 de agosto de 1949.

${ }^{106}$ GATT. Dispensa para manter as medidas notificadas com base no parágrafo 2 do artigo XVIII. Decisão de 10 e 11 de agosto de 1949.

${ }^{107}$ GATT. Dispensa acordada para o Ceilão com base no parágrafo 8 do artigo XVIII. Decisão de $1^{\circ}$ de abril de 1950.

${ }^{108}$ GATT. Dispensa acordada para o Haiti com base no parágrafo 12 do artigo XVIII. Decisão de 27 de novembro de 1950.
} 
retirada de concessões tarifárias para favorecer um determinado ramo de indústria Ceilão e Haiti.

Em cada um destes casos, um grupo de trabalho revisou criteriosa e rigorosamente cada proposta e sua respectiva condição específica em relação ao artigo XVIII. Tal atitude contrastava com a excessiva flexibilidade das medidas fundadas no artigo XII.

Além do rigor técnico por parte dos grupos de trabalho, houve igualmente uma vigilância sobre os países em desenvolvimento, no âmbito do sistema de solução de controvérsias do GATT. Prova disso é que quatro das cinco primeiras disputas no âmbito do sistema de solução de controvérsias do GATT foram reclamações de países desenvolvidos contra violações de países em desenvolvimento. ${ }^{109}$

A atitude demasiadamente severa em relação à aplicação do artigo XVIII é um dos motivos pelo qual tal dispositivo só foi invocado mais uma vez ao longo do período GATT, pelo próprio Ceilão (atual Sri Lanka). Tal caso será mencionado a seguir.

\section{b) A reforma de 1955: o "novo" artigo XVIII}

Em 1955, o Artigo XVIII é modificado mais uma vez. Todas as alterações alcançadas pelos países em desenvolvimento ao longo das negociações de Havana,

\footnotetext{
${ }^{109}$ Cuba - Taxas consulares: Uma reclamação da Holanda de 1948, de que Cuba estava aplicando taxas consulares de maneira discriminatória, em violação ao artigo I. O GATT determinou que a taxa consistia em violação à obrigação da cláusula da nação mais favorecida.

Cuba - Restrições às importações de têxteis: Uma reclamação dos EUA de 1948, de que Cuba impunha diversas restrições em violação ao artigo XI, que proíbe restrições quantitativas às importações. As medidas foram retiradas por Cuba sem necessidade de decisão do GATT.

Brasil - Taxas internas: Uma reclamação da França de 1949, contra tarifas internas impostas pelo Brasil sobre diversos produtos, incluindo conhaque, que aplicava-se apenas a produtos estrangeiros, em violação ao artigo III, o princípio do tratamento nacional. O GATT decidiu pela ilegalidade de tais tarifas, que foram retiradas pelo Brasil.

Cuba - Restrições às importações de têxteis II: Uma petição conjunta apresentada por EUA e Cuba em 1949, a fim de definir se Cuba poderia retirar certos compromissos tarifários que já estavam consolidados. O OSC não chegou a uma solução e ambas as partes negociaram bilateralmente o caso. in HUDEC. Op. cit., p. 38.
} 
que não haviam sido inseridas no GATT, mas na Carta da OIC, deveriam ser consolidadas igualmente no GATT, que já estava em vigor e seria o texto vigente a conduzir o sistema multilateral de comércio. Como a Carta da OIC nunca entrou em vigor, estas conquistas dos países em desenvolvimento, ao longo da Rodada de Havana, deveriam ser inseridas o quanto antes no acordo GATT. Isto ocorreu na Sessão de Revisão 1954-1955, na qual a alteração mais significativa, do ponto de vista dos países em desenvolvimento, foram as alterações do Artigo XVIII.

As principais alterações decorrentes dessa sessão de 1955 tiveram o intuito de permitir o uso de restrições quantitativas, ou quotas, que são proibidas pelo Artigo XII, desde que relacionadas a problemas de balanço de pagamentos, e para preservar o nível de reservas necessário a programas de desenvolvimento. Assim, o Artigo XII ficou reservado para os problemas de balanço de pagamentos dos países desenvolvidos, e o XVIII para os problemas dos países em desenvolvimento. ${ }^{110}$

Após passar por todas as reformas descritas acima, este artigo entrou em vigor nos mesmos termos até hoje. Nele está contemplado um amplo leque de flexibilidade para a utilização de medidas de proteção comercial, destinado exclusivamente, para países em desenvolvimento.

De acordo com o parágrafo 1, o artigo encontra-se ao alcance de dois tipos de partes contratantes:

1) Aquelas partes cuja economia suporta apenas baixos padrões de qualidade de vida e está nos estágios iniciais de desenvolvimento;

2) Aquelas partes cuja economia encontra-se em processo de desenvolvimento, mas que não se encontra em estágio inicial, tais quais as descritas acima.

O parágrafo 2 do artigo XVIII dispõe que:

"pode ser necessário para as Partes Contratantes previstas no parágrafo 1 que, com o objetivo de executar seus programas e suas políticas de desenvolvimento econômico orientados para a elevação do nível geral de vida de suas populações, venham a tomar medidas de proteção ou outras medidas que afetem as importações, e que tais medidas são justificadas na medida em que elas facilitem o alcance dos objetivos deste Acordo".

110 THORSTENSEN, Vera. Organização Mundial do Comércio: as regras do comércio internacional e a nova rodada de negociações multilaterais. São Paulo: Aduaneiras, 2001, p. 256. 
Continua o parágrafo 2 detalhando os tipos de medidas a disposição dos países em desenvolvimento que se enquadrarem nas categorias do parágrafo 1:

Estas Partes Contratantes deveriam usufruir facilidades adicionais que as possibilitem: (a) conservar na estrutura de suas tarifas aduaneiras suficiente flexibilidade para que elas possam fornecer a proteção tarifária necessária à criação de um ramo de produção determinado, e (b) instituir restrições quantitativas destinadas a proteger o equilíbrio de suas balanças de pagamento de uma maneira que leve plenamente em conta o nível elevado e permanente da procura de importação suscetível de ser criada pela realização de seus programas de desenvolvimento econômico.

A primeira categoria de países em desenvolvimento tem o direito de recorrer às seções $\mathrm{A}, \mathrm{B}$ e $\mathrm{C}$, enquanto aqueles que se enquadram na segunda categoria podem recorrer apenas aos dispositivos da seção D. Portanto, a primeira análise a ser feita diz respeito à consideração sobre qual economia está enquadrada de fato na primeira ou na segunda categoria.

O anexo 1 do GATT-47 traz duas notas interpretativas para este dispositivo:

1. Quando for necessário considerar se a economia de uma parte contratante "suporta apenas baixos padrões de qualidade de vida", as partes contratantes devem levar em consideração a posição normal da economia, e não fundar tal consideração em circunstâncias excepcionais, tais como aquelas resultantes de condições temporárias que afetam as economias de tais partes;

2. A frase "estágio inicial de desenvolvimento" não tem o objetivo de ser aplicada apenas às partes contratantes que apenas recentemente iniciaram seu processo de desenvolvimento econômico, mas também àquelas partes cujas economias estão implantando um processo de industrialização para corrigir uma excessiva dependência de produção primária.

Logo, toda parte contratante que se enquadrar em ambos os critérios estará juridicamente habilitada a recorrer às seções A, B e C do Artigo XVIII.

- Seção A (revisão das concessões tarifárias): De acordo com esta seção, uma parte pode elevar tanto as tarifas que estejam consolidadas em seu cronograma de concessões, e obviamente também aquelas que não estejam consolidadas.

Os requisitos para invocar a seção A estabelecem que o aumento tarifário deve ser considerado justificável se:

a) Promove o estabelecimento de uma indústria, de um ramo de indústria, ou uma mudança estrutural em alguma indústria já existente;

b) Visa o aumento dos padrões de qualidade de vida da população; 
c) Seja notificado às demais partes contratantes, com o objetivo de iniciar negociações, tanto com a parte com a qual tal tarifa já estivesse consolidada, quanto com qualquer outra parte que se sentir atingida por tal revisão.

Apenas quando tais critérios forem atendidos e as negociações levarem a um acordo entre as partes, é que tais tarifas poderão ser elevadas pelos países em desenvolvimento. Ou seja, a necessidade de consentimento prévio, que durante as negociações da OIC/GATT foi duramente negociada pelos países em desenvolvimento, é uma condicionante fundamental desta seção que inibe, quase que por completo, a ação dos países em desenvolvimento. A prova disso é que tal seção nunca foi invocada ao longo do período de vigência do GATT. Ademais, o direito de renegociação tarifária constante do artigo XXVIII, já permitia aos países em desenvolvimento levar adiante tal iniciativa, com menos requisitos que os constantes no artigo XVIII.

- Seção B (restrições ao balanço de pagamentos): O reconhecimento de que, na prática, os países em desenvolvimento estavam fazendo grande uso de restrições quantitativas, fundados nas exceções de balanço de pagamentos (artigos XII e XIV do GATT), fez com que a Sessão de Revisão inserisse, no artigo XVIII, a seção B, com as regras para o uso de tais medidas, quando se tratasse especificamente de países em desenvolvimento.

- Seção C (outras medidas necessárias): A seção C mostra-se, ao mesmo tempo, mais ampla e mais restrita que a seção B. Mais ampla, pois o parágrafo 13, da seção C, autoriza toda e qualquer medida necessária; e mais restrita, pois deve ser focada especificamente em uma indústria em particular, tal qual a seção A.

A seção C contém uma série de pré-requisitos para ser invocada por um país em desenvolvimento:

a) Uma conclusão fundamentada de que a ajuda do Estado é necessária;

b) A especificação da indústria em particular a ser promovida;

c) Deve prever a elevação dos padrões de qualidade de vida;

d) Nenhuma outra medida, das outras seções do artigo XVIII, é suficiente para alcançar tal objetivo;

e) Tal medida deve ser notificada de forma específica ao GATT;

f) Deve aguardar o prazo de 30 dias para consulta das outras partes;

g) A medida deve ser não-discriminatória; 
h) Se a medida atingir as importações de um produto constante no Cronograma do país solicitante, esta medida só poderá ser invocada se houver acordo com as partes contratantes atingidas por tais medidas.

Novamente nesta seção, a limitação decorrente da necessidade de consentimento prévio, levou a uma restrição no uso do artigo XVIII.

- Seção D (países com maior nível de desenvolvimento): A seção D fica, apenas, ao alcance das partes que se enquadram na segunda categoria de países em desenvolvimento descrita acima, ou seja, aqueles que já não se encontram em estágio inicial de desenvolvimento, e que estejam implantando um processo de industrialização para corrigir uma excessiva dependência de produção primária.

\section{c) Um balanço do artigo XVIII no período GATT}

Certamente, os problemas dos países em desenvolvimento revelavam-se demasiadamente complexos e difíceis para serem resolvidos tão somente por meio do artigo XVIII.

Assim, nos anos que se seguiram à Sessão de Revisão de 1955, a questão do relacionamento do GATT com os países em desenvolvimento continuava a ganhar importância. A questão ficou ainda mais crítica quando, nitidamente, as colônias francesas e britânicas, prestes a tornarem-se independentes, clamavam pelo apoio dos países em desenvolvimento, para que pudessem ingressar nas relações internacionais em uma condição de menor desvantagem possível. O movimento do Terceiro Mundo descrito no capítulo anterior tomava corpo e passaria a influenciar de maneira mais incisiva as negociações multilaterais a partir de então.

A respeito da tensão entre os países desenvolvidos e os países em desenvolvimento ao longo das negociações da OIC e do GATT, podem-se apontar algumas conclusões. Se é verdade que os países em desenvolvimento não lograram êxito com dispositivos efetivos e concretos, nos termos que desejavam, para fomentar o seu desenvolvimento econômico, no âmbito do GATT, também é 
verdade que, ao final das negociações, haviam conquistado em definitivo o reconhecimento da legitimidade das suas pretensões.

A partir do momento em que se criou, em 1946, o comitê especial para redação do Capítulo sobre Desenvolvimento Econômico, ao longo da primeira sessão preparatória, houve uma mudança fundamental na premissa das negociações: dali em diante, não era mais uma questão de "se" os países em desenvolvimento teriam direitos, mas de "quanto" os conquistariam ao final das negociações. ${ }^{111}$

Além disso, as reivindicações dos países em desenvolvimento por liberdade jurídica, leia-se policy space, foram a única forma que estes países encontraram, ao longo das negociações do sistema multilateral de comércio, fundado em direitos e obrigações, que pudesse se traduzir em oportunidades de desenvolvimento econômico. A respeito, Hudec afirma que:

Do ponto de vista das negociações internacionais, conceder liberdades jurídicas a outros países é uma concessão fácil de fazer, pois não requer nem mudança nas legislações nacionais nem o uso de algum dos poderes estatais. É possível conceder simplesmente ao concordar em fazer nada. Por isso, os governos de ambos os lados da mesa de negociações encontraram uma solução que mantinha a aparência de progresso nas negociações. ${ }^{112}$

Se a sessão de revisão deixou alguma lição, tanto para os países desenvolvidos, quanto para os países em desenvolvimento, é que as negociações no sistema multilateral de comércio girariam sempre em torno da existência de maior ou menor policy space dos países em desenvolvimento. A flexibilização do artigo XVIII foi uma prova dessa tendência de negociação. Nesse sentido, Hudec afirma que:

As reformas da sessão de revisão não aportaram maiores novidades nas relações jurídicas dos países desenvolvidos com os países em desenvolvimento no âmbito do GATT. Provavelmente seu maior impacto tenha sido de ordem principiológica: a consagração da ideia de que "liberdade jurídica" ajuda os países em desenvolvimento. Nesse sentido, a sessão de revisão repetiu a lição das negociações OIC/GATT que, uma vez que as negociações estejam postas, os países em desenvolvimento devem "ganhar" alguma coisa. Também repetiu a lição de que a

\footnotetext{
${ }^{111}$ SCOTT. op. cit., p. 18.
}

${ }^{112}$ HUDEC. op. cit., p. 27. 
concessão mais fácil a ser "dada" aos países em desenvolvimento era um pouco mais de liberdade jurídica. ${ }^{113}$

Desde a revisão de 1955, a primeira e única vez que tal dispositivo foi alvo de apreciação pelo Órgão de Solução de Controvérsias do Sistema Multilateral de comércio foi no caso Índia - Restrições Quantitativas, já na vigência da OMC, em 1999, que será analisado no capítulo seguinte.

John H. Jackson, ao fazer um balanço da vigência do artigo XVIII, ao final da década de 60, afirma:

\begin{abstract}
Um ponto parece certo: a abordagem passiva, que concedia aos países em desenvolvimento o direito de eximirem-se das obrigações do GATT, que era a abordagem do artigo XVIII, já não era mais suficiente para dar a estes países o impulso que eles necessitavam. Uma abordagem mais positiva é necessária e está atualmente sendo demandada. ${ }^{114}$
\end{abstract}

No mesmo sentido, Dominique Carreau afirma que podem ser identificadas duas fases do Período GATT no que se refere à consideração do desenvolvimento pelo Sistema Multilateral de Comércio: (i) a primeira, negativa, caracterizada por um regime de exceções e pela consagração do princípio da não-reciprocidade, por meio da inclusão da Parte IV; e (ii) a segunda fase, marcada por uma abordagem positiva, na qual se nota a emergência de um status especial aos países em desenvolvimento, pela legitimação das preferências comerciais a titulo derrogatório em 1971 (anterior a Rodada Tóquio) e, posteriormente, pela cláusula de habilitação em 1979. ${ }^{115}$

John H. Jackson, à época, constata com clareza o momento de transição que vivia o GATT:

O GATT atualmente reflete a transição de uma abordagem passiva dos anos 40 e 50 para uma abordagem positiva dos anos 60 . No entanto, é cedo para afirmar quando e como esta abordagem positiva se concretizará no âmbito do GATT. ${ }^{116}$

\footnotetext{
${ }^{113}$ HUDEC. op. cit., p. 34.

${ }^{114}$ JACKSON (1969). op. cit., p. 787.

${ }^{115}$ CARREAU, Dominique; JULIARD, Patrick. Droit International Economique. 1998, p. 712.

116 JACKSON (1969). op. cit., p. 788.
} 
Confirmando as previsões de Jackson, no ano seguinte entraria em vigor a Parte IV, considerada pela literatura como o marco regulatório que possibilitou a transição entre a fase negativa e a fase positiva do desenvolvimento no GATT.

\subsection{A PARTE IV DO GATT - COMÉRCIO E DESENVOLVIMENTO}

\section{a) O surgimento da Parte IV do GATT}

\section{i. A continuidade da insatisfação dos países em desenvolvimento}

Após a sessão de revisão de 1955, havia uma clara percepção de que se era necessário fazer mais para incrementar os fluxos comerciais com os países em desenvolvimento, e que somente assim os objetivos do GATT seriam alcançados. Somente mediante tais iniciativas se estimularia o desenvolvimento econômico destes países, se fortaleceria as industriais nacionais, e, consequentemente, se evitaria que tais países continuassem a utilizar restrições tarifárias e quantitativas.

Em 1961, é instalado um caso paradigmático no sistema de solução de controvérsias do GATT. O Uruguai apresentou uma reclamação, fundada no artigo XXIII, contra todos os 15 países desenvolvidos signatários do GATT à época. A reclamação uruguaia listou 576 restrições em todos os 15 mercados: a tese jurídica do Uruguai fundamentava-se no fato de que tais restrições reduziam seriamente as exportações uruguaias e que, portanto, tais medidas impediam o Uruguai de alcançar os objetivos gerais do GATT. Com base no artigo XXIII, tais medidas constituíam nullification or impairment das demais concessões tarifárias dos países desenvolvidos, razão pela qual o Uruguai sustentava que tais medidas deveriam ser eliminadas. 
A complexidade da demanda e a falta de fundamentação jurídica mais detalhada para o caso, fez com que o sistema de solução de controvérsias não conseguisse chegar a uma decisão especifica sobre cada uma das medidas, embora tenha emitido um parecer em que apontava as medidas mais graves que deveriam ser reduzidas, ou retiradas, pelos países desenvolvidos.

No entanto, a reclamação do Uruguai, embora tenha se revestido mais como uma manobra diplomática, logrou um importante êxito para os países em desenvolvimento: identificar, com especificidade, todas as barreiras que os países em desenvolvimento sofrem nos mercados dos países desenvolvidos e que, mesmo sendo consideradas legais pelo sistema de solução de controvérsias do GATT, demonstrariam que as atuais regras e compromissos do GATT não estavam satisfazendo os países em desenvolvimento.

Ainda, a escassez de reclamações dos países em desenvolvimento, no âmbito do GATT, até aquele momento, revelava a ausência de instrumentos jurídicos que os países em desenvolvimento detinham contra os países desenvolvidos. Das mais de 20 reclamações decididas pelos grupos de trabalho do GATT, antes do caso do Uruguai, apenas três se referiam a reclamações vitoriosas de países em desenvolvimento: ${ }^{117}$

Ao final, o caso do Uruguai foi mais uma manobra diplomática que antecedeu o lançamento da Rodada Kennedy, que viria a ser a Rodada de afirmação da posição desenvolvimentista no sistema multilateral de comércio.

\footnotetext{
117 Índia - Redução tributária para exportações: Reclamação do Paquistão de 1948, arguindo que a Índia não concedeu redução tributária para as exportações destinadas ao Paquistão, enquanto concedia as exportações destinadas a diversos outros países, razão pela qual tal medida violaria o artigo I. O GATT decidiu em favor do Paquistão e a Índia estendeu a redução tributária às exportações destinadas ao Paquistão.

Austrália - Subsídios para sulfato de alumínio: Reclamação do Chile, de1950, contra a Austrália, em razão de subsídios domésticos para a compra de sulfato de alumínio nacional. Embora legais frente ao GATT, estes subsídios anulavam os benefícios alcançados pelo Chile com a redução tarifária da Austrália para tal produto, em desacordo com o artigo XXIII. Por isso, o GATT, ao final decidiu em favor do Chile.

Reino Unido - Tarifas para bananas: Reclamação do Brasil, de 1961, contra o aumento da margem de preferência tarifária de bananas, em violação aos termos do waiver que regulava tais aumentos. $\mathrm{O}$ OSC decidiu em favor do Brasil e o aumento foi revogado. in HUDEC, op. cit., p.52.
} 


\section{ii. O Relatório Haberle}

Para contornar a situação dos países em desenvolvimento no sistema multilateral de comércio, um painel de especialistas foi formado, cujo relatório foi divulgado em outubro de 1958, e ficou conhecido como Relatório Haberle. Dentre os principais trechos do relatório, destacam-se os seguintes:

Consideramos que há fundamento na sensação de inquietude que atinge os países produtores de bens primários, de que as atuais regras sobre políticas comerciais são relativamente desfavoráveis a eles...

Enquanto os países subdesenvolvidos, produtores de bens primários, têm razões válidas para fazer uso mais livre de medidas de controle comercial, tais como cotas, do que os países industrializados, em muitas ocasiões tais países utilizaram-se de tais medidas em demasia....

A continuidade do progresso depende da vontade dos países industrializados e nãoindustrializados em negociar um amplo leque de políticas econômicas e financeiras para contornar tal situação... ${ }^{118}$

Com base neste relatório, as partes do GATT, reunidas na $13^{\mathrm{a}}$ sessão do GATT, de 1958, decidiram iniciar um "programa de ação" que deveria abarcar três tópicos fundamentais:

I. A possibilidade de novas negociações para redução tarifária;

II. Os problemas decorrentes da disseminação do uso de medidas não-tarifárias para proteção de agricultura;

III. Outros obstáculos para expansão do comércio, particularmente, aqueles referentes à manutenção e expansão das exportações dos países menos desenvolvidos.

Foram estabelecidos três comitês para desenvolver planos de ação em cada tópico. Os planos de ação do comitê I, voltado à redução tarifária levaram a Rodada Dillon em 1960. No entanto, a Rodada Dillon, que durou até 1962, foi considerada um fracasso, tendo em vista a pouca adesão às negociações e às pequenas reduções tarifárias.

Já o comitê II, envolvendo as questões agrícolas, não chegou a formular plano de ação, tendo em vista a recente criação das Comunidades Econômicas

\footnotetext{
${ }^{118}$ GATT, Trends in International Trade 11 (Haberle Report 1958-3).
} 
Européias (CEE) e de sua Política Agrícola Comum (PAC), demasiadamente complexa para ser tratada por meio de um plano de ação.

Por fim, o plano de ação do comitê III, dedicado aos países em desenvolvimento, levou a uma reunião ministerial do GATT, em 1963. Nesta reunião ministerial, foi formado o "Comitê para o Marco Institucional e Jurídico do GATT relacionado a Países Menos Desenvolvidos". Tal comitê, em 1964, elaborou a primeira versão do "Capítulo sobre Comércio e Desenvolvimento", o que viria a tornar-se a Parte IV do GATT.

Neste momento, em paralelo aos trabalhos desta reunião ministerial, é convocada a primeira Conferência das Nações Unidas para Comércio e Desenvolvimento, UNCTAD, apresentada e analisada no capítulo anterior.

Do ponto de vista institucional, duas últimas iniciativas devem ser apontadas. Em $1^{\circ}$ de maio de 1964, foi criado o Centro de Comércio Internacional ou International Trade Center (ITC), órgão criado em conjunto pelo GATT e pela UNCTAD, que tem por objetivo dar apoio técnico aos países em desenvolvimento nas negociações e na implantação de políticas comerciais. Também, em fevereiro de 1965, houve a criação do Comitê sobre Comércio e Desenvolvimento no âmbito do GATT.

\section{b) A Parte IV: Aspectos Jurídicos}

A Parte IV é composta por três artigos: o artigo XXXVI, intitulado princípios e objetivos, o artigo XXXVII, que corresponde aos compromissos, e o artigo XXXVIII, que trata da ação coletiva.

O artigo XXXVI, 1 equivale aos preâmbulos de um tratado internacional ao dispor que:

1. As Partes Contratantes,

(a) considerando que os objetivos fundamentais do presente Acordo incluem a elevação dos níveis de vida e o desenvolvimento das economias de todas as Partes 
Contratantes e considerando que o alcance desses objetivos é especialmente urgente para as Partes Contratantes menos desenvolvidas;

(b) considerando que os ingressos de exportação das Partes Contratantes menos desenvolvidas podem representar um papel fundamental em seu desenvolvimento econômico e que a extensão dessa contribuição se mede pelos preços que as Partes Contratantes menos desenvolvidas pagam pela importação de produtos essenciais, pelo volume de suas exportações e dos preços que recebem pelas mesmas;

(c) constatando que existe um desnível acentuado entre os padrões de vida dos países menos desenvolvidos e dos demais países;

(d) reconhecendo que a ação individual e coletiva torna-se indispensável para promover o desenvolvimento econômico das Partes Contratantes menos desenvolvidas e para assegurar a rápida elevação dos padrões de vida desses países; (e) reconhecendo que o comércio internacional, considerado como um instrumento de progresso econômico e social, deve ser regido por regras e regulamentos - e por medidas conformes a tais regras e regulamentos - que sejam compatíveis com os objetivos citados no presente Artigo;

(f) constatando que as Partes Contratantes podem autorizar as Partes Contratantes menos desenvolvidas a aplicarem medidas especiais destinadas a promover o seu comércio e desenvolvimento;

Concordam com o que segue.

A partir da leitura dos preâmbulos do capítulo IV, consagrados no parágrafo 1 do artigo XXXVII, pode-se perceber que há, pela primeira vez, um reconhecimento formal pelas partes do sistema multilateral de comércio, de que a lógica estabelecida no imediato pós-guerra, em termos de comércio internacional, já não mais servia à comunidade internacional. As noções de igualdade e reciprocidade entre as partes, já não eram mais sustentáveis. A discrepância entre os países desenvolvidos e países em desenvolvimento estava cada vez aumentando mais, e o sistema multilateral de comércio, em vez de aproximar-se, cada vez mais se distanciava de ambos os mundos.

Os parágrafos 2 a 9 do artigo XXXVI estabelecem diretrizes no sentido de que, daquele momento em diante, orientarão as relações comerciais entre países desenvolvidos e países em desenvolvimento, no âmbito do sistema multilateral de comércio.

2. Torna-se necessário, assegurar um aumento rápido e estável dos ingressos de exportação das Partes Contratantes menos desenvolvidas.

3. Torna-se necessário desenvolver esforços positivos destinados a assegurar às Partes Contratantes menos desenvolvidas, uma participação no crescimento do comércio internacional, correspondente às necessidades do seu desenvolvimento econômico.

4. Tendo em vista que numerosas Partes Contratantes pouco desenvolvidas continuam dependendo da exportação de uma gama limitada de produtos primários, é necessário assegurar para esses produtos, na mais ampla margem possível, condições de acesso mais favoráveis e aceitáveis aos mercados mundiais e, se for o caso, adotar medidas destinadas a estabilizar e melhorar as condições dos 
mercados mundiais para esses produtos, inclusive medidas destinadas a atingir preços estáveis, eqüitativos e remuneradores, permitindo desta forma, uma expansão do comércio mundial e da demanda e um crescimento dinâmico e constante dos ingressos reais de exportação desses países, proporcionando-lhes recursos crescentes para o seu desenvolvimento econômico.

5. A expansão rápida das economias das Partes Contratantes menos desenvolvidas será facilitada pela diversificação da estrutura de suas economias, bem como evitando a dependência excessiva na exportação de produtos primários. É por essa razão que se torna necessário assegurar da forma mais ampla possível e sob condições favoráveis, um maior acesso aos mercados para os produtos processados e manufaturados, cuja exportação apresenta ou possa vir a apresentar um especial interesse para as Partes Contratantes menos desenvolvidas.

6. Em virtude da deficiência crônica dos ingressos de exportação e de outros ingressos em divisas pelas Partes Contratantes menos desenvolvidas existe importante ligação entre o comércio e a assistência financeira para o desenvolvimento. Torna-se, portanto, necessário que as Partes Contratantes e as instituições financeiras internacionais mantenham um entrosamento perfeito e permanente, para que possam contribuir com a máxima eficácia no sentido de aliviar os encargos que as Partes Contratantes menos desenvolvidas são obrigadas a suportar a fim de fazer face ao seu desenvolvimento econômico.

7. Torna-se necessária a colaboração adequada entre as Partes Contratantes, outras organizações intergovernamentais e os organismos e instituições das Nações Unidas, cujas atividades estão relacionadas com o comércio e desenvolvimento econômico dos países menos desenvolvidos.

8. As Partes Contratantes desenvolvidas não esperam obter reciprocidade com relação aos compromissos assumidos em negociações comerciais destinadas a reduzir ou suprimir tarifas ou remover, barreiras ao comércio das Partes Contratantes menos desenvolvidas.

9. A adoção de medidas destinadas a cumprir estes princípios e objetivos, será objeto de um esforço consciente e decidido pelas Partes Contratantes, quer individual, quer coletivamente.

Neste sentido, os compromissos vigentes a partir da entrada em vigor da Parte IV, que estão previsto no artigo XXXVII, parágrafo 1, são os seguintes:

1. As Partes Contratantes desenvolvidas deverão, na maior extensão possível - salvo se impedidas, por razões imperiosas, inclusive eventualmente de ordem jurídica tornar efetivas as disposições seguintes:

(a) conceder alta prioridade à redução e à eliminação das barreiras que se opõem ao comércio dos produtos cuja exportação apresenta ou possa vir a apresentar interesse especial para as Partes Contratantes menos desenvolvidas, incluindo os direitos aduaneiros e outras restrições que diferenciam de maneira injustificável os produtos em sua forma primária e em sua forma elaborada;

(b) se abster de criar ou agravar os direitos aduaneiros ou barreiras não tarifárias à importação de produtos cuja exportação apresenta ou possa vir a apresentar um interesse particular para as Partes Contratantes menos desenvolvidas;

(c) (i) se abster de adotar novas medidas fiscais; $\mathrm{e}$

(ii) atribuir em qualquer reforma tributária a mais alta prioridade a redução e à eliminação das medidas fiscais em vigor, que venham a impedir ou que impeçam, de maneira significativa, o aumento do consumo de produtos primários em sua forma bruta ou elaborada, produzidos parcial ou totalmente nos territórios das Partes Contratantes menos desenvolvidas quando essas medidas se apliquem especificamente a esses produtos. 
Os parágrafos 2 e 3 do artigo XXXVII estabelecem os procedimentos a serem observados pelas partes na implantação da Parte IV, em matéria de negociações multilaterais, revisão dos cronogramas de concessões, consultas bilaterais, tanto das partes diretamente envolvidas, quanto das demais partes interessadas, a fim de dar o máximo de publicidade e controle multilateral à operacionalização da Parte IV. Com isto, estes parágrafos acabaram por constituir um sistema de solução de controvérsias, com disposições específicas para os países em desenvolvimento.

Por fim, o artigo XXXVIII regula a questão da ação coletiva. Com base neste dispositivo, as partes se comprometeram a engajar-se em negociações nos mais diversos foros, tanto no âmbito do GATT, nos órgãos e agências da ONU, quanto em negociações regionais e bilaterais, para a consecução dos objetivos previstos na Parte IV.

\section{c) A Rodada Kennedy: primeira rodada na vigência da Parte IV}

Diferentemente das primeiras 5 rodadas que foram destinadas exclusivamente às negociações tarifárias, embora durante a $4^{\mathrm{a}}$ rodada tenha havido a "sessão de revisão" de 1954-1955, a Rodada Kennedy foi lançada em 1964. Nesta época, o movimento do Terceiro Mundo, em prol do direito internacional do desenvolvimento, caminhava em plena atividade, ganhando legitimidade nos foros internacionais.

Em novembro de 1964, uma sessão especial do GATT foi convocada, a fim de concluir a redação do capítulo sobre comércio e desenvolvimento que havia sido iniciada a partir do Relatório Haberle. Como decorrência desta sessão, o protocolo de emenda ao GATT, contendo a Parte IV, foi submetido à aprovação das partes contratantes, finalizado em fevereiro de 1965. Finalmente, em 27 de junho de 1966, a Parte IV entrou em vigor.

Do ponto de vista das forças de negociação, alguns acontecimentos refletiram de maneira fundamental na Rodada Kennedy: em primeiro lugar, a 
adesão do Japão em 1955; em segundo lugar, a adesão das CEE em 1957; em terceiro lugar, a articulação coordenada dos países em desenvolvimento, liderados por Brasil, Índia e Egito. ${ }^{119}$

No que se refere às reduções tarifárias, os resultados foram considerados modestos. Entretanto, uma mudança fundamental no método de negociação, ocorrida ao longo da Rodada Kennedy, marcou para sempre o processo negociador do sistema multilateral de comércio. As negociações deixaram de ser produto-aproduto, e, daquele momento em diante, absorveram o sistema de redução tarifária global.

Dessa forma, a Rodada Kennedy tinha como objetivo fazer com que os países desenvolvidos estabelecessem reduções tarifárias lineares, através de um corte de $50 \%$ de todo o conjunto de tarifas, com a regra de que todas as exceções deveriam ser listadas e justificadas.

A dinâmica da Rodada Kennedy, em linhas gerais, foi a seguinte: os países em desenvolvimento foram convidados a tabular suas demandas por reduções tarifárias, em produtos que lhes interessassem, e os países desenvolvidos deveriam considerar estas demandas, quando formulassem suas ofertas de redução linear. Depois de formuladas suas ofertas, com as devidas exceções, os países em desenvolvimento teriam a oportunidade de confrontar as exceções listadas pelos países desenvolvidos, com as listas de produtos que haviam elaborado, reivindicando, assim, alguma revisão por parte dos países desenvolvidos, até que chegassem a algum acordo. Como se pode depreender, o método das negociações foi um tanto unilateral, no qual os países desenvolvidos ofereciam, e os países em desenvolvimento reclamavam por mais. Os países desenvolvidos tratavam as exigências dos países em desenvolvimento com uma simples concessão ou negativa.

\footnotetext{
${ }^{119}$ A perda de hegemonia dos EUA e o surgimento da tríade - EUA, CE e Japão - nas negociações no GATT é um elemento marcante que se reflete ainda atualmente. A influência dos países em desenvolvimento igualmente é uma tendência que, surgiu de maneira mais institucionalizada ao longo da Rodada Kennedy e que vem se afirmando e fortalecendo gradualmente ao longo das negociações.
} 
Os resultados da Rodada Kennedy mostraram-se ainda mais pífios. Os países industrializados não cumpriram inteiramente com os "compromissos" da Parte IV. Muitos produtos de importância considerável para os países em desenvolvimento, tais como têxteis e vestuários, foram totalmente excluídos das listas de ofertas dos países desenvolvidos. A abertura em relação a produtos tropicais, um dos pontos mais importantes para o Programa de Ação pós-Relatório de Haberle, foi igualmente insignificante. No que se refere à negociação de regras para medidas não-tarifárias, seus resultados foram mais modestos do que os esperados, culminando no Código Antidumping.

Durante a Rodada Kennedy, as concessões tarifárias dos países desenvolvidos abrangeram produtos industriais de interesse futuro dos países em desenvolvimento, ao contrário de produtos industriais já em produção nos países em desenvolvimento. Dos produtos já em produção, 24\% não sofreram redução alguma, outros $29 \%$ sofreram redução de menos de $50 \%$, e, os $47 \%$ restantes tiveram uma redução superior a $50 \% .{ }^{120}$

\section{d) A Relevância da Parte IV para o Sistema Multilateral de Comércio}

A Rodada Kennedy foi anunciada pelos negociadores como o grande momento de atender as reivindicações por uma inserção mais bem posicionada dos países em desenvolvimento no Sistema Multilateral de Comércio (SMC). No entanto, mesmo após a conquista dos países em desenvolvimento em inserir a Parte IV no âmbito do GATT, tais países não se contentaram com os resultados da Rodada Kennedy, buscando, por sua vez, ampliar e aprofundar sua pauta de negociações no âmbito do sistema multilateral de comércio. Propugnavam soluções mais radicais e pragmáticas, não se contentando com as retóricas da Parte IV que, como se demonstrou na prática da Rodada Kennedy, que não se materializou.

Por outro lado, do ponto de vista dos países desenvolvidos, a Rodada é considerada um êxito histórico, tendo em vista a amplitude - e em alguns setores, a

\footnotetext{
${ }^{120}$ BAHLA, Raj. Modern GATT Law: a Treatise on the General Agreement on Tarffs and Trade.
} Londres: Sweet \& Maxwell, 2005, p. 245. 
profundidade - dos cortes tarifários, um movimento de abertura comercial conjunta dos países desenvolvidos que, até então, tinha sido inédito na história do comércio internacional. Da mesma forma, os países desenvolvidos afirmam que os setores nos quais houve cortes, embora não fossem de interesse imediato dos países em desenvolvimento, eram setores que gerariam oportunidades futuras para exportações dos países em desenvolvimento.

Em linhas gerais, é fato que este novo capítulo do GATT não estabelece, concretamente, direitos e obrigações mais cogentes às partes e contratantes. Ele tem uma natureza muito mais principiológica e programática. No entanto, Jackson alerta que "a relevância da Parte IV não deve ser subestimada, simplesmente por conter uma linguagem jurídica soft". ${ }^{121}$

Os avanços normativos relativos à Parte IV transformaram, senão a letra, o espírito do GATT, proporcionando um novo contexto de interpretação dos princípios inspiradores do SMC. É neste sentido que se pode afirmar que a Parte IV surge para consolidar uma reorientação ideológica do SMC.

A Parte IV foi apenas o início deste processo de consolidação do paradigma desenvolvimentista no âmbito do sistema multilateral de comércio. Por mais vaga e imprecisa a redação deste artigo, foi com base nele e a partir deste capítulo que se originaram as negociações que viriam em seguida, gerando o Tratamento Especial e Diferenciado (TED), o Sistema Geral de Preferências (SGP) e o Sistema Global de Preferências Comerciais (SGPC), todos consolidados no âmbito da Cláusula de Habilitação.

Uma vez alcançada uma intensidade relativamente importante da construção do policy space para o desenvolvimento, por meio o artigo XVIII e da Parte IV, o salto definitivo vai se produzir durante a Rodada Tóquio.

${ }^{121}$ JACKSON (1969). op. cit., p. 647. 


\subsection{A CLÁUSULA DE HABILITAÇÃo}

a) $\mathrm{O}$ contexto do comércio internacional nos anos $\mathbf{7 0}$

i. O aumento da presença dos países em desenvolvimento no Período GATT

Das 23 partes contratantes originárias do GATT, 10 eram países em desenvolvimento: Brasil, Burma (atual Mianmar), China, Ceilão (atual Sri Lanka), Chile, Cuba, Índia, Paquistão, Síria e Líbano. Nos primeiros anos, China, Líbano e Síria se retiraram do acordo.

Nas negociações de Annecy, em 1949, outros 4 países em desenvolvimento aderiram: Haiti, Nicarágua, República Dominicana e Uruguai. Indonésia aderiu em 1950. Peru e Turquia negociaram sua adesão em 1951. Ao final das negociações de Torquay, o total de países em desenvolvimento era 14, enquanto havia 20 países desenvolvidos.

Ao longo da década de 1950, a adesão de países em desenvolvimento permanece inalterada até a adesão de Gana e Malásia, em 1957. Ao final da década de 1950, a situação começou a mudar, em razão do grande número de ex-colônias, recém-independentes.

Ao longo da década de 1960, enquanto apenas 4 países desenvolvidos aderiram ao GATT, 36 novos países em desenvolvimento juntaram-se ao sistema multilateral de comércio, dentre os quais se destacam Argentina, Israel, Coréia, República Árabe Unida (atual Egito) e Iugoslávia, além do grupo de países africanos e caribenhos, que eram colônias francesas e britânicas. Portugal e Espanha também aderiram neste período, reivindicando a condição de país em desenvolvimento, status que alteraram quando da formação da CE. 
Em maio de 1970, havia 77 partes contratantes do GATT, das quais 25 eram países desenvolvidos e 52 países em desenvolvimento. Nas duas décadas seguintes, até o lançamento da Rodada Uruguai, o número de partes contratantes atingiu 95, quando todos estes novos ingressantes o fizeram na condição de país em desenvolvimento, com exceção de Hungria e Romênia.

Essa presença maciça dos países em desenvolvimento nos fóruns multilaterais, tanto na ONU e em suas agências, como ECOSOC e UNCTAD, bem como junto ao GATT, foi paulatinamente se transformando em influência efetiva na condução das agendas destes fóruns internacionais.

Ao mesmo tempo, a formação do G-77 aumentou o poder de barganha dos países em desenvolvimento, que passaram a atuar internacionalmente em bloco. Esta ação conjunta foi uma das principais causas para o surgimento da UNCTAD. A partir de então, as relações entre países desenvolvidos e países em desenvolvimento ficaram divididas entre dois fóruns internacionais: o GATT e a recém criada UNCTAD.

Este paradigma desenvolvimentista, liderado pelos países da América Latina, Índia, Egito, e depois apoiado por um amplo grupo de países da Ásia e África, fundou-se com a necessidade premente de aprimorar os seus termos comerciais, reduzir a dependência da exportação de produtos primários, corrigir a volatilidade e desequilíbrios dos balanços de pagamentos e promover a industrialização por meio da proteção de indústrias nascentes e de subsídios à exportação, entre outros objetivos.

ii. O contexto das negociações nos anos de 1970

No início dos anos 70, as partes contratantes do GATT começaram a planejar a nova rodada de negociações multilaterais, denominada Negociações Comerciais Multilaterais (MTN em inglês), conhecida como a Rodada Tóquio. As discussões começaram em 1972 e a Rodada foi oficialmente lançada em setembro 
de 1973. As negociações começaram lentamente e foram se intensificando mais para o final da década de 70, tendo sido encerradas apenas em 1979.

A década na qual se desenrolou a Rodada Tóquio presenciou mudanças significativas em matéria de políticas comerciais, no âmbito do GATT, especialmente em razão da grave crise mundial que assolou os EUA no início dos anos 70 .

Em 1971, a mais grave crise financeira e monetária desde o pós-guerra assola o mundo. A falência do sistema de conversibilidade do dólar estadunidense em ouro, e dos sistemas de taxas fixas de conversibilidade, pôs fim ao sistema monetário internacional estabelecido pelo Acordo de Bretton Woods.

Do ponto de vista comercial, isto fez com que os produtores estadunidenses passassem a sofrer com a forte competitividade das importações, especialmente aquelas advindas dos países em desenvolvimento mais bem estruturados industrialmente, que já estavam gozando dos benefícios dos 2 grandes movimentos liberalizantes em favor dos países em desenvolvimento: as reduções da Rodada Kennedy e o início do Sistema Geral de Preferências (SGP).

Por isso, os EUA iniciaram uma política comercial de graduação dos países em desenvolvimento, tendência do início de 1970, que viria a influenciar fortemente o futuro do GATT, por meio da Cláusula de Habilitação, e, depois, se consolidar institucionalmente na OMC, como se verá mais adiante.

A lógica da graduação nos EUA era simples: o volume de exportações dos países em desenvolvimento mais avançados estava começando a causar desconfortos entre os produtores dos EUA, que passaram a reclamar da natureza unilateral da liberalização feita pelos EUA, ao longo da Rodada Kennedy, em favor dos países em desenvolvimento, e exigiam que se impusessem restrições comerciais contra eles, à medida que os volumes de importação aumentassem. O Brasil, a Coréia do Sul e Taiwan foram casos emblemáticos desse início da graduação comercial dos países em desenvolvimento pelos EUA. 
A nova política comercial dos EUA surgiu quando os países em desenvolvimento articulavam a maior campanha diplomática dos países em desenvolvimento no campo das relações econômicas internacionais até então, que previa reformar radicalmente o direito das relações econômicas internacionais. Dentre os objetivos dos países em desenvolvimento, o que mais interessava ao GATT era o que já estava em pauta desde o seu surgimento, em 1947: de um lado, maiores preferências comerciais para os países em desenvolvimento por parte dos países desenvolvidos; do outro, maior liberdade jurídica, policy space, frente às regras do GATT.

Como já mostrado anteriormente, o auge dessa campanha, ao longo dos anos 1970, foi a aprovação, no âmbito da ONU, de suas resoluções históricas: a Declaração de uma Nova Ordem Econômica Internacional (NOEI) e a Carta de Direitos e Deveres Econômicos dos Estados.

Quando a Rodada Tóquio estava prestes a começar, os países em desenvolvimento do GATT já possuíam uma agenda de reformas em mãos. A ideia seria passar de uma concepção negativa, de não-reciprocidade, que dominou as negociações ao longo dos anos 1960, para uma concepção positiva, de tratamento especial, diferenciado, mais favorável aos países em desenvolvimento, não apenas em temas de liberalização tarifária, mas em todos os temas que viessem a ser debatidos no âmbito do GATT.

Levando em consideração as negociações e os resultados efetivos que decorreram da inserção da Parte IV, tanto os EUA quanto a CE resolveram aceitar, sem maiores resistências, a proposta de Tratamento Especial e Diferenciado para a Rodada Tóquio.

O contraste que esta permissibilidade dos anos 70 manifestava, em relação aos embates dos anos 50 e 60, fazia transparecer que os países desenvolvidos tinham definitivamente aceitado, expressamente, a necessidade de reconhecer uma condição jurídica diferenciada para os países em desenvolvimento na ordem internacional. 
Mais uma vez, os países desenvolvidos, por considerarem tais instrumentos mera retórica, soft law, estavam subestimando o significado destas novas regras. A Rodada Tóquio seria o momento no qual tal retórica geraria, pela primeira vez, regras cogentes, hard law, em favor dos países em desenvolvimento.

iii. Os movimentos de liberalização em prol dos países em desenvolvimento nos anos 70

Houve dois movimentos de liberalização e redução tarifária em favor das exportações dos países em desenvolvimento ao longo dos anos 70: o SGP e as negociações da Rodada Tóquio.

Os esquemas de SGP dos países desenvolvidos reduziram e, em alguns casos, eliminaram tarifas de uma quantidade razoável de produtos exportados pelos países em desenvolvimento. Depois de mais de uma década de reivindicações de parte dos países em desenvolvimento sobre a necessidade de concessões unilaterais, os países desenvolvidos tinham finalmente feito algo. Nenhuma reciprocidade foi exigida dos países em desenvolvimento participantes do SGP.

A crescente tendência de gradualismo dentro do esquema de SGP dos EUA foi um elemento que não chamou a devida atenção dos países em desenvolvimento, e tal mecanismo viria a ser a tônica das negociações dos EUA ao longo da Rodada Tóquio, ao tratar de Tratamento Especial e Diferenciado aos países em desenvolvimento.

Muito embora a Rodada Tóquio seja mais conhecida pelas negociações dos Códigos e pela inserção da Cláusula de Habilitação, as reduções tarifárias foram igualmente um grande feito dessa rodada de negociações. Os mesmos procedimentos da Rodada Kennedy foram adotados: os países desenvolvidos estabeleciam a meta de redução tarifária global, os países em desenvolvimento apresentavam a lista de produtos de interesse, e os países desenvolvidos apresentavam suas ofertas de liberalização. No entanto, desta vez, os países desenvolvidos pressionaram os países em desenvolvimento mais avançados para 
que estes se comprometessem com algum nível de concessão tarifária. Ao aderirem a estas negociações sob tais condições, subentende-se que os países em desenvolvimento mais avançados automaticamente partilharam da ideia de que o princípio da não-reciprocidade poderia ser mitigado pela concepção de gradualismo.

Em matéria de reduções tarifárias, a média de redução dos 10 maiores países desenvolvidos em bens industriais foi de 33\%. Já a redução naqueles produtos de interesse imediato dos países em desenvolvimento foi menor, de $26 \%$. ${ }^{122}$ Mais uma vez, os países em desenvolvimento haviam saído da mesa de negociações tarifárias com consideráveis ganhos de acesso a mercados, sem terem feito concessões comerciais de maior impacto.

No entanto, ao mesmo tempo em que os países desenvolvidos estavam sendo mais generosos nas mesas de negociações do SGP e do GATT, davam início a uma estratégia de contenção de exportações, por meios dos Acordos de Restrição Voluntária às Exportações (ARVE).

Os ARVE eram acordos através dos quais os países em desenvolvimento aceitavam limitar quantitativamente as exportações para os mercados dos países desenvolvidos, em bens sensíveis aos próprios países desenvolvidos, em razão de suas ameaças em impor restrições quantitativas indiscriminadas, amparadas pelo artigo XII do GATT.

Com isso, os países desenvolvidos estabeleciam uma política comercial de give and take, pois estavam simultaneamente promovendo uma abertura comercial de suas economias em favor dos países em desenvolvimento, enquanto restringiam quantitativamente as exportações dos mesmos beneficiados, o que, de fato, neutralizava as conquistas dos países em desenvolvimento. Também, com esta política de dupla face, os países desenvolvidos, especialmente os EUA, conseguiram frear os impactos negativos internos sobre os produtores nacionais,

\footnotetext{
${ }^{122}$ HUDEC. op. cit. , p. 69.
} 
decorrentes das concessões diplomáticas aos países em desenvolvimento, nos fóruns internacionais. ${ }^{123}$

Em suma, ao final dos anos 70, os países em desenvolvimento haviam obtido êxito em liberalizar os mercados dos países desenvolvidos por meio de duas frentes de negociação, o SGP e a Rodada Tóquio. No entanto, tais conquistas foram minadas pelo uso desmedido de ARVE, que reduziam substancialmente os ganhos dos países em desenvolvimento obtidos com a liberalização.

Uma das lições da Rodada Tóquio para os países em desenvolvimento consubstanciou-se na necessidade de investimento em uma estratégia, até então, não priorizada por eles: garantir a segurança jurídica de suas conquistas, ao longo das negociações. Isto deveria ser alcançado por duas frentes: passar a negociar textos de acordos que tivessem obrigações mais cogentes e claras, e menos retóricas, e, também, passar a negociar uma reforma do sistema de solução de controvérsias do GATT, que viabilizasse aos países em desenvolvimento uma maior realização das suas prerrogativas jurídicas.

iv. Os países em desenvolvimento no âmbito do OSC ao longo das décadas de 70 e 80

As reclamações apresentadas pelos países em desenvolvimento no âmbito do OSC do GATT, embora pouco numerosas, aumentaram ao longo e a partir da Rodada Tóquio. Entre 1977 e 1995, o GATT recebeu 80 reclamações, das quais 12 eram de países em desenvolvimento contra países desenvolvidos. Isto representava o dobro do percentual de reclamações das décadas de 50 e 60 . Sete das 12

\footnotetext{
${ }^{123}$ A proliferação destes ARVE foi um item presente nas negociações da Rodada Tóquio, por meio de uma proposta dos PED de tentar reescrever o artigo XIX do GATT, que regulava de maneira completamente insuficiente tais medidas A proposta era negociar um Código sobre Salvaguardas, que ao final da Rodada Tóquio, não vingou. Portanto, os ARVE permaneceram sendo adotados como medidas dos países desenvolvidos, praticamente sem regulação, até a entrada em vigor da OMC, quando finalmente se conquistou negociar o Acordo sobre Salvaguardas.
} 
reclamações transformaram-se em procedimentos formais perante os painéis do GATT. As reclamações são as seguintes: ${ }^{124}$

\section{Tabela 4. Reclamações de países em desenvolvimento no período pós-Parte IV}

(a) Chile: European Economic Community Export Refunds on Malted Barley. Referred to conciliation, then withdrawn. See GATT Documents L/4588 and C/M/123 (1977).

(b) Republic of Korea: European Economic Community Article XIX Restrictions on Televisions. Settled. See GATT Documents C/M/124 (1978). and C/M/134 (1979).

(c) Hong Kong: Norwegian Restrictions on Textiles. Panel ruling of GATT violation. See BISD, 27th Supplement (1981), p. 119.

(d) Brazil: European Economic Community Export Refunds on Sugar. Panel report, unable to make definite ruling. See BISD, 27th, Supplement (1981), p. 69.

(e) Chile: European Economic Community Restrictions on Imports of Apples. Panel ruling of GATT violation. See BISD, 27th Supplement (1981), p. 98.

(f) India: Japanese Import Restrictions on Leather. Invoked special Article XXIII procedure for developing countries (see text at notes 22 and 23, Chapter 4): Case settled in 1981. See GATT Document L/5653 (1984).

(g) India: United States Countervailing Duty Without Injury Finding. Panel appointed, settled after first hearing. See BISD, 28th Supplement (1982), p. 113.

(h) Hong Kong: European Economic Community (French) Quantitative Restrictions. Panel ruling of violation. See BISD, 30th Supplement (1984), p. 129.

(i) Argentina, Brazil, Colombia, Cuba, Dominican Republic, India, Nicaragua, Peru and Philippines (with Australia): European Economic Community Sugar Regime (Export Subsidies). Further proceedings deferred pending commodity agreement negotiations. See GATT Documents L/5309 (1982) and $\mathrm{C} / \mathrm{M} / 166$ (1983).

(j) Argentina: European Economic Community Falklands War Embargo. Claim of violation not resolved. Decision concerning Article XXI procedures adopted. See GATT Document L/5317 (1982) and $B I S D$, 29th Supplement (1983), p. 23.

(k) Nicaragua: United States' Discriminatory Quotas on Sugar. Panel ruling of GATT violation. See $B I S D, 31^{\text {st }}$ Supplement (1985), p. 67 (panel report).

(1) Nicaragua: United States' Trade Measures Affecting Nicaragua. Panel ruling of non-justiciability. See GATT Focus, No. 42, November-December 1986, p. 4.

Apesar de não terem ganhado algum caso substancialmente relevante, em matéria de política comercial, os países em desenvolvimento, a cada novo caso, ganhavam mais confiança para levar um país desenvolvido ao painel do GATT.

Em sentido contrário, os países desenvolvidos também continuavam pressionando os países em desenvolvimento no âmbito do sistema de solução de controvérsias do GATT. Entre 1970 e 1985, das 80 reclamações apresentadas ao

\footnotetext{
${ }^{124}$ HUDEC. op. cit., p. 70.
} 
GATT, 8 eram de países desenvolvidos direcionados aos países em desenvolvimento. ${ }^{125}$

Nestes casos, a posição dos países em desenvolvimento sempre esteve fundada juridicamente na Parte IV do GATT. Segundo eles, a Parte IV justificava que as partes contratantes pudessem evadir-se das obrigações do GATT, quando tais medidas, em tese, incompatíveis, objetivassem o avanço do desenvolvimento econômico previsto na Parte IV. Como analisado na seção anterior deste capítulo, em nenhum momento, o texto da Parte IV dispõe nesse sentido. A posição estava baseada nos princípios da Parte IV, que reconhece a necessidade de acelerar o processo de desenvolvimento econômico dos países em desenvolvimento. Portanto, segundo os países em desenvolvimento, qualquer medida nesse sentido estaria atendendo os objetivos da Parte IV.

Muito embora nenhuma das decisões dos painéis tenha corroborado esta tese dos países em desenvolvimento - a ideia de que a Parte IV do GATT lhes concedia imunidade jurídica - estes casos representaram um avanço importante na relação dos países em desenvolvimento com o GATT. Os casos proporcionaram aos países em desenvolvimento um espaço para reivindicar e fortalecer os argumentos em torno da Parte IV, de forma a "judicializar" os princípios em favor dos países em desenvolvimento, até então consagrados no âmbito do GATT.

Apesar deste intento de "judicialização" da Parte IV não ter sortido resultado concreto, preparou e capacitou os países em desenvolvimento para as

125 (a) United States: Greek Tariff Preferences. Settled without panel proceedings. See GATT Documents L/3384, C/M/62, and C/M/65 (1970).

(b) United States: Jamaican Margins of Tariff Preference. Panel ruling of GATT violation and recommendation of waiver. See BISD, 18th Supplement (1972), p. 183.

(c) United States: United Kingdom Dollar Area Quotas on Citrus. Panel adjudication, settled after several hearings. See BISD, 20th Supplement (1974), pp. 230 and 236.

(d) United States: Spanish Restrictions Affecting Soybeans. Panel ruling of no GATT violation, but possibility of non-violation nullification; ruling not approved. See GATT Documents L/5142 (1981).

(e) United States: European Economic Community Tariff Discrimination on Citrus. Panel ruling of nonviolation nullification; settled, but decision neither adopted nor rejected. See GATT Document $\mathrm{L} / 5776$

(f) United States: Brazilian Export Subsidies on Poultry. Subsidies Code complaint,

(g) European Economic Community: Spanish Homologation Requirements. Standard Codes complaint resolved by decision of Standards Committee recommending compliance. See BISD, 31st Supplement (1985), p. 239.

(h) European Economic Community: Chilean Measures Affecting Imports of Dairy Products. 
negociações que estavam em andamento, na Rodada Tóquio, e para os novos casos que surgiriam no futuro dos painéis do GATT. Cada vez mais as prerrogativas jurídicas dos países em desenvolvimento, no âmbito do GATT, apresentavam autoridade moral, política e jurídica.

\section{b) A Rodada Tóquio}

i. As novidades da Rodada Tóquio

A celebração desta Rodada, entre 1973 e 1979, acontece em plena vigência da Nova Ordem Econômica Internacional, razão pela qual importa salientar, ainda que brevemente, os principais fundamentos - ideológicos e jurídicos - desta Nova Ordem, para em seguida, analisar os fatos mais marcantes da Rodada de Tóquio. Dentre os quais, destaca-se a criação da Cláusula de Habilitação, um entendimento, por meio do qual, se enquadrou e consolidou juridicamente uma série de avanços que já haviam sido alcançados pelos países em desenvolvimento, tais como o Tratamento Especial e Diferenciado, o SGP, o SPGC, bem como condições especiais para a integração regional entre países em desenvolvimento.

A $7^{\mathrm{a}}$ rodada, A Rodada Tóquio, que se inicia em 1973, com o objetivo de gerar mudanças normativas no sistema multilateral de comércio, desenvolve-se em duas esferas:

a) $\mathrm{Na}$ esfera geral, uma possível reforma do Acordo Geral, centrada fundamentalmente na viabilização deste acordo para realizar seus objetivos, que levou a um funcionamento mais equitativo e eficaz, especialmente ao tratar dos países em desenvolvimento;

b) Nas esferas específicas, a necessidade de dar tratamento jurídico mais específico às medidas não-tarifárias, que careciam de regras mais claras no âmbito 
do sistema multilateral de comércio, tais como subsídios e direitos compensatórios, valoração aduaneira, licenças de importação, salvaguardas, dentre outras.

As negociações referentes ao objetivo geral destinadas a melhorar e/ou reformar o sistema multilateral de comércio, foram estabelecidas em 1976, a partir de uma proposta do Brasil, apoiada por numerosos países em desenvolvimento e alguns países desenvolvidos.

Ao final, esta rodada foi a que mais trouxe novidades para o sistema multilateral de comércio até então. Foram elaborados nove novos acordos e quatro entendimentos, relacionados aos mais diversos temas, envolvendo medidas nãotarifárias. $^{126}$

A Rodada Tóquio representa o momento mais marcante para o sistema multilateral de comércio até então, só sendo superado posteriormente pela Rodada Uruguai, pois foi ao longo da Rodada Tóquio que, ao mesmo tempo, ocorreu uma grande ampliação temática do Sistema Multilateral de Comércio, e, também, garantiu maior reconhecimento dos direitos dos países em desenvolvimento, que até aquele momento só eram reconhecidos por exceções, waivers e derrogações temporais.

Do ponto de vista dos países em desenvolvimento, a Rodada Tóquio foi o momento no qual se consolidou uma série de conquistas alcançadas desde a incorporação da Parte IV. O instrumento por meio do qual esta consolidação se deu foi a Cláusula de Habilitação, um dos entendimentos aprovados ao final da Rodada.

No entanto, o viés da NOEI influenciou muitos outros âmbitos da Rodada Tóquio. A condição diferenciada dos países em desenvolvimento foi levada em

\footnotetext{
${ }^{126}$ Novos entendimentos: Tratamento especial e diferenciado, reciprocidade e maior participação dos países em desenvolvimento; Declaração sobre medidas comerciais tomadas visando balanço de pagamentos; Medidas de salvaguarda em favor do desenvolvimento; Entendimento concernente a notificação, consulta, solução de controvérsias e supervisão.

Novos acordos: Barreiras técnicas ao comércio; Compras públicas; Subsídios; Acordo relacionado a carne bovina; Acordo relacionado a produtos lácteos; Implementação do Artigo VII (Valoração Aduaneira); Procedimentos para licenciamento de importações; Comércio de aeronaves civis; Implementação do Artigo VI (Direitos antidumping)
} 
consideração, tanto nas negociações setoriais - agricultura e produtos tropicais que representavam interesses estratégicos para estes países, bem como nas questões relacionadas à medidas não-tarifárias.

Além da Cláusula de Habilitação, outros entendimentos foram firmados em benefício dos países em desenvolvimento:

- um entendimento relativo a problemas de balanço de pagamentos, que além de permitir a utilização de sobretaxas pelos países em desenvolvimento, flexibilizava o mecanismo de revisão das restrições dos países em desenvolvimento;

- outro entendimento relativo ao artigo XVIII que, além de estender a aplicação das exceções para proteção de indústrias nascentes, remove uma das questões mais controvertidas das negociações dos anos 50 e 60: a exigência de autorização prévia das partes do GATT para implantar medidas de proteção a indústrias nascentes.

Em troca, por conceder estes entendimentos, os EUA exigiram que os países em desenvolvimento aceitassem reconhecer o principio da graduação, por meio da cláusula evolutiva da cláusula de habilitação. Tal princípio se consolida e aprofunda na Rodada Uruguai e nos acordos resultantes da mesma, razão pela qual será aprofundado na Parte II desta tese.

A Rodada Tóquio foi considerada uma grande vitória dos países em desenvolvimento, em especial do G-77, e da influência dos trabalhos da UNCTAD junto ao GATT, tendo em vista as diversas conquistas em matéria de policy space que haviam alcançado ao final da Rodada.

No entanto, o GATT se encontrava em uma situação paradoxal. O ano era 1979 e estava o GATT, de um lado, ainda imensamente preocupado em angariar a adesão dos países em desenvolvimento, e, de outro, reconhecendo cada vez mais que as suas próprias regras não se aplicavam aos países em desenvolvimento. A relação entre ambas as lógicas, tão dissonantes, se revelava cada vez mais viva no GATT. 


\section{ii. A Cláusula de Habilitação}

A Cláusula de Habilitação, formalmente denominada "Decisão sobre Tratamento Especial e Diferenciado, Reciprocidade e Maior Participação dos Países em Desenvolvimento", foi adotada em 28 de novembro de 1979. Ela representou a sistematização jurídica de uma série de preferências comerciais concedidas aos países em desenvolvimento, com base no princípio do tratamento especial e diferenciado.

A partir da Cláusula de Habilitação, o tratamento especial e diferenciado não mais seria considerado condição excepcional e temporal ao sistema, mas sim, permanente, tendo em vista que os problemas a serem enfrentados pelos países em desenvolvimento não eram resolúveis em curto prazo e tampouco as políticas de desenvolvimento a ser implantadas poderiam ser planejadas e executadas seguindo prazos impostos pelo GATT, de forma desconexa às necessidades locais.

A Cláusula de Habilitação, em seu parágrafo 2, compreende a legalização de 4 âmbitos de políticas comerciais:

a) As preferências tarifárias reguladas no âmbito do Sistema Geral de Preferências;

b) As preferências não-tarifárias reguladas nos códigos recém-criados ao longo da Rodada Tóquio;

c) As preferências tarifárias e, em certa medida, as não-tarifárias, que os países em desenvolvimento estabelecem entre si no âmbito multilateral, inter-regional, ou regional;

d) O tratamento especial e diferenciado em favor dos países de menor desenvolvimento relativo.

São estas prerrogativas consagradas na Cláusula de Habilitação que serão analisadas ora em diante. 
iii. A Cláusula Evolutiva (Graduação dos Países em Desenvolvimento)

Um último ponto deve ser analisado antes de se ingressar no estudo de cada prerrogativa da Cláusula: a questão do parágrafo 7 da Cláusula de Habilitação, a chamada Cláusula Evolutiva.

O parágrafo 7 dispõe o seguinte:

“(...) As partes contratantes em desenvolvimento esperam que sua capacidade de fazer contribuições, ou concessões negociadas, ou de adotar outras medidas mutuamente conveniadas, em conformidade com as disposições e procedimentos do Acordo Geral, aumente com o desenvolvimento progressivo de sua economia e o melhoramento da sua situação comercial, e esperam, conseqüentemente, participar mais plenamente no marco de direitos e obrigações do Acordo Geral".

A Cláusula Evolutiva é um dispositivo que prevê que, à medida que os países em desenvolvimento forem efetivamente "se desenvolvendo", passem a participar do sistema multilateral de comércio, menos fundados no Tratamento Especial e Diferenciado e mais suscetíveis aos direitos e às obrigações gerais do GATT.

Nesse sentido, a cláusula evolutiva exerce um duplo efeito sobre os países em desenvolvimento: um primeiro, de ordem motivacional, que decorre do otimismo da previsão de que os países em desenvolvimento efetivamente conseguirão alcançar os objetivos fundamentais do preâmbulo e da Parte IV do GATT, quais sejam o maior desenvolvimento econômico e a melhoria da situação comercial das partes contratantes, em especial, as partes em desenvolvimento. A segunda consequência é que, à medida que alcancem tal desenvolvimento, será exigido destas partes que não mais recorram ao Tratamento Especial e Diferenciado e que passem a integrar o sistema multilateral de comércio, nas condições previstas dos direitos e obrigações gerais do GATT.

\section{c) O Sistema Geral de Preferências}


A introdução do Sistema Geral de Preferências (SGP) é mais uma consequência da atuação da UNCTAD, no âmbito da II Conferência da UNCTAD, em Nova Déli. ${ }^{127}$

O SGP surge em decorrência do seguinte cenário: enquanto os EUA e o resto do mundo estavam sujeitos a um grande esquema global de comércio - o GATT - a Comunidade Europeia (CE) instituiu ambos os sistemas, um global, de amplo alcance a todos os países em desenvolvimento, e outro, um esquema adicional, apenas para alguns países com os quais a CE mantinha laços históricos e coloniais.

Por isso, os EUA aceitaram criar o SGP com o intuito de pressionar a CE a abandonar sua política de preferências especiais para países do mediterrâneo e da África, e em especial, as preferências reversas, que tais países estavam obrigados a conceder a CE.

Nesse sentido, o SGP marca um ponto de inflexão decisivo na história das relações econômicas internacionais, porque parte de um ponto de vista até então inédito, superando o enfoque regional tradicional das preferências comerciais estabelecidas pelos países desenvolvidos, em favor das antigas colônias. Passa-se, portanto, do regionalismo para o universalismo das preferências outorgadas aos países em desenvolvimento.

Este sistema proposto pela UNCTAD assenta-se em dois pilares: nãoreciprocidade e não-discriminação. Trata-se de um sistema não-recíproco, pois supõe a redução tarifária de maneira unilateral pelos países desenvolvidos, sem que os países em desenvolvimento estejam obrigados a realizar uma redução similar, e, igualmente, não-discriminatório, pois supera o âmbito seletivo de preferências tradicionalmente outorgadas e prevê sua extensão generalizada a todos os países em desenvolvimento.

Sistema este que, em linhas gerais, objetiva aumentar os ganhos dos países em desenvolvimento em razão do aumento das suas exportações, favorecendo a industrialização dos países em desenvolvimento e acelerando seu ritmo de

${ }^{127}$ Resolução n ${ }^{\circ} 21$ da UNCTAD, de 26 de março de 1968. 
crescimento econômico. Sua pretensão é a de alcançar tais objetivos por meio de um sistema de preferências tarifárias, no qual se desenvolve a redução dos direitos aduaneiros aos produtos originários dos países em desenvolvimento, que não seriam reduzidos para os mesmos produtos advindos de países desenvolvidos.

Do ponto de vista material, se está diante de uma regra comercial destinada a promover as exportações industriais dos países em desenvolvimento, facilitando seu acesso aos mercados dos países desenvolvidos. Neste sentido, distinguem-se dois tipos de Estados: os Estados concedentes de preferências (países desenvolvidos) e os Estados beneficiários (países em desenvolvimento).

Por outro lado, as preferências se configuram como uma prerrogativa dos países desenvolvidos na sua relação com os países em desenvolvimento, o que gera duas consequências fundamentais, uma negativa e outra. A consequência negativa: o alcance do sistema fica reduzido, por depender da concessão voluntária dos países desenvolvidos, e por ser temporário. A consequência positiva: ao configurarse como uma concessão unilateral, voluntária e temporária, os países desenvolvidos estavam mais cômodos para utilizar tal sistema, pois os compromissos eram menores. $^{128}$

A viabilidade jurídica da proposta de SGP da UNCTAD dependia da sua assunção no âmbito do GATT. Nesse sentido, por meio da Decisão de 25 de junho de 1971 das partes contratantes do GATT, a proposta foi autorizada pelas partes como uma derrogação da Cláusula da Nação Mais Favorecida (NMF), na forma de dois waivers, que permitiam dois tipos de esquemas preferenciais.

a) Um deles era um waiver com prazo de 10 anos que afastava o Artigo I, a cláusula NMF, para permitir a instituição dos SGP.

b) O outro waiver também tinha prazo de 10 anos e permitia aos PED negociar preferências tarifárias entre si, não extensíveis as demais partes do GATT, por meio de um Protocolo de Negociações Comerciais (PTN 1971), que viria a ser a base jurídica para as negociações do SGPC.

${ }^{128}$ SALVADOR, Ana Manero. OMC y Desarrollo: evolución y perspectivas del trato desigual en el derecho del comercio internacional. Valência: Tirant Lo Blanch, 2006, p. 131. 
Nove anos mais tarde, em 1979, ambos estes waivers foram tornados permanentes por meio da Cláusula de Habilitação.

Nesse sentido, o SGP se constituiu como uma derrogação temporal - de 10 anos - da cláusula da nação mais favorecida, do artigo I do Acordo. Esta derrogação mostrou-se fundamental para permitir que os países desenvolvidos pudessem conceder tratamento especial aos produtos dos países em desenvolvimento, de maneira geral, sem que estivessem automaticamente vinculados e obrigados a estender tais benefícios para as demais partes contratantes.

Discute-se se este foi o método mais apropriado para a inserção do SGP no quadro do GATT, devido à natureza que tal sistema assumiu, de derrogação à Cláusula NMF, tendo em vista que tal enfoque, de outorga de preferências por meio de waivers do artigo XXV.5 - tradicionalmente utilizado pelo GATT - padecia de falta de perspectiva, já que não considerava o problema desde uma perspectiva mais ampla.

Olivier Long realiza uma análise dos efeitos jurídicos negativos da utilização do waiver. Segundo este autor:

Isto traz consigo uma interpretação exorbitante do artigo XXV.5 do GATT, já que o termo derrogação tem uma clara conotação negativa, ao autorizar uma medida que, a priori, não está conforme as obrigações das partes contratantes do GATT. A utilização de uma Declaração teria sido a opção mais idônea, tendo em vista que estaríamos ante um ato positivo, por meio do qual estaria manifesta a vontade das partes contratantes de promover os objetivos da Parte IV do GATT, mais concretamente, do artigo XXXVI, para favorecer o comércio dos PED como instrumento essencial do seu desenvolvimento. ${ }^{129}$

Nesse sentido, ao incorporar o SGP ao sistema multilateral de comércio por meio de um waiver, o artigo I, a Cláusula NMF, se mantém como pilar jurídico de todo a arquitetura do GATT, enquanto o SGP não é mais do que uma derrogação temporal, que tolera violações às regras gerais de natureza liberal, se fundadas no fomento do desenvolvimento dos países em desenvolvimento.

Além disso, outro problema de implantação do SGP é que este sistema deveria alcançar todos os produtos manufaturados e semi-manufaturados

${ }^{129}$ LONG, Olivier. Law and its limitations in the GATT Multilateral Trading System. Nova York: Kluwer Law International, 1987, p. 121. 
exportados pelos países em desenvolvimento. No entanto, na prática, aqueles produtos denominados sensiveis - têxteis, vestuário, aço, couro, etc. - estiveram, e seguem estando, fora do escopo do SGP.

Os defeitos do SGP são, portanto, de ordem material, - pela limitação dos produtos abarcados e dos países beneficiários - assim como de caráter formal - pela provisoriedade, caráter derrogatório, discricionariedade dos países desenvolvidos na hora de conceder as preferências. Tudo isso reflete a limitação do alcance e da sua inadequação às necessidades de desenvolvimento dos países em desenvolvimento.

Segundo Jackson:

Os esquemas adotados por cada país desenvolvido, concessionário de preferências, para implantar o SGP, varia em termos de produtos abrangidos, países beneficiários, níveis de redução tarifária, regras de origem, sujeição do produto a medidas não-tarifárias, tais como quotas. Além disso, todos os esquemas incluem medidas de salvaguarda, tais medidas de escape ou limitações quantitativas ao comércio, dentro de tais esquemas. ${ }^{130}$

O fato de a Cláusula de Habilitação ter contemplado o SGP corrigiu a discrepância analisada acima, de que tal sistema estivesse enquadrado juridicamente no sistema multilateral de comércio como derrogação temporal, como uma violação temporariamente tolerada do artigo primeiro do GATT. A partir da Cláusula de Habilitação, o SGP deixou de ser temporário e se tornou permanente. $^{131}$

\section{d) O Sistema Global de Preferências Comerciais}

A Cláusula de Habilitação foi constituída com o objetivo de criar uma base jurídica mais sólida para as medidas de preferências comerciais. Supunha-se que a

130 JACKSON, John. The jurisprudence of GATT \& the WTO: Insights on Treaty Law and Economic Relations. Cambridge: Cambridge University Press, 2000, p. 65.

131 Os sites dos principais SGP são os seguintes: SGP dos EUA - http://www.ustr.gov/tradetopics/trade-development/preference-programs/generalized-system-preference-gsp; SGP da UE http://ec.europa.eu/trade/wider-agenda/development/generalised-system-of-preferences/; SDP do Japão - http://www.mofa.go.jp/policy/economy/gsp/index.html. 
posterior elaboração e implantação das medidas ocorreria ao longo da década de 80. Uma das áreas nas quais se esperavam avanços era nas iniciativas de comércio preferencial entre países em desenvolvimento. Duas iniciativas se destacaram: uma no âmbito do GATT e outra no âmbito da UNCTAD.

A iniciativa no âmbito do GATT começou em 1971 com o Protocol Relating to Trade Negotiations among Developing Countries (PTN). O Protocolo era um miniGATT entre países em desenvolvimento, contendo cronograma de concessões e uma série de dispositivos idênticos ao GATT, para estabelecer o marco regulatório destas concessões entre os países em desenvolvimento. O PTN entrou em vigor em fevereiro de $1973 .^{132}$

Em 1976, na reunião ministerial de 1976, em Nairobi, o Secretário da UNCTAD divulgou estudo próprio que propunha a formação de um Sistema Global de Preferências Comerciais (SGPC), um sistema mundial que substituiria os diversos esquemas de preferências comerciais regionais e abrangeria, além de medidas tarifárias, todas as medidas não-tarifárias.

Paulatinamente, a ideia foi gradualmente tomando corpo com as sucessivas reuniões do G-77 de Arusha (1979) e Caracas (1981). Em 1982, em Nova York, os ministros do G77 definiram os elementos básicos do acordo e estabeleceram um acordo-quadro para as negociações. Em 1984, em Genebra, o G77 iniciou os trabalhos preparatórios nos vários aspectos do acordo-quadro. Em 1986, na reunião ministerial de Brasília, a estrutura provisória do acordo estava estabelecida e a primeira rodada de negociações foi lançada. Em 1988, em Belgrado, a rodada de negociações foi concluída, juntamente com a adoção do texto final do acordo, que entrou em vigor em $1989 .{ }^{133}$

O SGPC foi estabelecido como um fórum no qual os países em desenvolvimento poderiam fazer concessões e outorgar preferências comerciais

132 O PTN do GATT de 1971 não foi recebido com tanto ímpeto, mesmo depois da Clausula de Habilitação em 1979. Inicialmente, o PTN tinha 16 signatários em 1971, e ao final de 1984, havia se somado apenas 2 novos PED. Em 1993, a India se retirou. A Espanha igualmente se retirou, por não mais se considerar PED. Atualmente, os signatários do PTN são os seguintes: Bangladesh; Brasil; Chile; Coréia do Sul; Egito; Filipinas; Israel; México; Paquistão; Paraguai; Peru; Sérvia; Tunísia; Turquia; Uruguai. Os signatários continuaram reunindo-se no âmbito do Comitê de Comercio e Desenvolvimento do GATT, no entanto, as negociações nunca ocorreram.

${ }^{133}$ Site do SGPC: http://www.unctadxi.org/templates/Page 1879.aspx 
entre si, para fomentar o comércio, sem necessariamente estendê-las aos demais países, signatários do GATT. ${ }^{134}$

Conforme o Acordo de Belgrado, a cooperação econômica entre países em desenvolvimento é um elemento-chave na estratégia de autonomia coletiva, e um instrumento essencial para promoção de mudanças estruturais que visem contribuir com um processo de desenvolvimento econômico global mais balanceado e equitativo.

Neste sentido, O SGPC propõe-se a abranger todos os produtos e commodities, seja in natura, semi-processados ou processados. Consiste em um acordo sobre tarifas e medidas não-tarifárias, medidas relacionadas ao comércio e acordos setoriais é exclusivo para os países em desenvolvimento Membros do G-77. ${ }^{135}$

O SGPC leva em consideração as limitações dos países em desenvolvimento, no que se refere à capacidade de conduzir as negociações comerciais. Portanto, as negociações do SGPC podem ser conduzidas em âmbito bilateral, plurilateral ou multilateral, por meio de abordagens "produto-a-produto", "reduções tarifárias globais" ou "setoriais".

No que se refere às assimetrias entre os países em desenvolvimento participantes do acordo, os benefícios do SGPC são menos claros. Nos acordos e declarações vigentes, o tema é tratado de forma controversa. Em primeiro lugar, no Acordo de Belgrado, de 1988, o artigo 3 (f) estabelece que as necessidades dos países de menor desenvolvimento relativo devem ser claramente reconhecidas, além de medidas preferenciais concretas devem ser acordadas em seu favor, e que tais países não deverão fazer concessões em bases recíprocas.

Ademais, o artigo 17, sobre tratamento especial para países com menor desenvolvimento relativo (PMDR), estabelece que estes não deverão ser demandados a fazer concessões e devem se beneficiar de toda e qualquer concessão

\footnotetext{
${ }^{134}$ Deve se observar que esta conquista esta diretamente relacionada a atuação tanto do Grupo dos 77 (G77) quanto da UNCTAD. De fato, com o apoio da UNCTAD, os países em desenvolvimento concentraram sua posição ao longo da Rodada de Tóquio, liderados especialmente pelo Brasil, Egito, Índia e a antiga Iugoslávia.

${ }^{135}$ Além disso, o artigo 18 do acordo dispõe que este deve complementar - e não substituir - os agrupamentos econômicos dos países Membros do G-77, seja regionais, sub-regionais ou interregionais.
} 
tarifária ou não-tarifária que sejam multilaterais, e que eles podem buscar assistência técnica da ONU, a fim de identificar os produtos de exportação para os quais devem buscar concessões nos mercados dos demais participantes.

\section{e) Integração Regional e Desenvolvimento}

A relação entre acordos regionais de comércio (ARC) e desenvolvimento não figurava com muita clareza nos primórdios do GATT. Até 1979, ano em que a Cláusula de Habilitação foi estabelecida, diversos países em desenvolvimento recorriam à Parte IV do GATT para justificar os acordos regionais de comércio, que eram inconsistentes com o artigo XXIV. O caso da Associação Latino Americana de Livre Comércio (ALALC), quando autorizou o surgimento do Pacto Andino, resta emblemático nesse sentido. Tal caso será aprofundado no capítulo seguinte.

$\mathrm{O}$ artigo XXIV do GATT estabelece as bases para permitir os acordos regionais de comércio como exceção à Cláusula NMF. Com base no artigo XXIV, há dois tipos de acordos regionais de comércio: as zonas de livre comércio e as uniões aduaneiras.

Uma Zona de Livre Comércio (ZLC) é um acordo por meio do qual os Membros estabelecem a obrigação de eliminar tarifas e barreiras não-tarifárias para produtos importados de outros Membros da Zona de Livre Comércio. Uma Zona de Livre Comércio é definida pelo artigo XXIV, 8:b do GATT, nos seguintes termos:

Artigo XXIV, 8.b. GATT - entende-se por zona de livre comércio um grupo de dois ou mais territórios aduaneiros entre os quais os direitos aduaneiros e outras regulamentações restritivas das trocas comerciais (com exceção, na medida necessária, das restrições autorizadas nos termos dos artigos XI, XII, XIII, XIV, XV e XX) são eliminados para a maioria das trocas comerciais relativas aos produtos originários dos territórios constitutivos da zona de livre comércio. 
Em uma União Aduaneira (UA) há, novamente, a exigência de eliminação de tarifas e barreiras não-tarifárias no comércio intra-Membros da integração. No entanto, para cada categoria de produtos há uma tarifa comum a ser aplicada pelos países Membros da União Aduaneira, em relação aos demais países não-Membros da União Aduaneira. Esta é comumente denominada de Tarifa Externa Comum (TEC). Uma União Aduaneira é definida pelo Artigo XXIV, 8.a. do GATT, nos seguintes termos:

Artigo XXIV, 8.a. GATT - entende-se por união aduaneira, a substituição, por um só território aduaneiro, de dois ou mais territórios aduaneiros, de modo que :

(i) os direitos aduaneiros e outras regulamentações restritivas das trocas comerciais (com exceção, na medida necessária, das restrições autorizadas nos termos dos artigos XI, XII, XIII, XIV, XV e XX) sejam eliminados para a maioria das trocas comerciais entre os territórios constitutivos da união, ou ao menos para a maioria das trocas comerciais relativas aos produtos originários desses territórios;

(ii) e, à exceção das disposições do parágrafo 9 os direitos aduaneiros e outras regulamentações idênticas em substância sejam aplicadas, por qualquer Membro da união, no comércio com os territórios não compreendidos naqueles.

Pela análise dos dispositivos do artigo XXIV, podem ser extraídas quatro regras básicas, com as quais os signatários do GATT se comprometeram com a finalidade de que as Zona de Livre Comércio e União Aduaneira fossem consideradas compatíveis:

1) Obrigação de notificação: a primeira regra é uma exigência procedimental: notificar ao GATT sobre a criação de um acordo regional de comércio para a sua revisão por um grupo de trabalho composto para este fim específico.

2) Obrigação extra-bloco: a segunda regra é uma exigência em relação ao comércio exterior dos Membros do acordo regional de comércio. Os Membros do acordo regional de comércio se comprometem a, no mínimo, manter o mesmo nível de acesso aos mercados, nos níveis anteriores ao de sua celebração, estando proibidos de aumentar o nível de proteção em relação aos países não-Membros do acordo. 
3) Obrigação intra-bloco: a terceira regra estabelece o compromisso de liberalizar substancialmente todo o comércio entre os Membros do acordo regional de comércio, os proibindo de criar um acordo para cobrir apenas setores produtivos e comerciais específicos.

4) Obrigação temporal: a quarta regra determina que a implantação de um acordo regional de comércio deve se dar em um período razoável de tempo, sem definir tal prazo.

Ao longo da vigência do artigo XXIV, a principal regra não observada por esses acordos regionais de comércio, envolvendo os países em desenvolvimento, devido às assimetrias intra-regionais, era o artigo XXIV: 8 (a) e (b) que exigia a liberalização de "substancialmente todo o comércio".

Com o surgimento do princípio da não-reciprocidade instituído com a Parte IV, os países em desenvolvimento desenvolveram a sustentação argumentativa para aqueles acordos regionais de comércio que estavam sendo formados, levando em consideração "substancialmente parte do comércio", aquela parte que interessava aos países em desenvolvimento. ${ }^{136}$

A partir da Cláusula de Habilitação, são estabelecidas regras específicas para os acordos regionais de comércio envolvendo os países em desenvolvimento. Um acordo regional de comércio envolvendo um ou mais países em desenvolvimento é definido pelo parágrafo 2(c) da Cláusula de Habilitação:

"Acordos regionais ou globais celebrados entre partes contratantes menos
desenvolvidas visando a redução ou eliminação mútua de tarifas e, de acordo com
os critérios e condições a serem definidas pelas partes contratantes, para a redução
ou eliminação mutua de medidas não-tarifárias, sobre produtos importados um do
outro".

O parágrafo 3 da Cláusula de Habilitação define as condições para que estes acordos regionais de comércio sejam considerados compatíveis com as regras do GATT:

"Qualquer tratamento diferenciado e mais favorável concedido com base nesta cláusula:

${ }^{136}$ FEUER, Guy; CASSAN, Hervé. Droit International du Développment. Paris: Dalloz, 1985, p. 523. 
(a) deve ser desenhado de forma a facilitar e promover o comércio entre paises em desenvolvimento e não para aumentar barreiras ou criar dificuldades inde4vidas para o comércio com outras partes contratantes;

(b) Não deve constituir impedimento para a redução ou eliminação de tarifas e outras restrições ao comércio com base na cláusula da nação mais favorecida;

(c) No caso de tal tratamento ser concedido por partes contratantes desenvolvidas para países em desenvolvimento, deve ser desenhado e, se necessário, modificado, para responder positivamente ao desenvolvimento, e as necessidades comerciais e finaceiras dos paises em desenvolvimento".

Nesse sentido, os acordos regionais de comércio entre países em desenvolvimento são aqueles nos quais as partes concedem acesso preferencial, tanto a bens, quanto a serviços a seus parceiros. $\mathrm{O}$ acesso preferencial não precisa abarcar todos os bens, nem exige a completa remoção das tarifas sobre os bens incluídos no acordo.

Estes acordos têm duas características principais: (i) são fundados no princípio da não-reciprocidade, que permite aos países em desenvolvimento não reduzir tarifas na mesma medida que os países desenvolvidos Membros do acordo; (ii) de acordo com o princípio do Tratamento Especial e Diferenciado, aplicável aos acordos regionais de comércio, as concessões oferecidas pelos países desenvolvidos para os países em desenvolvimento no âmbito de acordos regionais de comércio não são automaticamente estendidos a outros Membros do GATT.

Finalmente, de acordo com o princípio geral da transparência do GATT, o parágrafo 4 da Cláusula de Habilitação estabelece a obrigação das partes de notificar todo acordo regional de comércio para o Comitê competente.

É com base nestes dispositivos da Cláusula de Habilitação que os países em desenvolvimento iniciam um movimento de integração regional com características diferenciadas em relação aos anteriormente em vigor. 


\section{CONCLUSÕES DO CAPÍTULO 2.}

O capítulo 2 trata do processo de incorporação do direito internacional do desenvolvimento no âmbito do sistema multilateral de comércio, até transformar-se em um conjunto de prerrogativas jurídicas à disposição dos países em desenvolvimento, ao longo da vigência do GATT-47. Este conjunto de prerrogativas que foi construído e colocado à disposição dos países em desenvolvimento, no âmbito do sistema multilateral de comércio, é fruto da universalização do direito internacional do desenvolvimento apresentado no capítulo anterior, quando este passou a se manifestar por meio de outras organizações e fóruns internacionais, tais como o GATT.

Muito embora o sistema multilateral de comércio tenha sido originariamente idealizado e constituído pelos países vencedores da Segunda Guerra Mundial, quando tal proposta foi submetida à comunidade internacional para apreciação e aprovação, os países em desenvolvimento, desde o princípio, contestaram a ausência de prerrogativas jurídicas no âmbito do GATT-47. Em razão desta parte da história ser constantemente omitida pela literatura dominante sobre o sistema multilateral de comércio, fez-se questão de apresentar com mais detalhamento a participação e a posição dos países em desenvolvimento nas negociações da OIC e do GATT.

Neste momento, Brasil e Índia desempenharam papel de destaque. Uma das conquistas dessa postura de reivindicações dos países em desenvolvimento foi o direito à proteção de indústrias nascentes, por meio do artigo XVIII, existente no GATT, desde o seu surgimento em 1947, mas que se consolidou em definitivo em 1955, quando foram incorporadas todas as reivindicações dos países em desenvolvimento.

Ao final da década de 50, o movimento de articulação do Terceiro Mundo já extrapolava os limites da ONU e reverberava nas questões reguladas no âmbito do GATT. O surgimento da UNCTAD foi o elo entre a ONU e o sistema multilateral de comércio, possibilitando consolidar o reconhecimento jurídico da desigualdade econômica entre os Estados, por meio da introdução da Parte IV do GATT. 
Através dos princípios da não-reciprocidade e do tratamento especial e diferenciado, a Parte IV flexibiliza tanto o processo de negociação, quanto o rigor de aplicação das regras do GATT para os países em desenvolvimento.

No entanto, a natureza demasiadamente principiológica desta Parte IV, fez com que os países em desenvolvimento passassem a reivindicar um novo conjunto de prerrogativas mais pragmáticas e menos excepcionais como estava sendo concedido até então, por meio de derrogações parciais (waivers). Para que os países em desenvolvimento pudessem fazer políticas de desenvolvimento com maior estabilidade institucional e segurança jurídica, fez-se necessário consolidar estes waivers.

Foi isto que alcançaram em 1979, por meio da Cláusula de Habilitação, que abrangia: o direito à não-reciprocidade comercial com os países desenvolvidos (por meio do SGP); o direito de estabelecer relações comerciais entre os países em desenvolvimento, não extensíveis aos países desenvolvidos (SGPC); e o direito de estabelecer processos de integração regional com regras mais flexíveis por envolver países em desenvolvimento.

Como pode se perceber, policy space para o desenvolvimento representa um tema constante, ao longo das negociações do período GATT, desde as primeiras reuniões preparatórias para a OIC, até a Rodada Tóquio.

Pode-se identificar duas etapas dessa postura pró-policy space dos países em desenvolvimento.

Na primeira, até o inicio da década de 1960, os esforços giraram em torno da capacidade de impor medidas não-tarifárias (cotas, restrições tarifárias, etc.) contra as importações dos países desenvolvidos. Nesse sentido, as negociações estavam centradas em torno do artigo XVIII, do aumento da flexibilidade para invocá-lo, e da dispensa de autorização prévia das partes do GATT para aplicá-lo.

Na segunda, do início da década de 60 em diante, apesar de as posições de negociação se intensificarem e se ampliarem,o foco muda radicalmente. Em vez de manter uma postura negociadora centrada, fundamentalmente, no protecionismo 
anti-países desenvolvidos, passa-se a uma postura de reivindicação de abertura comercial. Fundada na ideia de não-reciprocidade, os países em desenvolvimento exigiam acesso ao mercado dos países desenvolvidos, e reivindicavam a possibilidade de comércio sul-sul, não extensiva aos países desenvolvidos.

A partir do momento em que os países em desenvolvimento perceberam a insustentabilidade da manutenção de modelos de desenvolvimento demasiadamente endógenos, como foi o caso da primeira fase dos Modelos de Industrialização por Substituição de Importações (ISI) que será analisado na Parte II desta tese, fez-se necessário ampliar a abrangência destes modelos, fomentando as trocas comerciais que pudessem estimular as indústrias nascentes.

Neste sentido, há uma convergência entre ambos os pilares do policy space para o desenvolvimento do período GATT: enquanto a proteção da indústria nascente estava fundada no artigo XVIII, o crescimento e a consolidação desta indústria estavam baseados no SGP, na integração regional (artigo XXIV combinado com a cláusula de habilitação) e no SGPC.

Com base neste pequeno, mas relevante, arsenal de direitos, especialmente a Cláusula de Habilitação, os países da América do Sul passaram a fundamentar juridicamente suas políticas de integração e desenvolvimento, criadas ao longo da segunda metade do século XX. É acerca da relação entre estas políticas de integração e desenvolvimento da América do Sul e o sistema multilateral de comércio que tratará o capítulo 3.

A título de conclusão deste capítulo, percebe-se que a Era GATT presenciou a ascensão e consolidação da demanda dos países em desenvolvimento por policy space. O movimento de ascensão, influenciado em larga medida pelas concepções do DID referidas no capítulo 1, levou a uma reforma de grande relevância nas regras do sistema multilateral de comércio.

A partir da incorporação das premissas desenvolvimentistas pelo GATT, os países em desenvolvimento, dentre eles os latino-americanos, fizeram uso intenso de tais prerrogativas jurídicas. Neste sentido, destacam-se o Modelo ISI, os processos de integração regional, os acordos comerciais não-recíprocos com os 
países desenvolvidos, e a criação de uma rede de preferências comerciais que beneficiam apenas os países em desenvolvimento, posteriormente chamada de comércio sul-sul. 


\section{CAPÍTULO 3. O EXERCÍCIO DAS PRERROGATIVAS JURÍDICAS DESENVOLVIMENTISTAS NA INTEGRAÇÃO SUL-AMERICANA DO SÉCULO XX}

Os países membros realizarão as ações necessárias
para estabelecer e desenvolver vínculos de
solidariedade e cooperação com outras áreas de
integração fora da América Latina, mediante a
participação da Associação nos programas que se
realizam em nível internacional em matéria de
cooperação horizontal, na execução dos princípios
normativos e compromissos assumidos no contexto
da Declaraçãa e Plano de Ação para a criação de
uma Nova Ordem Econômica Internacional e da
Carta de Direitos e Deveres Econômicos dos
Estados.

Tratado Constitutivo da ALADI, artigo 26, 1980 


\section{APRESENTAÇÃO DO CAPÍTULO 3.}

O objetivo do capítulo 3 é comprovar que a América do Sul fez uso intensivo do policy space que foi construído no âmbito do GATT. A partir do surgimento de prerrogativas jurídicas específicas para países em desenvolvimento, os países da América do Sul lançaram mão de diversas iniciativas desenvolvimentistas, tanto nos planos de integração regional quanto sub-regional.

No subcapítulo 3.1, serão analisados, em linhas gerais, os fundamentos teóricos do modelo desenvolvimentista levado adiante na América do Sul, por meio da industrialização por substituição de importações, o Modelo ISI, e a sua relação com o artigo XVIII do GATT.

A partir do subcapítulo 3.2, o foco recai sobre o estreitamento entre o desenvolvimentismo e a integração regional, que levou a estender os processos de industrialização para o plano regional e sub-regional. Para tanto, serão analisadas a ALALC e a sua compatibilidade com o artigo XXIV do GATT, que limitava a possibilidade de implantar as políticas desenvolvimentistas idealizadas na região.

No subcapítulo 3.3, será detalhada a formação da ALADI, viabilizada sob o amparo da Cláusula de Habilitação, que possibilitou a instauração de uma série de novidades em relação à iniciativa ALALC. Neste subcapítulo, tal qual nos dois seguintes, será feito um balanço da fase desenvolvimentista e da passagem para a fase neoliberal, sob a égide do regionalismo aberto. No caso da ALADI, merecerá destaque o Acordo de Cartagena, que institucionalizou esta nova fase da ALADI.

A partir do subcapítulo 3.4, passa-se à análise das iniciativas sub-regionais dos Andes e do Cone Sul. Em um primeiro momento, o foco se dará na integração andina, iniciada por meio do Pacto Andino, inspirada pela Parte IV do GATT e consolidada com base na Cláusula de Habilitação. Atenção será dada às principais características desta fase desenvolvimentista inicial, até as principais transformações ocorridas quando da criação da Comunidade Andina de Nações, a CAN, já sob o reflexo das transformações da fase neoliberal da América do Sul. 
Por fim, no subcapítulo 3.5, a análise recairá na iniciativa do Mercado Comum do Sul, o MERCOSUL. Constituído já nos tempos do regionalismo aberto, foi amparada tanto no artigo XXIV do GATT quanto na Cláusula de Habilitação. Esta dupla fundamentação jurídica permitiu aos países Membros, ao longo dos primeiros anos da existência do MERCOSUL, implantar algumas práticas desenvolvimentistas em meio a um processo eminentemente neoliberal. Essa dualidade viria a marcar uma existência contraditória do MERCOSUL desde o seu surgimento. 


\subsection{O MODELO DESENVOLVIMENTISTA DA AMÉRICA DO SUL}

\section{a) A América do Sul no contexto do pós-guerra}

A América do Sul, ao contrário da África e da Ásia, tornou-se independente e descolonizada ainda nos séculos XVIII e XIX. Por isso, a história do desenvolvimento da América do Sul começa muito antes da Segunda Guerra Mundial. Ocorre que, durante o século XIX e a primeira metade do século XX, os países da América do Sul não estavam sujeitos a tratados multilaterais que pudessem restringir ou inviabilizar as suas políticas comerciais e industriais. A América do Sul só passou a estar sujeita a tais regras a partir dos anos de 1940 e 1950. Esta tese está delimitada a apresentar a história das políticas da América do Sul apenas a partir deste momento.

Na década de 1950, começou a tomar corpo na América latina a ideia da integração latino-americana. Tal ideário tinha como base três elementos: a) $o$ bolivarianismo: a integração latino-americana tem raízes em Simon Bolívar e nos independentistas da década do século XVIII; b) as experiências recentes da integração europeia: que estavam se consolidando e influenciando novas iniciativas regionais ao redor do mundo; c) as formulações teóricas da CEPAL: que, como será apresentado a seguir, além de formular os preceitos do modelo de industrialização latinoamericano, condicionou tal modelo às iniciativas de integração regional, como instrumentos fundamentais para o sucesso do desenvolvimento latino-americano.

O contexto internacional do pós-guerra foi marcado pela novidade do predomínio dos EUA na geopolítica e na geoeconomia global. Enquanto os países europeus padeciam de uma destruição terrível, a capacidade produtiva dos EUA aumentou em 50\% durante a guerra. Em 1945, os EUA produziam mais da metade de todos os bens manufaturados do mundo, e souberam transformar rapidamente sua capacidade produtiva, desenvolvida durante a guerra, para o novo contexto de paz. Mais além, os EUA possuíam mais da metade dos meios de transporte marítimos no mundo, comparados com apenas $14 \%$ em 1939, e subministravam 
um terço da exportação mundial, ao tempo que absorviam uma décima parte da importação mundial. ${ }^{137}$

Para a América Latina, duas estratégias se colocavam nesse contexto: i) voltar a ter como força dinâmica o setor exportador criado no período colonial, caracterizado pela produção de bens primários, e manter-se como importador de bens industrializados; ou ii) dar continuidade a um processo de substituição de importações que já teria sido, num primeiro momento, motivado por fatores externos. ${ }^{138}$

A primeira estratégia faria a América Latina retornar ao padrão de internacionalização do século XIX, que estaria fadada a perpetuar as desigualdades e os baixos níveis de subdesenvolvimento. A segunda estratégia incorporava uma importante questão. Várias economias latino-americanas experimentaram, ainda que de forma heterogênea, um processo de substituição, induzido pelas dificuldades oriundas do desarranjo do sistema de comércio internacional, que prevaleceu durante a primeira metade do século XX, em razão das duas guerras mundiais e da grande depressão.

Portanto, caso a alternativa eleita fosse a primeira, os países deveriam arcar com os custos de se desfazer toda uma estrutura industrial que já havia se criada. Ou seja, era uma situação em que já havia sido criada uma estrutura industrial na América Latina e cujas transformações políticas, econômicas e sociais já se faziam notar. ${ }^{139}$

A reestruturação iniciada na América Latina dos anos 30 continuou durante a Segunda Guerra Mundial e seguia avançando. Os Estados latinos haviam adquirido diversas ferramentas de política econômica nunca antes vistas na região, como uma maior discricionariedade sobre os instrumentos aduaneiros e monetários, além de formularem uma base tributária mais ampla. ${ }^{140}$

\footnotetext{
${ }^{137}$ THORP, Rosemary. Progreso, pobreza y exclusión: una historia económica de América Latina en el siglo XX. Washington: Banco Interamericano de Desenvolvimento, 1998, p. 137.

${ }^{138}$ BRAGA, op.cit., p. 90.

${ }^{139}$ BRAGA. op. cit., p. 91.

140 Nesses anos da metade do século XX, uns poucos governos nacionais da América Latina aceitaram a responsabilidade de fomentar o desenvolvimento econômico. Ampliaram a
} 
A Comissão Econômica para América Latina (CEPAL) deu o apoio técnico e institucional para o crescente consenso sobre a importância da industrialização, e passou dedicar-se à criação das premissas e principais características deste modelo latino-americano de desenvolvimento, que ficou conhecido como o modelo de industrialização pela substituição de importações, o Modelo ISI.

\section{b) O Modelo ISI e as contribuições da CEPAL}

Como mencionado no capítulo 1, a principal contribuição do pensamento cepalino para a compreensão das relações econômicas internacionais foi o conceito centro-periferia, através do qual se procura explicar a forma particular pela qual os países em desenvolvimento se vinculam economicamente aos países desenvolvidos. Dentro do sistema de relações econômicas internacionais, os países industrializados seriam o centro, e os não-industrializados, a periferia. Nesse conceito, está a idéia de um desenvolvimento desigual originário que a teoria das vantagens comparativas não leva em consideração.

Em linhas gerais, a crítica latino-americana à teoria do liberalismo econômico se centra na contestação das premissas de David Ricardo: de acordo com o modelo de vantagens comparativas, a América Latina deveria produzir alimentos e exportar matéria-prima, para importar produtos industrializados, em razão de sua "propensão natural" à produção de bens primários.

Ocorre que, conforme constatado pelos estudos da CEPAL, os preços dos produtos primários teriam uma tendência a cair secularmente em relação aos produtos industriais, o que deterioraria o poder de compra das economias latinoamericanas. Portanto, para superar a condição de periferia econômica, os Estados da América Latina deveriam adotar um modelo de industrialização capaz de transformar suas estruturas econômicas, inerentes ao processo de desenvolvimento.

infraestrutura econômica, criaram empresas públicas, fomentou o surgimento de novos empresários, por meio de importantes contratos públicos para construção de estradas, represas, serviços públicos. Vide THORP. op. cit. p. 135. 
Nesta época, A América Latina formulou uma diversidade de teorias de oposição ao pensamento econômico ortodoxo, por meio da teoria do subdesenvolvimento, da teoria da dependência e da teoria centro-periferia. ${ }^{141}$

A nova perspectiva latino-americana considerava que, devido ao fato de estar localizada na periferia da economia mundial, e por não contar com tecnologia, a América Latina estava condenada a assumir, permanentemente, o papel de exportadora de matérias-primas e, dessa maneira, aceitar a deterioração dos termos de troca. Por isso, se o continente latino-americano desejava desenvolver-se, deveria colocar em prática um protecionismo coletivo tendente à substituição de importações, acordado em nível regional e orientado para a industrialização induzida, construindo economias de maior escala por meio da integração, às quais redundariam em maior utilização das capacidades ociosas e crescente diminuição dos coeficientes de importação, oriunda de países estranhos a região.

O objetivo central induzia à industrialização por meio do desenvolvimento de indústrias (de bens e serviços) complementares da região, levando em conta as vantagens comparativas que cada país apresentava em nível regional, somando-se a isso uma proteção tarifária adequada para competir tanto em nível regional como mundial, o que traria como consequência o desenvolvimento econômico dos países envolvidos nos processos de integração regional.

No entanto, Raul Prebisch, ao contrário do que muitos pensam, jamais foi contra o livre comércio. A industrialização substitutiva de importações não seria o objetivo final das propostas, mas um passo anterior a um projeto maior: o aumento da participação da América Latina no comércio internacional de manufaturas. Como forma de capacitar as indústrias latino-americanas, ele pensou a integração econômica regional como trampolim para o comércio internacional. ${ }^{142}$

${ }^{141}$ Os principais teóricos latino-americanos, responsáveis pela criação e afirmação desta nova perspectiva das relações internacionais, foram Raul Prebisch, Celso Furtado, Maria da Conceição Tavares, Fernando Henrique Cardoso, Enzo Faletto, Andre Gunder Frank, Immanuel Wallertstein, Ruy Mauro Marini, Teotônio dos Santos, dentre outros in BIELSCHOWSKY, Ricardo (Org.). Cinquenta anos de pensamento na Cepal. Rio de Janeiro: Record, 2000, p. 13.

${ }^{142}$ BRAGA, op. cit., p. 77. 
No âmbito do GATT, a teoria da CEPAL rompe com o princípio da igualdade da ONU e da universalidade do GATT. A situação de periferia se transforma em uma condição jurídica diferenciada, reconhecida por alguns Estados, por estabelecer diferentes condições jurídicas, de acordo com a condição econômica.

Além disso, a política proposta pela CEPAL, como vetor de desenvolvimento dos países da América Latina, a industrialização por meio da substituição de importações, só seria possível através da negação expressa de diversos princípios vigentes no GATT.

A industrialização substitutiva de importações, proposta pelos primeiros trabalhos da CEPAL, em sua própria concepção, demandava uma ação ativa do governo em torno de uma política comercial. O Modelo ISI partia do pressuposto de que investimentos domésticos e capacidades tecnológicas podem ser estimulados pela proteção temporária de produtores nacionais contra as importações.

Em paralelo à estratégia do Modelo ISI, deveria ocorrer uma estratégia de integração dos países da América Latina, a fim de resolver os problemas da limitação dos mercados, bem como da ausência de concorrência. Assim, o processo de industrialização teria melhor eficiência produtiva e maiores ganhos de economias de escala, por trabalhar não mais em dimensão nacional, mas sim, continental.

As primeiras orientações mais explícitas para a formulação de uma política de industrialização, fundada na substituição de importações, foram tratadas no documento intitulado "A cooperação internacional na política de desenvolvimento latino-americana", de 1954. Neste documento, Prebisch estabelece as medidas que viabilizariam um Modelo ISI, confrontadas com as regras internacionais:

\footnotetext{
Se o desenvolvimento da indústria for inicialmente impraticável e antieconômico, só restaria a proteção para compensar as diferenças de produtividade, seja mediante direitos aduaneiros ou mediante subsídios, posto que as restrições diretas a importação são menos aconselháveis como meio de política industrial, a não ser temporariamente. ${ }^{143}$
}

${ }^{143}$ PREBISH, Raul. A cooperação internacional na política de desenvolvimento latino-americana (1954). Apud BRAGA, op. cit., p. 78. 
Através destes textos, foram inauguradas as propostas e premissas da CEPAL para o modelo de industrialização de substituições, para os processos de integração econômica regional e para a inserção internacional da América Latina.

Além de Prebisch, outro latino-americano que contribuiu para o fortalecimento teórico dessa perspectiva foi Celso Furtado. Para Celso Furtado, o núcleo do sistema de proteção deveria ser formado por uma combinação de tarifas elevadas sobre bens acabados, isenção de tarifas para muitos bens de capital e produtos intermediários, além de uma taxa de câmbio sobrevalorizada.

Isto faria com que os produtos que os países latino-americanos realmente quisessem importar, ficassem muito baratos, enquanto aqueles que estavam nos setores nascentes, ficassem economicamente proibidos de serem importados. Logo, o diferencial de preço, construído pela combinação tarifa x câmbio, conduzia à seleção de métodos de produção que favoreciam bens de capital importados, e junto com eles, tecnologia importada.

Acreditava-se que a industrialização substitutiva de importações, não necessariamente poderia enfraquecer um esquema de liberalização comercial no plano multilateral, pois ocorreria de maneira seletiva e que, em vez de reduzir e fechar a América Latina ao comércio internacional, apenas provocaria uma mudança na composição das importações; projeto que, se bem sucedido, afetaria a composição das exportações.

Nesse sentido, Braga conclui que:

Para Furtado, o desenvolvimento latino-americano não poderia se resumir
apenas à busca de formas mais eficientes de produção dentro de uma
estrutura produtiva inicialmente pelo colonialismo e depois pelo modelo
denominado por Prebisch de centro-periferia. As características internas de
região e a sua particular inserção nas relações econômicas internacionais
demandavam mudanças estruturais que pudessem elevar a taxa de
crescimento econômico e reduzir as visíveis diferenças no nível de renda
entre os países. Tais mudaçças deveriam ocorrer a partir de uma ruptura da
divisão baseada em trocas de bens primários por manufaturas. Essa
ruptura somente seria possível a partir da industrialização, viável apenas
com protecionismo. (grifo do autor) ${ }^{144}$

${ }^{144}$ BRAGA. op. cit. p. 78 


\section{c) O enquadramento do Modelo ISI no GATT}

Desde o seu princípio, o Modelo ISI foi concebido por Prebisch, e pela CEPAL, como uma política comercial que deveria estar inserida em um processo de cooperação internacional. Isto porque, simultaneamente ao início das atividades da CEPAL, o GATT entrava em vigor para os países da América Latina.

Dentre as 23 partes contratantes originárias do GATT, os únicos países da América do Sul eram Brasil e Chile. Os demais países da América Latina foram tornando-se signatários ao longo da Era GATT, conforme se depreende da tabela abaixo:

\section{Tabela 5. Adesão da América Latina ao GATT/OMC ${ }^{145}$}

\begin{tabular}{|l|l|}
\hline PARTE CONTRATANTE / & ANO \\
\hline MEMBRO & 1948 \\
\hline Cuba & 1948 \\
\hline Chile & 1949 \\
\hline Republica Dominicana & 1950 \\
\hline Haiti & 1950 \\
\hline Nicarágua & 1950 \\
\hline Peru & 1951 \\
\hline Uruguai & 1953 \\
\hline Trinidad e Tobago & 1962 \\
\hline Jamaica & 1963 \\
\hline Guiana & 1966 \\
\hline Argentina & 1967 \\
\hline Barbados & 1967 \\
\hline Suriname & 1978 \\
\hline Colômbia & 1981 \\
\hline Belize & 1983 \\
\hline México & 1986 \\
\hline Antígua e Barbuda & 1987 \\
\hline Bolívia & 1990 \\
\hline Costa Rica & 1990 \\
\hline Venezuela & 1990 \\
\hline El Salvador & 1991 \\
\hline Guatemala & 1991 \\
\hline
\end{tabular}

\footnotetext{
${ }^{145}$ Elaboração própria pelo autor a partir da base de dados da OMC, com a relação de signatários do GATT e posteriores Membros da OMC in http://www.wto.org/english/thewto e/gattmem e.htm. Acessado em 05/10/2010.
} 


\begin{tabular}{|l|l|} 
Dominica & 1993 \\
\hline São Vicente e Granadinas & 1993 \\
\hline Santa Lúcia & 1993 \\
\hline Granada & 1994 \\
\hline Honduras & 1994 \\
\hline Paraguai & 1994 \\
\hline São Cristóvão e Nevis & 1994 \\
\hline Equador & 1996 \\
\hline Haiti & 1996 \\
\hline Panamá & 1997 \\
\hline \multicolumn{2}{|c|}{ Fonte: OMC (2011) }
\end{tabular}

Desde o surgimento do GATT, o Modelo ISI foi viável, do ponto de vista de sua conformidade com as regras do GATT, por enquadrar-se como política de Proteção à Indústria Nascente, prevista no Artigo XVIII.

A fim de avaliar as principais características do Modelo ISI na sua compatibilidade com o artigo XVIII, devem ser destacados os seguintes instrumentos do Modelo ISI: a) uso de tarifas; b) uso de subsídios; c) recurso às quotas de importação; d) proteção temporária (salvaguardas); e) proteção setorial.

Logicamente, o Modelo ISI apresentava-se muito mais complexo do que estas medidas (câmbio, preços, atração de investimentos estrangeiros, relação do Estado com a iniciativa privada...). No entanto, do ponto de vista da sua compatibilidade com o GATT, estas eram as medidas que interessavam.

A título ilustrativo, o quadro apresentado abaixo permite perceber o nível de proteção tarifária que havia sido alcançado na América do Sul:

\section{Tabela 6. Protecionismo na América Latina ${ }^{146}$}

\begin{tabular}{|l|l|l|l|l|l|l|}
\hline \multicolumn{7}{|c|}{ Proteção nominal na América Latina, em 1960 (em percentual) } \\
\hline País & $\begin{array}{l}\text { Bens não- } \\
\text { duráveis }\end{array}$ & $\begin{array}{l}\text { Bens } \\
\text { duráveis }\end{array}$ & $\begin{array}{l}\text { Bens semi- } \\
\text { elabrados }\end{array}$ & $\begin{array}{l}\text { Matérias primas } \\
\text { elaboradas }\end{array}$ & $\begin{array}{l}\text { Bens de } \\
\text { capital }\end{array}$ & Média \\
\hline Argentina & 176 & 266 & 95 & 55 & 98 & 131 \\
\hline Brasil & 260 & 328 & 80 & 106 & 82 & 168 \\
\hline Chile & 328 & 90 & 98 & 111 & 45 & 138 \\
\hline Colômbia & 247 & 108 & 28 & 57 & 18 & 112 \\
\hline México & 114 & 147 & 28 & 38 & 14 & 61 \\
\hline Uruguai & 23 & 24 & 23 & 14 & 27 & 21 \\
\hline CEE & 17 & 19 & 7 & 1 & 13 & 13 \\
\hline
\end{tabular}

${ }^{146}$ THORP. op. cit. p. 147. 
Como se pode depreender da análise da tabela acima, nos anos de 1960, os países da América do Sul mantinham um alto nível tarifário, em todas as categorias de produtos de importação, desde matérias-primas até bens de capital. As variações nacionais, em relação aos picos tarifários, revelam as prioridades de cada Modelo ISI implantado em cada país. No entanto, o que se percebe é que o foco do protecionismo girava em torno dos bens de consumo duráveis e não-duráveis. Nesta época, as iniciativas de industrialização por substituição de importações eram levadas adiante exclusivamente no plano nacional. É ao longo da década de 1960 que o Modelo ISI passa a ser dimensionado para o contexto regional.

\title{
d) A relação entre integração e desenvolvimento na América Latina
}

Sobre a relação entre o Modelo ISI e os processos de integração da América Latina, Márcio Bobik Braga constata que:

\begin{abstract}
A ideia implícita era a de que, apesar do processo de substituições de importações ser caracterizado por uma política protecionista, a integração econômica dos países da região poderia evitar, de alguma forma, as armadilhas em se criar indústrias em economias fechadas. Nesse sentido, (...) a integração econômica era vista como complemento fundamental desta política. Em outras palavras, a formação de um bloco econômico na região seria considerada como uma condição necessária para uma industrialização mais eficiente, a partir do aproveitamento de economias de escala na produção, viabilizadas pela ampliação dos mercados. ${ }^{147}$
\end{abstract}

Ocorre que, quando começou a debater-se abertamente a questão da industrialização no plano regional, entre os dirigentes latino-americanos, os níveis de industrialização já alcançados tornavam o tema da integração uma questão complicada. Isto porque, um dos grandes obstáculos enfrentados pela América Latina, desde o início da idealização do Modelo ISI em nível regional, foi a excessiva integração vertical da região, isto é, cada país havia desenvolvido, em

147 BRAGA, Marcio Bobik; PAIVA, Donizete (2007). Integração Econômica Regional e Desenvolvimento Econômico: Reflexões Sobre a Experiência Latino-Americana. in: Revista de Desenvolvimento Econômico, v. 16, p. 62. 
maior ou menor medida, uma cadeia produtiva razoavelmente completa no plano nacional. ${ }^{148}$

Originariamente, as concepções cepalinas não eram bem vistas pelo FMI, pelos EUA e pelas CE. O surgimento, no campo internacional, de uma nova fortaleza comercial gerava desconfianças. O projeto latino-americano provocaria mudanças artificiais nos fluxos comerciais e de investimentos estrangeiros, dificultando o desenvolvimento industrial dos EUA e da Europa do pós-guerra, por restringir os mercados consumidores das indústrias que estavam re-emergindo no pós-guerra.

Nos anos 1960, a realidade da América Latina se caracterizou pela instabilidade política, pela existência de conflitos entre países da região, e também conflitos internos de cada país. Tudo isso reforçado por um clima de desconfiança mútua, grande nacionalismo e forte repúdio à intervenção estrangeira nos assuntos internos, o que constituía um panorama pouco propício para a evolução favorável de um processo de integração.

Devido aos acontecimentos ocorridos em Cuba no final dos anos 1950, e o sucesso da revolução comunista, os EUA reviram sua posição em relação ao processo de integração da América Latina, passando a apoiar mais enfaticamente a formação do Mercado Comum Centro-Americano (MCCA).

Já nos anos 1960, os EUA iniciam um projeto de cooperação com a região, intitulado Aliança para o Progresso. Em 1960, o Presidente John F. Kennedy atuou com rapidez e estabeleceu tal iniciativa oficialmente em 1961. A ideia central era que os países poderiam receber recursos adicionais, em apoio a projetos de reforma nacional. Com uma contribuição de 20 bilhões de dólares dos EUA, durante um período de 10 anos, os temas abrangidos pela Aliança englobavam integração,

\footnotetext{
${ }^{148}$ A princípio dos anos 1960, os países sul-americanos, grandes e médios, contavam com uma ampla gama de indústrias, com forte e, às vezes, excessiva integração vertical. Neste cenário, já era muito tarde para se alcançar uma racionalização completa por países. Fazê-lo exigiria dispor de um mecanismo de negociação de compensações para os perdedores, a fim de conciliar os interesses em conflito, que logicamente ocorreriam, em um processo de liberalização econômica em nível regional.
} 
planejamento, reforma tributária, reforma agrária, modernização e investimentos e setores sociais. ${ }^{149}$

Em 1963, foi criado um procedimento para avaliação dos países, que levou a cabo o Comitê Interamericano da Aliança para o Progresso. Prebisch teve um papel destacado na criação deste sistema, em virtude da qual uma "comissão de expertos" colaborava com a equipe de planejamento de cada país. Para obter recursos da Aliança era importante que a comissão aprovasse os planos.

Para concluir, a América do Sul encontrava-se diante de um dilema conceitual, que até então não havia enfrentado pragmaticamente. A ideia de um processo de integração seria conceitualmente oposta ao nacionalismo imperante à época, porque implicaria renunciar a certos atributos de soberania muito caros à ideologia dos governos militares, desejosos de manter o máximo de poder de decisão no plano nacional. Não obstante, a convicção sobre os benefícios da integração econômica considerada como motor de um processo de redução dos níveis de subdesenvolvimento lhes permitiu angariar muitos adeptos na região nas duas iniciativas inaugurais da integração, tanto na América Central (MCCA) quanto na América do Sul (ALALC).

Além disso, os processos de integração apresentavam-se igualmente opostos ao liberalismo econômico e comercial, dominantes no imediato pós-guerra, consolidado por meio do GATT. No entanto, como debatido anteriormente, a existência do artigo XXIV proporcionou o policy space necessário para as iniciativas de integração econômica que emergiam em paralelo à constituição do sistema multilateral de comércio, seja a política de acordos bilaterais dos EUA, seja as CE, e posteriormente a ALALC, que será analisada a seguir.

\subsection{A ASSOCIAÇÃO LATINO-AMERICANA DE LIVRE COMÉRCIO} (ALALC)

\footnotetext{
${ }^{149}$ THORP. op. cit., p.155.
} 


\section{a) Principais objetivos e mecanismos de ação}

$\mathrm{Na}$ década de 1960, surge a primeira iniciativa de integração regional na América Latina: a Associação Latino-Americana de Livre Comércio (ALALC), em 1960. Em 18 de fevereiro daquele ano, em Montevidéu, Argentina, Brasil, Chile e Uruguai firmaram o Tratado Constitutivo da ALALC, chamado de Tratado de Montevidéu (TM-60), através do qual se propuseram a estabelecer uma zona de livre comércio, a qual em seguida aderiram Paraguai, México e Peru, e mais adiante Colômbia, Equador, Venezuela e Bolívia. Assim, em 1967, A ALALC contava com 11 países participantes. ${ }^{150}$

Com base no artigo $2^{\circ}$ do TM-60, a meta principal desse tratado era a constituição de uma área de livre comércio no prazo de 12 anos, por meio da eliminação gradual e progressiva das tarifas alfandegárias e dos demais obstáculos ao comércio.

Além do objetivo de liberalização comercial intra-bloco, havia um segundo objetivo principal da ALALC, mais estruturalista, que visava o desenvolvimento industrial dos Membros, por meio dos acordos de complementação econômica. Estes poderiam ser voltados à complementação industrial (acordos setoriais para estimular a cadeia produtiva regional) e à coordenação de políticas industriais e econômicas (promover a redução de assimetrias dos parques produtivos).

Os quatro mecanismos criados com vistas a alcançar os objetivos da ALALC, na constituição de uma zona de livre comércio continental, foram os seguintes: ${ }^{151}$

1) Programa de liberalização comercial: a negociação periódica de vantagens comerciais, produto a produto, como forma de promover a ampliação do comércio

\footnotetext{
150 Documentos da ALALC disponíveis em: http://dai-mre.serpro.gov.br/atosinternacionais/multilaterais/alalc/. Acesso em 18 de junho de 2012.

${ }_{151}$ Ver ARAUJO, Leandro. Associação Latino-Americana de Integração (ALADI). In CELLI, Umberto et al (Orgs.). Blocos econômicos e integração na América Latina, África e Ásia. Curitiba: Juruá, 2008, pp. 113-136.
} 
intra-regional. Este modelo foi adotado como forma de permitir a adaptação do processo de desgravamento comercial aos interesses de cada Estado-Membro. Desse modo, cada país negociava as franquias que desejava receber (lista comum) e as compensações que deviam receber (lista nacional).

É importante ressaltar que, no âmbito do programa de liberalização comercial, o artigo 32 do TM-60 permitia que (i) fossem concedidas vantagens aos países de menor desenvolvimento relativo, não-extensiva aos demais, (ii) condições mais favoráveis ao cumprimento do programa de liberalização, e, (iii) o direito de adotar medidas restritivas para corrigir eventuais desequilíbrios na balança de pagamentos. Tais exceções do artigo 32 serão comentadas abaixo.

2) Complementação industrial setorial: esta era uma forma adicional do processo de desgravamento. Por meio de acordos de complementação, previam-se programas que se referiam a determinados setores ou ramos da indústria. Após a Resolução n. 99, de 1964, os acordos de complementação tornaram-se os instrumentos mais dinâmicos do processo de liberalização comercial da ALALC, posto que a referida resolução bilateralizou os acordos, ou seja, restringiu a incidência da Cláusula NMF, permitindo que tais acordos não fossem automaticamente extensíveis aos demais.

Esta segunda frente da ALALC já estava em vigor no plano nacional de alguns países sul-americanos que haviam instituído o Modelo ISI, como apresentado acima. Essa frente igualmente apresentava respaldo jurídico no GATT, por meio do artigo XVIII.

3) Harmonização e coordenação das politicas macroeconômicas: mecanismo típico de processos mais avançados de integração, a ALALC propôs-se a harmonizar e coordenar problemas de ordem aduaneira, de política industrial, agrícola, financeira, monetária, transportes e harmonização de legislações nacionais.

4) As listas nacionais e a lista comum: o objetivo da redução tarifária progressiva foi idealizado para ser alcançado a partir de negociações periódicas entre as partes, em torno de listas nacionais (art. $4^{\circ}$, a e $5^{\circ}$, TM-60) e uma lista comum (art. $4^{\circ} \mathrm{b}$, TM-60). 
Segundo o art. $4^{\circ}$, a, combinado com o art. $5^{\circ}$ do TM-60, as listas nacionais compreendem as reduções anuais de gravames e demais restrições que cada estadoMembro conceda aos demais Estados-Membros, sendo que cada um deverá conceder, anualmente, aos demais, reduções de gravame equivalentes a $8 \%$ da média ponderada dos gravames vigentes para terceiros países, até alcançar a eliminação dos mesmos para o essencial de suas importações de zona.

Já o art. $4^{\circ} \mathrm{b}$ do TM-60 estabelece que uma lista comum compreende uma relação dos produtos cujos gravames e demais restrições com os quais os EstadosMembros se comprometem, por decisão coletiva, a eliminar integralmente para o comércio intra-regional.

As listas nacionais constituíam uma relação de produtos com compromissos de reduções anuais de tarifas. Tais compromissos caracterizavam-se por unilaterais e reversíveis, e representavam as concessões que cada país outorgava à zona regional, orientados a cumprir a Lista Comum, negociada e irreversível, dos produtos para os quais convergiriam as listas nacionais. Ou seja, enquanto a Lista Comum seguia a lógica da Cláusula $\mathrm{NMF}$, as listas nacionais seguiam a lógica da concessão unilateral. Essa duplicidade de lógicas nas negociações da ALALC viria a ser um dos grandes óbices ao avanço da integração no âmbito desse projeto.

Por fim, cabe apontar que, tendo em vista a grandiosidade dos objetivos propostos, em paralelo à distância econômica abissal entre os Estados Membros, o prazo de 12 anos foi ampliado por meio do Protocolo de Caracas, de 12 de dezembro de 1970, prorrogando até 31 de dezembro de 1980 para a realização dos objetivos centrais do tratado.

\section{b) A compatibilidade com o artigo XXIV do GATT}


A ALALC foi constituída com personalidade jurídica de organização internacional e notificada junto à Secretaria do GATT com base no artigo XXIV: 5. $\mathrm{b}$, que possibilita a formação de zona de livre comércio. ${ }^{152}$

Os países Membros da ALALC eliminariam gradualmente os gravames aduaneiros, mediante rodadas de negociação multilaterais, ou seja, extensíveis a todos os Membros da ALALC, como exigia o artigo XXIV do GATT. Do ponto de vista de sua compatibilidade com o artigo XXIV, seria necessário agregar ao projeto de liberalização comercial, substancialmente, todo o comércio da região. Ocorre que, para dar conta do segundo pilar da ALALC, o desenvolvimento industrial da região, a proteção das indústrias nascentes dos países menos avançados excluía, praticamente, todos os bens com valor agregado da liberalização, fazendo com que a ALALC perpetuasse o histórico do comércio intrazona, liberalizando bens primários e protegendo bens manufaturados.

Nesse sentido, chama a atenção o capítulo VIII do TM-60, sobre medidas em favor de países de menor desenvolvimento econômico relativo. Esse capítulo foi criado quando ainda não existia a possibilidade de tratamento especial e diferenciado no GATT. Portanto, ao mesmo tempo em que esse capítulo violava a Cláusula NMF intra-regional, exigida pelo artigo XXIV, ele também pode ser considerado um capítulo visionário, que antecipou as modificações que ocorreriam em seguida nas regras do GATT, e levariam ao tratamento especial dos países andinos, com a criação do Pacto Andino.

Além disso, diversos problemas foram suscitados pelas resoluções que obrigavam à inclusão, nas listas nacionais, dos resultados das liberalizações concretizadas nos acordos bilaterais. Isto levou à proposta de modificação parcial da Cláusula NMF, que regia a Lista Comum, na IV Conferência da ALALC, a qual permitiu certo grau de sub-regionalidade nas concessões, pela via dos acordos de complementação.

Do ponto de vista da compatibilidade com o GATT, o artigo XXIV não permitia que esta sub-regionalização da liberalização ocorresse. Isto só seria permitido a partir da cláusula de habilitação, em 1979. Os acordos de

\footnotetext{
${ }^{152}$ A respeito das regras do artigo XXIV, ver capítulo 2 desta tese.
} 
complementação econômica, por terem fundamentos mais estruturalistas, eram permitidos com base no artigo XVIII do GATT.

\section{c) A dinâmica e a crise da ALALC}

O grupo de países que integrava a ALALC apresentava um alto grau de disparidade interna, pois era configurado por alguns pequenos países com muito pouca ou nenhuma indústria (Bolívia, Equador, Paraguai), países medianamente industrializados (Colômbia e Chile) e países com maior desenvolvimento industrial e tecnológico (Argentina, Brasil e México).

Por isso, a ideia central que guiava o objetivo de desenvolvimento industrial era dar aos produtos originários dos países Membros acesso a mercados maiores, por meio de mecanismos de preferências recíprocas. Nesse contexto, países pequenos, que pelo tamanho da sua população, não podiam instalar indústrias eficientes e de grande porte, mas poderiam explorar economias de escala a partir do processo de integração.

Os resultados iniciais do processo foram positivos, pois as exportações intraregionais, em termos globais, cresceram de 7\% em 1961 para 10\% em 1970 e $14 \%$ em 1980.

A maior parte das preferências outorgadas no âmbito da ALALC recaiu sobre dois tipos de produtos, matérias primas e exportações não-competitivas. $\mathrm{Na}$ verdade, as tarifas sobre bens manufaturados aumentaram ao longo do tempo. A maioria dos países Membros era de produtores e consumidores dos mesmos produtos, o que constituiu um problema importante, criando obstáculos praticamente insuperáveis para cumprir o objetivo principal do tratado, isto é, o incremento do comércio intra-regional, por meio da liberalização total até 1980.

Nas três primeiras rodadas anuais de negociação, se avançou de maneira contundente na eliminação de barreiras ao comércio e, em meados dos anos 60 , o comércio intra-ALALC havia recuperado os níveis máximos do período pós- 
guerra. No entanto, a partir daí, as negociações estancaram quando o processo começou a alcançar o ponto de afetar os interesses nacionais, pois começaria a reordenar o processo de integração vertical intra-nacional, para um processo de integração horizontal, intra-regional.

O funcionamento da ALALC foi insatisfatório, insuficiente, desequilibrado e dinamicamente decrescente. O fracasso dessa associação se deve, em parte, ao fato que os objetivos fixados foram demasiadamente ambiciosos e irreais. Por outra parte, o fato da ALALC ter objetivos contraditórios em si mesmos - liberalização e industrialização por substituições de importações - impediu a concretização simultânea de ambas as prioridades.

No entanto, ainda que a ALALC não tenha alcançado os objetivos do Tratado de Montevidéu de 1960, e apesar de todos os problemas, atingiu resultados importantes. O acordo, de fato, contribuiu muito para o crescimento do comércio intra-regional. Em 20 anos (de 1960 a 1980), as exportações dentro da América Latina duplicaram como proporção do total exportado, o que tornou possível certa especialização e uma maior utilização da capacidade instalada. $\mathrm{O}$ avanço mais destacado foi alcançado no crescimento do comércio de manufaturas, que passou de $10,6 \%$ do comércio total da América Latina em 1960, para 46,1\% em 1980. ${ }^{153}$

Os últimos anos da década de 1970 mostraram uma ALALC dividida e com poucos êxitos no que diz respeito ao desenvolvimento industrial e ao incremento do comércio intra-regional. O desenvolvimento industrial, que perfazia a grande esperança em relação ao futuro da região, somente teve avanços nos países que já contavam previamente com um grande setor industrial, tais como Argentina, Brasil e México, desenvolvidos sob o cabedal de medidas protecionistas adotadas por cada um desses Estados, analisados na tabela apresentada acima.

\section{d) A demanda pela integração sub-regional e os efeitos do Pacto Andino}

${ }^{153}$ THORP. op. cit. p.161. 
Passou a ficar evidente que as diferenças nos níveis de desenvolvimento dos países Membros prejudicavam o processo de integração, e que o livre comércio intra-regional, que constituía o objetivo original, não se expandiria no âmbito da ALALC, enquanto não fosse reconhecida a necessidade de tratamento especial e diferenciado intra-regional, em favor dos Estados menos desenvolvidos.

Por esse motivo, alguns países começaram a demandar a possibilidade de configurar sub-zonas de integração, integradas por países com características semelhantes. Em primeiro lugar, isto diminuiria os problemas decorrentes dos diferentes níveis de desenvolvimento de seus Membros, e em segundo lugar, lhes permitiria desenvolvimento industrial mais eficiente, com possibilidades de participar de mercados maiores quando estivessem mais bem estruturados dentro da sub-zona.

Essa ideia, de formar pequenas zonas comerciais dentro do programa regional da ALALC, não era percebida como um atentado aos objetivos maiores do processo continental, nem constituía obstáculo a isso. Pelo contrário, acelerava o processo, pela diminuição das assimetrias entre países com níveis de desenvolvimento mais próximos e equitativos.

No entanto, do ponto de vista da compatibilidade com as regras do GATT, o artigo XXIV não permitia a criação de zonas de livre comércio, que não fossem fundadas na Cláusula NMF. Portanto, tais zonas sub-regionais, caso instituídas, seriam contrárias ao direito do SMC.

Ocorre que, como analisado anteriormente, em 1964, com a criação da Parte IV do GATT, sobre Comércio e Desenvolvimento, os países em desenvolvimento signatários do GATT passaram a ter um embasamento jurídico para reivindicar tratamento especial e diferenciado nas negociações do GATT, bem como nas iniciativas de comércio internacional em vigor. Com isso, a Parte IV, embora não tratasse expressamente da questão do Tratamento Especial e Diferenciado no âmbito dos acordos de integração regional, passou a permitir, tacitamente, tais exceções com base no princípio da não-reciprocidade da Parte IV.

Nesse sentido, Marcio Bobik Braga explica que: 
Estas relações intra-bloco tornaram-se possíveis principalmente porque, em 1964, ainda no contexto da ALALC, a denominada Cláusula da Nação Mais Favorecida, já havia sido relativizada. Com isto, os países se viram livres da obrigatoriedade de estender aos demais países do bloco os benefícios acordados de forma bilateral ou sub-regional. ${ }^{154}$

Por isso, a ALALC autorizou em 1967, por meio das Resoluções $202^{155} \mathrm{e}$ $222^{156}$, a formação de dois subgrupos, que teriam autonomia para estabelecer suas próprias regras em determinadas áreas, enquanto em outras, seria preciso ter como referência as disposições do TM-60. Assim surgiram o Grupo Andino e Grupo dos países da Bacia do Prata.

A partir destas resoluções, o Pacto Andino foi constituído por meio da Resolução 179, de 1979, do Conselho de Ministros da ALALC. Assim, o Pacto Andino põe fim, em definitivo, à não-discriminação no âmbito da ALALC, que se transformaria em um dos principais trunfos da futura ALADI: a permissão para celebração acordos de alcance parcial.

\section{e) Conclusões sobre a ALALC}

Um dos principais desafios enfrentados para a consecução dos objetivos da ALALC foi a excessiva rigidez dos instrumentos e metas, em um processo de integração que envolve participantes dotados de características estruturais tão dispares como Brasil, Argentina e México, de um lado, e Bolívia, Paraguai e Equador, do outro.

Nesse sentido, a ALALC serviu de exemplo no sentido de que, para que a integração regional entre países em desenvolvimento avance, o espaço para negociações e para políticas públicas (o policy space) não pode ser demasiadamente limitado. Não se devem impedir acordos sub-regionais, aplicando a Cláusula NMF em processos de integração, com participantes tão díspares. O artigo XXIV

\footnotetext{
${ }^{154}$ BRAGA; PAIVA. op. cit., p. 66.

${ }^{155}$ ALALC/CM-II/Resolución 202 (VI-E) de 2 de setembro de 1967.

${ }^{156}$ ALALC/CON/Resolución 222 (VII) de 17 de dezembro de 1967.
} 
obrigava tal tipo de limitação. A Cláusula de Habilitação, posteriormente, veio permiti-la e é com base nela que surgirá a ALADI.

\subsection{A ASSOCIAÇÃO LATINO-AMERICANA DE INTEGRAÇÃO (ALADI)}

\section{a) A ALADI vis-a-vis a Cláusula de Habilitação}

Diante do fracasso da ALALC, o processo de integração latino-americano prosseguiu por meio de uma nova organização internacional, criada para continuar os esforços de integração iniciados, porém buscando solucionar as carências evidenciadas pelo funcionamento do tratado anterior.

Nesse sentido, em 12 de agosto de 1980, a ALALC é substituída pela Associação Latino-Americana de Integração (ALADI) por meio da constituição de um novo Tratado Constitutivo, denominado igualmente de Tratado de Montevidéu (TM-80). Da mesma forma que a ALALC, a ALADI foi constituída com personalidade jurídica de organização internacional. O TM-80 da ALADI dispõe expressamente, por meio dos artigos 65 e 66, que a nova organização internacional substitui a ALALC, revogando, portanto, o TM-60. ${ }^{157}$

Os países originários do TM-80 foram as mesmas partes do Tratado da ALALC, isto é, Argentina, Bolívia, Brasil, Chile, Colômbia, Equador, México, Paraguai, Peru, Uruguai e Venezuela. Em 1998, Cuba foi aceito como país Membro. 
A assinatura do tratado constitutivo da ALADI necessita igualmente ser compreendida à luz das regras do SMC, tendo em vista sua composição por países já signatários do GATT, e outros que ainda pretendiam aderir ao acordo (Bolívia, Colômbia, Equador, México, Paraguai e Venezuela não eram signatários do GATT à época da criação da ALADI).

Em 1980, o GATT já havia passado pelas reformas expostas no capítulo anterior, e estava mais adaptado aos interesses dos países em desenvolvimento, especialmente pelo surgimento da Cláusula de Habilitação, em 1979. Como a Cláusula de Habilitação já estava em vigor quando da criação da ALADI, esta organização foi notificada em com base nela, em 01/07/1982. ${ }^{158}$

O fato de a ALADI ter sido constituída com base na Cláusula de Habilitação, e não com fulcro no artigo XXIV, como a antecessora ALALC, representou uma vantagem. Isto porque, ao estar fundado na Cláusula de Habilitação, os países da ALADI puderam "flexibilizar" os objetivos anteriores da ALALC e possibilitar, no âmbito da ALADI, as relações bilaterais e sub-regionais intra-bloco (por meio dos acordos de alcance parcial), além de permitir expressamente o Tratamento Especial e Diferenciado para países menos avançados no âmbito do acordo de integração regional.

Para balizar as políticas de Tratamento Especial e Diferenciado da ALADI, esta classificou seus integrantes em três categorias: menor desenvolvimento relativo (Bolívia, Equador e Paraguai), desenvolvimento intermediário (Chile, Colômbia, Peru, Uruguai e Venezuela) e maior desenvolvimento (Argentina, Brasil e México).

A ALADI, ao ser constituída, respirava os ares do seu tempo. O artigo 26 é o reconhecimento expresso desta relação com o contexto internacional.

Artigo 26 - Cooperação com outras áreas de integração econômica

Os países Membros realizarão as ações necessárias para estabelecer e desenvolver vínculos de solidariedade e cooperação com outras áreas de integração fora da América Latina, mediante a participação da Associação nos programas que se realizam em nível internacional em matéria de cooperação horizontal, na execução dos princípios normativos e compromissos assumidos no contexto da Declaração e Plano de Ação para

\footnotetext{
${ }^{158}$ Para acessar a documentação oficial da notificação e do exame da ALADI junto ao GATT, ver http://rtais.wto.org/UI/PublicShowRTAIDCard.aspx?rtaid=135.
} 
a criação de uma Nova Ordem Econômica Internacional e da Carta de Direitos e Deveres Econômicos dos Estados.

\section{b) As novidades em relação à ALALC}

A necessidade de não repetir os erros da ALALC promoveu, no âmbito da ALADI, as seguintes modificações: a) o programa de liberalização multilateral foi substituído por uma zona de preferências tarifárias; b) o caráter essencialmente comercial da ALALC foi substituído por um esquema mais integral, que compreende a promoção e regulamentação do comercio recíproco, a complementação econômica e o desenvolvimento de ações de cooperação; e c) a incorporação de um sistema de apoio aos países de menor desenvolvimento relativo, reconhecendo a existência de países de desenvolvimento intermediário.

Outra importante mudança de cenário, que contrastou a formação da ALADI com a ALALC, foi o fato de que, na época da criação da ALADI, diversos países da América Latina estavam passando por um processo de redemocratização, o que conferiu grande impulso à integração latino-americana, especialmente entre Brasil e Argentina.

Entre as modificações introduzidas no novo acordo, cabe destacar que foi deixado de lado o método multilateral de negociações regionais, ou seja, com base na Cláusula NMF. Dessa forma, os mecanismos de integração da ALADI são mais flexíveis, pois se baseiam em enfoques setoriais, com diversas extensões: acordos de âmbito regional, que abarcam todos os Membros da organização e acordos de alcance parcial, firmados por dois ou mais Membros.

Os objetivos da ALADI estão expressamente estabelecidos nos artigos $1^{\circ}, 2^{\circ}$ e $3^{\circ}$ do capitulo I, sob o título "Objetivos, funções e princípios", onde se afirma que "o processo terá como objetivo de longo prazo o estabelecimento, de forma gradual e progressiva, de um mercado comum latino-americano", motivo pelo qual é importante o desenvolvimento da "promoção da regulação do comércio recíproco, a complementação econômica, e desenvolvimento de ações de cooperação econômica que ajudem a ampliação dos mercados". 
Outro ponto de diferenciação diz respeito ao prazo de implantação. Enquanto a ALALC, previa um prazo para conclusão da zona de livre comércio para cumprir o art. XXIV, a ALADI, por estar constituída com base na Cláusula de Habilitação, não precisou prever tal prazo, dando maior margem para a atuação da organização internacional.

Esse novo esquema não se limita a uma zona de livre comércio, como dispunha a ALALC, mas utiliza a expressão "integração", para englobar as diversas modalidades e temáticas que poderiam ser experimentadas pelos diferentes Estados por parte do TM-80.

Em conformidade com o disposto no artigo $3^{\circ}$, e com a finalidade de atingir o objetivo maior, qual seja, o da formação de um mercado comum latinoamericano, os países Membros estabeleceram os seguintes princípios como novos parâmetros da integração:

- Pluralismo: sustentado na vontade dos países Membros para sua integração, acima da diversidade existente na região em matéria política e econômica.

-Convergência: se traduz na multilateralização progressiva dos acordos de alcance parcial, mediante negociações periódicas entre os países Membros, em função do estabelecimento do mercado comum latino-americano.

- Flexibilidade: caracterizada pela capacidade de permitir a concertação de acordos de alcance parcial, regulamentados de forma compatível com a consecução progressiva de sua convergência e o fortalecimento dos vínculos da integração.

- Tratamentos diferenciados: estabelecidos da forma que for determinada em cada caso, tanto nos mecanismos de alcance regional como nos de alcance parcial, com base em três categorias de países (países de desenvolvimento intermediário, países de menor desenvolvimento relativo, países de maior desenvolvimento), que se integrarão levando em consideração suas peculiaridades econômico-estruturais.

- Multiplicidade: Para possibilitar diferentes formas de concertação entre os países Membros, em harmonia com os objetivos e funções do processo de integração, utilizando todos os instrumentos capazes de dinamizar e ampliar os mercados em nível regional.

Como se percebe, os princípios constantes no artigo $3^{\circ}$ condizem com o espírito da Cláusula de Habilitação, por explorar objetivos que reconhecem a 
desigualdade entre os Estados Membros da ALADI, bem como por estabelecer mecanismos capazes de atuar no tratamento destas desigualdades.

\section{c) Os principais mecanismos da ALADI}

O TM-80 está constituído como uma área de preferências econômicas, com dinâmicas em dois níveis: iniciativas no plano regional, que abrange a todos os Membros, e iniciativas no plano sub-regional, que abrange apenas parcela dos Membros. Será analisada, a seguir, cada uma das iniciativas, tanto em plano regional, quanto sub-regional, previstas pela ALADI.

A Preferência Tarifária Regional (PTR) é um dos instrumentos mais importantes para a promoção do comércio intra-regional. Em busca de consolidação de um mercado comum latino-americano, e em cumprimento ao artigo $2^{\circ}$ do TM-80, os países Membros estabeleceram uma área de preferências econômicas, na qual a Preferência Tarifária Regional que seria outorgada reciprocamente, com respeito à tarifa vigente para países terceiros, constituiria o principal instrumento de alcance multilateral.

Prevista no artigo $5^{\circ}$, a Preferência Tarifária Regional consiste em uma redução percentual dos gravames aplicáveis às importações provenientes de terceiros países, que os países Membros se outorgam reciprocamente para as importações de produtos originários dos seus respectivos territórios.

A Preferência Tarifária Regional é fixada de acordo com o nível de desenvolvimento dos países, com maiores preferências para os menos desenvolvidos. Ele abrange todo o universo tarifário, salvo determinados produtos que cada país pode excetuar dos benefícios desta preferência.

A Preferência Tarifária Regional, atualmente em um nível básico de 20\%, se aplica em magnitudes diferenciadas e com níveis de exceção diversos, conforme cada país pertença a uma das três categorias (menor desenvolvimento relativo, desenvolvimento intermediário ou maior nível de desenvolvimento). 
Um segundo mecanismo da ALADI são os Acordos de Alcance Regional (AAR). De acordo com o artigo $6^{\circ}$, os AAR são aqueles dos quais participam todos os Estados Membros da ALADI. Celebrados no quadro dos objetivos e disposições do tratado, podem referir-se às matérias e compreender os instrumentos previstos para os acordos de alcance parcial. Dentre os AAR, destacam-se dois: o Programa de Recuperação e Expansão do Comércio (PREC) e a Nomenclatura de Abertura de Mercados (NAM).

O PREC é um programa que visa a substituir importações de terceiros países por meio da negociação de uma lista positiva de produtos, cuja importação, a partir de países da área, será beneficiada com preferências tarifárias, segundo a categoria de desenvolvimento dos países. Já a NAM é um conjunto de listas que serve como mecanismo de apoio aos Membros de menor desenvolvimento relativo da ALADI e objetivam assegurar uma repartição equitativa dos custos e benefícios do processo de integração. Nesse sentido, os produtos incluídos nas listas são beneficiadas com a eliminação total, sem reciprocidade, de gravames aduaneiros e outras restrições por parte dos demais Estados-Membros.

Entretanto, tais listas foram pouco utilizadas, em grande parte devido à própria inexistência de oferta exportável desses países, bem como em razão da infra-estrutura de comercialização pouco adequada ou obstáculos diversos de ordem econômica e administrativa.

No âmbito sub-regional, a ALADI previu a criação de dois tipos de mecanismos: os Acordos de Alcance Parcial (AAP) e os Acordos de Complementação Econômica (ACE).

Os AAP foram constituídos com o objetivo de contribuir para o aprofundamento do processo de integração, por meio da liberalização do comércio entre dois ou mais países da ALADI, para apoiar a consolidação de um mercado ampliado, e que, por meio de uma convergência progressiva, coadjuvasse a formação de um mercado comum latino-americano. 
Esses acordos podem assumir diversas naturezas: comerciais, de complementação econômica, agropecuários, de promoção de comércio, ou servir para adotar outras modalidades, com base no artigo 14 .

Por sua flexibilidade, tais acordos se tornaram o instrumento mais utilizado na integração regional da ALADI, de maneira que o comércio negociado nos AAP demonstrou maior dinamismo no conjunto do comércio intra-regional. Dentre os AAP, destacam-se os Acordos de Complementação Econômica (ACE).

Os ACE tem por objetivo promover o máximo aproveitamento dos fatores de produção, estimular a complementação econômica, assegurar condições equitativas de competição, facilitar a inserção de produtos no mercado internacional e impulsionar o desenvolvimento equilibrado e harmônico dos países Membros.

Atualmente, existem 36 acordos em vigor, que podem ser classificados em 3 tipos de ACE:

- Acordos regionais, como o firmado entre o MERCOSUL e a CAN (ACE$56)$.

- Acordos plurilaterais ou bilaterais, que preveem o estabelecimento de uma zona de livre comércio entre seus signatários, por exemplo, entre Chile e Colômbia (ACE 24), Bolívia e México (ACE 31), MERCOSUL com o Chile (ACE 35) e MERCOSUL com Bolívia (ACE 36).

- Acordos bilaterais do tipo tradicional, que em sua maioria incluem listas positivas de produtos aos quais se concede um tratamento preferencial estático, que foram negociados produto a produto; grande parte deles tem vigência temporária, o que obriga a sua renovação periódica.

\section{d) Balanço crítico da ALADI ao longo do século $\mathrm{XX}$}


São muitas as críticas tecidas ao Tratado da ALADI: ausência de prazos; disposições programáticas; ser um mero acordo-quadro; não regular a coordenação e harmonização de políticas macroeconômicas, como se propõe no acordo; ser uma soma de acordos bilaterais; não ter órgãos supranacionais, etc.

No entanto, como balanço das primeiras décadas da ALADI, esta demonstrou ser, em algumas regiões, um mecanismo adequado para a criação de especialização, com a consequente ampliação do mercado e aumento de produtividade. Em seu âmbito foram firmados numerosos acordos de alcance parcial, dentre os quais se destaca o acordo do MERCOSUL, significando contribuições positivas para o processo de integração regional.

O fato de a ALADI ter desenvolvido um processo de integração de duas velocidades, um mais lento, abrangendo a todos, e um mais rápido, mais dinâmico, abrangendo apenas dois grupos de Membros - MERCOSUL e Comunidade Andina - gerou fôlego a um processo de integração que vinha estagnado, desde a época da ALALC, pelo fato de estar obrigado a conceder tratamento igualitário a países díspares, sendo balizada pelo art. XXIV do GATT.

A partir da Clausula de Habilitação, os processos de integração nos quais estavam envolvidos países em desenvolvimento, passaram e ter o direito de conceder Tratamento Especial e Diferenciado intra-bloco, o que foi o caso da ALADI, e que depois viria a repercutir nas duas iniciativas sub-regionais da ALADI: a CAN e o MERCOSUL.

Nesse sentido, a mudança de fundamento jurídico da integração latinoamericana proporcionou à região desenvolver iniciativas e projetos que seriam incompatíveis juridicamente com o GATT original.

No entanto, apesar das críticas de que a ALADI é um mero acordo-quadro, sob o qual todos os acordos sul-americanos são firmados, o que se percebe é que, na verdade, ao longo dos últimos aos, o princípio da convergência, consolidado no artigo $3^{\circ}$ do TM-80, de fato está sendo seguido, pois a grande maioria dos AAP e dos ACE está hoje concentrada em torno do MERCOSUL e da CAN. Mais 
recentemente, em 2002, estes processos de integração passaram a convergir para aproximação e estreitamento das duas iniciativas, por meio do ACE-56.

Nesse sentido, o que se percebe é que, passados 30 anos desde o lançamento da ALADI, o caminho rumo ao Mercado Comum Latino-Americano está sendo lentamente construído. É verdade que esta construção está ocorrendo de maneira pulverizada e ausente de coordenação supranacional, mas é possível perceber que este conjunto de iniciativas, lentamente, vai propiciando a convergência..

Da mesma forma que a Cláusula de Habilitação revelou-se como um direito fundamental para permitir a evolução da integração latino-americana - da ALALC para a ALADI - ; o surgimento da OMC criou uma grande quantidade de prerrogativas jurídicas à disposição dos países latino-americanos, que ainda não foram implantadas no âmbito da ALADI. As oportunidades e os desafios apresentados à ALADI, no âmbito do atual contexto do direito internacional do desenvolvimento da $\mathrm{OMC}$, serão objeto de análise na Parte II desta tese.

\subsection{O PACTO ANDINO}

\section{a) O surgimento no âmbito da ALALC}

Em 1966, Colômbia, Chile, Equador, Peru e Venezuela decidiram lançar um processo sub-regional de integração, no quadro da ALALC, organização a qual todos pertenciam, que pudesse reverter a tendência de subdesenvolvimento que assolava tais países.

Isto porque, como visto acima, os benefícios advindos da criação da ALALC não foram equitativamente distribuídos entre todos os parceiros do continente. Os países mais desenvolvidos aumentaram suas exportações de bens de 
maior valor agregado para a região. Já os países com menor desenvolvimento relativo permaneceram na delicada situação de importadores de produtos industrializados e fornecedores de matéria-prima. Essa situação refletiu o caráter eminentemente "comercialista" da ALALC, contra a qual o grupo de países andinos estava insatisfeito.

Por isso, firmaram em 16 de agosto daquele ano, a Declaração de Bogotá, pela qual foi criada uma comissão mista encarregada de estudar esse projeto do ponto de vista técnico, especialmente do ponto de vista da compatibilidade do mesmo com a ALALC. Quando criada a comissão, a Bolívia passou a integrar tal iniciativa.

Em 26 de maio de 1969, após intensas negociações entre as partes, foi subscrito na cidade de Cartagena das Índias, na Colômbia, que se denominou Acordo de Integração Sub-Regional, mais conhecido por Acordo de Cartagena. Com base na Resolução 179, de 1979, do Conselho de Ministros da ALALC, foi criado o Pacto Andino, com personalidade jurídica de organização internacional.

O Pacto surgiu integrado por Bolívia, Colômbia, Chile, Equador e Peru. A Venezuela aderiu ao Pacto em fevereiro de 1973, enquanto o Chile, em seguida, em outubro de 1976, abandonou o grupo. Mais recentemente, o Chile voltou a se incorporar ao Pacto em setembro de 2006, como Membro associado, enquanto a Venezuela, no mesmo ano, se retirou do acordo. ${ }^{159}$

Desde o seu surgimento, o Pacto Andino menciona expressamente diversas vezes a sua relação direta com a ALALC. Seu preâmbulo menciona como fundamento o TM-60, além de duas resoluções do Conselho de Ministros da ALALC. O artigo $1^{\circ}$, que tratava dos objetivos do Pacto, referia-se ao TM-60 e a sua vinculação com a ALALC. O artigo $3^{\circ}$, sobre os mecanismos que os EstadosMembros deveriam adotar com vistas a atingir seus objetivos de liberalização comercial, tinha como parâmetro o Programa da ALALC. O artigo 60, sobre a cooperação necessária para estabelecer o Programa de Liberalização Comercial, levava em consideração o Programa congênere da ALALC. O Capítulo XII criou

159 Os principais documentos referentes ao Grupo Andino, atual Comunidade Andina, estão disponíveis em http://www.sice.oas.org/Andean/instmt e.asp e também no sitio da organização internacional http://www.comunidadandina.org/. 
um regime especial para Bolívia e Equador, tal qual foi realizado no TM-60, visando criar um regime especial e mais favorável ao desenvolvimento destes países. Enfim, as metas colocadas pelos Membros do Pacto Andino estavam intrinsecamente vinculadas aos objetivos da ALALC.

Essas referências expressas a ALALC foram, no entanto, eliminadas quando das revisões sofridas pelo Acordo de Cartagena, especialmente por meio do Protocolo de Sucre, ocasião na qual o Pacto Andino passou a se constituir como processo de integração autônomo e independente, embora subordinado já a nova organização de alcance continental, a ALADI.

\section{b) Principais características do Pacto Andino}

O Pacto Andino nasceu com objetivos bastante ambiciosos, muito além dos objetivos da ALALC, que estavam eminentemente focados na liberalização comercial como instrumento de criação de um mercado comum latino-americano. Ao contrário, o Pacto Andino origina-se com o propósito de gerar desenvolvimento sub-regional, para o qual a liberalização comercial seria apenas um mecanismo dentre vários outros levados adiante pelo Pacto. $\mathrm{O}$ mercado comum andino seria resultado da conjunção bem sucedida de diversas frentes.

Os objetivos do Acordo de Cartagena são os seguintes: ${ }^{160}$

i) promover o desenvolvimento equilibrado e harmônico dos paísesMembros;

ii) acelerar seu crescimento e geração de trabalho;

iii) assegurar sua participação no processo de integração regional como forma de possibilitar a formação de um mercado comum latino-americano; iv) diminuir a vulnerabilidade externa e melhorar a posição dos paísesMembros no contexto econômico internacional;

v) fortalecer a solidariedade sub-regional e reduzir as diferenças de desenvolvimento existentes entre os países-Membros.

Para alcançar tais objetivos, o Pacto prevê os seguintes mecanismos de ação: ${ }^{161}$

\footnotetext{
${ }^{160}$ Artigo $1^{\circ}$ do Acordo de Cartagena.
} 
i) harmonização gradual das políticas econômicas e sociais e aproximação das legislações nacionais nas matérias pertinentes;

ii) programação conjunta e intensificação da industrialização sub-regional;

iii) programa de liberalização comercial;

iv) adoção de uma tarifa externa comum;

v) programas para acelerar o desenvolvimento de setores agropecuário e agroindustrial;

vi) obtenção de recursos para financiamento dos investimentos necessários na integração;

vii) integração física;

viii) tratamento preferencial para a Bolívia e o Equador.

O Programa de Liberalização Comercial tem como objetivo eliminar todos os gravames e restrições que incidem sobre a importação de quaisquer produtos originários de países-Membros. Já o programa de convergência à tarifa externa comum está pautado na necessidade de aplicação de um parâmetro mínimo e comum a todos os países Membros de importações advindas de países terceiros.

O prazo para a plena realização de ambos os programas, originariamente, era dezembro de 1980. Esse prazo foi prorrogado diversas vezes até que, em 31 de janeiro de 1993, consolidou-se a zona de livre comércio entre os países Membros, exceto o Peru. ${ }^{162}$ Uma Tarifa Externa Comum estruturada em quatro níveis entrou em vigor em 1995: 0\%, 5\%, 10\% e 20\%. Apenas a Bolívia não aplicaria alíquotas de $20 \%$.

Além dos programas para a zona de livre comércio e para a Tarifa Externa Comum, o Pacto Andino leva adiante desde o seu surgimento os Programas Setoriais de Desenvolvimento Industrial. Tais programas visam desenvolver a região por meio de programas de industrialização. O primeiro desses programas a ser constituído foi o Programa Metal-Mecânico (1972), depois o Programa Petroquímico (1975) e em seguida o Programa Automotor (1977).

Paralelo aos Programas Setoriais de Desenvolvimento Industrial, o Pacto Andino igualmente priorizou, desde o princípio, o mecanismo de harmonização de políticas macroeconômicas e de legislações pertinentes. Logo em 1970, foi aprovado o regime comum de tratamento de capitais estrangeiros, bem como o

${ }^{161}$ Artigo $3^{\circ}$ do Acordo de Cartagena, alterado pelo artigo $2^{\circ}$ do Protocolo de Sucre.

${ }_{162}$ O Peru recebeu autorização para suspender as obrigações decorrentes do Programa de Liberalização Comercial em agosto de 1992, para que em 1997, fosse retomada a sua gradual inserção na zona de livre-comércio andina. 
regime sobre marcas, patentes, licenças e benefícios. ${ }^{163}$ Posteriormente, foram aprovados acordos sobre dupla tributação ${ }^{164}$ (1970), bem como um regime único para empresas multinacionais andinas ${ }^{165}(1971)$.

O Pacto Andino tinha consciência, desde o seu surgimento, de que a distribuição equitativa dos benefícios da integração seria essencial para o sucesso de qualquer iniciativa integracionista. Por isso, desde o princípio, dispensou-se atenção especial à Bolívia e ao Equador, como países menos desenvolvidos na região. Este tratamento especial e diferenciado repercutia em disposições específicas relacionadas à industrialização, à liberalização comercial, à Tarifa Externa Comum, entre outros projetos específicos para destinação de recursos voltados à integração.

\section{c) Aspectos desenvolvimentistas da integração andina}

Como se pode depreender da breve análise acima, o Pacto Andino, desde que nasceu, apresentou peculiaridades que o diferenciam do modelo existente a época (ALALC), tendo sido pioneiro em projetos que, mesmo as iniciativas posteriores (ALADI e MERCOSUL), jamais conseguiram implantar.

Isto porque esse processo de integração afastou-se do caráter excessivamente comercialista e se concentrou no desenvolvimento industrial, mediante a tentativa de criação de uma indústria pesada, que pudesse gerar a agregação de valor que os países andinos até então não haviam alcançado, separadamente, nos planos nacionais. Ainda, procurou gerar dimensão econômica para competir, senão em igualdade, ao menos em melhores condições, com os grandes da região. Também foi dotado de uma estrutura institucional muito mais parecida com o modelo comunitário europeu, do que com os modelos intergovernamentais da América Latina.

\footnotetext{
163 Decisão 24/1970.

${ }^{164}$ Decisão 40/1970.

${ }^{165}$ Decisão 46/1971.
} 
Desde o início, o acordo resgatou, com muita ênfase, a necessidade de dar tratamento especial e diferenciado às economias menores, Equador e Bolívia, e sempre sustentou a integração como um caminho orientado para o desenvolvimento, sobretudo no campo industrial, do qual o Estado não deve se ausentar.

Os países andinos respiravam os ares do seu tempo. O projeto estava alinhado com os discursos e propósitos do Terceiro Mundo, repercutindo todas as virtudes e padecendo dos mesmos vícios de todas as iniciativas levadas a cabo pelo Sul, ao longo das décadas de 70 e 80.

É possível apontar, como contribuições originais do Pacto Andino às iniciativas de integração de países em desenvolvimento, os seguintes mecanismos:

\section{1) Politica industrial}

Para garantir uma melhor distribuição dos benefícios da integração, a Comunidade Andina deu a cada um dos países participantes a possibilidade de desenvolver, para toda a área, determinadas atividades industriais, inibindo o desenvolvimento das mesmas atividades em outros países e protegendo-as da concorrência externa por meio de uma tarifa externa comum.

Nesse sentido, a indústria eletromecânica pesada, a de máquinas para mineração e a de equipamentos ferroviários foi atribuída ao Chile, o Peru se ocupou da maquinaria de elevação e caixas de câmbio, máquinas para mineração e eletrodomésticos; o Equador, da micromecânica e sistemas hidráulicos: a Colômbia, da maquinaria agrícola, equipamento para indústria alimentar e ferramentas forjadas; e Bolívia, de equipamento de ar comprimido, sobretudo para mineração.

Esse interessante projeto foi frustrado pelo fato de privilegiar o interesse dos países em detrimento do custo de produção, pela falta de unificação do processo de produção entre os diferentes países, quando cada um deles se ocupava de uma parte do produto industrial, e pela inexistência de cultura industrial empreendedora adequada em todos os países. 


\section{2) Regime único de investimentos estrangeiros}

Por meio da decisão 24/1970, o então Pacto Andino aprovou o "Regime Comum de Tratamento de Capitais Estrangeiros e sobre Marcas, Patentes, Licenças e Royalties", que para efeito de aplicação, classificava as empresas em nacionais, estrangeiras e mistas, reservando às primeiras atividades consideradas básicas (serviços públicos, seguros, bancos, atividades financeiras, transporte interno, radio, televisão, publicidade, etc.) e obrigando as segundas a submeter-se a um registro, a um exame que demonstrasse a utilidade do investimento a ser realizado e a limitações para a remessa de lucros ao exterior. O regime, único para toda a área, procurava evitar que, mediante negociações individuais com cada país separado, as grandes empresas multinacionais obtivessem benefícios excessivos para radicar seus investimentos.

Embora a homogeneidade dos países do sistema andino teoricamente pudesse ajudar na realização dessas aspirações, a pequena vinculação comercial entre os países, a falta de infraestrutura física que pudesse uni-los, a falta de complementaridade das economias, e as incompatibilidades que foram sendo geradas pela evolução do sistema político de cada país, frustrou os objetivos de sustentar a integração baseada na uniformização da legislação em investimentos estrangeiros.

O sistema demonstrou flexibilidade, já que passou do modelo originalmente fechado, estatizante, baseado em substituições de importações, tarifas elevadas e altas restrições, para o investimento estrangeiro. Na década de 90, passou a um modelo de integração mais aberto, mais orientado pela lógica do mercado e de acordo com os padrões internacionais impostos pela Organização Mundial do Comércio. A Parte II da tese tratará desta mudança de modelo da integração andina. 


\subsection{O MERCADO COMUM DO SUL (MERCOSUL)}

\section{a) O surgimento do MERCOSUL no âmbito da ALADI}

Historicamente, o primeiro tratado de livre comércio entre Argentina e Brasil foi firmado em 21/11/1941 e tinha por objetivo construir uma união aduaneira entre ambos os países. A seguir, foi firmado o Pacto $A B C$, entre Argentina, Brasil e Chile (1950-1953) e a Operação Pan-Americana (1958-1959). ${ }^{166}$ No entanto, é na década de 80 que Argentina e Brasil estreitaram pragmaticamente laços entre si, e com os vizinhos do Cone Sul, Paraguai e Uruguai.

Dentre os acordos que aproximaram Argentina e Brasil destacam-se:

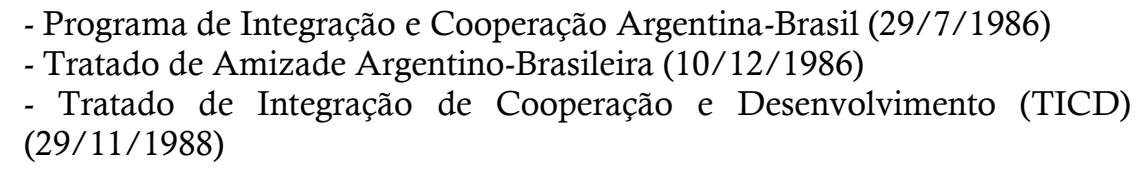

Além dos acordos Argentina-Brasil, ambos os países iniciaram uma aproximação, por meio de acordos bilaterais, com Uruguai e Paraguai. O Convênio Argentino-Uruguaio de Cooperação Econômica (1974) promoveu a aproximação física entre os países, com uma represa binacional de Salto Grande e a construção de várias pontes, significando expansão comercial. Durante 12 anos, houve aumento constante nas exportações uruguaias para a Argentina, ajudando a diminuir o déficit da balança comercial que o Uruguai possuía com a Argentina. Além desse, o Protocolo de Expansão Comercial Brasil-Uruguai (1983), que teve o mesmo efeito de aumentar as exportações e reduzir o déficit de balança comercial do Uruguai para com o Brasil. Acordos similares a estes dois foram negociados também por Argentina e Brasil com o Paraguai. ${ }^{167}$

\footnotetext{
${ }^{166}$ BOHLKE, Marcelo. Integração regional e autonomia do seu ordenamento jurídico. Curitiba: Juruá, 2002, p. 129.

${ }^{167}$ BAPTISTA, Luiz Olavo. O MERCOSUL, suas instituições e ordenamento jurídico. São Paulo: LTr, 1998, p. 30.
} 
Os acordos Argentina-Brasil, inclusive os mais de 20 protocolos firmados entre 1985 e 1990, foram todos firmados no âmbito do Acordo de Alcance Parcial (AAP) $n^{\circ} 1$ da ALADI.

No âmbito do AAP n.1, foi firmada em 30/11/1985, a Declaração de Iguaçu, por Brasil e Argentina, pela qual ambos os países sinalizaram o início de uma aproximação bilateral fundado em noções de harmonia e cooperação. Através da Declaração, foi criada uma Comissão Mista de Cooperação e Integração Bilateral, responsável por uma série de reuniões entre os chefes de Estado, ministros, empresários e industriais dos dois países.

Desta Comissão, resultou o mais avançado conjunto de documentos integracionistas da história do Cone Sul, dentre os quais se destacam a Ata para Integração Argentino-Brasileira, de 29/07/1986, o Programa de Integração e Cooperação Argentina-Brasil, da mesma data, que era composto por uma série de protocolos. $\mathrm{Na}$ data da assinatura da ata, já havia 12 protocolos consensuados. Ao longo dos dois anos seguintes, outros 12 protocolos foram aprovados. ${ }^{168}$

Outro instrumento jurídico relevante nesse processo de aproximação bilateral que antecedeu o MERCOSUL foi o Tratado de Integração de Cooperação e Desenvolvimento (TICD), de 29/11/1988. O TICD esboçou o objetivo de constituir um mercado comum, que depois viria a se consolidar nos acordos do MERCOSUL.

O TICD estabelecia como meta a criação de um "espaço econômico comum" envolvendo os territórios dos dois Estados-partes. Esse mercado comum, se realizaria em duas etapas. A primeira envolvia a eliminação de barreiras tarifárias e não-tarifárias por meio da celebração de protocolos adicionais, dentro de um prazo de 10 anos. Isto abrangia tanto o comércio de bens, quanto de serviços. A segunda etapa envolvia a harmonização gradual de todas as outras políticas necessárias para a formação de um mercado comum (políticas aduaneira,

\footnotetext{
${ }^{168}$ Os protocolos regulavam a integração de áreas especificas entre os dois Estados, e abrangiam uma diversidade de temas, tais como: comercialização de bens de capital, abastecimento alimentar, expansão comercial, cooperação em matéria de biotecnologia, energia nuclear, aeronáutica, exploração petrolífera, comunicações, cooperação entre bancos centrais, além de vários outros. Para maiores detalhes, ver BAPTISTA. op. cit. p. 31 e BOHLKE. op. cit. pp. 133 e 134.
} 
comercial, agrícola, transportes, comunicações, tecnológicas, cientificas, fiscal, cambiaria e de capitais). ${ }^{169}$

O TICD entrou em vigor em 24/08/1989, no entanto, jamais se realizaram negociações sob seus auspícios, tendo em vista a necessidade de aproximação com Paraguai e Uruguai, a fim de ampliar o projeto de mercado comum. ${ }^{170}$

Todos os acordos, declarações, atas e protocolos que haviam sido celebrados desde o AAP $\mathrm{n}^{\circ} 1$ foram consolidados junto à ALADI por meio do ACE $\mathrm{n}^{\circ} 14$, que entrou em vigor em $1^{\circ}$ de janeiro de 1991. Essa consolidação junto à ALADI teve dois motivos: i) para que as concessões mutuamente outorgadas não estivessem expostas à Cláusula NMF do artigo 44 do TM80, e assim, estivessem obrigados a estendê-las aos demais Membros da ALADI; e ii) para que não houvesse irregularidades frente às normas do GATT. ${ }^{171}$

Um elemento importante do ACE n.14, que repercute até hoje, especialmente nos meios de comunicação, é a criação de uma lista de exceções, no qual seriam elencados bens que não estariam sujeitos aos compromissos lineares de redução tarifária. Juntamente com a lista de exceções, foi prevista a possibilidade de se celebrar novos acordos setoriais que pudessem compensar os impactos do desagravamento tarifário sobre determinados setores industriais dos países Membros.

Como se verá ao longo deste subcapítulo, a lógica da lista de exceções surgida neste momento, se consolidou e expandiu ao longo das negociações do MERCOSUL, e tornou-se uma das pedras basilares do processo negociador.

\footnotetext{
${ }^{169}$ Artigos $4^{\circ}$ e $5^{\circ}$ do TICD.

${ }^{170}$ Ocorre que, no início, o Uruguai foi resistente ao projeto de mercado comum, preferindo continuar com os acordos bilaterais existentes, porque seu setor industrial estava em enorme desvantagem de competitividade em relação aos dois vizinhos maiores. ${ }^{170}$ Por sua vez, o ingresso do Paraguai era ainda mais difícil, tendo em vista que este país ainda se encontrava sob o regime ditatorial militar. Apenas com o golpe de Estado de 3 de fevereiro de 1989 contra o governo de Alfredo Stroessner, é que o regime militar se dissolveu. Para sustentar a recente democracia paraguaia e evitar que Uruguai e Paraguai ficassem isolados de seus sócios comerciais mais importantes da região, os presidentes Julio Sanguinetti, do Uruguai, e Andres Rodriguez, do Paraguai, acolheram o convite para criar um espaço econômico subregional integrado.

${ }^{171}$ BOHLKE, op. cit., p. 136.
} 
Uma das premissas desta tese é que, sob a ótica da dialética neoliberalismo $\mathrm{X}$ desenvolvimentismo vivida pelo MERCOSUL à época da sua criação, as listas seriam um dos poucos mecanismos criados para institucionalizar a lógica da proteção das indústrias nascentes na integração regional, lógica existente no âmbito da ALADI, mas desacreditada pelo novo ideário vigente na América do Sul dos anos 90 .

\section{b) O Tratado de Assunção}

O Tratado de Assunção (TA), firmado em 26/03/1991, entrou em vigor internacionalmente em 29/11/1991. Fundamentalmente, o TA é constituído com base no ACE $\mathrm{n}^{\circ} 14$ e no TICD. Por se constituir em novo tratado, com novos integrantes, e novos objetivos, é submetido à ALADI, que o aprova sob a denominação de Acordo de Complementação Econômica no 18 (ACE nº18).

A partir do Tratado de Assunção, o ideal de integração no Cone Sul consolida novas dimensões, não só econômicas e comerciais, mas também geopolíticas. É também a partir do TA, surge o objetivo de criar um "Mercado Comum do Sul", no qual estão envolvidos, desde o princípio, Argentina, Brasil, Paraguai e Uruguai.

Conforme aponta Luiz Olavo Baptista, "o TA tem ao mesmo tempo característica de transitoriedade e permanência". ${ }^{172}$ Ele é essencialmente transitório, pois demarca o trânsito do regime atual da integração, para o de um mercado comum, declarando que deve ser alterado ao se cumprirem seus objetivos, a fim de se adaptar a uma nova situação.

A esse caráter transitório, associa-se dialeticamente uma natureza permanente, pois os efeitos da aplicação do tratado são praticamente irreversíveis, tendo em vista a profundidade dos vínculos comerciais, econômicos e jurídicos que são constituídos a partir do momento em que se ingressa em um projeto de mercado comum.

\footnotetext{
${ }^{172}$ BAPTISTA, op. cit., p. 39.
} 
Com efeito, o TA previu duas etapas - a provisória e a definitiva - para a implantação do MERCOSUL. Na primeira, se procederia a uma integração progressiva e, por isso, as instituições seriam provisórias. Já na fase definitiva, os principais problemas da implantação deveriam equacionar-se (o que não ocorreu) e o processo de integração se consolidaria através da implantação de estruturas definitivas. Estas nasceriam como o Protocolo de Ouro Preto ${ }^{173}$ (POP).

As normas que visavam a promoção do comércio e da formação do mercado comum foram repartidas por três objetivos: um programa de liberalização comercial, a fixação de uma tarifa externa comum, e a coordenação das políticas macroeconômicas.

Com isso, se percebe que o objetivo do TA não era apenas a formação de uma zona de livre comércio, mas sim uma união aduaneira, por se propor a harmonizar os direitos aduaneiros dos Estados-Membros nas suas relações comerciais com terceiros países.

De acordo com o artigo $1^{\circ}$, os objetivos do MERCOSUL podem ser apresentados da seguinte maneira:

1. Livre circulação de bens, serviços e fatores de produção

4. Programa de Liberalização Comercial

2. Estabelecimento de uma Tarifa Externa Comum

3. Adoção de uma Política Comercial Comum diante de Terceiros Países

5. Coordenação de Políticas Macroeconômicas

6. Harmonização das legislações

Para atingir seus objetivos, o processo de integração regional do MERCOSUL dispõe de certos instrumentos ou mecanismos. O emprego desses instrumentos ou mecanismos deve ocorrer sempre com base nos princípios norteadores do MERCOSUL, ou seja, nos princípios da gradualidade, flexibilidade, equilíbrio, reciprocidade, tratamento nacional e nação mais favorecida.

\footnotetext{
${ }^{173}$ A estrutura do TA baseou-se em dois eixos: o das normas de promoção do comércio, e o da estrutura institucional. $\mathrm{O}$ eixo da estrutura institucional viria a ser detalhada e aprofundada pelo Protocolo de Ouro Preto (POP), que não será analisado por não se constituir objeto desta tese, centrada no eixo dos compromissos econômicos e comerciais.
} 
Como se pode perceber, dentre os objetivos elencados pelo TA, não se encontra menção expressa a políticas de desenvolvimento, como políticas setoriais de industrialização. Ao contrário, o MERCOSUL se consolida como um projeto de integração fundado na lógica da liberalização, e que essa, por conseguinte, geraria desenvolvimento aos países Membros, e àqueles setores industriais que fossem suficientemente competitivos para a concorrência interna (decorrente da Zona de Livre Comércio) e externa (decorrente da Tarifa Externa Comum).

No entanto, o processo de integração perderia sua utilidade e função se tivesse, na mera constituição do mercado comum, o seu objetivo último. ${ }^{174}$ Nesse sentido, para Adriana Dreyzin de Klor ${ }^{175}$, os objetivos relacionados no preâmbulo e no artigo $1^{\circ}$ são objetivos imediatos, em contraponto aos objetivos mediatos, perenes, que formam o interesse comum do MERCOSUL, que, de acordo com a autora, devem ser:

i) o desenvolvimento de um espaço econômico latino-americano;

ii) a busca de uma adequada inserção internacional e uma maior autonomia decisória no marco da atual ordem internacional;

iii) lograr um desenvolvimento com justiça social e ambientalmente sustentável;

iv) promover um desenvolvimento harmônico e equilibrado dos países associados.

\section{c) A dinâmica da primeira década do MERCOSUL}

Os instrumentos previstos pelo TA deveriam se desenvolver durante o período de transição, que ocorreria entre a data da entrada em vigor do referido tratado e 31/12/1994. Com a conclusão do período transitório, haveria a instalação de uma zona de livre comércio entre os Estados-Membros do MERCOSUL.

$\underline{1^{a} \text { fase (1990-1995): O período de transição e o programa de liberalização comercial }}$

\footnotetext{
174 BOHLKE. op. cit., 156.

175 KLOR, Adriana Dreyzin. El Mercosur: generador de una nueva fuente de derecho internacional privado. Buenos Aires: Zavalia, 1997, apud BOHLKE. op. cit. , p. 156.
} 
Por meio de reduções tarifárias progressivas, lineares e automáticas se pretendia chegar em 31.12.1994 com tarifa zero no comércio intra-bloco. Ao mesmo tempo em que ocorreria a eliminação das barreiras tarifárias, pretendia-se excluir igualmente todos os outros gravames e restrições aplicadas no comércio recíproco.

O período compreendido entre a data da entrada em vigor do TA e 31.12.1994 é chamado de "período de transição". O MERCOSUL deveria constituir uma zona de livre comércio quase perfeita, que só se tornaria perfeita um ano depois, 31.12.1995, quando Paraguai e Uruguai passariam a aplicar tarifa zero.

A desagravação tarifária deveria ocorrer em conformidade com a tabela disposta no Anexo I ao TA. Logo nos primeiros seis meses, em 30.06.1991 haveria redução de 47\% nas alíquotas de imposto de importação cobrados no comércio recíproco entre os Membros. A partir daí, a cada semestre, haveria redução de 7\%, atingindo, dessa forma, 100\% em final de 1994. A redução deveria ser aplicada sobre as alíquotas vigentes em 01/01/1991 para terceiros que não fizessem parte da ALADI. Isso implica que, caso houvesse redução de tarifas para terceiros países não-Membros da ALADI, a desagravação deveria ser aplicada sobre as alíquotas reduzidas.

Durante o período de transição, cada um dos Estados-Membros poderia apresentar Listas de Exceções, contendo certos produtos que ficariam fora do cronograma de desagravação geral. Com base nos itens da Nomenclatura ALADI, a Argentina poderia indicar 394 produtos, o Brasil, 324, produtos, o Paraguai, 439 produtos, e o Uruguai, 960 produtos. ${ }^{176}$

Essas Listas de Exceções seriam reduzidas de duas formas. Para Argentina e Brasil, a redução no número de itens seria na razão de $20 \%$ anuais. Para Uruguai e Paraguai, a redução seria na razão de $10 \%$ no primeiro ano, e depois, na razão de $20 \%$ até o final de 1995 .

Notadamente, os prazos do TA não foram cumpridos e o MERCOSUL se viu forçado a inaugurar uma nova fase de negociações entre as partes, para que se

\footnotetext{
${ }^{176}$ Artigo $6^{\circ}$ do Anexo I do Tratado de Assunção.
} 
adequassem aos compromissos e pudessem concretizar os mecanismos para formação da zona de livre comércio e da união aduaneira.

O prazo estabelecido para alcançar o mercado comum foi claramente irrealista e ambicioso. Em face disso, esgotou-se o prazo sem que as metas tivessem sido efetivamente alcançadas. O período posterior, que deveria contar com estrutura definitiva, encontra diversas características que, em princípio, estariam presentes no período de transição.

A conseqüência imediata do descumprimento dos objetivos estabelecidos pelo TA foi a criação de políticas alternativas de readequação das metas do MERCOSUL. Por isso, além do período de transição, o processo de implantação dos objetivos do MERCOSUL passou por um novo período: o Regime de Adequação Final à União Aduaneira.

Um balanço interessante desta primeira fase do MERCOSUL é feita por Tatiana Prazeres:

\begin{abstract}
Muito embora durante o chamado "período de transição" não tenha sido estabelecido mercado comum conforme previsto, a fase de 1991 a 1994 trouxe bons resultados ao MERCOSUL. Em apenas 4 anos, a participação das exportações intrazona no PIB da região aumentou mais de $60 \%$. Houve de fato liberalização do comercio no bloco: em janeiro de 1995, mais de $85 \%$ dos fluxos de comercio intra-regional se beneficiavam da alíquota zero de imposto de importação. As exceções ao livre comércio intrazona foram incluídos no Regime de Adequação. Além dessas exceções, foram adotados os regimes especiais temporários para açúcar e automóveis. No balanço, de fato, parte muito expressiva das barreiras comerciais intrazona foram eliminadas logo nos primeiros anos do MERCOSUL e os fluxos comerciais cresceram de maneira expressiva no bloco. ${ }^{177}$
\end{abstract}

\title{
$\underline{2^{a} \text { fase (1995-2000): O regime de adequação final à União Aduaneira }}$
}

Ao longo de 1994, o Conselho Mercado Comum, ao perceber que o prazo para a liberalização completa do comércio intra-regional de bens no MERCOSUL estava se esgotando e os objetivos não seriam cumpridos, formulou uma série de

\footnotetext{
${ }^{177}$ PRAZERES, Tatiana. A OMC e os Blocos Regionais. São Paulo: Aduaneiras, 2008, p. 224.
} 
medidas destinadas a dar continuidade a este processo. Este conjunto de medidas foi denominado "Regime de Adequação Final a União Aduaneira". ${ }^{178}$

De acordo com o Regime de Adequação, uma lista reduzida de produtos faria parte do processo linear e automático de desagravação diferenciado daquele previsto originalmente no Programa de Liberalização Comercial do período de transição.

O Regime de Adequação permitiu que os produtos a ele submetidos pudessem seguir novo prazo de desagravação linear e automático. Esse prazo seria estabelecido dependendo do Estado-Membro envolvido. Para Argentina e Brasil, o Regime de Adequação permitia prazo extra de quatro anos (até 01/01/1999) para atingir a completa eliminação de tarifas aduaneiras no comércio recíproco. Para Paraguai e Uruguai, o novo prazo permitia cinco anos adicionais (até 01/01/2000). Com isso, a constituição definitiva da zona de livre comércio no MERCOSUL foi adiada por pelo menos mais cinco anos.

Ao mesmo tempo em que se formulou este Regime de Adequação para formação da Zona de Livre Comércio, foi igualmente constituído, ao longo de 1994, o "Projeto de Tarifa Externa Comum do MERCOSUL". ${ }^{179}$

De acordo com este projeto, a alíquota sobre bens de capital deveria convergir até 01/01/2001 a uma Tarifa Externa Comum de 14\%. Paraguai e Uruguai teriam cinco anos adicionais, até 01/01/2006, para convergir para a mesma alíquota. Para bens de informática e telecomunicações, o prazo de convergência a Tarifa Externa Comum seria comum a todos os Membros, em $01 / 01 / 2006$.

Seguindo a lógica do MERCOSUL, o Projeto, ao criar as regras, cria igualmente um enorme leque de exceções. Foi estabelecido o número de produtos que cada Estado-Membro poderia apresentar como exceções à Tarifa Externa Comum. Argentina e Brasil poderiam manter 300 produtos fora da Tarifa Externa

\footnotetext{
${ }^{178}$ Decisão CMC n ${ }^{\circ}$ 5, de 5/08/1994 e Resolução GMC nº 48, de 14.10.1994.

${ }^{179}$ Decisão CMC n. 7, de 5/08/1994.
} 
Comum até 01/01/2001. Paraguai e Uruguai poderiam manter até 399 produtos fora da Tarifa Externa Comum.

Para setores específicos como bens de capital, informática e telecomunicações, foram criadas Listas de Convergência para os setores de bens de capital, informática e telecomunicações, que teriam regimes diferenciados e excepcionais para a Tarifa Externa Comum. ${ }^{180}$

Com a criação definitiva da Tarifa Externa Comum, foram estabelecidas três listas de produtos que ficariam fora do regime da Tarifa Externa Comum: as Listas de Exceções do Regime de Adequação; as Listas de Convergência para setores específicos e as Listas de Exceções Nacionais à Tarifa Externa Comum.

As mesmas críticas feitas à concepção de Tratamento Especial e Diferenciado dos novos acordos da OMC podem ser repetidas aqui. Para o MERCOSUL do século XX, o Tratamento Especial e Diferenciado foi sinônimo de prazos mais extensos para Paraguai e Uruguai. Jamais estes países conseguiriam consolidar, em qualquer nível, os setores industriais que possuíam ou que pretendiam por meio de medidas paliativas, como listas de exceções à Zona de Livre Comércio e prorrogações de prazos para enquadramento na Tarifa Externa Comum.

\section{d) Aspectos desenvolvimentistas da primeira década do MERCOSUL}

Do ponto de vista da liberalização comercial, e sua consequente compatibilidade com as exigências do artigo XXIV do GATT, o MERCOSUL pode ser visto como um sucesso, tendo em vista ter atendido as exigências de ter liberalizado substancialmente todo o comércio intrazona "substantially all the trade", com mais de $85 \%$ das linhas tarifárias estarem com alíquota zero. Além disso, a Tarifa Externa Comum foi instituída de maneira bem sucedida, ainda que com exceções.

\footnotetext{
${ }^{180}$ Decisão CMC n. 22, de 17/12/1994.
} 
Até 1997, houve um crescimento bastante significativo do comércio intrabloco. A partir daí, as relações entre os países começaram a se deteriorar e foram agravadas consideravelmente a partir da crise brasileira, de 1999, com a desvalorização do Real, mas principalmente com a crise econômica argentina, de 2000 .

Dentre tantas críticas recebidas pelo MERCOSUL está a questão de que, passados os primeiros 10 anos de existência, nenhum dos seus objetivos foi plenamente alcançado: a Zona de Livre Comércio tem demasiadas exceções; a União Aduaneira é "imperfeita"; e a livre circulação dos fatores de produção trabalhadores, serviços, capitais, está ainda em estágio inicial de desenvolvimento.

O insucesso do MERCOSUL em cumprir os seus objetivos parece ser culpa dos seus integrantes. Ora, e se o problema for analisado pelo viés contrário? O MERCOSUL, quando da sua criação, atendia aos objetivos "reais" dos seus Membros? Parece que não.

Historicamente, os países Membros do MERCOSUL sempre tiveram a preocupação de fomentar suas políticas industriais, por meio de proteções tarifárias, subsídios, isenções. No entanto, na hora de celebrarem um acordo de integração regional, o fazem em total descompasso com as prioridades nacionais. Obviamente o choque seria grande, como de fato foi.

Talvez se o MERCOSUL tivesse priorizado uma integração voltada para o desenvolvimento, como o fez o Pacto Andino nas suas primeiras décadas, sua história poderia ser outra: uma história de sucesso no que se refere ao desenvolvimento industrial da sub-região, tornando-a capaz de promover uma integração comercial mais aberta entre os seus Membros.

Como se pode perceber desse breve apanhado histórico do processo de formação do MERCOSUL, praticamente todos os esforços destinados pelo MERCOSUL enquanto organização internacional, e pelos seus Estados-Membros, giraram em torno do processo de liberalização comercial de bens, em uma constante luta em torno das listas de exceções, dos prazos e níveis de desagravação, 
das exceções às alíquotas da Tarifa Externa Comum, etc., como se a história do MERCOSUL pudesse ser contada pelas exceções, e não por suas regras.

Isso demonstra que os objetivos comercialistas e liberalizantes do projeto de integração estavam em total descompasso com as vontades e necessidades dos Estados. A carência de políticas industriais, a fim de consolidar as indústrias nascentes da região, torna-se manifesta a partir do momento em que é possível contar a história do MERCOSUL pelo viés das Listas de Exceções.

Além disso, as mesmas críticas que recaem sobre a concepção de Tratamento Especial e Diferenciado dos novos acordos da OMC servem para o MERCOSUL. Para o MERCOSUL do século XX, o Tratamento Especial e Diferenciado foi sinônimo de prazos mais extensos para Paraguai e Uruguai. Jamais estes países conseguiriam consolidar, em qualquer nível, os setores industriais que possuíam ou pretendiam possuir por meio de medidas paliativas, como listas de exceções à Zona de Livre Comércio e prorrogações de prazos para enquadramento na Tarifa Externa Comum. 


\section{CONCLUSÕES DO CAPÍTULO 3.}

O capítulo 3 apresenta a história do exercício destas prerrogativas jurídicas do sistema multilateral de comércio pelos países da América do Sul.

Nesta época, a América do Sul já vinha implantando o modelo de industrialização pela substituição de importações e, por isso, muitos países foram reticentes para tornarem-se parte do sistema multilateral de comércio. Tanto é assim que apenas três países da América do Sul foram signatários originários do GATT-47. A grande maioria se tornou signatária ao longo dos anos 1950 e 1960, quando do movimento de afirmação do Terceiro Mundo.

A partir do surgimento de prerrogativas jurídicas específicas para países em desenvolvimento, os países da América Latina lançaram de diversas iniciativas amparadas nestas prerrogativas. Tanto no plano regional como no plano multilateral, a América Latina fez uso intensivo do policy space que foi construído no âmbito do GATT.

$\mathrm{O}$ artigo XVIII, que permitia a proteção a indústrias nascentes, foi a prerrogativa que viabilizou a compatibilidade entre o sistema multilateral de comércio e os modelos de industrialização pela substituição de importações, que estavam amplamente difundidos entre os países em desenvolvimento, especialmente na América do Sul. Sem a existência do artigo XVIII, provavelmente o processo de adesão dos países em desenvolvimento ao sistema multilateral de comércio teria sido completamente diferente.

A partir da década de 50, o modelo ISI da América do Sul passou a exercer uma singularidade em relação aos demais modelos dos países em desenvolvimento: estava concebido para ser desenvolvido no plano continental. Foi com este espírito que emergiu a ALALC. No entanto, à época, os processos de integração regional eram regidos pelo artigo XXIV do GATT, que não reconhecia diferença entre iniciativas de integração regional envolvendo países em desenvolvimento.

Foi apenas com a criação da Parte IV do GATT que a integração sulamericana incorporou elementos do direito internacional do desenvolvimento, mais 
precisamente, o tratamento especial dos países menos desenvolvidos da região. Neste momento, ao final da década de 60, a ALALC outorgou aos países andinos o direito de estabelecerem um sub-processo de integração regional, o Pacto Andino.

A passagem da ALALC para ALADI, em 1980, também só foi possível em razão do surgimento da Cláusula de Habilitação em 1979. Há uma série de diferenças entre o Tratado de Montevidéu de 1960 e o de 1980 que decorre das prerrogativas do desenvolvimento do sistema multilateral de comércio. Destas, sem dúvida a mais importante evolução da ALALC para a ALADI foi a possibilidade dos Membros constituírem acordos sub-regionais de integração, de onde surgiram o Pacto Andino, em 1969, e o MERCOSUL, em 1991.

O Pacto Andino, desde o seu surgimento, sempre levou em consideração o desenvolvimento como paradigma do seu processo de integração. Trata-se de uma iniciativa constituída com base nas prerrogativas da Cláusula de Habilitação. O Acordo de Cartagena é um tratado em que constantemente se faz menção à prioridade à industrialização regional, ao reconhecimento da diversidade econômica dos países Membros e à condição secundária da liberalização comercial e da integração comercial com o mundo. Estas tônicas da integração andina só foram alteradas ao final da década de 1980, quando da emergência do Consenso de Washington, que atingiu de forma mais contundente a América do Sul, e do surgimento do "Novo Regionalismo da Cepal", quando o Pacto Andino se transformou na Comunidade Andina de Nações.

O MERCOSUL é contemporâneo da Comunidade Andina, e se orientou igualmente pelas premissas vigentes ao final da década de 1980 e início da década de 1990. Por isso, muito embora o MERCOSUL seja constituído juridicamente e notificado ao GATT sob o amparo da Cláusula da Habilitação, o Tratado de Assunção não faz menção direta, em dispositivo algum, à industrialização regional, ao tratamento especial dos países em desenvolvimento e à prioridade do desenvolvimento em detrimento da liberalização comercial. Diferentemente do Pacto Andino, o MERCOSUL é uma iniciativa fundada com base nas prerrogativas do desenvolvimento apenas de maneira formal. 
Como pode se perceber, prima facie, o MERCOSUL, desde seu nascimento, já surge com propósitos e objetivos bastante distintos do Pacto Andino. Enquanto o Tratado de Assunção revela uma natureza predominantemente comercialista e liberalizante para o MERCOSUL, o Acordo de Cartagena optou por priorizar o eixo do desenvolvimento industrial como objetivo do Pacto Andino. A liberalização comercial, no caso andino, era um meio para um fim maior, o desenvolvimento industrial da sub-região. No caso do MERCOSUL, a liberalização foi tratada desde seu surgimento como um fim em si mesmo.

Esta diferença entre ambos os projetos sub-regionais, embora fundamentados juridicamente nos mesmos preceitos (ambos são ACE no marco da ALADI e ambos são acordos regionais com base na Cláusula de Habilitação do GATT), revela o zietgeist, o espírito do tempo, em que cada iniciativa foi lançada. Uma das provas disso é que, quando do "relançamento do Pacto Andino", no final da década de 80, o Protocolo de Quito modificou profundamente o Acordo de Cartagena, tornando-o mais próximo dos parâmetros que viria a adotar o MERCOSUL, menos estatizante e dirigista e mais liberalizante, pró-mercado.

Salvo os institutos das Listas de Exceções e dos Programas de Compensação Setorial, o MERCOSUL revela pouca ou nenhuma importância para a questão do fomento industrial dos Estados-Membros. Isto seria uma situação a ser resolvida seguindo as teses neoclássicas do comércio e da integração, e não por meio do planejamento regional e da intervenção dos Estados-Membros.

O esvaziamento e esgotamento desse modelo de política pública de desenvolvimento levado adiante na América Latina, não foi causado exclusivamente pelos constrangimentos jurídicos do sistema multilateral de comércio. O modelo latino-americano de desenvolvimento que perdurou entre as décadas de 50 a 80 - aquele que uniu o processo de substituições de importações com os fenômenos da integração regional e as oportunidades de comércio preferencial norte-sul e sul-sul - esgotou-se por diversas causas.

De acordo com Marcio Bobik Braga, a primeira e mais importante foi a crise econômica mundial desencadeada pelos choques do petróleo de 1973 e 1979. A crise mundial levou à retração do crescimento dos países desenvolvidos, o que 
acarretou na diminuição do ritmo das exportações latino-americanas para estas regiões. Além disto, a diminuição da liquidez internacional levou a um aumento das taxas de juros e da redução dos fluxos de financiamento e investimentos para os países em desenvolvimento. Isto se fez sentir de forma muito austera na América Latina, que tinha fundado o Modelo ISI, em grande parte, em investimentos estrangeiros. Consequentemente, a crise resultou em graves desequilíbrios macroeconômicos para os países da região, que levou a uma crise de dívida externa na América Latina. ${ }^{181}$

Nesse sentido, restou claro que o modelo de desenvolvimento, baseado no processo de substituição das importações, estava esgotado.

Em uma perspectiva global, as décadas de modelo desenvolvimentista na América do Sul e ao redor do mundo em desenvolvimento, permitem fazer algumas afirmações em favor deste modelo. Em 1965, países em desenvolvimento forneciam menos de um vigésimo da produção mundial de manufaturas; em 1995, forneciam mais de um quinto do total. A "ascensão do resto" mudou a face da economia mundial. ${ }^{182}$

Estes países de industrialização tardia desafiaram os princípios fundamentais da economia política liberal, não confiando nas "forças do mercado". Ao contrário, apoiaram-se em extensas políticas de subsídios às indústrias de manufaturas. Segundo Dani Rodrik, a herança desse processo não foi, de modo algum, negativa no todo:

O Modelo ISI deu certo por quase duas décadas. Até a $1^{\text {a }}$ crise do petróleo, em 1973, 42 países em desenvolvimento cresceram mais de 2,5\% ao ano. Destes, a maioria seguia o Modelo ISI, dos quais 12 se encontravam na América Latina; 6 no Oriente Médio e Norte da África; 14 na África subsaariana. ${ }^{183}$

No mesmo sentido, Alice Amsden afirma que, a partir do Modelo ISI:

\footnotetext{
${ }^{181}$ BRAGA; PAIVA, op. cit., p. 65.

${ }^{182}$ Para a autora, os países que compõem o "Resto" são: Argentina, Brasil, Chile, China, Índia, Indonésia, Coréia do Sul, Malásia, México, Taiwan, Tailândia e Turquia. ver AMSDEN, Alice. A Ascensão do resto: os desafios ao ocidente de economias com industrialização tardia. São Paulo, Editora UNESP, 2009.

${ }^{183}$ RODRIK, Dani. Development strategies for the next century. World Bank, Annual World Bank Conference on Development Economics. 2001.
} 
Houve uma mudança no centro de gravidade das economias de tais países, deslocando-se dos bens de produção primária para bens de produção dependente de tecnologia. $\mathrm{O}$ fato que estas políticas industriais intervencionistas tiveram papel fundamental no desenvolvimento, tanto de países industrializados quanto de países de industrialização tardia, propõe um argumento sólido para a adoção de políticas similares em países em desenvolvimento, dentre eles os latino-americanos. ${ }^{184}$

A tabela abaixo confirma tal afirmação de Alice Amsden, por comprovar os impactos das décadas de políticas industriais intervencionistas, que levaram a um aumento significativo do valor percentual dos produtos manufaturados na pauta de exportações dos países da América do Sul.

Tabela 7. Exportações de manufaturas - 1980-2000

\begin{tabular}{|c|c|c|c|c|c|}
\hline Mercado (em percentuais) & 1980 & 1986 & 1992 & 1998 & 2000 \\
\hline \multicolumn{6}{|l|}{ CAN } \\
\hline Intra-regional & 29,5 & 47,5 & 45,5 & 56,0 & 46,5 \\
\hline Extra-regional & 3,6 & 6,9 & 11,3 & 12,8 & 10,0 \\
\hline \multicolumn{6}{|l|}{ MCCA } \\
\hline Intra-regional & 74,3 & 72,5 & 63,7 & 59,2 & 54,7 \\
\hline Extra-regional & 5,7 & 10,7 & 17,1 & 36,5 & 38,9 \\
\hline \multicolumn{6}{|l|}{ MERCOSUL } \\
\hline Intra-regional & 40,7 & 33,7 & 49,3 & 55,8 & 55,7 \\
\hline Extra-regional & 28,1 & 35,4 & 38,2 & 35,1 & 39,7 \\
\hline \multicolumn{6}{|l|}{ AMÉRICA LATINA } \\
\hline Intra-regional & 46,3 & 50,7 & 57,9 & 60,8 & 55,9 \\
\hline Extra-regional & 10,5 & 26,2 & 38,9 & 54,0 & 56,1 \\
\hline
\end{tabular}

Fonte: Banco Interamericano de Desenvolvimento (2003)

A partir do Consenso de Washington, o abandono do paradigma desenvolvimentista em favor do paradigma neoliberal se deu com muita intensidade na América Latina, ao longo da década de 90. No entanto, embora a América Latina tenha demonstrado a maior coerência dentre todas as regiões do

${ }^{184}$ AMSDEN, op. cit., p. 430.

185 Banco Interamericano de Desenvolvimento. O Novo Regionalismo na América Latina:

Relatório de Progresso Econômico e Social na América Latina. Washington: IADB, 2003. 
mundo na adoção do consenso neoliberal, não houve uniformidade na intensidade e no ritmo das reformas internas requeridas pelo novo modelo de inserção internacional.

Este modelo de modernização do Estado foi concebido pelos dirigentes como sinônimo de abertura de mercado de bens e serviços, além da privatização das empresas públicas, como sugeria o centro hegemônico do capitalismo. Vários dirigentes passaram a cunhar a expressão Estado normal, para designar o processo de adaptação ante o novo paradigma. ${ }^{186}$

\title{
Como afirma Amado Luiz Cervo:
}

Ser normal converteu-se, contudo, no desideratum de todos os países da América Latina, exceto Cuba, que se apressavam em agradar a matriz do novo sistema internacional, os Estados Unidos, porque com eles os vínculos eram os mais fortes, e cada um desses países trabalhava com a hipótese de poder tirar os melhores proveitos dessa subserviência. Assim, a transição do Estado desenvolvimentista para o Estado normal significou, no anos 1990, na América Latina, a adoção de um processo de modernização concebido pelo centro do sistema internacional em substituição à formulação fundada na inteligência local, no tradicional pensamento da CEPAL. ${ }^{187}$

Este período foi também decisivo para modificar a posição dos Estados latino-americanos na sua relação com o policy space, ou margem de manobra, como menciona Amado Cervo:

\begin{abstract}
As margens de manobra da política internacional da América Latina, que o paradigma desenvolvimentista implementara durante 60 anos e que denominara de $3^{a}$ posição ou Política Externa Independente, foram consideradas, nos anos 1990, inadequadas para os tempos de globalização. De fato, o Estado normal não admitia o conceito de margens de manobra e introduzia, em seu lugar, os conceitos de consentimento diante das matrizes e de padronização de condutas em matéria de macropolíticas internas e externas. ${ }^{188}$
\end{abstract}

Neste processo de normalização dos Estados latino-americanos e de incorporação de um modelo único, emanado do Consenso, o acervo cepalino de ideias estruturalistas, que inspirou a política dos países latino-americanos em sua estratégia de superação do subdesenvolvimento, foi despachado para o arquivo histórico pelos novos presidentes de orientação neoliberal. Em poucos anos, a

\footnotetext{
186 CERVO, Amado Luiz. Relações Internacionais da América Latina: velhos e novos paradigmas. $2^{\text {a }}$ edição. São Paulo: Saraiva, 2007, p. 216.

${ }^{187}$ CERVO, op. cit., p. 217.

${ }^{188}$ CERVO, op. cit., p. 218.
} 
América Latina avançou no caminho da desconstrução do núcleo central do seu modelo de Estado, erguido em 60 anos de esforços nacionais e regionais. 
PARTE II. O IMPACTO DA ORGANIZAÇÃO MUNDIAL DO COMÉRCIO SOBRE O POLICY SPACE DAS ORGANIZAÇÕES DE INTEGRAÇÃO DA AMÉRICA DO SUL 


\section{APRESENTAÇÃO DA PARTE II}

O objetivo da Parte II é o de analisar o impacto causado pelo surgimento da OMC e de seu arcabouço jurídico sobre as organizações internacionais de integração da América do Sul então existentes, a ALADI, o MERCOSUL e a CAN. Para realizar tal análise, a Parte II compõe-se por dois capítulos.

O capítulo 4 apresenta a criação da Organização Mundial e Comércio $(\mathrm{OMC})$ e a consequente relativização do desenvolvimento enquanto princípio jurídico das relações internacionais. Em seguida, avaliam-se as limitações jurídicas que os novos acordos trouxeram aos seus Membros. Outro ponto que merecerá atenção é a mudança conceitual e a operacionalização, e as consequentes limitações, do novo Tratamento Especial e Diferenciado do Período OMC, seja enquanto princípio no sistema multilateral de comércio, seja enquanto dispositivos específicos espalhados nos diversos acordos. Por fim, uma breve apresentação dos únicos dois casos levados ao órgão de solução de controvérsias (OSC) da OMC, referentes ao artigo XVIII e à Cláusula de Habilitação.

Já o capítulo 5 avalia os processos de compatibilização das organizações de integração sul-americana com as regras da OMC. De maneira específica, será apresentado um levantamento dos acordos e protocolos celebrados no âmbito das organizações sul-americanas, ALADI, MERCOSUL e CAN, que estejam relacionados aos novos temas decorrentes da OMC: comércio de serviços, investimentos e propriedade intelectual.

Como encerramento da Parte II, será realizada uma avaliação dos processos de análise de compatibilidade das organizações de integração da América do Sul que tramitaram e tramitam junto à $\mathrm{OMC}$, nos diversos Conselhos e Comitês competentes, relacionados às organizações de integração sul-americanas, desde a constituição da ALALC, passando pelas notificações de ALADI e CAN, até o atual estágio de análise do MERCOSUL. Menção será finalmente feita aos casos julgados pelo OSC sobre o MERCOSUL, a única das organizações de integração sul-americanas que já teve os fundamentos jurídicos da sua integração regional avaliados pelo OSC. 


\section{CAPÍTULO 4. A CRIAÇÃO DA ORGANIZAÇÃO MUNDIAL DE COMÉRCIO E A RELATIVIZAÇÃO DO DIREITO INTERNACIONAL DO DESENVOLVIMENTO}

Os últimos quarentas anos poderiam ser chamados de era do desenvolvimento. Uma era que está chegando ao fim. As condições históricas que deram origem à perspectiva desenvolvimentista deixaram de existir. Esse é o momento adequado para escrever seu obituário.

Wolfgang Sachs, Dicionário do desenvolvimento, 1991 


\section{APRESENTAÇÃO DO CAPÍTULO 4}

O capítulo 4 corresponde ao período de consolidação institucional, política e jurídica do neoliberalismo, por meio do surgimento da OMC e dos novos acordos do sistema multilateral de comércio.

No subcapítulo 4.1, será analisado o processo de criação da OMC bem como dos diversos acordos negociados ao longo da Rodada Uruguai, dando especial atenção à postura e às reivindicações dos países em desenvolvimento ao longo das negociações. Será dada atenção igualmente aos resultados dos compromissos assumidos, a fim de se identificar se houve de fato, redução de policy space dos países em desenvolvimento.

No subcapítulo 4.2, o foco de análise passa a ser o instituto do Tratamento Especial e Diferenciado, sob cuja égide se concentrou a grande maioria das prerrogativas jurídicas dos países em desenvolvimento. Ao analisar o Tratamento Especial e Diferenciado, dar-se-á atenção às questões em torno da condição jurídica de Membro em desenvolvimento, que é fundamental para reivindicar ditas prerrogativas. Também serão avaliadas as limitações do Tratamento Especial e Diferenciado, conceitualmente diferente daquele do período GATT, bem como o esgotamento dos direitos de Tratamento Especial e Diferenciado logo nos primeiros anos da OMC.

Por fim, o subcapítulo 4.3 trata de um breve estudo dos casos nos quais as prerrogativas jurídicas do desenvolvimento foram analisadas pelo OSC, quais sejam, o Caso Índia - Restrições Quantitativas, referente ao artigo XVIII, e o Caso CE - Preferências Tarifárias, que interpreta a Cláusula de Habilitação. 


\subsection{A RELATIVIZAÇ̃̃O DO DESENVOLVIMENTO QUANDO DA CRIAÇÃO DA ORGANIZAÇÃO MUNDIAL DO COMÉRCIO}

\section{a) O desenvolvimento nas negociações da Rodada Uruguai}

\section{i. O lançamento da Rodada Uruguai}

A criação da Organização Mundial do Comércio (OMC) tem origem nas negociações da Rodada Uruguai, iniciadas em 1986, em Punta Del Este, Uruguai, e finalizadas em 1994, em Marraqueche, Marrocos. A Rodada Uruguai foi a mais ampla e complexa das negociações do sistema multilateral de comércio até então. Por isso, foi também a mais longa.

Logo após a Rodada Tóquio, em 1979, os EUA já propunham a necessidade de uma nova rodada, por uma série de motivos, dentre os quais se destacam:

\footnotetext{
a) os códigos da Rodada Tóquio não haviam sido firmados pelos PED e as barreiras não-tarifárias continuaram sendo um grande obstáculo ao comércio internacional;

b) o aumento do volume do comercio de serviços no PIB dos países ricos fez com que tais países pressionassem por um marco regulatório internacional para os setores de serviços;

c) o desejo de um forum shifting para os temas de propriedade intelectual, da OMPI para o sistema GATT, tendo em vista o nível de atividade do OSC;

d) a necessidade de regulação do comercio agrícola no âmbito do sistema GATT, tendo em vista o aumento da intervenção da Política Agrícola Comum (PAC) da CE.
}

Houve oposição, tanto da Comunidade Europeia (CE) quando dos países em desenvolvimento, para o lançamento de uma nova rodada. A CE hesitava inicialmente em regular comércio de serviços, tendo em vista as diferenças regulatórias que a $\mathrm{CE}$ tinha em relação aos EUA. A CE tampouco queria reformar a PAC, pois tinha acabado de passar por uma das suas diversas reformas, que gerava um custo político interno muito alto. Por outro lado, os países em desenvolvimento estavam preocupados com os impactos e os custos que as novas 
regulações internacionais, em matéria de propriedade intelectual e serviços, poderiam gerar para eles.

Em setembro de 1986, em Punta Del Leste, Uruguai, foi realizada uma reunião ministerial para lançar uma nova rodada de negociações comerciais. Muitas das dissidências foram sanadas nesta reunião ministerial e, ao final, foi emitida a Declaração Ministerial de Punta del Este, a mais ambiciosa de todas as pautas de negociações lançadas até hoje no âmbito do sistema multilateral de comércio.

Curiosamente, apesar das pretensões da declaração, esta não faz menção alguma às negociações sobre a constituição de uma nova organização internacional. Este tema surgiu na metade final da pauta da Rodada, praticamente por necessidade, tendo-se em vista o avanço e a amplitude das negociações. Supunha-se que seria impossível implantar todos os novos acordos que estavam por se concluir sem uma organização internacional que os gerenciasse.

\section{ii. A desarticulação dos países em desenvolvimento no lançamento da Rodada Uruguai}

Os países em desenvolvimento chegaram desarticulados à Rodada Uruguai, por vários motivos. Em primeiro lugar, houve uma revisão conceitual das estratégias de desenvolvimento em grande parte dos países em desenvolvimento, que abandonaram a estratégia baseada na substituição de importações e na promoção de indústrias nascentes.

Esta revisão se deu por uma série de motivos de ordem interna, tais como a falta de efetividade dos investimentos públicos, os altos custos públicos que estavam gerando um déficit, as limitações decorrentes do tamanho do mercado doméstico consumidor, etc. Vários desafios de ordem externa estavam igualmente postos: a queda no preço das commodities no início dos anos 1980 forçou os países dependentes das exportações de matérias primas a pensar em diversificar a sua estrutura exportadora; o aumento da competitividade no mercado mundial levou os países a tornarem-se competitivos no mercado interno. 
Este conjunto de fatores estava levando diversos países em desenvolvimento a liberalizarem suas políticas comerciais ao final dos anos 1970 e início dos anos 1980 e passarem a perseguir estratégias de desenvolvimento e industrialização fundadas em exportações.

Ao mesmo tempo, uma série de países em desenvolvimento continuava implantando estratégias de desenvolvimento fundadas na substituição de importações, enquanto outros, ainda mais atrasados na escada do desenvolvimento industrial, continuavam dependentes de exportação de commodities. O resultado dessa mudança de cenário, no qual alguns países em desenvolvimento abandonavam a máxima do Modelo ISI, significava que não haveria mais consenso entre os países em desenvolvimento sobre suas estratégias de desenvolvimento e suas respectivas políticas comerciais.

Além disso, os países em desenvolvimento que haviam sido bem sucedidos em suas estratégias de exportação de bens processados ou manufaturados estavam mais interessados em garantir que a abertura dos seus mercados exportadores continuasse em bases incondicionais, isto é, seguindo a Cláusula NMF. Estes setores incluíam produtos agrícolas, têxteis e vestuários, ainda não regulados pelo GATT até então.

Os países em desenvolvimento que estavam implantando estratégias de desenvolvimento orientadas por exportações estavam interessados em endereçar um conjunto completamente diferente de questões ao longo das negociações da Rodada Uruguai. Apesar das reduções tarifárias sobre importações de manufaturados negociados e consolidados no âmbito do SGP, os temas que começavam a preocupar eram as medidas não-tarifárias: os acordos de restrição voluntária às exportações; o aumento no uso de medidas anti-dumping e medidas compensatórias; aumento das tarifas sobre produtos manufaturados $\mathrm{e}$ industrializados que eram de interesse dos países em desenvolvimento; o aumento de quotas em têxteis e vestuários, com base no Acordo Multifibras; e a redução gradual da efetividade das regras do GATT em comércio agrícola, especialmente por meio das restrições e dos subsídios dos países desenvolvidos. 
A heterogeneidade que havia se alcançado entre os países em desenvolvimento ao final dos anos 1980 também fez emergir dilemas em relação a forma com que o Tratamento Especial e Diferenciado estava sendo percebido. Alguns consideravam que a abordagem empregada era demasiadamente ideológica, trazendo ranços e representando cisões do passado que não mais se aplicavam. Por isso, diferentemente das Rodadas anteriores, os países em desenvolvimento, enquanto conjunto, não insistiram no princípio da não-reciprocidade e participaram ativamente de todas as negociações. Seus objetivos nestas negociações eram o de aceitar uma diluição do Tratamento Especial e Diferenciado em troca de acesso a mercados e de maior rigor jurídico das regras do SMC. ${ }^{189}$

\section{ii. O single undertaking como estratégia contrária à não-reciprocidade do GATT}

A Rodada Uruguai é descrita por muitos autores como a "grande barganha", isto por que ao longo das negociações, foi estabelecida uma clara divisão de interesses entre os países desenvolvidos, que defendiam a introdução de novos temas como comércio de serviços, propriedade intelectual e investimentos, e países em desenvolvimento, que defendiam a introdução de temas como agricultura e têxteis, que sempre estiveram excluídos das regras gerais do GATT. Neste sentido, a grande barganha em tese beneficiaria ambos os lados. Tudo dependeria do processo de negociação e do quanto cada lado cederia em cada um dos "grandes temas" da Rodada Uruguai.

Esta grande barganha assumiu dimensões ainda mais sérias a partir do momento em que as negociações foram abordadas desde a ideia de single undertaking. O single undertaking combinava todos os resultados da Rodada Uruguai com as regras pré-existentes do período GATT em um único pacote. Sob este escopo, os governos deveriam decidir entre aceitar todo o pacote ou deixar o sistema multilateral de comércio.

${ }^{189}$ PANGESTU, Mari. Special and Differential treatment in the Millenium: special for whom and how different? P. 1287. In SALVADOR, op. cit. p. 196-197. 
$\mathrm{Na}$ essência, esta nova abordagem reestruturou completamente as relações países desenvolvidos $\mathrm{x}$ países em desenvolvimento no âmbito das negociações do sistema multilateral de comércio e afetou fulminantemente o princípio da nãoreciprocidade, como será analisado mais adiante.

No centro desta grande barganha estava a inserção da agricultura, de têxteis e vestuários na regulamentação do sistema multilateral de comércio.

Um grande grupo de países em desenvolvimento estava interessado na liberalização dos mercados agrícolas dos países desenvolvidos, e da eliminação das grandes distorções provocadas pelos países desenvolvidos, decorrentes do grande uso de subsídios, quotas tarifárias, barreiras técnicas, etc. ${ }^{190}$ Os países em desenvolvimento estavam igualmente interessados em renovar as regras multilaterais sobre comércio de têxteis e vestuário e pôr fim ao Acordo Multifibras, que permitia sistemas de quotas pelos países desenvolvidos para as importações de têxteis e vestuários oriundas de países em desenvolvimento.

Do outro lado, os países em desenvolvimento estavam extremamente relutantes em aceitar qualquer tipo de vinculação jurídica com o sistema GATT dos novos temas propostos pelos países desenvolvidos, que estivessem "relacionados ao comércio", mas que não eram comércio de bens em si mesmo, tais como propriedade intelectual, serviços e investimentos.

Nesse sentido, a grande barganha consistia no fato de os países desenvolvidos aceitarem disciplinar o comércio da agricultura e dos têxteis, em troca dos países desenvolvidos aceitarem disciplinas em propriedade intelectual, serviços e investimentos. Para tanto, o single undertaking foi a lógica criada para que ambos os lados não pudessem evadir-se ao longo das negociações de determinados acordos. Em especial, que os países em desenvolvimento não pudessem repetir a mesma experiência das negociações da Rodada Tóquio.

\footnotetext{
${ }^{190}$ A respeito dos impactos da regulamentação do comércio agrícola na OMC sobre a América Latina, ver SALLES, Marcus Maurer de. O dilema da resistência européia ao livre comércio agrícola. In BARRAL, Welber; PIMENTEL, Luiz Otávio (Orgs.) (2006). Comércio internacional e desenvolvimento. Florianópolis: Fundação Boiteux.p.335-382.
} 
b) Os efeitos da OMC: Institucionalização, alargamento e aprofundamento

A Rodada Uruguai representou ao mesmo tempo um aprofundamento e uma ampliação das regras do sistema multilateral de comércio, bem como a criação de uma nova organização internacional. A OMC tornou-se a organização guardiã do novo direito internacional do comércio, que emergiu da Rodada Uruguai. Um novo marco regulatório, que se estendia além de um "novo" acordo GATT.

\section{i. A Organização Mundial do Comércio enquanto organização internacional}

Além da inserção de uma série de novos temas, tanto de interesse dos países desenvolvidos como dos países em desenvolvimento, decidiu-se por constituir uma organização internacional, com personalidade jurídica de direito internacional, que fosse responsável pela coordenação das negociações e pela supervisão do cumprimento dos acordos. É com este status que surge a OMC.

Esta transformação sofrida pelo sistema multilateral de comércio, passando de um sistema fundado no GATT - um simples acordo provisório com um secretariado gestor, sem status nem competências de organização internacional para um sistema centrado na OMC, deu nova configuração, estabilidade e permanência às relações comerciais internacionais.

$\mathrm{O}$ nascimento da $\mathrm{OMC}$, além de supor uma revolução da regulação do comércio internacional, trouxe consigo uma mudança de mentalidade importante, pois foi a primeira organização internacional, com personalidade jurídica própria, com vocação universal, nascida depois do fim da Guerra Fria.

Nesse sentido, a criação desta nova organização internacional não foi alheia ao entorno político da época, ao refletir o ideário liberal que imperou com a queda do muro de Berlim, o desaparecimento da União Soviética, e o sepultamento da via comunista. 
A criação da OMC e dos novos acordos trouxe consigo simultaneamente mudanças e continuidades no sistema multilateral de comércio.

A OMC significou continuidade pois o GATT de 1994 integrou o GATT de 1947, por meio dos artigos I do GATT de 1994 e do artigo II.4 do Acordo de Marraqueche, por constituir a base jurídica do novo sistema de comércio internacional, um sistema aperfeiçoado no que diz respeito ao anterior, com estabilidade institucional, que goza de uma forte consistência normativa e que mantém uma linha de continuidade com o anterior. Com base no artigo XVI.1 do Acordo de Marraqueche, o atual sistema assume o acervo do GATT 1947 nos seguintes termos:

Salvo disposição em contrário no presente Acordo e nos acordos comerciais multilaterais, a OMC se regerá por decisões, procedimentos e práticas consuetudinárias das Partes Contratantes do GATT 1947 e dos órgãos estabelecidos no marco do mesmo.

Cabe apontar também a relevância da institucionalização de um Órgão de Solução de Controvérsias (OSC), criado para dirimir conflitos entre os Estados Membros, em relação a temas regulados no âmbito da OMC.

Desde o lançamento da Rodada Uruguai, as partes haviam concordado em estabelecer um sistema de solução de controvérsias mais rigoroso. Os países em desenvolvimento tinham particular interesse na questão, tendo em vista o histórico de inefetividade das suas reclamações durante o Período GATT. Quanto maior a enforceability, maior seria a capacidade de pressão dos países em desenvolvimento sobre os países ricos. Os países mais ricos também tinham interesse em um OSC mais eficaz, e especialmente, independente da aprovação coletiva para autorizar as retaliações, como ocorria ao longo do Período GATT.

Com o final da Rodada Uruguai, foi aprovado o Entendimento sobre o Sistema de Solução de Controvérsias da OMC. Dentre as principais inovações em relação ao Sistema de Solução de Controvérsias do GATT, a mais relevante para o interesse dos países em desenvolvimento foi o fim da exigência de consenso para se dar início a um procedimento de disputas. A partir da OMC, instituiu-se o consenso 
negativo, que significava que para que uma disputa fosse impedida de tramitar no OSC, todos os Membros deveriam se opor. ${ }^{191}$

O fato de o OSC ter sido constituído com natureza quase-judicial, confluindo métodos diplomáticos e jurídicos para a solução das controvérsias, deu a este sistema uma legitimidade e um poder distinto e superior a outros sistemas de solução de controvérsias existentes em outras organizações internacionais contemporâneas. ${ }^{192}$

\section{ii. O alargamento temático da liberalização}

A OMC representa mudanças em razão dos seguintes elementos: a institucionalização do sistema de comércio internacional, aportando um sistema de solução de controvérsias aperfeiçoado, a ampliação do campo de atuação, através da inserção de novos setores, desde agricultura e têxteis, a serviços, propriedade intelectual e investimentos, bem como as medidas não-tarifárias e as medidas de defesa comercial.

Isto significa que o sistema multilateral de comércio não está mais balizado por apenas um acordo multilateral (GATT), mas por diversos novos acordos (GATS e TRIPS, bem como os acordos anexos ao GATT), todos sujeitos a condução da OMC e à jurisdição do OSC.

Em relação aos acordos sob supervisão da OMC e do seu OSC, deve-se destacar que, além de incorporar o conjunto de acordos já existentes na Era GATT,

\footnotetext{
191 Outras inovações relavantes foram as seguintes: maior detalhamento nos procedimentos e encurtamento nos prazos, para maior celeridade na solução das disputas; a criação de um "duplo grau de jurisdição", um órgão de apelação competente para revisar as recomendações dos painéis, antes de que se tornar vinculantes; por fim, a proibição de medidas unilaterais em caso de disputas comerciais. Os Membros devem utilizar o OSC em todas as etapas da solução da controvérsia.

${ }^{192}$ LAFER, Celso. O sistema de solução de controvérsias da Organização Mundial do Comércio. In MERCADANTE, Araminta; CASELLA, Paulo (1998). Guerra Comercial ou Integração Mundial pelo Comércio. São Paulo: LTr. P. 729-755.
} 
foram negociados mais de uma dezena de acordos ao longo da Rodada Uruguai. A relação total de acordos vigentes atualmente no âmbito da OMC é a seguinte: ${ }^{193}$

\section{Tabela 8. Acordos firmados ao final da Rodada Uruguai}

\begin{tabular}{|l|}
\hline Anexo $1^{\text {a }}$ \\
\hline Nota Interpretativa ao Anexo $1^{\text {a }}$ \\
\hline GATT 1994 \\
\hline Entendimento sobre a Interpretação do Artigo II 1(b) \\
\hline Entendimento sobre a Interpretação do Artigo XVII \\
\hline Entendimento sobre a Interpretação do Artigo XVIII (Balanço de Pagamentos) \\
\hline Entendimento sobre a Interpretação do Artigo XXIV \\
\hline Entendimento sobre Derrogações (Waivers) de Obrigações \\
\hline Entendimento sobre a Interpretação do Artigo XXVIII \\
\hline Protocolo de Marraqueche \\
\hline Acordo sobre Agricultura \\
\hline Acordo sobre a Aplicação de Medidas Sanitárias e Fitossanitárias \\
\hline Acordo sobre Têxteis e Vestuário \\
\hline Acordo sobre Barreiras Técnicas ao Comércio \\
\hline Acordo sobre Medidas de Investimento Relacionadas ao Comércio (TRIMS) \\
\hline Acordo sobre a Implementação do Artigo VI (Antidumping) \\
\hline Acordo sobre a Implementação do Artigo VII (Valoração Aduaneira) \\
\hline Acordo sobre Inspeção Pré-Embarque \\
\hline Acordo sobre Regras de Origem \\
\hline Acordo sobre Procedimentos para o Licenciamento de Importações \\
\hline Acordo sobre Subsídios e Medidas Compensatórias \\
\hline Acordo sobre Salvaguardas \\
\hline Anexo 1B: Acordo Geral sobre o Comércio de Serviços (GATS) \\
\hline Anexo 1C: Acordo sobre Aspectos dos Direitos de Propriedade Intelectual (TRIPS) \\
\hline Anexo 2: Entendimento Relativo às Normas e Procedimentos sobre Solução de Controvérsias \\
\hline Anexo 3: Mecanismo de Exame de Políticas Comerciais (TPR) \\
\hline Anexo 4: Acordos Plurilaterais (Adesão Opcional) \\
\hline Anexo 4A: Acordo sobre Comércio de Aeronaves Civis \\
\hline Anexo 4B: Acordo sobre Compras Governamentais \\
\hline Anexo 4C: Acordo Internacional de Produtos Lácteos \\
\hline Anexo 4D: Acordo Internacional sobre Carne Bovina \\
\hline
\end{tabular}

\section{Fonte: MDIC (2011)}

Deste conjunto de acordos, os que mais se destacaram, no que se refere ao alargamento temático da liberalização comercial no âmbito da OMC foram os acordos atinentes aos direitos de propriedade intelectual, o Agreement on Trade Related Intelectual Propriety Rights (TRIPS), ao comércio de serviços, o General Agreement on Trade in Services (GATS) e aos temas relacionados a investimentos, o Agreement on Trade Related Investiment Meseaures (TRIMS). A respeito destes acordos, serão tecidos breves comentários sobre suas linhas gerais e sobre os temas

${ }^{193}$ Para acesso ao texto completo de todos os acordos da OMC, em língua portuguesa, acesse http://www.mdic.gov.br/sitio/interna/interna.php?area=5\&menu=367. Acessado em 12/01/2011. 
intrínsecos aos mesmos que mais interessaram aos países em desenvolvimento ao longo das negociações da Rodada Uruguai.

a) As linhas gerais do TRIPS

A questão concernente aos direitos de propriedade intelectual foi um dos pontos em que houve maior avanço nas negociações da Rodada Uruguai. Quando se iniciaram os debates para inclusão dos temas de propriedade intelectual no sistema multilateral de comércio, no início da década de 80 , houve grande oposição dos países em desenvolvimento, tendo-se em vista os impactos e os custos que tal regulação lhes geraria. A extensão dos direitos de propriedade intelectual aos países em desenvolvimento significaria que os mesmos teriam que arcar com os custos de todos os avanços tecnológicos que estavam recebendo até então sem pagar.

Os proponentes das obrigações de propriedade intelectual eram os países industrializados, que arguiam que a propriedade intelectual criada nos seus territórios estava sendo utilizada sem a devida contrapartida, por meio de consumo e reprodução de diversas atividades originalmente criadas, inventadas ou desenvolvidas por tais países. Esta atitude dos países industrializados desempenhou papel relevante nos primeiros anos da Rodada Uruguai e fez com que a questão da propriedade intelectual assumisse uma conotação de um direito moral dos países industrializados, deixando pouca margem de contestação aos países em desenvolvimento.

Uma das maiores motivações dos países industrializados para inserir os direitos de propriedade intelectual no sistema multilateral de comércio era o respeito que o sistema de solução de controvérsias do GATT tinha adquirido. Mesmo com todas as limitações apresentadas ao longo do período GATT, seu sistema conseguia manter um nível razoável de cumprimento das regras dentro do sistema multilateral de comércio. Nesse sentido, a proposta de forum shifting revelava-se ainda mais coerente caso as negociações da Rodada Uruguai 
culminassem, igualmente, na criação de uma organização internacional e de um sistema mais complexo de solução de controvérsias, tal como de fato ocorreu.

Além disso, os direitos de propriedade intelectual fizeram parte do pacote da Grande Barganha, adicionado ao comércio de serviços, o qual os países em desenvolvimento deveriam estar aptos a aceitar, caso os países industrializados aceitassem negociar têxteis e agricultura.

O Acordo sobre Direitos de Propriedade Intelectual relacionado ao Comércio (TRIPS, na sigla em inglês), estabelece padrões mínimos de proteção para cada categoria de direitos de propriedade intelectual. Tais padrões devem ser garantidos pelo direito nacional de cada Membro da OMC e seguem os princípios básicos da organização, quais sejam: a não-discriminação e o tratamento nacional.

Os padrões acordados no TRIPS incorporam e estendem a todos os Membros da OMC as obrigações da Organização Mundial da Propriedade Intelectual (OMPI), especialmente as convenções de Berna (sobre direitos autorais) e de Paris (sobre propriedade industrial). A adesão às Convenções de Berna e Paris já estava disseminada entre a maioria dos países em desenvolvimento quando das negociações da Rodada Uruguai.

Muitos dos países em desenvolvimento já reconheciam e protegiam os direitos de propriedade intelectual com base nos princípios da não-discriminação e do tratamento nacional. No entanto, o escopo de tal proteção variava de país para país. Dessa forma, o TRIPS tinha como objetivo maior: a harmonização, em nível internacional, dos direitos e dos sistemas de proteção de propriedade intelectual nos Membros da OMC.

Para além das obrigações já existentes na OMPI, o TRIPS estabelece novos padrões ainda não cobertos, que abrangem particularmente: a) padrões e categorias de direitos de propriedade intelectual até então não regulamentados, como patentes; b) regras relacionadas ao enforcement de tais direitos; e c) sujeição ao mecanismo efetivo de solução de controvérsias da OMC. 
As obrigações do TRIPS tiveram um período de transição para serem cumpridas pelos Membros da OMC, nos seguintes termos: os países desenvolvidos tiveram 1 ano; os países em desenvolvimento tiveram 5 anos; os países com menor desenvolvimento relativo tiveram 11 anos, com possibilidade de extensão. Além disso, acordos setoriais de transição foram firmados com os países em desenvolvimento que, quando da entrada em vigor da $\mathrm{OMC}$, não concediam patente em setores específicos, tais como farmacêuticos e agrotóxicos. Nesses casos, uma extensão temporal foi concedida para que tais países pudessem prolongar o tempo de implantação do acordo TRIPS.

\section{b) As linhas gerais do GATS}

Durante a década de 80, vários grupos políticos e empresas vinham vislumbrando a necessidade de algum tipo de regramento internacional para o comércio de serviços. O setor de serviços é extraordinariamente complexo, consistindo em mais de 150 setores específicos, mas em seu conjunto começava a representar a parcela majoritária do PIB da maior parte dos países industrializados, superando a produção de bens.

Algumas empresas de serviços estavam explorando a possibilidade de exportar as suas atividades, e encontravam dificuldades decorrentes de ações de governos estrangeiros, que restringiam as suas atividades preservando o mercado para as empresas de serviços nacionais. Assim, vários grupos privados passaram a pressionar os seus respectivos governos a criar algum tipo de mecanismo de cooperação internacional que desenvolvesse regras contra estas espécies de medidas protecionistas, antes que tais medidas se proliferassem e fortalecessem no interior dos potenciais novos países importadores de serviços.

O Acordo Geral de Comércio de Serviços (GATS, na sigla em inglês) é composto por dois elementos: a) o acordo em si, contendo 29 artigos e uma série de anexos e decisões ministeriais; e b) o cronograma de concessões de cada Membro, 
no qual estão consolidados os graus de abertura de cada setor e subsetor do comércio de serviços. O texto do acordo e seus anexos são comuns a todos os signatários, enquanto os cronogramas de concessões, juntamente com as exceções NMF, são individuais, Membro-a-Membro.

De acordo com o GATS, o comércio de serviços pode ser classificado em categorias, ou modos. Nesse sentido, o artigo $2^{\circ}$ define os quatro modos de prestação de um serviço:

a) Comércio transfronteiriço: Do território de um Membro a outro;

b) Consumo no exterior: No território de um Membro aos consumidores de serviço de qualquer outro Membro;

c) Presença comercial: Pelos prestadores de serviço de um Membro, por intermédio da presença comercial, no território de qualquer outro Membro; d) Movimento de pessoas fisicas: Pelo prestador de serviço de um Membro, por intermédio da presença de pessoas naturais de um Membro no território de qualquer outro Membro.

A cobertura setorial do GATS é ampla. Em 1991, ao longo das negociações sobre comércio de serviços, o universo de serviços foi classificado em 12 setores e 160 subsetores. Esta definição da cobertura foi muito importante para harmonizar a conceituação dos setores entre os negociadores da Rodada Uruguai. ${ }^{194}$

No entanto, embora haja uma definição de escopo tão ampla, o GATS não se aplica a serviços providos no exercício da autoridade governamental, o que significa serviços públicos. Houve dificuldade em definir o que era serviço público, portanto, foram estabelecidos dois requisitos para tal definição: a) estes serviços públicos não podem ser prestados em base comercial; b) tampouco podem ter concorrência com outros fornecedores.

Embora a cobertura do GATS se proponha a ser universal, os compromissos de liberalização seguem a lógica das listas positivas. Cada Membro apresenta uma lista na qual arrola as condições de acesso ao mercado e ao tratamento nacional para fornecedores de serviços estrangeiros nos setores e modos com os quais aquele Membro se comprometeu.

${ }^{194}$ MTN GNS/W/120 de 1991. 
Portanto, o nível de abertura de mercado para uma atividade de serviços resta condicionado ao regime regulatório existente, à existência de limitações de acesso ao mercado por prestadores de serviços estrangeiros, e à existência de tratamento nacional pelo país importador.

De acordo com o Banco Mundial, que classifica os Estados em países de renda alta - high income countries (HIC) - e países de renda média e baixa - low or middle income countries (LMIC), ao final da Rodada Uruguai, os HIC haviam aceitado compromissos em cerca de $45 \%$ dos seus setores de serviços, enquanto os LMIC consolidaram apenas $12 \%$ dos seus setores. Nesse sentido, os cinco setores nos quais houve o maior número de compromissos foram os seguintes: ${ }^{195}$

Tabela 9. Compromissos por setores do GATS

\begin{tabular}{|l|l|l|l|}
\hline & $\begin{array}{l}\text { Número de de } \\
\text { setores } \\
\text { módulos }\end{array}$ & $\begin{array}{l}\text { Média de } \\
\text { compromissos } \\
\text { dos HIC }\end{array}$ & $\begin{array}{l}\text { Média } \\
\text { compromissos } \\
\text { dos LMIC }\end{array}$ \\
\hline Serviços financeiros & 60 & $(31,3)$ & $(12,4)$ \\
\hline Serviços bancários & 108 & $(56,5)$ & $(12,2)$ \\
\hline Telecomunicações & 28 & $(18,7)$ & $(5,0)$ \\
\hline $\begin{array}{l}\text { Serviços recreativos } \\
\text { e culturais }\end{array}$ & 48 & $(13,3)$ & $(4,6)$ \\
\hline $\begin{array}{l}\text { Serviços de } \\
\text { informática }\end{array}$ & 20 & $(15,5)$ & $(4,2)$ \\
\hline
\end{tabular}

Quando da celebração das listas de concessões, ao final da Rodada Uruguai, toda e qualquer medida que fosse considerada inconsistente com a Cláusula NMF deveria ter sido listada. Mediante isso, com base na cláusula Stand Still, nenhuma outra exceção poderia ser criada pelos Estados-Membros.

Essa á a razão pela qual pouquíssimas concessões foram feitas em termos de comércio de serviços ao final da Rodada Uruguai. As concessões seriam negociadas a partir da entrada em vigor do acordo, sob os auspícios da OMC. Por isso, afirmase que o GATS foi constituído com uma Built-in Agenda. ${ }^{196}$

195 BANCO MUNDIAL. Global Economic Prospects and the Developing Countries. Washington D.C.: The World Bank, 1995.

196 CELLI JR., Umberto. Comércio de Serviços na OMC: liberalização, condições e desafios. Curitiba: Juruá, 2009. 
O Acordo sobre Medidas de Investimento Relacionadas ao Comércio (TRIMS, na sigla em inglês) é considerado o mais modesto dos acordos da Rodada Uruguai. Mesmo assim, do ponto de vista dos países em desenvolvimento, ele é um dos acordos com maior impacto em matéria de policy space.

Muito embora o TRIMS não tenha acabado com a abrangência pretendida pelos países desenvolvidos e não tenha definido expressamente medidas de investimento relacionadas ao comércio, o principal impacto do TRIMS foi a definição de uma lista ilustrativa de práticas proibidas, no Anexo I do acordo.

Uma tabela relaciona os princípios gerais da OMC com e a lista proibida pelo TRIMS:

Tabela 10. Relação entre princípios do GATT e as medidas proibidas do TRIMS

\begin{tabular}{|l|l|}
\hline Artigo GATT & Medida proibida \\
\hline Artigo III - Tratamento Nacional & $\begin{array}{l}\text { Exigências de conteúdo local (que certa } \\
\text { quantidade de elementos da produção seja de } \\
\text { origem local) }\end{array}$ \\
\hline $\begin{array}{l}\text { Exigências de balanço comercial (que as } \\
\text { importações devam ter certa proporção com as } \\
\text { exportações) }\end{array}$ \\
\hline Artigo XI - Proibição de restrições quantitativas & $\begin{array}{l}\text { Restrições de balanço comercial (idem acima) } \\
\text { Restrições de remessa de lucros (limitando a } \\
\text { disponibilidade de divisas estrangeiras para } \\
\text { importações a uma proporção das divisas } \\
\text { estrangeiras arrecadas com as exportações) }\end{array}$ \\
\hline & $\begin{array}{l}\text { Exigências de destinação local (que uma certa } \\
\text { quantidade da produção seja reservada ao } \\
\text { mercado doméstico) }\end{array}$ \\
\hline
\end{tabular}

Os Membros da OMC utilizavam em larga medida as medidas elencadas na lista do TRIMS até a entrada em vigor da OMC. A partir daí, tinham 90 dias para notificar a OMC das medidas que estavam em vigor, para que pudessem 
gradualmente eliminá-las, dentro dos respectivos prazos: os países desenvolvidos tiveram 2 anos, os países em desenvolvimento tiveram 5 anos, e os países com menor desenvolvimento relativo tiveram 7 anos.

O acordo também estabelece sua própria revisão e complementação a fim de abranger a relação entre as regras de políticas de investimentos e as políticas de concorrência. Isto deveria ter ocorrido a partir da entrada em vigor do TRIMS, sob os auspícios da OMC.

iii. O aprofundamento dos compromissos tarifários de acesso a mercados

Além do alargamento temático do arcabouço normativo no âmbito do sistema multilateral de comércio, houve igualmente um grande aprofundamento dos compromissos tarifários com os quais as partes contratantes do GATT já estavam comprometidas quando das negociações da Rodada Uruguai.

De acordo com a tabela abaixo, elaborada pelo Secretariado da OMC, a proporção da totalidade do comércio internacional que se consolidou por meio de compromissos tarifários ao final da Rodada Uruguai passou de 68\% para 87\%, tal aumento é decorrente majoritariamente do aumento do volume de compromissos tarifários dos países em desenvolvimento. Percebe-se que houve considerável aumento no acesso aos mercados com a redução nas médias tarifárias dos Membros: $40 \%$ nos países desenvolvidos, 30\% nos países em desenvolvimento, e $30 \%$ nos países com menor desenvolvimento relativo.

Tabela 11. Compromissos tarifários em bens industriais ${ }^{197}$

\begin{tabular}{|c|c|c|c|}
\hline Grupo de países & $\begin{array}{c}\text { Número de linhas } \\
\text { tarifárias }\end{array}$ & $\begin{array}{c}\text { \% de linhas } \\
\text { tarifárias } \\
\text { consolidadas (pré- } \\
\text { RU) }\end{array}$ & $\begin{array}{c}\text { \% de linhas tarifárias } \\
\text { consolidadas (pós- } \\
\text { RU) }\end{array}$ \\
& & \begin{tabular}{c} 
RU) \\
\hline
\end{tabular} &
\end{tabular}

${ }^{197}$ GALLAGHER, Peter. Guide to the WTO and Developing Countries. Londres: Kluwer Law International, 2000, p. 23. 


\begin{tabular}{|c|c|c|c|}
\hline Total & 249.573 & 43 & 83 \\
\hline Países desenvolvidos & 86.369 & 78 & 99 \\
\hline Países em desenvolvimento & 163.204 & 221 & 73 \\
\hline Economias em Transição & 18.692 & 73 & 98 \\
\hline & & & 100 \\
\hline América Latina & 64.136 & 38 & \\
\hline
\end{tabular}

Um aspecto apontado ao final da Rodada Uruguai é o da erosão tarifária, referindo-se à redução das preferências tarifárias que os países em desenvolvimento gozavam por meio do SGP e que, em decorrência das reduções feitas pelos países desenvolvidos no âmbito da Rodada Uruguai, tais preferências em relação aos demais Membros da OMC já não os distinguiam tanto quanto antes. Consequentemente, o acesso dos países em desenvolvimento aos mercados dos países que ofertavam SGP - EUA, CE e Japão - estava sendo reduzido.

Outro aspecto debatido ao longo da Rodada Uruguai, no que se refere à redução tarifária, dizia respeito ao escalonamento tarifário, ou aumento das tarifas na proporção do nível de processamento industrial dos bens. Ou seja, quanto mais industrializado, maior a categoria tarifária de determinado bem. O principal impacto do escalonamento tarifário sobre os países em desenvolvimento é a redução das potencialidades da industrialização dos países em desenvolvimento, pois quanto maior o nível de industrialização dos bens, maior o nível de proteção nos mercados dos países desenvolvidos.

Tabela 12. Tarifas dos países desenvolvidos sobre importações de produtos industrializados dos países em desenvolvimento, por estágio de processamento ${ }^{198}$

\begin{tabular}{|l|c|c|c|c|}
\hline Grupo de produtos & $\begin{array}{c}\text { Valor de } \\
\text { importação }\end{array}$ & $\begin{array}{c}\text { Média tarifária } \\
\text { (Pré-RU) }\end{array}$ & $\begin{array}{c}\text { Redução } \\
\text { absoluta }\end{array}$ & \% redução \\
\hline Matérias-primas & 36,665 & 2.1 & 1.1 & 52 \\
\hline Semi-manufaturados & 36,464 & 5.3 & 2.4 & 45 \\
\hline Produtos acabados & 96,534 & 9.1 & 2.7 & 30 \\
\hline Total & 169,663 & 6.8 & 2.3 & 34 \\
\hline
\end{tabular}

${ }^{198}$ GALLAGHER, op. cit., p. 36 
Por fim, com relação aos compromissos tarifários dos países em desenvolvimento, análise especial deve ser conferida à America Latina. Na Rodada Tóquio, o Chile foi o único país da América Latina que se comprometeu a consolidar $100 \%$ das suas linhas tarifárias. Costa Rica, El Salvador, México e Venezuela consolidaram $100 \%$ das suas tarifas quando da sua adesão ao GATT, durante a Rodada Uruguai. Ao final da Rodada Uruguai, a América Latina, como um todo, já estava com $100 \%$ das suas linhas tarifárias consolidadas no SMC. ${ }^{199}$

\section{c) A nova concepção do desenvolvimento decorrente da criação da OMC}

O período no qual foi realizada a Rodada Uruguai, entre 1988 e 1994, foi marcado por uma série de características: o apogeu do Consenso de Washington, a crise do DID, graves crises econômicas nos países em desenvolvimento, a desarticulação diplomática dos países em desenvolvimento. Estes fatores influenciaram em grande medida os resultados da Rodada Uruguai.

Do processo de negociação que se desenrolou ao longo da Rodada Uruguai, sob inspiração do Consenso de Washington, depreende-se de que modo a questão do desenvolvimento foi tratada ao longo da Rodada Uruguai. Neste momento, há uma ampliação temática das negociações em torno de novos temas, para além do comércio de bens, e passa-se a abranger desde os temas de serviços, propriedade intelectual e investimentos até os temas de agricultura e têxteis.

A ampliação temática divide e desarticula os países em desenvolvimento enquanto coalizão internacional. Tanto a crescente heterogeneidade entre os autoproclamados países em desenvolvimento, quanto o descrédito ideológico dos modelos de desenvolvimento que haviam sido implantados até então, resultaram no grande impasse sofrido pela Rodada Uruguai. A Rodada Uruguai se recupera em 1992 por meio do Acordo de Blair House, entre EUA e CE, e as conquistas dos países em desenvolvimento em matéria de policy space para o desenvolvimento

\footnotetext{
${ }^{199}$ Idem.
} 
limitaram-se ao Tratamento Especial e Diferenciado, que lhes concedeu apenas prazos mais extensos e setores temporariamente isentos de obrigações.

A característica mais marcante da Rodada Uruguai, no que atine à diminuição do policy space dos países em desenvolvimento, foi o fato de as negociações da Rodada Uruguai terem sido estruturadas com base na lógica do single undertaking, que condicionava todas as partes negociadoras a aderir a todo o conjunto de acordos que resultariam da Rodada. Esta estratégia contrastava radicalmente com o formato das negociações da última rodada de negociações, a Rodada Tóquio, na qual os acordos (códigos da Rodada Tóquio) haviam sido concebidos para que as partes aderissem caso desejassem. O resultado foi que quase a totalidade dos países em desenvolvimento não aderiram a quaisquer dos códigos da Rodada Tóquio, razão pela qual a Rodada Tóquio criou a expressão "GATT a la carte".

Do ponto de vista da experiência histórica dos países em desenvolvimento, em matéria de política de desenvolvimento, um dos mais importantes impactos da criação da OMC foi o fortalecimento do quadro multilateral de regras e acordos, a ampliação destas regras a novos setores do comércio internacional, e especialmente, a inserção dos países em desenvolvimento como Membros incondicionais deste novo sistema de regras.

A partir de então, os países em desenvolvimento ficaram limitados, quase sempre proibidos, de lançar mão das políticas desenvolvimentistas que historicamente fundaram suas estratégias de desenvolvimento, tais como: elevação de tarifas não-consolidadas no GATT; subsídios domésticos e subsídios à exportação; medidas de salvaguarda; tratamento discriminatório mais benéfico de empresas nacionais em relação a estrangeiras, dentre outras.

A Rodada Uruguai, ao mesmo tempo em que proporcionou aos países em desenvolvimento maior acesso aos mercados dos países industrializados, tirou dos mesmos uma grande parte das ferramentas que utilizavam para fomentar suas indústrias para poder, de fato, acessar tais mercados. Por isso, a abertura dos mercados não surtiu grande efeito para os países em desenvolvimento, pois estes não puderam impulsionar suas indústrias para ganhar tais mercados. 
Com efeito, a criação da OMC leva a uma mudança fundamental no que se refere à concepção dos países em desenvolvimento no sistema multilateral de comércio. A partir de então, a lógica da progressiva inserção de todos os Membros no comércio internacional é percebida como elemento chave para o desenvolvimento, razão pela qual os países em desenvolvimento são inseridos em definitivo no sistema, sujeitando-se a todas as regras do SMC, em todos os âmbitos, estando respaldados apenas nas ressalvas de Tratamento Especial e Diferenciado.

Com a entrada em vigor da OMC, a lógica passa a ser outra. Todos os seus Membros - desenvolvidos, em desenvolvimento e de menor desenvolvimento relativo - estão incondicionalmente sujeitos à $\mathrm{OMC}$ e aos seus acordos. Não há waivers, derrogações, ou isenções do tipo que perduraram ao longo do período GATT. Todos os Membros estão sujeitos às obrigações da $\mathrm{OMC}$, inclusive sujeitos a serem questionados por eventuais violações no âmbito do OSC da OMC.

Isto insere os países em desenvolvimento e os países com menor desenvolvimento relativo, em definitivo, dentro das regras liberais fundadas sobre os princípios da reciprocidade e da não-discriminação, traduzidos juridicamente na cláusula da nação mais favorecida e do tratamento nacional, sobre os quais está fundado o corpo normativo da OMC. Apenas excepcionalmente e por um tempo determinado, os países em desenvolvimento e os países com menor desenvolvimento relativo poderão desviar-se destes princípios.

O sistema multilateral de comércio, comparado ao Período GATT, assumiu uma condição de maior legitimidade e poder, a partir do surgimento da OMC, do seu OSC, e da lógica de inclusão integral dos países em desenvolvimento em um rule-based system. Apesar disso, Esse novo arcabouço institucional, o novo e ampliado quadro regulatório, bem como a ineficácia do Tratamento Especial e Diferenciado concedido ao final da Rodada Uruguai, acabou por afetar diretamente o policy space dos Membros da OMC. Esta ineficácia do Tratamento Especial e Diferenciado da OMC, será objeto de análise detalhada a seguir. 


\title{
4.2. AS LIMITAÇÕES DO DESENVOLVIMENTO POR MEIO DO TRATAMENTO ESPECIAL E DIFERENCIADO
}

\section{a) A condição jurídica de "Membro em desenvolvimento" na OMC}

Para analisar mais detalhadamente o status jurídico do policy space para o desenvolvimento no atual marco regulatório da OMC, é necessário, em primeiro lugar, compreender a definição da condição jurídica de Membro em desenvolvimento e Membro de menor desenvolvimento relativo. Somente assim será possível avaliar os direitos inerentes a tais condições jurídicas, consolidadas no Tratamento Especial e Diferenciado, para, por fim, avaliar criticamente o esgotamento de tais direitos, tendo-se em vista o termo final dos prazos e isenções previstos ao final da Rodada Uruguai.

De acordo com o Preâmbulo do Tratado Constitutivo da OMC, o desenvolvimento deve ser concebido da seguinte forma:

\begin{abstract}
Relações na esfera da atividade comercial e econômica devem objetivar a elevação dos níveis de vida, o pleno emprego e um volume considerável e em constante elevação de receitas reais e demanda efetiva, o aumento da produção e do comércio de bens e de Serviços, permitindo ao mesmo tempo a utilização ótima dos recursos mundiais em conformidade com o objetivo de um desenvolvimento sustentável e buscando proteger e preservar o meio ambiente e incrementar os meios para fazê-lo, de maneira compatível com suas respectivas necessidades e interesses segundo os diferentes níveis de desenvolvimento econômico.
\end{abstract}

Além disso, o preâmbulo do Tratado Constitutivo da OMC reconhece igualmente a necessidade de se dar tratamento especial dos países em desenvolvimento e países com menor desenvolvimento relativo:

É necessário realizar esforços positivos para que os países em desenvolvimento, especialmente os de menor desenvolvimento relativo, obtenham uma parte do incremento do comércio internacional que corresponda as necessidades de seu desenvolvimento econômico. 
No entanto, a identificação de qual Estado deva ser considerado Estado em desenvolvimento sempre foi um problema difícil no sistema multilateral de comércio. Nem o regime do GATT 1947, nem o regime da OMC estabeleceram definições jurídicas precisas para o termo "Estado em desenvolvimento".

A página de internet da OMC intitulada "quem são os países em desenvolvimento na OMC?" é o único documento institucional da organização que traz luz à definição desta condição jurídica e estabelece que:

Não há definições na OMC de países desenvolvidos e países em desenvolvimento. Membros auto-declaram se são países "desenvolvidos" ou "em desenvolvimento". No entanto, outros Membros podem questionar a decisão do Membro de fazer uso dos dispositivos existentes para países em desenvolvimento. ${ }^{200}$

Portanto, em princípio, qualquer Membro da OMC pode se autodesignar "Membro em desenvolvimento". Na verdade, todos os Membros da OMC já o fizeram ao menos uma vez, exceto os países da UE ${ }^{201}$, EUA, Canadá, Japão, Suíça, Noruega, Austrália e Nova Zelândia. ${ }^{202}$

Todos os países latino-americanos podem se auto-intitular "Membros em desenvolvimento", exceto o Haiti, que é classificado pela UNCTAD como "Membro de menor desenvolvimento relativo".

Há um conjunto de dificuldades para se definir o que constitui um "Membro em desenvolvimento". Por um lado, a heterogeneidade entre os países em desenvolvimento. Por outro, a dinâmica na mudança de desempenho econômico.

Em relação à questão da heterogeneidade, os países em desenvolvimento são muito diferentes entre si em muitos aspectos. ${ }^{203}$ Do ponto de vista econômico, alguns países como a Coréia do Sul tem um PIB per capita de cerca de

\footnotetext{
${ }^{200}$ http://wto.org/english/tratop_e/devel_e/d1who_e.htm. Acesso em 18/05/2012.

${ }^{201}$ Portugal e Espanha reivindicaram a condição de pais em desenvolvimento ainda no Período GATT, antes de aderirem a então Comunidade Européia.

${ }^{202}$ CUI, Fan. Who are the developing countries in the WTO? In The Law and Development Review, Vol. 1. Issue 1. 2008. P. 123.

${ }^{203}$ Os países em desenvolvimento são diferentes entre si também em questões geográficas (tamanho, população, acesso ao mar), sociais (níveis educacionais e acesso à saúde) e políticas (regimes de governo, transparência).
} 
US\$20.000,00 enquanto o PIB per capita do Timor Leste não ultrapassa os US\$ 400,00. Alguns países têm crescido rapidamente. A Guiné Equatorial, por exemplo, saltou de um PIB per capita menor do que US\$1.000,00 em 1989 para mais do que US\$50.000,00 em 2005.

Esta heterogeneidade entre os países em desenvolvimento causa dificuldades na definição de Membro em desenvolvimento na $\mathrm{OMC}$, não apenas porque seja difícil encontrar critérios técnicos suficientemente consistentes para tal definição, mas também porque os países em desenvolvimento em diferentes situações têm interesses distintos e até mesmo conflitantes no âmbito das negociações da OMC.

Em razão dessa dificuldade de definição, um número cada vez maior de países acaba sendo tratado como Membros em desenvolvimento, o que leva aqueles que mais precisam de Tratamento Especial e Diferenciado muitas vezes a não gozarem das preferências necessárias e suficientes para alavancar seu desenvolvimento.

Esta massificação do reconhecimento da condição jurídica de país em desenvolvimento é a razão que justifica dois fenômenos: primeiro, a inserção na Cláusula de Habilitação, em 1979, da Cláusula Evolutiva (apresentada no capítulo anterior), que propôs uma graduação entre os países em desenvolvimento na medida em que foram avançando economicamente; segundo, também por isso foi modificado o sistema de negociações da Rodada Uruguai, não mais fundada na não-reciprocidade e sim na Cláusula da nação mais favorecida (como apresentado acima, neste capítulo).

A dinâmica do desempenho econômico também é um desafio relevante para a definição de Membro em desenvolvimento. Todo pais experimenta altos e baixos no seu desempenho econômico. Algumas vezes estas variações são tão dramáticas que podem alçar um país como a Guiné Equatorial, citado anteriormente, de um dos países mais pobres do mundo a um dos países mais ricos do mundo, em menos de 15 anos. A Coréia do Sul também reivindica o status de país em desenvolvimento, apesar de seu PIB per capita superar US\$20.000,00. 
a) a definição do artigo XVIII do GATT

A complexidade em torno da definição de país em desenvolvimento é, na verdade, um desdobramento da complexidade do conceito de desenvolvimento. Fan Cui elenca e analisa diversos métodos para tentar identificar os países em desenvolvimento: a) a definição do artigo XVIII do GATT; b) as listas; c) as classificações; d) autodesignação; e) reconhecimento no SGP. ${ }^{204}$

Tecnicamente, não é correto afirmar que o sistema multilateral de comércio não apresenta uma definição de Membro em desenvolvimento. Na verdade, desde as negociações da OIC/GATT, há uma tentativa de definição presente no artigo XVIII.

O artigo XVIII, parágrafo 1, dispõe que:

1. As Partes Contratantes reconhecem que a realização dos objetivos do presente Acordo será facilitada pelo desenvolvimento progressivo de suas economias, em particular nos casos das Partes Contratantes cujas economias não asseguram à população senão um baixo nível de vida e que estejam nos primeiros estágios de seu desenvolvimento.

Já o parágrafo 4(a) do mesmo artigo esclarece que:

4. (a) Em conseqüência, qualquer Parte Contratante cuja economia não pode assegurar à população senão um baixo nível de vida e que se encontra nos primeiros estágios de seu desenvolvimento, terá a faculdade de dispensar-se, temporariamente, das disposições dos outros artigos do presente Acordo, na forma prevista nas seções A, B e C do presente artigo.

Assim, os parágrafos 1 e 4 estabelecem dois critérios: $i$. baixo nível de vida e, ii. primeiros estágios do desenvolvimento. As questões são as seguintes: Quão baixo deve ser este nível de vida? Qual estágio pode ser considerado entre os primeiros estágios do desenvolvimento?

${ }^{204}$ CUI, op. cit., p. 133. 
O anexo 1 do GATT-47 traz duas notas interpretativas para responder a estas questões:

1. Quando for necessário considerar se a economia de uma parte contratante "suporta apenas baixos níveis de qualidade de vida", as partes contratantes devem levar em consideração a posição normal da economia, e não fundar tal consideração em circunstâncias excepcionais, tais como aquelas resultantes de condições temporárias que afetam as economias de tais partes;

2. A frase "primeiros estágios de desenvolvimento" não tem o objetivo de ser aplicada apenas às partes contratantes que apenas recentemente iniciaram seu processo de desenvolvimento econômico, mas também àquelas partes cujas economias estão implantando um processo de industrialização para corrigir uma excessiva dependência de produção primária.

Logo, em tese, toda parte contratante que se enquadrar em ambos os critérios estará na condição jurídica de recorrer às seções A, B e C do artigo XVIII. Ocorre que, tendo em vista a amplitude e a imprecisão destas notas interpretativas, estas não auxiliam em quase nada na definição de Membro em desenvolvimento. Tal definição do artigo XVIII foi levada ao Painel do antigo GATT, em 1957, quando o Ceilão (atual Sri Lanka) invocou tal condição jurídica. ${ }^{205}$

b) as listagens da ONU, do BIRD e do ASMC

Caso houvesse definição precisa de Membro em desenvolvimento, a listagem dos países enquadrados em tal condição jurídica seria meramente

\footnotetext{
${ }^{205} \mathrm{O}$ Painel enquadrou o Ceilão em ambos as condições apresentadas acima. Para a primeira condição - baixo nível de vida - o Painel entendeu que o PNB per capita de Ceilão em 1955 era estimado em US $\$ 128,00$, que era superior aos PNB de países como Mianmar e Índia, mas inferior a Grécia, Cuba e República Dominicana, e substancialmente inferior aos países industrializados da Europa Ocidental. Em relação a segunda condição - primeiros estágios do desenvolvimento - o Painel levou em consideração o percentual de produtos manufaturados, mineração e construção na composição do PNB. No caso do Ceilão, este percentual representa $10 \%$, uma proporção menor que Grécia e Mianmar, e muito menor que nos países industrializados. Ao final, o Painel considerou que o Ceilão era titular dos direitos invocados referentes ao artigo XVIII. No entanto, o Painel não esclareceu porque utilizou, por exemplo, o PNB ao invés do PIB, e também por que incluiu alguns setores econômicos e não outros. Os critérios pareceram muito arbitrários e foi uma das razões pelas quais os PED se afastaram do artigo XVIII ao longo do Período GATT, como apresentado no capítulo anterior.
}

GATT - Relatório do Painel. Ceylon - Aplicação do Artigo XVIII. 26/11/1957. 
ilustrativa. No entanto, como não há tal precisão na definição, as listagens podem ser um método auxiliar na identificação dos Membros em desenvolvimento.

A vantagem das listagens é que elas conferem uma maior certeza na identificação dos países em desenvolvimento. Enquanto um país estiver incluído em uma lista, não haverá problemas na definição do seu status. Por outro lado, para os países desenvolvidos que concedem Tratamento Especial e Diferenciado por meio do SGP, por exemplo, as listas retiram a flexibilidade que interessa tanto aos países desenvolvidos, o que acabaria por, na dúvida, excluindo alguns países em desenvolvimento das listas.

A lista mais difundida e comumente aceita é a lista da ONU para os países menos avançados. Esta lista é revisada a cada três anos pelo Comitê para Políticas de Desenvolvimento da ONU, de acordo com o mandato estabelecido pelo ECOSOC. ${ }^{206}$

A atual lista, definida em 2009, contém 49 países. ${ }^{207}$ A definição de países menos avançados se dá pela combinação dos seguintes critérios: i. Renda nacional bruta, ii. Índice de desenvolvimento humano; iii. Índice de vulnerabilidade econômica, iv. Tamanho da população inferior a 75 milhões. ${ }^{208}$

O Banco Mundial historicamente utiliza uma classificação como critério para as políticas de empréstimos. Há quatro categorias para o Banco Mundial, com base no PNB per capita: i. países de baixa renda ( $\$ 1,005$ ou menos), ii. países de renda média baixa $(\$ 1,006$ - $\$ 3,975)$, iii. países de renda média alta $(\$ 3,976$ $\$ 12,275)$, iv. países de renda alta $(\$ 12,276$ ou mais). Nestas categorias, o Banco

\footnotetext{
${ }^{206}$ Sitio oficial: http://www.un.org/esa/analysis/devplan/index.html. Acesso em 20 de maio de 2012.

${ }^{207}$ Nome e ano de inclusão na lista: Afeganistão (1971), Angola (1994), Bangladesh (1975), Benin (1971), Bhutan (1971), Burkina Faso (1971), Burundi (1971), Cambodia (1991), Central African Rep. (1975), Chad (1971), Comoros (1977), Dem. Rep. of the Congo (1991), Djibouti (1982), Equatorial Guinea (1982), Eritrea (1994), Ethiopia (1971), Gambia (1975), Guinea (1971), GuineaBissau (1981), Haiti (1971), Kiribati (1986), Lao People's Dem. Rep. (1971), Lesotho (1971), Liberia (1990), Madagascar (1991), Malawi (1971), Maldives (1971), Mali (1971), Mauritania (1986), Mozambique (1988), Mianmar (1987), Nepal (1971), Niger (1971), Ruanda (1971), Samoa (1971), Sao Tome e Principe (1982), Senegal (2000), Sierra Leone (1982), Solomon Islands (1991), Somalia (1971), Sudan (1971), Timor-Leste (2003), Togo (1982), Tuvalu (1986), Uganda (1971), United Rep. of Tanzania (1971), Vanuatu (1985), Yemen (1971), Zambia (1991).

208 Maiores explicações sobre os critérios para composição da lista em http://www.un.org/esa/analysis/devplan/profile/criteria.html
} 
Mundial, em 2010, classificou os 216 países nas seguintes proporções: 35 países de baixa renda, 56 países de renda média baixa, 54 países de renda média alta, e 70 de renda alta.

O método de listagem é também utilizado pelo Acordo sobre Subsídios e Medidas Compensatórias da OMC. De acordo com o parágrafo 2(a) do artigo 27, a proibição de subsídios à exportação não se aplica aos países menos avançados e aos 20 países listados no anexo VII. ${ }^{209}$ Para estes 20 países, eles têm os mesmos direitos que os países menos avançados enquanto o seu PNB per capita não superar US\$1.000,00. Caso supere, passarão a ser tratados enquanto Membros em desenvolvimento.

No entanto, como se verá mais adiante, ao longo da Rodada Doha, surgiram projetos de regulamentação da condição de Membro em desenvolvimento, a fim de dar maior segurança jurídica e efetividade para os direitos inerentes a tal condição, intimamente ligados ao Tratamento Especial e Diferenciado. É o que se verá a seguir.

\section{b) A natureza jurídica dos direitos do Tratamento Especial e Diferenciado na OMC}

Muito embora comumente se faça menção aos direitos dos países em desenvolvimento no sistema multilateral de comércio, há uma diferença terminológica entre o Período GATT e o Período OMC. No Período GATT, se chamava Tratamento especial e diferenciado. No Período OMC, se denomina Tratamento especial e mais favorável. Para além de mera mudança terminológica, houve uma mudança na técnica legislativa.

A técnica adotada pelas partes negociadoras da Rodada Uruguai para consolidar o Tratamento Especial e Diferenciado nos diversos acordos da OMC orientou-se não pela noção de não-reciprrcidade, da Parte IV, mas pela ideia de

\footnotetext{
${ }^{209}$ Bolívia, Camarões, Congo, Costa do Marfim, Egito, Filipinas, Gana, Guatemala, Guiana, Índia, Indonésia, Quênia, Marrocos, Nicarágua, Nigéria, Paquistão, República Dominicana, Senegal, Sri Lanka, Zimbábue.
} 
gradualidade, da cláusula evolutiva de 1979. A técnica que utiliza a OMC no fomento ao desenvolvimento passa pela integração dos países em desenvolvimento ao comércio internacional. Portanto, trata-se de uma mudança de tendência em relação ao período GATT. Essa evolução encontra-se no Acordo de Marraqueche, no que se aponta a necessidade de:

Realizar esforços para que os países em desenvolvimento, e especialmente os menos avançados, obtenham uma parte do incremento do comercio internacional que corresponda às necessidades do seu desenvolvimento econômico.

O artigo XI, parágrafo 2 dispõe que:

Dos países de menor desenvolvimento relativo, reconhecidos como tal pelas Nações Unidas, serão requeridos compromissos e concessões apenas na proporção adequadas as suas necessidades de desenvolvimento, financeiras, e comerciais, ou a sua capacidade administrativa e institucional.

Isto reflete a ideia que de o SMC não esteja consolidado mais sob um paradigma dialético país desenvolvido versus país em desenvolvimento, mas sim, sob o paradigma da igualdade, com exceções temporárias para que os países em desenvolvimento paulatina e progressivamente sejam inseridos no sistema do Direito da OMC, agora orientado pela tendência de uniformização do sistema multilateral de comércio.

Como apontado no início deste capítulo, houve uma grande mudança na atitude dos países em desenvolvimento em relação ao Tratamento Especial e Diferenciado durante as negociações da Rodada Uruguai. Devidamente, antes do início da Rodada Uruguai, muitos países em desenvolvimento já estavam implantando um amplo leque de reformas, no âmbito dos Programas de Ajuste Estrutural administrados pelo FMI e pelo Banco Mundial. Dentro de tais programas, a premissa da liberalização comercial era pré-requisito essencial.

Por isso, os países em desenvolvimento passaram a levar como objetivo central das suas negociações a aceitação da diluição do Tratamento Especial e 
Diferenciado em troca de melhor acesso aos mercados dos países desenvolvidos e o fortalecimento das regras comerciais, especialmente pela institucionalização do OSC. Entretanto, como se afirmou precedentemente, nem o fortalecimento das regras comerciais, nem a institucionalização do OSC geraram os efeitos esperados pelos países em desenvolvimento.

Com este espírito, os países em desenvolvimento ingressaram nas negociações da Rodada Uruguai. O resultado da Rodada Uruguai em matéria de Tratamento Especial e Diferenciado, desde o ponto de vista contemporâneo, depois de passado o encanto com o Consenso de Washington, pode ser considerado decepcionante.

A propósito, o Tratamento Especial e Diferenciado é reconhecido por 145 dispositivos nos diferentes acordos multilaterais da OMC. O secretariado da OMC classifica o conjunto de dispositivos de Tratamento Especial e Diferenciado em favor dos países em desenvolvimento em cinco categorias:

i. Dispositivos que visam o aumento das oportunidades comerciais dos Membros em desenvolvimento;

ii. Dispositivos segundo os quais os Membros da OMC devem salvaguardar os interesses dos Membros em desenvolvimento;

iii. Flexibilidades nos compromissos, de ação e de uso de instrumentos políticos;

iv. Períodos de transição;

v. Assistência técnica.

No entanto, mesmo com esse conjunto grande de dispositivos, Welber Barral sustenta que, atualmente, as principais regras diferenciadoras em favor dos países em desenvolvimento são: ${ }^{210}$

a) O princípio da não-reciprocidade: como exceção genérica, esse princípio permite que vantagens concedidas por países desenvolvidos a países em desenvolvimento não necessariamente implicarão em concessões recíprocas dos países em desenvolvimento beneficiados;

b) A cláusula de habilitação: cláusula pela qual as concessões comerciais a países em desenvolvimento não se estendem automaticamente aos demais Membros da OMC, logo, se tornou uma ressalva a cláusula da nação mais favorecida;

c) Concessão de prazos diferenciados para a implantação dos compromissos assumidos nos acordos da OMC.

${ }^{210}$ BARRAL, Welber. Desenvolvimento na Rodada Doha da OMC. In CHEREM, Mônica Teresa; DI SENA JÚNIOR, Roberto (Org.). Comércio internacional e desenvolvimento: uma perspectiva brasileira. São Paulo: Saraiva, 2004. p. 126. 
A análise do Tratamento Especial e Diferenciado nos Acordos da OMC tem sido tradicionalmente feita seguindo essencialmente a sistemática dos próprios acordos. A necessidade de uma abordagem mais jurídica, que identifique a natureza de cada tipo de dispositivo, auxiliaria a compreender as oportunidades e as limitações de cada uma desta longa lista de dispositivos de Tratamento Especial e Diferenciado da OMC.

Tendo em vista a vagueza e ambiguidade de grande parte destes dispositivos de Tratamento Especial e Diferenciado, sua aplicabilidade resta prejudicada, razão pela qual o Comitê de Comércio e Desenvolvimento da OMC propôs uma classificação visando ordenar os dispositivos de Tratamento Especial e Diferenciado em função do grau de concreção dos direitos e obrigações inerentes a cada dispositivo. Deveras, a fim de conceber maior clareza no caráter jurídico das disposições, o Comitê as enquadrou em duas categorias: disposições de natureza obrigatória e não-obrigatória, também chamadas declaratórias.

De acordo com os relatórios do Comitê de Comércio e Desenvolvimento, a divisão que pode ser estabelecida entre estes dispositivos reside em sua redação:

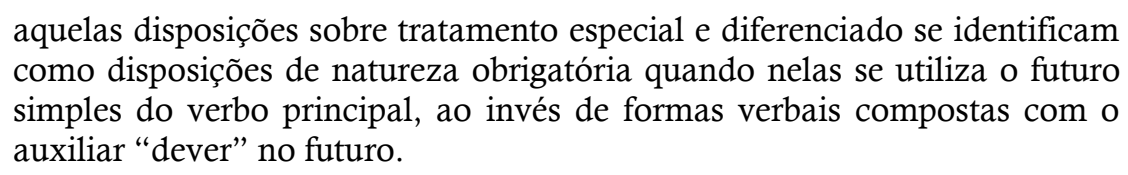

Trata-se de um corpo jurídico de grandes proporções e muito variado. Não obstante, pode-se encontrar uma particularidade comum a todas as disposições que reconhecem o Tratamento Especial e Diferenciado: estabelecem, ao menos, uma distinção entre os Membros da OMC em função das suas necessidades econômicas e supõem uma exceção ou uma atenuação de determinadas obrigações.

Contudo, existe uma crítica dominante em relação aos dispositivos sobre o Tratamento Especial e Diferenciado, quais sejam, seus problemas de aplicação, já que a maioria das disposições está redigida em uma linguagem qualificada como soft law. Nas palavras de Jackson, uma abordagem demasiadamente vaga e 
aspiracional, ${ }^{211}$ o que representa um verdadeiro obstáculo ao recurso a esta normativa no OSC e mais à identificação das obrigações derivadas de muitas delas.

De acordo com Olivares:

A utilização desta linguagem soft podia justificar-se durante o período GATT, quando o GATT era a la carte, mas sua utilização é injustificável e paradoxal desde a criação da OMC, já que estamos ante um rule-based system, no qual os direitos e obrigações dos Membros tem um caráter obrigatório e efetivo através do Mecanismo de Solução de Controvérsias. ${ }^{212}$

Desde uma análise do conjunto do marco regulatório da $\mathrm{OMC}$, podem-se analisar os dispositivos de Tratamento Especial e Diferenciado. De um lado, aqueles de natureza obrigatória, composto por normas que superaram o status meramente declaratório e se converteram em hard law, seguindo a tendência estabelecida pela criação da OMC e pela judicialização do sistema de solução de controvérsias.

Por outro, constata-se a existência de normas declaratórias. A presença destas normas no sistema OMC, como bem critica Olivares, é paradoxal, já que, com a entrada em vigor dos acordos da OMC e com a generalização do avanço do soft law para hard law, os Membros mais carentes tornam-se os mais vulneráveis diante do atual sistema multilateral de comércio.

A falta de aplicabilidade destas disposições vem sendo reclamada pelos países em desenvolvimento desde a entrada em vigor da $\mathrm{OMC}$, pois a redação em uma linguagem exortativa, que carece de obrigações concretas, denota a ausência de obrigatoriedade e condena os países em desenvolvimento à insegurança jurídica e à impossibilidade de recurso perante o OSC.

Ora, os países em desenvolvimento encontram-se ainda mais vulneráveis do que no sistema anterior, de vigência do GATT-47. Com a entrada em vigor da $\mathrm{OMC}$, as normas que estavam amparadas nos princípios gerais - tratamento nacional e cláusula NMF - tornaram-se hard law, enquanto as amparadas na exceção - tratamento especial e diferenciado -, mantiveram a natureza de soft law.

\footnotetext{
${ }^{211}$ JACKSON (1997).op. cit. P. 319.

${ }^{212}$ OLIVARES, G.. The case of giving effectiveness to GATT/WTO rules on Developing Countries and LDCs. JWT, 2001, vol. 35 (3), P. 548.
} 
Esta situação constitui um dos maiores defeitos normativos da $\mathrm{OMC}$, pois, além de situar o princípio do Tratamento Especial e Diferenciado em uma categoria inferior aos princípios gerais, dificulta sua juridicização junto ao OSC, tendo-se em vista a resistência deste órgão para avaliar soft law.

De acordo com Salvador:

\begin{abstract}
Não é apenas a variedade de disposições sobre tratamento especial e diferenciado que leva a confusão e a inefetividade do Tratamento Especial e Diferenciado. Desde a Declaração de Punta Del Leste à Declaração de Marraqueche, passando pelos acordos, as decisões, e as declarações ministeriais, faz-se menção a consagração deste tratamento aos PED e aos PMDR na OMC. Mas esta profusão de alusões não está acompanhada de uma definição ou de uma delimitação do seu conteúdo, pois novamente topamos com uma enorme dificuldade na hora de estabelecer no que efetivamente consiste o tratamento especial e diferenciado, sem estabelecer obrigações, se estas disposições são invocáveis perante o OSC, etc. ${ }^{213}$
\end{abstract}

Outra categorização pode ser interessante para compreender o conjunto de dispositivos sobre o Tratamento Especial e Diferenciado, a diferenciação entre obrigações de meio, ou de comportamento, e as obrigações de resultado.

Há dois tipos de obrigação de resultado: quando a norma estabelece um resultado, sem prever os meios para alcançá-lo, ou quando a norma estabelece um resultado e prevê os meios para alcançá-lo. Há igualmente dois tipos de obrigação de meio: aquelas positivas, ativas, de fazer, ou aquelas negativas, passivas, de nãofazer.

A formulação do Tratamento Especial e Diferenciado se realiza a partir de uma perspectiva teleológica, com vistas à inserção dos países em desenvolvimento no comércio internacional e na luta contra o subdesenvolvimento e a pobreza. Assim, o Acordo de Maraqueche estabelece que:

É necessário realizar esforços positivos para que os países em desenvolvimento, e especialmente os menos avançados, obtenham uma parte do incremento do comércio internacional que corresponda às necessidades do seu desenvolvimento econômico.

Sob este prisma, é possível considerar que se trata de uma situação de obrigação de resultado, enquanto objetivo da própria Organização Internacional -

${ }^{213}$ SALVADOR, op. cit., p. 187. 
incremento do comércio internacional que corresponda às necessidades do seu desenvolvimento econômico - que concretiza os meios para alcançá-lo nos dispositivos sobre tratamento especial e diferenciado reconhecidos ao longo dos anexos? Parece que a resposta para tal questão pode ser afirmativa.

As obrigações de meio encontradas nos acordos da OMC são muito variadas. Podem ter como devedores os países desenvolvidos, tanto prevendo obrigações de fazer - prestação de assistência técnica - como contemplando obrigações de não-fazer (de tolerar) - permitindo através de preferências comerciais o acesso dos produtos dos países em desenvolvimento aos mercados dos países desenvolvidos.

Também encontramos obrigações de resultado nas disposições sobre Tratamento Especial e Diferenciado que tendem a recair sobre os países desenvolvidos e sobre os Estados Membros da OMC como um todo. No entanto, as disposições com obrigações de resultado padecem de profundas deficiências normativas, por não preverem claramente direitos e obrigações.

Essa breve análise da heterogeneidade das disposições sobre Tratamento Especial e Diferenciado revela uma tendência dentro dos acordos da OMC: a maior parte das obrigações de resultado (aquelas que têm como sujeitos obrigados os países desenvolvidos) estabelece objetivos indeterminados; já aquelas que prevêem obrigações de cumprimento (em sua maioria direcionadas aos países em desenvolvimento), estabelecem obrigações positivas que, em geral, gozam de maior concretude.

Levando em consideração as categorizações normativas de acordo com o grau de obrigatoriedade, é possível classificar e exemplificar as disposições de Tratamento Especial e Diferenciado da seguinte maneira ${ }^{214}$ :

\section{Tabela 13. Dispositivos obrigatórios e declaratórios do Tratamento Especial e Diferenciado}

\footnotetext{
${ }^{214}$ Elaboração própria com base na proposta de classificação de SALVADOR, op. cit., p. 191-194.
} 
I) Dispositivos obrigatórios:

i) Concessão de prazos de transição - art. 15.2, AARU / art. 5.2, TRIMS / art. 65.2, TRIPS

ii) Obrigações positivas

iii) Isenções - art. IV, GATS

- art. 27.2.a, $A S M C$

iv) Supervisão dos acordos - art. 12.10, AOTC / art. 27.14, ASMC

v) Assistência técnica - art. XXV.2, GATS / art. 20.3, AVA

II) Dispositivos declaratórios (os mais numerosos dentro dos acordos OMC)

i) Considerações gerais sobre os PED - art. 10.1 e 10.4, AMSF / art. XIX.2, GATS

ii) Considerações gerais sobre os PMDR - art. 6.6, ATV

iii) Adoção de medidas especiais - art. 12.4, AOTC

iv) Prazos de transição - art. 10.2, AMSF

v) Assistência técnica - Art. 9.2, AMSF

\subsection{AS PRERROGATIVAS JURÍDICAS DO DESENVOLVIMENTO NO OSC DA OMC}

a) $\mathrm{O}$ artigo XVIII interpretado: o caso Índia - Restrições Quantitativas

Ao longo do período GATT, os países em desenvolvimento fizeram grande uso das medidas previstas nos artigos XII e XVIII, referentes ao balanço de pagamentos. Havia grande discricionariedade por parte dos países em desenvolvimento para imposição de medidas restritivas ao comércio, especialmente quotas, sob a alegação de problemas de balanço de pagamentos. Este recurso aos artigos XII e XVIII se intensificou após a Rodada Tóquio, de 1979. ${ }^{215}$

${ }^{215}$ Como apresentado no capítulo 2, juntamente com a Cláusula de Habilitação, foram aprovados dois entendimentos: o Entendimento sobre balanço de pagamentos, um acordo-quadro que relativizou algumas exigências na revisão das restrições dos PED em caso de problemas de balanço de pagamentos; e o Entendimento do artigo XVIII, um acordo que ampliou a concepção de 
Já na Rodada Uruguai, foi aprovado o Entendimento sobre as disposições relativas ao Balanço de Pagamentos da Rodada Uruguai, que levou a diversas alterações na dinâmica da proteção das indústrias nascentes. Primeiro, definiu-se que osMembros devem priorizar a proteção por meio de medidas tarifárias, tal como a sobretaxa, em substituição à continuação do uso de quotas. Em segundo lugar, o Entendimento continuou permitindo o recurso a tais dispositivos sem aprovação prévia. No entanto, estabeleceu procedimentos de consultas de partes interessadas, além de mecanismos de revisão periódicas em caso de medidas de restrição fundadas no artigo XII e XVIII.

De fato, os Membros têm dado pouca significância à possibilidade proteção de indústrias infantes com base no Artigo XVIII do GATT. ${ }^{216}$ Até 1994 , quando da conclusão da Rodada Uruguai, a seção A do artigo XVIII havia sido invocada apenas nove vezes na história do GATT, pelas seguintes partes contratantes: Grécia (em 1956 e 1965); Indonésia (em 1983); Coréia do Sul (em 1958); Sri Lanka (duas vezes em 1955, em 1956 e 1957) e Suriname (em 1958). ${ }^{217}$

Nos anos que se seguiram à conclusão da Rodada Uruguai, os Membros da OMC, em especial os países em desenvolvimento, provocaram as instâncias da OMC para saber se as práticas do Período GATT relacionadas aos países em desenvolvimento estavam realmente fadadas à extinção, ou se a permissibilidade característica daquele período se manteria. Os países em desenvolvimento colocaram em xeque o espírito das negociações da Rodada Uruguai, que teve uma clara conotação contrária à liberdade jurídica no que lhes tangia, bem como os novos acordos e entendimentos da OMC, que limitaram muito a vertente de atuação dos países em desenvolvimento, para verificar se tais obrigações se instituiriam na prática.

\footnotetext{
"indústria nascente" a fim de ampliar o uso de tais medidas. A mais importante alteração de todas, nos acordos de 1979, foi a remoção da necessidade de aprovação prévia no âmbito do GATT para imposição de tais medidas, que era uma reivindicação dos PED desde as negociações originárias da OIC e do GATT.

${ }^{216}$ Até 2005, os Membros que haviam apresentado consultas ao Comitê de Balanço de Pagamentos foram: Bangladesh, Bulgária, Hungria, Índia, Nigéria, Paquistão, República Checa, República Eslovaca, Romênia, Sri Lanka e Tunísia.

${ }^{217}$ RAJ BHALA. Op. cit. P. 1033.
} 
Em linhas gerais, este foi o espírito da postura da Índia no caso Índia Restriçooes Quantitativas (DS90), ${ }^{218}$ um dos poucos leading cases sobre policy space dos países em desenvolvimento na OMC.

Neste caso, a Índia reivindicava a continuidade da abordagem menos rígida existente no período GATT sobre o acesso dos países em desenvolvimento às exceções de balanço de pagamentos. O Órgão de Apelação neste caso apresentou o significado do Entendimento sobre as disposições relativas ao Balanço de Pagamentos da Rodada Uruguai, e sujeitou as medidas dos Membros da OMC, que estivessem amparadas nos artigos XII e XVIII, ao escrutínio do OSC. Antes do advento da OMC, estas medidas eventualmente eram submetidas aos painéis do GATT, mas os países em desenvolvimento estavam acostumados a reivindicar tais medidas sem maiores análises jurídicas. ${ }^{219}$

Em 1997, os EUA, seguidos de Austrália, Canadá, Nova Zelândia, Suíça e a Comunidade Europeia, pela primeira vez questionaram as medidas de restrição quantitativa fundadas no balanço de pagamentos da Índia perante o OSC da OMC.

A Índia arguiu que o Comitê de Balanço de Pagamentos era o único órgão da OMC com competência exclusiva para avaliar as medidas fundadas nos artigos XII e XVIII, para tentar excluir tal apreciação do OSC que, de acordo com a Índia, não tinha competência para analisar o mérito das justificativas de balanço de pagamentos.

Tanto o painel quanto o Órgão de Apelação determinaram que, ao contrário dos argumentos da Índia, o OSC da OMC possuía sim competência para revisar a legalidade das medidas de balanço de pagamentos, bem como as justificativas para tais restrições, na medida em que tais restrições fossem submetidas ao OSC pois, de acordo com a nota de rodapé $\mathrm{n}^{\circ} 1$ do Entendimento sobre as disposições relativas ao Balanço de Pagamentos da Rodada Uruguai:

\footnotetext{
${ }^{218}$ WT/DS90. India - Quantitative Restrictions on Imports of Agricultural, Textile and Industrial Products. ${ }^{219}$ A Índia historicamente vinha apresentando tanto ao GATT quanto ao Comitê de Balanço de Pagamentos da OMC restrições decorrentes de balanço de pagamentos desde 1957. O Comitê de Balanço de Pagamentos tinha competência apenas para aprovar ou reprovar tais medidas. Para tanto, era necessário consenso. Tal consenso nunca foi alcançado e as medidas da Índia foram desde 1957, sempre permitidas por omissão, por ausência de posição do GATT e posteriormente do Comitê da OMC.
} 
Os artigos XXII e XXIII do GATT 94 (que dispõem sobre os princípios jurisdicionais do OSC) ao serem interpretados e aplicados pelo Entendimento do OSC, podem ser invocados quando se diga respeito a questões envolvendo a aplicação de medidas de restrição às importações tomadas com base em balanço de pagamentos.

Com base nesse dispositivo, o argumento preliminar da Índia foi rechaçado tanto pelo Painel quanto pelo Órgão de Apelação, que reivindicaram a jurisdição sobre o mérito das justificativas para impor medidas de restrições fundadas no artigo XVIII.

Desse modo, a decisão preliminar do OSC exerceu impacto fundamental na definição de policy space para o desenvolvimento dos países em desenvolvimento, que, ao contrário do período GATT, gozavam de ampla liberdade jurídica para imposição de medidas fundadas no artigo XVIII. A partir de tal interpretação do OSC da OMC, tal liberdade foi amplamente restringida, tendo-se em vista os países em desenvolvimento estarem sujeitos ao escrutínio jurídico do OSC.

Quanto à questão de mérito, ressalta-se a pressão internacional pelo fim da política de substituição de importações que a Índia vinha implantando desde sua independência. A Índia mantinha restrições quantitativas para as importações de produtos agrícolas, têxteis e industriais. ${ }^{220}$

Em 1997, a Índia propôs à OMC a eliminação de tais restrições em um período de sete anos. Os EUA, com base nos relatórios do Fundo Monetário Internacional (FMI), argumentavam que sete anos seria mais tempo que o necessário, e reivindicava que este período de eliminação das quotas fosse mais curto. Um fato interessante deste caso é que o Painel da OMC convidou o FMI a exercer um papel de "consultor econômico", para arrazoar as suas decisões sobre o caso.

\footnotetext{
${ }^{220}$ Desde sua independência em relação a colonização britânica em 1947, a Índia exige licenças de importação e sujeitas as importações a restrições quantitativas. Estas medidas fazem parte da sua estratégia de desenvolvimento fundado em substituição de importações, para incentivar a produção doméstica de itens e evitar a dependência de importações estrangeiras, especialmente de países industriais e antigos colonizadores. Esta estratégia abrangia um total de 2,714 linhas tarifárias, todas justificadas ao longo do período GATT com base na seção B do artigo XVIII.
} 
O painel, fundado nos pareceres do FMI, considerou que as medidas eram incompatíveis com as regras da OMC, mais especificamente, o artigo XVIII:11, que a Índia não teria direito ao período de transição (phase out period), e que as medidas deveriam ser removidas imediatamente. ${ }^{221}$

A Índia submeteu a decisão do Painel para revisão do Órgão de Apelação. A questão analisada pelo Órgão era se a Índia estava correta em afirmar que, com base na cláusula proviso do artigo XVIII:11, estava-se afirmando à Índia que "uma mudança nas políticas de desenvolvimento" tornaria as restrições quantitativas desnecessárias. ${ }^{222}$

O Órgão de Apelação decidiu negativamente. Isto é, a Índia não estava sendo pressionada para mudar sua política de desenvolvimento e assim justificar a eliminação das quotas em prazo menor do que os sete anos. Segundo o Órgão de Apelação, nenhum Estado, nem os EUA, ou qualquer outro Membro da OMC, tampouco o FMI, poderiam obrigar a Índia a abandonar as quotas rapidamente, por modificar suas políticas de desenvolvimento. ${ }^{223}$

De acordo com Raj Bahla:

O relatório do Órgão de Apelação é uma declaração para qualquer país em desenvolvimento que deseja invocar a cláusula proviso do artigo XVIII:11, que uma política macroeconômica comumente utilizada para defender e fortalecer uma moeda frente à outras moedas, e consequentemente, evitar a erosão do balanço de pagamentos decorrente da retirada de restrições quantitativas, não é considerada nova política de desenvolvimento. Ao contrário, esta espécie de medida macroeconômica esta na caixa de ferramentas de todo e qualquer ministro da fazenda e banco central. ${ }^{224}$

O caso Índia-Restrições Quantitativas é relevante tanto por sua decisão preliminar quanto pela decisão de mérito. Em relação à questão preliminar, o fato

\footnotetext{
${ }^{221}$ WT/DS90/R. Report of the Panel India - Quantitative Restrictions on Imports of Agricultural, Textile and Industrial Products. 6 de abril de 1999. p. 187.

${ }^{222}$ A Índia argumentou que uma mudança em sua política de desenvolvimento estava sendo exigida e moldada por forças exteriores. A Índia arguiu que os EUA e o FMI estavam dizendo a ela como lidar com balanço de pagamentos caso alterasse sua política de restrições quantitativas. Afirmavam que a Índia poderia utilizar instrumentos de política macroeconômica para lidar com problemas de balanço de pagamentos que poderiam emergir após a retirada das restrições quantitativas.

${ }^{223}$ WT/DS90/AB/R. Report of the Apellate Body India - Quantitative Restrictions on Imports of Agricultural, Textile and Industrial Products. 23 de agosto de 1999, p. 36.

${ }^{224}$ RAJ BHALA. op. cit., p. 1034.
} 
de o OSC ter invocado para si o direito de avaliar a conformidade das medidas fundadas no artigo XVIII reduziu drasticamente o nível de discricionariedade dos países em desenvolvimento para adotar medidas de proteção das indústrias nascentes.

Por outro lado, como desdobramento da questão de mérito, o Órgão de Apelação manteve algum grau de discricionariedade aos países em desenvolvimento, no que se refere à eleição das medidas necessárias ao controle do balanço de pagamentos visando a proteção das indústrias nascentes. O Órgão de Apelação limitou o grau de ingerência do FMI na definição de tais medidas, mantendo alguma margem de manobra, no âmbito do artigo XVIII, para os países em desenvolvimento.

\section{b) A Cláusula de Habilitação interpretada: o caso CE - Preferências Tarifárias}

O caso Comunidades Européias - Preferências Tarifárias (DS246) ${ }^{225}$ é o leading case referente à Cláusula de Habilitação e à interpretação do Tratamento Especial e Diferenciado da OMC.

Em 2002, a Índia apresentou consultas à $C E,{ }^{226}$ em torno do esquema de SGP da CE que, segundo a Índia, violava a Cláusula NMF do Artigo I:1. Esta violação seria decorrente da diferença de tratamento dado aos beneficiários do SGP em geral, em comparação aos beneficiários qualificados para os cinco esquemas de “Acordos Especiais de Incentivo" que a CE tinha em vigor. ${ }^{227}$ Em suma, a Índia

\footnotetext{
${ }^{225}$ WT/DS246. European Communities - Conditions for the Granting of Tariff Preferences to Developing Countries. $1^{\circ}$ de dezembro de 2003.

${ }^{226}$ A Índia foi apoiada por diversos Membros na condição de terceiros, todos PED, com a exceção dos EUA: Bolívia; Brasil; Colômbia; Costa Rica; Cuba; El Salvador; Equador; Estados Unidos; Guatemala; Honduras; Ilhas Mauricio; Nicarágua; Paquistão; Panamá; Paraguai; Peru; Sri Lanka; Venezuela. Esse caso foi particularmente relevante para a Comunidade Andina

${ }^{227}$ A CE dispunha de 5 acordos de preferência comercial:

- Acordo Geral, com base no artigo $7^{\circ}$ do Regulamento do Conselho n ${ }^{\circ}$ 2501/2001.

- Acordo Especial de Incentivo para combater a produção e tráfico de drogas

- Acordo Especial de Incentivo para encorajar a proteção de direitos trabalhistas

- Acordo Especial de Incentivo para encorajar a proteção ambiental

- Acordo Especial de Incentivo para países menos avançados.
} 
acusava a $\mathrm{CE}$ de criar um programa discriminatório, que estabelecia categorias diferenciadas entre países em desenvolvimento, sem fundamentação legal.

Em linhas gerais, o esquema de SGP da CE funcionava da seguinte maneira: havia uma lista de países que eram elegíveis para receber as preferências tarifárias do Acordo Geral. Tais preferências tarifárias eram divididas em dois grupos: o primeiro grupo, de produtos não-sensíveis, para os quais havia a eliminação das tarifas; o segundo grupo, de produtos sensíveis, para os quais havia a redução ad valorem das tarifas. Os quatro acordos especiais de incentivo concediam, de maneira adicional, tratamento mais favorável do que o Acordo Geral. À critério da CE, apenas alguns países beneficiavam-se do Acordo Geral e beneficiavam-se também de alguns dos acordos especiais.

A reclamação da Índia era especifica em relação a um acordo especial, o "acordo sobre drogas", pois apenas 12 países pré-determinados gozavam dos benefícios deste acordo: Bolívia, Colômbia, Costa Rica, Equador, El Salvador, Guatemala, Honduras, Nicarágua, Paquistão, Panamá, Peru e Venezuela. A Índia se beneficiava do SGP com base no Acordo Geral, no entanto, não se beneficiava dos demais acordos especiais, incluindo o Acordo sobre Drogas.

O principal dispositivo invocado pela Índia era o parágrafo 2 , nota de rodapé 3, da Cláusula de Habilitação:

O tratamento tarifário preferencial concedido por países desenvolvidos a produtos originários e países em desenvolvimento, com base no Sistema Geral de Preferências, deve ser estabelecido observando preferências generalizadas, não-recíprocas e não-discriminatórias aos países em desenvolvimento.

Os argumentos no âmbito do Órgão de Apelação centraram-se em duas questões centrais: por um lado, a relação entre a Cláusula NMF e a Cláusula de Habilitação; por outro, a relação do Acordo sobre Drogas com a Cláusula de Habilitação. Em 2004, o Órgão de Apelação emanou uma importante decisão no que diz respeito às condições que a $\mathrm{CE}$ impunha para conceder preferências tarifárias aos países em desenvolvimento e, de maneira geral, ao escopo das condicionalidades/reciprocidades que estavam sendo aplicadas no âmbito dos programas de SGP, especialmente pelos EUA e pela CE. 
O Órgão de Apelação concluiu que a exigência da Cláusula de Habilitação para tratamento não-discriminatório entre os países em desenvolvimento não requer que haja formalmente tratamento idêntico, mas requer tratamento idêntico a beneficiários que estejam em "condições similares". Para tanto, o Órgão de Apelação estabeleceu que tal distinção entre os beneficiários do SGP, para manterse consistente com a Cláusula de Habilitação, deveria responder positivamente às necessidades dos países em desenvolvimento. Com essa decisão do Órgão de Apelação, a reciprocidade ficou restrita, no sentido de que os países desenvolvidos exigiram concessões políticas em troca de inserção dos países em desenvolvimento no SGP.

A CE questionou a decisão do Painel, que dispunha que o termo "nãodiscriminatório" do parágrafo 2, nota de rodapé 3, da Cláusula de Habilitação, requer preferências tarifárias idênticas para todos os países em desenvolvimento sem diferenciação, exceto em casos de limitações a priori existentes.

O painel havia decidido que as únicas discriminações permitidas eram aquelas em favor de países com menor desenvolvimento relativo, bem como aquelas associadas a exigências de graduação. Com base numa análise histórica da Cláusula de Habilitação, o painel determinou que o termo "não-discriminatório" da nota de rodapé 3 exigia preferências tarifárias idênticas para todos os países em desenvolvimento sem diferenciação.

A CE argumentou que o parágrafo 3.c da Cláusula de Habilitação, que requer que os programas SGP sejam projetados de forma que "respondam positivamente" às necessidades de desenvolvimento dos países em desenvolvimento, permite que se diferenciem os países em desenvolvimento com base nos diferentes níveis de necessidade que teriam cada categoria.

O Órgão de Apelação interpretou a Cláusula de Habilitação com base no preâmbulo do tratado constitutivo da OMC, segundo o qual, "é necessário realizar esforços positivos para que os países em desenvolvimento, em especial os países de menor desenvolvimento relativo, obtenham uma parte do incremento do comércio internacional, que corresponda às necessidades do seu desenvolvimento econômico". Assim, os Membros da OMC devem "fazê-lo de maneira compatível 
com suas respectivas necessidade e interesses dos países em desenvolvimento, segundo os diferentes níveis de desenvolvimento econômico". ${ }^{228}$

O Órgão de Apelação decidiu que, embora o preâmbulo da OMC permita tratamento diferenciado de acordo com os diferentes níveis de desenvolvimento econômico dos Membros, tal tratamento deve ser garantido com base em padrões positivos e objetivos. Nesse sentido, o Órgão de Apelação condenou o SGP europeu ao constatar que:

O termo não-discriminatório da nota de rodapé 3 não proíbe o país desenvolvido de conceder tratamento tarifário diferenciado para produtos originários de diferentes beneficiários do SGP, desde que tal tratamento diferenciado esteja em consonância com as demais condições da Cláusula de Habilitação. No entanto, ao conceder tal tratamento, os países concedentes devem, em razão do termo "não-discriminatório" assegurar que o tratamento idêntico esteja acessível a todo beneficiário de SGP que tenha as "necessidades econômicas, financeiras e comerciais" cujas medidas objetivam atender. ${ }^{229}$

A principal contribuição deste caso diz respeito ao SGP, mais especificamente ao direito dos países desenvolvidos de graduaram os países em desenvolvimento dentro dos esquemas estabelecidos. Isto veio a consolidar o princípio do gradualismo dos países em desenvolvimento lançado na Rodada Tóquio e consolidada na Rodada Uruguai. Como já analisado anteriormente, a prática da graduação, por parte dos países desenvolvidos, ao mesmo tempo em que afasta os países em desenvolvimento com maior nível econômico dos tratamentos tarifários mais favoráveis, beneficia os países em desenvolvimento com menor nível econômico.

No entanto, tal caso, apesar de ser considerado o leading case sobre a Cláusula de Habilitação, tem sérias deficiências. Nem o Painel nem o Órgão de Apelação se manifestaram sobre o status de país em desenvolvimento. Tampouco o Órgão explica sobre as exigências para graduação entre países em desenvolvimento, nem o que significa estar em diferentes níveis de necessidade econômica, financeira e comercial.

\footnotetext{
${ }^{228}$ Trechos do Preâmbulo do Acordo de Marraqueche.

${ }^{229}$ WT/DS246/AB/R. Report of the Appelate Body. European Communities - Conditions for the Granting of Tariff Preferences to Developing Countries. $1^{\circ}$ de dezembro de 2003.p. 190.
} 


\section{CONCLUSÕES DO CAPÍTULO 4}

Ao final da Era GATT, influenciado pelo Consenso de Washington, presenciou-se o movimento de declínio dos modelos desenvolvimentistas em substituição a novos modelos de orientação liberal que rechaçavam o exercício de policy space por fomentar a ineficiência e distorcer a "ordem natural" do comércio internacional.

Com efeito, a partir das décadas de 80 e 90, as políticas públicas fundadas nas prerrogativas desenvolvimentistas do GATT continuaram em vigor; No entanto, modificaram-se em substância. Os diversos setores industriais que vinham se desenvolvendo na América Latina tiveram que enfrentar a abertura comercial em plano global, o que levou a maioria dos setores à falência. As iniciativas de integração regional passaram por uma reorientação ideológica e deixaram de ser processos inspirados nas ideias cepalinas, de desenvolvimento endógeno, e passaram a ser percebidos como patamares preliminares à liberalização total, no plano multilateral. Integrar-se passou a ser sinônimo de liberalização em nível regional, e não mais de fomento ao desenvolvimento regional.

A partir das reformas decorrentes do Consenso de Washington, os países em desenvolvimento estavam preparados para se envolverem na Rodada de Negociações mais importante, até hoje, do sistema multilateral de comércio: A Rodada Uruguai. A existência do Consenso, tanto entre os países desenvolvidos como entre os países em desenvolvimento, tornava esta Rodada um momento fundamental para aprofundar o processo de liberalização do comércio internacional. Acreditava-se que não haveria mais espaço para argumentos dissidentes, pró-desenvolvimentistas, ao longo da Rodada Uruguai.

Com a criação da Organização Mundial do Comércio e a celebração de um grande conjunto de acordos internacionais em matéria de comércio internacional, o sistema multilateral de comércio passou tanto por um alargamento temático quanto por um processo de aprofundamento tarifário, que levou a um nível até então inédito de liberalização econômica e comercial mundial, avançando em relação ao período regido pelo antecessor GATT-47. Isto impactou diretamente a capacidade 
dos países em desenvolvimento de continuar implantando políticas de desenvolvimento, nos moldes das implantadas até os anos 1980.

Isto porque este movimento de regulação dos novos temas não foi acompanhado de um movimento consistente e coerente de reivindicações de prerrogativas jurídicas mais favoráveis para os países em desenvolvimento, a fim de que pudessem manter autonomia na implantação das suas políticas públicas de integração e desenvolvimento. Este choque de modelos se deu de maneira particularmente forte na América do Sul, como será demonstrado no próximo capítulo.

Ao final da Rodada Uruguai, o direito internacional do desenvolvimento vigente no âmbito do sistema multilateral de comércio ficou limitado ao Tratamento Especial e Diferenciado, que foi concebido em termos de prazos mais largos para implantação de regra, que não tiveram utilidade alguma, tendo em vista a desproporção entre a complexidade da liberalização e prazo extremamente curto. Ademais, o Tratamento Especial e Diferenciado foi concebido de maneira a tratar diferentemente alguns regimes setoriais, tais como agricultura, têxteis, serviços, que teriam regras distintas das regras gerais do GATT e traziam em si uma built in agenda, que até hoje, passados mais de 15 anos, não se concretizou.

No entanto, mesmo em meio a este cenário de rejeição ao policy space para o desenvolvimento, que marcou a Rodada Uruguai, o Tratamento Especial e Diferenciado concedido aos países em desenvolvimento ficou consagrado em praticamente todos os acordos da OMC, razão pela qual se pode afirmar que o policy space conquistado ao longo do período GATT-47, limitado ao Tratamento Especial e Diferenciado, foi, no mínimo, mantido quando da entrada em vigor da OMC.

Ocorre que o viés de Tratamento Especial e Diferenciado que se consolidou nos acordos da OMC é atinente a prazos mais flexíveis e a setores temporariamente isentos de obrigações. Como restou evidente nos primeiros anos de vigência da OMC, por meio do caso Índia - Restrições Quantitativas, o sistema não concebia mais políticas de desenvolvimento consistentes e de longo prazo. Ora, é 
impossível implantar políticas de desenvolvimento fundamentando-se apenas em exceções e isenções temporárias.

Os acordos da Rodada Uruguai reduziram em grande medida a natureza não-recíproca do sistema multilateral de comércio que havia sido alcançada ao longo do Período GATT. A partir da OMC, os países em desenvolvimento estavam obrigados juridicamente dentro do Sistema OMC como um todo, pois os waivers e as derrogações que vigiam até então haviam sido extintos em $1^{\circ}$ de janeiro de 1995. Entretanto, não foi apenas a extinção destas exceções que reduziram o policy space dos países em desenvolvimento.

Antes da Rodada Uruguai, o Tratamento Especial e Diferenciado incluía diversas regras específicas e abordagens que poderiam ser categorizadas em três níveis: a) não-reciprocidade, b) acesso preferencial a mercados e c) proteção legitima. A não-reciprocidade englobava o conceito, difundido desde meados de 1960, em que não se esperava nem se exigia reciprocidade, em matéria de concessões comerciais, de países mais pobres, no âmbito do sistema multilateral de comércio; o acesso preferencial a mercados incluía os sistemas SGP e SGPC, que viabilizavam as aspirações dos países em desenvolvimento de acesso preferenciais aos mercados dos países industrializados, bem como no comércio entre países em desenvolvimento; a proteção legitima decorria da maior flexibilidade concedida aos países em desenvolvimento para utilizarem medidas de proteção às industriais nacionais, especialmente aquelas previstas nos artigos XII e XVIII, relacionadas a balanço de pagamentos.

Ao longo da Rodada Uruguai, estas três categorias de Tratamento Especial e Diferenciado passaram por uma mudança conceitual que marcou profundamente as negociações, bem como os resultados da Rodada. O princípio da não-reciprocidade foi modificado, senão abandonado, ao longo das negociações. Tanto a questão do single undertaking quanto o noção de graduação, que deram a tônica da Rodada Uruguai, fizeram com que os países em desenvolvimento estivessem sempre sendo exigidos a comprometerem-se nas negociações, fosse para realizar concessões em matéria de bens, de propriedade intelectual ou de serviços. O fato de os países em desenvolvimento terem se beneficiado com prazos maiores ou compromissos menores nos acordos da Rodada Uruguai, não reflete o princípio da não- 
reciprocidade da Parte $I V$, mas sim, a ideia de contida na cláusula evolutiva da Cláusula da Habilitação.

Já o acesso preferencial a mercados foi reduzido ao longo da Rodada Uruguai, em razão das negociações multilaterais para reduções tarifárias, especialmente em bens industriais, que acabaram por minimizar os privilégios alcançados pelos países em desenvolvimento por meio dos SGP. Por fim, a proteção legitima foi igualmente restringida, por ocasião do Entendimento sobre Disposições de Balanço de Pagamentos da Rodada Uruguai.

De fato, a partir da Rodada Uruguai, um novo Tratamento Especial e Diferenciado emergiu. Este novo Tratamento Especial e Diferenciado possuía duas facetas: períodos de transição para implantação dos novos compromissos decorrentes da Rodada Uruguai, tais prazos são mais extensos do que os países industrializados, e estão presentes em praticamente todos os acordos da Rodada Uruguai. A outra faceta é a assistência técnica para implantação dos novos acordos, que também está presente em praticamente todos os acordos da Rodada Uruguai.

\section{Segundo Welber Barral:}

Um balanço da experiência internacional do tratamento especial e diferenciado traz à tona as seguintes constatações: em primeiro lugar, as prerrogativas dos Estados em desenvolvimento na OMC têm caráter apenas retórico e principiológico; em segundo lugar, mesmo considerando as regras que efetivamente criam obrigações materiais de diferenciação, estas estão distantes de criar uma relação mais equilibrada entre os Membros da OMC; em terceiro lugar, mesmo os mecanismos tradicionais de diferenciação no comércio internacional, como o princípio da nãoreciprocidade, mostram sinais de esgotamento e de ineficácia como instrumentos de equalização econômica entre os Membros da OMC. ${ }^{230}$

Todas estas dificuldades de implantar os dispositivos de Tratamento Especial e Diferenciado vêm sendo denunciadas desde o surgimento da OMC, e mais enfaticamente, desde o lançamento da Rodada de Doha, através do parágrafo 44 da Declaração Ministerial, com a proposta de criação de um Acordo-Quadro sobre Tratamento Especial e Diferenciado. Tema que será analisado mais adiante, no capítulo seguinte.

${ }^{230}$ BARRAL, op. cit., p. 133. 
Várias são as dificuldades dos países em desenvolvimento e dos países com menor desenvolvimento relativo no que se refere à concretização do Tratamento Especial e Diferenciado no âmbito da OMC:

a) Insegurança jurídica decorrente da redação imprecisa dos dispositivos;

b) Ausência de garantias de efetivo acesso a mercados;

c) Problemas para invocar tais dispositivos junto ao OSC;

d) necessidades de assistência técnica, em uma tríplice perspectiva: primeiro, para adequar suas legislações internas aos acordos da OMC; segundo, para garantir o uso efetivo das disposições que lhes permita melhor seu desenvolvimento; terceiro, para poder recorrer ao OSC.

Estabelecida esta análise mais detalhada do Tratamento Especial e Diferenciado, pode-se considerar que se está frente a um direito de receber tratamento especial e diferenciado no âmbito do sistema multilateral de comércio? A primeira vista, parece difícil responder afirmativamente. No entanto, a partir da Rodada de Doha, uma série de transformações no cenário internacional e no sistema multilateral de comércio permitem certo otimismo em relação à consolidação do Tratamento Especial e Diferenciado a fim de que efetivamente possa ser considerado como um direito do desenvolvimento. 


\section{CAPÍTULO 5. A COMPATIBILIZAÇÃO DAS ORGANIZAÇÕES DE INTEGRAÇÃO SUL-AMERICANA COM AS REGRAS DA ORGANIZAÇÃO MUNDIAL DO COMÉRCIO}

Mas que caminho percorreram essas nações adolescentes em pouco tempo e que fulgrantes rombos nos dormentes! Evitemos julgar o mundo do alto de nossos mil anos de história! Quem teria pensado a trinta anos atrás que as ditaduras militares mais arraigadas se eclipsariam uma a uma e que a democracia se consolidaria em plena crise econômica internacional? Quem imaginaria que os Estados da América Latina se tornariam porta-voz dos países do Sul, negociando ativamente e propondo planos econômicos e comerciais ao mundo? Não apenas a América Latina entrou em cena com seus procedimentos de concerto e seus atores internacionais, mas no subcontinente, a história está de novo em marcha. Seria um erro ignorá-lo.

Alain Roquie, O Extremo Ocidente, 1991 


\section{APRESENTAÇÃO DO CAPÍTULO 5}

O capítulo 5 avalia os processos de compatibilização das organizações de integração sul-americana com as regras da OMC. Tal capítulo se justifica em razão da necessidade de compreender em que medida a adesão à OMC, a incorporação dos novos acordos internacionais, bem como a sujeição aos órgãos da OMC, impactaram o policy space dos Estados da América do Sul.

O subcapítulo 5.1. discute os parâmetros deste novo cenário internacional, no qual a América do Sul se insere, decorrente do Consenso de Washington e do Regionalismo Aberto da CEPAL e de como estes causaram uma profunda transformação, em razão da adequação dos antigos modelos de desenvolvimento, nacionais e regionais, aos novos parâmetros jurídicos, políticos e econômicos do neoliberalismo.

O subcapítulo 5.2 apresenta o processo de internalização e implantação dos acordos de OMC pelas organizações de integração da América do Sul. De maneira específica, será apresentado um levantamento dos acordos e protocolos celebrados no âmbito das organizações sul-americanas, ALADI, MERCOSUL e CAN, relacionados aos novos temas decorrentes da OMC: comércio de serviços, investimentos e propriedade intelectual.

Por fim, o subcapítulo 5.3 faz uma avaliação dos processos de análise de compatibilidade das organizações de integração da América do Sul que tramitaram e tramitam junto à OMC, nos diversos Conselhos e Comitês competentes, relacionados às organizações de integração sul-americanas, desde a constituição da ALALC, passando pelas notificações de ALADI e CAN, até o atual estágio de análise do MERCOSUL. Menção será finalmente feita aos casos julgados pelo OSC sobre o MERCOSUL, a única das organizações de integração sul-americanas que já teve os fundamentos jurídicos da sua integração regional avaliadas pelo OSC. 


\subsection{O REGIONALISMO NEOLIBERAL DA AMÉRICA DO SUL}

\section{a) Da "década perdida" ao Consenso de Washington}

A década de 1980 representou para os países em desenvolvimento, em especial os da América do Sul, um período conhecido como a "década perdida", considerando-se os altos níveis de dívida externa, o baixo crescimento econômico, bem como a deterioração dos termos comerciais. A América do Sul foi confrontada por crises de dívida externa, pressões de agências e organizações econômicas internacionais, e estagnação econômica, razão pela qual os países em desenvolvimento passaram a afastar-se dos modelos econômicos desenvolvimentistas, estatizados, e passaram a mover-se em direção às políticas econômicas mais orientadas para o mercado.

Até os anos 1980, as políticas de industrialização de muitos países em desenvolvimento eram baseadas na substituição de importações para promover as indústrias nascentes. Barreiras comerciais, controles cambiais e regulações mais favoráveis às indústrias nacionais foram instrumentos que estavam a serviço desta estratégia. Dentre as medidas comerciais adotadas, destacam-se:

- Restrições quantitativas às importações;

- Restrições ao licenciamento de importações;

- Altas tarifas, não comprometidas nos compromissos do GATT;

- Subsídios domésticos e subsídios às exportações para indústrias nascentes.

- Incentivos fiscais para industriais nacionais, não extensíveis às indústrias estrangeiras.

$\mathrm{Na}$ década de 80 , os países em desenvolvimento efetuaram mudanças fundamentais em suas políticas econômicas e nas respectivas estratégias de desenvolvimento, que passaram a se orientar por uma extensa agenda de liberalização econômica e comercial. No início dos anos 80, muitos países em desenvolvimento que tinham economias com grande intervenção estatal estavam estagnados e sendo mantidos por excessivos empréstimos internacionais. Quando a 
dívida externa cresceu para além do sustentável, os governos passaram a balizar suas políticas econômicas por outras diretrizes, que não as de seu passado recente.

Nesse contexto, os organizações e agências econômicas internacionais que estavam realizando os empréstimos para a América do Sul, tais como FMI e BIRD, passaram a condicionar novos empréstimos à reformas econômicas que viabilizaram futuros empréstimos.

Estas prescrições que o FMI e o BIRD iniciaram nesta época foram denominadas como Consenso de Washington. Dentre as principais prescrições do Consenso, destacam-se: ${ }^{231}$

\section{Tabela 14. Premissas do Consenso de Washington}

\begin{tabular}{|l|}
\multicolumn{1}{|c|}{ Premissas do Consenso de Washington } \\
1. \\
2. Disciplina fiscal \\
3. Reorientação dos gastos públicos \\
4. Liberalização financeira \\
5. \\
6. Taxas de câmbio unificadas e competitivas \\
7. Aberalização comercial para investimentos estrangeiros diretos \\
8. Privatização \\
9. Desregulação \\
10. Direitos de propriedade intelectual \\
11. Reformas jurídico-políticas \\
12. Instituições regulatórias \\
13. Combate à corrupção \\
14. Flexibilização das regras trabalhistas \\
15. Adesão aos acordos da OMC \\
16. Adoção de códigos e padrões financeiros \\
17. Abertura monetária \\
18. Regimes cambiais não-intermediários \\
19. Redes de seguridade social \\
20. Redução da pobreza \\
\hline
\end{tabular}

Durante esse período, passou a viger a perspectiva contrária à lógica do desenvolvimentismo. A partir de então, o desenvolvimento se produziria graças às liberdades econômicas de mercado, de livre comércio e livre estabelecimento,

${ }^{231}$ RODRIK, Dani. Development strategies for the next century. World Bank, Annual World Bank Conference on Development Economics, 2001. 
garantidas por governos democráticos que respeitassem os direitos humanos e o Estado de Direito.

Nesse sentido, o Consenso de Washington afirmava que o impedimento ao desenvolvimento dos países pobres, em muitos casos se deu precisamente por ocasião da existência de governos ineficientes e corruptos, que interferiam indevidamente em suas economias, impedindo o desenvolvimento normal dos mercados. A transparência, o bom governo, o respeito ao Estado de Direito, o livre comércio e a internacionalização das economias tornaram-se instrumentos-chave para assegurar o desenvolvimento econômico.

Muito embora o núcleo das reformas oriundas do Consenso fosse de natureza financeira e monetária, os elementos de política comercial e os relacionados ao comércio formavam parte importantíssima desse período de reformas das estruturas estatais dos países em desenvolvimento.

Do ponto de vista comercial, as estratégias de desenvolvimento deveriam estar fundadas nas seguintes premissas:

- Políticas de desenvolvimento setorialmente neutras, que não apoiasse setores específicos, especialmente industriais, à custa de outros, tais como agricultura;

- Crescimento fundado em exportações;

- Industrialização baseada em vantagens comparativas.

Nesse sentido, a Rodada Uruguai apresentava-se como um momento fundamental para a consolidação jurídica de diversas premissas do Consenso de Washington. Embora o Consenso tenha sido demasiadamente rígido e excessivo para com os países em desenvolvimento, muitas das suas premissas permanecem vigentes no seio das organizações econômicas internacionais, inclusive da OMC e influenciaram permanentemente a constituição dos modelos econômicos, nacionais e regionais, da América do Sul. 


\section{b) O regionalismo aberto da CEPAL}

Nos anos 1990, as iniciativas de integração regional da América do Sul passaram por uma série de transformações, a fim de se adaptar às premissas neoliberais propugnadas pelo Consenso de Washington, e para se adaptar ao regionalismo aberto da CEPAL.

Por ocasião da elaboração de documento da CEPAL em 1994, utilizou-se o conceito de "Regionalismo Aberto", definido como um processo de integração que tem como objetivo:

Fazer da integração um alicerce que favoreça uma economia internacional mais aberta e transparente, em vez de ela se converter num obstáculo que a impeça, com isso restringindo as opções ao âmbito dos países da América Latina e Caribe. Isso significa que os acordos de integração devem tender a eliminar as barreiras aplicáveis à maior parte do comércio de produtos e serviços entre os signatários, no contexto de suas políticas de liberalização em relação a terceiros, ao mesmo tempo em que é favorecida a adesão de novos Membros aos acordos. ${ }^{232}$

De acordo com Marcio Bobik Braga:

Em suma, o regionalismo aberto, tal como concebido pela CEPAL, pode ser entendido como uma estratégia de se buscar uma maior eficiência econômica a partir da integração regional, tendo como objetivo melhorar a posição da região no novo contexto econômico internacional, caracterizado pelas intenções no sentido de se buscar um comércio mais livre, intenções estas que têm se manifestado pelas inúmeras rodadas de negociação no âmbito do GATT/Organização Mundial do Comércio $\mathrm{OMC}^{233}$

Portanto, há uma mudança fundamental em relação ao ideal presente entre os anos 60 e 80 , em que o objetivo era criar estruturas produtivas com base na ampliação dos mercados regionais; a partir do regionalismo aberto, a competitividade seria alcançada pela ampliação do mercado para o plano global. Este ideário passa a repercutir no âmbito das organizações de integração regional da América do Sul, tanto no plano regional, com a abertura da ALADI, quanto nos planos subregionais, com os avanços da integração no MERCOSUL e na CAN.

\footnotetext{
${ }^{232}$ CEPAL, 1994, p.945 in BRAGA; DONIZETE. op. cit. p. 66
}

${ }^{233}$ BRAGA; DONIZETE. op. cit. p. 67. 


\section{c) A abertura da ALADI}

Em 10 de março de 1994, reuniram-se na cidade de Buenos Aires os ministros da Economia e de Relações Exteriores dos quatros Estados Membros do MERCOSUL, a pedido do Brasil, com a finalidade de avaliar a estratégia a adotar, diante das consequências que a entrada em vigor do NAFTA ( $1^{\circ}$ de janeiro de 1994) teria para os processos de integração regional da América do Sul. A participação do México no bloco do Norte afetaria significativamente a dinâmica da ALADI.

Isso porque o ingresso do México no NAFTA acarretava a concessão de preferências aduaneiras a seus novos sócios (Canadá e Estados Unidos), sem estendê-las aos demais Membros da ALADI, conforme o México estava obrigado a fazer, nos termos do artigo 44 do TM-80.

$\mathrm{O}$ artigo 44 dispõe que:

As vantagens, favores, franquias, imunidades e privilégios que os paísesMembros apliquem a produtos originários de ou destinados a qualquer outro Estado Membro ou não, por decisões ou acordos que não estejam previstos no presente Tratado ou no Acordo de Cartagena, serão imediata e incondicionalmente estendidas aos demais Estados Membros.

Devido ao descumprimento das obrigações assumidas pelo México no TM80, o Brasil propôs sua exclusão da ALADI, como sanção exemplar contra países que adotassem semelhante posição, conspirando contra a integração regional latino-americana, exclusivamente em benefício do desenvolvimento nacional.

A fim de não ter de pagar o custo político decorrente do seu afastamento da ALADI para unir-se a um país como os EUA, historicamente rejeitado pelo discurso político regional, o México tratou de forçar a modificação dos postulados do TM-80. A aplicação estrita do tratado da ALADI obrigava-o a estender aos Membros da ALADI os benefícios outorgados aos sócios do NAFTA, e a não extensão implicava a incompatibilidade da presença do México nos dois esquemas. 
Assim, a proposta brasileira não obteve apoio da maioria dos Membros da ALADI, que acabaram por aprovar e assinar o Protocolo Interpretativo do Art. 44 do Tratado de Montevidéu de 1980, juntamente com as Normas para o Período de Transição até a entrada em vigor do Protocolo Interpretativo, conhecido como Protocolo de Cartagena.

O Protocolo enfraqueceu o conteúdo do artigo 44, relativizando um preceito fundamental de todo processo de integração, a cláusula da nação mais favorecida, que prioriza os Estados Membros em detrimento de países terceiros. $\mathrm{O}$ artigo $2^{\circ}$ do Protocolo determinou que:

\footnotetext{
Sem prejuízo do estabelecido no artigo anterior (artigo 44), os paísesMembros que fizerem parte dos acordos a que se refere esse artigo poderão solicitar ao Comitê de Representantes a suspensão temporária das obrigações estabelecidas no artigo 44 do Tratado de Montevidéu 1980, fornecendo os fundamentos que apoiam sua solicitação.
}

No entanto, se é verdade que o Protocolo de Cartagena enfraqueceu a unidade do processo de integração, por ser reflexo do período de regionalismo aberto vivenciado pela América Latina, é igualmente verdade que este protocolo permitiu uma abertura da integração sul-americana, proporcionando aos Estados Membros da ALADI celebrar acordos comerciais com terceiros países, alternativa que antes do Protocolo estava proibida.

Se, na época, o Protocolo de Cartagena foi considerado uma declaração de óbito da unidade latino-americana, a abertura internacional pela qual passa a ALADI na primeira década do século XXI pôde the conferir novo fôlego, como se depreende das diversas iniciativas extrarregionais dos Membros da ALADI, tais como os acordos extrarregionais do MERCOSUL, dos Membros da Comunidade Andina e do Chile. Isto será tema de análise da Parte III desta tese.

\section{d) Os avanços e obstáculos no MERCOSUL e na CAN}


A primeira década do MERCOSUL presenciou o estabelecimento da Zona de Livre Comércio, da União Aduaneira e de sua estrutura institucional. A partir de então, o progresso na integração tornou-se cada vez mais difícil. A Zona de Livre Comércio e a União Aduaneira não se completaram, os compromissos foram perdendo credibilidade, tendo-se em vista a ausência de internalização em cada Estado Membro, e uma multiplicação de conflitos inter-setoriais que não encontravam eco nos canais institucionais na estrutura vigente da organização internacional. A divergência entre as políticas macroeconômicas alcançou seu apogeu quando da desvalorização cambial levada adiante pelo Brasil em 1999.

A CAN também avançou nos anos 1990, alcançando uma completa liberalização de comércio de bens, e um relevante progresso institucional. Assim como no MERCOSUL, o comércio intra-regional da CAN cresceu com maior dinâmica na primeira metade da década de $90 .{ }^{234}$ Além disso, a estrutura institucional incorporou o Conselho Presidencial Andino e o Conselho Andino de Ministros, a Secretaria Geral.

Tal qual no caso do MERCOSUL, a CAN enfrentou uma série de desafios ao final da década de 90, no que se refere à implantação definitiva da Zona de Livre Comércio e da Tarifa Externa Comum. As tensões eram particularmente agudas em relação às negociações com os países desenvolvidos, já que a CAN nunca criou uma regra, tal qual a do MERCOSUL, que obrigasse a negociação e celebração conjunta dos acordos internacionais.

Ambas as iniciativas, constituídas no âmbito da ALADI, tornaram-se os principais eixos da integração sul-americana durante a década de 90, época em que as políticas de substituição de importações estavam sendo abandonadas. A nova ambição destes dois novos projetos consolidava, ao mesmo tempo: a liberalização do comércio de bens e serviços, a proteção dos investimentos, o estabelecimento de uma tarifa externa comum.

De fato, ambas as iniciativas progrediram muito em termos de liberalização comercial. No entanto, após o sucesso inicial, ambas perderam o brilho e enfrentaram uma série de obstáculos. Tais obstáculos foram agravados pelas

\footnotetext{
${ }^{234}$ INTAL-IADB. Andean Report n. 1, 2002-2004, Buenos Aires: BID, 2005.
} 
sucessivas crises do final dos anos de 1990: Brasil (1998), Equador (1999), Argentina (2000) e Bolívia (2001).

Enfim, apesar de as iniciativas integracionistas - MERCOSUL e CAN terem alcançado relativo sucesso na liberalização comercial de bens, progrediram pouco nos demais temas relacionados ao comércio, introduzidos na agenda internacional da época com a criação da OMC, tais como regras de origem, medidas sanitárias e fitossanitárias, barreiras técnicas e demais questões aduaneiras.

Ainda menos progresso se alcançou em relação aos temas da propriedade intelectual, serviços, investimentos e compras governamentais. Tendo-se em vista a relevância destes temas para o aprofundamento dos processos de integração da América do Sul, será analisado com mais detalhe o processo de regulação de tais temas no âmbito do MERCOSUL e da CAN.

\subsection{A INCORPORAÇÃO DAS REGRAS DA OMC NA INTEGRAÇÃO SUL-AMERICANA}

a) Comércio de serviços na integração sul-americana

\section{i. Comércio de serviços na ALADI}

Desde a entrada em vigor da ALADI, o tratado constitutivo já previa a negociação para a liberalização do comércio de serviços. O artigo 14 do TM80 refere-se, ao menos indiretamente, ao comércio de serviços, por fazer menção, "entre outras matérias, à promoção do turismo".

Este artigo foi regulado de maneira mais precisa pela Resolução $\mathrm{n}^{\circ} 54$ do Comitê de Representantes Permanentes, de agosto de 1986 que, no artigo $1^{\text {o }}$, autoriza expressamente os Estados Membros da ALADI a firmarem acordos de 
alcance parcial (AAP) em matéria de serviços, na modalidade de acordos de complementação econômica (ACE).

Com o avanço das negociações na Rodada Uruguai, e pouco antes da entrada em vigor do GATS, o Conselho de Ministros expressou a necessidade de elaborar um Acordo-Quadro sobre serviços, que foi apresentado, em 1993, como um anteprojeto. Trata-se do "Acordo-Quadro de Princípios e Normas para o Comércio Regional de Serviços".

Tal acordo nunca foi firmado e atualmente os compromissos sobre serviços contraídos pelos países Membros da ALADI estão sujeitos ao GATS, estendidos a todos os demais Membros da OMC. As exceções a esta regra são os compromissos firmados no âmbito de ACE.

Atualmente, existe um grande universo de ACE que contem disposições sobre comércio de serviços no âmbito da ALADI. ${ }^{235}$ No entanto, os dois mais relevantes decorreram das negociações sub-regionais, que culminaram na Decisão CMC n $n^{\circ} 13 / 97$ do MERCOSUL, Protocolo de Montevidéu, e na Decisão $n^{\circ}$ 439/98 da Comunidade Andina, que foi recentemente complementada pela Decisão $n^{\circ}$ 659/06.

\section{ii. Comércio de Serviços no MERCOSUL}

A liberalização do comércio de serviços esteve na agenda do MERCOSUL desde os primeiros momentos do processo de integração. No entanto, foi apenas em novembro de 1997 que se celebrou um protocolo sobre comércio de serviços no MERCOSUL, chamado de Protocolo de Montevidéu. Como em todo acordo sobre comércio de serviços, além do texto geral do acordo, foi necessário negociar e consolidar os setores para os quais os compromissos do acordo serão aplicáveis. A redação de tais anexos foi concluída apenas no ano seguinte.

\footnotetext{
${ }^{235}$ Ver relação de ACE envolvendo comércio de serviços no âmbito da ALADI na página http://www.aladi.org/nsfaladi/nuevostemas.nsf/vtema/comercio\%20de $\% 20$ servicios?OpenDocum ent $\&$ Start $=1 \&$ Count $=120 \&$ Collapse $=1$. Acesso em 03/09/2012.
} 
O Protocolo de Montevidéu entrou em vigor após a ratificação de três dos Membros, Argentina, Brasil e Uruguai, em 7 de dezembro de 2005. O Paraguai ainda está pendente de ratificação. ${ }^{236}$

O Protocolo de Montevidéu expressamente dispõe que é parte integrante do Tratado de Assunção. Trata-se de um acordo entre quatro Membros da OMC, razão pela qual estes optaram em projetá-lo à luz do GATS, adotando a maioria das suas disposições sem qualquer modificação ou adaptação.

Com base no artigo $1^{\circ}$, o objetivo do Protocolo é promover o livre comércio de serviços dentro do MERCOSUL. Para que isto se concretize, esta liberalização deve acontecer de maneira compatível com as condições estabelecidas pelo GATS, no artigo VI, que requer essencialmente que acordos de integração econômica tenham uma "cobertura substancial dos setores", além de providenciar a eliminação de "substancialmente todas as discriminações".

Com base no Protocolo, o Programa de Liberalização do Comércio de Serviços contem um mecanismo para avançar na liberalização comercial através da negociação de compromissos específicos em acesso a mercados e tratamento nacional.

Tal mecanismo fundamenta-se por meio de uma "lista positiva", que consiste em uma estratégia de liberalização gradual pela qual os Membros inscrevem em suas listas nacionais de compromissos os setores com os quais eles pretendem firmar compromissos específicos sobre acesso a mercados e tratamento nacional.

Com base no Programa, os Estados Membros devem conduzir rodadas sucessivas de negociações com vistas à inclusão progressiva de setores, subsetores atividades e modos de oferta de serviços, bem como a redução ou eliminação de medidas restritivas ao comércio de maneira que assegure efetivo acesso a mercado.

\footnotetext{
${ }^{236}$ A página para acompanhar o andamento das ratificações dos instrumentos jurídicos do MERCOSUL é o site do Ministério das Relações Exteriores do Paraguai, depositário de todos os instrumentos jurídicos

do MERCOSUL.http://www.mre.gov.py/dependencias/tratados/mercosur/registro\%20mercosur/me rcosurprincipal.htm
} 
Ocorre que, após sete rodadas de negociações, devido à ausência de vontade política, apenas uma consolidação parcial do status quo dos sistemas jurídicos dos Estados Membros foi alcançada até o momento. ${ }^{237}$

iii. Comércio de serviços na Comunidade Andina

Desde o surgimento do Pacto Andino, o Acordo de Cartagena prevê, no artigo 3, alínea "h", a criação de programas no campo de serviços e a liberalização do comércio intra-sub-regional de serviços. O capítulo VII do mesmo Acordo especifica, nos artigos 79 e 80, que a Comissão da Comunidade Andina, deve estabelecer um "marco geral de princípios e normas para alcançar a liberalização do comércio intra-sub-regional de serviços".

Nesse sentido, em 11 de junho de 1998, a Comissão aprovou, por meio da Decisão n ${ }^{\circ}$ 439/98, o Marco Geral de Princípios e Normas para a Liberalização do Comércio de Serviços na Comunidade Andina.

O Marco Geral estabelece as bases gerais para a liberalização da prestação de serviços da CAN. Define o campo de aplicação, o volume de liberalização de serviços, os diferentes regimes e as principais normas e princípios para liberalização na CAN.

A Decisão no 510 de 2001, da Comissão da Comunidade Andina, aprovou as listas nacionais dos Estados Membros. Como definido na Decisão n ${ }^{\circ} 439$, o método da liberalização foi o das listas negativas. Portanto, apenas os setores e subsetores listados na Decisão $n^{\circ} 510$ estariam excluídos das regras de liberalização.

Em 14 dezembro de 2006 se culminou o processo de aperfeiçoamento do comércio de serviços da CAN. Com a aprovação da Decisão n ${ }^{\circ}$ 659, a CAN

\footnotetext{
${ }^{237}$ As atas das sete Rodadas de Negociação sobre compromissos específicos para a liberalização de serviços no MERCOSUL estão disponíveis na página da ALADI, http://www.aladi.org/nsfaladi/nuevostemas.nsf/vtema/comercio $\% 20 \mathrm{de} \% 20$ servicios?OpenDocum ent\&Start $=1 \&$ Count $=120 \&$ Expand=3. Acesso em 03/09/2012.
} 
alcançou o processo de liberalização total do comércio de serviços. ${ }^{238}$ Apenas os setores de serviços financeiros e de Televisão Aberta Nacional estão regulados por normativas específicas setoriais de liberalização.

Por fim, cabe apontar que é facultado à Bolívia solicitar tratamento preferencial, sem reciprocidade, nos setores que considerar necessário, para o cumprimento das obrigações decorrentes da liberalização completa do comércio de serviços na CAN. Este Tratamento Especial e Diferenciado concedido à Bolívia foi estendido até dezembro de $2014 .^{239}$

iii. As diferenças de métodos de MERCOSUL e CAN em relação a serviços: lista positiva ou lista negativa?

A técnica de produção de listas negativas, que é absolutamente prevalecente hoje no grupo estatal ocidental, foi apresentada pela primeira vez no NAFTA, que entrou em vigor em $1^{\circ}$ de janeiro de 1994. Posteriormente, o México "exportou" esta técnica de liberalização para seus acordos bilaterais com Estados da América Central e do Sul (Bolívia, Chile, Costa Rica, Nicarágua), bem como para acordos regionais (Triangulo do Norte). Tal técnica foi igualmente adotada no CARICOM.

$\mathrm{Na}$ Comunidade Andina, também se utilizou essa modalidade de negociação. Contudo, de forma modificada, uma vez que ela postulou o alcance de uma liberalização global dentro de um determinado prazo.

Ao contrário da Comunidade Andina que, reconhecendo o modelo prevalecente do NAFTA e demais acordos bilaterais firmados pelos países da América do Sul, trabalha com o sistema de listas negativas; foi no âmbito do MERCOSUL que se utilizou com exclusividade na região, o método das listas positivas.

Somente o MERCOSUL adota o sistema de listas positivas na América Latina, introduzido pelo Protocolo de Montevidéu (1997), o qual, contudo, é

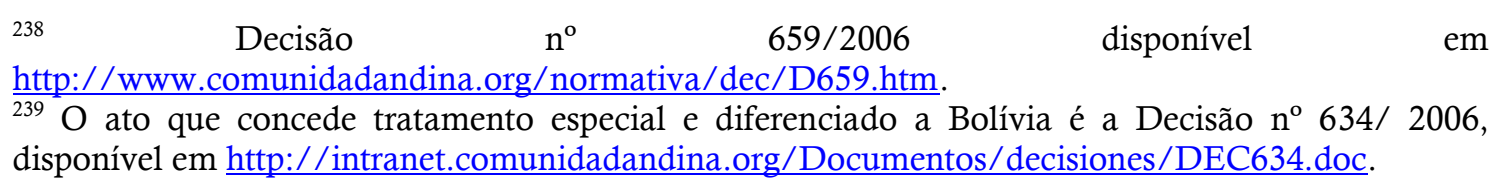
disponível em http://intranet.comunidadandina.org/Documentos/decisiones/DEC634.doc. 
classificado tanto com uma variante da modalidade de lista positiva, por ser uma forma de lista híbrida. Isto porque, através de rodadas anuais de negociação dentro de um período fixo de 10 anos depois da entrada em vigor do Protocolo, deve-se alcançar uma liberalização em todas as áreas de serviços.

Há também outra característica, decorrente da Resolução GMC n ${ }^{\circ}$ 36/00, conhecida como clausula Stand Still ou Status Quo, que proíbe a introdução de novas restrições a partir da metade de do ano de 2002, razão pela qual é também reconhecida como uma técnica de lista negativa. Por isso, afirma-se que a regulação do comércio de serviços no MERCOSUL tem uma natureza hibrida.

Nesse sentido, o fato do processo de liberalização estar vinculado ao direito à regulação dos Membros, isto é, manter o policy space para implantar políticas públicas legítimas em determinados setores ou subsetores, seria uma "contradição crassa" no contexto de um processo de integração como o MERCOSUL. ${ }^{240}$ Ao contrário, trata-se de um mecanismo de "equilíbrio", extremamente necessário, especialmente quando as assimetrias entre as partes são realmente levadas em consideração.

Umberto Celli Junior, ao analisar a escolha do método de listas positivas, afirma que:

\footnotetext{
Parece não haver razão para crer que também é o mecanismo mais apropriado para o Programa de Liberalização do Comércio de Serviços do MERCOSUL, tendo em vista a assimetria entre os Membros. É igualmente a estratégia mais segura para garantir o desenvolvimento de indústrias nascentes de serviços, que necessitam de proteção temporária. ${ }^{241}$
}

De todo modo, o Protocolo de Montevidéu essencialmente reproduz as principais características do GATS, que tende a favorecer os países em desenvolvimento: flexibilidade, liberalização progressiva por meio de listas positivas, e a manutenção de policy space dos Membros para implantar políticas públicas através da regulação de setores e subsetores de serviços. Tal qual o GATS, o Protocolo de Montevidéu deve manter sua essência e sua estrutura, se o objetivo fim da integração em matéria de serviços não for a mera liberalização per si.

${ }^{240}$ GARI, Gabriel. 2009, p.140.

${ }^{241}$ CELLI JR. Umberto. 2009, p. 126. 


\section{b) Comércio e investimentos no MERCOSUL e na CAN}

\section{i. Investimentos no MERCOSUL}

No marco regulatório do MERCOSUL, há dois Protocolos concernentes a investimentos: o Protocolo de Colônia sobre Proteção e Promoção Recíproca de Investimentos (1994) e o Protocolo de Buenos Aires para a Promoção e Proteção de Investimentos originários de países não Membros do MERCOSUL (1995).

O Protocolo de Colônia trata de investimentos intra-regionais, isto é, investimentos realizados por investidores de um Estado Membro em outro Estado Membro. O amplo conceito de investimento é adotado pelo Protocolo de Colônia. Também contém regras sobre a entrada e o estabelecimento de capitais, tratamento, proteção, transferência de fundos, garantias, solução de controvérsias, entre outros.

Já o Protocolo de Buenos Aires foi concebido com o propósito de harmonizar entre os Membros do MERCOSUL o tratamento advindo de Estados não Membros.

Nenhum dos protocolos está em vigor, tendo-se em vista as pendências nas ratificações dos Membros do MERCOSUL. A tabela abaixo apresenta o atual estágio das ratificações em cada Estado Membro.

Tabela 15. Processo de ratificação dos Protocolos sobre Investimentos do MERCOSUL $^{242}$

\begin{tabular}{|c|c|c|c|c|}
\hline & Argentina & Brasil & Paraguai & Uruguai \\
\hline $\begin{array}{l}\text { DEC. N } N^{0} 11 / 93 \text { - Protocolo de Colônia } \\
\text { para Promoção e Proteção Recíproca de } \\
\text { Investimentos no MERCOSUL, } 1994\end{array}$ & Pendente & Pendente & Pendente & Pendente \\
\hline $\begin{array}{l}\text { DEC. } \mathrm{N}^{\circ} 11 / 94 \text { - Protocolo de Buenos } \\
\text { Aires para Promoção e Proteção de } \\
\text { Investimentos Originários de Estados não- } \\
\text { Membros do MERCOSUL, } 1994\end{array}$ & $\begin{array}{l}\text { Lei: } \quad 24.554 \\
\text { Depósito: } \\
\text { 14/03/1996 }\end{array}$ & Pendente & $\begin{array}{l}\text { Lei: } \quad 593 \\
\text { Depósito: } \\
\text { 12/09/1995 }\end{array}$ & $\begin{array}{l}\text { Lei: } \quad 17.531 \\
\text { Depósito: } \\
\text { 11/07/2003 }\end{array}$ \\
\hline
\end{tabular}

\footnotetext{
${ }^{242}$ Ministério de Relações Exteriores do Paraguai. Acesso em 21/06/2010.
} 
Devido a ausência de regras comuns de investimentos, os Membros têm firmado acordos bilaterais de investimentos com diversos países.

Os Membros do MERCOSUL não podem mais tardar em ratificar ambos os protocolos. Todavia, isto não será tarefa fácil. Com base no Protocolo de Buenos Aires, as disputas devem ser resolvidas perante o International Centre for Settlement of Investment Disputes (ICSID), a quem o Brasil não está sujeito por não ser signatário da Convenção de Washington de 1965.

Assim que ratificados os protocolos, o MERCOSUL estará melhor preparado para negociar acordos regionais de comércio e celebrar acordos sul-sul. O maior desafio, no entanto, será negociar acordos nos quais as disposições apresentem um equilíbrio entre a necessidade de atrair, promover e proteger investimentos estrangeiros, e ao mesmo tempo preservar o policy space dos Membros para implantar políticas industriais para o desenvolvimento.

Tal como no caso do comércio de serviços, as disposições sobre investimentos serão parte integrante dos acordos de integração a serem firmados pelo MERCOSUL nos próximos anos com países desenvolvidos ou em desenvolvimento, seja com base na cláusula de habilitação ou no SGPC.

A questão surge sobre o modo que o MERCOSUL deve negociar tais acordos. Se quer ter regras comuns internas sobre investimentos, seja para investimentos intra-regionais, seja de países de fora do MERCOSUL. Isso permanece uma situação normativamente complicada.

\section{ii. Investimentos na Comunidade Andina}

O instrumento jurídico que contempla as regras em matéria de investimentos aplicáveis à Bolívia, Colômbia, Equador, Peru e Venezuela é a Decisão no 291, sobre o Regime de Tratamento aos Investimentos Estrangeiros, de março de 1991. Tal decisão abrange temas relacionados com: definição de investimento e investidor; tratamento nacional; exceções e reservas; compensações por prejuízos; e solução de controvérsias. 
Na Comunidade Andina há duas normas comunitárias em matérias de investimentos vigentes desde 1991: a Decisão 291243, sobre "Regime Comum de Tratamento dos Capitais Estrangeiros e sobre Marcas, Patentes, Licenças e Concessões"; e a Decisão $292^{244}$, sobre "Regime Uniforme para Empresas Multinacionais Andinas".

O regime comum de investimentos estrangeiros garante um tratamento igualitário e não-discriminatório aos Estados Membros e a liberdade de definir suas políticas de investimento através das suas respectivas legislações nacionais. Esta norma comunitária está atualmente em processo de revisão.

Já o regime de empresas multinacionais andina contempla medidas para preservar e estimular a associação de investidores nacionais nos Estados Membros, para a execução de projetos de interesse compartilhado e alcance multinacional.

De acordo com a Decisão n ${ }^{\circ} 292$, as empresas multinacionais andinas se definem como aquelas nas quais ao menos $60 \%$ do capital social pertence a investidores de dois ou mais países da Comunidade Andina. A estas empresas se outorga tratamento nacional em matérias de compras públicas de bens e serviços; o direito a envio de divisas com liberdade de conversão cambial na totalidade dos dividendos de direito; o tratamento nacional em matéria tributária; e o direito de estabelecer filiais em outros Estados Membros.

Desde 2003, está em andamento a Agenda Estratégica Andina de Promoção de Investimentos, no âmbito da qual deveria ser realizada a avaliação de ambas as normas comunitárias com o objetivo de atualizá-las. No entanto, tal agenda está atualmente paralisada.

No que se refere ao regime comum de investimentos estrangeiros, os Estados Membros da CAN estão levando adiante tal regulação por meio de tratados bilaterais de investimentos entre si. Atualmente, existem os seguintes tratados bilaterais dentro da CAN:

\begin{tabular}{|c|c|c|c|c|c|}
\hline & Decisão & $\mathrm{n}^{\mathrm{o}}$ & 291/1991. & Disponível & em \\
\hline 244 & omunida & g/no & ec/D291.ht & & \\
\hline
\end{tabular}


Tabela 16. Tratados Bilaterais de Investimentos Intra-CAN ${ }^{245}$

\begin{tabular}{|c|c|c|c|c|}
\hline & Bolívia & Colômbia & Equador & Peru \\
\hline Bolívia & & & Bilateral & Bilateral \\
\hline Colômbia & & & & Bilateral \\
\hline Equador & Bilateral & & & Bilateral \\
\hline Peru & Bilateral & Bilateral & Bilateral & \\
\hline
\end{tabular}

\section{c) Propriedade intelectual no MERCOSUL e na CAN}

\section{i. Propriedade intelectual no MERCOSUL}

No contexto do MERCOSUL, a partir da Decisão CMC nº 8/95, teve inicio as primeiras negociações para a elaboração de acordos - a partir das normas vigentes na matéria - que protegessem adequadamente os direitos de Propriedade Intelectual no MERCOSUL.

Assim, foi criado em 1995, por meio da Decisão $\mathrm{n}^{\circ}$ 8/95, o Protocolo de Harmonização de Normas sobre Propriedade Intelectual no MERCOSUL. ${ }^{246}$ Tal decisão tem um objetivo harmonizador, e não de criar um marco regulatório comum. Cada país manteve sua legislação nacional em matéria de propriedade intelectual.

O Protocolo de Harmonização já foi internalizado por Paraguai (1996) e Uruguai (1998). Na Argentina e no Brasil, ainda está pendente de ratificação.

As principais legislações nacionais sobre direitos de propriedade intelectual nos Membros do MERCOSUL são as seguintes: ${ }^{247}$

\footnotetext{
245

Disponível

em http://www.comunidadandina.org/Seccion.aspx?id=91\&tipo=TE\&title=inversiones. Acesso em $10 / 12 / 2012$.

${ }^{246}$ MERCOSUL/CMC/DEC. N 8/95 - Protocolo de harmonização de normas sobre propriedade Intelectual no MERCOSUL, em matéria de marcas, indicações de Procedência e denominações de origem.

${ }^{247}$ Para acessar a legislação vigente em matéria de direitos da propriedade intelectual nos paísesMembros do MERCOSUL, ver página da OMPI: http://www.wipo.int/wipolex/es/index.jsp. Acesso em 25/09/2012.
} 
Tabela 17. Legislações nacionais sobre propriedade intelectual no MERCOSUL

\begin{tabular}{|c|c|c|c|}
\hline Argentina & Brasil & Paraguai & Uruguai \\
\hline Leis de Propriedade & Lei de Propriedade & Lei de Patentes $n^{\circ}$. & Lei de Marcas $n^{\circ}$. \\
\hline Intelectual $\mathrm{n}^{\circ}$ & Industrial $\mathrm{n}^{\circ} 9.279 / 96$. & 1630/00; Lei de & 17.011/98 e Lei de \\
\hline 26.570/09, que & & Marcas n ${ }^{\circ} .1 .294 / 98 ;$ & Patentes $\mathrm{n}^{\circ} .17 .167 / 99$ \\
\hline atualiza a Lei & & Lei de Direitos do & \\
\hline $11.723 / 33$ & & Autor $\mathrm{n}^{\circ} .1 .328 / 96$ & \\
\hline
\end{tabular}

\section{ii. Propriedade intelectual na Comunidade Andina}

Ao contrário do MERCOSUL, a Comunidade Andina possui uma normativa comum, moderna e completa, em matéria de propriedade intelectual. $\mathrm{O}$ conjunto normativo andino que regula os direitos de propriedade intelectual é composto pelas seguintes normas comunitárias:

- Regime Comum de Propriedade Industrial (Decisão $\left.n^{\circ} 486 / 2000\right)^{248}$

- Regime Comum sobre Direitos do Autor e Direitos Conexos (Decisão n ${ }^{\circ}$ $351 / 1993)^{249}$

- Regime de Proteção dos Direitos dos Obtentores Vegetais (Decisão n ${ }^{\circ}$ $345 / 1993)^{250}$

- Regime Comum sobre Acesso aos Recursos Genéticos (Decisão n o 391/1996) 251

O Regime Comum de Propriedade Industrial da Comunidade Andina regula a outorga de marcas e patentes e protege os segredos industriais e as denominações de origem, entre outros. Este regime incorpora aspectos relevantes do Acordo TRIPS e foi projetado com vistas a atrair investimentos nacionais e estrangeiros,

\footnotetext{
${ }^{248}$ Disponível em http://www.comunidadandina.org/normativa/dec/D486.htm

${ }^{249}$ Disponível em http://www.comunidadandina.org/normativa/dec/D351.htm

${ }^{250}$ Disponível em http://www.comunidadandina.org/normativa/dec/D345.htm

${ }^{251}$ Disponível em http://www.comunidadandina.org/normativa/dec/D391.htm
} 
pelo fato de estabelecer uma maior proteção aos direitos de propriedade intelectual, bem como procedimentos mais ágeis e transparentes para os registros de marcas e a outorga de patentes.

Já o Regime Comum sobre Direitos do Autor e Direitos Conexos regula a proteção dos autores e demais titulares sobre as obras de invenção, no campo literário, artístico ou científico.

Há também o Regime de Proteção dos Direitos de Obtentores Vegetais, que protege as novas variedades vegetais obtidas pelos fitomelhoradores. $\mathrm{Na}$ Comunidade Andina, as pessoas que criam ou obtém uma nova variedade vegetal gozam de direito exclusivo de produção e comercialização de tal planta por um prazo entre 15 e 25 anos.

Por fim, o Regime Comum sobre Acesso aos Recursos Genéticos regula a proteção dos conhecimentos, inovações e práticas tradicionais das comunidades indígenas. Esta norma comunitária reconhece, de forma expressa, os direitos que têm as comunidades indígenas, afroamericanas e locais, sobre seus conhecimentos tracionais associados aos recursos genéticos e seus produtos derivados. Com base nesta decisão, quem desejar utilizar e desenvolver os princípios ativos que contém as plantas e micro-organismos da região andina deverá contar com a autorização do órgão competente nacionais dos Membros da Comunidade Andina.

\subsection{A COMPATIBILIDADE DA INTEGRAÇÃO SUL-AMERICANA COM A OMC}

O subcapítulo 5.3 apresenta o atual estágio de compatibilidade das organizações internacionais de integração da América do Sul na OMC, com base nos relatórios do CRTA, atinentes a ALADI, CAN e MERCOSUL, bem como nos relatórios do OSC que foram emanados acerca do MERCOSUL, a única das organizações internacionais da América do Sul já julgada pelo OSC da OMC. 
a) Esclarecimentos sobre o processo de consideração dos acordos regionais de comércio pelo GATT e OMC

Durante os anos GATT, o exame dos acordos regionais era conduzido por grupos de trabalho, constituídos ad hoc para cada caso. O estabelecimento do Comitê de Acordos Regionais de Comércio (CRTA) em fevereiro de 1996 pelo Conselho Geral da OMC, como órgão responsável pelo exame dos acordos regionais de comércio, ajudou a orientar o processo de consideração e criou um fórum de discussão sobre temas transversais que eram comuns à maioria, senão a todos, os acordos regionais.

As duas principais responsabilidades do CRTA são de um lado, examinar individualmente cada acordo regional notificado a OMC, e de outro, avaliar os impactos sistêmicos que os acordos regionais de comércio causam para o sistema multilateral de comércio.

O CRTA possui três órgãos auxiliares de avaliação, dependendo da natureza jurídica do acordo regional. Os acordos notificados com base no artigo XXIV são dirigidos ao Conselho de Comércio de Bens (CTG), que adota os termos de referência e transfere o acordo para exame pelo CRTA. A notificação dos acordos sujeitos à Cláusula de Habilitação é dirigido ao Comitê de Comércio e Desenvolvimento (CTD). Os acordos regionais sobre comércio de serviços, que envolvem países desenvolvidos ou países em desenvolvimento, são notificados ao Conselho de Comércio de Serviços (CTS).

Há uma peculiaridade em relação aos procedimentos de notificação dos acordos regionais sobre bens, quando entre países em desenvolvimento. Quando da criação da Cláusula de Habilitação, em 1979, foi introduzida uma modificação extremamente relevante nos processos de exame pelo Conselho do GATT. Segundo o artigo $4^{\mathrm{o}}$ da Cláusula de Habilitação, qualquer parte contratante que pretenda instituir um acordo de integração regional, deverá:

Notificar as partes contratantes, fornecendo-lhes todas as informações que estas julgarem necessárias; e propiciar oportunidades adequadas para consultas expedidas, a pedido de qualquer parte contratante interessada, relativamente a qualquer dificuldade, ou assunto que possa surgir e, no caso de um pedido em tal sentido, o Conselho providenciará consultas 
entre os peticionários e as partes contratantes envolvidas no acordo de integração econômica, com fins de encontrar soluções satisfatórias entre todas.

Portanto, a partir da introdução da Cláusula de Habilitação, o procedimento dos Grupos de Trabalho ficou circunscrito àqueles assuntos que as partes contratantes julgassem apropriadas. No caso de não haver constituição de um grupo de trabalho, as obrigações dos Estados partes de um acordo de integração regional, em face das partes contratantes, são de simplesmente notificar-lhes a criação do acordo de integração regional e de apresentar-lhes relatórios periódicos bienais sobre o andamento da implantação do empreendimento.

Este procedimento discricionário diferenciado criado pela Cláusula de Habilitação é de extrema relevância para o estudo a seguir, pois justifica o fato de as iniciativas da ALADI e da CAN terem se resumido apenas à notificação com base na Cláusula de Habilitação, sem ter havido procedimento para análise de compatibilidade, enquanto que, para o MERCOSUL, as partes contratantes decidiram constituir um grupo de trabalho para tal acordo, o que fez que o MERCOSUL passasse a ser objeto de análise por seus próprios órgãos competentes, avaliação esta que até hoje encontra-se em andamento.

Antes de ingressar na análise de cada acordo, deve se ressaltar que, em 2006, o Conselho Geral estabeleceu um novo mecanismo para consideração dos ACR. Com base na Decisão o mecanismo de transparência para ACR consiste em seis etapas: ${ }^{252}$

- Anúncio prévio: Membros que estejam participando de negociações visando a conclusão de um ACR devem informar o Secretariado da OMC sobre tais negociações.

- Notificação: A notificação do ACR pelos Estados Membros deve ocorrer o mais cedo possível, preferencialmente antes da sua entrada em vigor, isto é, antes de concluído o processo de ratificação pelas partes. As partes devem especificar com base em qual dispositivo está sendo notificado tal acordo e apresentar o texto completo do acordo, bem como os devidos cronogramas, anexos e protocolos.

- Procedimentos para reforçar a transparência: Ao tempo da notificação, o Secretariado da OMC apresenta um cronograma preciso Segundo o qual o comitê ou conselho competente avaliar o acordo notificado a OMC. Tal consideração é prevista para ocorrer em até um ano.

- Apresentação dos fatos: O Secretariado da OMC elabora uma apresentação dos dados, a ser circulada entre todos os Membros da OMC, em todas as línguas

${ }^{252}(\mathrm{WT} / \mathrm{L} / 671)$ 
oficiais da organização, a fim de que questionamentos ou comentários sejam submetidos aos conselhos ou comitês competentes.

- Notificações subsequentes: Qualquer mudança relacionada a um ACR já implantado deve ser notificada o mais breve possível. Da mesma forma que na notificação inicial, as partes devem apresentar um sumário das mudanças, acompanhadas dos respectivos textos, cronogramas, anexos e protocolos.

- Relatório final: O procedimento do mecanismo de transparência se encerra com um relatório por meio do qual o Secretariado e o órgão competente apresentam um resumo final dos fatos concernentes ao ACR.

De acordo com a OMC, em outubro de 2012, 511 notificações de ACR já haviam sido apresentadas, incluindo bens, serviços, acordos entre países em desenvolvimento, bem como adesões de partes a acordos já em vigor. Deste total, 348 estavam em vigor. ${ }^{253}$

No que se refere aos diferentes fundamentos jurídicos com base no quais os acordos regionais de comércio foram notificados, o total está subdivido da seguinte forma:

Tabela 18. Acordos regionais notificados à OMC por fundamento jurídico

\begin{tabular}{|l|l||}
\hline & Total \\
\hline \hline GATT Art. XXIV (ZLC) & 191 \\
\hline \hline GATT Art. XXIV (UA) & 15 \\
\hline \hline Cláusula de Habilitação & 35 \\
\hline \hline GATS Art. V & 107 \\
\hline \hline Total & $\mathbf{3 4 8}$ \\
\hline
\end{tabular}

Já em relação ao mecanismo de transparência, o status geral das análises por estágio é o seguinte:

Tabela 19. Acordos regionais notificados à OMC por estágio de análise

\begin{tabular}{||l|l||l||l|l||}
\hline \hline & $\begin{array}{l}\text { Cláusula } \\
\text { de } \\
\text { Habilitação }\end{array}$ & $\begin{array}{l}\text { GATS } \\
\text { Art. V }\end{array}$ & $\begin{array}{l}\text { GATT Art. } \\
\text { XXIV }\end{array}$ & Total \\
\hline
\end{tabular}

\footnotetext{
${ }^{253}$ Ambas as tabelas a seguir, bem como os dados atualizados em relação ao número de acordos regionais, notificações e estágios nos processos de análise estão disponíveis em http://rtais.wto.org/UI/publicsummarytable.aspx
} 


\begin{tabular}{|c|c|c|c|c|}
\hline Apresentação factual não distribuída & 111 & 29 & 71 & 111 \\
\hline Apresentação factual em espera & 0 & 4 & 0 & 4 \\
\hline Apresentação factual distribuída & 4 & 53 & 75 & 132 \\
\hline Resumo factual não distribuído & 0 & 0 & 2 & 2 \\
\hline Resumo factual distribuído & 11 & 21 & 41 & 73 \\
\hline Relatório adotado & 1 & 0 & 17 & 18 \\
\hline Sem Relatório & 8 & 0 & 0 & 8 \\
\hline Total & 35 & 107 & 206 & 348 \\
\hline
\end{tabular}

Foi junto a este sistema constituído pela OMC que as organizações de integração regional da América do Sul foram notificadas, e em alguns casos, avaliadas pelos respectivos órgãos, como será apresentado a seguir.

\section{b) A notificação e a análise da ALALC}

O TM-60, que constituiu a ALALC, foi notificado com base no artigo XXIV, ainda em 1959, enquanto estava em fase final de negociação e assinatura pelos Membros. Deve-se ressaltar que, nessa época, ainda não havia as regras específicas para os acordos regionais envolvendo países em desenvolvimento da Cláusula de Habilitação, que só viria a entrar em vigor em 1979.

O Grupo de Trabalho responsável pela análise da ALALC foi constituído na $16^{\text {a }}$ sessão do GATT em 1959, reuniu-se em junho de 1960 e concluiu seus trabalhos em 18 de novembro de 1960 , durante a realização da $17^{a}$ sessão, quando apresentou o relatório a respeito da ALALC. ${ }^{254}$

Seu relatório foi dividido em três partes: I. As disposições do Tratado de Montevidéu e seus efeitos sobre o comércio, no qual estão sumarizados os objetivos e os compromissos presentes no texto do tratado; II. A compatibilidade do Tratado de Montevidéu com o artigo XXIV, no qual são apresentadas as exigências do GATT; e III. Conclusões, que dispõe expressamente o seguinte:

\footnotetext{
${ }^{254}$ A respeito do procedimento de análise da ALALC, como não há mais documentação disponível junto à OMC e à ALADI, foi utilizado como referência o texto de Guido Soares. Ver SOARES, Guido. A compatibilização da ALADI e do MERCOSUL com o GATT in São Paulo in Perspectiva. Ano 9. Vol. 1. São Paulo: 1995. pp. 80-92.
} 
Após cuidadoso exame da documentação colocada a sua disposição, as PARTES CONTRATANTES aprovaram as seguintes conclusões:

- As PARTES CONTRATANTES examinaram, de acordo com o parágrafo $7^{\circ}$ do artigo XXIV do Acordo Geral, as disposições do Tratado de Montevidéu, assinados pelos governos da Argentina, Brasil, Chile, México, Paraguai, Peru e Uruguai255, cujo propósito é o estabelecimento de uma zona de livre comércio entre países da América Latina (...);

- No presente estágio de seu exame, as PARTES CONTRATANTES pensam que permanecem algumas questões de natureza jurídica e prática difíceis de resolver, unicamente com base no Tratado (...);

- Tal conclusão claramente não preclui os direitos conferidos às PARTES CONTRATANTES pelo artigo XXIV e não previne, de nenhuma maneira as partes do Tratado de Montevidéu de prosseguir com a aplicação deste tratado quando esteja ratificado.

Apesar deste relatório inconclusivo sobre a compatibilidade da ALALC com o GATT, esta organização foi instalada e funcionou até 12 de agosto de 1980, data na qual foi substituída, juntamente com todo o seu corpo normativo, pela ALADI, instituída pelo TM-80.

\section{c) A notificação da ALADI}

Em que pese ter ocorrido uma incorporação dos vários atos elaborados pela ALALC ao novo sistema da ALADI, houve uma evidente ruptura entre os TM-60 e TM-80, como foi apresentado precedentemente, na Parte I desta tese.

Ao ser instituído o novo sistema de integração regional da América do Sul, foi necessário proceder ao exame da sua compatibilidade com as normas do GATT, em um momento em que já estava em vigor a Cláusula de Habilitação, contendo disposições expressas para acordos de integração envolvendo países em desenvolvimento.

Assim, dentro do novo procedimento instituído no GATT pela Cláusula de Habilitação, a delegação do Uruguai, em representação aos Estados-Membros da ALADI, notificou em $1^{\circ}$ de julho de 1982, a adoção do TM-80, tratado constitutivo da nova organização, que havia sido assinado em 12 de agosto de 1980, e em vigor desde 18 de março de 1981. Ao ser notificado com base na Cláusula de Habilitação, declarou-se como um acordo que abrange apenas comércio de bens.

${ }^{255} \mathrm{O}$ relatório não faz menção aos demais países sulamericanos signatários do Tratado de Montevidéu, pois não eram signatários do GATT na época. 
O procedimento de análise da compatibilidade da ALADI frente ao GATT ocorreu praticamente de maneira unilateral, como uma espécie de prestação de contas por parte dos Membros da ALADI ao GATT. A notificação foi apreciada pela primeira vez na $47^{\mathrm{a}}$ Sessão do CTD, de 18 de agosto de 1980.

Merece destaque o fato de que, no exame de compatibilidade da ALADI pelo GATT, mesmo tendo havido discussões sobre a ALADI em sessões posteriores do CTD, não foi constituído um grupo de trabalho. Bastou a notificação de sua existência ao CTD. Após a notificação, que ocorreu por meio do documento L/5342, foram apresentados 4 relatórios bianuais. ${ }^{256}$ Todos sem haver manifestação formal do CTD em relação a eles.

Quais foram os benefícios ou prerrogativas advindos do fato da ALADI ser um acordo notificado com base na Cláusula de Habilitação e não com base no artigo XXIV do GATT?

A vagueza da Cláusula de Habilitação, nesse caso, do parágrafo $2^{\circ}$, c, possibilitou que alguns acordos regionais que não cumpriam minimamente os requisitos do artigo XXIV, fossem aceitos pelo GATT e pela OMC, como é o caso do TM-80, da ALADI.

Tal acordo, em hipótese alguma, se compatibilizaria com o artigo XXIV, mais especificamente com os requisitos dos parágrafos $5^{\circ}$ (prazo razoável) e $8^{\circ}$ (substantially all the trade), pois, primeiro, o tratado da ALADI não estabeleceu prazo para constituição da zona de livre comércio ou união aduaneira, e segundo, o tratado permite acordos de alcance parcial, aplicáveis apenas a algumas partes ou alguns setores comerciais. ${ }^{257}$

\section{d) A notificação da CAN}

O Acordo de Cartagena, que constituiu a CAN, foi assinado em 12 de maio de 1987 , entrou em vigor em 25 de maio de 1988 , e foi notificado ao GATT em $1^{\circ}$ de outubro de 1990. A CAN foi notificada como união aduaneira, com abrangência

\footnotetext{
${ }^{256} \mathrm{WT} / \mathrm{COMTD} / 7, \mathrm{WT} / \mathrm{COMTD} / 11, \mathrm{WT} / \mathrm{COMTD} / 59, \mathrm{WT} / \mathrm{COMTD} / 72$.

${ }^{257}$ CORREA, op. cit., p. 124.
} 
apenas para comércio de bens, sob o fundamento da Cláusula de Habilitação. O único documento constante no processo de avaliação da CAN é o da notificação. ${ }^{258}$

Pelas mesmas razões que o tratado da ALADI, a análise de compatibilidade do Tratado de Cartagena, não foi submetida ao procedimento vinculado a um Grupo de Trabalho, bastando apenas a notificação ao Comitê sobre Comércio e Desenvolvimento.

Desde 1993 existe uma zona de livre comércio na qual participam todos os Membros, e que abarca todas as linhas tarifárias consolidadas junto à OMC. Já a União Aduaneira ainda não se concretizou, porque a aplicação de uma Tarifa Externa Comum, embora tenha sido estabelecida em outubro de 2002, já sofreu várias postergações.

No que se refere ao processo de liberalização do comércio de serviços, até o momento a CAN não apresentou notificação com base no Art. 5, GATS. A CAN iniciou a integração em matéria de comércio de serviços em 1998, processo este que se concluiu com a liberalização completa em serviços em 2006. Mesmo assim, não há informação disponível a respeito dos motivos de tal omissão, tanto na Secretaria da OMC quanto na Secretaria da CAN.

\section{e) A notificação e a análise do MERCOSUL}

Tal como no caso da ALADI e da CAN, o exame do MERCOSUL pelo GATT dar-se-ia já em plena vigência da Cláusula de Habilitação. Firmado o Tratado de Assunção em 26/03/1991, foi o GATT informado pela primeira vez da sua existência no dia 17/02/1992, de maneira transversal, pelo Secretariado da ALADI. $^{259}$

Neste documento, além da ALADI apresentar várias das suas realizações, dentre elas a celebração do Acordo de Complementação Econômica $n^{\circ} 18$, cujo objetivo era "incorporar ao quadro legal da ALADI aqueles dispositivos do Tratado de Assunção que basicamente dizem respeito à integração do comércio entre tais

\footnotetext{
${ }^{258}$ Documentação referente ao processo de análise da CAN no GATT e na OMC está disponível em http://rtais.wto.org/UI/PublicShowRTAIDCard.aspx?rtaid=127.

${ }^{259}$ Doc. L/6.985, de 05/03/1992.
} 
países" e avisava que "no devido momento, as partes do Tratado de Assunção apresentariam as informações devidas às PARTES CONTRATANTES do GATT".

Porém, contrariamente ao caso da ALADI, o exame de compatibilidade do MERCOSUL com as regras do GATT ficou sujeito ao procedimento de constituição de um grupo de trabalho.

$\mathrm{Na} 72^{\mathrm{a}}$ sessão, o CTD teve de decidir entre um dos procedimentos quanto ao exame de compatibilidade do MERCOSUL com as normas do GATT: ou se tratava de um procedimento simples e que a uma notificação dos Estados-partes bastaria, conforme a Cláusula de Habilitação, ou se seria aplicável no caso, o procedimento previsto no artigo XXIV. A segunda opção se justificava, em tese, tendo-se em vista que, uma vez que se tratava de um acordo provisório para o estabelecimento de uma união aduaneira, envolveria uma ampla gama de aspectos da integração econômica, desde produtos, serviços até investimentos, com implicações importantes para terceiros países. ${ }^{260}$

Nesse sentido, dada a ausência de consenso sobre o procedimento a ser adotado, o CTD do GATT, na $74^{\mathrm{a}}$ sessão, estabeleceu um grupo de trabalho em 28/05/1993 com o seguinte objetivo:

Examinar o Acordo do Mercado Comum do Sul (MERCOSUL) à luz das disposições relevantes da Clausula de Habilitação e do Artigo XXIV do GATT, e transmitir um relatório com recomendações ao Comitê para submissão a partes contratantes, com uma cópia do relatório direcionada ao Conselho. O exame do grupo de trabalho deve ser baseada em uma notificação complete e em perguntas e respostas por escrito. ${ }^{261}$

De acordo com Guido Soares:

O fato das Partes Contratantes do GATT terem definido pelo estabelecimento do procedimento do grupo de trabalho denota que consideravam o MERCOSUL, desde o seu surgimento, um acordo de integração econômica de relevância para a economia dos países da região sub-região latino-americana. com importantes reflexos nas relações comerciais com terceiros países e naquelas com o resto do mundo, a ponto de ter-se julgado necessária a constituição de um grupo de trabalho, para justificar de forma mais eficaz a futura decisão das partes contratantes sobre a compatibilidade entre o MERCOSUL e as normas que regem suas relações globais. Tal precaução reforça o valor da importância que se tem

${ }^{260}$ SOARES, op.cit., p. 90.

${ }^{261}$ GATT/AIR/3545, 1994. 
atribuído ao MERCOSUL, como pólo de criação de comércio internacional. ${ }^{262}$

Nesse mesmo sentido, Luis Fernando Nigro Correa igualmente justifica que, em relação ao MERCOSUL, não é de se esperar que os Estados Membros, mormente os países considerados desenvolvidos, atribuam condições especiais na análise do MERCOSUL, primordialmente porque o MERCOSUL é, dos acordos notificados com base na cláusula de habilitação, aquele que congrega países em desenvolvimento com maior potencial para o desenvolvimento, $\mathrm{e}$ consequentemente, para concorrer no mercado internacional com os próprios desenvolvidos. ${ }^{263}$

Assim, o MERCOSUL, que congrega somente países em desenvolvimento, foi na prática submetido ao exame com base nos requisitos fincados no artigo XXIV.

Um dos documentos conclusivos desta fase foi a publicação, em 2005, pelo Secretariado da OMC, das médias das alíquotas tarifárias e direitos aduaneiros do MERCOSUL. Este relatório é central para o exame do MERCOSUL porque ele consolidou uma avaliação comparativa dos níveis de barreiras comerciais antes e depois do Tratado de Assunção entrar em vigor. ${ }^{264}$

TABELA 20. Médias das alíquotas tarifárias e direitos aduaneiros do MERCOSUL

\begin{tabular}{|l|l|l|l|}
\hline & $\begin{array}{l}\text { Pré-União } \\
\text { Aduaneira }\end{array}$ & $\begin{array}{l}\text { Aliquotas tarifarias } \\
\text { aplicadas em 1995 }\end{array}$ & $\begin{array}{l}\text { Tarifa externa } \\
\text { comum de 2006 }\end{array}$ \\
\hline $\begin{array}{l}\text { Média equilibrada das alíquotas } \\
\text { tarifárias (percentual) }\end{array}$ & 12.5 & 12.0 & 10.4 \\
\hline $\begin{array}{l}\text { Média dos direitos aduaneiros } \\
\text { (milhões US\$) }\end{array}$ & 4,768 & 4,545 & 3,945 \\
\hline
\end{tabular}

\footnotetext{
${ }^{262}$ SOARES, op.cit., p. 91.

${ }^{263}$ Segundo Correa, nesta escolha há um reflexo da noção de gradualidade trazida pela Clausula de Habilitação, pois afirma que, "nesse sentido, os EUA incentivam a ideia de se impor a alguns países "mais avançados" em desenvolvimento, que aceitem as obrigações advindas dos acordos da OMC de forma completa, abandonando-se as prerrogativas a eles atribuídas enquanto países em desenvolvimento". Nigro Correa. op. cit. p. 125.

${ }^{264}$ Documentação referente ao processo de análise do MERCOSUL no GATT e na OMC está disponível em http://rtais.wto.org/UI/PublicShowRTAIDCard.aspx?rtaid=130
} 
De fato, na reunião final do CTD após a apresentação destes dados, as delegações dos Membros do MERCOSUL arguiram que, se o Secretariado usasse como referência os anos Pré-Tratado de Assunção (1991) ao invés dos anos préUnião Aduaneira (1992 a 1994), teria avaliado que a evolução do MERCOSUL teria sido ainda maior. Neste período, a média das alíquotas tarifárias eram $18.34 \%$ na Argentina, $20.73 \%$ no Brasil, $14.09 \%$ no Paraguai e $23.40 \%$ no Uruguai. Tais tarifas, comparadas à média ponderada geral do MERCOSUL, de $12 \%$, revelam uma liberalização ainda mais expressiva do que a apresentada no relatório.

Após 4 reuniões do CTD, a avaliação final do MERCOSUL foi concluída em 2006. De acordo com Tatiana Prazeres:

\begin{abstract}
A grande quantidade de regras e exceções, bem como os déficits de implantação, foram fatores importantes que procrastinaram a conclusão desta fase elementar [...]. Durante os debates, a manutenção dos regimes açucareiros e automobilísticos - à parte das regras de liberalização comercial - motivou a maioria das questões e replicas. ${ }^{265}$
\end{abstract}

Mais recentemente, em 2006, o MERCOSUL celebrou um acordo regional de liberalização do comércio de serviços, o Protocolo de Montevidéu, que foi notificado à OMC com base no Artigo V, do GATS, Já houve apresentação factual, questionamentos e réplicas. O Protocolo foi finalmente examinado no CRTA da OMC em setembro de $2008{ }^{266}$ No entanto, ainda não há relatório final e conclusivo sobre a análise de compatibilidade do MERCOSUL no que se refere ao comércio de serviços.

Enquanto o CRTA até o momento tem falhado em analisar efetivamente os mais de 500 ACR notificados, o OSC da OMC, através do Painel e do Órgão de Apelação, proferiu poucas - mas relevantes - decisões a respeito da compatibilidade de ACR com as regras da OMC. Dessas, 3 dizem respeito ao MERCOSUL.

\title{
f) Os casos do OSC da OMC envolvendo o MERCOSUL
}

${ }^{265}$ PRAZERES, 2008.

${ }^{266} \mathrm{WT} / \mathrm{REG} / \mathrm{M} / 50,24 / 10 / 2008$. 


\section{i. Caso Turquia-Têxteis}

O leading case sobre ACR é o Turquia-Têxteis (DS34), através do qual foram esclarecidas algumas disposições do artigo XXIV. Adicionalmente, as implicações jurídicas do procedimento de exame do CRTA, além da competência do OSC para analisar a compatibilidade de ACR notificados, foram temas igualmente tratados no caso.

O caso diz respeito a uma reclamação apresentada pela Índia contra a Turquia, que havia imposto restrições quantitativas sobre os têxteis indianos, alegando que tais medidas eram necessárias para cumprir com as suas obrigações decorrentes do acordo Turquia - Comunidade Européia, voltado a formação de uma união aduaneira entre as partes. ${ }^{267}$

Do ponto de vista turco, como a $\mathrm{CE}$ mantinha seu próprio conjunto de quotas sobre os produtos têxteis indianos, a imposição de quotas, por parte da Turquia, perfazia exigência do parágrafo $8^{\circ}$ do artigo XXIV, que exige que Membros de uma união aduaneira apliquem os mesmos gravames aduaneiros para não-Membros da união aduaneira. O painel decidiu, no entanto, que tais quotas, por não estarem abrangidas pelo Acordo de Têxteis da OMC, eram inconsistentes com o artigo XI do GATT (Eliminação Geral de Restrições Quantitativas).

Além disso, de acordo com o Painel, o artigo XXIV jamais poderia ser invocado para validar uma exceção ilegal, tal qual a restrição quantitativa em vigor. No entanto, a decisão do Painel não foi mantida pelo Órgão de Apelação. O referido órgão decidiu que, em princípio, o artigo XXIV poderia sim ser invocado para validar uma exceção a priori ilegal perante o GATT, desde que duas condições fossem cumpridas: i) que a medida em questão fosse introduzida quando da formação de uma união aduaneira que cumprisse integralmente as exigências dos parágrafos 8(a) e 5(b) do artigo XXIV; e ii) a parte devesse demonstrar que a formação de uma união aduaneira seria dificultada se não pudesse introduzir a medida em questão. O ônus da prova no caso recai sobre a parte interessada comprovar a necessidade de tal medida.

${ }^{267}$ Para o Acordo CE-Truquia, ver: http://ec.europa.eu/trade/creating-opportunities/bilateralrelations/countries/turkey/. 
Este caso tem um impacto significativo na segurança jurídica dos ACR, especialmente em todos aqueles casos sobre os quais não foi elaborado relatório definitivo do CRTA sobre a sua compatibilidade com o artigo XXIV do GATT, bem como com o artigo V do GATS. O ônus da prova foi alterado, pois antes deste caso, assim que as partes notificassem o acordo, se os procedimentos do parágrafo 7 não resultarem em uma recomendação negativa, o ACR estaria assegurado juridicamente de questionamentos posteriores das demais partes, não signatárias daquele acordo. Agora, o inverso é verdadeiro. Enquanto um Membro de um ACR não obtém decisão definitiva e favorável do CRTA, esta parte detém o ônus da prova de demonstrar que o acordo, juntamente com todas as medidas decorrentes do mesmo, é compatível juridicamente com as regras da OMC.

Este foi o primeiro caso submetido ao OSC para a análise da legalidade de um ACR notificado à OMC, cuja avaliação ainda não havia sido concluída. Este é exatamente o atual status do MERCOSUL. Outra razão que confere importância a este caso para análise do MERCOSUL é o duplo teste de necessidade estabelecido no caso. Esse teste foi aplicado em ambos os casos envolvendo o MERCOSUL: no caso Argentina-Calçados, de 1998, e no caso Brasil-Pneus, de 2002, examinados a seguir.

\section{ii. Caso Argentina-Calçados}

O caso Argentina-Calçados (DS121) trata das medidas de salvaguarda aplicáveis no âmbito do ACR. Em 1998, a CE questionou a legalidade das medidas definitivas de salvaguarda impostas pela Argentina para a importação de calçados originários de todos os Membros da OMC, exceto dos países do MERCOSUL. A Argentina alegou que, de acordo com o artigo XXIV do GATT e do Acordo de Salvaguardas, estava autorizada a excluir os Membros do MERCOSUL das restrições, tendo em vista suas obrigações como união aduaneira.

O fundamento jurídico específico deste caso é a nota de rodapé do Artigo 2 do Acordo de Salvaguardas que estabelece: 
Uma união aduaneira pode aplicar medidas de salvaguarda como uma entidade única ou em nome de um Estado Membro Quando uma união aduaneira aplicar a medida de salvaguarda como uma entidade única, todas as exigências para a determinação de dano ou ameaça de dano estabelecidas neste Acordo devem estar fundadas em condições existentes na união aduaneira como um todo. Quando a medida de salvaguarda for aplicada em nome de um Estado Membro, todas as exigências para a determinação do dano ou ameaça do dano devem ser baseadas nas condições existentes no Estado-Membro e tal medida deve ser limitada a este Estado Membro. Nada neste acordo prejudica a interpretação da relação entre o artigo XIX e o parágrafo 8 do artigo XXIV do GATT.

No entanto, a CE arguiu que, quando a Argentina instaurou as investigações, levou em consideração, para fins de cálculo, as importações do MERCOSUL. A Argentina havia decidido excluir estas importações da aplicação de medidas de salvaguarda apenas posteriormente.

Além disso, a CE, juntamente com outras partes interessadas, tais como Indonésia e EUA, arguiram que estas medidas definitivas de salvaguarda não eram impostas pelo MERCOSUL, enquanto união aduaneira, mas exclusivamente pela Argentina, o que a impediria de invocar tanto o artigo XXIV do GATT quanto a nota de rodapé do artigo 2 do Acordo de Salvaguardas.

Indonésia e EUA foram além e argumentaram que o MERCOSUL não havia sido notificado com base no artigo XXIV, mas na Cláusula de Habilitação. Portanto, do ponto de vista destas partes, o MERCOSUL não poderia invocar o status de união aduaneira do artigo XXIV, nem da nota de rodapé do artigo 2 do Acordo de Salvaguardas.

O OSC se limitou a analisar especificamente as questões referentes ao Acordo de Salvaguardas e evitou endereçar a questão da compatibilidade do MERCOSUL com o artigo XXIV e com a Cláusula de Habilitação.

De acordo com o Painel:

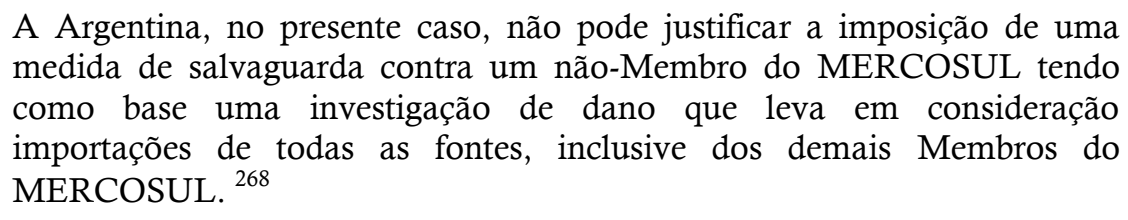

O Órgão de Apelação sustentou a decisão do Painel:

${ }^{268} \mathrm{WT} / \mathrm{DS} 121 / \mathrm{R}, 1999, \S 5.68$. 
Com base no Acordo de Salvaguardas, uma medida de salvaguarda deve ser aplicada para as importações de todas as fontes de importação que foram consideradas no processo de investigação correspondente. Portanto, a investigação da Argentina foi considerada inconsistente com o acordo, tendo em vista que excluiu as importações oriundas do MERCOSUL da aplicação das medidas de salvaguarda, enquanto havia incluído-as na investigação que embasou tal medida. ${ }^{269}$

Apesar de o OSC não ter examinado o MERCOSUL enquanto ACR, com base no artigo XXIV e na Cláusula de Habilitação, este caso pode ser considerado uma decisão fundamental para o MERCOSUL, por duas razões.

Primeiro, e mais importante, é a conclusão implícita do OSC de que o MERCOSUL, embora formalmente notificado com base na Cláusula de Habilitação, é considerado pela OMC como um acordo fundado no artigo XXIV. O OSC não afirmou isto expressamente, porém, quando analisou o MERCOSUL com fulcro no Acordo de Salvaguardas, implicitamente estendeu os direitos e obrigações do artigo XXIV ao acordo notificado pela Cláusula de Habilitação. Portanto, o argumento dos EUA e da Indonésia não foi levado em consideração.

Deste caso em diante é possível afirmar que, se o artigo XXIV é o gênero de ACR, os acordos fundados na Cláusula de Habilitação seriam uma espécie. As regras do artigo XXIV aplicam-se a todos os ACR, inclusive aqueles notificados com base na Cláusula de Habilitação.

A segunda consequência deste caso, igualmente crucial, diz respeito à evolução institucional do MERCOSUL. A partir desta decisão, o MERCOSUL foi induzido a levar adiante um dos objetivos fundamentais do Tratado de Assunção, qual seja, a condução de uma política comercial externa comum, especificamente, a questão de uma política de defesa comercial comum, decorrente da união aduaneira.

\section{iii. Caso Brasil-Pneus}

O segundo caso envolvendo o MERCOSUL é o caso Brasil-Pneus (DS332). Este caso, iniciado em 2002 pela CE contra o Brasil, envolve temas de meio

${ }^{269} \mathrm{WT} / \mathrm{DS} 121 / \mathrm{AB} / \mathrm{R}, 2000, \S 151$. 
ambiente e saúde pública combinados com integração regional. Essencialmente, o caso diz respeito à política comercial brasileira que baniu as importações de pneus remoldados de todo o mundo, mas continuou importando tais pneus originários do MERCOSUL.

De acordo com a CE, a medida era uma violação à Cláusula NMF e representava restrições quantitativas às suas exportações, o que seria incompatível com as regras da OMC. O Brasil alegou que a importação de enormes quantidades de pneus remoldados causava impactos ambientais gravíssimos ao país e que as restrições quantitativas estavam fundadas no artigo XX (b) do GATT:

\begin{abstract}
Desde que essas medidas não sejam aplicadas de forma a constituir, quer um meio de discriminação arbitrária, ou injustificada, entre os países onde existem as mesmas condições, quer uma restrição disfarçada ao comércio internacional, disposição alguma do presente capítulo será interpretada como impedindo a adoção ou aplicação, por qualquer Parte Contratante, das medidas: (b) necessárias à proteção da saúde e da vida das pessoas e dos animais e à preservação dos vegetais.
\end{abstract}

Ao mesmo tempo, a linha de defesa do Brasil deveria combinar este argumento com suas obrigações decorrentes do MERCOSUL para justificar tal tratamento discriminatório. Neste caso, o principal argumento do Brasil foi o cumprimento da decisão do Sistema de Solução de Controvérsias do MERCOSUL, que havia determinado que o país deveria eliminar todas as barreiras sobre as importações de pneus remoldados oriundos do MERCOSUL. Por isso, o Brasil havia modificado a sua política comercial e permitido a importação de pneus remoldados apenas de países do MERCOSUL.

O OSC, ao final, condenou a medida brasileira ao aplicar a rationale do caso Turquia-Têxteis, mesmo que a decisão do Brasil não estivesse fundada no artigo XXIV, como no caso da Turquia. Apesar de compreender que a lógica do artigo XX seja fundamental para o comércio internacional, com base no duplo teste de necessidade do caso Turquia-Têxteis, "a medida específica não constituía uma discriminação arbitrária ou injustificada entre países com as mesmas condições". ${ }^{270}$

O OSC sustentou que a medida constituía "uma discriminação arbitrária ou injustificada" porque a justificativa não estava relacionada com o objetivo da medida - a proteção da vida e da saúde humana, animal e vegetal. Se o Brasil

${ }^{270} \mathrm{WT} / \mathrm{DS} 332 / \mathrm{AB} / \mathrm{R}, 2007, \S 258$. 
continuasse a importar os pneus remoldados do MERCOSUL, a justificativa da medida seria mitigada. Assim, a lógica do artigo XX não seria atendida.

A conclusão do Órgão de Apelação foi a seguinte:

No nosso ponto de vista, a decisão emanada pelo tribunal arbitral do MERCOSUL não um argumento aceitável para a discriminação, porque não tem relação com o objetivo legitimo buscado com o banimento das importações, com base no artigo XX(b), e até contraria tal objetivo, mesmo que em pequena escala. Logo, somos da posição que a isenção do MERCOSUL resultou no fato de o banimento das importações ser aplicada de maneira a constituir uma discriminação arbitrária ou injustificada. ${ }^{271}$

Portanto, novamente o OSC resolveu o caso com base em um fundamento excepcional, o artigo XX. Novamente, este caso deu a oportunidade para o OSC de avaliar a compatibilidade do MERCOSUL com as regras sobre ACR da OMC, no entanto, o OSC novamente esquivou-se de tal tarefa e evitou emanar uma decisão objetiva e definitiva sobre a compatibilidade do MERCOSUL.

g) Considerações sobre os processos de análise de compatibilidade da integração sulamericana

O CRTA tem sido criticado por sua ineficácia. No entanto, deve-se ressaltar que tal ineficiência é em parte decorrente da vagueza da redação dos dispositivos cabíveis para apreciação de ACR (artigo XXIV, Cláusula de Habilitação e Artigo V).

Sua falta de dinamismo e objetividade em avaliar os ACR é visto como seu maior problema: ele foi incapaz de preencher o vazio existente hoje no marco jurídico da OMC, referente ao estabelecimento de regras, incompatibilidades e direcionamento ao grande desafio enfrentado pelo sistema multilateral de comércio, que é a proliferação global de ACR.

As dificuldades experimentadas pelo CRTA foram reconhecidas pelo próprio órgão, por meio do seu relatório de 2009:

Apesar de que progresso considerável ter sido alcançado na preparação de apresentações factuais, o Comitê continua a experimentar algumas

${ }^{271}$ Idem. 
dificuldades em cumprir o seu programa de trabalho. Isto ocorre devido a diversos fatores: atrasos em receber dados estatísticos das partes, discrepância de dados nas notificações das partes, e atrasos no recebimento de questões e comentários dos demais Membros da OMC. O Secretariado está trabalhando ativamente com os Membros, preocupados com os esforços para superar estas dificuldades. ${ }^{272}$

De qualquer maneira, o mecanismo de transparência, em vigor desde 2006, tem permitido um diálogo mais extenso entre as partes de acordos regionais de comércio, o CRTA e os demais Membros da OMC, como pôde-se apresentar de forma breve nos procedimentos de consideração do MERCOSUL. Entretanto, o fato é que, mesmo após 20 anos desde sua notificação, o exame de compatibilidade do MERCOSUL ainda não se concluiu. Portanto, não há uma conclusão oficial e definitiva a respeito da legalidade do MERCOSUL diante do direito da OMC.

O mesmo pode ser dito abrangendo ALADI e CAN. Por isso, talvez o único órgão que será, em algum momento, capaz de fazer tal conclusão seja o OSC da OMC. Em seguida serão levados a exame os casos nos quais o OSC se manifestou a respeito dos acordos regionais de comércio, dentre eles, o MERCOSUL.

Duas conclusões fundamentais podem ser traçadas deste subcapítulo. Uma se refere à falta de posicionamento oficial e definitivo sobre a compatibilidade do MERCOSUL com as regras da OMC. Tanto o CRTA quanto o OSC tiveram a possibilidade de expressar suas opiniões sobre a questão e não o fizeram. Como conseqüência desta conclusão, uma segunda e mais ampla conclusão deve ser destacada. Em mais de 400 casos submetidos ao OSC, apenas um foi tratado de diretamente abordado e decidido com base no artigo XXIV - o Caso TurquiaTêxteis.

A razão principal para esta ausência de decisões envolvendo regras sobre ACR pode ser uma síndrome "do telhado de vidro". ${ }^{273}$ Isto significa que um país evita questionar o ACR do outro porque ele mesmo está envolvido em um acordo potencialmente questionável. Uma evidência disso é que, desde o caso TurquiaTêxteis, nunca mais sequer um Membro da OMC questionou outro por seu envolvimento em um ACR.

\footnotetext{
${ }^{272} \mathrm{WT} / \mathrm{REG} / 20,2009$.

${ }^{273}$ PRAZERES, Tatiana. A OMC e os Blocos Regionais. São Paulo: Aduaneiras, 2008, p. 375.
} 
Outra razão estrutural pela ausência de decisões objetivas, seja do CRTA ou do OSC, é que os Membros da OMC parecem não quererem tornar clara a interpretação e aplicação das regras sobre acordos regionais de comércio porque tal esclarecimento poderia constranger a estratégia de política externa mais utilizada atualmente, em matéria comercial, qual seja, a assinatura de acordos comerciais.

Em suma, a ambiguidade sobre as regras de ACR parece não interessar a ninguém, ao mesmo tempo em que interessa a todos.

Portanto, a menos que haja uma mudança radical nos processos decisórios da OMC - tanto do CRTA quanto do OSC - em matéria de avaliação do status jurídico dos ACR frente ao sistema multilateral de comércio, o fenômeno mundial de proliferação de ACR continuará. Isto pode, em última instância, colocar todo o sistema multilateral de comércio em risco. A ausência de um status claro do MERCOSUL diante das regras da OMC é apenas mais uma ponta solta deste grande spaghetti bowl de acordos regionais. 


\section{CONCLUSÕES DO CAPÍTULO 5}

Os processos de integração sul-americanos foram originariamente constituídos no período de vigência do GATT. Naquele momento, vigoravam regras mais flexíveis no âmbito do sistema multilateral de comércio, que permitiam aos países em desenvolvimento levar adiante políticas de desenvolvimento nacional e regional. Assim fez a América do Sul, ao seu modo, e em conformidade com as regras do GATT.

O fato de a América do Sul, por meio da CEPAL, ter atuado de maneira assertiva na reforma e na flexibilização das regras do GATT em prol do desenvolvimento, lhe conferiu legitimidade para levar adiante seus projetos nacionais e regionais de desenvolvimento.

As crises do Petróleo dos anos 80 desestruturaram o sistema econômico mundial, que repercutiu em crises cambiais graves nos países desenvolvidos. Em razão das crises, os países desenvolvidos reorientaram seus investimentos, dos países em desenvolvimento para si mesmos. Foi questão de tempo para que as crises cambiais atingissem os países em desenvolvimento, em especial, na América do Sul, sempre extremamente dependente de recursos financeiros internacionais.

Esse novo sistema trouxe consigo uma capacidade de institucionalização jurídico-política para implantar os novos modelos de desenvolvimentos, fundados na liberalização mundial. Isto se reflete de maneira pulverizada nas relações internacionais, por meio das grandes organizações internacionais multilaterais, com as quais quase toda a comunidade internacional está vinculada, e lhes deve observância.

Com a criação da Organização Mundial do Comércio, um novo marco regulatório internacional emerge, para o qual os Estados-Membros, e suas respectivas Organizações de Integração Regional devem observância. Uma nova mentalidade econômica, de natureza menos estruturalista e mais liberal, se institucionaliza por meio de tratados, acordos e protocolos de natureza econômica e comercial, firmados tanto no âmbito da OMC quanto das organizações de integração regional. 
A implantação do conjunto jurídico, político, econômico, institucional e administrativo com a finalidade de adequar-se ao novo sistema multilateral de comércio, oriundo da OMC e das suas regras, causa transformações relevantes na América do Sul. Novos modelos de Estados e de Organizações de Integração Regional emergem.

Sob a regência deste novo cenário internacional, a América do Sul passa por uma profunda transformação para a adequação dos antigos modelos de desenvolvimento aos novos parâmetros jurídicos, políticos e econômicos do neoliberalismo. A internalização e a implantação dos acordos de OMC são uma das muitas formas de manifestação dessa adequação e "modernização" da América do Sul rumo à globalização prometida.

A incorporação das regras da OMC nas organizações de integração regional da América do Sul apresentou tanto semelhanças quanto diferenças, quando comparados a MERCOSUL e a CAN.

A CAN iniciou em 1998 o processo de integração regional em serviços por meio do método das listas negativas, que culminou na liberalização completa do comércio de serviços em 2006. Em razão disso, foi alcançada uma harmonização regulatória regional sólida em matéria de serviços. Há apenas dois níveis de exceção: uma setorial, que exclui os serviços de serviços financeiros e de Televisão Aberta Nacional, e outra relacionada ao Tratamento Especial e Diferenciado concedido à Bolívia para que, nos setores que considerar necessário, possa eximirse do cumprimento das obrigações decorrentes da liberalização completa do comércio de serviços até dezembro de 2014.

Por outro lado, o MERCOSUL encontra-se em um estágio completamente oposto da CAN no que se refere à integração em matéria de serviços. O protocolo foi firmado em 1997, mas entrou em vigor apenas em 2005, e ainda resta pendente de ratificação do Paraguai. ${ }^{274} \mathrm{O}$ método eleito pelo MERCOSUL foi o inverso da CAN. Optou-se por listas positivas, para que houvesse um processo gradativo de integração em serviços. No entanto, passadas 7 rodadas de negociação, não há o

\footnotetext{
${ }^{274}$ Com base nas informações apresentadas pela Secretaria do MERCOSUL em 16/10/2012. http: $/ /$ www. $m e r c o s u r$. int $/ \mathrm{t}$ ligaenmarco.jsp? contentid $=4823 \&$ site $=1 \&$ channel $=$ secretaria .
} 
mínimo de harmonização regional em matéria de serviços e o MERCOSUL ainda se encontra em estágio embrionário de integração em matéria de serviços.

Há um elemento fundamental que pode justificar as diferenças nas estratégias e atuais estágios de integração em serviços: o nível de assimetria interna dentro das sub-regiões. Há um equilíbrio evidentemente maior entre os níveis de desenvolvimento dos Membros da CAN se comparado ao MERCOSUL, no qual há uma grande assimetria tanto entre os Membros, quanto entre setores de serviços dos diversos Membros.

Do ponto de vista continental, a consolidação de uma ordem normativa comum em matéria de serviços perfaz-se fundamental para manter a unidade da integração sul-americana, tendo-se em vista a diversidade de acordos bilaterais e regionais que estão sendo firmados atualmente. A ausência desse quadro regulatório comum no MERCOSUL, tal qual na CAN, além de atrasar a integração intra-regional de serviços, impede também que haja avanços em matéria de liberalização de serviços com os recentes parceiros comerciais com os quais o MERCOSUL está firmando acordos bilaterais.

Já em matéria de investimentos, há semelhanças e diferenças entre ambas as organizações sul-americanas. A CAN possui desde 1991 um regime comum vigente, que está avançando por meio de acordos bilaterais de investimentos entre os próprios Membros da CAN. Tal regime consagrou, no plano regional, o texto do TRIMS que vinha sendo negociado na Rodada Uruguai.

O MERCOSUL adotou a mesma estratégia, de incorporação do TRIMS no plano regional por meio dos Protocolos de Colônia e Buenos Aires. Contudo, ambos os protocolos ainda não foram devidamente depositados pelos $\mathrm{Membros}^{275} \mathrm{e}$ o MERCOSUL, diferentemente da CAN, ainda não possui um regime comum, seja para o tratamento dos investimentos intra-regionais, seja para os investidores de fora do MERCOSUL. Tampouco o MERCOSUL avança em acordos bilaterais de investimentos entre os parceiros regionais, como faz a CAN.

Há uma diferença fundamental entre ambos os processos de integração, no que se refere à regulação de investimentos. A CAN criou a figura da empresa multinacional andina, a fim de fomentar a formação de empreendimentos

\footnotetext{
${ }^{275}$ Idem.
} 
empresariais e investimentos comuns entre os Membros da organização internacional. No MERCOSUL, tal figura não existe e os investidores oriundos dos Membros são tratados de maneira igualitária aos investidores de fora do MERCOSUL.

Por fim, em relação aos regimes jurídicos de propriedade intelectual, se encontram diferenças muito acentuadas em relação aos níveis de integração da CAN e do MERCOSUL. A integração andina estabeleceu, entre 1993 e 2000, um amplo regime jurídico comum sobre direitos de propriedade intelectual: há o Regime Comum de Propriedade Industrial, o Regime Comum sobre Direitos do Autor e Direitos Conexos, o Regime de Proteção dos Direitos dos Obtentores Vegetais e o Regime Comum sobre Acesso aos Recursos Genéticos.

Por outro lado, o MERCOSUL ainda carece de um mínimo de harmonização em matéria de propriedade intelectual. $O$ Protocolo de Harmonização do MERCOSUL, de 1995, que ainda não entrou em vigor, tem um mero objetivo harmonizador, e não o de criar um marco regulatório comum. Decidiu-se que cada país manteria sua legislação nacional em matéria de propriedade intelectual.

Tal avaliação a respeito dos diferentes métodos e estratégias de internalização das regras oriundas da OMC, levados adiante na América do Sul gera uma série de conclusões a respeito da questão anunciada na apresentação da Parte II. Esta diz respeito aos impactos da OMC no policy space da América do Sul, e se houve ou não redução dessa autonomia para políticas públicas de desenvolvimento nas organizações de integração da América do Sul.

Na ALADI, há uma total ausência de regimes próprios e comuns entre os seus Membros em praticamente todos os temas regulados pela OMC. Isso reflete um abandono da ALADI, enquanto organização internacional capaz de exercer algum nível de policy space regional em favor dos seus Membros. Caso houvesse regimes comuns em matéria de serviços, propriedade intelectual ou investimentos consolidados no plano regional, a margem de manobra das organizações subregionais estaria garantida. No entanto, parece que os países-Membros optaram por manter o maior nível de discricionariedade possível no âmbito da ALADI, sem consolidar compromissos e regimes comuns. Isto acabou por perpetuar, no plano 
da ALADI, as regras gerais da OMC que, como apresentado no capítulo anterior, não viabilizam tanto policy space quanto as regras decorrentes das organizações de integração regional.

No MERCOSUL, percebe-se uma prevalência da percepção da noção de policy space nacional em detrimento do policy space regional. Isto pode ser afirmado pelos seguintes motivos: a) os países-Membros terem optado pela lista positiva, ao invés da negativa, na integração de serviços; b) os países-Membros não harmonizarem, tampouco constituírem um regime comum, em matéria de propriedade intelectual, que está regulado pelas diversas legislações nacionais e ; c) o mesmo ocorre em matéria de investimentos pois, embora haja um protocolo de harmonização para regras de investimentos, não há um regime comum para os investimentos intrarregionais, o que descaracteriza a existência de um espaço regional comum para investimentos estrangeiros. Do ponto de vista do investidor estrangeiro, cada Membro do MERCOSUL possui um regime nacional, não necessariamente comum aos demais Membros da organização internacional.

É na CAN que existe a maior percepção da noção de policy space enquanto organização de integração regional. Nas três dimensões analisadas neste capítulo, a CAN optou por avançar consideravelmente nos processos de integração nas matérias de serviços, investimentos e propriedade intelectual. Muito embora existam discordâncias sobre a relação entre policy space e o método de listas negativas adotado para integração em matéria de serviços, os Membros da CAN decidiram outorgar à organização de integração regional, seja por meio da harmonização das regras nacionais, seja pela comunitarização dos regimes jurídicos, o policy space para o desenvolvimento, que deixou de estar vinculado aos interesses nacionais e passou a ser orientado pelos interesses regionais.

No entanto, como será visto na Parte III desta tese, a emergência do novo desenvolvimentismo, tanto no plano global quanto regional, faz com que as organizações de integração da América do Sul se lancem no estabelecimento de novas políticas públicas de desenvolvimento, avançando em áreas até então não tratadas no âmbito das mesmas, e indo além dos temas convencionalmente regulados na OMC, tais como políticas de correção de assimetrias regionais, 
políticas de infraestrutura regional e políticas de inovação tecnológica. É no âmbito destes novos vetores da integração sul-americana que o policy space regional se institucionalizou e aprofundou, de maneira inédita, na história da América do Sul. 
PARTE III. O NOVO DESENVOLVIMENTISMO NA ORGANIZAÇ̃̃O MUNDIAL DE COMÉRCIO E NA INTEGRAÇÃO SUL-AMERICANA: OPORTUNIDADES E DESAFIOS 


\section{APRESENTAÇÃO DA PARTE III}

A Parte III corresponde à emergência do novo desenvolvimentismo em três níveis: no plano do direito internacional, no plano do sistema multilateral de comércio, e no plano das organizações de integração regional da América do Sul. O objetivo central desta Parte III é identificar em que medida é possível afirmar que o desenvolvimento, enquanto fundamento jurídico, está ressurgindo, se renovando e se manifestando nos três respectivos níveis. Para tanto, esta Parte está estruturada em três capítulos.

O capítulo 6 aborda o ressurgimento do desenvolvimento enquanto fundamento jurídico das relações internacionais. A premissa deste capítulo é que, em decorrência deste ressurgimento, é possível afirmar que o DID permanece ativo e vigente ao longo da primeira década do século XXI. Para tanto, este capítulo analisará, em um primeiro momento, o movimento de normatização do direito ao desenvolvimento humano e do desenvolvimento sustentável ocorrido nos anos 90. Em um segundo momento, avaliará o conjunto de princípios e compromissos decorrentes dos Objetivos do Desenvolvimento do Milênio, com base nos quais emerge uma abordagem integralizadora do desenvolvimento, que abrange crescimento econômico, inclusão social humanista e preservação ambiental. Por fim, serão apresentados os impactos que o renascimento da UNCTAD ao longo desta década provoca nas negociações da OMC, em especial por meio da criação do conceito de policy space, enquanto idéia fundamental para a promoção do desenvolvimento na OMC.

Já o capítulo 7 apresenta o processo de emergência da tendência neodesenvolvimentista na OMC. Para isso, será analisado, em um primeiro momento o declínio do viés neoliberal da OMC decorrente da insatisfação dos países em desenvolvimento, que culminou nas discórdias das primeiras conferências da OMC, até chegar à crise de Seattle. Em um segundo momento, atenção será dada as negociações da Rodada Doha, bem como aos principais documentos e decisões resultantes da Conferência de Doha, a fim de traçar um panorama dos principais acontecimentos desta Rodada, até chegar ao cenário contemporâneo de crise global, que colocou a OMC em compasso de espera. A 
título de conclusão do capítulo, será realizada uma breve revisão da literatura especializada, de natureza mais reflexiva, que aporta fundamentos para uma interpretação neodesenvolvimentista da OMC e dos seus respectivos acordos.

Por fim, o capítulo 8, analisa o novo regionalismo desenvolvimentista das organizações de integração regional da América do Sul. A primeira seção resgata o processo de renovação e a ampliação da integração sul-americana em andamento desde o início da primeira década do século XXI, movimento este caracterizado como regionalismo pós-liberal, novo desenvolvimentismo, e regionalismo neodesenvolvimentista. A segunda seção identifica, em meio a este processo de renovação e ampliação da integração sul-americana, algumas novas instituições e vetores da integração, tanto no plano regional quanto nos planos subregionais, especialmente em relação a dois novos vetores que estão paulatinamente se institucionalizando na América do Sul: a infraestrutura regional e a inovação tecnológica. A título de conclusão, serão avaliados alguns desafios que se apresentam à consolidação do novo regionalismo desenvolvimentista nas organizações de integração da América do Sul. 


\title{
CAPÍTULO 6. O RESSURGIMENTO DO DIREITO INTERNACIONAL DO DESENVOLVIMENTO NA VIRADA DO MILÊNIO
}

\begin{abstract}
As ordens econômica, jurídica e política estabelecidas no passado, e impugnadas na época da descolonização, tinham levado três séculos para estender seus tentáculos a todos os setores vitais do planeta. Não é possível substituir bruscamente por uma nova organização de relações entre nações. Levaram algumas décadas para que as reivindicações do Terceiro Mundo chegassem ao ponto essencial. Com certeza, serão necessárias outras décadas mais para o estabelecimento efetivo de uma nova ordem econômica internacional.
\end{abstract}

Mohamed Bedjaoui, Pour un nouvel ordre économique international, 1978 


\section{APRESENTAÇÃO DO CAPÍTULO 6.}

O capítulo 6 trata do processo de retomada da construção do desenvolvimento enquanto princípio de direito internacional, ao longo da década de 1990 e da primeira década do século XXI, a fim de demonstrar as transformações e renovações pelas quais passou o DID, desde que foi decretada a sua extinção, ao final dos anos 80 .

O subcapítulo 6.1 examina a emergência dos conceitos de desenvolvimento humano e desenvolvimento sustentável ao longo dos anos 90. Para tanto, será analisada brevemente a quarta década da ONU para o desenvolvimento para, em seguida, analisar-se a consolidação do desenvolvimento no rol dos direitos humanos, bem como a sua aproximação com os debates em torno da preservação ambiental.

O subcapítulo 6.2 foca o processo de ampliação e aprofundamento da regulação em torno do desenvolvimento no início do século XXI, por meio da Declaração e dos Objetivos de Desenvolvimento do Milênio. Esta abordagem integral do desenvolvimento - concebendo crescimento econômico, preservação ambiental e justiça social - tem sido o principal parâmetro de atuação da comunidade internacional ao longo da última década. Igualmente investigada nesta seção, a Conferência de Monterrey de 2002, cujos resultados retomaram a lógica das décadas do desenvolvimento da ONU do século XX, estabelecendo metas e compromissos para o financiamento das políticas de desenvolvimento.

O subcapítulo 6.3 detalha a relevância que a UNCTAD voltou a ter na primeira década do século XXI. Deste modo, será necessário avaliar o contexto, os objetivos e os resultados tanto das Conferências da UNCTAD de 2000, em Bangkok, e de 2004, em São Paulo. Dentre os resultados, será dada especial atenção ao chamado Consenso de São Paulo, à tardia retomada do SGPC e a emergência do conceito de policy space que, como será analisado neste subcapítulo, embora seja um conceito recente nos fóruns internacionais, constitui, na verdade, reivindicação tradiciona do DID. 


\title{
6.1. O DIREITO AO DESENVOLVIMENTO HUMANO E SUSTENTÁVEL DOS ANOS 90
}

\section{a) A Quarta Década da ONU para o Desenvolvimento}

\section{i. As novidades da quarta década}

No início dos anos 1990, a brecha entre os países ricos e pobres continuava a agravar-se. As condições de vida e perspectivas de crescimento dos países pobres se deterioraram depois da queda dos regimes comunistas. Frente a este cenário, a AG adota a Resolução n ${ }^{\circ}$ 18/1990, que contém a Declaração sobre Cooperação Econômica Internacional, ${ }^{276}$ e em 20 de dezembro de 1990, a Resolução n ${ }^{\circ}$ 45/1990, que lança a Estratégia Internacional de Desenvolvimento para a $4^{a}$ Década das Nações Unidas para o Desenvolvimento. ${ }^{277}$

A estratégia de desenvolvimento lançada naquele ano já não faz mais alusão a NOEI e passa a se fundamentar prioritariamente na Declaração sobre Cooperação Econômica Internacional. Esta mudança de enfoque vem acompanhada pelo reconhecimento expresso do fracasso da terceira década.

O parágrafo $3^{\circ}$ da Resolução $n^{\circ} 45$ reconhece expressamente tal fracasso, ao dispor que:

\begin{abstract}
Durante a década de 1980 a taxa global de crescimento dos países em desenvolvimento foi, em média, 3\%, e o crescimento de renda per capita de $1 \%$, enquanto que as taxas alcançadas nas décadas de 1960 e 1970 para o crescimento global foi em média de $5,5 \%$ e o crescimento per capita de $3 \%$; portanto, na década de 1980 aumentou a brecha entre os países ricos e pobres, houve conflitos e tensões políticas, desastres naturais que causaram onerosos transtornos.
\end{abstract}

Com a avaliação da experiência anterior, a quarta década parte de um compromisso básico: tomar todas as medidas necessárias para prevenir as tendências negativas dos anos 80; e de um pressuposto necessário: a responsabilidade de cada país por seu próprio desenvolvimento.

\footnotetext{
${ }^{276}$ Resolução n ${ }^{\circ} 18 / 3$, de 1990 , do $18^{\circ}$ período extraordinário de sessões da AG.

${ }^{277}$ Resolução no 45 (CXCIX) da AG de 21 de dezembro de 1990.
} 
Como novidade em relação aos objetivos, cabe destacar que pela primeira vez a ONU deixa de quantificar o crescimento que a estratégia se propõe a alcançar, bem como, também pela primeira vez, vincula o desenvolvimento com as necessidades sociais e ambientais, referindo-se expressamente à noção de desenvolvimento racional e sustentável. A partir de agora, o desenvolvimento deveria prestar atenção às políticas necessárias para aliviar a pobreza, melhorar os recursos humanos e proteger o meio ambiente. A erradicação da fome, a educação, e a proteção do meio ambiente se converteriam nos aspectos prioritários do desenvolvimento. ${ }^{278}$

Junto a isso, se insiste na atenção especial para abordar os problemas dos países menos avançados, insistência essa que parte de constatação de um dado preocupante: o número de países classificados na categoria de países menos avançados, em vez de diminuir, aumentou de 24 em 1972, para 41 em 1990.

As medidas para concretizar a estratégia alcançam, como nas décadas anteriores, todas as esferas da economia (comércio internacional, produtos básicos, ciência e tecnologia, industrialização), dedicando especial atenção ao financiamento externo do desenvolvimento e ao problema da dívida externa dos países em desenvolvimento.

Dentre tais políticas, se estabelecem dois aspectos prioritários: a) a erradicação da pobreza e da fome; b) o desenvolvimento de recursos humanos e das instituições, centrando-se particularmente nas esferas da educação e dos serviços de saúde.

Além das novidades em relação aos objetivos e às políticas lançadas na quarta década da ONU para o desenvolvimento, algumas propostas de mudanças dentro do Sistema das Nações Unidas também foram relevantes para a renovação do DID e do Sistema ONU para o desenvolvimento.

ii. As reformas institucionais da quarta década

${ }^{278}$ VELASCO op. cit., pp. 327-328. 
Do ponto de vista da estrutura do Sistema ONU para o desenvolvimento, ao longo da quarta década da ONU, é retomada a preocupação com a reestruturação do sistema, tendo-se em vista o novo contexto mundial do fim da Guerra Fria. Neste sentido, a AG adotou, em 1991, a Resolução n 45/264 sobre Os princípios e diretrizes básicas para a reestruturação e revitalização das Nações Unidas na esfera econômica e social e esferas conexas.

Esta resolução partia da necessidade de ampliar as funções da ONU para a cooperação e o desenvolvimento, e de aprofundar, consequentemente, o processo de reforma da ONU. Ela foi acompanhada de outros documentos: a Resolução $\mathrm{n}^{\circ}$ 48/162 de 1993, que instituiu "novas medidas" para a reforma do sistema e o Informe A/51/950 do Secretário Geral da ONU, intitulado Renovação da ONU: um programa de Reforma. ${ }^{279}$

Em relação ao PNUD, mudanças de ordem institucional ocorreram, mas principalmente sobre seus objetivos: o PNUD passou a atuar direcionado ao desenvolvimento social e à eliminação da pobreza, ao desenvolvimento da gestão e à boa administração pública, às energias sustentáveis e ao meio ambiente, e à ciência e tecnologia. Assim, a mudança de objetivos do PNUD, juntamente com as reformas na UNCTAD e na UNIDO, representam uma mudança da natureza na atuação em prol do desenvolvimento da ONU na quarta década.

A UNCTAD também vivenciou diversas mudanças de orientação e prioridades a partir da década de 90. A VIII Conferência da UNCTAD, realizada em Cartagena, em 1992, foi um momento de sua adequação ao novo cenário internacional pós-Guerra Fria. A"renovação" da UNCTAD se deu em um duplo sentido. De um lado, ampliando a sua premissa fundacional, ao aliar o progresso econômico à paz e à segurança internacional. Por consequência, o desenvolvimento passa a constituir-se em prioridade da agenda internacional.

De outro, a UNCTAD passa a dar prioridade aos problemas dos países menos avançados e à luta contra a pobreza extrema, pois, como mencionado, o

\footnotetext{
${ }^{279}$ No entanto, o projeto de reforma do sistema ONU da $4^{\text {a }}$ década logrou alcançar reformas demasiadamente modestas se comparadas às demandas e desafios do cenário internacional da época. O que se alcançou, de fato, foi uma maior definição e clareza no estabelecimento das devidas competências e dos instrumentos de coordenação entre a Assembleia Geral, o ECOSOC e os órgãos subsidiários de ambos. VELASCO, op.cit., pp. 336-352.
} 
número de países menos avançados, ao invés de diminuir, aumentou de 24 em 1972 para 41 em 1990.

Por fim, outra novidade na UNCTAD é a incorporação da noção de desenvolvimento sustentável em sua agenda, que será analisada mais adiante neste capítulo. No entanto, as mudanças mais significativas em torno da UNCTAD acontecem na primeira década do século XXI, razão pela qual será dedicada seção específica neste capítulo.

\section{b) $\mathrm{O}$ desenvolvimento no rol dos direitos humanos}

Em relação à renovação do desenvolvimento enquanto princípio das relações internacionais, o fenômeno mais relevante da década de 1990, para a consagração da temática do desenvolvimento na ordem internacional, foi a sua inclusão no discurso dos direitos humanos.

No entanto, é ao longo da década de 90 que se consolida juridicamente a passagem da questão do desenvolvimento, como tema das relações econômicas internacionais, para o campo dos direitos humanos. Enquanto a questão do desenvolvimento perdeu força nos anos 80, com o esvaecimento das discussões interestatais em torno das relações Norte-Sul, o trabalho em torno de sua concretização se desenvolve no foro dos direitos humanos.

Historicamente, a interdependência entre os aspectos econômicos e sociais do desenvolvimento e dos direitos humanos foi reconhecida no âmbito da ONU, por meio da Resolução da AG no 2542 (XXIV) de 1969, intitulada "Declaração sobre o Progresso e o Desenvolvimento no Campo Social”. Já na década de 1970, houve uma incipiente aproximação da questão do desenvolvimento com os direitos humanos, quando em 1977, a Comissão de Direitos Humanos mencionou pela primeira vez a existência de um direito humano ao desenvolvimento. ${ }^{280}$

${ }^{280}$ OLIVEIRA, Silvia Menicucci. Barreiras Não-Tarifárias no Comércio Internacional e o Direito ao Desenvolvimento. Rio de Janeiro: Renovar, 2005, p. 515. 
Tal perspectiva se consolidará definitivamente apenas nove anos depois, com a adoção pela AG, em dezembro de 1986, da Resolução no 41/128, que contém a "Declaração sobre Direito ao Desenvolvimento".

Segundo seu artigo $1^{\circ}$, o direito ao desenvolvimento é um direito humano inalienável em virtude do qual todo ser humano e todos os povos estão facultados a participar de um desenvolvimento econômico, social, cultural e político, no qual podem realizar-se plenamente todos os direitos humanos e as liberdades fundamentais.

Os titulares do direito ao desenvolvimento seriam tanto indivíduos como povos, e os sujeitos obrigados a sua realização, os Estados. Por isso, o artigo $8^{\circ}$ da Declaração estabelece que os Estados devam garantir a igualdade de oportunidades para todos, no que se refere a recursos básicos, à educação, à saúde, aos alimentos, à habitação, ao emprego e à justa distribuição de renda.

Com fulcro na Declaração sobre Direito ao Desenvolvimento, ao longo dos anos 90, foram realizadas uma série de conferências da ONU cujo objetivo de desenvolvimento encontrava-se centrado no ser humano, dentre as quais se destacam:

\footnotetext{
- Conferência sobre Meio Ambiente e Desenvolvimento (Rio de Janeiro) - 1992

- Conferência Mundial para os Direitos Humanos (Viena) - 1993

- Conferência Internacional sobre População e Desenvolvimento (Cairo) - 1994

- Conferência Mundial sobre Desenvolvimento Social (Copenhague) - 1995

- Conferência Mundial sobre a Mulher (Pequim) - 1995

- Conferência da ONU sobre Assentamentos Humanos (Istambul) - 1996

- Conferência Mundial sobre Alimentação (Roma) - 1996
}

A Conferência das Nações Unidas sobre Meio Ambiente e Desenvolvimento, de 1992, por meio do principio $3^{\circ}$ da Declaração do Rio, proclamou o direito ao desenvolvimento, vinculando-o à proteção do meio ambiente, ao estabelecer que este direito deve ser exercido de forma a responder equitativamente às necessidades de desenvolvimento e ambientais das gerações presentes e futuras. A partir de então, emerge a noção de um direito ao desenvolvimento sustentável.

A Conferência Mundial para os Direitos Humanos, celebrada em 1993 em Viena, por meio da Declaração de Viena, consagra a interdependência entre democracia, desenvolvimento e respeito aos direitos humanos e às liberdades fundamentais. $\mathrm{O}$ 
parágrafo 10 reafirma o direito ao desenvolvimento, conforme estabelecido na Declaração sobre Direito ao Desenvolvimento, como um direito universal e inalienável, e forma parte integrante dos direitos humanos fundamentais.

Neste contexto, Maurice Flory afirma que:

\begin{abstract}
As profundas mudanças no equilíbrio internacional a partir de 1989 colocam em questão as medidas adotadas ou recomendadas durante 40 anos acerca do desenvolvimento. O Direito Internacional do Desenvolvimento não mais corresponde na atualidade às opções liberais da ONU, FMI, BM e OMC. Uma nova orientação parece haver sido apontada em favor do fomento da proteção dos direitos humanos de caráter social. Desse modo, o Direito Internacional do Desenvolvimento daria lugar ao Direito Internacional do Desenvolvimento Social. (sem grifo no original). ${ }^{281}$
\end{abstract}

Ao ser considerado como um direito coletivo dos povos, Estados e governos podem ser titulares do mesmo. Neste sentido, os Estados mais pobres continuarão sendo os principais responsáveis frente aos seus nacionais na hora de implantar o direito ao desenvolvimento.

De acordo com Silvia Menicucci, a constatação de que o desenvolvimento econômico deve caminhar de mãos dadas com o desenvolvimento social contribuiu para uma relativização da polarização Norte-Sul em face da natureza global dos problemas, e significou uma síntese entre duas tendências contraditórias: exigência liberal e reivindicações sociais. ${ }^{282}$

Do ponto de vista das relações internacionais, os Estados ricos teriam também a obrigação de ajudar os países em desenvolvimento a realizar o direito ao desenvolvimento, na medida das suas possibilidades. Essa responsabilidade implicaria em uma série de obrigações que iriam desde a abstenção de qualquer ação que violasse o direito ao desenvolvimento de um país pobre, como controle das empresas multinacionais, reforma do sistema multilateral de comércio, até o financiamento de atividades e programas que estivessem fora das possibilidades dos países em desenvolvimento, como a obrigação de destinar ajuda ao desenvolvimento.

\footnotetext{
${ }^{281}$ FLORY, Maurice. Mondialisation et Droit International Du Developpement. Revue Generale de Droit International Public. 101, v. 3, p. 625, in: OLIVEIRA, op. cit., p. 490.

${ }^{282}$ OLIVEIRA, op. cit., p. 491.
} 
Como se percebe, ao longo dos anos 1990, o desenvolvimento se converte em um processo econômico, social, cultural e político, que pressupõe a existência e cumprimento do resto dos direitos contidos no corpus internacional dos direitos humanos.

Houve uma significativa mudança de enfoque e de prioridades, se comparado ao período de ascensão do DID, entre os anos 60 e 80: enquanto as ideias e os princípios que inspiraram a NOEI foram paulatinamente desaparecendo de cena. Em substituição, emerge a primazia dos direitos humanos, dentre os quais, o respeito ao direito de desfrutar de um regime político democrático, que passa a tornar-se elemento-chave para o desenvolvimento.

As experiências das décadas anteriores, dos projetos de desenvolvimento nacionais levados adiante por países sob regimes militares, corruptos e violadores de direitos humanos, fez com que a comunidade internacional passasse a vincular o desenvolvimento econômico e social aos regimes políticos e às garantias dos direitos humanos.

Sob este escopo, a atenção da comunidade internacional se amplia para além da estrutura da ordem econômica internacional, e passa a compreender também as ordens internas dos Estados como obstáculos ao desenvolvimento. Assim, deixa-se de perceber o desenvolvimento como um processo de natureza essencialmente econômica, dirigido principalmente pelas elites econômicas e políticas, para passar a ser contemplado em suas dimensões econômicas, políticas, sociais e ambientais. Neste processo, a participação de todo o corpo social se converte em fator essencial. O desenvolvimento passou a ser visto como uma estratégia baseada em direitos humanos (rights based aproach).

O direito do desenvolvimento como direito humano se insere na chamada terceira geração de direitos, caracterizada pela titularidade coletiva, como o direito à paz e a um meio ambiente sadio. Ao ser colocado na temática dos direitos 
humanos, o desenvolvimento sai do campo exclusivo das relações econômicas para adentrar os âmbitos sociais, culturais e políticos. ${ }^{283}$

Claudia Perrone Moises, ao fazer um balanço sobre a incorporação do tema do desenvolvimento no rol dos direitos humanos, conclui que:

\begin{abstract}
O desenvolvimento ganha força no contexto jurídico dos direitos humanos enquanto os direitos humanos ampliam sua presença no contexto global. A questão do desenvolvimento parece beneficiar-se com essa mudança, pois sofre um adensamento de juridicidade. A inserção do tema no contexto internacional está definitivamente consagrada. Outra vantagem é o fato de não necessitar de sistematização nova, como foi o caso das tentativas de elaboração do direito internacional do desenvolvimento como novo ramo do direito internacional público. Mas, ao ser incorporada aos direitos humanos, a questão do desenvolvimento encontra uma estrutura teórica e instrumental nova, o que requer sua adaptação. ${ }^{284}$
\end{abstract}

Nesse sentido, a humanização do princípio do desenvolvimento, transferindo sua abordagem do campo econômico interestatal para o campo dos direitos humanos, ao invés de lhe retirar força, pelo contrário, confere-lhe legitimidade política, arcabouço jusfilosófico e aceitação de tendência universal, dos quais o DID era desprovido. Neste processo, a ampliação da noção do desenvolvimento, para além dos direitos humanos, adentrando igualmente a seara da preservação ambiental, confere uma roupagem nova para o já renovado DID dos anos 90.

\title{
c) O desenvolvimento sustentável
}

Há duas conferências paradigmáticas para a aproximação do tema do meio ambiente com as negociações sobre desenvolvimento no âmbito da ONU: Estocolmo, em 1972, e Rio de Janeiro, em 1992.

A Conferência de Estocolmo decorreu de dois acontecimentos paralelos do final dos anos 1960: de um lado, as chuvas ácidas e a poluição do ar na Europa, que os levou a propor, em 1968, a realização de uma reunião por meio do ECOSOC; do

${ }^{283}$ CARDIA, Fernando Antonio Amaral. Uma breve introdução à questão do desenvolvimento como tema de direito internacional. In AMARAL JÚNIOR, Alberto (Org.). Direito internacional e desenvolvimento. Barueri: Manole, 2005, p. 53.

${ }^{284}$ AMARAL JÚNIOR, Alberto e MOISES, Claudia Perrone (Orgs.). O cinqüentenário da Declaração Universal dos Direitos Humanos. São Paulo: Edusp, 1999, p. 186. 
outro, a criação no mesmo ano do Clube de Roma, que divulgaria mais tarde, em 1972, o relatório intitulado "os limites do crescimento".

O relatório do Clube de Roma defendia a necessidade de paralisação do crescimento econômico como forma de impedir o aumento da poluição e da degradação ambiental. Essa proposta não obteve respaldo, pois implicaria a paralisação no nível de desenvolvimento daquele momento. Este foi o primeiro sinal de que a Conferência de Estocolmo estaria dividida entre dois blocos: de um lado, os países desenvolvidos, do outro, os países em desenvolvimento.

A partir da indicação do ECOSOC, foi aprovada a realização da Conferência para 1972. No entanto, esse conflito de interesses entre Norte e Sul decorrente do Relatório do Clube de Roma, levou à realização de um Painel de Peritos, em 1971, no qual surgiu a tese de estabelecer medidas diferentes para países centrais e periféricos.

Nesse sentido, pode-se afirmar que os preparativos para a Conferência de Estocolmo respiravam os ares do DID reivindicado pelo Terceiro Mundo em outros fóruns internacionais e que, naquele momento, encontrava eco também nos debates sobre meio ambiente.

De acordo com José Augusto Fontoura Costa:

Os resultados do Painel de Peritos foram muito além das expectativas e consagraram as ideias em favor dos países em desenvolvimento não apenas nos princípios 9, 10,11, 12, 16, 20 e 26, mas também na cláusula preambular, que afirma que "nos países em desenvolvimento, a maioria dos problemas ambientais são causados pelo subdesenvolvimento. Milhões continuam a viver abaixo dos níveis mínimos necessários para uma existência humana, privados de alimentos, vestimenta, abrigo, educação e saúde". ${ }^{285}$

A Conferência das Nações Unidas sobre o Meio Ambiente Humano foi realizada de 5 a 16 de junho de 1972, e teve como resultados:

- A Declaração das Nações Unidas sobre Meio Ambiente Humano (Declaração de Estocolmo);

- O Plano de Ação para o Meio Ambiente;

${ }^{285}$ COSTA, José Augusto Fontoura. Aspectos fundantes da Conferência de Estocolmo de 1972. In COSTA, José Augusto Fontoura, DERANI, Cristiane (Orgs.). Direito Ambiental Internacional. Santos: Leopoldinum, 2001, pp. 11-26. 
Um fato relevante nessa caminhada entre a Conferência de Estocolmo e a do Rio de Janeiro foi a criação da Comissão Mundial sobre o Meio Ambiente e Desenvolvimento, em 1983, no âmbito da qual se elaborou um relatório que veio a ser apresentado em 1987, denominado de Nosso Futuro Comum, mais conhecido por Relatório Brundtland.

A relevância do Relatório Brundtland se dá por dois aspectos. Utilizou-se pela primeira vez a expressão "desenvolvimento sustentável", no sentido de que o desenvolvimento deve atender às necessidades das gerações atuais, sem comprometer a capacidade das futuras gerações. Também, foi o documento propulsor da realização de uma nova conferência mundial para tratar dos temas do meio ambiente e do desenvolvimento. ${ }^{286}$

De acordo com Rafael Santos de Oliveira:

\begin{abstract}
durante os 20 anos transcorridos entre a Conferência de Estocolmo e a do Rio de Janeiro houve um aumento na consciência das ameaças ao meio ambiente causadas pelas atividades humanas em âmbito global. Além disso, também ocorreu uma ampliação nas negociações e produção de instrumentos jurídicos internacionais sobre diversos temas ainda não regulados, tais como a contaminação do ar, a camada de ozônio, o direito do mar, a energia atômica e o transporte de cargas perigosas. ${ }^{287}$
\end{abstract}

Com base nos temas e nas conclusões do Relatório Brundtland, convocou-se a Conferência das Nações Unidas sobre Meio Ambiente e Desenvolvimento, realizada no Rio de Janeiro, em 1992.

Os principais resultados da Conferência do Rio, que ficou conhecida como ECO-92, foram a assinatura de duas concepções multilaterais: a ConvençãoQuadro das Nações Unidas sobre Mudança do Clima e a Convenção sobre a Diversidade Biológica. Ademais, outros três documentos de natureza declaratória,

\footnotetext{
${ }^{286}$ OLIVEIRA, Rafael Santos de. Direito Ambiental Internacional: o papel da soft law na sua efetivação. Ijui: Editora UNIJUI, 2007, p. 142.

${ }^{287}$ OLIVEIRA, Rafael Santos de., op. cit., p. 135.
} 
igualmente relevantes, decorreram da Conferência de 1992: A Declaração do Rio, a Declaração de Princípios sobre as Florestas e a Agenda $21 .{ }^{288}$

A Declaração do Rio expandiu o conteúdo tradicional do DID, ao promover um tipo de atividade econômica que fosse ambiental e socialmente sustentável. Segundo o seu Princípio 3, o direito ao desenvolvimento deve exercer-se de maneira que responda equitativamente, tanto às necessidades de desenvolvimento quanto às de preservação ambiental, das gerações presentes e futuras. Como consequência, o Princípio 4 estabelece que a proteção ao meio ambiente deverá constituir parte integrante do processo de desenvolvimento e não poderá ser considerado de forma isolada.

A partir da Declaração do Rio, o DID passava a sustentar-se sobre três pilares: o desenvolvimento econômico, os direitos humanos, e a preservação ambiental. Os esforços seguintes se dariam no sentido de buscar a integração destes três pilares. Deste modo surgiu o Programa 21, como um programa detalhado de ação, por meio do qual se efetivaria a Declaração do Rio. O Programa 21 estabelece os âmbitos e as pautas de ação para a realização de um processo de desenvolvimento sustentável na prática. ${ }^{289}$

O secretário geral da ONU à época, Boutros Ghali, afirmava ser o Programa 21:

o primeiro acordo internacional no qual se expressa no mais alto nível um consenso mundial e um compromisso político de ação em matéria de meio ambiente e progresso econômico, sob a égide do desenvolvimento sustentável. A partir da Conferência das Nações Unidas sobre Meio Ambiente e Desenvolvimento, as questões relativas ao meio ambiente ficam firmemente vinculadas entre os temas da cultura do desenvolvimento.

Sob este prisma, cabe observar que as declarações, princípios e programas adotados nas conferências giram, em grande medida, em torno das pautas

\footnotetext{
${ }^{288}$ Dois outros documentos emergiram como desdobramentos das Convenções: o Protocolo de Quioto, decorrente da Convenção sobre Mudanças Climáticas, e o Protocolo de Cartagena, decorrente da Convenção sobre Diversidade Biológica.

${ }^{289}$ No que se refere a avaliação dos progressos referentes aos compromissos da Declaração do Rio e da Agenda 21, já foram realizadas 4 conferências, uma a cada 5 anos: a Conferência da Terra +5 (1997), a Conferência Rio +10 (2002), a Conferência de Copenhague, a COP 15 (2007) e a recente Conferência Rio +20 (2012).
} 
estabelecidas no Programa 21 para o desenvolvimento sustentável e constituem, em seus respectivos âmbitos, um aprofundamento do mesmo.

De acordo com Silvia Menicucci de Oliveira:

A Conferência do Rio não foi apenas o corolário de um processo de negociações internacionais e conquistas acerca das questões ambientais e outras relativas ao desenvolvimento, com repercussão no âmbito doméstico nacional. Seus resultados jurídicos e institucionais significaram a reafirmação e o fortalecimento de princípios internacionais voltados a reger as relações internacionais e a guiar a criação de instrumentos internacionais paralelamente a reconsideração do caráter interdependente dos direitos humanos no seio da comunidade internacional, propiciada pelo termino das divergências existentes no período da Guerra Fria. ${ }^{290}$

Durante a década de 1990, a noção de desenvolvimento sustentável e o Programa 21 se configuram como o eixo central da ONU na esfera econômica e social, bem como na cooperação internacional para o desenvolvimento, estratégia que passa a integrar os direitos humanos $\mathrm{e}$ os grandes problemas de desenvolvimento humano e social. É essa lógica integradora da ONU em torno do desenvolvimento que vai pautar a sua estratégia de ação no início do século XXI.

\subsection{A ABORDAGEM INTEGRAL DO DESENVOLVIMENTO DO NOVO MILÊNIO}

\section{a) A Declaração e os Objetivos do Desenvolvimento do Milênio}

i. O lançamento da estratégia da primeira década do século XXI

A estratégia da ONU para o desenvolvimento, a ser implantada ao final da quarta década, começou a ser desenhada ao final dos anos 90. Em junho de 1997, a

\footnotetext{
${ }^{290}$ OLIVEIRA, Silvia Menicucci., op. cit., p. 566.
} 
AG adotou a Resolução $n^{\circ}$ 51/240, que propunha uma "Agenda para o Desenvolvimento", o primeiro documento da ONU a assumir uma aproximação integradora da questão do desenvolvimento, levando em consideração aspectos com a paz, o desenvolvimento econômico, a proteção ambiental, a justiça social e a democracia.

A partir desta Resolução, o Secretário Geral apresentou à AG um projeto sobre uma estratégia de desenvolvimento para a quinta década da ONU para o desenvolvimento, referente ao período 2000-2010. No entanto, este projeto não chegou a ser examinado pela AG, cuja atenção estava centrada na formulação de um documento com grande conjunto de objetivos e compromissos globais para o novo milênio.

Nesse sentido, a Resolução $n^{\circ} 55 / 2$ de 13 de setembro de 2000 lança a Declaração do Milênio, uma tentativa de combinar todos os esforços para fazer frente à pobreza e ao desenvolvimento econômico e social, de maneira holística e integradora. Por meio desta declaração, são lançados os oito Objetivos de Desenvolvimento do Milênio (ODM), e suas correspondentes metas a serem alcançadas até 2015.

\section{i. Os princípios}

O parágrafo $5^{\circ}$ da Declaração do Milênio estabelece, como sendo um dos valores e princípios contemporâneos da comunidade internacional o seguinte:

5. Se é certo que a globalização oferece grandes possibilidades, atualmente os seus benefícios, assim como os seus custos, são distribuídos de forma muito desigual. Reconhecemos que os países em desenvolvimento e os países com economias em transição enfrentam sérias dificuldades para fazer frente a este problema fundamental. Assim, consideramos que, só através de esforços amplos e sustentados para criar um futuro comum, baseado na nossa condição humana comum, em toda a sua diversidade, pode a globalização ser completamente equitativa e favorecer a inclusão. Estes esforços devem incluir a adoção de políticas e medidas, a nível mundial, que correspondam às necessidades dos países em desenvolvimento e das economias em transição e que sejam formuladas e aplicadas com a sua participação efetiva. 
Este trecho da Declaração assume relevância fundamental para a presente tese, pois ao longo da década de 90, os documentos da ONU não manifestavam expressamente a desigualdade de oportunidades e de custos dentre países desenvolvidos e em desenvolvimento, tal qual expresso no parágrafo $5^{\circ}$. $\mathrm{O}$ estabelecimento de um compromisso com a ideia de favorecer a inclusão dos países em desenvolvimento parece resgatar a construção do DID, que havia sido abandonada ao longo dos anos 90.

Dentre os capítulos da Declaração do Milênio, assume especial relevância o Capítulo III (parágrafos 11 a 20), intitulado "Desenvolvimento e erradicação da pobreza", no qual foram estabelecidos princípios e as metas específicas em torno das questões do desenvolvimento.

O parágrafo 11 destaca que as partes da declaração "estão empenhadas em fazer do direito ao desenvolvimento uma realidade para todos e em libertar toda a humanidade da carência e da pobreza extrema", enquanto o parágrafo 13 completa o parágrafo 11 ao definir que:

A realização deste objetivo depende, entre outras coisas, de uma boa governança em cada país. Depende também de uma boa governança no plano internacional e da transparência dos sistemas financeiros, monetários e comerciais. Propugnamos um sistema comercial e financeiro multilateral aberto, equitativo, baseado em normas, previsível e não discriminatório.

Já o parágrafo 14 da Declaração do Milênio esclarece a questão do financiamento do desenvolvimento, no qual as partes declaram:

Estamos preocupados com os obstáculos que os países em desenvolvimento enfrentam para mobilizar os recursos necessários para financiar o seu desenvolvimento sustentável. Faremos, portanto, tudo o que estiver ao nosso alcance para que a Reunião Intergovernamental de alto nível sobre o financiamento do desenvolvimento, que se realizará em 2001, tenha êxito.

Para cumprir com tais princípios, foram detalhados oito ODM, e suas correspondentes metas.

\section{ii. Os objetivos}


Os Objetivos do Desenvolvimento do Milênio, como apresentados no capítulo anterior, são oito objetivos de desenvolvimento internacional que os 192 Membros das Nações Unidas e uma série de organizações internacionais acordaram alcançar para o ano de 2015 com a finalidade de acabar com a pobreza.

Para a realização dos objetivos e valores da Declaração, foram estabelecidos objetivos e metas, a serem cumpridas até 2015. Estas metas podem ser agrupadas em oito grandes temas:

\section{Tabela 21. Objetivos de Desenvolvimento do Milênio}

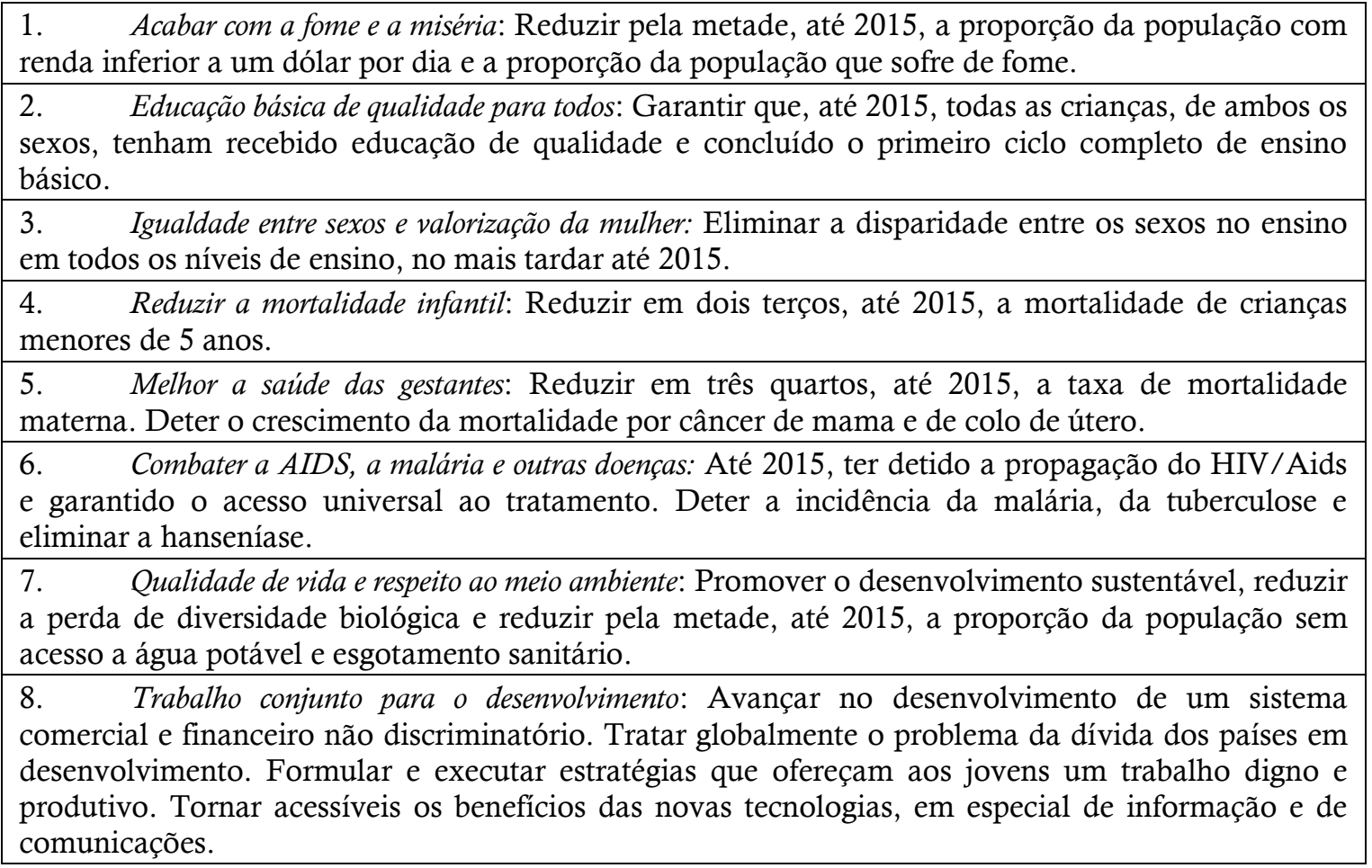

Com base nos parágrafos anteriores, os trabalhos da ONU sobre $\mathrm{o}$ desenvolvimento dos países subdesenvolvidos se centram em dois grandes âmbitos: a participação dos países subdesenvolvidos no comércio internacional como meio para promoção do desenvolvimento, e a necessidade de adotar um enfoque integral e inter-relacionado dos diversos problemas que confluem no financiamento ao desenvolvimento. 
Sobre a integração dos ODM com a questão do financiamento global para o desenvolvimento, faz-se necessário analisar a Conferência de Monterrey de 2002. Sobre a integração dos ODM com a questão do comércio internacional, há ODM específicos que atinem aos objetivos da OMC. Ambas as faces serão analisadas a seguir.

b) A relação entre os Objetivos de Desenvolvimento do Milênio e a Conferência de Monterrey

Em meados dos anos de 1980, constatou-se pela AG que "a transferência líquida de recursos dos países em desenvolvimento em seu conjunto adquiriu um caráter negativo devido a alta carga de pagamentos para cobrir o serviço da dívida". Nesse sentido, "a corrente de recursos externos se dirigiu dos países pobres para os ricos, ao invés de ir em direção contrária". ${ }^{291}$

Nesse sentido, na quarta década da ONU para o desenvolvimento, a estratégia em torno do financiamento para o desenvolvimento estava centrada na relação entre os financiamentos externos e a dívida externa dos países subdesenvolvidos. O objetivo, da quarta década em diante era reorientar esse fluxo de capitais, pelo aumento da corrente de recursos externos aos países em desenvolvimento, mas especialmente, pela redução da carga de pagamentos que estes países deveriam efetuar para cobrir os serviços da dívida externa.

Como afirma Velasco:

o Sistema ONU para o desenvolvimento nunca esteve acompanhado de um sistema de financiamento do desenvolvimento, capaz de assegurar os recursos econômicos necessários para a realização dos programas de desenvolvimento adotados pela ONU. Na realidade, trata-se de um financiamento incerto, escassamente coordenado, excessivamente dependente dos países industrializados e pouco diversificado em suas fontes. $^{292}$

Se a década de 90 é o período no qual a reversão dessa tendência foi eleita como foco primordial da estratégia de financiamento dos países em

${ }^{291}$ Resolução n ${ }^{\text {o }}$ 45/199, parágrafos 36 e 37.

${ }^{292}$ VELASCO, op. cit., p. 350. 
desenvolvimento, é a partir da Declaração do Milênio que uma nova orientação efetivamente se consolida no âmbito do Sistema ONU.

Essa reunião realizada em 2002, na cidade de Monterrey, México, foi chamada de Conferência Internacional sobre o Financiamento do Desenvolvimento. A resolução resultante dessa conferência foi denominada de Consenso de Monterrey. ${ }^{293}$

Há três aspectos que podem ser considerados como os princípios que orientam tal consenso:

a) a prioridade que se outorga a mobilização dos recursos internos como base do desenvolvimento e fonte de seu financiamento;

b) a necessidade de diversificar as fontes de financiamento do desenvolvimento;

c) a coordenação e cooperação entre as organizações internacionais competentes em questões financeiras, comerciais e de desenvolvimento.

Dentro deste marco, as medidas e compromissos adotados se referem aos seis ambitos seguintes:

a) a mobilização dos recursos financeiros nacionais para o desenvolvimento;

b) a mobilização dos recursos internacionais (investimentos estrangeiros diretos e outras fontes de capital privado);

c) o comércio internacional;

d) o aumento da cooperação internacional financeira e técnica;

e) a dívida externa;

f) o tratamento das questões sistêmicas.

De acordo com Velasco:

a novidade do processo foi o enfoque integral do financiamento do desenvolvimento e sua proposição no seio da ONU. O objetivo era tratar o financiamento do desenvolvimento de uma forma ampla e integral capaz de contemplar as distintas dimensões do desenvolvimento (econômico, social, sustentável, e vinculado a paz e segurança internacional, ao sistema democrático, e ao respeito dos direitos humanos), e de formular propostas de financiamento suscetíveis de adequar-se a diversidade de aspectos, situações e problemas que implica o desenvolvimento dos países subdesenvolvidos. ${ }^{294}$

293 Documento disponível em http://www.un.org/esa/ffd/monterrey/MonterreyConsensus.pdf. Acessado em 18/06/2012.

${ }^{294}$ VELASCO, op. cit., p. 351. 


\section{c) A relação entre os Objetivos de Desenvolvimento do Milênio e a OMC}

A Organização Mundial do Comércio (OMC), enquanto organização internacional voltada à regulação das relações econômicas e comerciais internacionais, assumiu importância crucial quando das negociações da Declaração do Milênio e da criação de um entorno global mais favorável para os países em desenvolvimento.

Muito embora a OMC não seja uma agência especializada da ONU, ela mantém fortes relações com a ONU e as suas agências desde sua criação. O Diretor Geral da OMC participa da Junta Executiva Principal da ONU, que é o órgão de coordenação do Sistema ONU, com as demais organizações internacionais e organizações não-governamentais. As relações ONU-OMC estão orientadas pela Comunicação do Diretor Geral da OMC “Arranjos para uma efetiva cooperação com outras organizações intergovernamentais: relações entre a OMC e as Nações Unidas", publicada em 15 de novembro de $1995 .{ }^{295}$

Os principais ODM que dizem respeito à OMC são, de maneira direta, o $8^{\circ}$, e de maneira mais ampla, os $1^{\text {o }}$ e $7^{\text {o }} .^{296}$

ODM 1: Erradicar a pobreza extrema e a fome

Meta 1a: Reduzir para a metade, a proporção de pessoas com salários inferiores a 1 dólar por dia.

Meta $1 b$ : Alcançar o emprego pleno e produtivo e o trabalho decente para todos, incluídos as mulheres e os jovens.

Meta 1c: Reduzir para a metade, a porcentagem de pessoas que são passam fome.

\section{ODM 7: Garantir a sustentabilidade do meio ambiente}

Meta 7a: Incorporar os princípios do desenvolvimento sustentável nas políticas e nos programas nacionais e reduzir a perda de recursos do meio ambiente.

Meta 7b: Ter reduzido e desacelerado consideravelmente a perda de diversidade biológica em 2010.

Meta 7c: Reduzir para a metade a proporção de pessoas sem acesso sustentável a água potável e a serviços básicos de saneamento.

\footnotetext{
295 Documento disponível em http://www.wto.org/spanish/thewto s/coher s/wto un s.htm. Acesso em 25/06/2012.

${ }^{296}$ Ver publicação institucional da OMC, "La OMC y los Objetivos del Desarrollo Del Milenio". Disponível em http://www.wto.org/english/thewto e/coher e/mdg e/mdg e.htm. Acesso em $10 / 02 / 2012$.
} 
Meta 7d: Ter melhorado consideravelmente, em 2020, a vida de pelo menos, 100 milhões de habitantes de bairros marginais.

\section{ODM 8: Fomentar uma aliança mundial para o desenvolvimento}

Meta 8a: Desenvolver ainda mais um sistema comercial e financeiro aberto, baseado em normas, previsível e não-discriminatório.

Meta 8b: Atender as necessidades especiais dos países menos avançados.

Meta 8c: Atender as necessidades especiais dos países sem litoral e dos pequenos países insulares em desenvolvimento.

Meta 8d: Encarar de maneira geral, os problemas da dívida dos países em desenvolvimento.

Meta 8e: Em cooperação com empresas farmacêuticas, proporcionar acesso a medicamentos essenciais nos países em desenvolvimento.

Meta 8f: Em colaboração com o setor privado, cuidar para que se possa aproveitar os benefícios das novas tecnologias, em particular, as tecnologias da informação e das comunicações.

O ODM 8 tem sua origem no reconhecimento de que, para que os países mais pobres alcancem os demais objetivos da Declaração do Milênio, é importante criar um entorno internacional que facilite sua consecução até 2015. Consequentemente, o ODM 8 é um importante elemento da estrutura global da Declaração, por ser mais do que um objetivo em si mesmo; é na verdade um objetivo-meio para alcançar os demais objetivos do milênio. Ele representa uma condição prévia para que todos esses objetivos sejam alcançáveis e sustentáveis em longo prazo.

A ideia de uma aliança mundial, tal qual propugnada pelo ODM 8, está igualmente contida no mandato da OMC de dar coerência à formulação das políticas nacionais na escala internacional. Nesse sentido, a OMC engloba igualmente o ODM 7.

É possível identificar, no âmbito da OMC, as seis metas elencadas no marco do ODM 8.

i. A Meta 8a, de desenvolver ainda mais um sistema comercial e financeiro aberto, baseado em normas, previsível e não-discriminatório, é um objetivo da OMC desde sua origem, por meio das Conferências Ministeriais.

ii. A Meta 8b, de atender as necessidades especiais dos países menos avançados, é no cerne da Rodada de Doha. Além disso, o lançamento a Quarta 
Conferencia das Nações Unidas sobre os Países Menos Avançados, que se celebrou na Turquia, teve participação da OMC. ${ }^{297}$

iii. A Meta 8c, de atender as necessidades especiais dos países sem litoral e dos pequenos países insulares em desenvolvimento, também é abarcada pela OMC. A OMC tem um programa de trabalho para os pequenos Estados insulares em desenvolvimento e contribui para os esforços internacionais para dar respostas as necessidades dos países sem litoral. ${ }^{298}$

iv. A Meta 8d, de encarar de maneira geral, os problemas da dívida dos países em desenvolvimento, é um tema predominantemente tratado pelo Banco Mundial e pelo FMI, muito embora, indiretamente, as negociações da OMC tratam sucessivamente da questão da dívida externa dos países em desenvolvimento.

v. A Meta 8e estabelece a necessidade de cooperação com empresas farmacêuticas, a fim de proporcionar acesso a medicamentos essenciais nos países em desenvolvimento. No âmbito da OMC, esta meta está diretamente relacionada com outro objetivo da ONU, o ODM n ${ }^{\circ}$ 6:

\section{ODM 6: Combater o HIV/AIDS, a malária e outras enfermidades}

Meta 6a: Deter e começar a reduzir a propagação do HIV/AIDS.

Meta 6b: Alcançar, para 2010, o acesso universal ao tratamento do $\mathrm{HIV} / \mathrm{AIDS}$ de todas as pessoas que o necessitem.

Meta 6c: Deter e começar a reduzir a incidência da malária e outras enfermidades graves.

Para atender a meta 8e em conjunto com o ODM 6, os Membros da OMC modificaram a normativa para dar aos países em desenvolvimento maior acesso a medicamentos essenciais. A este respeito, análise mais detalhada será dada no capítulo seguinte.

vi. Por fim, a Meta 8f estabelece a necessidade de colaboração com o setor privado, a fim de cuidar para que se possa aproveitar os benefícios das novas tecnologias, em particular, as tecnologias da informação e das comunicações. A

\footnotetext{
${ }^{297}$ Sitio oficial da Conferência: http://www.un.org/es/conf/ldc/. Acesso em 27/06/2012.

${ }^{298}$ Este foi um tema presente na Conferência de Cancún, de 2003, na qual os Estados-Membros discutirem, dentre outros assuntos, o impacto das mudanças climáticas nos Estados-Membros da OMC, dentre os quais existem diversos países insulares e sem litoral. Ver: http://www.wto.org/spanish/thewto s/minist s/min03 s/min03 s.htm. Acesso em 27/06/2012.
} 
OMC trata diretamente destas questões por meio da regulação da propriedade intelectual, por meio do Acordo TRIPS. É com base nesta meta que se sustentam as reivindicações dos países em desenvolvimento para avançar as negociações de Doha em matéria de transferência de tecnologia, fomento a inovação e aumento do capital humano, como se verá no capitulo seguinte.

Embora as metas do ODM 8 sejam anteriores ao lançamento da Rodada de Doha, ambas são fruto do mesmo movimento de renovação e expansão do DID. A complementaridade entre a atuação diplomática dos países em desenvolvimento em ambos os foros (ONU e OMC) e da produção normativa decorrente de ambos os foros manteve o DID vivo e presente, revelando sua natureza dinâmica e transformadora. No entanto, é no âmbito da UNCTAD que historicamente se desenvolveram as maiores ações em prol do desenvolvimento, e isto não foi diferente no início do século XXI.

\subsection{O RESSURGIMENTO DA UNCTAD NO INÍCIO DO SÉCULO XXI}

\section{a) A Conferência de Bangkok de 2000}

A X Conferência das Nações Unidas sobre o Comércio e Desenvolvimento, lançada em Bangcoc, Tailândia, em 13 de fevereiro de 2000, foi a primeira grande reunião internacional do século XXI, sobre temas econômicos e comerciais, a ser realizada fora do âmbito da OMC. ${ }^{299}$

Três meses antes, a Conferência Ministerial da OMC em Seattle havia sido um rotundo fracasso ${ }^{300}$, o que levou os Membros da comunidade internacional a

\footnotetext{
299 Os documentos referentes a X Conferência da UNCTAD estão disponíveis em http://unctad.org/en/Pages/MeetingsArchive.aspx?meetingid=4288. Acesso em 22/06/2012. ${ }^{300}$ A respeito da Conferência de Seattle, maior análise será realizada no capítulo seguinte.
} 
promover um balanço sobre a experiência da promoção global do desenvolvimento na segunda metade do século XX.

De acordo com Rubens Ricupero, então Secretário-Geral da UNCTAD, tal reflexão foi conduzida com base em três indagações fundamentais. Primeiro, o que deu certo ou errado nesse esforço e quais foram as razões dos acertos e fracassos. Segundo, o que teria faltado à abordagem original do desenvolvimento, quando o enfoque era, sobretudo, econômico e havia pouca ou nenhuma preocupação com aspectos como o meio ambiente, a distribuição da renda, o problema de persistência da pobreza, a marginalização da mulher, a insensibilidade para os investimentos em recursos humanos. Terceiro, quais são os problemas a enfrentar no futuro, as prioridades e maneiras de lidar com eles. ${ }^{301}$

A Conferência de Bangcoc foi intitulada "As estratégias de desenvolvimento em um mundo interdependente: aplicando as lições do passado para tornar a globalização um instrumento efetivo de desenvolvimento para todos os países e povos." Com este espírito, a Conferência de Bangcoc é lançada com base na seguinte premissa:

\begin{abstract}
O impacto da globalização sobre o desenvolvimento é variado: enquanto alguns países em desenvolvimento tem se beneficiado, outros não. As disparidades econômicas entre os países não reduziu, e o resultado é que muitos países em desenvolvimento, especialmente os PMA, enfrentam o risco de aumentar o nível de marginalização. As tensões e os desequilíbrios de natureza sistêmica também aumentaram e, dado o alto grau de interdependência na economia global, o risco de crises financeiras ultrapassarem as fronteiras nacionais e atingirem países e regiões vizinhas é cada vez maior. A comunidade internacional deve levar adiante uma revisão rigorosa e equilibrada do quadro institucional e político do comércio e das finanças internacionais (Grifo nosso).
\end{abstract}

Ao final da Conferência, a Declaração de Bangcoc apresentou um plano de ação, estruturado em torno de dois eixos básicos: o primeiro diz respeito às estratégias de desenvolvimento em um mundo cada vez mais interdependente, baseadas na aplicação das lições de experiência para tornar a mundialização um instrumento eficaz para o desenvolvimento de todos os países e pessoas; o segundo refere-se à necessidade de reforçar o papel da UNCTAD como centro de

${ }^{301}$ RICUPERO, Rubens. Esperança e ação: a ONU e a busca de um desenvolvimento mais justo. São Paulo: Paz e Terra, 2002, p. 43. 
coordenação da ONU para o tratamento integral do comércio e o desenvolvimento, bem como as questões interrelacionadas nos setores do financiamento, a tecnologia, os investimentos e o desenvolvimento sustentável, em um processo crescente de mundialização. ${ }^{302}$

No que se refere às regras sobre o comércio internacional, a Declaração de Bangcoc se centra prioritariamente na necessidade de facilitar o acesso dos países subdesenvolvidos ao comércio internacional e sua adesão à OMC, assim como a regulação multilateral de comércio baseado na aplicação de um tratamento especial e diferenciado mais efetivo para os países em desenvolvimento.

As medidas e propostas se referem aos seguintes âmbitos: liberalização de comércio, coerência das políticas, tratamento especial e diferenciado, produtos básicos, concorrência, serviços, cooperação econômica entre países em desenvolvimento e integração econômica.

Ademais, no contexto dos trabalhos preparatórios da X Conferência foi publicado pela UNCTAD um documento seminal elaborado por Alice Amsden, "Industrialization under new WTO law", referência no estudo do policy space no âmbito das regras da OMC ao qual será referenciado a seguir.

Rubens Ricupero afirma que havia um espírito de busca de consenso que prevalecera nas deliberações e o sentido geral do movimento de crescente convergência em direção a alguns postulados centrais do pensamento dominante à época, em matéria de desenvolvimento, em substituição ao desacreditado Consenso de Washington.

Por isso, a X Conferência da UNCTAD teria sido um momento definitivo de transição, no qual a comunidade internacional estaria passando do Consenso de Washington à Convergência de Bangcoc. ${ }^{303}$ Este processo de transição se consolidou quatro anos mais tarde, com a realização da XI Conferência, realizada em São Paulo, Brasil, que coincidiu com a celebração dos 40 anos da UNCTAD.

\footnotetext{
${ }^{302}$ VELASCO, op.cit., pp. 339-340.
}

${ }^{303}$ RICUPERO, op. cit., p. 55. 


\section{b) A Conferência de São Paulo de 2004}

Ao longo dos trabalhos preparatórios para a Conferência de São Paulo, bem como ao longo de sua realização, houve uma polarização das posições em relação ao mandato da UNCTAD. De um lado o G-77 e a China, que queriam ampliar os poderes e competências da Conferência e, do outro, os Estados Unidos e a União Européia, que desejavam evitar que a UNCTAD se convertesse em um foro de negociações prévias, especialmente no que tangia às negociações paralelas da Rodada Doha da OMC.

Ainda em relação ao processo preparatório da XI Conferência, deve se destacar que, da mesma forma que a Conferência de Bangcoc se realizou em seguida ao fracasso da Conferência Ministerial da OMC de Seattle, a Conferência da UNCTAD que estava sendo preparada para São Paulo, também sucederia um fracasso de negociações da OMC, ocorrido na Conferência Ministerial de Cancun, em 2003.

De acordo com as conclusões da Conferência de Bangcoc, de 2000, o tema principal estipulado para a XI Conferência de São Paulo seria "o aumento da coerência entre as estratégias nacionais de desenvolvimento e os processos econômicos mundiais em prol do crescimento econômico e o desenvolvimento, particularmente dos países em desenvolvimento".

A XI Conferência da UNCTAD de São Paulo, que ocorreu em junho de 2003, foi estruturada em torno de quatro subtemas:

\footnotetext{
- Subtema 1: as estratégias de desenvolvimento em uma economia mundial em vias de globalização

- Subtema 2: Fomento da capacidade de produção e da competitividade internacional

- Subtema 3: Obtenção de benefícios em matéria de desenvolvimento a partir do sistema comercial internacional e as negociações comerciais

- Subtema 4: Associação para o desenvolvimento
}

Ao final da Conferência, tanto as premissas quanto as iniciativas propostas pela Declaração de Bangcoc e por seu plano de ação foram confirmadas, reafirmadas e aprofundadas na Conferência de 2004, em São Paulo, na qual emergiu o chamado "Consenso de São Paulo". 
Como novidade, destaca-se a importância que o Consenso de São Paulo atribui à coerência entre os diversos níveis de atuação que confluem para o desenvolvimento. Ainda, destaca-se a incorporação da perspectiva integralizante do desenvolvimento, oriunda da Declaração do Milênio. A partir do Consenso de São Paulo, a UNCTAD estabelece para si, como meta fundamental, sua capacidade em contribuir e garantir o sucesso dos ODM da Declaração do Milênio.

Com efeito, o Consenso de São Paulo reforça o proposto em Bangcoc, ao reafirmar que a UNCTAD é o centro de coordenação da ONU para o tratamento integrado do comércio e do desenvolvimento, bem como de todos os temas conexos, reivindicando para si o compromisso de ser um órgão com responsabilidade central na persecução dos ODM.

Do ponto de vista da operacionalização do novo viés desenvolvimentista no âmbito dos temas relacionados ao comércio internacional, dois resultados da Conferência de São Paulo podem ser considerados concretos e relevantes: a retomada do SGPC e a criação do argumento em torno de policy space.

\section{c) A Retomada do SGPC}

Durante a XI Conferência da UNCTAD, foi lançada a $3^{\text {a }}$ Rodada de negociações do SGPC, a Rodada de São Paulo, com o objetivo de retomar o processo de cooperação comercial entre os países em desenvolvimento, que estava estagnado desde os anos 80 . Nos anos 90, com o avanço das políticas comerciais de natureza neoliberal e a criação da OMC, o SGPC foi deixado à margem da agenda internacional.

O Consenso de São Paulo clamava por um pacote de acordos substanciais de liberalização no âmbito do SGPC, que beneficiasse de maneira equitativa todos os seus participantes. Como forma de incentivar a participação dos países Membros, nesta rodada, o Comitê de Participantes aboliu a Cláusula NMF dentro do SGPC, o que permitia às partes fazer concessões apenas para países determinados, que não se estenderiam aos demais Membros do SGPC. 
Participaram da Rodada de São Paulo 22 países. ${ }^{304}$ Em 2008, na XII Conferência da UNCTAD em Gana, os países reconheceram a importância das negociações do SGPC e se comprometeram a agir rapidamente para concluir as negociações. ${ }^{305}$ Já em dezembro de 2009, em Genebra, os países adotaram uma decisão ministerial através da qual as partes se comprometiam a negociar visando estabelecer cortes tarifários de no mínimo 70\% nas suas linhas tarifárias. Por fim, em dezembro de 2010, foram apresentadas e aprovadas as listas nacionais de concessões tarifárias, por meio do Protocolo de Foz do Iguaçu.

Atualmente, o SGPC é composto por 43 Membros. ${ }^{306}$ No entanto, daqueles 22 países participantes da Rodada São Paulo, ${ }^{307}$ somente 11 adotaram o Protocolo de Foz do Iguaçu, no qual foram consolidados os compromissos nacionais de liberalização tarifária. O Protocolo permaneceu aberto para adesão dos demais Membros do SGPC.

O significado econômico potencial do SGPC para os países em desenvolvimento é crescente, tendo em vista que as exportações dos Membros do SGPC para o resto do mundo representam quase $14 \%$ das exportações globais de 2011. Além disso, as exportações e importações intra-SGPC representam, respectivamente, $18 \%$ e $19,4 \%$ das exportações e importações dos países do SGPC para o resto do mundo. ${ }^{308}$

Do ponto de vista político e diplomático, o SGPC permanece como um importante palco de confirmação da relevância do comércio Sul-Sul, especialmente para que os países em desenvolvimento dependam menos dos mercados dos países desenvolvidos.

\footnotetext{
304 Página da Rodada de São Paulo do SGPC: http://www.unctadxi.org/templates/Page__1879.aspx.

305 GSTP/CP/SSG/2, 2008

306 Argélia, Angola, Argentina, Bangladesh, Benin, Bolívia, Brazil, Chile, Colômbia, Coréia do Norte, Coréia do Sul, Cuba, Equador, Egito, Gana, Guiné, Guiana, Haiti, Índia, Indonésia, Irã, Iraque, (antiga) Iugoslávia, Líbano, Malásia, México, Marrocos, Moçambique, Nicarágua, Nigéria, Paquistão, Peru, Filipinas, Paraguai, Qatar, România, Singapura, Sri Lanka, Sudão, Tanzânia, Tailândia, Trinidad e Tobago, Tunísia, Uruguai, Venezuela, Vietnã, Zaire e Zimbábue.

${ }^{307}$ Argélia, Argentina, Brasil, Chile, Coréia do Norte, Coréia do Sul, Cuba, Egito, Índia, Indonésia, Irã, Malásia, México, Marrocos, Nigéria, Paquistão, Paraguai, Sri Lanka, Tailândia, Uruguai, Vietnã e Zimbábue. Chile, México e Tailândia participaram das negociações, mas decidiram não assinar o acordo.

${ }^{308}$ A respeito da conclusão da Rodada São Paulo e dos efeitos benéficos do SGPC para os PED, ver Briefing Note da $\quad$ UNCTAD $\quad$ disponível $\quad \mathrm{em}$ http://archive.unctad.org/en/docs/webecidc2011d1 en.pdf.
} 


\section{d) Policy Space: um novo conceito da UNCTAD}

A expressão policy space é empregada pela primeira vez nos documentos oficiais da ONU na Conferência de São Paulo.

Ao longo das negociações da Conferência de São Paulo, a noção de policy space abrangeu dois conceitos que, em português, equivaleram à margem de ação em matéria de políticas públicas e a nacionalismo aberto.

Nos documentos da Conferência de São Paulo, este espaço político era percebido como "o grau de poder decisório do qual dispõem os governos nacionais no que se refere à política econômica e, por consequência, o ponto até onde este poder está limitado por disciplinas e processos internacionais". Já o conceito de nacionalismo aberto se refere à necessidade de formular políticas coerentes que sejam de interesse nacional, isto é, que tenham efeitos benefícios sobre todos os setores da sociedade e sejam coerentes com a crescente integração do país na economia mundial. $^{309}$

Ambos estes conceitos, nacionalismo aberto e espaço político, estiveram presentes em todos os debates mantidos pelos países em desenvolvimento sobre a necessidade de impulsionar os setores econômicos nacionais estratégicos. Segundo o G-77, as disciplinas econômicas de caráter vinculante no plano internacional limitam cada vez mais a capacidade dos governos em elaborar e aplicar políticas econômicas específicas para cada país. ${ }^{310}$

Ao contextualizar a emergência do debate sobre policy space, Sheila Page explica que:

Acordos internacionais contendo obrigações juridicamente vinculantes necessariamente restringem a liberdade de manobra dos Estados, esta é a sua intenção. A criação do GATT refletiu esta escolha por maiores limitações: uma visão de que havia demasiado policy space para os países implantarem políticas comerciais contra os demais, como aconteceu na

\footnotetext{
${ }^{309}$ Ver documento informal intitulado Notes on the Concept of Economic Policy Space, Note prepared by the Secretariat of UNCTAD at the request of member states.

${ }^{310}$ Ver documento da Agência de Cooperação e Informação para o Comércio Internacional intitulado Nota Informativa referente aos trabalhos preparatórios para a XI UNCTAD. Circulação restrita em maio de 2004.
} 
guerra comercial dos anos de 1930. O debate atual questiona se este movimento em prol das limitações de policy space não foi longe demais. 311

O termo policy space surgiu nos documentos preparatórios da UNCTAD e adquiriu status oficial na XI Conferência da UNCTAD, no documento de encerramento, denominado Consenso de São Paulo.

O parágrafo $8^{\circ}$ do Consenso expressa que:

A interdependência crescente das economias nacionais em um mundo globalizado, bem como a emergência de regimes jurídicos das relações econômicas internacionais, se refletiu no espaço para políticas econômicas nacionais, por exemplo, o escopo das políticas domésticas, especialmente em áreas de comércio, investimento e desenvolvimento industrial, está sujeito a regras e compromissos internacionais, em consonância com objetivos comerciais globais. Cabe a cada governo avaliar o trade-off entre os benefícios de aceitar as regras e os compromissos internacionais, e as consequentes obrigações, que levam a uma perda de policy space. Isto é particularmente relevante para os países em desenvolvimento, ao levar em consideração seus objetivos e metas de desenvolvimento, que todos os países devem avaliar a necessidade de um equilíbrio apropriado entre o policy space nacional e os compromissos e regras internacionais (grifos nosso). ${ }^{312}$

Nesse mesmo sentido, o parágrafo $8^{\circ}$ do documento intitulado Espírito de São Paulo, relaciona a UNCTAD com as negociações da Rodada Doha:

As negociações multilaterais sobre comércio devem ser aceleradas, com base no Programa de Trabalho de Doha, como o fim de concluí-las com êxito, de maneira a refletir plenamente as ambições acordadas em Doha. Tal programa, que pela primeira vez põe o desenvolvimento em primeiro plano das negociações multilaterais sobre comércio, coincide com o mandato da UNCTAD e o reforça (grifo nosso).

Como decorrência das Conferências de Bangcoc e São Paulo, a UNCTAD acabou por gerar um Relatório que estava diretamente voltado à questão do policy

${ }^{311}$ PAGE, Sheila. Policy space: are WTO rules preventing development? Briefing Paper n. 14. Overseas Development Institute. Janeiro, 2007. Disponível em http://www.odi.org.uk/resources/docs/106.pdf. Acessado em 11/09/2011.

${ }^{312}$ Pela relevância deste parágrafo para a tese, este segue transcrito na língua original, em inglês: The increasing interdependence of national economies in a globalizing world and the emergence of rule-based regimes for international economic relations have meant that the space for national economic policy, i.e. the scope for domestic policies, especially in the areas of trade, investment and industrial development, is now often framed by international disciplines, commitments and global market considerations. It is for each Government to evaluate the trade-off between the benefits of accepting international rules and commitments and the constraints posed by the loss of policy space. It is particularly important for developing countries, bearing in mind development goals and objectives, that all countries take into account the need for appropriate balance between national policy space and international disciplines and commitments. 
space. O Trade and Development Report de 2006, intitulado Aliança Mundial e Politicas Nacionais para o Desenvolvimento, teve o policy space como tema central do relatório, nos diversos aspectos abarcados: regras monetárias, financiamento internacional, dívida externa, políticas industriais, políticas macroeconômicas e políticas comerciais stricto sensu. ${ }^{313}$

A expressão policy space, que até o relatório anterior a 2006, nunca havia aparecido nos documentos oficiais da ONU, aparece no Trade and Development Report de 2006 vinte e seis (26) vezes, o que por si só já indica a relevância do tema para os países em desenvolvimento, tanto na UNCTAD quanto na Rodada Doha da OMC. A relevância do conceito na Rodada Doha será objeto de estudo do capítulo a seguir.

\footnotetext{
${ }^{313}$ Relatório disponível em: http://unctad.org/en/Docs/tdr2006 en.pdf.
} 


\section{CONCLUSÕES DO CAPÍTULO 6}

Ao longo da década de 1990, se é verdade que o desenvolvimento, na sua vertente econômica e comercial entrou em crise, é precisamente nessa quarta década da ONU que o desenvolvimento passa a se revestir de dois novos vetores, aos quais até então não estava associado: a sua inter-relação com os direitos humanos, que levou à noção de desenvolvimento humano, e também à sua associação com a preservação ambiental, tendo resultado no conceito de desenvolvimento sustentável. Em torno de ambos os conceitos, produziu-se um amplo conjunto de textos de direito internacional que passou a orientar as relações internacionais, e de maneira indireta, lidar com a questão da desigualdade entre os países desenvolvidos e os países em desenvolvimento.

As diferentes décadas da ONU para o desenvolvimento e suas correspondentes estratégias de ação, não devem ser percebidas como fracassos, mas como avanços graduais na longa luta contra a desigualdade, a fome, a pobreza e o subdesenvolvimento. São esforços que formam parte de um conjunto de ações levadas adiante no âmbito da ONU e de suas agências especializadas, que repercutiram em diversas outras organizações internacionais. Em cada década, foi necessário reajustar-se às mudanças ocorridas no cenário internacional e situar os problemas globais dentro de contextos mais amplos.

Em razão disso, a presente tese sustenta que a produção normativa internacional em torno da questão do desenvolvimento ao longo da década de 1990 revela que o DID na realidade não morreu, como correntemente se afirma na literatura. Na realidade, ele passou por um processo de transformação dos seus valores, tornou-se menos ideologizado, menos adstrito ao antagonismo Norte e Sul, entre ricos e pobres, e mais condizente com a noção de interdependência global, que passou a orientar as relações internacionais na virada do século.

Mesmo assim, a comunidade internacional não ignorou o fato de que o abismo que distanciava os países desenvolvidos dos países em desenvolvimento continuou a crescer em velocidade ainda mais acelerada ao longo da década de 
1990. Sem contar que o número de países menos avançados aumentou, ao invés de diminuir.

Por isso, em 1999, o lançamento da nova estratégia da ONU para o desenvolvimento, por meio da Declaração do Milênio, levou ao estabelecimento dos Objetivos de Desenvolvimento do Milênio. Através dos ODM, todos os países Membros da ONU se comprometeram a alcançar resultados em diversos âmbitos (saúde, educação, mortalidade infantil, etc.).

Para a consecução de tais metas, todas as organizações internacionais do Sistema ONU foram envolvidas e abrangidas, dentre as quais, a OMC. É este movimento global de produção normativa e de estabelecimento de planos de ação em torno da questão do desenvolvimento que a presente tese se configura como um processo de renascimento do DID.

O DID vem enfrentando, desde o seu surgimento até os dias atuais, desafios fundamentais: o constante embate com a hegemonia dos princípios econômicos liberais; a crescente heterogeneidade dos países em desenvolvimento e; a consolidação de uma perspectiva jurídico-política (rule-based aproach) das relações internacionais.

Os ODM, por exemplo, a mais recente ideia-força produzida pela ONU, podem ser percebidos como os avanços mais recentes dentro do dinamismo internacional que pretende guiar as ações governamentais no diapasão dos direitos socioeconômicos. Os ODM se converteram, assim, na consolidação instrumental de um corpus internacional mínimo para garantir o cumprimento dos direitos humanos de conteúdo socioeconômico, vinculando as estratégias de desenvolvimento nacional às obrigações jurídicas dos Estados no plano internacional.

No âmbito desse abarcamento pela ideia-força dos ODM da ONU, a OMC envolveu-se num processo de revisão dos seus propósitos e objetivos. Este foi o momento que os países em desenvolvimento esperavam para, com a legitimidade decorrente desse movimento global, tentar rever e ampliar o conjunto de prerrogativas jurídicas para o desenvolvimento existentes no escopo da OMC. Com base nos documentos da UNCTAD, o policy space tornou-se argumento central das 
negociações da Rodada Doha. Este processo de renovação da OMC e das suas regras que será analisado no capítulo a seguir. 


\title{
CAPÍTULO 7. O NOVO DESENVOLVIMENTISMO NA ORGANIZAÇÃO MUNDIAL DO COMÉRCIO: OPORTUNIDADES CONTEMPORÂNEAS DE POLICY SPACE
}

\begin{abstract}
Não sabemos para onde estamos indo. Só sabemos que a história nos trouxe até este ponto. Contudo, uma coisa é clara. Se a humanidade quer ter um futuro reconhecível, não pode ser pelo prolongamento do passado ou do presente. Se tentarmos construir o terceiro milênio nessa base, vamos fracassar. $\mathrm{E}$ o preço do fracasso, ou seja, a alternativa para uma mudança da sociedade, é a escuridão.
\end{abstract}

Eric Hobsbawn, Era dos Extremos, 1995 


\section{APRESENTAÇÃO DO CAPÍTULO 7}

O capítulo 7 pretende apresentar o processo de emergência da tendência neodesenvolvimentista na OMC. Para isso, está estruturado em três seções.

O subcapítulo 7.1 analisa o declínio do viés neoliberal da OMC. Em uma primeira parte, deve-se resgatar os motivos que levaram à insatisfação dos países em desenvolvimento ao final da Rodada Uruguai e ao longo dos primeiros anos de implantação dos acordos da OMC. Em seguida, apresentar os principais pontos de negociação que levaram às discórdias e crises das primeiras conferências da OMC (Genebra, Singapura e Seattle).

O subcapítulo 7.2 trata da Rodada Doha, lançada a partir da Conferência de Doha, que foi organizada como um contraponto às mal-sucedidas conferências que a antecederam. Em seguida, será realizada uma breve apresentação dos principais documentos e decisões resultantes da conferência, especialmente a Declaração de Doha, que lança uma nova Rodada de negociações da OMC, a Rodada Doha. Feito isso, será traçado um panorama dos principais acontecimentos desta Rodada até o momento, passando pelas Conferências de Cancun e de Hong Kong, até chegar ao cenário contemporâneo de crise global, que colocou a OMC em compasso de espera. Por fim, será destacado um dos diversos pontos negociados ao longo da Rodada, que tem especial relevância para a tese: as propostas de definição de "Membro em desenvolvimento" que estão sendo discutidas na Rodada Doha.

O subcapítulo 7.3 apresenta, a título de conclusão do capítulo, uma breve revisão da literatura especializada, de natureza mais reflexiva, que aporta fundamentos para uma interpretação neodesenvolvimentista da OMC e dos seus respectivos acordos. 


\subsection{O DECLÍNIO DO PERÍODO NEOLIBERAL DA OMC}

\section{a) A insatisfação dos países em desenvolvimento}

Com a conclusão da Rodada Uruguai, não levou muito tempo para que fossem retomadas as negociações comerciais no âmbito da OMC. Isto se deve a três motivos.

Em primeiro lugar, já em 1995, diversos países em desenvolvimento estavam insatisfeitos com vários aspectos do pacote de acordos da Rodada Uruguai, seja porque lhes concediam poucos direitos, seja porque lhes atribuíam demasiadas responsabilidades, seja porque geravam altos custos de implantação. ${ }^{314}$ Havia entre os países em desenvolvimento uma sensação de desequilíbrio nos resultados da Grande Barganha da Rodada Uruguai, pois, os ganhos com os acordos sobre agricultura (AARU) e sobre têxteis e vestuário (ATV) pareciam muito mais distantes do que os custos com os quais teriam que arcar. Havia uma percepção de que as concessões não correspondiam aos ganhos. ${ }^{315}$

Em segundo lugar, diversos acordos da Rodada Uruguai continham uma "built-in agenda", que exigia a continuidade das negociações em praticamente todas as áreas da $\mathrm{OMC}$, exceto reduções tarifárias. $\mathrm{O}$ marco regulatório alcançado ao final da Rodada Uruguai não foi concebido para ser entendido como uma ordem

\footnotetext{
${ }^{314}$ Dentre os temas que geraram a reação mais imediata entre os PED foi o processo de implantação do TRIPS, em razão do alto custo gerado pela proteção dos direitos de propriedade intelectual, em especial as patentes, era mais alto que o imaginado, especialmente na área de saúde.

${ }^{315} \mathrm{Em}$ relação à agricultura, os PED, em conjunto com as ONG e a sociedade civil, estavam chamando a atenção para o problema dos enormes volumes de subsídios domésticos e subsídios à exportação aportados pelos $\mathrm{PD}$, especialmente os EUA e a CE. O principal argumento era de que a eliminação de tais espécies de subsídios por parte dos PD não deveria ser considerado altruísmo, muito menos estar condicionado a novas concessões dos PED, mas sim, a correção de uma assimetria absurda permitida dentro do AARU. Além disso, durante o período de implantação do AARU e do ATV, as obrigações de liberalização começaram a se consolidar e foi tornando-se cada vez mais claro que o cumprimento das obrigações por parte dos PD para remover restrições quantitativas e de aproximar os preços as tendências do mercado iria ao mesmo tempo, beneficiar alguns PED enquanto prejudicaria outros.
} 
positivada e rígida, mas um benchmark jurídico, do qual se retomariam as negociações após a entrada em vigor da OMC e dos acordos. ${ }^{316}$

Em terceiro lugar, diversas questões técnicas emergiram ao longo do processo de implantação dos diversos acordos, em razão dos procedimentos técnicos para colocá-los em vigor. Além disso, surgiram diversas nuances interpretativas sobre os acordos, considerando-se que cada Membro implantava conforme a interpretação que lhe favorecia e interessava.

Por isso, os Conselhos e Comitês da OMC, assim que criados, trabalharam intensamente para esclarecer e orientar este processo, tanto junto aos países industrializados quando aos países em desenvolvimento, mas especialmente, assessorando tecnicamente os países com menor desenvolvimento relativo. Nesse mesmo sentido, o OSC foi, desde o seu surgimento, provocado a se manifestar sobre os problemas de interpretação e implantação do novo marco regulatório que entrava em vigor, por meio das disputas que emergiram já nos primeiros anos da OMC. ${ }^{317}$

Para os países em desenvolvimento, era questão estratégica se os resultados da Rodada Uruguai deveriam ser considerados como "fato consumado" e se os novos acordos alcançavam novo status quo, ou se deveriam se conceber tais acordos como benchmarks para intensificar as negociações no pós-Rodada Uruguai. Caso considerassem fato consumado, os países em desenvolvimento só conseguiriam corrigir os descompassos e alcançar melhores condições dentro do SMC se fizessem novas concessões na mesa de negociações. Caso contrário, o avanço das negociações permitiria algumas flexibilidades e reequilíbrios dentro dos acordos, sem exigências de reciprocidade de parte dos países industrializados.

\footnotetext{
${ }^{316}$ Algumas negociações eram menos críticas e relevantes que as outras, mas todas exigiam uma postura ativa de negociações dos Membros, ao invés de gerar a sensação de acomodação com as regras alcançadas ao final da Rodada Uruguai. Isso ocorreu de maneira mais intensiva em temas relacionados à medidas sanitárias e fitossanitárias (AMSF), barreiras técnicas (ABT), compras governamentais (ACG), comércio de serviços (GATS), agricultura (AARU), propriedade intelectual (TRIPS), investimentos (TRIMS) e têxteis e vestuário (ATV).

${ }^{317}$ A primeira disputa foi instaurada junto ao OSC menos de 10 dias depois da entrada em vigor da OMC. Foi o caso Malásia - Proibição das importações de polietileno e polipropileno, de $10 / 01 / 1995$
} 
Um elemento determinante na posição diplomática dos países em desenvolvimento nesta etapa de retomada das negociações do pós-Rodada Uruguai foi a emergência das organizações não-governamentais (ONG) ligadas aos problemas e desafios dos países em desenvolvimento e países com menor desenvolvimento relativo, bem como a crescente atenção da mídia aos mesmos temas. O ponto alto deste movimento se deu na Conferência Ministerial de Seattle, que será analisada mais adiante.

A crescente influência das ONGs e da mídia não tardou em influenciar o cenário político interno dos países desenvolvidos, e a questão do apoio dos países em desenvolvimento passou a integrar os discursos políticos. Consequentemente, os países desenvolvidos ficaram cadencialmente com menos autoridade moral para continuar negando negociar novas flexibilidades para os países em desenvolvimento nos novos acordos da OMC, pois os desequilíbrios de tais acordos restavam cada vez mais evidentes.

Como mencionado, ao longo do período pós-Rodada Uruguai, houve diversos problemas envolvendo a questão da implantação dos acordos por parte dos países em desenvolvimento. Os países em desenvolvimento, e especialmente os países com menor desenvolvimento relativo, sofriam de uma carência técnica absoluta, que tornava extremamente difícil, além de desproporcionalmente caro, que implantassem os mecanismos e capacitassem os funcionários governamentais para a nova realidade de vigência dos acordos da Rodada Uruguai.

\section{b) As conferências ministeriais durante o período neoliberal da OMC}

A Conferência Ministerial é o órgão máximo da OMC. É composta por representantes de todos os Membros da OMC, normalmente seus ministros de comércio exterior ou ministros das relações exteriores, e, de acordo com o Acordo Constitutivo da OMC, deve se reunir pelo menos uma vez a cada dois anos.

As três primeiras conferências ministeriais, Singapura, em 1996, Genebra, em 1998, e Seattle, em 1999, testemunharam a queda da perspectiva neoliberal e a 
ascensão do novo desenvolvimentismo na OMC, razão pela qual merecerão breve análise a seguir.

\section{i. Conferência Ministerial de Singapura (1996)}

A OMC realizou a sua primeira conferência ministerial em dezembro de 1996, dois após sua entrada em vigor, tal qual previsto no Acordo de Marraqueche.

O objetivo da reunião foi fortalecer a recém-criada OMC como fórum para negociações, visando intensificar o processo de liberalização do comércio, bem como a necessidade de acompanhar e avaliar o processo de implantação dos acordos firmados ao final da Rodada Uruguai. A grande maioria dos Membros ainda não havia completado o processo de adaptação da legislação doméstica e de notificação à OMC. ${ }^{318}$

O elemento mais marcante desta conferência foi a tentativa dos países desenvolvidos em inserir novos temas no marco regulatório da OMC. Tais temas, que interessavam aos países desenvolvidos, eram: direitos trabalhistas, proteção ambiental, bem como os "Temas de Singapura", tal qual ficaram conhecidos: investimentos, concorrência, transparência em compras governamentais e facilitação ao comércio.

No entanto, como decorrência da percepção entre os países em desenvolvimento que eles haviam feito muitas concessões em relação aos ganhos obtidos com a Rodada Uruguai, foi muito difícil para os países desenvolvidos inserirem temas de seu interesse nas negociações do pós-Rodada Uruguai. Os países em desenvolvimento resistiram à inclusão dos temas relacionados a direitos trabalhistas e proteção ambiental dentro do âmbito da OMC, por temerem que tais temas pudessem servir de fundamento para imposição de barreiras comerciais contra seus produtos.

${ }^{318}$ THORSTENSEN, op. cit., p. 401. 
Nesse sentido, ao final desta conferência, foram criados três grupos de trabalho para examinar a relação entre: comércio e investimento, comércio e políticas de concorrência, transparência em compras governamentais e facilitação de comércio.

ii. Conferência Ministerial de Genebra (1998)

A segunda Conferência foi realizada em 1998, coincidindo com as comemorações dos 50 anos do sistema multilateral de comércio. A Conferência de Genebra teve como objetivo manter o momentum de expansão global do comércio e assim, dar início a uma nova rodada de negociações para uma nova etapa de aprofundamento e alargamento da liberalização comercial.

Nesse sentido, ao longo da Conferência de Genebra, ficou acordado que os Membros deveriam trazer propostas para uma nova Conferência a ser realizada no ano seguinte, em Seattle, com a finalidade de lançar uma nova rodada de negociações, que viria a ser denominada Rodada do Milênio.

Ocorre que o cenário econômico mundial iniciava uma transformação que viria a influenciar as negociações do ano seguinte. Destaca-se a crise financeira em alguns países em desenvolvimento, dentre as quais: Tigres Asiáticos, Rússia, Brasil e Argentina. O ressentimento dos países em desenvolvimento com o sistema econômico internacional, e com o neoliberalismo, começou a ficar evidente durante a Conferência e se intensificou ao longo dos trabalhos preparatórios para a Conferência de Seattle.

iii. Conferência Ministerial de Seattle (1999) 
Dando prosseguimento ao acordado na Conferência de Genebra, os Membros deram início aos trabalhos preparatórios para o lançamento da Rodada do Milênio. Tais trabalhos se desenvolveram em três fases: a primeira, dedicada a identificação dos temas a serem introduzidos na agenda; a segunda, na qual foram elaboradas propostas em torno dos temas indicados; e a terceira, quando os Membros tentaram negociar os textos-base (drafts) a serem debatidos e aprovados na Conferência de Seattle.

De acordo com Vera Thorstensen:

\begin{abstract}
Ao longo dos trabalhos preparatórios, foi se formando um quadro de inflexibilidade de posições, onde os diversos Membros da OMC passaram a se posicionar a favor ou contra cada um dos temas, com pouco ou nenhum grau de espaço negociador. Tal situação se manteve até as vésperas da própria reunião ministerial, não permitindo avanço das negociações, nem o delineamento de um balanço de ganhos e perdas, fundamental para o êxito de qualquer negociação internacional. ${ }^{319}$
\end{abstract}

A III Conferência Ministerial da OMC, de Seattle, que visava o lançamento da Rodada do Milênio, foi suspensa porque não se chegou a um acordo mínimo, nem sobre os temas que deveriam ser incluídos na rodada, nem sobre o mandato de negociação de cada tema. ${ }^{320}$

Os temas de interesse dos países em desenvolvimento estavam centrados em torno dos acordos já existentes. Tanto as questões de implantação, quando as demandas por uma revisão dos acordos já firmados, eram as suas pretensões dominantes. Havia a necessidade de se avaliar e modificar a forma como estavam sendo executados os acordos da Rodada Uruguai. De acordo com os países em desenvolvimento, os EUA e a CE não estavam cumprindo as cláusulas de Tratamento Especial e Diferenciado existentes nos diversos acordos vigentes da OMC. Para os países em desenvolvimento, enquanto não houvesse regularização e clareza em torno dos acordos vigentes, era impensável a incorporação de novos temas na OMC, como desejavam os países desenvolvidos.

\footnotetext{
319 THORSTENSEN, op. cit., p. 409.

320 Sobre a Conferência de Seattle, ver AMORIM, Celso. A OMC pós-Seattle. Revista Política Externa, Vol. 8. Março-maio. São Paulo: Paz e Terra, 2000; GONÇALVES, Reinaldo. O Brasil e o Comércio Internacional: transformações e perspectivas. São Paulo: Contexto, 2000.
} 
O texto que foi encaminhado para Seattle era o mesmo do início dos trabalhos preparatórios, e continha cerca de 360 propostas, de países desenvolvidos, países em desenvolvimento e países com menor desenvolvimento relativo, envolvendo um amplo leque de temas, regulados e não-regulados pela OMC. A ausência de consenso restava evidente.

Ademais, a participação dos movimentos sociais anti-globalização e das ONGs em favor dos países em desenvolvimento e países com menor desenvolvimento relativo tiveram influência decisiva para aumentar o clima de animosidade da Conferência. A OMC promoveu paralelamente a Conferência Ministerial, um simpósio global de ONGs sobre os temas relevantes do comércio internacional para o novo milênio. Cerca de 700 ONGs participaram deste simpósio. $^{321}$

Em razão da diversidade e da amplitude das propostas, que tornou inviável chegar a um mandato final de negociações, a Conferência de Seattle foi suspensa sem ser concluída.

\section{c) Conclusões sobre o fim do período neoliberal da OMC}

O fracasso do lançamento da Rodada do Milênio revelou uma série de desafios a serem enfrentados pelos Membros da OMC, bem como lições importantes para o sistema multilateral de comércio como um todo. Vera Thorstensen, citando Celso Amorim, o então Ministro das Relações Exteriores do Brasil que participou da Conferência de Seattle, aponta algumas destas lições. ${ }^{322}$

Estas podem ser analisadas em três níveis: a) a existência de uma nova dinâmica nas negociações do sistema multilateral de comércio, b) a demanda por transparência interna, entre os Membros, e externa, com a sociedade civil

\footnotetext{
$321 \quad$ Mais 
organizada, e c) o reequilíbrio dos interesses entre os países desenvolvidos e os países em desenvolvimento.

Em relação a esta nova dinâmica, constata-se que a Era do antigo GATT realmente chegou a seu termo final em Seattle. O sistema de negociações que perdurou de 1947 até então, estava esgotado. Tal sistema, no qual as decisões eram tomadas pelos Membros mais influentes e depois apoiadas pelos demais Membros, em troca de concessões, chegou ao seu limite. A partir de Seattle, um novo sistema de negociação deveria ser instaurado na OMC.

A segunda lição diz respeito à transparência e à participação da sociedade civil nos rumos da OMC. Com base no ocorrido em Seattle, a OMC passou a lidar com o clamor por transparência nas negociações internacionais. Do ponto de vista interno, a organização passou a ser cobrada pelos países em desenvolvimento e, especialmente pelos países com menor desenvolvimento relativo, no sentido de que houvesse maior clareza nos processos de negociação. A lógica das negociações diretas e das pequenas coalizões do período GATT, por estar superada, exigiria maior conhecimento de todos os Membros sobre as propostas e as negociações envolvendo cada um dos Membros da OMC.

Além disso, houve cobrança por transparência das atividades da OMC perante a sociedade civil. Isto levou a discussões acerca da necessidade de se abrir e ampliar a composição dos órgãos da OMC, para permitir participação das ONGs nos comitês, conselhos e no órgão de solução de controvérsias.

Outro resultado desta demanda por transparência levou à institucionalização dos Fóruns Públicos da OMC (WTO Public Forum), que passaram a ser promovidos anualmente desde 2001, com o objetivo de debater publicamente a agenda e encaminhar soluções, em consonância com a sociedade civil, para os desafios da OMC.

A terceira lição diz respeito à necessidade de reequilibrar a relação entre os países desenvolvidos e os países em desenvolvimento na OMC. Desta forma, o impacto mais relevante da crise de Seattle foi o despertar do mundo em 
desenvolvimento para retomar às mobilizações no âmbito do sistema multilateral de comércio.

As crises econômicas e financeiras sofridas pelos principais países em desenvolvimento da época, os Tigres Asiáticos, a Rússia, o Brasil e a Argentina, puseram o neoliberalismo e o Consenso de Washington em xeque. Os países em desenvolvimento passaram a reivindicar novamente algum nível de margem de manobra para reestruturar suas instituições e suas economias com base em novos parâmetros, que não aqueles emanados pelo Consenso.

Em relação às regras da $\mathrm{OMC}$, se intensificou a resignação dos países em desenvolvimento com as limitações dos dispositivos de Tratamento Especial e Diferenciado que haviam sido logrados na Rodada Uruguai. A concepção e a operacionalização do Tratamento Especial e Diferenciado não surtiu, entre os países em desenvolvimento, o efeito positivo esperado. A partir de então, tornou-se tema fundamental na agenda da OMC a necessidade de revisão e ampliação do Tratamento Especial e Diferenciado, bem como uma revisão geral dos acordos com vistas satisfazer os interesses dos países em desenvolvimento de modo mais coerente.

$\mathrm{O}$ fato de a grande maioria dos Membros da OMC atualmente ser países em desenvolvimento ou países de menor desenvolvimento relativo gerou uma mobilização destes países e colocou em questão o objetivo do sistema multilateral de comércio ao argumentar se, de fato, este deve promover a liberalização comercial per se, ou se toda a política de inserção no comércio internacional deve necessariamente ser orientada para a promoção do desenvolvimento econômico e social.

Nesse diapasão, houve uma mudança conceitual que se operou no âmbito da OMC, após a suspensão da Conferência de Seattle. O objetivo fundamental de uma futura rodada de negociações, que viesse a ser lançada na OMC, não deveria mais estar centrado no aprofundamento e no alargamento da liberalização do comércio mundial. A partir de então, a OMC deveria centrar-se na melhor distribuição dos ganhos, entre os Membros da OMC, provenientes do comércio internacional. 
É com este espírito que, em 2000, os Membros da OMC foram convocados para a nova Conferência Ministerial, que viria a ocorrer em 2001, em Doha, não mais para o lançamento da Rodada do Milênio, mas para encaminhar as negociações rumo a uma Rodada do Desenvolvimento.

Nesse sentido, Vera Thorstensen conclui que:

Como em tantas outras ocasiões na história das organizações internacionais, os impasses do passado devem servir de alerta para mostrar que o modelo de atuação pode estar esgotado, e que é chegada a hora de ajustar tal modelo, de modelo a permitir o ajuste da organização aos desafios do presente. A reunião de Seattle certamente ficará marcada na lembrança de todos aqueles que participaram, e na história da OMC, como um grande divisor de águas. ${ }^{323}$

\subsection{A EMERGÊNCIA DO NOVO DESENVOLVIMENTISMO NA RODADA DE DOHA}

\section{a) A Conferência Ministerial de Doha}

Desde o início de 2001, os Membros da OMC discutiram os pontos que deveriam constar na agenda da Conferência Ministerial de Doha. Ao longo dos trabalhos preparatórios, a grande questão que se colocava era se a Conferência deveria lançar uma nova rodada de negociações multilaterais, e correr o risco de um novo fracasso tal qual em Seattle, ou servir de reunião para um balanço geral das atividades da OMC desde a última conferência.

A percepção externa de que a OMC ficou paralisada ou em crise após o impasse de Seattle, está equivocada. Mesmo sem os trabalhos da rodada de negociações, as atividades de supervisão das práticas de comércio exterior continuaram dentro de seus comitês e conselhos, as decisões do OSC continuavam

${ }^{323}$ THORSTENSEN, op. cit., p. 420. 
criando jurisprudência, e uma nova fase de negociações estava prestes a ser iniciada. ${ }^{324}$

Ao final dos trabalhos preparatórios, emergiu um clima de consenso e confiança, especialmente entre os países em desenvolvimento, razão pela qual a Conferência Ministerial de Doha foi lançada para instaurar uma nova rodada de negociações da OMC.

Ao final da Conferência Ministerial de Doha, os ministros lograram alcançar um conjunto de declarações e decisões que, em seu conjunto, lançaram a Agenda do Desenvolvimento de Doha.

\section{Tabela 22. Textos Finais da Conferência Ministerial de Doha}

\section{- Declaração Ministerial de Doha}

- Declaração Ministerial relativa ao Acordo TRIPS e Saúde Pública

- Decisão Ministerial sobre as questões e preocupações relativas à implantação

- Decisão Ministerial sobre a derrogação para o Acordo de Associação CE-ACP

- Decisão Ministerial sobre o regime de transição da CE para importação de bananas

- Decisão do Comitê do ASMC sobre os procedimentos para extensão de subsídios à exportação

\section{i. Declaração Ministerial de Doha}

A Declaração Ministerial de Doha é o principal documento da Conferência. Por meio da Declaração de Doha, foram definidos os princípios orientadores da nova rodada de negociações, o programa de trabalho, com os temas em torno dos quais estarão centradas as negociações, e a organização e gestão do programa de trabalho, com a definição das competências e os procedimentos do processo negociador.

\footnotetext{
${ }^{324}$ Vide THORSTENSEN, op. cit., p. 427.
} 
Em relação aos princípios, destaca-se o parágrafo 2 da Declaração de Doha, que estabelece:

O comercio internacional pode desempenhar uma função de importância na promoção do desenvolvimento econômico e o alivio da pobreza. Reconhecemos a necessidade de que todos os nossos povos se beneficiem do aumento das oportunidades e os avanços do bem-estar que gera o sistema multilateral de comércio. A maioria dos Membros da OMC são países em desenvolvimento. Pretendemos colocar as suas necessidades e interesses no centro do Programa de Trabalho adotado com a presente declaração.

O parágrafo 2, ao não fazer menção a liberalização comercial, estabelece um novo parâmetro conceitual para a OMC. Afirma que o comércio internacional pode desempenhar função na promoção do desenvolvimento, na superação da pobreza, e no aumento do bem-estar, e que o sistema multilateral de comércio deve gerar oportunidades para tanto.

Além disso, o mesmo parágrafo expressa o fato de que a composição da OMC, por ser majoritariamente de países em desenvolvimento, deve atender, prioritariamente, os seus interesses, por meio do Programa de Trabalho. Este espírito da Declaração contrasta em muito com as Declarações das conferências anteriores, Singapura (1996) e Genebra (1998).

Seguindo o preceituado no parágrafo 2 da Declaração Ministerial, o Mandato do Programa de Trabalho de Doha abarca 19 temas, e todos eles, com a exceção de solução de controvérsias, aborda os problemas e necessidades específicos dos países em desenvolvimento.

\section{Tabela 23. Temas do mandato de negociação da Rodada de Doha}

1. Questões e preocupações relativas à aplicação

2. Agricultura

3. Serviços

4. Acesso aos mercados para produtos não-agrícolas

5. Direitos de propriedade intelectual

6. Comercio e investimentos

7. Comércio e políticas de concorrência

8. Transparência em compras governamentais

9. Facilitação do comercio

10. Normas da OMC

11. Solução de controvérsias 
12. Comércio e meio ambiente

13. Comércio eletrônico

14. Pequenas economias

15. Comércio, dívida e finanças

16. Comércio e transferência de tecnologia

17. Cooperação técnica

18. Países menos avançados

19. Tratamento especial e diferenciado

É em relação a esta lista de temas que as negociações da Rodada Doha vêm se desenvolvendo. Como se verá a seguir, em alguns temas, houve avanços significativos, enquanto em outros, as negociações não alcançaram avanço algum.

Por fim, cabe apontar que a Declaração Ministerial de Doha previu um ambicioso cronograma de trabalho para a consecução dos objetivos da Rodada do Desenvolvimento.

A lógica do cronograma de trabalho foi configurada de maneira que, em uma primeira fase, seria fortalecida a confiança dos países em desenvolvimento, ao resolver, de imediato, temas críticos para os mesmos, tais como as questões de implantação dos acordos da Rodada Uruguai, o Tratamento Especial e Diferenciado e a relação entre TRIPS e saúde pública. Esta primeira fase deveria ser concluída até dezembro de 2002. A segunda fase daria atenção específica para as negociações agrícolas, que deveria estabelecer as modalidades até março de 2003. O sucesso em ambas as fases geraria um cenário favorável para que os Membros iniciassem as negociações dos temas de Singapura na Conferência de Cancun. Finalmente, as negociações de Doha deveriam ser concluídas em dezembro de 2004.

ii. Declaração Ministerial relativo ao Acordo TRIPS e à Saúde Pública

A Declaração Ministerial relativa ao Acordo TRIPS e à Saúde Pública foi o documento que causou maior repercussão ao final da Conferência de Doha. Tal Declaração foi uma resposta da OMC ao debate mundial sobre o acesso a 
medicamentos e proteção patentária no contexto do sistema multilateral do GATT. Em destaque havia a preocupação, pelos países em desenvolvimento, de buscar esclarecer os requisitos de licenciamento compulsório de patentes de medicamentos nas situações em que o Art.31 do TRIPS fosse aplicado pelos Membros da OMC, particularmente quanto ao critério do uso predominante para abastecimento do mercado doméstico. ${ }^{325}$

A Declaração sobre TRIPS e Saúde Pública foi originalmente resultado da iniciativa do Grupo Africano dos Membros da OMC em resposta à gravidade dos problemas de saúde pública resultantes de doenças pandêmicas, tais como HIV/AIDS, tuberculose e malária. Assim que os países em desenvolvimento começaram a perceber os altos custos de cumprimento das exigências de proteção das patentes do TRIPS, especialmente no que se refere a produtos farmacêuticos, tais como remédios para HIV/AIDS, eles passaram a examinar o TRIPS em busca de brechas que lhes permitisse evadir-se de cumprir com tais obrigações.

Nesse sentido, a Declaração se fundada em noções de "bem-estar social", "equilíbrio entre direitos e obrigações", "flexibilidades para proteger a saúde pública", e que toda e qualquer medida deva ser consistente com o TRIPS.

O TRIPS foi concebido com a intenção de proibir a prática de licenciamento compulsório, mecanismo por meio do qual os governos licenciam a produção de determinada mercadoria usando uma patente tecnológica sem a permissão do detentor da patente. O Artigo 31 do TRIPS estabelece uma série de limitações ao uso de tal mecanismo. Provavelmente a limitação mais importante seja a que estabelece o licenciamento compulsório visando "predominantemente o abastecimento do mercado doméstico".

Dessa forma, grande parte dos países em desenvolvimento fica impossibilitada de usufruir de tal flexibilidade, tendo em vista a incapacidade técnica de se produzir os medicamentos em nível nacional. Por isso, ao longo as

\footnotetext{
${ }^{325}$ Para maiores esclarecimentos sobre a Declaração MInisiterial relativo ao Acordo TRIPS e à Saude Pública, ver POLIDO, Fabrício. Contribuições ao Estudo do Direito Internacional da Propriedade Intelectual na Era Pós-Organização Mundial do Comércio: Fronteiras da Proteção, Composição do Equilíbrio e Expansão do Domínio Público. Tese de Doutorado apresentada ao Departamento de Direito Internacional e Comparado da Faculdade de Direito da Universidade de São Paulo. São Paulo, 2010.
} 
negociações de Doha, um dos principais focos tem sido a possibilidade de permitir que, com base em uma licença compulsória, se possa produzir para atender a demanda de importações de países em desenvolvimento.

Assim, a Declaração de Doha sobre TRIPS e Saúde Pública foi considerada, à época de sua adoção, um instrumento concreto para a inclusão do Acordo TRIPS em um contexto mais amplo, nos níveis doméstico e internacional, de regulamentação do acesso global à saúde e acesso a medicamentos. ${ }^{326}$

Enquanto a Declaração de Doha sobre TRIPS e Saúde Pública esclareceu pontos obsuros relacionados ao tema (o que constitui uma emergência nacional ou outras circunstâncias de extrema urgência; permitir licenciamento compulsório sem autorização prévia ou negociação com o proprietário da patente), esta gerou apenas uma modificação formal ao direito da OMC: os Membros acordaram que os países com menor desenvolvimento relativo teriam 10 anos adicionais para implantar a proteção de patentes farmacêuticas.

Como se pode perceber, a questão do TRIPS aplicável aos produtos farmacêuticos é um bom exemplo do funcionamento das negociações entre países desenvolvidos e países em desenvolvimento e especialmente de como se contornam tais impasses: os países desenvolvidos logram manter os direitos de propriedade intelectual como regra do sistema, reivindicável juridicamente (hard), enquanto os países em desenvolvimento alcançam exceções específicas em relação a demandas pontuais, por meio de textos políticos, como a Declaração Ministerial, com capacidade duvidosa de ser reivindicada juridicamente no OSC (soft). Assim aconteceu no período GATT, no período da NOEI, e se repete na Rodada Doha. ${ }^{327}$

iii. Demais decisões e declarações

\footnotetext{
${ }^{326}$ Ver POLIDO, pp. cit., p. 72.
}

${ }^{327}$ HUDEC, op. cit., p. 122. 
A Decisão Ministerial sobre as questões e preocupações relativas à implantação ${ }^{328}$ veio atender uma das principais demandas dos países em desenvolvimento desde a conclusão da Rodada Uruguai, qual seja, encaminhar os problemas que estavam ocorrendo com a implantação dos acordos da OMC, especialmente no que se refere aos dispositivos relacionados ao desenvolvimento.

Mais de 100 questões relativas à implantação foram apontadas nesta decisão. Estas foram encaminhadas de duas formas: um grupo de mais de 40 questões foram solucionadas quando da Conferência de Doha, por serem questões de interpretação de dispositivos; as demais questões foram incorporadas as negociações da Rodada Doha. ${ }^{329}$

Outras duas decisões foram emitidas com o objetivo de atender especificamente os interesses da União Europeia, especialmente para atender as suas relações com países vinculados historicamente pelo período de colonização: a Decisão Ministerial sobre a derrogação para o Acordo de Associação $C E-A C P^{330}$ e a Decisão Ministerial sobre o regime de transição da CE para importação de bananas ${ }^{331}$.

A decisão sobre o Acordo $\mathrm{CE}-\mathrm{ACP}$ estabeleceu um waiver que permitiu à $\mathrm{CE}$ manter um acordo com os países da África, Caribe e Pacífico, sem precisar estender tais preferências aos demais Membros da OMC. Isto porque tal acordo não foi notificado com um acordo regional de comércio, seja com base no art. XXIV, seja na Cláusula de Habilitação. Trata-se um acordo fundado em um waiver de 1956 que se mantém até hoje, por laços históricos da descolonização.

Já a decisão sobre o regime de transição na importação de bananas é proveniente de uma condenação sofrida pela CE no âmbito do OSC da OMC, que obrigou a CE a abolir o regime de quotas de importação de bananas para os países da África, Caribe e Pacífico. A decisão de Doha estendeu o prazo para implantação do novo regime europeu de importações.

\footnotetext{
${ }^{328} \mathrm{http}$ ://wto.org/english/thewto e/minist e/min01 e/mindecl implementation e.htm .

${ }^{329}$ Para maiores informações sobre a decisão sobre as questões relativas a implantação, ver http://wto.org/english/tratop e/dda e/implem explained e.htm.

${ }_{330} \mathrm{http}: / / \mathrm{wto} .0 \mathrm{gr} /$ english/thewto e/minist $\mathrm{e} / \mathrm{min} 01 \mathrm{e} / \mathrm{mindecl}$ acp ec agre e.doc

331 http://wto.org/english/thewto e/minist $\mathrm{e} / \mathrm{min} 01 \mathrm{e} / \mathrm{mindecl}$ ec bananas e.doc
} 
Por fim, houve a Decisão do Comitê do ASMC sobre os procedimentos para extensão de subsídios à exportação ${ }^{332}$, que estendeu a possibilidade de determinados países em desenvolvimento recorrerem a subsídios em determinados programas de incentivo à exportação. Tal extensão, fundada no artigo 27.4 do ASMC, foi condicionada a notificações prévias ao Comitê do ASMC, para ensejar transparência em relação a utlização dos subsídios à exportação.

b) Principais avanços das negociações desde Doha até os dias atuais

i. Conferência de Cancun (2003)

A $5^{\mathrm{a}}$ Conferência Ministerial da OMC, realizada em Cancun, México, em setembro de 2003, acabou sem maiores resultados práticos. No entanto, os acontecimentos de Cancun ecoam até hoje no sistema multilateral de comércio.

A Conferência Ministerial de Cancun foi idealizada como prosseguimento da Conferência de Doha, para dar continuidade à nova Agenda de Desenvolvimento de OMC.

A partir da Conferência de Cancun, o conjunto de temas listados na Declaração de Doha foi agrupado em seis eixos de negociação: a) agricultura, b) temas de Singapura, c) acesso a mercados não-agrícolas (NAMA em inglês), d) temas relacionados ao desenvolvimento, e) algodão, e outras iniciativas.

Entre as Conferências de Doha e Cancun, houve dois avanços importantes. O primeiro avanço foi em agosto de 2003, quando o Conselho de Propriedade Intelectual da OMC emitiu uma decisão, intitulada Implantação do Parágrafo 6 da Declaração de Doha relativo ao Acordo TRIPS e à Saúde Pública. ${ }^{333}$

\footnotetext{
${ }^{332} \mathrm{http}: / /$ docsonline.wto.org/imrd/directdoc.asp?DDFDocuments/t/G/SCM/39.doc

${ }^{333}$ Disponível em http://wto.org/english/tratop e/trips e/implem para6 e.htm .
} 
Tal decisão objetivava estabelecer exceções para aqueles Membros que eram incapazes, por carências técnicas no setor farmacêutico, de implantar as disposições sobre licenciamento compulsório. Estes Membros foram autorizados, a partir desta decisão, a importar medicamentos, sujeitos apenas a realizar uma notificação ao Conselho do TRIPS. A partir de então, os países menos avançados estariam dispensados da autorização do Membro exportador dos medicamentos para realizar tal importação, sob o regime de licença compulsória.

O outro avanço se deu em matéria de comércio de serviços. O Conselho sobre Comércio de Serviços, em setembro de 2003, emitiu uma decisão denominada Modalidades para o Tratamento Especial de Membros Menos Desenvolvidos nas negociações sobre Comércio de Serviços. ${ }^{334}$

Com base nessa decisão, os países menos desenvolvidos foram autorizados a negociar em comércio de serviços sem serem obrigados a respeitar a Cláusula NMF para prestação de serviços em seus respectivos territórios, tampouco os países industrializados poderiam exigir dos países menos avançados a abertura em serviços como contrapartida, em hipótese alguma. Além disso, os países desenvolvidos se comprometiam a fortalecer programas de promoção de investimentos para estimular a capacidade dos serviços domésticos dos países menos avançados.

No espírito destes avanços alcançados ao longo de 2003, a Conferência de Cancun foi lançada com grande otimismo. No entanto, os resultados da Conferência foram um grande desapontamento.

A principal causa do fracasso das negociações de Cancun foi concernente ao tema agricultura. No entanto, a Conferência de Cancun não tentou tratar apenas de agricultura. Negociações foram lançadas também nos temas de Singapura e em acesso a mercados não agrícolas. Como não houve progresso em agricultura, as negociações não se intensificaram nos demais tópicos.

\footnotetext{
${ }^{334}$ Disponível em http://docsonline.wto.org/imrd/directdoc.asp?DDFDocuments/t/tn/s/13.doc
} 
À época, o volume de subsídios diretos à agricultura nos países da OCDE, superavam os 230 bilhões anuais ${ }^{335}$, e tais países não demonstraram disposição para eliminação, tampouco redução imediata, de tais subsídios. Tal resistência em relação à liberalização do comércio agrícola não era novidade nas negociações do sistema multilateral de comércio. ${ }^{336}$

A principal novidade em relação às negociações agrícolas de Cancun foi o surgimento da primeira aliança diplomática entre os países em desenvolvimento na Era OMC: o Grupo dos 20 (G-20). Tal grupo teve o Brasil como porta-voz e seu objetivo principal era aumentar o poder de negociação dos países em desenvolvimento, em todas as áreas da OMC, não apenas em agricultura. ${ }^{337}$

O G-20 em seu texto inaugural junto à OMC, propôs que as negociações fossem fundadas nos princípios da progressividade (reduções maiores nas maiores tarifas) e da proporcionalidade (compromissos menores para os países em desenvolvimento). Novamente, pode-se perceber que, ao invocar o princípio da proporcionalidade, os países em desenvolvimento novamente deixam de lado o princípio e a estratégia de negociação fundado na não-reciprocidade. ${ }^{338}$

A unidade dos países em desenvolvimento contra as posições dos EUA e da $\mathrm{CE}$, bem como a distância entre ambos os lados, fez com que não houvesse acordo em agricultura, e consequentemente, nos demais temas da Conferência.

O fracasso da Conferência de Cancun teve um efeito duradouro na OMC. Comparado com as negociações multilaterais da era GATT, esta Conferência foi fundamentalmente diferente, tendo-se em vista a capacidade de coalizão dos países em desenvolvimento, por meio do G20.

Do ponto de vista dos países em desenvolvimento, o fracasso da Conferência de Cancun foi considerado um sucesso, muito embora não tenham alcançado

\footnotetext{
${ }^{335}$ Banco Mundial. Acesso a mercados: reforma da política agrícola e países em desenvolvimento. Washington: Setembro, 2003.

${ }^{336}$ Maiores detalhes sobre a implantação do Acordo sobre Agricultura da Rodada Uruguai, ver SALLES, Marcus Maurer de. O dilema da resistência européia ao livre comércio agrícola. In BARRAL, Welber; PIMENTEL, Luiz Otávio (Orgs.). Comércio internacional e desenvolvimento. Florianópolis: Fundação Boiteux, 2006, p.335-382.

337 http://www.g20.org/index.aspx.

${ }^{338}$ HUDEC, op. cit., p. 120.
} 
resultado concreto algum ao longo das negociações. De acordo com Guiguo Wang, "a Conferência de Cancun mudou o status dos países em desenvolvimento na OMC", por terem conseguido demonstrar uma força que não foi sentida na Rodada Uruguai. $^{339}$

No entanto, o impasse nas negociações da Cancun levou os países desenvolvidos a perceberem que as negociações no plano multilateral seriam, a partir de então, cada vez mais complexas e difíceis. Por isso, é atribuído à Conferência de Cancun a responsabilidade pela proliferação de acordos bilaterais e regionais envolvendo os EUA e a CE. Caso tal fracasso não houvesse ocorrido, é muito provável que nem EUA nem CE teriam embarcado tão entusiasticamente nos seus planos de bilateralização e regionalização.

Wang, observador chinês da Conferência de Cancun, afirma que, no encerramento das negociações, o negociador comercial dos EUA, Robert Zoellick, anunciou que estava saindo de Cancun disposto a negociar uma longa lista de acordos bilaterais com países com os quais já havia alcançado um entendimento suficiente para celebrar acordos efetivos. ${ }^{340}$

Do ponto vista da reestruturação do sistema econômico global, Wang analisa os efeitos da Conferência de Cancun no seguinte sentido:

\footnotetext{
Uma razão mais profunda para o fracasso da Conferência de Cancun reside no enorme desequilíbrio gerado pela globalização econômica, que não proporcionou benefícios substanciais para os países em desenvolvimento. A globalização econômica, na primeira década do século XXI, ingressou em um período de ajuste estrutural em relação à evolução econômica global das últimas décadas. Nesta nova etapa da globalização econômica, as necessidades específicas dos paises em desenvolvimento deverão ser endereçadas de maneira efetiva. A conclusão deste processo de negociação iniciado em Doha é a conclusão de um grande ajuste estrutural e, portanto, o início de uma era de globalização econômica que lidará com um desenvolvimento mais equilibrado da comunidade internacional. ${ }^{341}$
}

\section{ii. Conferência de Hong Kong (2005)}

\footnotetext{
${ }^{339}$ WANG, Guiguo. The WTO after Cancun in CHARNOVITZ et al (Orgs). Law in the service of human dignity: essays in honor of Florentino Feliciano. Cambridge: Cambridge University Press, 2005, p. 234.

${ }^{340}$ WANG, op. cit., p. 222.

341 WANG, op. cit., p. 237.
} 
Depois do fracasso de Cancun, foi necessário um grande esforço político para retomar as negociações de Doha. Os governos, tanto de países desenvolvidos quanto de países em desenvolvimento, perceberam que tinham muito mais a perder do que a ganhar com o fracasso completo da Rodada de Doha, pois tal fracasso desacreditaria a OMC como um todo. Como afirma Peter Sutherland, "não foi a primeira vez, nem será a última, que o sistema precisou estar no ponto de ruptura para que o bom senso prevalecesse". ${ }^{342}$

Como apresentado precedentemente, as duas primeiras fases previstas no cronograma de trabalho da Agenda de Doha foram destinadas a atenderem prioritariamente os interesses dos países em desenvolvimento. Quando se chegou a Conferência de Cancun, os Membros haviam delineado um "pacote" com uma lista de 28 temas, abrangendo as 3 fases da Agenda de Doha. Como não houve acordo nos temas de interesse dos países em desenvolvimento, o pacote como um todo foi rechaçado ao final da Conferência.

A reunião do Conselho Geral de 2004 foi agendada pela OMC como uma tentativa de concluir o trabalho e encaminhar as decisões que ficaram pendentes na Conferência de Cancun, em especial, o referido pacote de temas. Ao final da reunião, foi aprovado pelo Conselho Geral o "Pacote de Julho", que tinha o objetivo de corrigir as ilusões do mandato original de Doha. O objetivo era que, a partir de 2004, os negociadores passariam a ter uma agenda mais concisa e um cronograma menos rígido para fazer avançar as negociações. ${ }^{343}$

Esse Pacote estava focado em 5 grandes linhas: agricultura, algodão, acesso a mercados não-agrícolas, temas de Singapura, e temas relacionados ao desenvolvimento. Dentre os temas relacionados ao desenvolvimento estavam abarcados: o tratamento especial e diferenciado, as questões de implantação dos

\footnotetext{
${ }^{342}$ SUTHERLAND, Peter. The Doha Development Agenda: political challenges to the World Trading System - a cosmopolitan perspective. in PETERSMANN, Ernst-Ulrich (Org.). Reforming the World Trading System: legitimacy, efficiency and democratic governance. Oxford: Oxford University Press, 2005, p. 44.

${ }^{343}$ ISMAIL, Faizel. A Development Perspective on the WTO July 2004 General Council Decision. In in PETERSMANN, Ernst-Ulrich (Org.). Reforming the World Trading System: legitimacy, efficiency and democratic governance. Oxford: Oxford University Press, 2005, p. 53.
} 
acordos da Rodada Uruguai, a assistência técnica, e os países de menor desenvolvimento relativo.

Muito embora os resultados práticos do Pacote de Julho tenham sido extremamente vagos, tal Pacote teve o mérito de manter as negociações da Rodada de Doha em andamento. As expectativas a partir de então foram centradas na VI Conferência Ministerial da OMC, que viria a ser realizada em 2005, em Hong Kong.

A Conferência Ministerial de Hong Kong ocorreu em dezembro de 2005, com o objetivo de negociar os pontos apresentados no Pacote de Julho, finalizado pelo Conselho Geral no ano anterior. No entanto, as polarizações dentre os Membros estava ainda mais acirrada. De um lado, a CE participou das negociações com uma postura extremamente conservadora, sem disposição para ceder em qualquer das cinco linhas de negociação do Pacote de Julho; do outro, o G20 se consolida e fortalece como aliança e passa a manter um alto nível de exigências e expectativas em relação às questões relacionadas ao desenvolvimento da Rodada Doha. ${ }^{344}$

Ao final da Conferência, não se alcançou avanço significativo em nenhum dos temas do Pacote de Julho. Dentre os resultados da Conferência de Hong Kong, o destaque positivo ficou por conta do fato dos ministros terem concordado em tornar permanente a solução do Parágrafo 6 da Declaração, por meio do qual os países que não apresentassem infraestrutura adequada estavam autorizados a importar produtos farmacêuticos de terceiros.

iii. A OMC em compasso de espera

\footnotetext{
${ }^{344}$ ISMAIL, Faizel. As assessment of the Sixth WTO Hong Kong Ministerial Conference from a development perspective. In HOHMANN, Harold (org). Agreeing and implementing the Doha Round of the WTO. Cambridge: Cambridge Univeristy Press, 2008, p. 98.
} 
Após os sucessivos fracassos em torno dos temas da Rodada Doha, as negociações foram declaradas suspensas de facto e sine die em julho de 2006. Isso acarretou a suspensão da Conferência Ministerial de 2007, que viria a ocorrer em Cancun, mas que nunca se concretizou.

As últimas conferências ministeriais da OMC ocorreram em Genebra, em 2009 e 2011, lançadas sem o propósito de servir de fórum de negociações da Rodada de Doha, mas serviram como meras rodadas para acompanhamento e balanço das atividades da OMC.

Na Conferência de 2011, a OMC decidiu finalmente pela adesão da Rússia, após mais de 15 anos de negociações de adesão. Foram igualmente aceitos Samoa, Vanuatu e Montenegro, alcançando a OMC o total de 157 Membros atualmente.

A grave crise econômica enfrentada pelos países mais desenvolvidos, em especial os EUA e a UE, e as suas reverberações ao redor do mundo, tem desmobilizado qualquer disposição para negociações econômicas internacionais, de natureza multilateral, em razão dos altos impactos econômicos que causam, ao contrário das negociações bilaterais que, por serem pontuais, tendem a gerar menores abalos econômicos no interior dos Estados envolvidos.

\section{c) Tentativas e propostas de classificação de países em desenvolvimento na Rodada de Doha}

Apesar de a OMC não ter um sistema de classificação expresso, os países em desenvolvimento já se encontram, de certa forma, classificados no âmbito do SMC. ${ }^{345}$

Há quatro categorias de países em desenvolvimento: a primeira são os países menos avançados; a segunda são os 20 países listados no anexo do ASMC; a terceira são as ditas economias em transição, aqueles países que estão no processo de transformação de uma economia centralizada e planejada pelo Estado para uma economia de mercado; e a quarta, os demais países em desenvolvimento.

\footnotetext{
${ }^{345}$ CUI, op. cit., p. 135.
} 
No Rodada de Doha, duas propostas de classificação têm sido levadas adiante: a proposta para uma nova abordagem ao Tratamento Especial e Diferenciado nas negociações agrícolas, do International Food and Agricultural Trade Policy Council (IPC), e a proposta mais ampla da União Europeia para classificação geral dos países em desenvolvimento no âmbito da OMC.

De acordo com a proposta do IPC, os países em desenvolvimento devem ser classificados em três categorias: os países menos avançados com PNB per capita inferior a US\$900,00, o que abarca um grupo maior do que o grupo listado pela ONU; os países em desenvolvimento com renda média baixa, que inclui países com PNB per capita entre US\$ 901,00 e US\$3.035,00; e os países em desenvolvimento com renda média alta, que inclui os países com PNB per capita entre US\$3.035,00 e US $\$ 9.385,00$.

Por outro lado, a proposta da União Européia classifica os países em desenvolvimento em três categorias: a primeira, dos atuais países menos avançados, tal qual elencada pela ONU; uma segunda, das economias pequenas e vulneráveis; e a uma terceira, dos paises em desenvolvimento mais avançados.

Tanto a proposta do IPC como a classificação do ASMC se limitam a setores específicos das negociações da OMC. A proposta europeia carece de critérios claros e precisos e serve apenas como forma da UE demonstrar que possui um escalonamento diferenciado dos países em desenvolvimento e provavelmente sirva de instrumento de negociação ao longo da Rodada de Doha, mais do que qualquer outra coisa.

Em três dos quatro esquemas de classificação apresentados rapidamente acima - o Banco Mundial, a proposta do IPC e a proposta da UE - os paises em desenvolvimento são classificados em 3 categorias distintas. Apenas na classificação do ASMC há a categoria das economias em transição, razão pela qual caso se avance na Rodada de Doha rumo a uma classificação dos países em desenvolvimento, uma proposta de 3 categorias poderia ser a mais aceita. Caso se tente fazer uma classificação mais refinada, com maior número de categorias, o princípio da NMF ficará cada vez mais relativizado e a construção geral do SMC pode ficar ainda mais vulnerável. 
A necessidade de adotar critérios objetivos para definição de países em desenvolvimento no âmbito da OMC leva a ponderação dos seguintes elementos: a) renda nacional; b) aspectos sociais do desenvolvimento; c) tamanho do país; d) competitividade setorial. ${ }^{346}$ Estes são os critérios utilizados pelo Comitê de Políticas de Desenvolvimento da ONU, sob o mandato da ECOSOC, e podem ser úteis para o avanço das negociações em torno de uma definição de Membro em desenvolvimento na OMC.

Provavelmente não haja critério de mensuração do grau de desenvolvimento mais aceito internacional do que o valor pecuniário que as pessoas podem produzir ou arrecadar a cada ano. Os dois indicadores de renda nacional mais utilizados são o Produto Interno Bruto (PIB) e o Produto Nacional Bruto (PNB).

Conforme apresentado acima, o PNB é o indicador que mais tem sido utilizado para a definição de pais em desenvolvimento. Foi utilizado nos anos de 1950 no caso levado ao GATT pelo Ceilão, tendo sido sistematicamente utilizado pelo Banco Mundial para suas políticas de empréstimo, e serve igualmente de referência para as novas propostas de classificação que estão sendo negociadas atualmente na Rodada de Doha.

Ocorre que o Produto Nacional Bruto (PNB), enquanto indicador, não consegue sozinho refletir todas as dimensões do desenvolvimento, mesmo que se considere apenas o desenvolvimento econômico.

Quando se leva em consideração questões como a qualidade de vida e a capacidade de gerar capital humano, o PNB ignora por completo tais elementos do desenvolvimento. Nesse sentido, a ONU vem desenvolvendo o Índice de Capital Humano (ICH) (Human Assets Index), que adota para a elaboração da lista dos países menos avançados. Os componentes do ICH incluem: o consumo médio de calorias como requisito nutricional, a mortalidade infantil inferior a cinco anos de idade, o número de matriculas em ensino secundário, e o analfabetismo adulto. ${ }^{347}$ Outro índice amplamente reconhecido internacionalmente é o Índice de

\footnotetext{
${ }^{346}$ CUI, op. cit. p. 143.

347 Para maiores informações sobre o ICH, ver http://www.un.org/en/development/desa/policy/cdp/ldc/ldc criteria.shtml\#hai. Acesso em 20 de maio de 2012.
} 
Desenvolvimento Humano (IDH) (Human Development Index). O IDH é a base dos relatórios de desenvolvimento humano da ONU e inclui informações como expectativa de vida ao nascimento, taxa de alfabetismo adulto, média combinada de matriculas em ensino primário, secundário e terciário, além do PIB per capita. ${ }^{348}$

Além dos aspectos da qualidade de vida, outro ponto interessante a ser monitorado por um eventual indicador para a OMC seja a estrutura econômica do país. O Índice de Vulnerabilidade Econômica (IVE), que é também utilizado pela ONU para a formação da lista dos países menos avançados, abrange: o percentual de manufaturas e serviços na composição do PNB, concentração de bens de exportação, instabilidade na produção agrícola, instabilidade nas exportações de bens e serviços. ${ }^{349}$ Já a UNIDO publica o Índice de Desempenho da Competitividade Industrial (IDCI), que reflete o nível de industrialização e de competitividade industrial de um país. O IDCI é composto por: valor agregado em manufaturas, exportações de manufatura per capita, intensidade de industrialização e qualidade de exportação. ${ }^{350}$

Um terceiro aspecto fundamental para a mensuração do nível de desenvolvimento de um país é a sustentabilidade do desenvolvimento. Embora não haja ainda um indicador amplamente aceito, atualmente está sendo implantado um indicador-piloto, o Índice de Desempenho Ambiental (IDA) (Environmental Performance Index). Este indicador está sendo construído para servir de parâmetro para o monitoramento das Metas de Desenvolvimento do Milênio da ONU e emitiu seu primeiro relatório no ano de 2012. O IDA abrange 22 indicadores, em torno de duas grandes áreas, a saúde ambiental e a vitalidade do ecossistema. ${ }^{351}$

Enfim, a compilação de todos estes índices e indicadores é um processo extremamente complexo. Cada um reflete um ou mais aspectos do desenvolvimento. Para a finalidade de definir os Membros em desenvolvimento da

\footnotetext{
${ }^{348}$ Para maiores informações sobre o IDH, ver http://hdr.undp.org/en/statistics/. Acesso em 21 de maio de 2012.

349 Para maiores informações sobre o IVE, ver http://www.un.org/en/development/desa/policy/cdp/ldc/ldc criteria.shtml\#evi. Acesso em 20 de maio de 2012.

${ }^{350}$ Para maiores informações sobre o IDCI, ver http://www.unido.org/index.php?id=5058. Acesso em 21 de maio de 2012.

${ }^{351}$ Para maiores informações sobre IDA, ver http://epi.yale.edu/. Acesso em 21 de maio de 2012.
} 
OMC, a utilização destes índices seria extremamente polêmica, pois referem-se a temas "não-relacionados a comércio", como a OMC normalmente se refere aos temas que não estejam diretamente ligados ao comércio.

Um ponto deve ser considerado como inequívoco para o avanço das negociações em torno de tal definição: os Membros da OMC devem desenvolver um método que seja juridicamente vinculante, a fim de identificar os Membros em desenvolvimento que sejam elegíveis para receber Tratamento Especial e Diferenciado. Para tanto, é necessário apontar critérios objetivos aceitáveis, especialmente parâmetros numéricos, que são os parâmetros já comumente aceitos nas demais organizações internacionais, como na ONU e no Banco Mundial.

O mecanismo de auto-designação atualmente vigente na OMC é insustentável, do ponto de vista da sua efetividade. Além de levar a uma série de decisões arbitrárias por partes dos Membros que concedem Tratamento Especial e Diferenciado, leva uma insegurança jurídica nas relações econômicas internacionais, e coloca os países em desenvolvimento muitas vezes em condições de ter de negociar com os países industrializados, e ceder às pressões de tais países, para que sejam reconhecidos como Membros em desenvolvimento. Essa pressão da parte dos países desenvolvidos acontece especialmente no âmbito do SGP dos EUA e da UE, que fazem uma série de exigências para que os países em desenvolvimento sejam elegíveis para os regimes preferenciais. Essas exigências, além de ilegais, por contrariarem o princípio da não-reciprocidade da Parte IV, são ilegítimas, por não corresponderem aos ideais da solidariedade e da interdependência.

\subsection{FUNDAMENTOS PARA UMA INTERPRETAÇÃO NEODESENVOLVIMENTISTA DOS ACORDOS DA OMC}


Desde a criação da OMC, o contexto jurídico para o desenho de políticas públicas de desenvolvimento modificou-se profundamente, como resultado das novas regras que passaram a governar o comércio internacional. As regras da OMC, em razão de sua coercitividade, criaram novos obstáculos para os países em desenvolvimento que desejam aprimorar a sua participação no mercado internacional.

Do ponto de vista do impacto interno da adesão de um Estado à $\mathrm{OMC}$, fazem-se necessários alguns apontamentos. A internalização dos acordos levou a um substancial aprofundamento do processo de liberalização do comércio internacional. Consequentemente, reduziu consideravelmente o policy space dos Estados Membros, sejam desenvolvidos, sejam em desenvolvimento, pois quanto maior o volume e a complexidade da regulação internacional das políticas comerciais nacionais, menor é a autonomia dos países para lançarem mão de políticas que lhes convier.

A partir do momento em que se tornam Membros da OMC e internalizam o conjunto de tratados sob os auspícios da organização internacional, tais países só poderão executar políticas públicas se permitidas pelos acordos da OMC. Caso contrário, estarão sujeitos a serem questionados no OSC por qualquer outro Membro que se sentir prejudicado por eventuais ilegalidades nas suas políticas.

Os acordos multilaterais progressivamente obrigaram os países a reduzirem as barreiras tarifárias e não-tarifárias ao comércio, tanto pelo GATT como pela negociação das diversas listas nacionais de concessões, nas quais os Estados consolidaram os seus limites tarifários. Além disso, as novas regras da OMC também restringiram o uso de diversos subsídios, por meio do Acordo sobre Subsídios e Medidas Compensatórias (ASMC), como de salvaguardas, pelo Acordo de Salvaguardas (AS).

Em termos de estrutura interna dos Estados, diversas mudanças institucionais decorrem da entrada em vigor na OMC e das suas regras. De um lado, limitações ao uso de quotas, tarifas e medidas não-tarifárias. Por outro lado, os direitos de propriedade intelectual ficam mais rígidos. Tais mudanças tolheram dos países em desenvolvimento, dentre eles os latino-americanos, os principais 
instrumentos para implantar políticas de catching-up, que foram amplamente utilizados pelos atuais países industrializados ao longo dos séculos XIX e XX. O grau de discricionariedade e liberdade deixado para as políticas públicas de intervenção na economia tornou-se questão fundamental.

Consequentemente, os constrangimentos jurídicos enfrentados pelos Estados-Membros por decorrência das regras da OMC podem ser considerados como condicionantes estruturais para execução de políticas públicas, por limitarem o policy space.

Neste sentido, Fernando Aguillar afirma:

\begin{abstract}
As políticas de liberalização alfandegária deixaram de ser uma opção nacional para adquirirem estatuto de verdadeiro dever por parte dos países signatários de acordos como o GATT. Firmado para vigorar a partir de 1948, o GATT teve como missão reduzir ou eliminar as restrições ao comércio mundial. Mas ganhou impulso principalmente após o ressurgimento das políticas liberais na economia, que culminou com a criação, em 1995, da Organização Mundial do Comércio (OMC), encarregada de implementar as políticas decorrentes do GATT. ${ }^{352}$
\end{abstract}

Com a entrada em vigor da OMC, é possível diagnosticar que algumas políticas públicas mantiveram-se inalteradas, enquanto outras passaram por modificações estruturais importantes. Dentre aquelas que podem ser vistas como políticas de continuidade, destacam-se de um lado, a manutenção indiscriminada das altas linhas tarifárias em bens industriais e, de outro, manutenção dos regimes de comércio norte-sul e sul, por meio tanto do SGP e do SGPC.

Já dentre aquelas que sofreram modificações decorrentes da entrada em vigor dos acordos da OMC podemos apontar as iniciativas de integração regional, mais especificamente o MERCOSUL e a CAN, que ao alinharem-se ao movimento de regionalismo aberto, passaram a reger-se mais pelo paradigma da liberalização comercial do que pelo viés desenvolvimentista. ${ }^{353}$

\footnotetext{
352 AGUILLAR, Fernando Herren (2009). Direito Econômico: do direito nacional ao direito supranacional. $2^{\text {a }}$ ed. São Paulo: Atlas, 2009, p. 62.

${ }^{353}$ Para maiores esclarecimentos em relação a esta mudança de modelos, ver CELLI JR, Umberto et al (2011). MERCOSUL in South-South Agreements: in the middle of two models of regionalism. Genebra: UNCTADVI. Disponível em http://vi.unctad.org/resources-mainmenu-64/digital$\underline{\text { library?act=search }}$
} 
No entanto, as transformações mais significativas foram aquelas decorrentes da internalização dos acordos GATS, TRIPS e TRIMS. Como foi demonstrado no capítulo 5, o processo de liberalização nos setores de comércio de serviços, propriedade intelectual e investimentos, em conjunto com o aprofundamento da liberalização do GATT impactou no policy space das organizações de integração regional da América do Sul.

Ocorre que, como foi apresentado na Parte I, desde a década de 60, o sistema multilateral de comércio tem levado em consideração a dualidade de países desenvolvidos - países em desenvolvimento, por meio do reconhecimento do princípio do tratamento especial e diferenciado a estes últimos. Neste sentido, se é fato que a internalização dos acordos da OMC leva a uma redução de policy space dos seus Membros, é fato também que esta redução se dá de maneira mais flexível quando se trata de países em desenvolvimento. Isto se aplica a todos os acordos da OMC.

Asif Qureshi ${ }^{354}$ sustenta que o movimento dos países em desenvolvimento em direção ao sistema multilateral de comércio tem uma natureza mais pró-ativa e que a essência do sistema multilateral de comércio é, na realidade, desenvolvimentista e não livre-cambista, pelas seguintes razões:

1) $\mathrm{O}$ tratado constitutivo da OMC estabelece que o objetivo central da organização internacional é a promoção do desenvolvimento sustentável a todos os Membros, ou seja, a liberalização comercial não é um fim em si mesmo, ela deve existir se promover o desenvolvimento;

2) Há mais de uma centena de dispositivos legais, espalhados nos acordos da OMC, que possibilitam a promoção de políticas de desenvolvimento, com base no princípio do tratamento especial e diferenciado; e

3) a Rodada de Doha, lançada com o objetivo de consolidar o viés desenvolvimentista da OMC, reforça a natureza da organização internacional e deve cumprir a sua missão de expandir os direitos e garantias de desenvolvimento nas novas regras a serem negociadas, sob pena de violar os objetivos do seu acordo constitutivo.

Portanto, embora tenha emergido como dissidência do mainstream das teorias econômicas e políticas das relações internacionais, e confrontando a hegemonia do Consenso de Washington, o princípio do desenvolvimento constitui

${ }^{354}$ QURESHI, Asif. International Trade for Development: The WTO as a Development Institution. In Jornal of World Trade 43, n. 1, 2009, pp. 173-188. 
o ethos do sistema multilateral de comércio e deve deixar de ser percebido como exceção, e sim, regra do sistema, sob pena de negar o desenvolvimento econômico e social para os dois terços dos Membros da OMC.

O novo desenvolvimentismo parte da constatação de que, à luz das regras da OMC, os modelos contemporâneos de desenvolvimento devem ser percebidos e projetados de maneira sistêmica, contemplando prerrogativas para além do GATT, devendo incorporar igualmente as prerrogativas existentes nos demais acordos da OMC, tais como GATS, TRIPS, TRIMS. Caso contrário, estes modelos poderão repetir os equívocos dos modelos de desenvolvimento implantados ao longo da segunda metade do século XX, no qual foi priorizada exclusivamente a proteção industrial, omitindo-se em relação às políticas de inovação tecnológica e de capacitação humana.

Logo, para implantar políticas de desenvolvimento, os "Membros em desenvolvimento" devem recorrer a dispositivos que não sejam direcionados apenas a eles, e recorrer a dispositivos que sejam de alcance geral. Com efeito, para além do Tratamento Especial e Diferenciado, há significativo policy space ao alcance dos países da América do Sul que estes devem fazer uso, a fim de estabelecerem políticas desenvolvimentistas condizentes com os desafios contemporâneos.

Com base nessa nova concepção, é possível classificar o direito do desenvolvimento vigente no âmbito da OMC em duas ordens:

a) Direitos clássicos do desenvolvimento, alcançáveis por meio de prerrogativas jurídicas que beneficiam o comércio de bens, tais como:

- Tratamento Preferencial e Diferenciado

- Manutenção dos SGP e SGPC

- Condições e prerrogativas especiais dispersas nos diversos acordos setoriais de comércio de bens: AARU, ASMC, AMSF, ATV, ABTC, AIPE, ARO.

b) Direitos do novo desenvolvimentismo, alcançáveis por meio do comércio de serviços, propriedade intelectual, e investimentos ligados ao comércio:

- TRIPS; contratos de transferência de tecnologia e a licença compulsória;

- TRIMS: captação de investimentos estrangeiros diretos e condicionamento a produção nacional 
- GATS: prestação doméstica de serviços essenciais, como educação, saúde, infraestrutura, etc.

Portanto, pode-se classificar em dois os tipos de instrumentos internacionais à disposição dos Estados que possibilitam a operacionalização deste direito do desenvolvimento: instrumentos de transferencia internacional, que abrangem acordos de cooperação técnica, contratos de transferência de tecnologia e a captação de investimentos estrangeiros diretos; e instrumentos de comércio internacional, através da cláusula de não-reciprocidade, o sistema geral de preferências e os acordos de comércio preferencial.

Neste contexto, análise especial deve ser dada ao retorno da tendência a industrialização dos países em desenvolvimento.

Para fins desta tese, entende-se como políticas de industrialização orientadas pelo novo desenvolvimentismo aqueles que incluem i) políticas de tecnologia e inovação, ii) políticas de educação e capacitação profissional; iii) políticas comerciais; iv) medidas específicas de apoio à indústria; v) políticas de competitividade setorial; vi) políticas de regulação da concorrência. ${ }^{355}$

A racionalidade em torno de políticas industriais, no sentido de promoção seletiva de indústrias, permanece robusta apesar da onda ortodoxa neoliberal do Consenso de Washington. O que mudou com o tempo, no entanto, foi o contexto no qual está inserida a política industrial. A globalização - entendida como uma predileção geral por políticas econômicas liberais e intensificação da abertura comercial - não fez com que a política industrial desaparecesse, mas levou a uma mudança fundamental na visão geral que os governos podem e devem ter para promover a industrialização.

A promoção da industrialização em países em desenvolvimento está no centro dos debates da economia política do desenvolvimento contemporânea. Contrário à percepção geral - decorrente da onda neoliberal que prevaleceu por muito tempo nos países em desenvolvimento - políticas industriais estão vivas. A fórmula bem sucedida de industrialização tardia - alocando subsídios, em troca de

${ }^{355}$ MAIO, M. Industrial policies in developing countries: history and perspective. In Cimoli, M.; Dosi, G.; and Sitglitz, J. Industrial Policy and Development. New York: Oxford University Press, 2009. 
padrões de desempenho monitorados pelo país e orientados por resultados comerciais - ainda são aceitas e cada vez mais necessárias.

Não obstante, o papel da política industrial está limitado pela crescente interferência da OMC naquilo que antigamente era considerado políticainterna. Apesar da redução geral de barreiras tarifárias, o uso de subsídios à exportação e de restrições quantitativas é atualmente proibido de acordo com as regras da OMC. As novas regras do comércio internacional abrangem também medidas relativas a investimentos estrangeiros (países não podem exigir condicionalidades nacionais nem exigir padrões de desempenho), bem como propriedade intelectual e comércio de serviços.

Uma distinção deve ser feita em relação a produtos intensivos em mão de obra e matéria prima, com os quais os países normalmente iniciam a sua industrialização, e produtos intensivos em baixa, média e alta tecnologia que começam a ser produzidos com o avanço industrial. Em cada estágio da sequência da industrialização, os países estabelecem proteção por determinado tempo; quando as indústrias vão ficando maduras e internacionalmente competitivas, a proteção deve começar a ser reduzida e eliminada. Uma implicação importante nesta sequencia de proteção é que, quanto mais se avança no processo, mais distante o país vai ficando da condição de "em desenvolvimento" ou "menor desenvolvimento relativo" previsto na OMC.

A realidade é que as políticas industriais estão se desenvolvendo de forma inexorável das últimas duas décadas - especialmente naquelas economias que inicialmente haviam adotado a agenda de reforma ortodoxa, batizado de Consenso de Washington. ${ }^{356}$

É evidente que a demanda por proteção seletiva de indústrias específicas nos países industrializados permanece na agenda política contemporânea; a discussão atual reside no papel que a política comercial exerce sobre a industrialização, especialmente depois da entrada em vigor da OMC e das suas regras. No entanto, apesar dos sucessos anteriores, simplesmente copiar as políticas e práticas do

\footnotetext{
${ }^{356}$ RODRIK, D. Growth after the crisis. Paper apresentado para "Commission on Growth and Development": Harvard Kennedy School, 2009.
} 
passado não é alcançável tampouco desejável para os países que estejam em pleno catching-up.

Ha-Joon Chang afirma que:

O uso de política industrial no Leste Asiático, China, Índia e Brasil é bem conhecido. De fato, há muitos poucos exemplos de industrialização bem sucedida nos quais não houve participação ativa dos governos na promoção industrial. ${ }^{357}$

Em relação às negociações da Rodada de Doha, Ha-Joon Chang alerta que os países em desenvolvimento devem ter muita precaução em relação a futuras reduções de tarifas industriais. As pressões por redução destas tarifas na Rodada de Doha merecem um foco de atenção crucial dos países que almejam o desenvolvimento por meio da industrialização ${ }^{358}$.

Com efeito, apesar de no atual contexto jurídico internacional, o policy space dos países em desenvolvimento estar muito reduzido, as tarifas existentes sobre manufaturas continuam a proporcionar aos países em desenvolvimento algum grau de proteção contra a competição estrangeira. As pressões por redução destas tarifas na Rodada de Doha, especialmente nas negociações sobre acesso a mercados de produtos não-agrícolas (NAMA) ${ }^{359}$, precisam ser um foco de atenção crucial dos países que almejam o desenvolvimento por meio da industrialização. ${ }^{360}$

Apesar da prevalência da ortodoxia neoliberal na formulação de políticas públicas dos países em desenvolvimento, políticas industriais permanecem importantes para a promoção do desenvolvimento. Estas regras modificaram o contexto, mas não a importância da política industrial para o desenvolvimento econômico e social de um país. O estado desenvolvimentista pode continuar a subsidiar novas indústrias onde for necessário, e assegurar que subsídios sejam orientados por resultados por meio de imposição de padrões de desempenho.

Ainda segundo Alice Amsden:

\footnotetext{
${ }^{357}$ CHANG, H. Kicking away the ladder: Development Strategy in Historical Perspective. London: Anthem Press, 2002.

${ }^{358}$ CHANG, H. J. Why developing countries need tariffs? How WTO NAMA negotiations could deny developing countries' right to a future. Genebra: South Centre, 2005.

${ }^{359}$ Sigla em inglês para a expressão Non-Agricultural Market Access, corrente nas negociações da Rodada de Doha.

${ }^{360}$ CHANG, Ha-Joon, op. cit., 2005.
} 
a OMC conforme constituída atualmente pode ser considerada uma organização que promove a ciência e a tecnologia, pois em nome da inovação, países que estiverem na condição de explorar as regras da OMC podem continuar apoiando suas próprias indústrias e estimular a competitividade nacional. ${ }^{361}$

Os problemas que atualmente enfrentam os países não-industrializados, distantes da fronteira tecnológica, não são os constrangimentos legais formais, mas os constrangimentos informais, de pressão política, exercidos pelas economias do Atlântico Norte em favor de aberturas radicais de mercado. Estes "late comers" carecem de uma visão que os guiem na contestação destas pressões. ${ }^{362}$

A viabilidade jurídica de uma abordagem independente que queira implantar, por exemplo, novos parques tecnológicos para gerar spill-over para o setor industrial, é perfeitamente possível. Programas nacionais de ciência e tecnologia financiados por meio de subsídios estarão sempre enquadrados na categoria de subsídios permitidos do ASMC.

Talvez a mudança mais significativa tenha ocorrido em relação ao papel da política comercial, que foi o principal instrumento de indução da indústria no passado. Embora permaneça como uma ferramenta política relevante, a redução geral das barreiras tarifárias e a maior coerção das regras da OMC, levou à diminuição da sua importância.

Nesse sentido, cabe retomar o questionamento: quão limitantes e coercitivas são as atuais regras da OMC? A resposta varia, por um lado, do setor envolvido, e por outro, da distância que cada país está da sua fronteira tecnológica. Aqueles países que estão distantes da fronteira tecnológica provavelmente não sintam as limitações decorrentes das regras da OMC, tanto quanto os países que estejam mais adiantados nas políticas de catching-up. ${ }^{363}$

Além da capacidade de implantar políticas industriais, devem ser levadas em consideração outras iniciativas relacionadas a integração regional que podem ser levadas adiante na América do Sul, que podem configurar-se como políticas

\footnotetext{
${ }^{361}$ AMSDEN, Alice, op. cit., p. 466.

${ }^{362}$ HAQUE, I. U. Rethinking industrial policy. UNCTAD Discussion Paper \#183, 2007.

${ }^{363}$ RODRIK, D. Development strategies for the next century. World Bank, Annual World Bank Conference on Development Economics, 2001.
} 
públicas de desenvolvimento, tais como: em matéria de política industrial, o estabelecimento de proteção tarifária e subsídios às indústrias de inovação e preservação ambiental; redução de assimetrias dentro dos processos de integração da América Latina, e; a expansão da cooperação comercial da América Latina com o Sul Global.

Neste sentido, Umberto Celli afirma:

Para que a liberalização comercial possa apoiar de modo mais efetivo o desenvolvimento sustentável, é necessário que os PEDs disponham de espaço e autonomia para utilizar políticas ativas e instrumentos de política para promover sua capacidade de fornecimento de bens e, em especial, serviços, ampliar os processos de assimilação de novas tecnologias e buscar competitividade. ${ }^{364}$

Neste retorno do pêndulo da história econômica em direção à ingerência estatal, em plena economia da informação, os países em desenvolvimento que, dentro do marco regulatório internacional da $\mathrm{OMC}$, formularem estratégias de desenvolvimento para além de políticas comerciais de bens e projetarem políticas de desenvolvimento fundados em serviços e propriedade intelectual, serão aqueles que melhor se habilitarão a tornarem-se potências emergentes do século XXI. ${ }^{365}$

Alice Amsden resume que, no final das contas:

as novas regras da OMC, um símbolo do neoliberalismo, são flexíveis e permitem aos países continuar estimulando as suas indústrias sob a bandeira da promoção da ciência e tecnologia". Portanto, conclui a autora, "o latido liberal da OMC é pior do que a sua mordida. ${ }^{366}$

É chegada a hora de se construir um "novo consenso", no qual figure a exploração de diversas formas de governança institucional para países em desenvolvimento que almejem acumulação de tecnologia, e rendam-se a uma exploração consciente da eficiência econômica de múltiplos interesses, de agentes motivados por lucro. Deverá ser um consenso sensível aos temas da igualdade e do

\footnotetext{
${ }^{364}$ CELLI JR., op. cit., 2009, p. 151.

365 MAIO, Michele. Industrial policy in developing countries: history and perspectives. In CIMOLI, M.; DOSI, G.; STIGLITZ, J. Industrial Policy and Development. New York: Oxford University Press, 2009, p. 136.

${ }^{366}$ AMSDEN, A.; HIKINO, T. The bark is worse than the bite: new WTO law and late industrialization. American Academy of Political and Social Science \#570, 2000.
} 
acesso ao compartilhamento dos benefícios do crescimento, movidos pelo aprendizado tecnológico e organizacional. ${ }^{367}$

${ }^{367}$ CIMOLI, M.; DOSI, G.; STIGLITZ, J. Industrial Policy and Development. New York: Oxford University Press, 2009. 


\section{CONCLUSÕES DO CAPÍTULO 7}

Logo nas primeiras Rodadas de Negociações da OMC - Singapura e Seattle - houve uma pressão enorme por parte dos países em desenvolvimento para a revisão do viés da natureza da $\mathrm{OMC}$, pois a falência dos modelos de desenvolvimento fundados no neoliberalismo ao redor do mundo clamava por uma reorientação ideológica nas relações econômicas internacionais, inclusive para as suas regras. Estava preparado o terreno para o retorno do viés (neo) desenvolvimentista ao sistema multilateral de comércio.

Com o esgotamento do Tratamento Especial e Diferenciado, além de um cenário controverso das relações econômicas internacionais, com crises em diversos países em desenvolvimento mundo afora, as Rodadas de Singapura e Seattle são um fracasso, que apontam para o fim do período neoliberal da OMC e paulatinamente vai se construindo um cenário com as devidas condições para a emergência de uma nova lógica dentro do sistema multilateral de comércio.

Os países em desenvolvimento perceberam ao longo dos primeiros anos de vigência da OMC que, para promover políticas de integração e desenvolvimento orientadas pelos parâmetros contemporâneos do novo desenvolvimentismo, fundadas em inovação tecnológica, fazia-se necessário gozar de prerrogativas jurídicas em áreas onde tais prerrogativas são escassas, tais como subsídios, investimentos, propriedade intelectual, serviços. E ainda, fazia-se necessário conceber as políticas de desenvolvimento para além do Tratamento Especial e Diferenciado.

O fracasso no lançamento da Rodada de Seattle, que visava aprofundar e ampliar ainda mais o processo de liberalização econômica e comercial em escala global foi fruto do despertar do mundo em desenvolvimento descrito ao longo do capítulo 5, que percebia a necessidade de retomar a construção e a renovação do direito internacional do desenvolvimento. No âmbito da OMC, isto significava a necessidade de aprofundar e ampliar as prerrogativas jurídicas no sistema multilateral de comércio. 
Como conseqüência, em 2001, a OMC lançou a Rodada de Doha, com natureza absolutamente diferente da tentativa anterior. A Rodada de Doha foi batizada de Rodada do Desenvolvimento e, com fulcro na Declaração Ministerial de Doha, se propôs a levar adiante uma ampla revisão dos acordos vigentes no escopo da OMC, a fim de melhor adaptá-los às necessidades dos países-Membros, atendendo em especial, as demandas dos países em desenvolvimento. Nesse sentido, a Rodada de Doha revela-se uma oportunidade para a renovação e a ampliação do direito internacional do desenvolvimento no âmbito da OMC.

Por isso, ao longo deste capítulo, foi realizada uma análise deste período (neo)desenvolvimentista da OMC, denominação que pode ser atribuída, tendo-se em vista que, ao menos em tese, desde o lançamento da Rodada de Doha, o desenvolvimento é o objetivo maior das negociações da OMC. Com a Declaração Ministerial de Doha, surge uma nova lupa para analisar a OMC e seus acordos. Ademais, o cenário global, de emergência de uma situação economicamente mais favorável para os países em desenvolvimento, provoca tais Estados a implantarem políticas sólidas de desenvolvimento, a fim de aproveitar o bonde da história que os favorece neste momento.

Imbuído deste Zeitgeist (neo)desenvolvimentista, e objetivando delimitar o quanto existe de policy space para os países latino-americanos, propôs-se uma "releitura" dos principais acordos vigentes da OMC, a fim de encontrar as "brechas" legais que possibilitem aos países em desenvolvimento a implantação de políticas desenvolvimentistas, especialmente aquelas voltadas à inovação tecnológica e à sustentabilidade.

No entanto, enquanto a Rodada de Doha não se encerra e os acordos da OMC não foram efetivamente reformulados, as regras da OMC vigentes permanecem aquelas mesmas, negociadas e aprovadas nos tempos do Consenso de Washington, de afirmação do neoliberalismo e de rechaço a toda e qualquer iniciativa desenvolvimentista no mundo em desenvolvimento.

Por tanto, a situação que se vive hoje é paradoxal: há um relativo consenso em torno da necessidade dos países em desenvolvimento levarem adiante políticas de desenvolvimento; contudo, as regras da $\mathrm{OMC}$, em geral, não permitem. 
Ademais, apresentam-se alguns aspectos do cenário internacional de crise do início do século XXI que marcam o lançamento e as negociações da Rodada de Doha, relevantes para a emergência desta nova lógica do sistema multilateral de comércio, quais sejam: a crise do neoliberalismo global, o fortalecimento do Sul Global, a adesão da China a OMC, os BRICs, o G-20, a proliferação de ARCs, culminando com a Crise Econômica Mundial, iniciada em 2008 da qual até agora a comunidade internacional não se viu livre.

A presente tese sustenta que a solução desse cenário paradoxal pode se resolver a partir de uma interpretação pró-desenvolvimentista dos atuais acordos, viabilizado pela Declaração de Doha, em conjunto com toda a produção normativa em torno do desenvolvimento, no âmbito da ONU e nas demais organizações internacionais, podendo-se constituir num marco jurídico pró-desenvolvimentista para realizar tal interpretação.

Imbuído desse viés pró-desenvolvimentista, é possível identificar uma série de prerrogativas jurídicas vigentes no âmbito da OMC a disposição dos países em desenvolvimento. Tal mapeamento descritivo da diversidade de prerrogativas jurídicas existentes nos diversos acordos não foi objeto da tese, por se tratar de um outro trabalho, que merece análise específica e aprofundada, e que seguramente será um desdobramento de futuras pesquisas. 


\title{
CAPÍTULO 8. O NOVO REGIONALISMO DESENVOLVIMENTISTA DAS ORGANIZAÇÕES DE INTEGRAÇÃO REGIONAL DA AMÉRICA DO SUL
}

\begin{abstract}
A tarefa não será fácil. Mas é muito grande o que está atualmente em jogo na América Latina para que possamos fugir a essas dificuldades. É preciso atacar tais dificuldades em todos os campos e não deixar que continuem semeando o desânimo, a indiferença e o derrotismo entre aqueles que não conseguem entender a significação verdadeira dos acontecimentos. Precisamos destruir esta situação condenada com as nossas próprias mãos, à nossa maneira, pois a história está oferecendo à América Latina, no seio de um mundo de antagonismos e contradições, a oportunidade única de construir novamente e projetar-se vigorosamente no processo irreprimível das grandes transformações.
\end{abstract}

Raul Prebisch. Os Obstáculos ao Mercado Comum Latino-Americano, 1966 


\section{APRESENTAÇÃO DO CAPÍTULO 8}

O capítulo 8 pretende analisar o novo regionalismo desenvolvimentista das organizações de integração regional da América do Sul. Em razão do fato de tal fenômeno ser recente e estar em plena construção teórica e pragmática, este capítulo tem um propósito eminentemente sistematizador das diversas experiências recentes que, em seu conjunto podem auxiliar na configuração deste novo modelo de regionalismo. A análise técnica e aprofundada de cada iniciativa tratada neste capítulo revela-se um desdobramento fundamental enquanto campo de pesquisa futuro desta tese.

O subcapítulo 8.1 resgata o processo contemporâneo de renovação e a ampliação da integração sul-americana, que tem levado a novas caracterizações dos modelos de integração da América do Sul, por estarem fundados em novos parâmetros, desencadeando definições como regionalismo pós-liberal, novo desenvolvimentismo, e regionalismo neodesenvolvimentista. Para tanto, dois movimentos devem ser apontados: nos planos subregionais, o relançamento tanto do MERCOSUL quanto da CAN; no plano regional, a criação da UNASUL.

O capítulo 8.2 busca identificar, em meio a este processo de renovação e ampliação da integração sul-americana, algumas novas instituições e vetores da integração, tanto no plano regional quanto nos planos subregionais. Por isso, são elencadas e apresentadas as novas instituições neodesenvolvimentistas da América do Sul, em especial, os diversos conselhos e fundos de fomento oriundos da UNASUL. Em seguida, propõe-se a análise de alguns projetos e iniciativas levadas adiante com base em dois novos vetores que estão paulatinamente se institucionalizando na América do Sul: de um lado, a infraestrutura regional, já relativamente consolidada e incorporada à agenda integracionista contemporânea; e do outro, a inovação tecnológica, ainda incipiente e secundária enquanto tema das organizações de integração da América do Sul.

Por fim, a título de conclusão, o subcapítulo 8.3 lança alguns desafios que se apresentam à consolidação do novo regionalismo desenvolvimentista nas organizações de integração da América do Sul: primeiramente, a UNASUL, cujo 
desafio centra-se na capacidade institucional de transformar retórica em prática; em seguida, a ALADI, que lida com a dualidade entre, de um lado, coordenar o processo de convergência intra-regional e de outro, supervisionar a abertura da América do Sul para celebração de acordos bilaterais; e por fim, MERCOSUL e CAN, que necessitam urgentemente de uma nova consolidação institucional das organizações internacionais, decorrentes das crises políticas contemporâneas que ambas vivem. 


\subsection{O RELANÇAMENTO E A RENOVAÇÃO DA INTEGRAÇÃO SUL-AMERICANA}

\section{a) O regionalismo pós-liberal da América do Sul}

A integração sul-americana mudou consideravelmente nos últimos 20 anos. Em tempos de renovação dos regionalismos da América do Sul, as iniciativas de integração comercial - CAN e MERCOSUL - coexistem com uma série de iniciativas levadas adiante ao redor do continente, seja no escopo da ALADI, seja decorrente de novos projetos de organizações de integração regional.

A engenharia institucional da integração sul-americana está se transformando em uma arena complexa e multifacetada na qual se entrelaçam os mais diversos interesses geopolíticos, ideológicos, econômicos e comerciais. A região atualmente convive com o desafio de harmonizar este fenômeno e aprender a coordenar estes projetos, para que sejam complementares, ao invés de conflitantes.

Esta harmonização depende de uma alta dose de pragmatismo que seja capaz de levar adiante uma série de novas iniciativas pró-desenvolvimentistas em conjunto com as iniciativas liberalizantes já instaladas. Só assim, a alternativa da integração regional sul-americana continuará sendo mais interessante que as opções nacionalistas e bilateralistas.

Muito embora o cenário seja extremamente dinâmico, é necessário tentar observar e apontar as mais recentes iniciativas de modo a, primeiramente identificar os cenários que estão sendo planejados e efetivamente construídos, para depois avaliar, tanto as potenciais incompatibilidades intra-regionais, quanto a compatibilidade das mesmas com as regras da OMC.

Neste contexto, o avanço na região de governos "progressistas" da "nova esquerda" desempenhou um papel decisivo na revisão dos processos de integração sul-americanos. Isto parece ter sido uma resposta regional a dois conjuntos de desafios, intrinsecamente relacionados que marcaram a América Latina na virada 
do século: o crescente aumento das mobilizações populares e a ampla opinião pública contra os efeitos que as reformas neoliberais haviam causado aos países da região.

Ambas as reações refletiram uma grande insatisfação com os resultados das estratégias de reformas neoliberais, impulsionadas em parte pela incorporação das regras da OMC, que falharam em gerar altos níveis de crescimento, bem como sua incapacidade de promover modelos de distribuição de renda mais equilibrados e justos. Esta percepção, de ter arcado com um custo demasiadamente alto por resultados tão modestos, deu às organizações regionais já existentes um novo fôlego.

$\mathrm{Na}$ América do Sul do século XXI, muitos governantes chegaram ao poder céticos em relação às recomendações do pensamento econômico convencional dos anos 90, e ampliaram o escopo e a escala da intervenção estatal e alterou a direção das políticas públicas. Esta reação política contra as orientações econômicas mais ortodoxas que prevalecia entre os policymakers e dominava a agenda de reforma do continente, estimulou e aprofundou tal debate, sobre "o declínio do Estado".

Um novo e incipiente modelo de desenvolvimento foi tomando forma nos países da América do Sul. Este modelo resgata o Estado como ponto fulcral, mas de maneira relativamente distinta se comparada ao papel dirigista, de mão firme, que o Estado desenvolvimentista exercia. Esta pró-atividade se manifesta por meio de quatro conjuntos de políticas: 1. Política comercial; 2. Política Industrial e Políticas CT\&I; 3. Instituições de financiamento ao desenvolvimento e; 4. Políticas sociais.

O novo modelo de ativismo estatal que emergiu gerou um ciclo virtuoso de crescimento econômico com redução de pobreza e desigualdade e o avanço em indicadores sociais básicos - em suma, um período de desenvolvimento inclusivo.

Há dois movimentos complementares nas políticas públicas e ações estatais. De um lado, há um aumento de ambiente mais pró-mercado e pró-empresarial por meio do fortalecimento da intervenção estatal na vida econômica e social. Por outro, esta intervenção estatal em apoio à criação desse ambiente pró-mercado é 
acompanhada de uma significativa expansão da proteção social e dos esforços para combater não apenas a pobreza e a desigualdade.

Significa que a abertura da economia não representou o eclipse do Estado, tampouco a expansão do ativismo estatal provocou o colapso do mercado. Pela primeira vez na história da América do Sul, tal combinação parece virtuosa no que diz respeito à redução da pobreza, mais particularmente, na desigualdade de renda.

Ao se definir "alcançar" (catching up) como a habilidade para competir baseada no preço dos produtos de exportação, a lista dos setores e das áreas que evoluíram na América do Sul seria extensa. Em muitos segmentos, a participação brasileira, por exemplo, no comércio internacional cresceu rapidamente, como na indústria de aviões, do petróleo, na agricultura e mineração. Alcançar, nesse sentido, indica acúmulo de capacidade produtiva. Porém, no que se refere à catching up, projeta-se um movimento mais amplo e ambicioso, relativo à transição de uma estrutura que produz para uma economia que capacita para a inovação.

Se é certo que a inovação fincou raízes nos panoramas econômico e político nacionais, consolidando-se alternativa viável entre os policy-makers e alastrando-se como perspectiva no meio empresarial, a incorporação de sua dimensão estratégica no plano regional está longe de mostrar-se consensual.

\section{b) O relançamento do MERCOSUL e da CAN}

MERCOSUL e CAN foram relançados com base no paradigma do regionalismo pós-liberal, ou pós-comercial, com um forte tom pródesenvolvimentista, com uma preocupação de manter e aumentar o nível de policy space, e de considerar os impactos redistribuitivos da liberalização comercial, por meio de políticas de correção de assimetrias.

Além disso, o regionalismo pós-liberal passou a questionar a natureza exclusivamente comercial das organizações regionais existentes, passando a incorporar um conjunto de setores e atores excluídos dos processos nos anos 1990. 
A agenda da integração começou a ser estendida e ampliada para incluir temas políticos e sociais, enquanto a dimensão comercial passou a ser percebida pela ótica das assimetrias políticas e estruturais.

Impulsionado pelo boom do crescimento econômico vivido pelo continente em 2003, o MERCOSUL foi "relançado" uma vez mais, na Cúpula de Assunção, com Nestor Kirchner e Luiz Inácio da Silva como os chefes de Estado de Argentina e Brasil entre 2003 e 2007. Nesse relançamento estiveram presentes Bolívia, Chile e Venezuela, como países convidados, o que indicava uma aproximação tanto com o bloco subregional andino, quando com o Chile, vizinho que historicamente optou por projetos de desenvolvimento fundado no bilateralismo.

Dois elementos contribuíram para o relançamento do MERCOSUL. Primeiro, a convergência econômica entre os dois maiores parceiros comerciais Argentina e Brasil - que havia sido iniciada no primeiro "relançamento" do MERCOSUL em 2000, surtia resultado. Segundo, a superação das graves crises econômicas pelas quais ambos haviam passado recentemente, contribuía para o sentimento positivo da Cúpula.

Alinhada com o novo paradigma pós-liberal, a Cúpula resultou na declaração que propugnava pela necessidade de aprofundar o chamado MERCOSUL "político". Isto exigiria avançar com instrumentos que iriam além da integração comercial, e incorporar temas como compromissos democráticos, acordos em temas sociais e trabalhistas, liberdade de circulação de trabalhadores e de residência, redução do desemprego regional, proteção de direitos humanos, promoção cultural, envolvimento das organizações da sociedade civil, dentre outros. ${ }^{368}$

No que se refere ao tratamento das assimetrias internas, o MERCOSUL originariamente foi constituído seguindo a lógica do Tratamento Especial e Diferenciado da OMC, discutida na Parte II desta tese, por meio de concessões temporárias e exceções em favor dos países menos desenvolvidos da região, Uruguai e Paraguai.

Tanto o Tratado de Assunção quanto o Protocolo de Ouro Preto não fazem uma única menção à expressão "assimetrias". Há apenas concessões de extensões

${ }^{368}$ Decisão CMC n ${ }^{\circ}$ 26/03. 
temporárias, flexibilidades nos compromissos de liberalização comercial, e as listas de exceções para a formulação da Tarifa Externa Comum.

Com o relançamento do MERCOSUL, e a consequente expansão de sua agenda foi expandida, a questão das assimetrias foi ganhando espaço nas discussões. Gradativamente, a questão das assimetrias foi afastando-se da sua conotação original, de ser tratada por meio de políticas negativas, isto é, exceções e prorrogações temporais, para um conjunto de politicas positivas, que pudesse agir diretamente sobre os países menos desenvolvidos, especialmente por meio de programas de natureza estrutural e social.

Em termos econômicos e comerciais, novas iniciativas foram lançadas, tais com o Fundo para a Convergência Estrutural (FOCEM), o Programa para Pequenas e Médias Empresas, o Fundo de Integração Produtiva e o Fundo para Agricultura Familiar.

Além disso, do ponto de vista da estrutura institucional do MERCOSUL, novas e relevantes iniciativas institucionais de aprofundamento da integração foram lançadas, tais como o Tribunal Permanente de Revisão (2002), o Parlamento do MERCOSUL (2006) e mais recentemente o Código Aduaneiro Comum (2010).

O MERCOSUL parecia ter encontrado o ambiente político adequado para se aprofundar e solidificar enquanto organização de integração regional não mais fundada nos preceitos dos anos 90, da integração dirigida pelo mercado (Market-led integration), e condizente com os novos preceitos dos anos 2000, de uma integração dirigida pelo Estado (State-led integration).

A CAN também passou por uma mudança de natureza integracionista equivalente ao MERCOSUL. Em 2004, os Estados Membros da CAN constituíram um novo mandato para a organização internacional por meio do Plano de Desenvolvimento Social Integrado. ${ }^{369}$ Com base neste plano, uma diversidade de temas de dimensão social foram incorporados ao Sistema Andino de Integração, tais como a participação dos povos indígenas, os direitos trabalhistas, cultura regional, igualdade de oportunidades para gêneros, educação, dentre outros.

Encorajados pelo clima político favorável, MERCOSUL e CAN assinaram um memorando de entendimento em 2004 com o qual propugnavam a

\footnotetext{
${ }^{369}$ Decisão CCA n ${ }^{\circ}$ 601/04.
} 
intensificação da integração entre ambos os processos de integração. Desde o seu surgimento, tal projeto encontrava um duplo desafio: um jurídico, decorrente da dificuldade de realizar tal convergência no quadro da ALADI, oriundo da sobreposição de uma complexa rede de preferências tarifárias concedidas entre os Membros, e outro político, proveniente das tensões políticas e ideológicas entre os Membros envolvidos.

A aproximação comercial MERCOSUL-CAN havia se institucionalizado em 2000, por meio de um Acordo de Alcance Parcial no 56 junto à ALADI, para outorga de preferências comerciais isoladas. Em 2002, foi firmado um novo Acordo de Complementação Econômica $n^{\circ} 59$, desta vez com o propósito de formação de uma zona de livre comércio que abrangesse ambas as sub-regiões. O objetivo inicial era que houvesse negociações conjuntas de ambos os lados. No entanto, na medida em que as diferenças e os impasses emegiram, especialmente do lado andino, as negociações gradualmente tornaram-se bilaterais, entre o MERCOSUL e cada um dos Membros da CAN individualmente considerados.

A respeito deste processo de cisão entre as organizações sub-regionais, serão tecidos comentários mais adiante, ao analisarmos os desafios atuais da ALADI.

\section{c) A criação da União de Nações Sul-Americanas}

A renovação da integração sul-americana desenhada ao longo da primeira década do século XXI culminou com a constituição de um projeto de integração de natureza absolutamente inédita na história da América do Sul, a União de Nações Sul-Americanas (UNASUL).

A UNASUL foi originariamente constituída como Comunidade SulAmericana de Nações (CSN), em 8 de dezembro de 2004. Por meio da Declaração de Cuzco, os chefes de Estado e governo dos 12 países da América do Sul decidiram lançar um novo espaço de integração política, social, econômica, ambiental e de infraestrutura, com vistas à formação de um bloco unitário com voz e pesos próprios em nível internacional. 
A CSN foi originariamente composta por Argentina, Bolívia, Brasil, Colômbia, Chile, Equador, Guiana, Paraguai, Suriname, Uruguai e Venezuela.

A primeira reunião formal de chefes de Estado da já constituída CSN ocorreu em Brasília, em setembro de 2005. Nesta ocasião, se estabelece uma agenda prioritária e um plano de ação em torno dos seguintes temas:

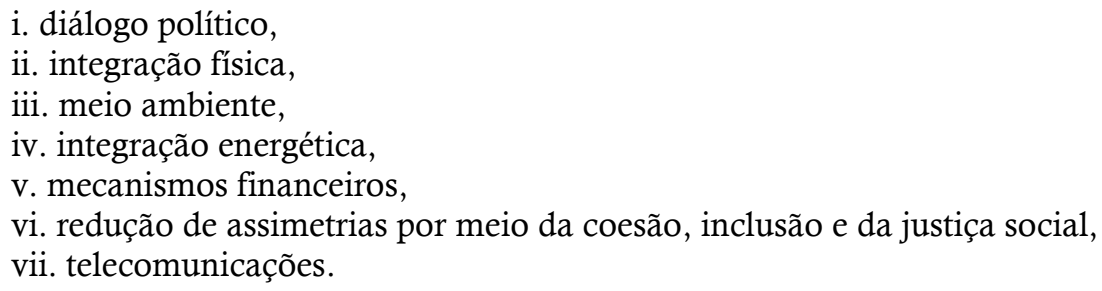

Foi apenas em abril de 2007 que a CSN teve o seu nome alterado para União de Nações Sul-Americanas, a UNASUL. Em seguida, em maio de 2008, foi aprovado o Tratado Constitutivo dessa nova organização internacional do América Sul.

$\mathrm{O}$ artigo $1^{\mathrm{o}}$ do tratado dispõe expressamente que os Estados-partes decidem constituir a UNASUL como uma organização dotada de personalidade jurídica internacional.

Os objetivos gerais desta nova organização internacional sul-americana, com base no artigo $2^{\circ}$, são os seguintes:

\begin{abstract}
Construir, de maneira participativa e consensuada, um espaço de integração e união no âmbito cultural, social, econômico e político entre seus povos, priorizando o diálogo político, as políticas sociais, a educação, a energia, a infraestrutura, o financiamento e o meio ambiente, entre outros, com vistas a eliminar a desigualdade socioeconômica, alcançar a inclusão social e a participação cidadã, fortalecer a democracia e reduzir as assimetrias no marco do fortalecimento da soberania e independência dos Estados.
\end{abstract}

Dentre os 21 objetivos específicos detalhados no artigo $3^{\circ}$ destacam-se para fins da presente tese os seguintes:

b) o desenvolvimento social e humano com equidade e inclusão para erradicar a pobreza e superar as desigualdades na região;

d) a integração energética para o aproveitamento integral, sustentável e solidário dos recursos da região; 
e) o desenvolvimento de uma infraestrutura para a interconexão da região e de nossos povos de acordo com critérios de desenvolvimento social e econômico sustentáveis;

h) o desenvolvimento de mecanismos concretos e efetivos para a superação das assimetrias, alcançando assim uma integração equitativa;

m) a integração industrial e produtiva, com especial atenção às pequenas e médias empresas, cooperativas, redes e outras formas de organização produtiva;

n) a definição e implantação de políticas e projetos comuns ou complementares de pesquisa, inovação, transferência e produção tecnológica, com vistas a incrementar a capacidade, a sustentabilidade e o desenvolvimento científico e tecnológico próprios;

A partir da celebração do tratado constitutivo da UNASUL, foi dado início à constituição da estrutura institucional, através da criação dos diversos Conselhos competentes para levar adiante os princípios da organização. Em 2008, foram criados o Conselho de Saúde Sul-Americano e o Conselho de Defesa SulAmericano. Em 2009, foram criados outros Conselhos específicos, ligados ao combate do tráfico de drogas, infraestrutura, desenvolvimento social e ciência, tecnologia e inovação. Por fim, em 2011, o tratado constitutivo entra em vigor e é estabelecida a sede da Secretaria Geral da UNASUL em Quito, Equador.

Os atuais Membros da UNASUL são Argentina, Bolívia, Brasil, Colômbia, Chile, Equador, Guiana, Peru, Paraguai, Suriname, Uruguai e Venezuela.

Desde o princípio, a UNASUL teve uma abordagem eminentemente estratégica, com grande ênfase na integração física e energética da América do Sul. No entanto, a agenda da infraestrutura, como será visto mais adiante, foi lançada muito antes da UNASUL, em 2000, por meio da Iniciativa para a Integração da Infraestrutura Regional da América do Sul (IIRSA). Tal iniciativa foi idealizada para servir de fórum de discussão para as autoridades responsáveis por transporte, energia e telecomunicações dos 12 países sul-americanos. Com a criação da UNASUL, tal iniciativa foi encampada pela nova organização em razão da criação do Conselho Sul-americano de Infraestrutura e Planejamento (COSIPLAN), que se tornou o órgão gestor da IIRSA. ${ }^{370}$

\footnotetext{
${ }^{370}$ Ver http://www.iirsa.org.
} 
Além de infraestrutura, outros dois temas foram fundamentais nos primeiros anos da constituição da UNASUL: a criação de um conselho de defesa regional e a constituição de um banco multilateral sul-americano.

O Conselho de Defesa Sul-Americano foi criado em 2008 como instância de consulta, cooperação e coordenação em matéria de Defesa, com o objetivo primordial de zelar pela observância do Tratado Constitutivo da UNASUL.

Para tanto, o Conselho de Defesa tem como políticas prioritárias:

a. Rede para troca de informações sobre defesa;

b. Modernização conjunta dos ministérios de defesa;

c. Transparência sobre informações com gastos militares;

d. Definição conjunta de enfoques conceituais;

e. Identificação de fatores de risco para a segurança regional;

f. Articulação de posições conjuntas da região em foros multilaterais sobre defesa;

g. Propor o estabelecimento de um mecanismo de consultas frente a situações de atentado a paz.

Desde a sua constituição, o Conselho de Defesa já se manifestou em diversas situações críticas da América do Sul: o Golpe no Equador em 2009; a crise de Honduras em 2010; no $30^{\circ}$ aniversário das Malvinas em 2012; o anúncio de retirada conjunta dos países sul-americanos da Minustah em final de 2012.

Em matéria de integração financeira, o projeto do Banco do Sul foi idealizado em 2007, originariamente para atuar como um banco de desenvolvimento, embora alguns países pretendam que este estenda as suas atividades e se torne um fundo monetário regional, auxiliando os países em situações de crise de balanço de pagamentos.

Com um capital inicial planejado em torno de US\$ 20 bilhões, a iniciativa ainda gera dúvidas de economistas sobre a capacidade de oferecer taxas de juros baixas e tornar-se mais atraente que BIRD e BID. Atualmente, são signatários do acordo constitutivo do Banco do Sul a Argentina, Bolívia, Brasil, Equador, Paraguai, Uruguai e Venezuela. O acordo está aguardando o processo de ratificação para a sua entrada em vigor.

Feita essa apresentação geral da UNASUL, há iniciativas decorrentes da mesma que merecem análise detalhada a seguir, em razão da natureza neodesenvolvimentista das mesmas. 


\title{
8.2. OS NOVOS VETORES NEODESENVOLVIMENTISTAS DAS ORGANIZAÇÕES DE INTEGRAÇÃO DA AMÉRICA DO SUL
}

\author{
a) Instituições neodesenvolvimentistas específicas da América do Sul
}

Como apresentado anteriormente, a UNASUL foi constituída com o objetivo de integrar a América do Sul em temas até então não regulados pelas organizações de integração regional existentes.

Com base nos objetivos que podem caracterizar a UNASUL como uma organização neodesenvolvimentista estão:

b) o desenvolvimento social e humano com equidade e inclusão para erradicar a pobreza e superar as desigualdades na região;

d) a integração energética para o aproveitamento integral, sustentável e solidário dos recursos da região;

e) o desenvolvimento de uma infraestrutura para a interconexão da região e de nossos povos de acordo com critérios de desenvolvimento social e econômico sustentáveis;

h) o desenvolvimento de mecanismos concretos e efetivos para a superação das assimetrias, alcançando assim uma integração equitativa;

m) a integração industrial e produtiva, com especial atenção às pequenas e médias empresas, cooperativas, redes e outras formas de organização produtiva;

n) a definição e implantação de políticas e projetos comuns ou complementares de pesquisa, inovação, transferência e produção tecnológica, com vistas a incrementar a capacidade, a sustentabilidade e o desenvolvimento científico e tecnológico próprios;

Para levar adiante tais objetivos, foram constituídos diversos órgãos, cujas competências podem torná-los importantes centros para criação e implantação de projetos de natureza neodesenvolvimentista.

A incipiência de tais órgãos ainda não permite avaliar o nível de efetividade, tampouco a natureza dos projetos que conduzirão. No entanto, os seus objetivos e propósitos tornam estes órgãos estratégicos para implantação e efetivização deste 
projeto de regionalismo desenvolvimentista que está sendo levado adiante pela América do Sul.

a) Conselho Sul-americano de Infraestrutura e Planejamento

O Conselho Sul-americano de Infraestrutura e Planejamento (COSIPLAN) foi criado em 28 de janeiro de 2009, com o objetivo de servir de instância de discussão política e estratégica, através da consulta, avaliação, cooperação, planejamento e coordenação de esforços e articulação dos programas para implantar a integração da infraestrutura regional dos Estados Membros da UNASUL.

Com base no seu Estatuto ${ }^{371}$, o COSIPLAN tem os seguintes objetivos:

a) Desenvolver uma infraestrutura para a integração regional reconhecendo e dando continuidade às conquistas e avanços da IIRSA, incorporando-os ao seu plano de trabalho.

b) Fomentar a cooperação regional em planejamento e infraestrutura, mediante alianças estratégicas entre os Estados Membros.

c) Promover a compatibilização dos marcos normativos existentes nos Estados Membros da UNASUL que regulam o desenvolvimento e a operação da infraestrutura na região.

d) Identificar e impulsionar a execução de projetos prioritários para a integração e avaliar alternativas para seu financiamento.

Atualmente, o COSIPLAN está levando adiante duas frentes de trabalho, uma mais bem institucionalizada, a IIRSA e o seu conjunto de projetos regionais e subregionais, e uma ainda incipiente, o Anel Óptico, voltado à integração em matéria de tecnologias de informação e telecomunicações. Ambas as frentes de trabalho serão analisadas a seguir.

371 
O Conselho Sul-americano de Educação, Cultura, Ciência, Tecnologia e Inovação (COSECCTI) foi criado em 14 de março de 2010, como o propósito de ser um órgão político, de caráter intergovernamental para a integração, destinado a definir, coordenar e promover políticas e projetos comuns ligados ao conhecimento, em especial aquelas orientadas à educação, à cultura, à ciência e tecnologia e à inovação.

Em novembro de 2011, foi estabelecida a primeira agenda de trabalho deste conselho, definida em torno de dois temas centrais: a inovação inclusiva e a apropriação social do conhecimento.

De acordo com o Estatuto do COSECCTI, serão constituídos grupos de trabalho especializados para cada uma destas áreas temáticas. Em dezembro de 2011, foi criado um grupo de trabalho para a cultura, e em 2012, um voltado à educação. As atas das reuniões destes grupos de trabalho revelam que ainda se encontram em estágio embrionário de trabalho, não apontando ainda projetos concretos sob suas respectivas supervisões.

c) Sistema de Cooperação Regional em Propriedade Industrial

O Sistema de Cooperação Regional em Propriedade Industrial (PROSUR) foi criado em 2008, com o apoio do Banco Interamericano de Desenvolvimento (BID) e, posteriormente, da Organização Mundial de Propriedade Intelectual (OMPI). Participam atualmente os escritórios de propriedade intelectual dos seguintes países: Argentina, Brasil, Chile, Colômbia, Equador, Paraguai, Peru, Suriname e Uruguai. Embora o PROSUR ainda não esteja de fato em atividade, os objetivos aos quais se propõe, e a temática que trata, merecem breve análise. 
Os objetivos do PROSUR são: - Estabelecer uma política de cooperação regional em questões gerais de
propriedade intelectual, incluindo a realização de exames comuns de
patenteabilidade;
- Estabelecer uma plataforma eletrônica comum para a integração dos
dados e os sistemas de informações entre os escritórios nacionais de
propriedade intelectual;
- Oferecer produtos e serviços de alcance regional para os usuários do
sistema de propriedade industrial.
- Atualizar os sistemas nacionais de proteção de propriedade intelectual
para adaptaram-se aos conceitos de inovação.

O PROSUR foi constituído para melhorar os serviços prestados pelas oficinas nacionais de propriedade intelectual aos nacionais e estrangeiros que utilizam seus sistemas, por meio do desenvolvimento de uma plataforma comum de integração, troca de informações e compatibilidade dos sistemas das nove oficinas.

O grupo de Estados Membros solicitou auxilio à OMPI a fim de que fornecesse a infraestrutura necessária para a efetivação do sistema de cooperação, mediante o uso da plataforma eletrônica e a formação de examinadores de patentes e outros profissionais de propriedade intelectual. A plataforma eletrônica permite que as oficinas nacionais de propriedade industrial compartilhem dados e relatórios sobre as pesquisas e análise dos pedidos de patentes.

Para estabelecer um sistema efetivo de cooperação regional em propriedade intelectual, o PROSUR visa atrair as empresas regionais para o sistema de proteção de propriedade intelectual, bem como promover a aquisição de direitos de propriedade intelectual não apenas na região como em todo mundo, criando melhores condições para a participação das empresas sul-americanas nos sistemas globais abertos de inovação.

O mapeamento de tecnologias existentes, dos atores mais destacados e das dinâmicas globais da inovação em setores importantes, torna-se fundamental para orientar empresas e políticas públicas na América do Sul. Este mapeamento pode vir a ser uma importante função do PROSUR. A partir de ambientes legais mais favoráveis, faz-se necessário incluir as empresas da região nas redes internacionais 
de inovação. Para isso, devem ser realizadas ações que contribuam para a internacionalização das empresas e o fortalecimento da cooperação regional, buscando um melhor posicionamento global.

d) Rede interamericana de compras governamentais

A Rede Interamericana de Compras Governamentais (RICG), embora não esteja constituída no âmbito da UNASUL, envolve todos os Membros desta organização e está constituída em torno de um tema crucial para as políticas de desenvolvimento e inovação da América do Sul. ${ }^{372}$

A RICG foi constituída em 2005, e é composta por praticamente todos os Estados das Américas (não participam EUA, Canadá e Cuba), e é apoiada pela Organização dos Estados Americanos (OEA) e pelo o BID.

No âmbito da rede, já foram realizados sete conferências anuais sobre compras governamentais nas Américas.

As três iniciativas mais relevantes no âmbito da RICG, no que se refere ao viés neodesenvolvimentista da integração sul-americana, dizem respeito a: a) o Programa de Bens Públicos Regionais; b) Projeto de Compras Públicas Sustentáveis; c) Compras Públicas nos Acordos de Integração Regional e de Livre Comércio.

Tendo-se em vista que nenhum Estado sul-americano é signatário do Acordo de Compras Governamentais (ACG) da OMC, a região não está obrigada a respeitar os princípios da não-discriminação e do tratamento nacional. Consequentemente, a RICG pode se revelar um importante fórum para idealização e implantação de um projeto de preferências em matéria de compras governamentais, para bens e serviços intra-ALADI, intra-MERCOSUL e intra-

\footnotetext{
${ }^{372}$ Página official em http://ricg.info:8080/Plone.
} 
CAN. É possível inclusive estabelecer preferências adicionais se forem derivados tanto de inovação quanto de sustentabilidade ambiental.

Para isso, é necessário harmonizar leis de licitações dos Membros, readequar e definir, de maneira conjunta as regras de origem, bem como definir coletivamente o que seja produto derivado de políticas de inovação.

As organizações de integração regional da América do Sul praticamente silenciam em relação a compras governamentais. Não há regulação sobre compras governamentais na ALADI, tampouco na CAN. No MERCOSUL, há a Decisão CMC no 40/03, que estabeleceu o Protocolo sobre Contratações Públicas do MERCOSUL. Porém, tal decisão ainda não está em vigor.

Em razão da ausência de um marco jurídico comum, tanto no plano regional, quanto nos planos sub-regionais, a atual Lei de Licitações brasileira pode se revelar um projeto paradigmático para os Estados sul-americanos, por conceder tanto preferências relacionadas com inovação, quanto com integração regional e acordos bilaterais.

No âmbito do Programa de Aceleração do Crescimento, o Brasil modificou, em 2007, sua Lei de Licitações (Lei $n^{\circ}$ 8666/93), a fim de criar margens de preferência para a inovação tecnológica, e também margens de preferência para bens ou serviços oriundos do MERCOSUL. Está previsto, inclusive, margem de preferência para bens ou serviços oriundos de parceiros comerciais com os quais o Brasil celebre acordos internacionais.

A Lei de Licitações dispõe o seguinte: ${ }^{373}$

- Margem de preferência - preferência para produtos manufaturados e
serviços nacionais, limitada a até $25 \%$ acima do preço dos manufaturados e
serviços estrangeiros.
- Margem de preferência adicional para a inovação - respeitado o limite
estabelecido na lei, poderá ser estabelecida margem de preferência
adicional para os produtos manufaturados e para os serviços nacionais
resultantes de desenvolvimento e inovação tecnológica realizados no País.
- Extensão da margem de preferência para MERCOSUL - a margem de
preferência será estendida aos bens e serviços originários do MERCOSUL,
após a ratificação do Protocolo de Contratações Públicas celebrado em 20
de julho de 2006 .

${ }^{373}$ Disponível em http://www.jusbrasil.com.br/legislacao/103866/lei-de-licitacoes-lei-8666-93 
- Extensão para demais países - A preferência poderá ser estendida, total ou parcialmente, aos bens e serviços originários de outros países, com os quais o Brasil venha assinar acordos sobre compras governamentais.

\section{b) A infraestrutura como novo vetor da integração sul-americana}

A infraestrutura enquanto pauta recente da agenda de integração sulamericana, leva à análise das principais iniciativas de coordenação e fomento da integração em infraestrutura, o IIRSA e o FOCEM, bem como dos projetos que estão atualmente financiando.

\section{i. A Iniciativa para Integração da Infraestrutura Regional da América do Sul}

A Iniciativa para Integração da Infraestrutura Regional da América do Sul (IIRSA) foi criada em 2000. Tal iniciativa foi idealizada para servir de fórum de discussão para as autoridades responsáveis por transporte, energia e telecomunicações dos 12 países sul-americanos. Estrategicamente, a IIRSA visa criar novas referências geoeconômicas para o planejamento territorial sulamericano.

A IIRSA é fruto da articulação das organizações financeiras multilaterais da região, o Banco Interamericano de Desenvolvimento (BID), a Cooperação Andina de Fomento (CAF) e o Fundo Financeiro para o Desenvolvimento da Bacia do Prata (FONPLATA).

Como mencionado anteriormente, a criação da UNASUL, a IIRSA foi encampada pela nova organização em razão da criação do Conselho Sul-americano de Infraestrutura e Planejamento (COSIPLAN), em 2009, que se tornou o órgão gestor dos projetos sob a égide da IIRSA. 
Quando da sua criação, foi estabelecido um Plano de Ação 2000-2010, que esteve fundado em Eixos de Integração e Desenvolvimento. Os 10 Eixos geográficos do IIRSA são os seguintes:

- Eixo Andino

- Eixo Andino do Sul

- Eixo do Capricórnio

- Eixo da Hidrovia Paraguai-Paraná

- Eixo do Amazonas

- Eixo do Escudo Guianês

- Eixo do Sul

- Eixo Interoceânico Central

- Eixo MERCOSUL-Chile

- Eixo Peru-Bolívia

Em relação aos setores temáticos abrangidos pelo IIRSA, esta abrange sete áreas consideradas estratégicas para o desenvolvimento da infraestrutura regional:

- Instrumentos de Financiamento

- Energia

- Fronteiras

- Tecnologias de informação e comunicação

- Transporte aéreo

- Transporte marítimo

- Transporte multimodal

Com base nos dados de 2011, 531 projetos já haviam sido encampados pela IIRSA. Estes se centravam nos setores de infraestrutura de transporte, energia e comunicações. Este conjunto de projetos representa um investimento estimado de US\$ 116 bilhões. Destes, 11,9\% já se encontravam concluídos, 29,9\% estavam em execução e 29,6\% estavam em pré-execução.

ii. O Fundo de Convergência Estrutural do MERCOSUL

O tema de infraestrutura não consta nos tratados constitutivos do MERCOSUL. Isto revela o período neoliberal em que a organização internacional foi constituída, época na qual a integração era sinônima apenas de liberalização 
comercial. Mesmo assim, as necessidades de melhoria de infraestrutura sempre existiram.

O Fundo de Convergência Estrutural do MERCOSUL (FOCEM) foi criado em 2004, e está ativo desde 2006. Objetiva combater assimetrias regionais e fortalecimento estrutural e institucional.

O FOCEM teve os seus primeiros projetos aprovados em 2007. Existem projetos em três níveis: a) institucionais, para financiar o reforço da estrutura institucional da organização internacional; b) nacionais, para fomentar projetos exclusivamente nacionais; e c) plurinacionais, que atingem dois ou mais Membros do MERCOSUL.

O FOCEM se subdivide em quatro programas específicos:

- Programa de Convergência Estrutural;

- Programa de Desenvolvimento da Competitividade;

- Programa de Coesão Social;

- Programa de Fortalecimento da Estrutura Institucional e do Processo de Integração.

Este fundo foi idealizado com base na noção de Tratamento Especial e Diferenciado aos países menos desenvolvidos da região, razão pela qual há uma relação inversamente proporcional no que se refere a financiamento versus destinação dos recursos.

Com base nos dados de 2012, o financiamento do fundo está distribuído da seguinte forma: $60 \%$ - Brasil, 35\% - Argentina, 3\% - Uruguai, 2\% - Paraguai. Já em relação à destinação dos recursos, a proporção é oposta: 43\% - Paraguai, 42\% Uruguai, 7\% - Argentina, 5\% - Brasil.

O orçamento de 2012 do FOCEM atinge a cifra de US\$ 788 milhões, dos quais mais de US\$ 400 milhões são decorrentes do aporte brasileiro.

A partir de uma análise geral dos projetos atualmente financiados pelo fundo, percebe-se que o tema da integração energética é a prioridade do MERCOSUL. Para o projeto de renovação das linhas de transmissão elétrica de 
Itaipu, são destinados cerca de US\$ 370 milhões. Já para a conexão elétrica BrasilUruguai, são destinados outros US\$ 65 milhões. Isto equivale a quase metade do orçamento anual do FOCEM.

Como contraponto, deve-se destacar que o FOCEM destina parcela proporcionalmente irrisória, se comparada ao montante destinado à infraestrutura energética, para os projetos voltados à educação e à inovação tecnológica. Neste tema, o projeto com maior orçamento é destinado a estruturação da Universidade Federal da Integração Latino-Americana (UNILA), com US\$17 milhões. Os demais projetos na área de inovação tecnológica financiados são voltados à pesquisa e educação para biotecnologia em saúde (US\$1,5 milhões), fortalecimento de pequenas e médias empresas exportadoras de bens de capital (US\$500 mil), e incentivo a novos setores de software, biotecnologia e eletrônica (US\$ 15 mil).

iii. Projetos de financiamento conjunto IIRSA-FOCEM

A título ilustrativo, cabe destacar três projetos estruturais que são atualmente financiados, de maneira conjunta, pela IIRSA e pelo FOCEM.

O primeiro diz respeito à integração energética sul-americana. Em 2008, a UNASUL criou o Conselho Energético Sul-Americano. Tal conselho visa atuar sobre os seguintes temas:

- Aspectos legais e regulatórios de natureza energética,

- Desenvolvimento de biocombustíveis.

- Avaliação e estudos do mercado energético regional.

- Desenvolvimento e complementaridade de estrutura energética

- Aspectos ambientais e energias alternativas.

- Acesso universal e não discriminatório à energia.

No âmbito deste conselho, foi elaborado, em 2010, um projeto de tratado internacional intitulado Tratado de Integração Energética. O projeto do Tratado Energético pretende realizar estudos comparados sobre legislações internacionais similares, a fim de levar em conta os projetos de integração energética em marcha e 
em estudo por parte dos países da UNASUL e projetos análogos de legislação em outras regiões do mundo.

Muito embora nem o Conselho nem o Tratado estejam operacionalmente em vigor, a análise dos orçamentos e projetos apontam que a temática da integração energética como sendo a prioridade dos fundos da IIRSA e do FOCEM. Na IIRSA, o pilar principal do seu Plano de Ação é a Estratégia para a Integração Energética Regional aprovada no escopo da UNASUL. Já no FOCEM, como foi apresentado, praticamente metade do orçamento do fundo estrutural do MERCOSUL é destinado à integração energética.

Com a entrada em vigor do Tratado Energético, bem como a operacionalização do Conselho Energético da UNASUL, haverá um reforço substancial na institucionalização do tema de integração energética na América do Sul. Isso fomentará ainda maior cooperação com os fundos sub-regionais do MERCOSUL e da CAN.

O segundo projeto que possui financiamento tanto regional quanto subregional é o chamado Anel óptico. Segundo dados da CEPAL, a porcentagem média de acesso à internet por banda larga na América Latina é de 4,1\% (cifras de 2011). Venezuela (com 12,2\%) e Chile (com 9,8\%) são os países com maior acesso. Em relação a custos, outro estudo revela que a América Latina, seguida do Oriente Médio e da África, é a região com o acesso à internet mais cara do mundo. Atualmente a metade do tráfego de dados sul-americano passa pelos EUA. ${ }^{374}$

Para reduzir este gap tecnológico, a UNASUL criou, em 2011, um projeto de unificação e modernização das redes de telecomunicações dos países da América do Sul, através da criação de infraestrutura para as tecnologias da informação e das telecomunicações. Tal projeto está sendo idealizado no âmbito do COSIPLAN.

374 
Em janeiro de 2012, foi realizada a primeira reunião do Grupo de Trabalho sobre Comunicações do COSIPLAN. O projeto ainda se encontra em estágio de definição dos aspectos financeiros, logísticos e operacionais para viabilizar esta interconexão.

Um dos grandes incentivadores deste Anel Óptico é do Ministério das Comunicações do Brasil, juntamente com a Telebrás. Em razão disso, o MERCOSUL está garantindo financiamento complementar do IIRSA, por meio do FOCEM, para as questões de telecomunicações.

O terceiro projeto é talvez o mais impactante, em termos estruturais, para a América do Sul. São os chamados corredores bioceânicos da América do Sul. Esta iniciativa está sendo financiada por diversas instituições multilaterais e regionais (BIRD, BID, IIRSA, FOCEM, BNDES, UE) e se propõe a criar infraestrutura em matéria de transportes para ambas as ligações oceânicas.

Há questões geoestratégicas em torno dos corredores bioceânicos: criar para os países da América do Sul independência em relação ao Canal do Panamá; permitir ao Brasil acesso mais favorável aos mercados asiáticos a partir do Oceano Pacífico; da mesma forma, permitir aos demais países da América do Sul acesso mais favorável aos mercados ocidentais por meio do Oceano Atlântico.

Os corredores bioceânicos estão sendo concebidos de maneira multimodal, a fim de abranger transporte rodoviário, ferroviário e marítimo, razão pela qual estão canalizando investimentos em estradas, renovando as ferrovias, e modernizando os portos sul-americanos.

Atualmente, estão sendo projetados três corredores bioceânicos: o Corredor Ferroviário, que abrange Brasil, Paraguai, Argentina e Chile; o Corredor Rodoviário, que cruza Brasil, Bolívia e Chile; e as Rodovias interoceânicas, que interligam Brasil e Peru.

iv. Conclusões sobre os projetos de integração estrutural da América do Sul 
As questões de infraestrutura e planejamento foram preocupações dos países sul-americanos durante o período desenvolvimentista da região, entre os anos 50 e 80. A perspectiva histórico-estruturalista da CEPAL apontou, desde a falta de infraestrutura como condicionante do subdesenvolvimento.

No entanto, há uma ausência histórica de políticas para a infraestrutura regional na América do Sul. Apenas a Comunidade Andina implantou políticas sub-regionais de infraestrutura e planejamento industrial. As demais iniciativas ocorreram exclusivamente no plano nacional dos Estados.

Com o advento do neoliberalismo, as iniciativas de infraestrutura não constavam no Consenso de Washington, razão pela qual foram abandonadas pelos Estados. A integração regional da América do Sul esteve centrada fundamentalmente na lógica da liberalização comercial.

A emergência do novo regionalismo sul-americano do início do século XXI elevou o tema da integração física à prioridade estratégica dos governos da região. A UNASUL pode representar um espaço de cooperação e diálogo para coordenar as iniciativas e superar os entraves da integração em infraestrutura.

A natureza dos projetos que estão atualmente sendo idealizados e implantados na América do Sul colocarão, de maneira irreversível, o tema dos investimentos em infraestrutura na agenda da integração sul-americana.

Um breve balanço dos fundos de investimento regional permite concluir que, tanto IIRSA quanto FOCEM apresentam uma amplitude orçamentária e temática significativa para projetos nacionais e regionais de infraestrutura. Ao mesmo tempo, sofrem de falta de foco e com entraves burocráticos para financiamentos.

Dentre tais entraves, a harmonização legislativa é um tema fundamental para integração em infraestrutura. Os desafios regulatórios para a integração em infraestrutura abrangem a questão dos investimentos estrangeiros, as compras 
governamentais e a prestação de serviços (trabalhadores e empresas) estrangeiros, dentre outras.

\section{c) A emergência da inovação enquanto tema da integração sul-americana}

\section{i. Ciência, Tecnologia e Inovação no MERCOSUL}

Os temas da ciência, tecnologia e inovação são presentes na estrutura institucional do MERCOSUL desde a sua constituição. Já em 1992, o Conselho Mercado Comum, criou a Reunião Especializada em Ciência e Tecnologia (RECyT) com o objetivo de harmonizar as tarefas e posições no campo científico e tecnológico. ${ }^{375}$

A RECYT tem como objetivo central a promoção do desenvolvimento científico e tecnológico dos países-Membros do MERCOSUL assim como de modernizar suas economias para ampliar a oferta e a qualidade dos bens e serviços disponíveis, a fim de melhorar as condições de vida de seus habitantes. Suas ações estão estruturadas no sentido de aumentar a produtividade das economias do MERCOSUL e aumentar a competitividade dos segmentos produtivos do MERCOSUL em terceiros mercados.

A RECyT foi constituída para atuar tanto no campo internacional quanto regional. A atuação da RECyT no campo internacional se propõe a participar em negociações em diversos foros, multilaterais, regionais ou bilaterais, sobre temas relativos à ciência e tecnologia. No plano regional, um dos principais campos de atuação da RECyT é servir à promoção e ao incentivo da pesquisa em todos os níveis, apontando a busca de soluções de problemas comuns aos países da região e buscando contribuir assim para o processo de integração regional.

A RECyT promove também a difusão de informação sobre as realizações e os avanços no campo científico e tecnológico para todos os países Membros e a

\footnotetext{
${ }^{375}$ Página oficial disponível em http://www.mercosur.int/recyt/.
} 
definição de campos de conhecimento (áreas temáticas) e setores prioritários com vistas a identificar e solucionar problemas de um determinado setor ou região e organizar plataformas (foros onde as partes interessadas da sociedade se reúnem para identificar os gargalos ligados a um determinado setor ou região para definir ações prioritárias com o fim de eliminá-los).

Apenas em 2006 foi realizada a $1^{\text {a }}$ Reunião de Ministros e Altas Autoridades de Ciência e Tecnologia do MERCOSUL e países associados. Como resultado da mesma, se aprovou um Plano de Ação como o objetivo de elaborar um Programa Quadro de Ciência e Tecnologia do MERCOSUL e Países Associados.

Nesse sentido, em agosto de 2008, foi aprovada a Decisão CMC n ${ }^{\circ} 03 / 08,{ }^{376}$ que aprovou o Programa Quadro de Ciência e Tecnologia do MERCOSUL e Países Associados, para o período 2008-2012.

Em linhas gerais, o Programa Quadro é um plano de desenvolvimento que abarca o Período 2008-2012 e pretende reorientar a agenda em ciência e tecnologia para agregar valor à produção regional, contribuindo assim para superar as assimetrias existentes entre os Estados Partes.

O Programa Quadro tem como fundamento geral:

promover a integração regional, dar visibilidade a projetos estratégicos de transformação regional e estabelecer uma posição harmonizadora e de conjunto. Para isso, são necessários projetos sustentáveis e de alto impacto que privilegiem o desenvolvimento social e produtivo com base na ciência, a tecnologia e a inovação como garantias do desenvolvimento sustentável. ${ }^{377}$

Foram definidos sete temas prioritários para tal período: biotecnologia, energia, nanotecnologia, recursos hídricos, sociedade da informação, popularização da ciência e da tecnologia, desenvolvimento tecnológico e inovação.

Muito embora o Programa tenha previsto que o seu financiamento estaria previsto pelo FOCEM, como foi visto anteriormente, o volume total de investimentos em projetos ligados a educação, ciência, tecnologia e inovação, não

\footnotetext{
${ }^{376}$ MERCOSUL/CMC/DEC. $\mathrm{N}^{\circ}$ 03/08.

377 Programa-Quadro disponível em http://www.recyt.mincyt.gov.ar/files/ProgramaMarco/programa quadro portugues.pdf.
} 
corresponderam a 3\% (US\$ 19 milhões) do total do orçamento de 2012 do fundo do MERCOSUL.

ii. Ciência, Tecnologia e Inovação na CAN

O tema da inovação é presente na integração andina desde a formação do Pacto Andino. Em 1974, foi aprovada a Decisão n ${ }^{\circ}$ 84/74, que estabeleceu as Bases para una Politica Tecnológica Subregional. Tal decisão contemplava as premissas para o estabelecimento de uma política subregional de desenvolvimento tecnológico. Abrangendo desde temas de importação e assimilação de tecnologias ao processo de geração e proteção de tecnologias.

Em seguida, em 1980, por meio da Decisão $\mathrm{n}^{\circ}$ 154/80, foi instituído o Sistema Andino de Informação Tecnológica. Tal sistema visava criar uma estrutura institucional, com órgãos, competências, procedimentos e orçamento para levar adiante a política tecnológica andina. Tal estrutura foi complementada em 1983, pela Decisão $n^{0}$ 179/83, com a criação do Conselho Andino de Ciência e Tecnologia (CACYT), órgão responsável pelos temas ligados à inovação até o presente momento na CAN.

No entanto, ao longo dos anos 80 e 90, os temas da ciência, tecnologia e inovação ficaram à margem do processo de integração da CAN. Isto se deve, em grande medida, à adequação pela qual passou para adaptar-se aos novos parâmetros do neoliberalismo que vigia na América do Sul naquele período.

Apenas em 2010, a CAN decidiu reativar o CACYT e definir uma nova agenda de trabalho que pudesse permitir à CAN converter a ciência e a tecnologia em um dos elementos centrais das políticas comunitárias da sub-região andina. ${ }^{378}$

Atualmente, está em marcha o processo de negociação da nova Agenda Temática Andina de Ciência e Tecnologia. ${ }^{379}$

\footnotetext{
${ }^{378}$ Disponível em http://www.comunidadandina.org/prensa/notas/np2-7-10a.htm.
} 


\subsection{OS DESAFIOS PARA A CONSOLIDAÇÃO DO NOVO REGIONALISMO DESENVOLVIMENTISTA DA AMÉRICA DO SUL}

\section{a) UNASUL: a operacionalização de uma organização sul-americana OMC-Extra}

Do ponto de vista da engenharia jurídica e institucional, o surgimento da UNASUL leva a algumas considerações, tanto em relação à estrutura da UNASUL em si, quanto da sua capacidade de articular das demais organizações regionais da América do Sul.

Do ponto de vista da estrutura institucional da UNASUL, a incipiência da atuação dos diversos órgãos e projetos constituídos dificulta uma apreciação a respeito da real capacidade de transformação que os mesmos estão exercendo na América do Sul.

No entanto, o fato da UNASUL ser, em tese, uma organização de natureza não-comercial, não a sujeita às regras da OMC. Por isso, pode se afirmar que a UNASUL se configura como uma organização OMC-Extra. No escopo de atuação da UNASUL, os países sul-americanos encontram policy space praticamente ilimitado. Portanto, se os objetivos expressos no tratado constitutivo da UNASUL, bem como dos estatutos dos diversos conselhos, forem, efetivamente levados adiante ao longo dos próximos anos, a América do Sul poderá implantar políticas sólidas de desenvolvimento sem maiores preocupações com questionamentos advindos dos Estados-Membros da OMC e do seu OSC.

Já do ponto de vista da relação entre a UNASUL e as demais organizações de integração regional, os desafios são igualmente crescentes. As organizações de integração herdadas do século XX - ALADI, MERCOSUL e CAN - agora

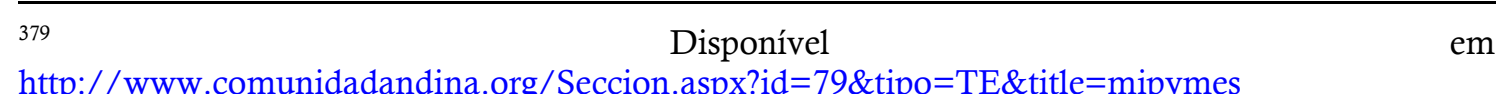

http://www.comunidadandina.org/Seccion.aspx?id=79\&tipo=TE\&title=mipymes 
coexistem com uma nova organização internacional com natureza diferenciada, voltada para temas não-comerciais.

A UNASUL está constituída de forma a integrar as três organizações regionais, por meio de temas transversais ao continente: estabilidade política, defesa, energia, infraestrutura, saúde, entre outros, razão pela qual não há, em princípio, incompatibilidades jurídicas entre a UNASUL e as demais.

No entanto, diferenças começam a aparecer entre o MERCOSUL, a partir da adesão da Venezuela, e a CAN, aliada ao Chile no novo viés bilateralista. Enquanto os países andinos estão reorientando as suas políticas externas para fortalecer os laços com os países desenvolvidos, o MERCOSUL vem priorizando a sua inserção internacional por meio de relações Sul-Sul.

Uma saída para este desalinhamento na integração regional sul-americana poderia ser reforçar o pragmatismo dos processos de integração, especialmente no que se refere ao tratamento das assimetrias intra-regionais.

A crescente cisão entre as duas organizações sub-regionais leva a uma análise dos desafios apresentados a ALADI, enquanto organização internacional responsável pela condução do MERCOSUL e da CAN.

\section{b) ALADI: entre a convergência regional e a abertura global}

A ALADI se depara atualmente com um desafio vital, enquanto organização de integração regional com o mínimo de credibilidade na América do Sul. Este desafio emerge de um duplo movimento, antagônico, que está ocorrendo em seu seio. De um lado, a tentativa de estimular a convergência entre os seus Membros, para consolidar o processo de integração regional em nível continental; do outro, o aumento do número de acordos bilaterais celebrados por seus Membros com parceiros extra-regionais ameaça desestruturar a arquitetura jurídica da América do Sul decorrente da ALADI. 
Quando as negociações para a criação da UNASUL já se encontravam em estágio avançado, na época em que a Comunidade Sul-Americana de Nações já havia sido instituída, um grande conjunto de relatórios temáticos foi aprovado em 2006, intitulado Convergência Comercial dos Países da América do Sul rumo a Comunidade Sul-americana de Nações. ${ }^{380}$

O fato de MERCOSUL e CAN terem formalizado o desejo de estabelecer uma zona de livre comércio entre ambas as regiões, por meio do ACE $\mathrm{n}^{\circ} 59$, foi o estopim para que a ALADI finalmente consolidasse o princípio previsto no artigo $3^{\circ}$, alínea c, do TM-80, o princípio da convergência.

Estes relatórios tiveram duplo objetivo: primeiro, analisar o atual estágio da integração nos três níveis (ALADI, MERCOSUL e CAN) e segundo, propor iniciativas necessárias para aumentar o nível de convergência intraregional. Todos os projetos fazem análises comparativas do status quo das normas vigentes nas três organizações internacionais, em todos os setores atualmente regulados na integração sul-americana.

\section{Tabela 24. Projetos de convergência ALADI-MERCOSUL-CAN}

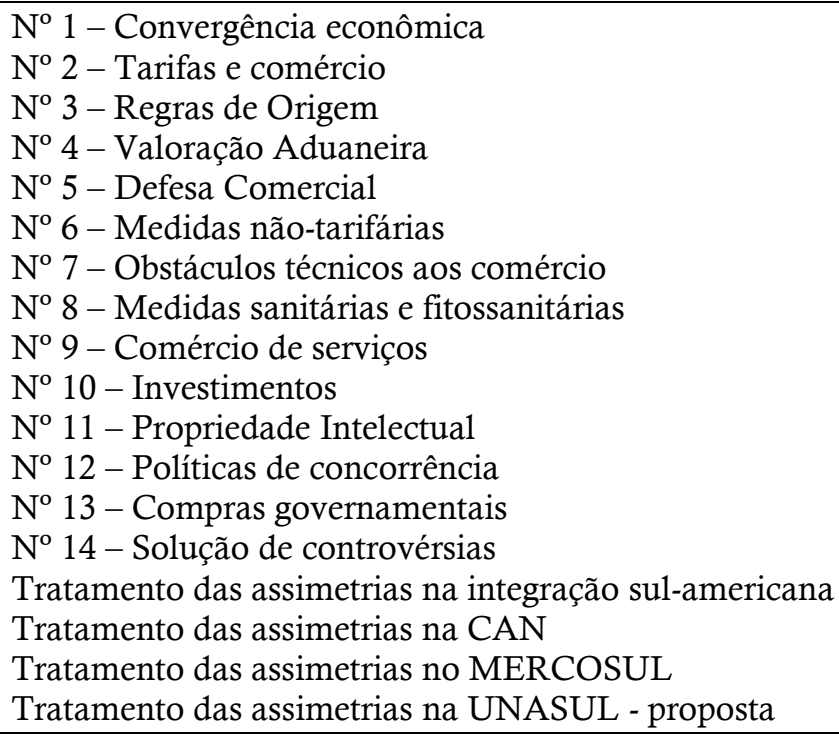

A falta de consenso político dentro da CAN levou a tensões críticas a partir de 2005. Em 2006, diferentes visões políticas sobre o direcionamento que a CAN

\footnotetext{
${ }^{380}$ Disponíveis em http://www.comunidadandina.org/unasur/estudios.htm
} 
deveria tomar, bem como a heterogeneidade dos interesses comerciais, culminaram nas negociações bilaterais de Colômbia e Peru com os EUA. Como protesto, a Venezuela decidiu desvincular-se da CAN, denunciando o Acordo de Cartagena, para tornar-se Membro do MERCOSUL.

A saída da Venezuela e a implantação dos acordos bilaterais que os seus Membros começaram a firmar a partir de então se transformaram em grandes desafios para a CAN, tanto no sentido de avançar em seu processo de integração, mas especialmente no desafio de manter a unidade da CAN enquanto União Aduaneira, tendo em vista a erosão da Tarifa Externa Comum em razão dos acordos bilaterais.

Paralelamente aos acordos bilaterais da CAN, o MERCOSUL igualmente lançou-se na iniciativa de celebrar acordos bilaterais, porém com uma clara orientação Sul-Sul.

$\mathrm{O}$ atual conjunto de acordos bilaterais em vigor, celebrados pelos Estados Membros de MERCOSUL e CAN, é o seguinte: ${ }^{381}$

Tabela 25. Acordos extra-regionais do MERCOSUL em vigor

- Índia (2004)

- Marrocos (2010)

- SACU (2004)

- Israel (2007)

- CAN (2004)

Tabela 26. Acordos extra-regionais dos países andinos em vigor

- Peru - China (2010)

- Peru - Associação Européia de Livre Comércio (2011)

- Peru - Japão (2012)

- Peru - Singapura (2009)

- Peru - Coréia do Sul (2011)

- Peru - Tailândia (2011)

- Peru - Estados Unidos (2009)

- Peru - Canadá (2009)

- Bolívia - México (2010)

- Colômbia - Canadá (2011)

- Colômbia - Associação Européia de Livre Comércio (2011)

${ }^{381}$ Disponível em http://www.sice.oas.org/. 
Esta atual proliferação de acordos comerciais dos Membros da ALADI com parceiros extra-regionais é o desafio mais importante, do ponto de vista da unidade jurídica da integração sul-americana.

A diversidade de compromissos e preferências que estão sendo celebrados em matéria de bens, serviços, propriedade intelectual e investimentos, está paulatinamente erodindo os esquemas de preferências intra-regionais, em favor de preferência extra-regionais. Além disso, a possibilidade do surgimento de temas ainda não regulados na integração sul-americana, tais como a cláusula ambiental e a cláusula social, podem inserir na agenda da integração sul-americana os chamados temas OMC-Plus.

Estes dois caminhos, absolutamente antagônicos entre si - de um lado a convergência intra-regional, do outro, a abertura internacional - não podem coexistir. A atual arquitetura jurídica e institucional da América do Sul não está preparada para este duplo fenômeno. A ALADI é uma organização dos anos 80 , que reflete um período largamente ultrapassado das relações econômicas internacionais.

Por isso, duas alternativas se apresentam à América do Sul. A primeira opção é a reconstrução jurídica e institucional da ALADI para que esta possa ser uma organização internacional condizente com os novos tempos, e assim tornar ambas as tendências - convergência intra-regional e abertura extra-regional compatíveis. A outra opção seria a do abandono em definitivo do princípio da convergência, e a consequente falência da ALADI.

\section{c) A consolidação institucional de MERCOSUL e da CAN}

A saída da Venezuela da CAN e a sua adesão do MERCOSUL, em 2005, está levando ambas as organizações de integração regional a uma crise institucional que pode colocar em xeque as iniciativas mais bem consolidadas da América do Sul. O principal motivo que levou a Venezuela a sair da CAN foi a prevalência dos interesses dos demais países andinos em negociar acordos bilaterais extra-regionais, especialmente com os EUA. Desde então, os Estados Membros da CAN já firmaram mais de uma dezena de acordos bilaterais. 
Ora, isto acaba por completo com a unidade andina por tornar a Tarifa Externa Comum, instrumento fundamental da União Aduaneira, absolutamente secundária e irrelevante. Isto pode, caso se perpetue e acentue a tendência dos países andinos em celebrar acordos bilaterais, faz com que a CAN abandone um dos seus pilares de integração, a União Aduaneira, e consolide-se apenas como uma zona de livre comércio.

$\mathrm{Na}$ CAN, cada Estado é livre para celebrar acordos internacionais de maneira individual. A CAN carece de uma regra, tal qual existe no MERCOSUL,

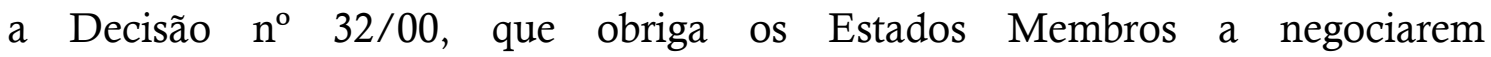
internacionalmente em conjunto. Tal regra poderia ser um reforço institucional fundamental para manter a já desintegrada unidade andina.

O MERCOSUL também passa por uma grave crise interna, que está transformando radicalmente a estrutura institucional da organização internacional, em razão do processo de adesão da Venezuela ao MERCOSUL.

Desde que postulou o ingresso, a Venezuela enfrentou resistências, especialmente pelo Paraguai. Os demais Membros já ratificaram o Tratado de Adesão da Venezuela. O congresso paraguaio tardou mais de cinco anos para internalizar tal tratado.

Ocorre que, recentemente, em junho de 2012, o presidente do Paraguai Fernando Lugo sofreu um impeachment sumário, que foi considerado pelos demais Membros do MERCOSUL como um atentado à estabilidade democrática do país. Por isso, em observância aos Protocolos de Ushuaia I e II, os Membros do MERCOSUL decidiram suspender temporariamente o Paraguai da organização internacional.

Sem adentrar no mérito da constitucionalidade do impeachment, considerado por alguns um golpe de Estado, tal suspensão permitiu aos demais Membros finalmente incorporar a Venezuela ao MERCOSUL.

O Paraguai, Membro fundador do MERCOSUL, está temporariamente suspenso até maio de 2013. Essa situação põe em risco a unidade da organização 
internacional, tendo em vista que, durante este período de suspensão, o Paraguai pode alegar que não está obrigado pelas regras do MERCOSUL. Tal cenário permite, em tese, que o Paraguai realize acordos comerciais bilaterais em contrariedade à Decisão $n^{\circ} 32 / 00$. O próprio Paraguai já sinalizou a intenção de negociar um acordo bilateral com os EUA. ${ }^{382}$

Um balanço deste cenário presente em ambas as organizações de integração sub-regionais da América do Sul leva a algumas considerações. A abertura internacional tanto da CAN quanto do MERCOSUL, cada qual por seus motivos, pode levar as duas iniciativas mais bem consolidadas da América do Sul a crises em suas estruturas institucionais. $\mathrm{O}$ aumento das desconfianças regionais poderá minar a unidade política, jurídica e ideológica na América do Sul. Caso os Membros do MERCOSUL e CAN prossigam em acordos bilaterais com países desenvolvidos, como os EUA, poderá ser o início do fim do novo regionalismo desenvolvimentista sul-americano.

\footnotetext{
382 Ver entrevista do Embaixador paraguaio $\quad \mathrm{em}$ http://diplomatizzando.blogspot.com.br/2012/08/paraguay-en-el-mercosur-entrevista-al.html.
} 


\section{CONCLUSÕES DO CAPÍTULO 8}

O capítulo 8 trata das retomada do desenvolvimentismo no âmbito das iniciativas de integração regional da América do Sul.

Se, por um lado, a década de 1990 viu a ascensão e o declínio do neoliberalismo enquanto fundamento das políticas de integração e desenvolvimento da América do Sul, por outro, a virada do século viu a emergência do regionalismo pós-liberal e o novo desenvolvimentismo na América do Sul.

Esta transformação foi acompanhada igualmente de outra mudança de paradigma: a América do Sul passou a alinhar-se de maneira mais efetiva no eixo Sul-Sul, em substituição o eixo norte-sul da década de 90 . Tanto é que as negociações bilaterais com Estados Unidos e com a União Europeia foram abandonadas. Ambas as iniciativas teriam afastado ainda mais a América do Sul dos fundamentos jurídicos do desenvolvimento, em razão da quantidade de compromissos de liberalização que teriam sido firmados. O policy space seria ainda mais reduzido.

A primeira década do século XXI foi um período no qual se sucedeu uma renovação dos propósitos e práticas dos processos de integração regional e subregional da América do Sul.

As organizações sul-americanas de integração regional (ALADI, CAN, MERCOSUL e UNASUL) vivem um momento peculiar, seja comparado ao período do desenvolvimento e do regionalismo endógeno, seja comparado ao período do neoliberalismo e do regionalismo aberto.

Ao longo da primeira década do século XXI, estas organizações se revestiram de elementos novos, que indicam novas orientações conceituais e políticas, caracterizadas pelo novo desenvolvimentismo e pelo regionalismo pós-liberal.

A emergência do regionalismo pós-liberal e do novo desenvolvimentismo na América do Sul se fez sentir em três níveis da integração: em um nível mais amplo, a integração regional sul-americana presenciou o surgimento da União Sul- 
Americana de Nações (UNASUL). No âmbito da integração econômica e comercial, houve uma renovação da importância estratégica da ALADI nesta primeira década do século XXI. No âmbito das iniciativas sub-regionais, o MERCOSUL e a Comunidade Andina estão vivenciando uma mudança de propósitos que está gerando novos modelos de integração, fundado em parâmetros inéditos para ambas as iniciativas.

A UNASUL surge em um contexto de alinhamento político e ideológico na América do Sul, no qual há o abandono do projeto ALCA e o estabelecimento da prioridade do fortalecimento da integração da América do Sul. Originariamente constituída como Comunidade Sul-Americana de Nações, a UNASUL, apresenta um grande conjunto de objetivos, muitos dos quais revestem natureza nãocomerciais, chamados de extra-OMC.

O contraste entre a amplitude de objetivos e as limitações em termos de estrutura institucional da UNASUL enquanto organização internacional é um grande desafio para a consecução dos seus objetivos. Mesmo assim, em seu âmbito está abarcada uma série de iniciativas inéditas: o IIRSA, a RICG, e o PROSUR são alguns exemplos.

Já a ALADI, embora seja a organização internacional mais antiga da América do Sul, está passando atualmente por uma renovação da sua relevância estratégica para região. Isto por que o regionalismo aberto dos anos 90, que apregoava a abertura comercial de região, levou à celebração do Protocolo de Cartagena, que permitia a celebração de acordos comerciais com países nãoMembros da ALADI. Foi o Protocolo de Cartagena que viabilizou a adesão do México ao NAFTA e que atualmente está proporcionando a celebração de uma vasta gama de acordos comerciais entre os Membros da ALADI e países de fora da organização internacional.

Essa proliferação é atualmente o maior desafio para a manutenção da ALADI. Ainda, há fato de que MERCOSUL e CAN possuem diretrizes distintas em relação a acordos extra-regionais: o MERCOSUL desde 2000 obriga os Membros a celebrarem em conjunto tais acordos, enquanto na CAN os Membros têm autonomia para celebrar tais acordos. Caso a América do Sul deseje manter o 
mínimo de unidade jurídica em matéria de integração econômica e comercial, tem a necessidade de passar por uma ampliação temática da regulação com viés pródesenvolvimentista no âmbito da ALADI, a fim de constituir um marco regulatório comum da ALADI nos temas não-tarifários, tais como serviços, propriedade intelectual, investimentos, compras governamentais, etc.

Por fim, é no âmbito sub-regional que se encontram os desafios mais marcantes da América do Sul. Tanto o MERCOSUL quanto a CAN passaram por transformações e evoluções ao longo da década de 90, a fim de acompanhar as tendências globais de incorporação dos fundamentos jurídicos neoliberais em detrimento dos fundamentos desenvolvimentistas.

Atualmente, percebe-se o retorno do desenvolvimentismo como fundamento de ambas as iniciativas, em uma série de temas antes negligenciados nos planos sub-regionais. Neste aspecto, destaca-se o tratamento da inovação e da sustentabilidade que, embora ainda em estágio embrionário, revela que ambas as iniciativas começam a incorporar as premissas do novo desenvolvimentismo em suas respectivas ordens jurídicas. No entanto, o maior desafio apresentado a ambas as iniciativas é aquela iniciada em 2004, que objetiva a convergência MERCOSULCAN no marco da ALADI.

O surgimento e a consolidação deste novo regionalismo desenvolvimentista na América do Sul apresenta ao mesmo tempo uma série de novidades e desafios.

Entre as novidades, há que se destacar a natureza dos projetos de redução de assimetrias que estão sendo levados adiante desde a constituição da IIRSA e do FOCEM, sobretudo se comparado à ausência de projetos desta natureza no século passado. Os investimentos em energia, transporte, telecomunicações e planejamento industrial atuam diretamente sobre as raízes do subdesenvolvimento, abandonando o esquema antigamente vigente, de tratar assimetrias apenas por meio de tratamento especial aos países menos desenvolvidos.

No entanto, os desafios continuam sendo grandes, tendo-se em vista que os níveis de desenvolvimento humano e social da região continuam entre os mais 
baixos do mundo. Este deve ser o foco de toda e qualquer política voltada à redução de assimetrias regionais.

Ocorre que, quando se analisa o volume de investimentos da IIRSA e do FOCEM para projetos em educação e inovação tecnológica, o total não corresponde a 5\% do total investido em 2012. Este enfoque na educação e na inovação tecnológica é um dos vetores fundamentais para corrigir as assimetrias e as desigualdades nos níveis de desenvolvimento.

As organizações sul-americanas de integração regional devem, com urgência, ampliar as suas prioridades, no que se refere aos investimentos estruturais, e conceber que as políticas voltadas à educação, à ciência e a tecnologia, e à inovação, são tão estruturais quanto as políticas de renovação das malhas viárias e energéticas do continente. Caso contrário, a América do Sul corre o risco de perpetuar os traços mais candentes da desigualdade, tanto em termos intra-regionais, quanto em termos das assimetrias que separam a região do resto do mundo.

Além disso, a América do Sul não pode continuar relegando a liberalização comercial para segundo plano, tal qual está fazendo hoje. A integração estrutural deve ser uma prioridade complementar à integração comercial. Caso tal prioridade não seja retomada, os países da região continuarão suscetíveis ao assédio para celebração de acordos bilaterais com parceiros extra-regionais.

A institucionalização de um modelo neodesenvolvimentista de regionalismo na América do Sul deve necessariamente passar pelos seguintes vetores: a) reduzir efetivamente as assimetrias entre os parceiros; b) garantir o equilíbrio entre coordenação macroeconômica e liberalização comercial; c) promover a integração muito além de liberalização de bens; d) utilizar todo policy space possível existente nas regras da OMC.

A crise global está criando oportunidades sem precedentes para o desenvolvimento dos países em desenvolvimento. Se a América do Sul não orientar o novo regionalismo desenvolvimentista para a inovação, aproveitando este momento para fortalecer sua produção industrial e aumentar a produção e 
fabricação de produtos de alto valor agregado, continuará sua tradição de provedor histórico de matérias-primas.

A posição atual do pêndulo que balança entre o liberalismo e o desenvolvimentismo deve ser bem aproveitada pelos países em desenvolvimento, em especial, os da América do Sul. Trata-se de um momento único para a América do Sul superar as raízes históricas do subdesenvolvimento. Para tanto, o enfoque deve necessariamente passar para a integração fundada na inovação.

O impasse na Rodada de Doha cria um cenário para a revisão das normas e critérios interpretativos da OMC, com o fim de obter maior permissibilidade para as políticas de desenvolvimento fundadas em inovação.

Enquanto isso, as organizações internacionais de integração regional perfazem as melhores plataformas para implantar tais políticas, tendo-se em vista que é no âmbito dos acordos de integração regional fundados na Cláusula de Habilitação que existe a maior margem de manobra, dentro do intrincado sistema de regras da OMC. 


\section{CONCLUSÕES}

A presente tese se propôs a responder, ao longo do texto, ao seguinte questionamento: É correto afirmar que o regionalismo desenvolvimentista sulamericano, implantado ao longo do século XX, e o novo regionalismo desenvolvimentista, implantado ao longo da primeira década do século XXI, são compatíveis com as regras do sistema multilateral de comércio? Em outras palavras, as organizações de integração regional da América do Sul têm balizado as suas políticas desenvolvimentistas no policy space decorrente das prerrogativas jurídicas para o desenvolvimento do sistema multilateral de comércio?

Como foi demonstrado ao longo da tese, a resposta é afirmativa. Para alcançar tal conclusão, a tese foi estruturada em três partes: a Parte I, referente ao período de vigência do GATT-47; a Parte II, que corresponde ao período de criação da OMC e da entrada em vigor dos novos acordos do sistema multilateral de comércio; e a Parte III, que atine ao período a partir do lançamento da Rodada Doha no âmbito da OMC até os dias atuais.

Ao final de cada capítulo da tese, foram apresentados as conclusões e resultados parciais. No entanto, para melhor sistematização, será apresentado a seguir um apanhado global das conclusões parciais e finais da tese.

\section{Parte I}

Com o processo de descolonização do pós-guerra, a comunidade internacional, passou por uma transformação radical, tanto do ponto de vista quantitativo, pelo aumento vertiginoso do número de novos Membros, quanto qualitativo, pelo surgimento de alianças diplomáticas das antigas colônias, novos Estados independentes.

Em razão do amplo processo de libertação e independência das antigas colônias e o consequente surgimento e articulação do Terceiro Mundo, a mera 
igualdade formal já não mais bastaria para a manutenção da ordem internacional. O Terceiro Mundo alegava que era necessário o reconhecimento jurídico da desigualdade econômica entre os Estados e, a partir daí, construir um novo sistema jurídico-político internacional, no âmbito das organizações internacionais, que pudesse ser condizente com a nova configuração mundial.

Esta transformação na geopolítica internacional levou à articulação do Terceiro Mundo e à institucionalização do Movimento dos Não-Alinhados e do Grupo dos 77. No âmbito de tais articulações é gerido o direito internacional do desenvolvimento, com um objetivo revolucionário: tentar transformar as premissas - jurídicas e políticas - vigentes para passar a consolidar a questão do desenvolvimento enquanto fundamento jurídico efetivo das relações internacionais.

No âmbito da ONU e de seus órgãos, a mudança na composição estrutural da comunidade internacional se fez sentir de maneira mais emblemática, permitindo que a ONU servisse de plataforma para alavancar reformas em outras organizações internacionais e tratados internacionais, especialmente o GATT. Nesse momento, tanto a CEPAL quanto a UNCTAD exerceram papel de destaque na formulação e na condução desse sistema internacional emergente.

$\mathrm{Na}$ medida em que o direito internacional do desenvolvimento foi paulatinamente sendo incorporado às regras do sistema multilateral de comércio ao longo do século XX, as organizações de integração regional da América do Sul foram se reformulando e renovando a fim de usufruir dos novos direitos e das novas flexibilidades nas obrigações que emergiam no âmbito do direito internacional do comércio.

O processo de incorporação do direito internacional do desenvolvimento no âmbito do sistema multilateral de comércio levou a um conjunto de prerrogativas jurídicas à disposição dos países em desenvolvimento vigentes no período GATT. Assim, o movimento terceiro-mundista logrou criar no âmbito do GATT as seguintes prerrogativas: i) o direito à industrialização, de 1955 (artigo XVIII, GATT); ii) o direito à não-reciprocidade, de 1964 (Parte IV, GATT) e; iii) o direito ao tratamento especial e diferenciado, de 1979 (Cláusula de Habilitação). 
Foi precisamente no âmbito da Cláusula de Habilitação que os países em desenvolvimento conquistaram o direito de estabelecer processos de integração regional com regras mais flexíveis, e assim, potencializar as políticas de desenvolvimento. A relativização dos prazos para a integração econômica; a possibilidade de conceder tratamento especial e diferenciado para países menos desenvolvidos; o direito de utilizar mecanismos como subsídios, incentivos fiscais, elevação de barreiras tarifárias, são alguns exemplos de instrumentos que passaram a ser permitidos aos países em desenvolvimento no âmbito dos processos de integração.

Com base neste pequeno, mas relevante, arsenal de direitos, especialmente a Cláusula de Habilitação, os países da América do Sul passaram a fundamentar juridicamente suas políticas de integração e desenvolvimento, criadas ao longo da segunda metade do século XX.

Pode-se identificar duas etapas dessa postura pró-policy space dos países em desenvolvimento nas negociações do sistema multilateral de comércio durante a vigência do GATT.

Na primeira, até o inicio da década de 1960, os esforços giraram em torno da capacidade de impor medidas não-tarifárias (cotas, restrições tarifárias, etc.) contra as importações dos países desenvolvidos. Nesse sentido, as negociações estavam centradas em torno do artigo XVIII, do aumento da flexibilidade para invocá-lo, e da dispensa de autorização prévia das partes do GATT para aplicá-lo.

$\mathrm{Na}$ segunda, do início da década de 60 em diante, apesar de as posições de negociação se intensificarem e se ampliarem, o foco muda radicalmente. Em vez de manter uma postura negociadora centrada, fundamentalmente, no protecionismo anti-países desenvolvidos, passa-se a uma postura de reivindicação de abertura comercial. Fundados na ideia de não-reciprocidade, os países em desenvolvimento exigiam acesso ao mercado dos países desenvolvidos, e reivindicavam a possibilidade de comércio Sul-Sul, não extensiva aos países desenvolvidos. 
A partir do momento em que os países em desenvolvimento perceberam a insustentabilidade da manutenção de modelos de desenvolvimento nacional demasiadamente endógeno, como foi o caso da primeira fase dos modelos de Industrialização por Substituição de Importações, fez-se necessário ampliar a abrangência destes modelos para o plano regional, a fim de fomentar as trocas comerciais que pudessem estimular as indústrias nascentes.

Neste sentido, há uma convergência entre ambos os pilares do policy space para o desenvolvimento do período GATT: enquanto a proteção da indústria nascente estava fundada no artigo XVIII, o crescimento e a consolidação destas economias eram viabilizadas pelo direito à integração regional (artigo XXIV combinado com a cláusula de habilitação) e pelas preferências comerciais decorrentes do SGP e do SGPC.

A partir da incorporação das premissas desenvolvimentistas pelo GATT, os países em desenvolvimento, dentre eles os sul-americanos, fizeram uso intenso de tais prerrogativas jurídicas. Neste sentido, destacam-se o Modelo ISI, os processos de integração regional, os acordos comerciais não-recíprocos com os países desenvolvidos, e a criação de uma rede de preferências comerciais que beneficiam apenas os países em desenvolvimento, posteriormente chamada de comércio SulSul.

$\mathrm{O}$ artigo XVIII, que permitia a proteção às indústrias nascentes, foi a prerrogativa que viabilizou a compatibilidade entre o sistema multilateral de comércio e os modelos de industrialização pela substituição de importações, que estavam amplamente difundidos entre os países em desenvolvimento, especialmente na América do Sul. Sem a existência do artigo XVIII, provavelmente o processo de adesão dos países em desenvolvimento ao sistema multilateral de comércio teria sido completamente diferente.

A partir da década de 50, o modelo ISI da América do Sul passou a representar uma singularidade em relação aos demais modelos dos países em desenvolvimento: estava concebido para ser desenvolvido no plano continental. Foi com este espírito que emergiu a ALALC. No entanto, à época, os processos de integração regional eram regidos pelo artigo XXIV do GATT, que não reconhecia 
diferença entre iniciativas de integração regional envolvendo países em desenvolvimento.

Foi apenas com a criação da Parte IV do GATT que a integração sulamericana incorporou elementos do direito internacional do desenvolvimento, mais precisamente, o princípio da não-reciprocidade. Neste momento, ao final da década de 60, a ALALC outorgou aos países andinos o direito de estabelecerem um subprocesso de integração regional, o Pacto Andino.

A passagem da ALALC para ALADI, em 1980, também só foi possível em razão do surgimento da Cláusula de Habilitação em 1979. Há uma série de diferenças entre o Tratado de Montevidéu de 1960 e o de 1980 que decorre das prerrogativas do desenvolvimento do sistema multilateral de comércio. Destas, sem dúvida a mais importante evolução da ALALC para a ALADI foi a possibilidade dos Membros constituírem acordos sub-regionais de integração, com base nos quais foi incorporado o Pacto Andino e criado o MERCOSUL, em 1991.

O Pacto Andino, desde o seu surgimento, sempre levou em consideração o desenvolvimento como paradigma do seu processo de integração. Trata-se de uma iniciativa constituída com base nas prerrogativas da Cláusula de Habilitação. O Acordo de Cartagena é um tratado em que constantemente se faz menção à prioridade dada à industrialização regional, ao reconhecimento da diversidade econômica dos países Membros e à condição secundária da liberalização comercial e da integração comercial com o mundo.

Estas tônicas da integração andina só foram alteradas ao final da década de 1980, quando da emergência do Consenso de Washington, que atingiu de forma mais contundente a América do Sul, e do surgimento do "Novo Regionalismo" da CEPAL, quando o Pacto Andino se transformou na Comunidade Andina de Nações, em 1997.

O MERCOSUL se orientou igualmente pelas premissas vigentes ao final da década de 1980 e início da década de 1990. Por isso, muito embora o MERCOSUL seja constituído juridicamente e notificado ao GATT sob o amparo da Cláusula da Habilitação, o Tratado de Assunção não faz menção direta, em dispositivo algum, 
à industrialização regional, ao tratamento especial dos países em desenvolvimento e à prioridade do desenvolvimento em detrimento da liberalização comercial. Diferentemente do Pacto Andino, o MERCOSUL é uma iniciativa fundada com base nas prerrogativas do desenvolvimento apenas de maneira formal.

Como pode se perceber, prima facie, o MERCOSUL, desde seu nascimento, já surge com propósitos e objetivos bastante distintos do Pacto Andino. Enquanto o Tratado de Assunção revela uma natureza predominantemente comercialista e liberalizante para o MERCOSUL, o Acordo de Cartagena optou por priorizar o eixo do desenvolvimento industrial como objetivo do Pacto Andino. A liberalização comercial, no caso andino, era um meio para um fim maior, o desenvolvimento industrial da sub-região. No caso do MERCOSUL, a liberalização foi tratada desde seu surgimento como um fim em si mesmo.

Esta diferença entre ambos os projetos sub-regionais, embora fundamentados juridicamente nos mesmos preceitos (ambos são ACE no marco da ALADI e ambos são acordos regionais com base na Cláusula de Habilitação do GATT), revela o zietgeist, o espírito do tempo, em que cada iniciativa foi lançada. Uma das provas disso é que, quando do "relançamento do Pacto Andino", no final da década de 80, o Protocolo de Quito modificou profundamente o Acordo de Cartagena, tornando-o mais próximo dos parâmetros que viria a adotar o MERCOSUL, menos estatizante e dirigista e mais liberalizante, pró-mercado.

Assim, ao final do Período GATT, influenciado pelo Consenso de Washington, presenciou-se o movimento de declínio dos modelos desenvolvimentistas em substituição a novos modelos de orientação liberal que rechaçavam o exercício de policy space por fomentar a ineficiência e distorcer a "ordem natural" do comércio internacional.

Era o fim do período desenvolvimentista das relações econômicas internacionais, que repercutiu tanto no sistema multilateral de comércio quanto nas organizações de integração regional da América do Sul. 


\section{Parte II}

Na Parte II, foi constatado que, com a criação da Organização Mundial do Comércio e a celebração de um grande conjunto de acordos internacionais em matéria de comércio internacional, o sistema multilateral de comércio passou tanto por um alargamento temático quanto por um processo de aprofundamento tarifário, que levou a um nível até então inédito de liberalização econômica e comercial mundial, avançando em relação ao período regido pelo antecessor GATT-47. Isto impactou diretamente a capacidade dos países em desenvolvimento de continuar implantando políticas de desenvolvimento, nos moldes das implantadas até os anos 1980.

Isto porque este movimento de regulação dos novos temas não foi acompanhado de um movimento consistente e coerente de reivindicações de prerrogativas jurídicas mais favoráveis para os países em desenvolvimento, a fim de que pudessem manter autonomia na implantação das suas políticas públicas de integração e desenvolvimento. Este choque de modelos se deu de maneira particularmente forte na América do Sul.

Ao final da Rodada Uruguai, o direito internacional do desenvolvimento vigente no âmbito do sistema multilateral de comércio ficou limitado ao Tratamento Especial e Diferenciado, concebido em termos de prazos mais longos para implantação dos acordos. Tal extensão não teve utilidade alguma, tendo em vista a desproporção entre a complexidade da liberalização e prazo extremamente curto. Ademais, o Tratamento Especial e Diferenciado foi idealizado de maneira a tratar diferentemente alguns regimes setoriais, tais como agricultura, têxteis, serviços, que teriam regras distintas das regras gerais do GATT e traziam em si uma built in agenda, que até hoje, passados mais de 15 anos, não se concretizou.

No entanto, mesmo em meio a este cenário de rejeição ao policy space para o desenvolvimento, que marcou a Rodada Uruguai, o Tratamento Especial e Diferenciado concedido aos países em desenvolvimento ficou consagrado em praticamente todos os acordos da OMC, razão pela qual se pode afirmar que o policy space conquistado ao longo do período GATT-47, limitado ao Tratamento 
Especial e Diferenciado, foi, no mínimo, mantido quando da entrada em vigor da OMC.

Ocorre que o viés de Tratamento Especial e Diferenciado que se consolidou nos acordos da OMC é atinente a prazos mais flexíveis e a setores temporariamente isentos de obrigações. Como restou evidente nos primeiros anos de vigência da OMC, por meio do caso Índia - Restrições Quantitativas, o sistema não concebia mais políticas de desenvolvimento consistentes e de longo prazo. Depreendeu-se daí ser impossível implantar políticas de desenvolvimento fundamentando-se apenas em exceções e isenções temporárias.

Os acordos da Rodada Uruguai reduziram em grande medida a natureza não-recíproca do sistema multilateral de comércio que havia sido alcançada ao longo do Período GATT. A partir da OMC, os países em desenvolvimento estavam obrigados juridicamente dentro do Sistema OMC como um todo, pois os waivers e as derrogações que vigiam até então haviam sido extintas em $1^{\circ}$ de janeiro de 1995. Entretanto, não foi apenas a extinção destas exceções que reduziram o policy space dos países em desenvolvimento.

De fato, a partir da Rodada Uruguai, um novo Tratamento Especial e Diferenciado emergiu. Este novo Tratamento Especial e Diferenciado possuía duas facetas: periodos de transição para implantação dos novos compromissos decorrentes da Rodada Uruguai, tais prazos sendo mais extensos do que os dos países industrializados, e estando presentes em praticamente todos os acordos da Rodada Uruguai. A outra faceta é a assistência técnica para implantação dos novos acordos, também presente em praticamente todos os acordos da Rodada Uruguai.

Portanto, com a criação da Organização Mundial do Comércio, um novo marco regulatório internacional emerge, para o qual os Estados Membros, e suas respectivas organizações de integração regional, devem observância. Uma nova mentalidade econômica, de natureza menos estruturalista e mais liberal, se institucionaliza por meio de tratados, acordos e protocolos de natureza econômica e comercial, firmados tanto no âmbito da OMC quanto das organizações de integração regional. 
A implantação do conjunto jurídico, político, econômico, institucional e administrativo com a finalidade de adequar-se ao novo sistema multilateral de comércio, oriundo da OMC e das suas regras, causa transformações relevantes na América do Sul. Novos modelos de Estados e de organizações de integração regional emergem.

Sob a regência deste novo cenário internacional, a América do Sul passa por uma profunda transformação para a adequação dos antigos modelos de desenvolvimento aos novos parâmetros jurídicos, políticos e econômicos do neoliberalismo. A internalização e a implantação dos acordos de OMC são uma das muitas formas de manifestação dessa adequação e "modernização" da América do Sul rumo à globalização prometida.

Em relação aos processos de integração sul-americanos, a CAN iniciou em 1998 o processo de integração regional em serviços por meio do método das listas negativas, que culminou na liberalização completa do comércio de serviços em 2006. Em razão disso, foi alcançada uma harmonização regulatória regional sólida em matéria de serviços. Houve apenas dois níveis de exceção: uma setorial, que exclui os serviços de serviços financeiros e de Televisão Aberta Nacional, e outra relacionada ao Tratamento Especial e Diferenciado concedido à Bolívia para que, nos setores que considerasse necessário, pudesse eximir-se do cumprimento das obrigações decorrentes da liberalização completa do comércio de serviços até dezembro de 2014.

Por outro lado, o MERCOSUL encontra-se em um estágio completamente oposto da CAN no que se refere à integração em matéria de serviços. O protocolo foi firmado em 1997, mas entrou em vigor apenas em 2005, e ainda resta pendente de ratificação do Paraguai. O método eleito pelo MERCOSUL foi o inverso da CAN. Optou-se por listas positivas, para que houvesse um processo gradativo de integração em serviços. No entanto, passadas 7 rodadas de negociação, não há o mínimo de harmonização regional em matéria de serviços e o MERCOSUL ainda se encontra em estágio embrionário de integração em matéria de serviços.

Há um elemento fundamental que pode justificar as diferenças nas estratégias e atuais estágios de integração em serviços: o nível de assimetria interna 
dentro das sub-regiões. Há um equilíbrio evidentemente maior entre os níveis de desenvolvimento dos Membros da CAN se comparado ao MERCOSUL, no qual há uma grande assimetria tanto entre os Membros, quanto entre setores de serviços dos diversos Membros.

Do ponto de vista continental, a consolidação de uma ordem normativa comum em matéria de serviços revelou-se fundamental para a manutenção da unidade da integração sul-americana, tendo-se em vista a diversidade de acordos bilaterais e regionais que estão sendo firmados atualmente. A ausência desse quadro regulatório comum no MERCOSUL, tal qual na CAN, além de atrasar a integração intra-regional de serviços, impede também que haja avanços em matéria de liberalização de serviços com os recentes parceiros comerciais com os quais o MERCOSUL está firmando acordos bilaterais.

Já em matéria de investimentos, há semelhanças e diferenças entre ambas as organizações sul-americanas. A CAN possui desde 1991 um regime comum vigente, que está avançando por meio de acordos bilaterais de investimentos entre os próprios Membros da CAN. Tal regime consagrou, no plano regional, o texto do TRIMS que vinha sendo negociado na Rodada Uruguai.

O MERCOSUL adotou a mesma estratégia, de incorporação do TRIMS no plano regional por meio dos Protocolos de Colônia e Buenos Aires. Contudo, ambos os protocolos ainda não foram devidamente depositados pelos Membros e o MERCOSUL, diferentemente da CAN, ainda não possui um regime comum, seja para o tratamento dos investimentos intra-regionais, seja para os investidores de fora do MERCOSUL. Tampouco o MERCOSUL avança em acordos bilaterais de investimentos entre os parceiros regionais, como faz a CAN.

Há uma diferença fundamental entre ambos os processos de integração, no que se refere à regulação de investimentos. A CAN criou a figura da empresa multinacional andina, a fim de fomentar a formação de empreendimentos empresariais e investimentos comuns entre os Membros da organização internacional. No MERCOSUL, tal figura não existe e os investidores oriundos dos Membros são tratados de maneira igualitária aos investidores de fora do MERCOSUL. 
Por fim, em relação aos regimes jurídicos de propriedade intelectual, se encontram diferenças muito acentuadas em relação aos níveis de integração da CAN e do MERCOSUL. A integração andina estabeleceu, entre 1993 e 2000, um amplo regime jurídico comum sobre direitos de propriedade intelectual: há o Regime Comum de Propriedade Industrial, o Regime Comum sobre Direitos do Autor e Direitos Conexos, o Regime de Proteção dos Direitos dos Obtentores Vegetais e o Regime Comum sobre Acesso aos Recursos Genéticos.

Por outro lado, o MERCOSUL ainda carece de um mínimo de harmonização em matéria de propriedade intelectual. $\mathrm{O}$ Protocolo de Harmonização do MERCOSUL, de 1995, que ainda não entrou em vigor, tem um mero objetivo harmonizador, e não o de criar um marco regulatório comum. Decidiu-se que cada país manteria sua legislação nacional em matéria de propriedade intelectual.

Tal avaliação a respeito dos diferentes métodos e estratégias de internalização das regras oriundas da OMC, levados adiante na América do Sul gera uma série de conclusões que dizem respeito aos impactos da OMC no policy space da América do Sul, e se houve ou não a redução dessa autonomia para políticas públicas de desenvolvimento nas organizações de integração da América do Sul.

$\mathrm{Na}$ ALADI, há uma total ausência de regimes próprios e comuns entre os seus Membros em praticamente todos os temas regulados pela OMC. Isso reflete um abandono da ALADI, enquanto organização internacional capaz de exercer algum nível de policy space regional em favor dos seus Membros. Caso houvesse regimes comuns em matéria de serviços, propriedade intelectual ou investimentos consolidados no plano regional, a margem de manobra das organizações subregionais estaria garantida. No entanto, parece que os países-Membros optaram por manter o maior nível de discricionariedade possível no âmbito da ALADI, sem consolidar compromissos e regimes comuns. Isto acabou por perpetuar, no plano da ALADI, as regras gerais da OMC que não viabilizam tanto policy space quanto as regras decorrentes das organizações de integração regional. 
No MERCOSUL, percebe-se uma prevalência da percepção da noção de policy space nacional em detrimento do policy space regional. Isto pode ser afirmado pelos seguintes motivos: a) os países-Membros terem optado pela lista positiva, ao invés da negativa, na integração de serviços; b) os países-Membros não harmonizarem, tampouco constituírem um regime comum, em matéria de propriedade intelectual, que está regulado pelas diversas legislações nacionais e ; c) o mesmo ocorre em matéria de investimentos pois, embora haja um protocolo de harmonização para regras de investimentos, não há um regime comum para os investimentos intrarregionais, o que descaracteriza a existência de um espaço regional comum para investimentos estrangeiros. Do ponto de vista do investidor estrangeiro, cada Membro do MERCOSUL possui um regime nacional, não necessariamente comum aos demais Membros da organização internacional.

$\mathrm{Na}$ CAN existe a maior percepção da noção de policy space enquanto organização de integração regional. Nas três dimensões analisadas a CAN optou por avançar consideravelmente nos processos de integração nas matérias de serviços, investimentos e propriedade intelectual. Muito embora existam discordâncias sobre a relação entre policy space e o método de listas negativas adotado para integração em matéria de serviços, os Membros da CAN decidiram outorgar à organização de integração regional, seja por meio da harmonização das regras nacionais, seja pela comunitarização dos regimes jurídicos, o policy space para o desenvolvimento, que deixou de estar vinculado aos interesses nacionais e passou a ser orientado pelos interesses regionais.

\section{Parte III}

A Parte III revelou que a emergência do novo desenvolvimentismo ao longo da primeira década do século XXI, tanto no plano global quanto regional, fez com que as organizações de integração da América do Sul se lançassem no estabelecimento de novas políticas públicas de desenvolvimento, avançando em áreas e temas até então não tratadas no regionalismo sul-americano. Ao ir além dos temas convencionalmente regulados na OMC, passaram a abranger políticas de 
correção de assimetrias regionais, políticas de infraestrutura regional e políticas de inovação tecnológica. É no âmbito destes novos vetores da integração sulamericana que o policy space regional se institucionalizou e aprofundou, de maneira inédita, na história da América do Sul.

Ao longo da década de 1990, ao mesmo tempo em que o desenvolvimento sofreu uma crise em sua vertente econômica e comercial, também se revestiu de dois novos vetores, impulsionados pela quarta década da ONU. Trata-se de dois novos ambitos regulatórios aos quais até então o desenvolvimento não estava associado: a sua inter-relação com os direitos humanos, que levou à noção de desenvolvimento humano, e também à sua associação com a preservação ambiental, tendo resultado no conceito de desenvolvimento sustentável. Em torno de ambos os conceitos, produziu-se um amplo conjunto de normativa de direito internacional que passou a orientar as relações internacionais, e de maneira indireta, lidar com a questão da desigualdade entre os países desenvolvidos e os países em desenvolvimento.

Em razão disso, a presente tese sustenta que a produção normativa internacional em torno da questão do desenvolvimento ao longo da década de 1990 revela que o direito internacional do desenvolvimento na realidade não se extinguiu como correntemente se afirma na literatura. $\mathrm{Na}$ realidade, ele passou por um processo de transformação dos seus valores, tornou-se menos ideologizado, menos adstrito ao antagonismo Norte e Sul, entre ricos e pobres, e mais condizente com a noção de interdependência global, que passou a orientar as relações internacionais na virada do século.

As diferentes décadas da ONU para o desenvolvimento e suas correspondentes estratégias de ação não devem ser percebidas como fracassos, mas como avanços graduais na longa luta contra a desigualdade, a fome, a pobreza e o subdesenvolvimento. São esforços que formam parte de um conjunto de ações levadas adiante no âmbito da ONU e de suas agências especializadas, que repercutiram em diversas outras organizações internacionais. Em cada década foi necessário reajustar-se às mudanças ocorridas no cenário internacional e situar os problemas globais dentro de contextos mais amplos. 
O lançamento da atual estratégia da ONU para o desenvolvimento, por meio da Declaração do Milênio, levou ao estabelecimento dos Objetivos de Desenvolvimento do Milênio. Para a consecução de tais objetivos, todas as organizações internacionais do Sistema ONU foram envolvidas e abrangidas, dentre as quais, a OMC. É este movimento global de produção normativa e de estabelecimento de planos de ação em torno da questão do desenvolvimento que a presente tese sustenta ser um processo de renascimento do direito internacional do desenvolvimento.

No âmbito desse abarcamento pela ideia-força dos objetivos de desenvolvimento do milênio da ONU, a OMC envolveu-se num processo de revisão dos seus propósitos e objetivos. Tal momento tornou-se oportuno para os países em desenvolvimento para que, com a legitimidade decorrente desse movimento global, pudessem tentar rever e ampliar o conjunto de prerrogativas jurídicas para o desenvolvimento existentes no escopo da OMC.

Logo nas primeiras Rodadas de Negociações da OMC - Singapura e Seattle - houve uma grande pressão por parte dos países em desenvolvimento para a revisão do viés da natureza da OMC, pois a falência dos modelos de desenvolvimento fundados no neoliberalismo ao redor do mundo clamava por uma reorientação ideológica nas relações econômicas internacionais, inclusive para as suas regras. Período que refletiu a preparação do retorno do viés (neo) desenvolvimentista ao sistema multilateral de comércio.

Com o esgotamento do Tratamento Especial e Diferenciado, além de um cenário controverso das relações econômicas internacionais, com crises em diversos países em desenvolvimento mundo afora, as Rodadas de Singapura e Seattle são um fracasso, que apontam para o fim do período neoliberal da OMC.

O fracasso no lançamento da Rodada de Seattle, que visava aprofundar e ampliar ainda mais o processo de liberalização econômica e comercial em escala global, foi fruto do despertar do mundo em desenvolvimento que percebia a necessidade de retomar a construção e a renovação do direito internacional do desenvolvimento. No âmbito da OMC, isto significou a necessidade de aprofundar e ampliar as prerrogativas jurídicas no sistema multilateral de comércio. 
Como conseqüência, em 2001, a OMC lançou a Rodada de Doha, com natureza absolutamente diferente da tentativa anterior. Rodada batizada como Rodada do Desenvolvimento que, com fulcro na Declaração Ministerial de Doha, se propôs a levar adiante uma ampla revisão dos acordos vigentes no escopo da $\mathrm{OMC}$, com a finalidade de melhor adaptá-los às necessidades dos países-Membros, atendendo em especial, as demandas dos países em desenvolvimento. Nesse sentido, a Rodada de Doha revelou-se uma oportunidade para a renovação e a ampliação do direito internacional do desenvolvimento no âmbito da OMC.

Com a Declaração Ministerial de Doha, surge uma nova lupa para analisar a OMC e seus acordos. Ademais, o cenário global, de emergência de uma situação economicamente mais favorável para os países em desenvolvimento incita tais Estados a implantarem políticas sólidas de desenvolvimento a fim de aproveitar o bonde da história que os favorece neste momento.

É neste contexto histórico que se dá a retomada do desenvolvimentismo no âmbito das organizações de integração regional da América do Sul. A primeira década do século XXI foi um período no qual se sucedeu uma renovação dos propósitos e práticas dos processos de integração regional e sub-regional da América do Sul.

Se, por um lado, a década de 1990 viu a ascensão e o declínio do neoliberalismo enquanto fundamento das políticas de integração e desenvolvimento da América do Sul, por outro, a virada do século viu a emergência do regionalismo pós-liberal e o novo desenvolvimentismo na América do Sul.

As organizações sul-americanas de integração regional (ALADI, CAN, MERCOSUL e UNASUL) vivem um momento peculiar, seja comparado ao período do desenvolvimento e do regionalismo endógeno, seja comparado ao período do neoliberalismo e do regionalismo aberto.

Ao longo da primeira década do século XXI, estas organizações se revestiram de elementos novos, que indicam novas orientações conceituais e políticas, caracterizadas pelo novo desenvolvimentismo e pelo regionalismo pós-liberal. 
A emergência do regionalismo pós-liberal e do novo desenvolvimentismo na América do Sul se fez sentir em três níveis da integração: em um nível mais amplo, a integração regional sul-americana presenciou o surgimento da União SulAmericana de Nações (UNASUL). No âmbito da integração econômica e comercial, houve uma renovação da importância estratégica da ALADI nesta primeira década do século XXI. No âmbito das iniciativas sub-regionais, o MERCOSUL e a Comunidade Andina estão vivenciando uma mudança de propósitos que está gerando novos modelos de integração, fundado em parâmetros inéditos para ambas as iniciativas.

A UNASUL surge em um contexto de alinhamento político e ideológico na América do Sul, no qual há o abandono do projeto ALCA e o estabelecimento da prioridade do fortalecimento da integração da América do Sul. Originariamente constituída como Comunidade Sul-Americana de Nações, a UNASUL, apresenta um grande conjunto de objetivos, muitos dos quais revestem natureza nãocomerciais, chamados de extra-OMC.

O contraste entre a amplitude de propósitos e as limitações em termos de estrutura institucional da UNASUL enquanto organização internacional é um grande desafio para a consecução dos seus objetivos. Mesmo assim, em seu escopo está abarcada uma série de iniciativas inéditas: o IIRSA, a RICG, e o PROSUR são alguns exemplos.

Do ponto de vista da estrutura institucional da UNASUL, a incipiência da atuação dos diversos órgãos e projetos constituídos dificulta uma apreciação a respeito da real capacidade de transformação que os mesmos estão exercendo na América do Sul.

No entanto, o fato da UNASUL ser uma organização de natureza nãocomercial, não a sujeita às regras da OMC. Por isso, pode se afirmar que a UNASUL se configura como uma organização OMC-Extra. No escopo de atuação da UNASUL, os países sul-americanos encontram policy space praticamente ilimitado. Portanto, se os objetivos expressos no tratado constitutivo da UNASUL, bem como dos estatutos dos diversos conselhos, forem, efetivamente levados adiante ao longo dos próximos anos, a América do Sul poderá implantar políticas 
sólidas de desenvolvimento sem maiores preocupações com questionamentos advindos dos Estados-Membros da OMC e do seu OSC.

Já do ponto de vista da relação entre a UNASUL e as demais organizações de integração regional, os desafios são igualmente crescentes. As organizações de integração herdadas do século XX - ALADI, MERCOSUL e CAN - agora coexistem com uma nova organização internacional com natureza diferenciada, voltada para temas não-comerciais.

No entanto, diferenças começam a aparecer entre o MERCOSUL, a partir da adesão da Venezuela, e a CAN, aliada ao Chile no novo viés bilateralista. Enquanto os países andinos estão reorientando as suas políticas externas para fortalecer os laços com os países desenvolvidos, o MERCOSUL vem priorizando a sua inserção internacional por meio de relações Sul-Sul.

A crescente cisão entre as duas organizações sub-regionais leva a uma análise dos desafios apresentados a ALADI, enquanto organização internacional responsável pela condução do MERCOSUL e da CAN.

A ALADI, embora seja a organização internacional mais antiga da América do Sul, está passando atualmente por uma renovação da sua relevância estratégica para região. O Protocolo de Cartagena, que viabilizou a adesão do México ao NAFTA, atualmente está proporcionando a celebração de uma vasta gama de acordos comerciais entre os Membros da ALADI e países de fora da organização internacional.

Essa proliferação é atualmente o maior desafio para a manutenção da ALADI. Ainda, há fato de que MERCOSUL e CAN possuem diretrizes distintas em relação a acordos extra-regionais: o MERCOSUL desde o ano 2000 obriga os Membros a celebrarem em conjunto tais acordos, enquanto na CAN os Membros têm autonomia para celebrar tais acordos. Caso a América do Sul deseje manter o mínimo de unidade jurídica em matéria de integração econômica e comercial, tem a necessidade de passar por uma ampliação temática da regulação com viés pródesenvolvimentista no âmbito da ALADI, a fim de constituir um marco regulatório 
comum da ALADI nos temas não-tarifários, tais como serviços, propriedade intelectual, investimentos, compras governamentais, etc.

A ALADI se depara atualmente com um desafio vital, enquanto organização de integração regional com o mínimo de credibilidade na América do Sul. Este desafio emerge de um duplo movimento, antagônico, que está ocorrendo em seu seio. De um lado, a tentativa de estimular a convergência entre os seus Membros, para consolidar o processo de integração regional em nível continental; do outro, o aumento do número de acordos bilaterais celebrados por seus Membros com parceiros extra-regionais ameaça desestruturar a arquitetura jurídica da América do Sul decorrente da ALADI.

A falta de consenso político dentro da CAN levou a tensões críticas a partir de 2005. Em 2006, diferentes visões políticas sobre o direcionamento que a CAN deveria tomar, bem como a heterogeneidade dos interesses comerciais, culminaram nas negociações bilaterais de Colômbia e Peru com os EUA. Como protesto, a Venezuela decidiu desvincular-se da CAN, denunciando o Acordo de Cartagena, para tornar-se Membro do MERCOSUL.

A saída da Venezuela e a implantação dos acordos bilaterais que os seus Membros começaram a firmar a partir de então se transformaram em grandes desafios para a CAN, tanto no sentido de avançar em seu processo de integração, mas especialmente no desafio de manter a unidade da CAN enquanto União Aduaneira, tendo em vista a erosão da Tarifa Externa Comum em razão dos acordos bilaterais.

Paralelamente aos acordos bilaterais da CAN, o MERCOSUL igualmente lançou-se na iniciativa de celebrar acordos bilaterais, porém com uma clara orientação Sul-Sul. Esta atual proliferação de acordos comerciais dos Membros da ALADI com parceiros extra-regionais é o desafio mais importante, do ponto de vista da unidade jurídica da integração sul-americana.

A diversidade de compromissos e preferências que estão sendo celebrados em matéria de bens, serviços, propriedade intelectual e investimentos, está paulatinamente erodindo os esquemas de preferências intra-regionais, em favor de 
preferência extra-regionais. Além disso, a possibilidade do surgimento de temas ainda não regulados na integração sul-americana, tais como a cláusula ambiental e a cláusula social, podem inserir na agenda da integração sul-americana os chamados temas OMC-Plus.

Estes dois caminhos, absolutamente antagônicos entre si - de um lado a convergência intra-regional, do outro, a abertura internacional - não podem coexistir. A atual arquitetura jurídica e institucional da América do Sul não está preparada para este duplo fenômeno.

Por isso, duas alternativas se apresentam à América do Sul. A primeira opção é a reconstrução jurídica e institucional da ALADI para que esta possa ser uma organização internacional condizente com os novos tempos, e assim tornar ambas as tendências - convergência intra-regional e abertura extra-regional compatíveis. A outra opção seria a do abandono em definitivo do princípio da convergência, e a consequente falência da ALADI.

Por fim, é no âmbito sub-regional que se encontram os desafios mais marcantes da América do Sul. Tanto o MERCOSUL quanto a CAN passaram por transformações e evoluções ao longo da década de 90, a fim de acompanhar as tendências globais de incorporação dos fundamentos jurídicos neoliberais em detrimento dos fundamentos desenvolvimentistas.

Atualmente, percebe-se o retorno do desenvolvimentismo como fundamento de ambas as iniciativas, em uma série de temas antes negligenciados nos planos sub-regionais. Neste aspecto, destaca-se o tratamento da inovação e da sustentabilidade que, embora ainda em estágio embrionário, revela que ambas as iniciativas começam a incorporar as premissas do novo desenvolvimentismo em suas respectivas ordens jurídicas. No entanto, o maior desafio apresentado a ambas as iniciativas é aquela iniciada em 2004, que objetiva a convergência MERCOSULCAN no marco da ALADI.

A saída da Venezuela da CAN e a sua adesão ao MERCOSUL, em 2005, está levando ambas as organizações de integração regional a uma crise institucional que pode colocar em xeque as iniciativas mais bem consolidadas da América do 
Sul. O principal motivo que levou a Venezuela a sair da CAN foi a prevalência dos interesses dos demais países andinos em negociar acordos bilaterais extra-regionais, especialmente com os EUA. Desde então, os Estados Membros da CAN já firmaram mais de uma dezena de acordos bilaterais.

Ora, isto acaba por completo com a unidade andina por tornar a Tarifa Externa Comum, instrumento fundamental da União Aduaneira, absolutamente secundária e irrelevante. Isto pode, caso se perpetue e acentue a tendência dos países andinos em celebrar acordos bilaterais, fazer com que a CAN abandone um dos seus pilares de integração, a União Aduaneira, e consolide-se apenas como uma zona de livre comércio.

$\mathrm{Na}$ CAN, cada Estado é livre para celebrar acordos internacionais de maneira individual. A CAN carece de uma regra, tal qual existe no MERCOSUL, a Decisão $n^{\circ}$ 32/00, que obriga os Estados Membros a negociarem internacionalmente em conjunto. Tal regra poderia ser um reforço institucional fundamental para manter a já desintegrada unidade andina.

O MERCOSUL também passa por uma grave crise interna, que está transformando radicalmente a estrutura institucional da organização internacional, em razão do processo de adesão da Venezuela.

Desde que postulou seu ingresso, a Venezuela enfrentou resistências, especialmente pelo Paraguai. Os demais Membros já ratificaram o Tratado de Adesão da Venezuela. O congresso paraguaio tardou mais de cinco anos para internalizar tal tratado.

Com a problemática gerada pelo impeachment no Paraguai, este país, membro fundador do MERCOSUL, está temporariamente suspenso até maio de 2013. Essa situação põe em risco a unidade da organização internacional, tendo em vista que, durante este período de suspensão, o Paraguai pode alegar que não está obrigado pelas regras do MERCOSUL. Tal cenário permite, em tese, que o Paraguai realize acordos comerciais bilaterais em contrariedade à Decisão $\mathrm{n}^{\circ}$ 32/00. O próprio Paraguai já sinalizou a intenção de negociar um acordo bilateral com os EUA. 
Um balanço deste cenário presente em ambas as organizações de integração sub-regionais da América do Sul leva a algumas considerações. A abertura internacional tanto da CAN quanto do MERCOSUL, cada qual por seus motivos, pode levar as duas iniciativas mais bem consolidadas da América do Sul a crises em suas estruturas institucionais. $\mathrm{O}$ aumento das desconfianças regionais poderá minar a unidade política, jurídica e ideológica na América do Sul. Caso os Membros do MERCOSUL e CAN prossigam em acordos bilaterais com países desenvolvidos, como os EUA, poderá ser o início do fim do novo regionalismo desenvolvimentista sul-americano.

\section{Conclusões gerais}

São muitos os desafios apresentados à consolidação deste novo paradigma desenvolvimentista no sistema multilateral de comércio e nas organizações de integração regional da América do Sul.

Do ponto de vista do cenário internacional, a situação que se vive hoje é paradoxal: há um relativo consenso em torno da necessidade dos países em desenvolvimento levarem adiante políticas de desenvolvimento; contudo, as regras da OMC, em geral, não permitem.

A presente tese sustenta que a solução desse cenário paradoxal pode se resolver a partir de uma interpretação pró-desenvolvimentista dos atuais acordos. Imbuído deste Zeitgeist (neo)desenvolvimentista, viabilizado pela Declaração de Doha, em conjunto com toda a produção normativa em torno do desenvolvimento, no âmbito da ONU e nas demais organizações internacionais, pode-se constituir num marco jurídico pró-desenvolvimentista para realizar tal interpretação.

No entanto, enquanto a Rodada de Doha não se encerra e os acordos da OMC não forem efetivamente reformulados, as regras da OMC vigentes permanecem as mesmas, negociadas e aprovadas nos tempos do Consenso de Washington, de afirmação do neoliberalismo e de rechaço a toda e qualquer iniciativa desenvolvimentista no mundo em desenvolvimento. 
Já do ponto de vista regional, o surgimento e a consolidação deste novo regionalismo desenvolvimentista na América do Sul apresenta ao mesmo tempo uma série de novidades e de desafios.

Entre as novidades, há que se destacar a natureza dos projetos de redução de assimetrias que estão sendo levados adiante desde a constituição da IIRSA e do FOCEM, sobretudo se comparado à ausência de projetos desta natureza no século passado. Os investimentos em energia, transporte, telecomunicações e planejamento industrial atuam diretamente sobre as raízes do subdesenvolvimento, abandonando o esquema antigamente vigente, de tratar assimetrias apenas por meio de tratamento especial aos países menos desenvolvidos.

No entanto, os desafios continuam sendo grandes, tendo-se em vista que os níveis de desenvolvimento humano e social da região continuam entre os mais baixos do mundo. Este deve ser o foco de toda e qualquer política voltada à redução de assimetrias regionais.

Ocorre que, quando se analisa o volume de investimentos da IIRSA e do FOCEM para projetos em educação e inovação tecnológica, o total não corresponde a 5\% do total investido em 2012. Este enfoque na educação e na inovação tecnológica é um dos vetores fundamentais para corrigir as assimetrias e as desigualdades nos níveis de desenvolvimento.

As organizações sul-americanas de integração regional devem, com urgência, ampliar as suas prioridades, no que se refere aos investimentos estruturais, e conceber que as políticas voltadas à educação, à ciência e a tecnologia, e à inovação, são tão estruturais quanto as políticas de renovação das malhas viárias e energéticas do continente. Caso contrário, a América do Sul corre o risco de perpetuar os traços mais candentes da desigualdade, tanto em termos intra-regionais, quanto em termos das assimetrias que separam a região do resto do mundo.

Além disso, a América do Sul não pode continuar relegando a liberalização comercial para segundo plano, tal qual está fazendo hoje. A integração estrutural deve ser uma prioridade complementar à integração comercial. Caso tal prioridade 
não seja retomada, os países da região continuarão suscetíveis ao assédio para celebração de acordos bilaterais com parceiros extra-regionais.

A institucionalização de um modelo neodesenvolvimentista de regionalismo na América do Sul deve necessariamente passar pelos seguintes vetores: a) reduzir efetivamente as assimetrias entre os parceiros; b) garantir o equilíbrio entre coordenação macroeconômica e liberalização comercial; c) promover a integração muito além de liberalização de bens; d) utilizar todo policy space possível existente nas regras da OMC.

O direito do desenvolvimento que está emergindo na América do Sul, tanto nas organizações de integração regional (UNASUL, ALADI, MERCOSUL, CAN), quanto em cada Estado, deve ser identificado, catalogado, comparado e analisado, nas suas mais diversas naturezas (constitucional, administrativo, econômico, financeiro, tributário, aduaneiro, bancário, investimentos, serviços, propriedade intelectual, etc.).

O propósito disso seria constituir uma base de dados sobre "boas práticas" normativo-institucionais da América Latina, a fim de construir um consenso próprio, em torno das prerrogativas jurídicas existentes nas regras do sistema multilateral de comércio e que apenas recentemente as organizações internacionais e os Estados latino-americanos passaram a explorar. O intercambio de experiências neste momento é fundamental para aperfeiçoar as práticas regionais e nacionais.

No entanto, tal consenso não pode repetir o mesmo erro fatal do consenso da década de 90, qual seja, ter a pretensão de propor modelo único cabível a todos. Se uma lição a ser tirada das experiências da década de 80 e 90 é a de que a pretensão homogenizadora e uniformizadora de qualquer modelo de desenvolvimento automaticamente torna o modelo inútil.

A engenharia jurídica necessária para construir políticas de desenvolvimento dentro dos limites da legalidade do policy space existente no marco regulatório da OMC é tarefa de grande complexidade e apresenta desafios de monta para os policy makers latino-americanos. Por isso, fóruns para compartilhar experiências nacionais e sub-regionais, tais como o PROSUR, para temas de propriedade intelectual, e o 
RICG, para temas de compras governamentais, se revelam imprescindíveis para consolidar a emergência deste direito latino-americano do desenvolvimento.

A crise global está criando oportunidades sem precedentes para o desenvolvimento dos países em desenvolvimento. Se a América do Sul não orientar o novo regionalismo desenvolvimentista para a inovação, aproveitando este momento para fortalecer sua produção industrial e aumentar a produção e fabricação de produtos de alto valor agregado, continuará sua tradição de provedor histórico de matérias-primas.

A posição atual do pêndulo que balança entre o liberalismo e o desenvolvimentismo deve ser bem aproveitada pelos países em desenvolvimento, em especial, os da América do Sul. Trata-se de um momento único para a América do Sul superar as raízes históricas do subdesenvolvimento. Para tanto, o enfoque deve necessariamente passar para a integração fundada na inovação.

O impasse na Rodada Doha cria um cenário para a revisão das normas e critérios interpretativos da OMC, com o fim de obter maior permissibilidade para as políticas de desenvolvimento fundadas em inovação.

Enquanto isso, as organizações internacionais de integração regional perfazem as melhores plataformas para implantar tais políticas, tendo-se em vista que é no âmbito dos acordos de integração regional fundados na Cláusula de Habilitação que existe a maior margem de manobra, dentro do intrincado sistema de regras da OMC.

\section{Desdobramentos futuros de pesquisa}

A presente tese, embora revele natureza pragmática e casuística, se insere em um contexto de debate contemporâneo da teoria do direito internacional, sobre a fragmentação ou a unidade do direito internacional. 
Em linhas gerais, o debate da fragmentação do direito internacional gira em torno da constatação de que, na ausência de uma autoridade central nas relações internacionais, o desenvolvimento normativo expresso em regimes diferentes e descoordenados, poderia conduzir a conflitos entre normas ou sistemas de regras, com o afastamento das práticas institucionais e eventual perda da dimensão geral do direito.

Apesar de não ser o objetivo central ou secundário desta tese, do ponto de vista deste debate teórico do direito internacional, este estudo pode, indiretamente, revelar-se como um exercício de demonstração de uma concepção unitária do direito internacional. A presente tese pode apresentar elementos para a unidade do direito internacional, seja por meio da lógica da compatibilidade, da hierarquia, da convergência ou da coerência entre as regras dos diversos subsistemas do direito internacional.

Ao escrever uma tese sobre o exercício de policy space na América do Sul, revela-se como pressuposto da investigação, uma visão fundada na necessidade de compatibilidade ou convergência existente entre o direito da integração sulamericana e o direito internacional, mais especificamente, o direito da OMC.

Outro exercício de enquadramento do problema de tese no debate teórico do direito internacional revela uma concepção hierárquica do direito internacional. Do ponto de vista hierárquico, existiria em um primeiro plano, o direito internacional geral. O direito internacional do desenvolvimento contemporâneo, por abranger os temas de interesse comum da humanidade, como os direitos humanos e a preservação ambiental, poderia estar abrindo caminho para tornar-se parte do corpo normativo do jus cogens? É um questionamento relevante para a perspectiva desta tese.

Em um nível hierarquicamente inferior, está o direito internacional do comércio. A natureza dinâmica dessa ordem jurídica é fruto da influência das ideologias econômicas hegemônicas de cada período histórico, ora de orientação mais mercadológica (market-oriented), ora mais afeito à intevenção estatal (stateoriented). Esta flutuabilidade a que está sujeito o direito internacional do comércio 
faz com que os Estados estejam vulneráveis às variações ideológicas dessa ordem jurídica.

Caso se aceite que existe uma unidade, e também uma hierarquia dentro do direito internacional, o direito internacional do comércio pode ser percebido à luz do direito internacional do desenvolvimento para que exista, nos diferentes períodos ideológicos, a primazia dos interesses comuns da humanidade.

A tese revelou que as organizações de integração regional da América do Sul compreendem o direito internacional como uma unidade, pois, como demonstrado ao longo da pesquisa, as políticas criadas respeitaram o policy space, ou seja, agiram em conformidade com o direito internacional da OMC. A América do Sul, por meio das suas organizações de integração regional, vem atuando historicamente, e segue atualmente, atuando com base no primado do direito internacional.

$\mathrm{O}$ fato do novo regionalismo desenvolvimentista sul-americano estar finalmente se constituindo para além do policy space do sistema multilateral de comércio, não configura, a priori, uma incompatibilidade dos processos de integração com as regras da $\mathrm{OMC}$, razão pela qual contribui para fortalecer o primado do direito internacional na América do Sul. 


\section{BIBLIOGRAFIA}

ADDA, Jacques. As origens da globalização da economia. Barueri: Manole, 2004.

AGARWALA, A.N.; SINGH, S.P. (Org.). A Economia do Subdesenvolvimento.

Rio de Janeiro: Contraponto, 2010.

AGUILLAR, Fernando Herren. Direito Econômico: do direito nacional ao direito supranacional. 2a Ed. São Paulo: Atlas, 2009.

. Metodologia da Ciência do Direito. $4^{\mathrm{a}}$ Ed. São Paulo: Atlas, 2009.

ALMEIDA, Paulo Roberto. O Brasil e o Multilateralismo Econômico. Porto Alegre: Livraria do Advogado, 1999.

AMARAL JÚNIOR, Alberto. A solução de controvérsias na OMC. São Paulo: Atlas, 2008.

. Comercio Internacional e a Proteção do Meio Ambiente. São Paulo: Atlas, 2011.

(Org.). Direito internacional e desenvolvimento. Barueri: Manole, 2005.

(Org.). Direito do Comércio Internacional. Porto Alegre: Editora Juarez de Oliveira, 2002.

Introdução ao Direito Internacional Público. São Paulo: Atlas, 2008.

; MOISES, Claudia Perrone (Org.). O cinqüentenário da Declaração Universal dos Direitos Humanos. São Paulo: Edusp, 1999.

AMSDEN, Alice. A Ascensão do resto: os desafios ao ocidente de economias com industrialização tardia. São Paulo, Editora UNESP, 2009. .; HIKINO, Takashi. The bark is worse than the bite: new WTO law and late industrialization. American Academy of Political and Social Science \#570, 2000.

ARBIX, Glauco; MARTIN, Steve. Beyond developmentalism and market fundamentalism in Brazil: inclusionary state activism without statism. Workshop "States, Development, and Global Governance". University of Wisconsin-Madison, 2010. 
et al (Org.). Brasil, México, África do Sul, Índia e China: diálogo entre os que chegaram depois. São Paulo: EDUSP, 2002.

BAPTISTA, Luiz Olavo. O MERCOSUL, suas instituições e ordenamento jurídico. São Paulo: LTr, 1998.

BARONA, Ignacio et al. Lecciones de derecho internacional público. Valencia: Tirant Lo Blanch, 2011.

BARRAL, Welber (Org.). Direito e desenvolvimento: análise da ordem jurídica brasileira sob a ótica do desenvolvimento. Florianópolis: Singular, 2005.

; PIMENTEL, Luiz Otávio (Orgs.). Comércio internacional e desenvolvimento. Florianópolis: Fundação Boiteux, 2006.

. (Orgs.). Direito ambiental e desenvolvimento. Florianópolis:

Fundação Boiteux, 2006.

Florianópolis: Fundação Boiteux, 2007.

_ $;$ - (Orgs.). Teoria jurídica e desenvolvimento. Florianópolis: Fundação Boiteux, 2007.

BEDJAOUI, Mohammed. Hacia un nuevo orden económico internacional. Salamanca: Sígueme, 1979.

BENCHIKH, Madjid. Droit international du sous-développment: houvel ordre dans la dependence. Paris: Berger-Levrault, 1981.

BENNOUNA, Mohamed. Droit international Du development: tiers monde et interperllation du droit international. Paris: Berger-Levrault, 1981.

BERMANN, George, MAVROIDIS, Petros. WTO Law and Developing Countries. Nova York: Cambridge University Press, 2007.

BETHELL, Leslie (Org). História da América Latina (Vols. 3, 4, 6 e 7). São Paulo: EDUSP, 2009.

BIELSCHOWSKY, R. (Org.). Cinqüentas anos de pensamento na CEPAL (Vols. 1 e 2). Rio de Janeiro: Record, 2000. 
Pensamento Econômico Brasileiro: o ciclo ideológico do desenvolvimento. Rio de Janeiro: Contraponto, 2004.

BHAGWATI, Jagdish. The Wind of the Hundred Days: how Washington mismanaged globalization. Boston, MIT Press, 2000.

BHALA, Raj. Modern GATT Law: a treatise on the General Agreement o Tariffs and Trade. Londres: Sweet \& Maxwell, 2005.

BOHLKE, Marcelo. Integração Regional e autonomia do seu ordenamento jurídico. Curitiba: Juruá, 2002.

BRAGA, Marcio Bobik. Raul Prebisch e o Livre Comércio: as origens do pensamento econômico estruturalista. In Cadernos PROLAM/USP (Ano 7 - Vol. 2). 2008. p. 76-99.

; PAIVA, Donizete. Integração Econômica Regional e Desenvolvimento Econômico: Reflexões Sobre a Experiência Latino-Americana. in Revista de Desenvolvimento Econômico, v. 16, 2007p. 61-71.

BRESSER-PEREIRA, Luis Carlos. Globalização e competição: por que alguns países emergentes têm sucesso e outros não. São Paulo: Elsevier, 2010.

BULMER-THOMAS, Victor. The Economic History of Latin America since Independence. Cambridge: Cambridge University Press, 2003.

CANÇADO TRINDADE, Antonio Augusto. Direitos humanos e meio ambiente: paralelos dos sistemas de proteção internacional. Porto Alegre: Fabris, 1993.

CARREAU, Dominique. and JUILLIARD, Patrick. Droit International Économique. $3^{\text {a }}$ ed. Paris, LGDJ, 2007

CELLI JUNIOR, Umberto. A Organização Mundial do Comércio e o regionalismo do século XXI. In Revista Densidades. nº 9. Maio. 2012. . Acordos de Investimentos e Políticas Industriais. in KLOR, Adriana et al (Org.), Revista DeCITA número 3, direito do comércio internacional: temas e atualidades. Florianópolis, Editora Fundação Boiteux, 2005, p. 117. 
, et al (Org.). Blocos Econômicos e Integração na América Latina, África e Ásia. Curitiba: Juruá, 2008.

Comércio de Serviços na OMC: liberalização, condições e desafios. Curitiba: Juruá, 2009.

; et al. MERCOSUL in South-South Agreements: in the middle of two models of regionalism. Genebra: UNCTADVI, 2011. Disponível em http://vi.unctad.org/resources-mainmenu-64/digital-library?act=search

- Políticas de Liberalização do Comércio de Serviços (GATS) com Regulação Redistributiva. In Cadernos PROLAM/USP (Ano 8 - Vol. 1). 2009. p. 124-148.

CEPAL. Panorama de la inserción internacional de América Latina y el Caribe: Crisis y espacios de cooperación regional. Santiago: CEPAL, 2009.

CERVO, Amado Luiz; RAPOPORT, Mario. História do Cone Sul. Brasília: Editora UnB, 1998.

_. Relações Internacionais da América Latina: velhos e novos paradigmas. $2^{a}$ edição. São Paulo: Saraiva, 2007.

CHANG, Ha-Joon. Kicking away the ladder: Development Strategy in Historical Perspective. Londres: Anthem Press, 2002. Why developing countries need tariffs? How WTO NAMA negotiations could deny developing countries' right to a future. Genebra: South Centre, 2005.

CHARNOVITZ, Steve; STEGER, Debra; VAN DEN BOSSCHE, Peter. Law in the service of human dignity: essays in honour of Florentino Feliciano. Cambridge: Cambridge University Press, 2005.

CIENFUEGOS, Manuel; MELLADO, Noemi (Orgs). Los cambios en la infraestructura regional y sus impactos ambientales en clave de mejorar la gobernabilidad en el MERCOSUR. Córdoba: Lerner, 2011.

CIMOLI, Mario; DOSI, Giovani; STIGLITZ, Joseph. Industrial Policy and Development. New York: Oxford University Press, 2009. 
CORREA, Luis Fernando. O MERCOSUL e a OMC: Regionalismo e Multilateralismo. São Paulo, LTr, 2001.

COSTA, José Augusto Fontoura; DERANI, Cristiane (Orgs.). Direito Ambiental Internacional. Santos: Leopoldianum, 2001.

CROOME, John. Reshaping the World Trading System: a history of the Uruguay Round. Haia: Kluwer Law International, 1999.

CUI, Fan. Who are the developing countries in the WTO?. Berkeley: The Law and Development Review. Vol.1. 2008.

DOWBOR, Ladislau. Formação do Terceiro Mundo. São Paulo: Brasiliense, 1994.

ESTEVADEORDAL, Antoni. et. al (Orgs). Integrating the Americas: FTAA and Beyond. Cambridge: Harvard University Press, 2004.

FEUER, Guy; CASSAN, Hervé. Droit international du développment. Paris: Dalloz, 1985.

FLORY, Maurice. Droit International de Développment. Paris: Presse Universitaires de France, 1977.

FUKASAKU, Kiichiro. Special and Differential Treatment for Developing Countries: Does It Help Those Who Help Themselves?, Working Paper n. 197. Brugge, World Institute for Development Economic Research, The United Nations University, 2000.

FURTADO, Celso. A Economia Latino-Americana: formação histórica e problemas contemporâneos. $4^{\mathrm{a}}$ Ed. São Paulo: Paz e Terra, 2007.

Criatividade e Dependência na Civilização Industrial. São Paulo: Paz e Terra, 2008.

. Desenvolvimento e subdesenvolvimento. Rio de Janeiro: Contraponto, 2009.

Introdução ao desenvolvimento: enfoque histórico-estrutural. $3^{\mathrm{a}}$ ed. São Paulo: Paz e Terra, 2000. 
. Teoria e Política do Desenvolvimento Econômico. 10 ed. São Paulo: Paz e Terra, 2000.

O mito do desenvolvimento econômico. $3^{\mathrm{a}}$ edição. São Paulo: Paz e Terra1996.

. O capitalismo global. 7ª Ed. São Paulo: Paz e Terra, 1998.

. Raízes do subdesenvolvimento. Rio de Janeiro: Civilização Brasileira, 2003.

GAlEANO, Eduardo. As veias abertas da América Latina. 48ª Ed. São Paulo: Paz e Terra. 2008.

De pernas pro ar: a escola do mundo ao avesso. Porto Alegre: LPM, 2011.

GALLAGHER, Kevin. Putting Development First: the Importance of Policy space in the WTO and IFIs. Londres: Zed Books, 2005.

GALlAGHER, Peter. Guide to the WTO and Developing Countries. Haia: Kluwer Law International, 2000.

GILPIN, Robert. The political economy of international relations. Nova Jersey: Princeton University Press, 1987.

GUARDIOLA-RIVERA, Oscar. What if Latin America ruled the World? How the south will take the north into the $22^{\text {nd }}$ century. Londres: Bloomsbury, 2010.

HAQUE, I. U. Rethinking industrial policy. UNCTAD Discussion Paper \#183, 2007.

HOECKMAN, Bernard. Developing Countries and the WTO: a pro-active agenda. Oxford: Blackwell Publishing, 2003.

Operationalizing the Concept of Policy space in the WTO: Beyond Special and Differential Treatment. Journal of International Economic Law. Vol 8, No. 2. Oxford University Press, 2005. pp. 405-424. 
; KOSTECKI, Michel. The political economy of the World Trading System: the WTO and beyond. 2a ed. Nova York: Oxford University Press, 2002.

HOHMAN N, Harold (Org.). Agreeing and implementing the Doha Round of the WTO. Cambridge: Cambridge University Press, 2008.

HUDEC, Robert. Developing Countries in the GATT Legal System. Cambridge: Cambridge University Press, 1987.

HURELL, Andrew; et al. Os BRICs e a Ordem Global. São Paulo: Editora FGV, 2009.

IPEA. Como colocar o comércio global a serviço da população. Brasília: IPEA, 2004.

JACKSON, John. H. Sovereignty, the WTO and Changing Fundamentals of International Law. Cambridge: University Press, 2006.

The World Trading System: law and policy of international economic relations. $2 \mathrm{a}$ ed. Cambridge: MIT, 2002.

World trade and the law of GATT. Indianapolis: Bobbs-Merrill, 1969.

JAGUARIBE, Hélio; et al (Org).. A dependência político-econômica da América Latina. São Paulo: Loyola, 1976.

JAKOBSEN, Kjeld. Comércio internacional e desenvolvimento: do GATT à OMC. São Paulo: Fundação Perseu Abramo, 2005.

KESSIE, E. Enforceability of the Legal Provisions Relating to Special and Differential Treatment under the WTO Agreements. Paper apresentado no Seminário "the WTO Seminar on Special and Differential Treatment for Developing Countries". 7 de Março de 2000, Genebra, Suíça.

KEYNES, John Maynard. As consequências econômicas da paz. São Paulo: Imprensa Ocficial do Estado, 2002.

KINGSTONE, Peter. The political economy of Latin America. Nova York: Routledge, 2011. 
KLEEN, P. and Page, Sheila. Special and Differential Treatment of Developing Countries in the World Trade Organization. Série Global Development Studies no. 2, EGDI, Suécia:Overseas Development Institute, 2004

LANDAU, Alice. Conflits et cooperation dans les relations économiques internationals: le cas de 1'Uruguay Round. Bruxelas: Bruylant, 1996.

LESTER, Simon; MERCURIO, Bryan. World Trade Law. Oxford: Hart, 2008.

LORENZO, Fernando; VAILLANT, Marcel. E1 Mercosur y la Creación del Área de Libre Comercio de las Américas. Montevideo: Konrad Adenauer, 2003.

LOVE, Joseph. Las fuentes del estrucuturalismo latino-americano. Desarrollo Económico (Vol. 38. No. 141.). Instituto de Desarollo Económico y Social, 1996.

MAGALHÃES, José Carlos. Direito Econômico Internacional: tendências e perspectivas. Curitiba: Juruá, 2005.

MARINI, Ruy Mauro. A Dialética da Dependência. Rio de Janeiro: Vozes, 2000.

MATSUSHITA, M. and LEE, Y.S. Proliferation of Free Trade Agreements and Some Systemic Issues - In relation to the WTO disciplines and Development Perspectives. The Law and Development Review. Vol. 1, Ed. 1,2008 .

MERCADANTE, Araminta; CASELLA, Paulo (Orgs). Guerra Comercial ou Integração Mundial pelo Comércio. São Paulo: LTr, 1998.

Consolidação das normas do GATT 47, GATT 94 e OMC: legislação brasileira. São Paulo: Quartier Latin, 2007.

MIALHE, Jorge Luís. ALCA: aspectos jurídicos. Piracicaba: Instituto Hugo Grotius, 2003.

NARLIKAR, A. International Trade and Developing Countries: Bargaining coalitions in the GATT \& WTO. London, Routledge, 2003.

NASSER, Rabih Ali. A OMC e os países em desenvolvimento. São Paulo: Aduaneiras, 2002. 
OCAMPO, José Antonio; BERTOLA, Luís. Desenvolvimento, Vicissitudes e Desigualdade: uma história econômica da América Latina desde a Independência. Madri: Secretaria Geral Ibero-americana, 2011.

OCAMPO, Raúl Granillo. Direito Internacional Público da Integração. São Paulo: Campus, 2009.

PELlET, Alain et al. Direito Internacional Público. $2^{a}$ Ed. Lisboa: Fundação Calouste Gulbenkian, 2003.

PETERSMANN, Ernst-U1rich. Reforming the World Trading System: legitimacy, efficicency, and democratic governance. Nova York: Oxford University Press, 2005.

PRAZERES, Tatiana. A OMC e os Blocos Regionais. São Paulo: Aduaneiras, 2008.

Comércio internacional e protecionismo: As barreiras técnicas na OMC. São Paulo: Aduaneiras, 2003.

PREBISCH, Raul. Transformações e desenvolvimento: a grande tarefa da América Latina. Rio de Janeiro: Fundação Getúlio Vargas, 1973.

POLIDO, Fabrício Bertini. Contribuições ao estudo do Direito Internacional da Propriedade Intelectual na Era Pós-Organização Mundial do Comércio: fronteiras de proteção, composição do equilibro e expansão do domínio público. Tese de Doutorado (Faculdade de Direito). São Paulo: Universidade de São Paulo, 2010.

QURESHI, Asif. International Trade for Development: the WTO as a development institution?. In Journal of World Trade. Vol. 43. No. 1, 2009. Interpreting WTO agreements: problems and perspectives. Cambridge: Cambridge University Press, 2006.

RAINELLI, Michel. Comércio internacional. Barueri: Manole, 2004.

RAJAGOPAL, Balakrishnan. International Law from Below: Development, Social Movements and Third World Resistance. Cambridge: Cambridge University Press, 2003. 
RICUPERO, Rubens. Esperança e Ação: A ONU e a busca de desenvolvimento mais justo. São Paulo: Paz e Terra, 2002.

RIST, Gilbert. Le development: histoire d'une croyance occidentale. Paris: Presse de Science Po, 1996.

RODRIK, Dani. Development strategies for the next century. World Bank, Annual World Bank Conference on Development Economics 2001.

Growth after the crisis. Paper apresentado para "Commission on Growth and Development": Harvard Kennedy School, 2009.

. Has the Globalization Gone Too Far?. Washington D.C.,Peterson Institute of International Economics, 1997.

Industrial policy for the twenty-first century. Paper apresentado para UNIDO: Harvard Kennedy School, 2004

RODRIGUEZ, José R. (Org.) O Novo Direito e Desenvolvimento: presente, passado e futuro. São Paulo: Saraiva, 2009.

ROESSLER, Frieder. The legal structure, functions and limits of the world trade order. Londres: Cameron May, 2001.

ROSAS, José David E. Derecho internacional económico: instituciones y críticas contemporáneas. México: Editorial Porrúa, 2006.

ROUQUIÈ, Alain. O extremo ocidente - introdução à América Latina. São Paulo: Editora Edusp, 1991.

SACHS, Wolfgang. Dicionário do Desenvolvimento: guia para o conhecimento como poder. Rio de Janeiro: Vozes, 2000.

SADER, Emir. A nova toupeira: os caminhos da esquerda latino-americana. São Paulo: Boitempo, 2009. .; SANTOS, Theotonio. A América Latina e os Desafios da Globalização: ensaios dedicados a Ruy Mauro Marini. São Paulo: Boitempo, 2009.

SALGADO, Germánico. El Grupo Andino: eslabón hacia la integración de Sudamérica. Quito: UASB, 2007.

SALIN, Pascal. Que sais-je le libre-echange. Paris: PUF, 2002. 
SALVADOR, Ana Manero. OMC y desarrollo: evolución y perspectivas del trato desigual en el derecho del comercio internacional. Valencia: Tirant Lo Blanch, 2006.

SCOTT, James. Developing countries in the ITO and GATT negotiations. In Journal of International Trade Law and Policy. (Vol. 9 No. 1). 2010. pp. 524.

SEIDEL-HOHENVELDREN, Ignaz. International Economic Law. $3^{\text {a }}$ Ed. Haia: Kluwer Law International, 1999.

SEITENFUS, Ricardo; VENTURA, Deisy. Direito Internacional Público. $4^{\mathrm{a}}$ Ed. Porto Alegre: Livraria do Advogado, 2006

SEN, Amartya. Desenvolvimento como liberdade. São Paulo: Companhia das Letras, 2000.

SHAN, Wenhua; SIMONS, Penelope; SINGH; Dalvinder (Orgs.). Redefining sovereignty in international economic law. Oregon: Hart Publishing, 2008.

STIGLITZ, Joseph. A Globalização e seus malefícios: a promessa não-cumprida de benefícios globais. São Paulo: Futura, 2002.

Development policies in a world of globalization. Paper apresentado no seminário "New International Trends for Economic Development". Rio Janeiro: BNDES, 2002.

THORP, Rosemary. Progresso, pobreza e exclusão: uma história econômica da América Latina no século XX. Nova Iorque: Banco Interamericano de Desenvolvimento, 1998.

THORSTENSEN, Vera. Organização Mundial do Comércio: as regras de comércio internacional e a nova rodada de negociações multilaterais. $2^{\mathrm{a}}$ Ed. São Paulo: Aduaneiras, 2001.

TORRENT, Ramon; et al (Orgs). Diálogo sobre gobernabilidad, globalización y desarrollo. Barcelona: Universitat de Barcelona, 2005.

; ESTEVADEORDAL, Antoni. (Orgs). Regionalismo global: los dilemas de America Latina. Barcelona: CIDOB, 2005. 
TRACHTMAN, Joel P. Developing countries in the WTO Legal System. Londres: Oxford University Press, 2009.

. The International Economic Law Revolution and the Right to

Regulate. Londres: Cameron May, 2007.

. The economic structure of international law. Londres: Harvard University Press, 2008

ULYANOV, Vladimir Ilyich. O imperialismo: fase superior do capitalismo. São Paulo: Global, 1987.

UNCTAD. The History of UNCTAD: 1964-1984. Nova York: UNCTAD, 1984. . Beyond Conventional Wisdom in Development Policy: an Intellectual

History of UNCTAD 1964-2004. Genebra: UNCTAD, 2004.

VELASCO, Manuel Diez. Las organizaciones internacionales. $15^{\mathrm{a}}$ ed. Madri: Tecnos, 2008.

VENTURA, Deisy. As assimetrias entre o MERCOSUL e a União Européia: os desafios de uma associação inter-regional. Barueri: Manole, 2003.

VERLOREN VAN THEMAAT, Pieter. The changing structure of international economic law. Haia: Martinus Nijhouf Publishers, 1981.

VOITOVICH, Sergei. International Economic Organizations in the International Legal Process. Dordrecht: Martinus Hijhoff Publishers, 1995.

WIONCZEK, Miguel (org.). Integração Econômica da América Latina: experiências e perspectivas. Rio de Janeiro: Cruzeiro, 1966.

WISE, Timothy. Is Development back in the Doha Round?. Disponível em www.southcentre.org, 2009. 